\author{
SZEGEDI TUDOMÁNYEGYETEM \\ TÖRTÉNELEMTUDOMÁNYI DOKTORI ISKOLA
}

Pető Bálint

\title{
A szentesi nyomtatott tömegtájékoztatás kezdetei (1871-1883)
}

\author{
A helyi sajtó szerepe a kiegyezés utáni polgári fejlödés előmozditásában \\ egy dél-alföldi városban
}

\section{PhD-értekezés}

Témavezető:

\section{Dr. Zakar Péter}

föiskolai tanár

Szeged

2018 


\section{Tartalom}

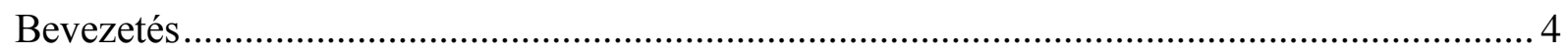

1. A magyarországi sajtó vázlatos történeti áttekintése 1867-től 1883-ig ............................. 10

1.1. A sajtókérdés jogi szabályozása a kiegyezés után ...................................................... 11

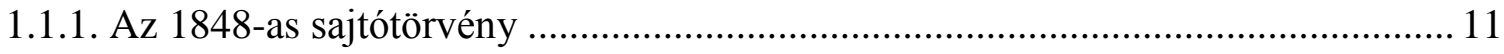

1.1.2. A szabad sajtóviszonyokat megteremtő egyéb intézkedések............................... 13

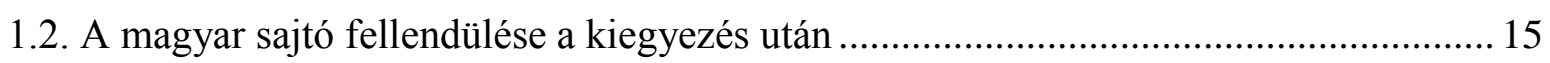

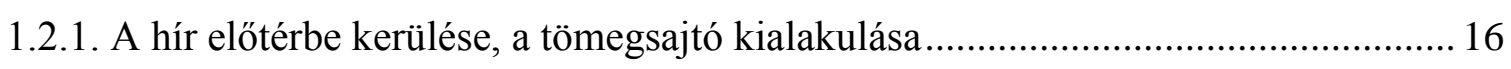

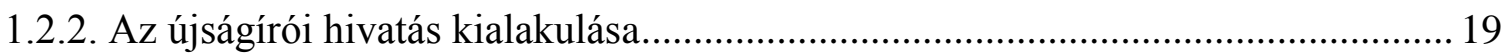

1.2.3. A lapok belső struktúrája, szerkesztési módszerek ........................................... 20

1.2.4. Hirdetések, bevételek - a sajtó, mint üzlet........................................................ 22

1.2.5. A legfontosabb országos lapok (1867-1883) ..................................................... 23

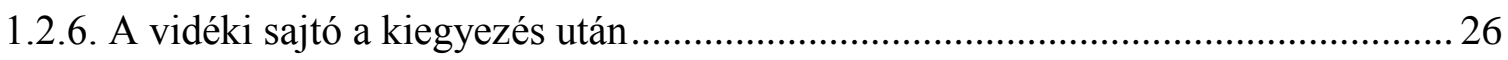

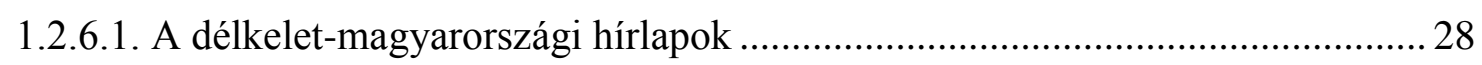

1.2.6.1.1. A Csongrád vármegyei sajtó a kiegyezés után ........................................ 30

2. Szentes város történetének vázlatos áttekintése 1867-től 1883-ig .................................... 32

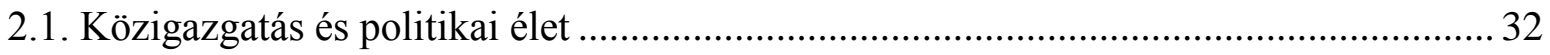

2.2. A megyeszékhelyi státusz elnyerése.................................................................. 38

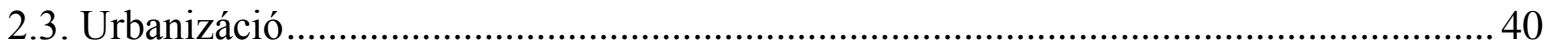

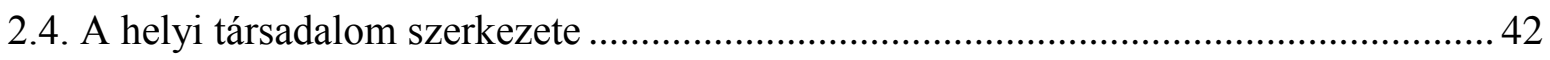

2.5. A társadalmi élet színterei: egyletek, népkörök........................................................ 46

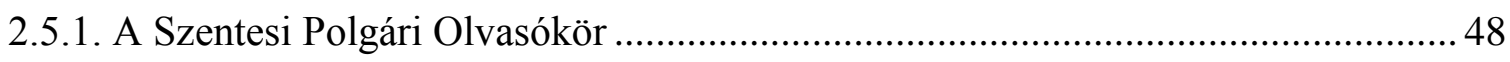

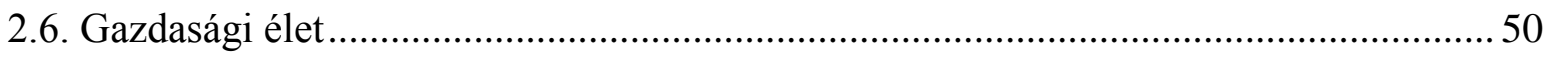

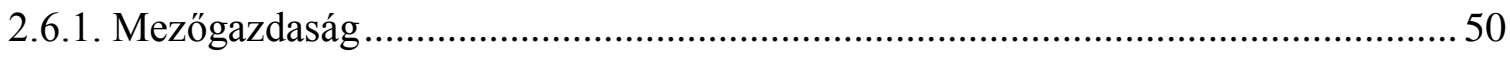

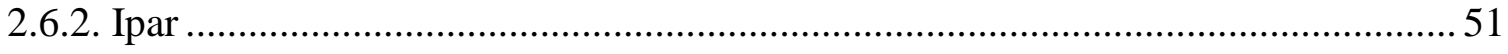

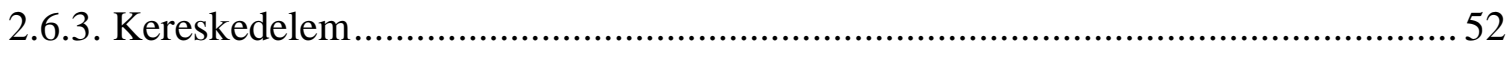

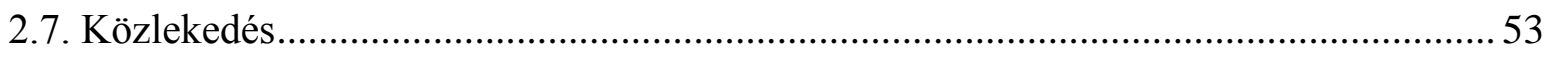

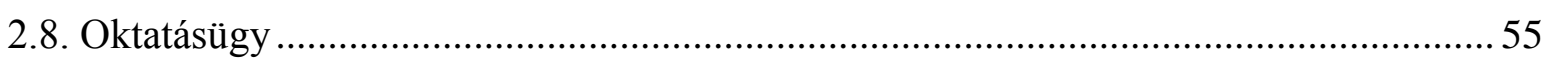

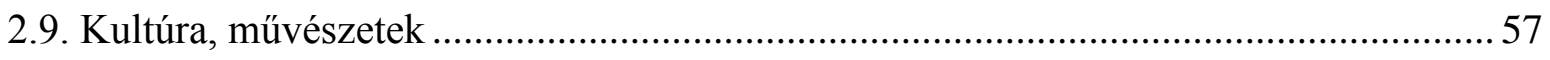

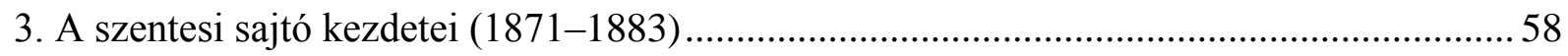

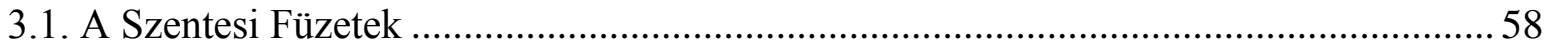

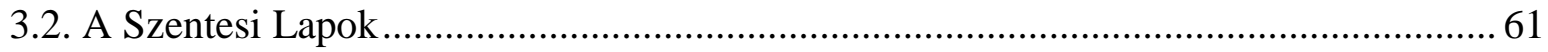

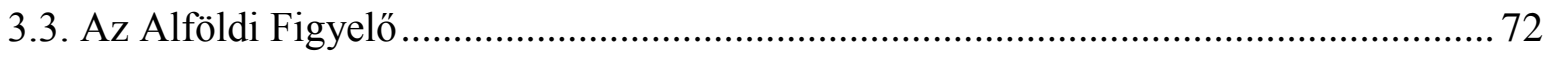

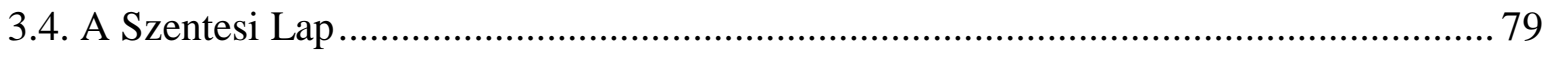

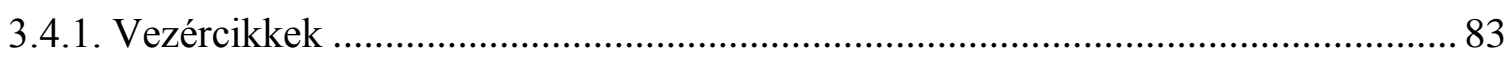

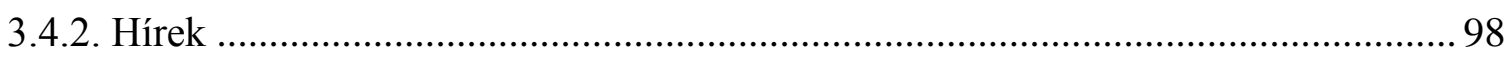




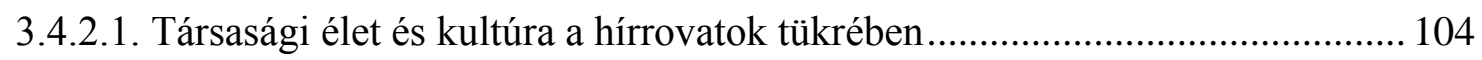

3.4.2.2. Fejlesztésekre ösztönzés, közérdekü figyelemfelhívások ............................ 107

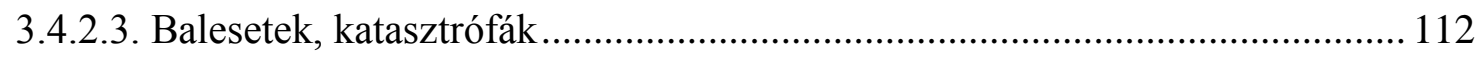

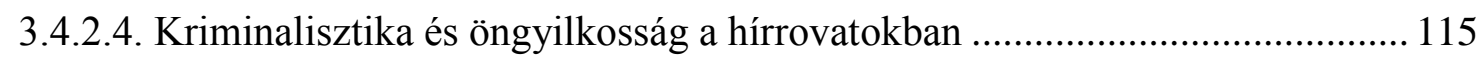

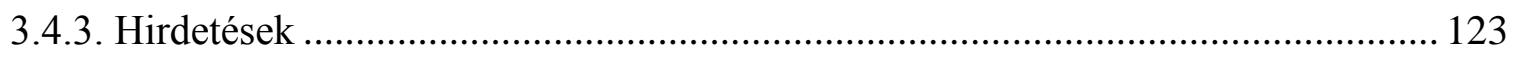

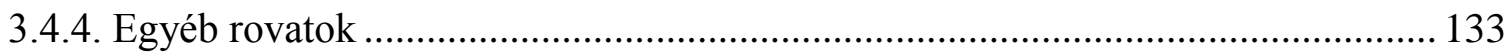

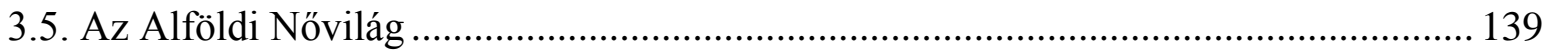

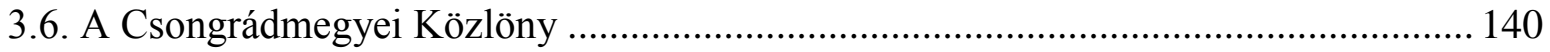

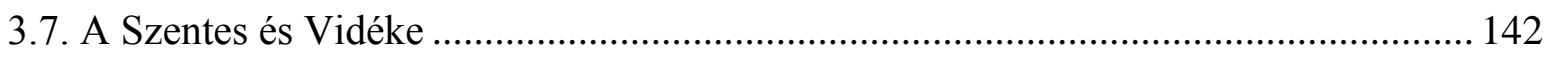

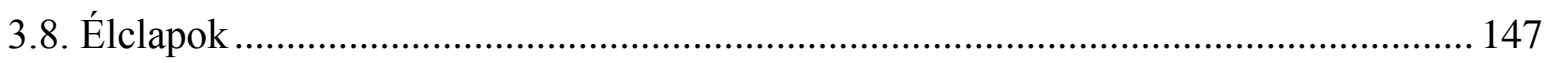

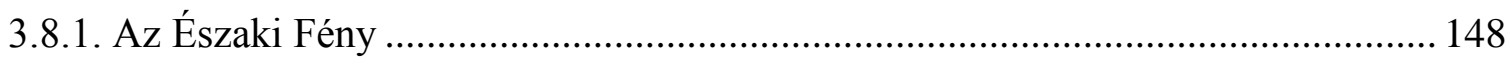

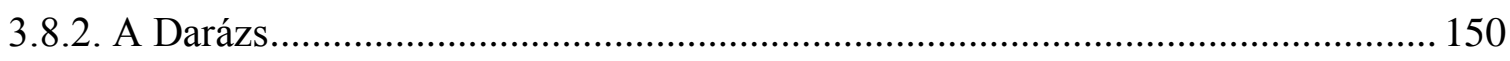

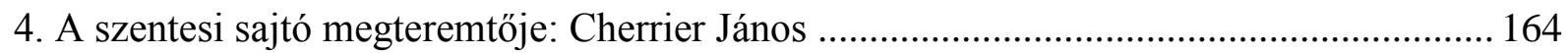

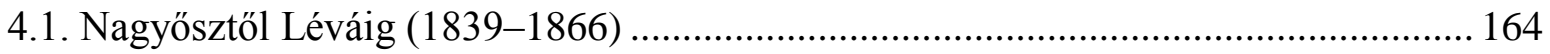

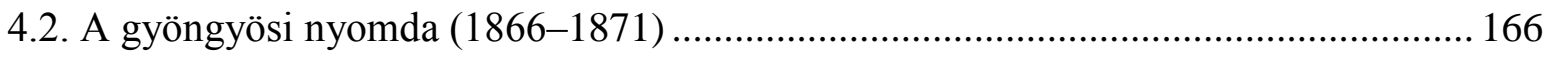

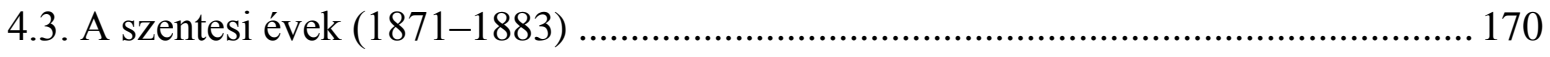

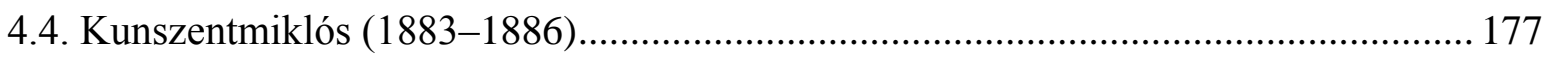

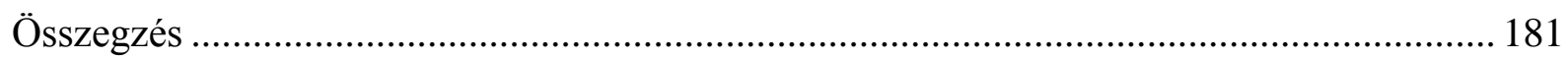

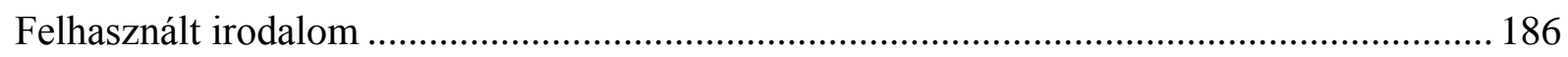

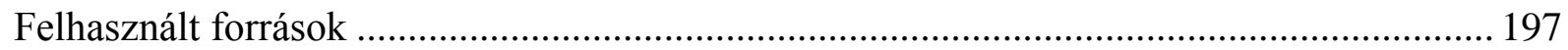

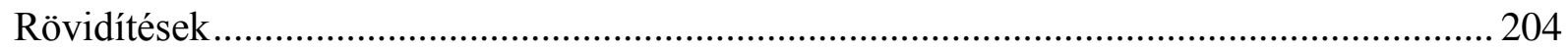

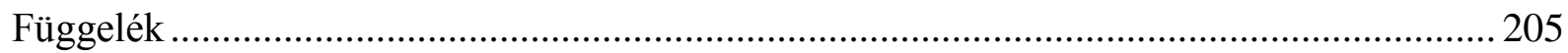




\section{Bevezetés}

Disszertációmban az 1867-es kiegyezés utáni vidéki sajtó megjelenését, azon belül pedig a dél-alföldi Szentes nyomtatott tömegtájékoztatásának kezdeteit vázolom fel, vagyis a település sajtótörténetének 1871-től 1883-ig terjedő korszakát. Kutatásom kilenc lapra, a Szentesi Füzetek szakfolyóiratra, a közéleti tematikájú Szentesi Lapokra, Alföldi Figyelöre, Szentesi Lapra, Szentes és Vidékére, Csongrádmegyei Közlönyre, a divatlap Alföldi Növilágra, illetve két élclapra, az Északi Fényre és a Darázsra terjed ki. Az időintervallum kezdőpontja adott, hiszen Szentes első önálló sajtóterméke 1871-ben jelent meg, a végpont meghatározása pedig véleményem szerint több szempontból is indokolt: először is, 1883-ban költözött el a településről a szentesi hírlapkiadás megteremtője, Cherrier János nyomdász és könyvkereskedő. Másfelől - az előbbi ténnyel szoros összefüggésben -, a helyi véleményformálás vezető orgánuma, a Szentesi Lap új tulajdonos kezébe került, akinek köszönhetően az újság jelentős átalakuláson ment keresztül: véglegesen lezárult útkereső, kísérletező korszaka, s új célokat tüzött ki maga elé. Harmadrészt pedig, az említett esztendő végén avatták fel a város főterén ma is eredeti pompájában látható vármegyeházát, így Szentes - átvéve Szegvártól a stafétabotot - Csongrád vármegye székhelyévé vált. Mindezzel új korszak kezdődött a helység politikai, gazdasági és társadalomtörténetében, ráadásul, ha nem is egyedülálló, mindenképpen sajátos dimenziókkal - amely a többségében függetlenségi érzelmű helyi lakosság, valamint a kormánypárti megyei vezetés éles szembenállásából következett -, mint azt a későbbiekben látni fogjuk.

Jómagam Szentesen nőttem fel, s az ebből adódó, szoros érzelmi kötődésem a településhez megkönnyítette témaválasztásom. A dolgozatban használt módszerek meghatározása, valamint alkalmazásuk mértéke, aránya azonban már felvetett bizonyos kérdéseket, tekintve a terjedelmi korlátokat, illetve a közismert tényt, miszerint a sajtótörténeti munkákkal szemben támasztott szakmai elvárások számottevő változáson mentek keresztül az utóbbi évek során. A hagyományosabb megközelítés szerint ugyanis a sajtótörténet-írás alapvetően deskriptív jellegü feladat: a történész felvázolja az adott lap megjelenésének előzményeit, körülményeit, életgörbéjének sarkalatos pontjait, majd megszünésének okait; általában csupán említésszinten felsorolja az ott dolgozó szerkesztőket, újságírókat; bemutatja az újság formai jellegzetességeit, rovatszerkezetét; végül pedig tartalmi ismertetést közöl, elsődlegesen a fajsúlyosabb vagy egyéb szempontból nagyobb érdeklődésre számot tartó cikkekre koncentrálva. Mindennek talán legnagyobb hiányossága az, hogy egy ilyen jellegü, föként irodalomtörténészek, valamint történészek által készített sajtómonográfia 
kizárólag „a történeti és az irodalomtörténeti kutatásoknak alárendelten volt képes megfigyelni és leirni a sajtó történetét".

A politika- és irodalomtörténeti felfogás mellett azonban megjelent a társadalomtörténeti, elsődlegesen analitikus módszert használó megközelítés, amely nem csupán kiegészíti az előbb említett, hagyományosabbnak tekinthető szemléletet, hanem kiemeli a sajtótörténet-írást a segédtudományok közül, és új alapokra helyezi azt. Ennek lényegét Gyáni Gábor 2006-ban így foglalta össze: „A sajtó mint sajátos társadalmi szervezet vagy intézmény fogalma számos új kérdés vizsgálatára teremt számunkra lehetöséget. [...] A szóba jövö elsö kutatási probléma a sajtó elöállitásának és készitésének gazdaság- és társadalomtörténete. További égetően fontos kérdés lehet az újságírók társadalomtörténete; nem kevésbé figyelemre méltó a sajtó mint tömegkultúra-médium kutatása. Ez az utóbbi kérdés közvetlenül is érinti a sajtó, valamint a politikai kultúra (és nemcsak a pártpolitikai élet) szoros érintkezését és belsö összefüggését, amely szintén érdemi kutatások tárgya lehet a jövőben.” ${ }^{2} \mathrm{Az}$ új megközelítés tehát „képessé válhat hozzáadott értékkel szolgálni a hagyományos, a tartalmat ismertetö, a kulturális-társadalmi kontextust mellöző sajtótörténeti felfogáshoz képest. Ez a módszer új szempontok, elemzési módok, valamint források kutatásba történő bevonását jelenti."”

Lengyel András a következőképpen fogalmaz: „A kutató, ha munkába kezd, kinyomtatott szövegekkel találkozik, amelyek jellegük és tartalmuk szerint nagyon sokfélék [...] a szövegek nem magukban jelentik a problémát, amelyet meg kell oldani-megszületésüknek ugyanis elözetes szociokulturális és technikai föltételei vannak, és maguk a szövegek is csak azért érdekesek, mert olvasókhoz jutnak el: olvassák őket." Lengyel szerint a szövegek elött, illetve megszületésük után egy bonyolult összefüggésrendszer van jelen, amely megkerülhetetlen a szövegek termelése és fogyasztása szemszögéből. „A sajtótörténet-irásnak tehát, ha meg akar felelni feladatának, e föltételrendszert is kutatnia kell."4

Szintén az új, társadalomtörténeti felfogást vallotta a közelmúltban elhunyt Lipták Dorottya, az MTA-OSZK Res Libraria Hungariae Kutatócsoport munkatársa, aki szerint ,a társadalom nem csupán befogadója, hanem alkotója, szabályozója és felhasználója is az újságnak. Az újság manipuláló hatású, és egyben manipulált is mint közvetítő eszköz." 5 Meglátása szerint a sajtó nem csak egy illusztráció, amellyel a történész igazolhatja az általa

\footnotetext{
${ }^{1}$ Szajbély 2005.71.

${ }^{2}$ Gyáni 2006. 58.

${ }^{3}$ Döbör 2015. 5.

${ }^{4}$ Lengyel 2013. 20-21.

${ }^{5}$ Lipták 1997.
} 
preferált érvrendszert, hanem jóval több annál: a nyomtatott tömegtájékoztatási eszközöket tágabb összefüggésben, jóval szélesebb kontextusban, a társadalmi kommunikációs rendszer történeti fejlődésében szükséges értelmezni, és a vizsgálati módszereket (pl. statisztikai elemzések) is ennek megfelelően kell megválasztani. ${ }^{6}$ Emellett, Gyánihoz hasonlóan, ő is kiemelten fontosnak tartotta bemutatni a sajtóterméket a kapitalista termelés-terjesztésfogyasztás gazdaságtanának vonatkozásában, tehát a sajtót tőkés vállalkozásként is elemezte. ${ }^{7}$

Dolgozatomban igyekeztem a fentebb említett látásmódok mindegyikét figyelembe venni. A deskriptív megközelítés markánsan jelen van munkámban, hiszen választott témám alapvetően feldolgozatlan, így a megértéshez, a további vizsgálatokhoz elkerülhetetlen volt a hagyományosabb szemlélet, a szövegelemző módszertan széles körü alkalmazása. A szentesi sajtó fejlődési folyamatáról Labádi Lajos történész, a helyi levéltár egykori vezetője írt ugyan egy néhány oldalas összegzést, ${ }^{8}$ emellett tartott már a témában - az interneten, írott formában is elérhető - előadást, ${ }^{9}$ azonban nagyobb terjedelmü, a modern kutatási módszereket is magáénak valló feldolgozás mindeddig nem született, jelen disszertáció pedig erre tesz kísérletet, az említett időhatáron (1871-1883) belül. Fontos azonban leszögezni, hogy bár a 2. fejezetben vázlatosan összefoglaltam a település korabeli politika- és közigazgatás-történetét, az egyes újságok elemzésekor ennek az aspektusnak a vizsgálatára részletesen nem, legfeljebb említésszinten térek ki, hiszen Labádi Lajos 1995-ben megjelent kiváló monográfiája mindezt a teljesség igényével ismerteti. ${ }^{10}$ (Éppen emiatt nem foglalkozom például az egyes sajtóorgánumokban rendszeresen megjelenő városi és megyei közgyűlési tudósítások, illetve az aktuálpolitikai témákban született publicisztikák beható elemzésével.)

A dolgozat a dualizmus első másfél évtizedének helyi társadalmi, kulturális és gazdasági jellegzetességeire helyezi a fő hangsúlyt, azonban alapvetően nem társadalomvagy gazdaságtörténeti monográfia, hanem sajtótörténeti tanulmány. Az 1. fejezetben - a legfontosabb, eddig megjelent önálló kötetek és tanulmányok alapján összefoglalom a kiegyezés megkötése utáni magyar sajtóviszonyokat (törvényi szabályozás átalakulása, legfontosabb országos lapok, kiadók, nyomdák, újságírói hivatás kialakulása stb.), majd szükebb kontextusba helyezem a témát a dél-magyarországi, illetve ezen belül a Csongrád vármegyei nyomtatott tömegtájékoztatás korabeli történetének ismertetésével. Ezt követően, mint már említettem, szintén szekunder források - elsősorban Labádi már idézett kötete,

\footnotetext{
${ }^{6}$ Lipták 2002. 9-28.

${ }^{7}$ Lipták 2011. 1123-1125.; Gyáni 2006. 59.

${ }^{8}$ Lásd: Kis-Rácz 2000. (1.10.8. - A korszak sajtója)

${ }^{9}$ Lásd: Labádi 2013.

${ }^{10}$ Lásd: Labádi 1995. 5-280.
} 
valamint az 1928-ban kiadott, Nagy Imre által szerkesztett Szentes-monográfia felhasználásával bemutatom a korabeli település politikai, közigazgatási, gazdasági, oktatási, vallási, demográfiai és kulturális viszonyait.

A 3. fejezetben rátérek a disszertáció lényegi részére: felvázolom az első helyi lapok megszületésének, illetve megszünésének körülményeit, ismertetem a kiadók, a szerkesztők személyét, az egyes újságok formai és tartalmi jellegzetességeit. Hangsúlyos szempontom továbbá a kiegyezés utáni új gazdasági, társadalmi és kulturális lehetőségek, valamint a számos területen jelentős elmaradottsággal küzdő, posztfeudális viszonyokkal rendelkező város ellentétének vizsgálata, illetve annak ismertetése, hogy a szárnyait bontogató helyi sajtó hogyan próbált élére állni az urbanizációnak, a polgári fejlődésnek nem csupán fizikai, hanem szellemi értelemben is. Az előzőekhez szervesen kapcsolódva, további célom, hogy a sajtó tükrén keresztül átfogó képet nyújtsak a sajátos szentesi társadalom mindennapjairól is az 1870-es években, illetve a következő évtized első harmadában. Utóbbi nem egyszerü feladat, hiszen: „Az átlagember életének tényei, a viselkedést irányitó normák, erkölcsi meggyözödések, hitbéli elvek feltárása a történetírói megismerés valami egészen új módját feltételezi, amely elüt mind a hagyományos - narratív - politikai eseménytörténettöl, mind a strukturális és funkcionális összefüggéseket elemzö »társadalomtudományos « történetírás gyakorlatától. A téma sajátos megválasztásának első és szembetünő következménye, hogy az élet banális tényeinek megközelitése a teljesen konkrét idö- és térbeli kereteket részesíti előnyben, ezért a kis egységekhez és a rövid időtartamokhoz tartja magát. Ennek eredményeként kerül mindjobban elötérbe a mikrotörténet, mint ami látszólag egyedüli letéteményese a mindennapi történelem, vagyis a peremre szorult jelenségek s vele a másság történetírói megértésének és hiteles bemutatásának." ${ }^{11}$ Emellett azt is vizsgálom, hogyan hatott egymásra termék és fogyasztó, vagyis a lap és az olvasó, milyen kölcsönhatások alakították akár az egyiket, akár a másikat (pl. a rovatszerkezet többszöri átalakulása, illetve a hírek mennyiségének jelentős növekedése az olvasói igényekhez igazítva, vagy fordítva: a sajtó társadalomformáló, manipulatív szerepe).

Az egyes lapok ismertetésének részletessége tekintetében - a terjedelmi korlátok okán - muszáj volt súlyoznom, amelyhez alapvetően három szempontot vettem figyelembe: a megjelenés időbeni hosszúságát, a kiadótulajdonos személyét, valamint a lapnak a szentesi sajtótörténetben betöltött szerepét. Ez alapján kissé nagyobb teret szentelek a mindössze egyetlen számot megélt Szentesi Füzeteknek, hiszen az első helyi sajtótermékről van szó.

\footnotetext{
${ }^{11}$ Gyáni 1999. 11.
} 
Részletesebben elemzem a szintén rövid ideig létező, Darázs címü élclapot is, mivel durva hangnemével, uszító, bizonyos népcsoportokat gyalázó cikkeivel azóta is példa nélkül áll a szentesi sajtó történetében. A legalaposabban a tárgyalt korszakunkban szinte végig (1872-től) megjelenő Szentesi Lapot taglalom, amelynek esetében elvégeztem az első tizenhárom évfolyam teljes tartalmi feldolgozását, illetve a nyert adatok rendszerezését, ennek segítségével pedig - több szempont alapján - különféle statisztikákat készítettem, s azokból következtetéseket tudtam levonni. Mindemellett a kiadó Cherrier János - dolgozatom leghangsúlyosabb személye - előző két hetilapjára (Szentesi Lapok, Alföldi Figyelő) is nagyobb figyelmet fordítok.

A lapok vizsgálatakor azon rovatokra koncentráltam, amelyek tartalmilag a fentebb említett célokat szolgálják: elsősorban természetesen a hírekre, ezen kívül a vezércikkekre (illetve egyéb, a helyi társadalmi vagy kulturális viszonyokat elemző publicisztikákra), valamint a hirdetőkre. Jelen tanulmányban éppen emiatt a szépirodalmi tematikájú rovatokkal - pl. tárca - részletesen nem foglalkoztam, azok vizsgálata, elemzése egy következő dolgozat témája lehet.

Végül, szempontom volt az is, hogy megvizsgáljam a helyi sajtót, mint tőkés vállalkozást, bár ez egy vidéki város esetében jóval nehezebb feladat, hiszen - ellentétben több országos lappal - itt nem maradtak fent primer források a példányszámokról, és a levéltárak egyéb dokumentumokat (számlákat, elismervényeket, megbízási vagy adásvételi szerződéseket, mérlegkimutatásokat stb.) is csak elvétve őriztek meg az egyes sajtótermékek viszonylatában. Így például az előfizetők számával, a laptulajdonosok bevételeivel, illetve kiadásaival kapcsolatban is nagyrészt csupán az egyes cikkekben ritkán felbukkanó adatokra vagy pusztán feltételezésekre - hagyatkozhatunk. Mindenesetre, e cél érdekében született a 4. fejezet, amelyben a már említett Cherrier János lapkiadót, nyomdászt és könyvkereskedőt, a modern értelemben vett szentesi sajtó megteremtőjét, dolgozatom „főhősét” mutatom be, akinek életútjával igyekszem megrajzolni egy a korszakban kevésbé tipikusnak mondható, több szempontból sajátos és érdekes fordulatokkal tarkított karriertörténetet.

A disszertáció elsődleges primer forrásait természetesen a korabeli szentesi lapok jelentették, amelyek fennmaradt példányainak másolatait részben az Országos Széchényi Könyvtárból (Északi Fény, Csongrádmegyei Közlöny, Szentes és Vidéke) szereztem be, részben a Magyar Nemzeti Levéltár Csongrád Megyei Levéltár szentesi fióklevéltárából (Szentesi Lapok, Alföldi Figyelő, Darázs), emellett jelentősen megkönnyítette munkámat, 
hogy az elsődleges fontosságú Szentesi Lap teljes állománya digitalizált formában elérhető már interneten is. ${ }^{12}$

Egyéb levéltári forrásokat elsősorban a Cherrier Jánossal kapcsolatos kutatásaim igényeltek: Egerben, a Magyar Nemzeti Levéltár Heves Megyei Levéltárban találtam számos dokumentumot, amelyek segítségével sikerült megismerni a nyomdász Gyöngyösön töltött éveit; a már említett szentesi levéltárban szintén felleltem több értékes iratot, emellett kutattam Kecskeméten (a Magyar Nemzeti Levéltár Bács-Kiskun Megyei Levéltárban) a kunszentmiklósi időszak kapcsán; valamint Románia Nemzeti Levéltárában Temesváron, ahol hosszas kutatás után megtaláltam Cherrier születési anyakönyvi bejegyzését. Kunszentmiklósra személyesen is ellátogattam: Vangel Imre plébános úr betekintést engedett az ottani római katolikus halotti anyakönyvekbe, ezúton is köszönöm a segítségét. Hálás vagyok Marta Švoliková szlovákiai történésznek is, aki Cherrier János pályájának kezdetéröl, tehát nyitrai és lévai müködéséről írt szlovák nyelvü tanulmányt, emellett önzetlenül rendelkezésemre bocsátotta személyes kutatásai eredményét, vagyis a nyomdászra vonatkozó összes fennmaradt irat másolatát a nyitrai levéltárból. ${ }^{13}$ Ezen kívül számos, a Cherriernyomdában készült kisnyomtatványt tekintettem meg az Országos Széchényi Könyvtár kézirattárában. Megemlítendő még, hogy a dolgozat értékét talán tovább növelte volna, ha sikerül a Magyar Nemzeti Levéltár Országos Levéltár Belügyminisztériumi Levéltárának K 148. szekciója nyilvántartásaiban szereplő, Cherrier Jánosra vonatkozó iratokat megtekintenem - sajnos azonban ezek a dokumentumok már nem találhatók, feltehetően a XX. század történelmi viharaiban megsemmisültek.

A dolgozatban dőlt betűvel szedtem az idézeteket, az egyes sajtóorgánumokat fejezeten vagy alfejezeten belüli első említéskor, valamint a cikk- és rovatcímeket, illetve az egyéb mücímeket. Más kiemelést ezzel a technikai megoldással - például hangsúlyozási, figyelemfelhívási célból - csak különösen indokolt esetben alkalmaztam. A korabeli lapok neveit, a belölük vett idézeteket, illetve más primer forrásokból idézett szövegeket eredeti helyesírással közlöm, a nemritkán előforduló hibákra pedig csak akkor hívom fel a figyelmet a megszokott jelzéssel, amennyiben nem a korban még sok szempontból lazább, szabadabb írásmódról (pl. rövid vagy hosszú magánhangzókkal, egybeírással-különírással kapcsolatos következetlenségek stb.), hanem egyértelmüen szedési vagy a nyelvtani szabályok nem kellő mértékü ismeretéből fakadó hibáról van szó.

\footnotetext{
${ }^{12} \mathrm{http}: / /$ epa.oszk.hu/html/vgi/kardexlap.phtml?id=1889

${ }^{13}$ A nyitrai primer forrásokra jelen dolgozatban külön nem hivatkozom: Marta Švoliková kiváló tanulmányában a teljesség igényével feldolgozta azokat.
} 
Végül, a már említetteken kívül szeretném megköszönni minden olyan személynek a szakmai és baráti segítségét, aki hozzájárult dolgozatom elkészüléséhez: elsősorban dr. Zakar Péternek, aki konzulensként támogatta munkámat. Rajta kívül kiemelném még dr. Döbör Andrást, Labádi Lajost, Balogh Mihályt, Fejős Sándort, Kasza Juditot, Gergely Sándort, illetve hálás vagyok a Magyar Nemzeti Levéltár szentesi, egri, budapesti és kecskeméti munkatársainak is. Emellett köszönet illeti a családomat - feleségemet, Póka Tündét, illetve két leányomat, Rékát és Csengét - az alkotáshoz szükséges háttér folyamatos biztosításáért.

\section{A magyarországi sajtó vázlatos történeti áttekintése 1867-től 1883-ig}

1867. június 8-án magyar királlyá koronázták I. Ferenc Józsefet, amely esemény a szimbolikus csúcspontját jelentette a hosszas, évekig tartó tárgyalássorozatnak Ausztria és Magyarország között. Négy nappal később az új uralkodó szentesítette a március 20-án elfogadott közösügyi törvényjavaslatot (1867:XII. tc.), így megszületett a kiegyezés. A törvény kimondta, hogy az uralkodó személye és a Pragmatica Sanctio két szuverén államot kapcsol össze, emellett - tekintve a Habsburg-tartományok felbonthatatlan öröklési közösségét - közös ügynek számít a külügy, a hadügy, valamint az ezekre fedezetet biztosító pénzügy. ${ }^{14}$ Az Osztrák-Magyar Monarchia létrehozása - a magyar történetírás álláspontja szerint - új fejezetet nyitott mindkét ország történetében, s bár a kiegyezést eltérően fogadták hazánkban, ${ }^{15}$ illetve annak jelentőségét, gazdasági, politikai és társadalmi hatásait azóta is sokféleképpen értelmezik, ${ }^{16}$ vitathatatlan, hogy alapvetően kompromisszumról volt szó. ${ }^{17}, A$ magyarok elfogadták a nem teljes állami szuverenitás tényét azért, hogy a Habsburg Monarchia fennmaradjon. Az uralkodóház viszont elfogadta azt a tényt, hogy a magyarok éljenek a nem teljes értékü szuverenitással. Ök tehát feladták az egységes birodalom eszméjét" - fogalmaz Gerő András. ${ }^{18}$

\footnotetext{
14 1867:XII. tc. 1-16.§, Gergely 1998. 340.

${ }^{15}$ Erdélyben és a nemzetiségek lakta vidékeken a kiegyezés támogatottsága jóval nagyobb arányú volt, mint a többségében magyarok lakta területeken. (Kozári 2005. 33.)

${ }^{16}$ Gyáni Gábort idézve: „Napjainkban, midőn a történetírói diskurzust egyre inkább a kánonok pluralizmusa kezdi jellemezni, nem hat már a meglepetés erejével, hogy a Habsburgok (és persze az Osztrák-Magyar Monarchia) történeti értékelését szintén az anarchiára emlékeztetö sokféleség keriti a maga hatalmába. Ma még nem tudható, hogy az újból visszanyert, a globalizáció következtében azonban (megint csak) korlátozott szuverenitással járó nemzetállami önállóság perspektívájából milyen új értékelési szempontok fogják a jövőben megszabni múltunk e kivételesen fontos időszakának a megközelitését." (Gyáni 2004. 627.)

${ }^{17}$ Gerő 2017. 17., Gergely 1978. 40-44.

18 Gerő 2017. 17.
} 


\subsection{A sajtókérdés jogi szabályozása a kiegyezés után}

A kiegyezés megkötését követően a magyar sajtó újra szabaddá vált, az egységes birodalmi sajtóirányítás megszűnt. A Magyar Korona Országaiban 1867. március 17-én ismét életbe léptek az 1848-as áprilisi törvények szabad sajtóra vonatkozó paragrafusai (1848:XVIII. tc.), de nem minden területen: a katonai határőrvidéken továbbra is érvényben volt az 1862. évi sajtópátens; Horvátországban, Fiumében, valamint Erdélyben hatályos maradt az 1852-es sajtórendtartás, viszont utóbbi esetében a kiegyezés megkötése után négy esztendővel szintén bevezették az 1848-as törvény módosított változatát. A széttagolt jogi szabályozás így a magyar nyelvü tömegtájékoztatásnak viszonylagos szabadságot biztosított, viszont a nemzetiségekkel szemben megőrizte az abszolutizmus előnyeit. (Ausztriában továbbra is az 1862. évi sajtópátens maradt érvényben.) ${ }^{19}$

\subsubsection{Az 1848-as sajtótörvény}

A négy fejezetből, illetve negyvenöt paragrafusból álló törvény első mondata deklarálja: ,Az elözö vizsgálat eltöröltetvén örökre, s a sajtószabadság visszaállíttatván, ennek biztositékául ideiglenesen rendeltetnek" -, majd az első fejezet előtt lévő két paragrafusa leszögezi:

„1.§ Gondolatait sajtó utján mindenki szabadon közölheti, és szabadon terjesztheti.

$2 . \S$ Sajtóutoni közlés alatt értetik: minden ollyan közlés, melly vagy szavakban, vagy ábrázolatokban, nyomda, könyomda s metszés által eszközöltetik, és a mellyek közzététele, a példányok akár ingyen kiosztásával, akár eladásával, már megkezdődött."20

Az I. fejezet ezután (3-16.§) a sajtóvétségek témakörét szabályozza, s összességében megállapítható, hogy a sajtószabadság kinyilvánítása ellenére igen szigorú rendelkezéseket tartalmaz: a köz- és vallásos erkölcs megsértéséért is akár egy év szabadságvesztés és/vagy 400 forint pénzbüntetés is kiszabható volt. Rágalmazás esetén félévnyi börtönre és/vagy 300 forintos maximális pénzbírságra lehetett számítani. A legsúlyosabban (hat év szabadságvesztés és/vagy 3000 forint pénzbírság) a király megsértését szankcionálták. ${ }^{21}$

A II. fejezet a bírói eljárás rendjét szabályozza, amelynek legfontosabb eleme, hogy a sajtóvétségek ügyében nyilvános esküdtszékek ítélkeznek, az esküdtbíróságok megalakítását

\footnotetext{
${ }^{19}$ Buzinkay 1993. 61.

${ }^{20}$ 1848:XVIII. tc., $1-2 . \S$

${ }^{21} 1848$ :XVIII. tc. $3-16 . \S$
} 
pedig minisztériumi hatáskörbe utalja. ${ }^{22}$ A törvény III. fejezete az időszaki lapok kiadásának feltételeiről rendelkezik: a területileg illetékes hatósághoz való bejelentési kötelezettséget ír elö, amelyben közölni kell az új sajtótermék legfontosabb adatait: a tulajdonos, a kiadó vagy a felelős szerkesztő nevét, lakhelyét, valamint a sokszorosító vállalkozást - az adott hatóság pedig a bejelentést köteles továbbítani a minisztérium felé. Továbbá a részben vagy egészben politikai témájú napilapok esetében 10000 , a ritkábban megjelenő, szintén politikai újságoknál 5000 forint kauciót kellett letétbe helyezni, amely a sajtóvétségek miatt kirótt bírságok fedezeteként szolgált. ${ }^{23}$ A törvény egyértelműen kijelöli a felelősség kereteit is: ha egy megjelent cikk tartalmáért a szerzőt nincs lehetőség elmarasztalni, úgy a tulajdonos, a kiadó vagy a szerkesztő számíthat büntetésre. ${ }^{24}$ Miután a sajtóperben kirótt büntetést levonták, a kauciót ki kellett egészíteni az eredeti összegre, amelyet az alapító visszakapott, ha a lap megszünt. ${ }^{25}$ A IV. fejezet a nyomdák müködését és a lapterjesztői tevékenységet szabályozza: a nyomdaalapítást a belügyminisztériumhoz történő bejelentéshez, illetve szintén kaució - a fővárosban 4000, más helyen 2000 forint - letételéhez köti; ezen kívül rendelkezik köteles példányok beszolgáltatásáról is. Mindemellett a törvény engedélyezi, hogy a nyomdák termékeiket szabadon terjeszthessék, a házaló és zugárusítást azonban megtiltja. ${ }^{26}$

A sajtótörvényt 1848. április 11-én hirdették ki, miután az uralkodó is szentesítette. A törvényszöveg több területet tartósan rendezetlenül hagyott, amely újabb vitás kérdéseket vetett fel: ilyen volt például, hogy vajon érvényesek-e a paragrafusok a litográfiai eljárással készült, nem a közvéleménynek szánt, a hírújságok részére friss információkat szállító, ún. 'kőnyomatos' lapokra? „Mindezen könyomatos vagy bár betünyomda által elöállitott tudósító lapoknál a közzététel, publicatio, vagyis a nagy nyilvánosság elé bocsátás hiányozván, azok közleményei csak mint a nagyobb lapokhoz küldött $s$ kézirat gyanánt szolgáló magántudósitások és még kiadatlan közlemények jöhetnek szóba és így önmagukban véve nyomtatványoknak nem tekinthetök" - írja Kenedi Géza ${ }^{27}$ a múlt század fordulóján a magyar sajtójogot taglaló munkájában, amely hosszas és szakszerü, konkrét jogesetekkel alátámasztott értelmezést is tartalmaz az 1848:XVIII. törvénycikk kapcsán. ${ }^{28}$

\footnotetext{
22 1848:XVIII. tc. 17-29.§

23 Székely 1997. 22.

${ }^{24}$ 1848:XVIII. tc. 30-36.§

${ }^{25}$ Buzinkay 2008. 61.

${ }^{26}$ 1848:XVIII. tc. $37-45 . \S$

${ }^{27}$ Kenedi Géza sajtóperekre szakosodott ügyvéd, emellett tekintélyes újságíró és 1881-től lapszerkesztő a Pesti Hírlapnál, valamint $A z$ Ujság c. napilap főmunkatársa; később munkapárti országgyülési képviselő, az 1914-es sajtótörvény (1914: XIV. tc.) előkészítő munkálatainak aktív résztvevője. (Buzinkay 2012. 283., Voit 2000. 499.)

${ }^{28}$ Kenedi 1903. 60-61.
} 
A radikálisok oldaláról a sajtótörvény több pontját éles bírálat érte - például a nagy összegü kauciók miatt -, de tény, hogy minden hibája ellenére olyan szabályozás született, amely „a feudális rendszer gyakorlatától alapvetően különbözött, és amely mégis igen lényeges fordulatot hozott". ${ }^{29}$ A törvény hiányosságait végrehajtási rendelettel igyekeztek orvosolni, amely szerint például a sajtóvétségekben eljáró esküdtszékeket nem törvényhatóságok szerint, hanem a királyi és a kerületi táblákon kellett felállítani. Az esküdtszékek ezután Pesten, Kőszegen, Nagyszombaton, Debrecenben és Eperjesen müködtek, illetve 1871-től Marosvásárhelyen. Az intézkedést bírálták a nemzetiségek, hiszen előfordulhatott, hogy az általuk kiadott sajtóorgánumok peres ügyeit is magyar többségü területen tárgyalták, így az esküdtszékekben számos esetben a magyar akarat érvényesült. ${ }^{30}$

\subsubsection{A szabad sajtóviszonyokat megteremtő egyéb intézkedések}

A hazai szabad sajtó fellendülését jelentősen befolyásolta az ún. kolportázs bevezetése: az önkényuralom időszakában a lapokhoz hozzájutni csak előfizetés útján volt lehetséges, majd az 1867. június 26-án kiadott új szabályozás (1713/R. sz. belügyminiszteri rendelet) a törvényhatóságokat felhatalmazta, hogy a helyi rendőrségnek való előzetes bemutatást követően területükön engedélyezzék a lapok szabad, utcai árusítását. Ez a postán kívüli hírlapszállítás megszervezését vonta maga után, s számos kiadó maga intézte az újságok terjesztését, lapkihordó munkatársak alkalmazásával. ${ }^{31}$ A kolportázs engedélyezését követően trafikok, könyvkereskedések, vidéken pedig elsősorban szatócsboltok és füszerüzletek foglalkoztak hírlapárusítással, de az olvasók nagy része ezután is jó ideig még előfizetés útján vásárolta a sajtótermékeket, hasonlóan az olvasókörökhöz, kávéházakhoz, klubokhoz vagy egyesületekhez. Utóbbiak miatt egy adott lap tényleges olvasottsága nehezen megbecsülhető, de minden bizonnyal sokszorosa volt a példányszámnak. ${ }^{32}$

Szintén jelentős változást hozott a hírlapi bélyeg eltörlése. ${ }^{33}$ Ez egyfajta vállalkozói adó volt a Bach-korszak idején, viszont az 1870. január 1-jétől hatályos rendelkezésnek

\footnotetext{
${ }^{29}$ Kosáry 1985a. 50.

${ }^{30}$ Magyar sajtójogi szabályok 1867-1914 - Ministeri elöterjesztés 1867. febr. 25-röl, a sajtóügyben, az 1848: 18. t. cz. életbeléptetése, az esküdtszékeknek Pesten, Debreczenben, Eperjesen, Nagyszombatban és Köszegen felállitása, s a sajtó ügyekben a királyi, illetőleg a kerületi táblák biráskodása tárgyában (forrás: http://mtmi.hu/dokumentum/913/Magyar_sajtojogi_szabalyok_18671914.pdf. letöltés: 2017. július 5.)

${ }^{31}$ Buzinkay 1997.

${ }^{32}$ Kókay 1994. 143-144.

33 1869:XXIII. tc.
} 
köszönhetően már könyvárusok is szabadon terjeszthették a sajtótermékeket. ${ }^{34}$ Mindezt kiegészítette az iparszabadság törvényi megteremtése: az 1872:VIII. tc. a felvilágosult polgárság érdekében, a nagyipar megteremtése céljából született, s a korlátlan iparszabadság elvéből indult ki. ${ }^{35}$ „A magyar korona területén minden nagykoru vagy nagykorunak nyilvánitott egyén, nemre való tekintet nélkül, ezen törvény korlátai közt, bármely iparágat, ideértve a kereskedést is, bárhol, önállólag és szabadon gyakorolhat" ${ }^{36}$ A törvény emellett kimondta a céhek megszűnését, az ipartestületek létrehozásának lehetőségét, s nem tett különbséget az egyes ipari tevékenységek között, tehát minden ipar űzése szabaddá vált. ${ }^{37}$ Az iparszabadság deklarálásának eredményeképpen már több mint háromszáz nyomda müködött a fővárosban az 1880-as évek elején, majd néhány esztendővel később kialakult a budapesti sajtócentrum a Nagykörút és a Rákóczi út kereszteződésének környékén. ${ }^{38}$

A korszak legjelentősebb lapkiadó nyomdavállalata az Emich Gusztáv által 1868 nyarán alapított Athenaeum Részvénytársaság, amely - többek között - A Hont, a Nemzetet, a Pesti Naplót, a Borsszem Jankót és a Budapesti Közlönyt is sokszorosította. ${ }^{39}$ A cég nem köteleződött el egyik párt vagy eszme mellett sem, viszont a szélsőséges irányzatoknak nem adott teret. ${ }^{40}$ Meghatározó volt még a Pester Lloyd Társulat, a Pesti Könyvnyomda Részvénytársaság, a Franklin Társulat, a Pallas Részvénytársaság vagy a Légrády Testvérek. Fejlödött a technika is: a síknyomtató gépeket követően kezdtek elterjedni a rotációs gépek az 1870-es években, eleinte külföldről importálták őket. A kézi szedést a századforduló után felváltották a szedőgépek. A betükészletek eleinte szintén külföldröl érkeztek, egy idő után azonban e téren sem kényszerült az ország behozatalra: 1890-ben megnyitotta kapuit az Első Magyar Betüöntöde Részvénytársaság. ${ }^{41}$ A külföldi tőkéből létrehozott vállalat sokáig Délkelet-Európa egyetlen ilyen jellegü gyára volt, és több mint négyszáz hazai nyomda betüszükségletét elégítette ki. ${ }^{42}$ Mindeközben nem csak a fövárosi, hanem a vidéki nyomdák száma is nagymértékben megnövekedett. 1867-ben a fővároson kívül százhat nyomdaipari vállalkozás müködött, a századfordulón ez a szám meghaladta az ötszázat. Szegeden például az 1900-as évek elején már tizenkét nyomdát találunk, Hódmezővásárhelyen ötöt. ${ }^{43}$

\footnotetext{
${ }^{34}$ Buzinkay 1993. 63.

${ }^{35}$ Kollega 1997. 572.

36 1872:VIII. tc. $1 . \S$

${ }^{37}$ Kollega 1997. 572.

${ }^{38}$ Dezsényi 1954. 158.

${ }^{39}$ Végh 1976. 61-63.

${ }^{40}$ Szabó 1918.

${ }^{41}$ Végh 1976. 68., Buzinkay 1993. 64.

${ }^{42}$ Nagy 1992. 25-31.

${ }^{43}$ Kőszegfalvi 1991. 6.
} 
Végül, meg kell még említenünk az igazságügyi miniszter 1871. július 1-jén kiadott (1769/1871 IM) rendeletét, amely a sajtóperben elmarasztalt egyének fogva tartásának körülményeit szabályozta. Az intézkedés megkülönböztetett bánásmódra kötelezte a büntetésvégrehajtási intézményeket a sajtóvétség miatt börtönbe vonuló személyekkel kapcsolatban: az illető saját, bútorozott cellát kapott, személyes tárgyait magánál tarthatta, és a személyzetnek kötelessége volt illemtudóan viselkedni vele szemben. ${ }^{44}$ Utóbbira jó példa a több lapnál is publikáló Ádám Imre esete, akit 1914 januárjában „sajtó útján elkövetett rágalmazás vétsége" miatt tíznapi fogházbüntetésre ítélték, amelyet a szabadkai börtönben töltött le. „Sajtóvétség, gondnok ur. Tessék a szerkesztő urnak külön szobát adni, könyveket, hogy kellemesen gondoljon vissza a mi vendégszeretetünkre..." - idézi későbbi cikkében Ádám Imre a föügyészt, aki bekísérte őt a fogházba. ${ }^{45}$

A fenti intézkedések eredményeképpen kialakult a sajtószabályozás dualizmus kori rendszere, amely lényegében az első világháború kitöréséig fennállt, meghatározva a korszak sajtóvállalkozásainak mindennapjait, és elindítva a magyar sajtó újabb virágkorát. Az új törvényi háttér védte a nyilvánosságot, ezzel pedig szabad teret engedett a kormánypárti és az ellenzéki lapok megjelenésének is. A hatalomnak - a sajtópereken kívül - így elsősorban pozitív sajtóirányítási eszközök maradtak a kezében, mint például a lapok szubvenciója, emellett ingyen példányok terjesztése a főispánok által, illetve a kaució és a hírlapi bélyeg állami átvállalása. ${ }^{46}$

\subsection{A magyar sajtó fellendülése a kiegyezés után}

Az 1867-es kiegyezés Ausztria és Magyarország között a magyar sajtó felvirágzásának időszaka, mind mennyiségi, mind minőségi értelemben - az 1800-as évek végére már közel ezer magyar, illetve nem magyar nyelvü lap jelent meg hazánkban. ${ }^{47} \mathrm{~A}$ nagymértékü átalakulás eredményekképpen megszülettek a ma is meglévő hírlap- és folyóirat-irodalom uralkodó formái. ${ }^{48}$ A század közepétől megjelenő technikai, illetve a nagyléptékű gazdasági és társadalmi fejlődésnek köszönhetően a nyomtatott tömegtájékoztatás valódi iparággá nőtte ki magát, s beindult a hazai sajtó nagyüzemi, nagyvállalkozói, régiók feletti korszaka. ${ }^{49}$

\footnotetext{
${ }^{44}$ Buzinkay 1993. 63-64.

${ }^{45}$ Kanizsai Ujság, VII. évf. (1914) 3. sz. 2.

46 Döbör 2018. 357.

${ }^{47}$ Székely 1997. 22.

${ }^{48}$ Dezsényi 1954. 157.; Kosáry 1985b. 13.

${ }^{49}$ Kosáry 1985b. 14.
} 
A dualizmus kori sajtót alapvetően három nagy időszakra bonthatjuk: az első az úgynevezett „eszmehirdető” korszak, amelynek legfőbb jellegzetessége a kiegyezés megkötéséhez kapcsolódó anomáliák miatt a politikai sajtó megmerevedése. Az Ausztriával kötött történelmi megállapodást támogató és ellenző tábor szellemi vezéralakjai - például Kossuth Lajos, Deák Ferenc, Trefort Ágoston, Eötvös József, Irányi Dániel, Toldy István - az újságok lapjain igyekeztek hangot adni véleményüknek. A második az ún. „üzleties” korszak - az 1875-ös pártfúziótól az 1880-as évek elejéig -, amikor ugyan megmaradt a pártkötöttség a vezető lapoknál, viszont a kiadók, illetve szerkesztők egyre inkább üzleti vállalkozásnak kezdték tekinteni a lapkiadást. Publikálták valamennyi közismert személyiség írását, de a kevésbé híres szerző tollából származó cikkeket is szívesen fogadták, amennyiben az nagy érdeklődést válthatott ki, főként a tárca- és a levelezés-rovatban. A szerkesztők egyik fő célja volt, hogy újságírói tevékenységüknek köszönhetően országos hírnévre tegyenek szert, ezáltal lehetőséget biztosítsanak önmaguk számára a politikai felemelkedésre is. ${ }^{50}$ (Mint a későbbiekben látni fogjuk, jó példa lesz erre a szentesi Sima Ferenc, aki a helyi lapoknál kezdte újságíróként, majd néhány évvel később a 48-as ellenzék egyik meghatározó tagja, illetve országgyülési képviselő lett.) A harmadik korszak az 1880-as évek elejétől, derekától datálható, amelyet leginkább a tömegsajtó megindulása jellemez. Ekkor a nagyvállalkozói tőke, a piaci szemlélet véglegesen meghatározóvá vált a lapkiadásban. ${ }^{51}$

\subsubsection{A hír előtérbe kerülése, a tömegsajtó kialakulása}

Fontos változás volt a korszakban, hogy a korábbi, nevelő és politikai szempontból manipulációs célzatú, hosszabb eszmefuttatások mellett egyre inkább teret nyertek a rövid hírek a demokratizálódó közélet, illetve a rohamosan fejlődő gazdaság jeleként, illetve az írniolvasni tudók arányának növekedése is maga után vonta a nagyközönség fokozott információigényét nem csak a fövárosban, hanem vidéken is. ${ }^{52}$ A már említett eszmehirdető korszakot követően tehát a lapkiadók, illetve a szerkesztőségek egyre inkább felismerték,

\footnotetext{
${ }^{50}$ Kosáry 1985b. 17-19.

${ }^{51}$ Kosáry 1985b. 18-19.

${ }^{52}, A$ sajtótörténet egyik fontos jelensége az a vizuálisan is nyomon követhetö folyamat, amint a hosszú eszmefuttatások mellé benyomulnak a rövidebb híradások. Az értékek felmutatása, az értékelések elötérbe állitása helyett fontosabbá válnak a tények és az azokat közvetitö hírek. A hír mind a demokratizálódó politikai élet, mind a fellendülö ipar és kereskedelem, az üzlet nélkülözhetetlen kíséröje, de nem »objektivitása « állitható szembe az értékelö-nevelö újságirás »szubjektivitásával«. A véleménynyilvánitás közvetlensége helyett minél több információ összegyüjtése válik fö céllá, s a nevelésböl orientálás lesz, a kimondásból a válogatásba visszahúzódó, rafináltabb szerkesztés.” (Kókay 1994. 127-128.)
} 
hogy a kiegyezés megkötése körüli viták lecsendesedésével - s különösen az 1875-ös pártfúziót követően - a sajtónak már elsősorban nem a politikai pártokra kell koncentrálnia, a cél e helyett az egyre szélesedő olvasóközönség kíváncsiságának kielégítése kell, hogy legyen, amely kíváncsiság pedig elsődlegesen az országban, valamint a nagyvilágban történt aktuális eseményekre irányult. ${ }^{53}$

Mindez azonban nem kizárólag magyar sajátosság, ahogyan Lipták Dorottya is rámutat: „Ez összhangban van az általános európai jelenséggel, miszerint a közönség fokozatosan elpártol az egymással foglalkozó, szük pártpolitikai érdekeket képviselö és ez által kissé egyhangúvá és szárazzá váló lapoktól, és előnyben részesiti a szinesebb, sokoldalúbb, üzleti szempontokat szem elött tartó, az olvasó igényeire is tekintettel lévö liberális sajtót. Ugyanakkor a magyar társadalom szerkezetéböl és a politikai felépitmény jellegéböl adódóan ezek a lapok sohasem válnak a szó igazi értelmében pártok felettivé. Lényeges különbség azonban az elözö korszakhoz képest, hogy már nem a parlamenti politikáról szóló informálást tekintik elsődleges feladatuknak, hanem a »depolitizáltan politizáló « és a szórakozni vágyó olvasóközönség kiszolgálását."54

Mindez véget vetett a politikai pártsajtó közel fél évszázados uralmának, a vezető szerepet az üzleti érdekeken alapuló, független tömegsajtó vette át, amelynek fő célja ,az emberek minél nagyobb körének igényeire figyelni s ezért óvakodni a pártelfogultságoktól." 55 Az 1900-as évek elejére pedig ,már teljes mértékben kifejlődött az üzleti sajtó túlhajtása, a szenzációsajtó”. ${ }^{56}$ A szemléletbeli változásról Lakatos Éva a következőképpen fogalmaz: „A lapkiadás: üzlet. Ez azt jelentette, hogy hogy újságot, folyóiratot stb. a kiadó elsősorban azért állitott elő, mert ezáltal pénzre, »haszonra« kívánt szert tenni, méghozzá minél többre. [...] A magasabb példányszámért folyó harc ilyenformán a tőkés lapkiadás kulcskérdése. Ezen állt vagy bukott az egyes vállalkozások felvirágzása vagy megszünése." 57

A megváltozott fogyasztói igények kielégítésére hamarosan kialakult hazánkban a szervezett, intézményesített hírszolgálat. A külföldi híreket java részben Bécsből szerezték be, míg a belföldi hírekre több vállalkozás is indult. Ilyen volt a Futtaky Gyula által 1875-ben alapított Budapester Correspondenz, illetve a Budapesti Tudósitó - utóbbi már magyar nyelven közölt friss híreket. A nagyvilágban történt eseményekröl a nevesebb külföldi lapok jelentettek hírforrást - pl. az osztrák Wiener Zeitung, az angol Daily News vagy a francia

\footnotetext{
${ }^{53}$ Dezsényi 1954. 160.

${ }^{54}$ Lipták 2002. 36.

${ }^{55}$ Kókay 1994. 139.

${ }^{56}$ Kókay 1994. 140.

${ }^{57}$ Lakatos 2004. 16.
} 
Liberté - is, amelyek számos esetben élénk sajtóvitát folytattak a hazai orgánumokkal. Ilyen, hosszúra nyúlt vita zajlott például a bécsi és a pesti újságok között a kiegyezés kérdésében. ${ }^{58}$

A különféle rendeleteket, tisztviselői kinevezéseket, állami közleményeket a Budapesti Közlöny hivatalos lap tartalmazta ${ }^{59}$ emellett fontos megemlíteni az 1869-től kiadott, szintén kőnyomatos Országgyülési Értesitoott, a bírósági újdonságokat közlő Magyar Híradót és a rendőrségi híreket ismertető Gyors Futárt. Budapest központi szerepét, az országos politika prioritását jelezte az is, hogy a vidéki közélet területére nem alakult szakosodott hírszolgálat, amely megmaradt az önkéntes levelezők által beküldött tudósítások szintjén. Jelentős szerepet töltött be a tájékoztatásban a kormány érdekeit képviselő miniszterelnökségi sajtóosztály, a rendszeres hírszolgáltatás céljából pedig 1881-ben megalakult a Magyar Távirati Iroda, mely 1918-ig magáncégként müködött. ${ }^{60}$ Emellett a lapok egymástól is átvettek érdekesebb híreket, gyakran a forrás megjelölése nélkül. ${ }^{61}$

Ami az egyes lapok számát illeti: a magyar főváros sajtóviszonyai a kiegyezést követően felvették a versenyt a nyugat-európai országokkal, sőt néhány tekintetben meg is haladták őket. Az 1870-es években Pesten több mint másfél tucat magyar nyelvü politikai napilap jelent meg, valamint még három-négy vidéken - ez több, mint amennyi Bécsben vagy akár Londonban -, emellett országosan harmincnál több politikai hetilapot adtak ki. A példányszámokban azonban már jelentős elmaradottság mutatkozik: a közéleti tematikájú, magyar nyelvü sajtótermékeknek legfeljebb tízezer fős előfizetői közönsége volt ebben az időszakban - a párizsi Figaro önmagában négyszer ekkora olvasótábort tudhatott magáénak. A magyar lapok elterjedését nehezítette a kezdetben csekély érdeklődés a friss hírek iránt, illetve a hazánkban publikált német nyelvủ újságok dominanciája, ${ }^{62}$ amely majd csak az 1870es évek végén kezdett átfordulni a magyar nyelvü sajtóorgánumok javára. ${ }^{63}$

A példányszámok tekintetében a legtöbb esetben csak találgatásokra hagyatkozhatunk, hiszen minden lap féltve örzött üzleti titokként kezelte a kérdést. A Hon büszkén állította, hogy ő rendelkezik a legtöbb előfizetővel: 1873 elején körülbelül 4500 példányban jelent meg; a Pesti Naplóból ugyanekkor 3000-et nyomtattak. ${ }^{64}$ A legtöbb közéleti lap azonban csak

\footnotetext{
${ }^{58}$ Kosáry 1985b. 36.

59 A Budapesti Közlönynek voltak nem hivatalos oldalai is: a külpolitikai rovat például a legmagasabb színvonalúnak számított a korban, míg a szintén igényes irodalmi rovatba rendszeresen publikált Arany László. (Dezsényi 1954. 165.)

${ }^{60}$ Buzinkay 1993. 66.

${ }^{61}$ Kosáry 1985b. 36.

${ }^{62}$ A német polgárság túlsúlyának köszönhetően, a kiegyezés után a külföldi, elsősorban a bécsi, valamint a hazai német nyelvü sajtóorgánumok kétszer-háromszor népszerübbek voltak a magyar nyelvü lapoknál. A vezető német nyelvü újság a Pester Lloyd volt, a kormány félhivatalos lapja. (Ujvári 2014. 37.)

${ }^{63}$ Kosáry 1985b. 36.

${ }^{64}$ Balogh 2007. 82.
} 
néhány száz példányban jelent meg, amely már nem volt elég a nyereséges müködéshez. Kiugróan magas példányszámot csupán a jelentősebb hírlapi polémiák voltak képesek generálni - például Kossuth Lajos nyílt leveleiről szóló vita -, de csak ideiglenesen. ${ }^{65} \mathrm{Az}$ 1870-es és 1880-as években - számos orgánum esetében - fokozatosan emelkedtek a példányszámok, ${ }^{66}$ hiszen a potenciális újságolvasók száma 1869 és 1890 között közel megduplázódott, így az újságolvasásra való igény növekedett. ${ }^{67}$ Az olvasás viszont még ekkor sem tekinthető a tömegkommunikáció kizárólagos eszközének, mert továbbra is szokás volt az egyes hírlapok hangos felolvasása az olvasókörökben, klubokban, ${ }^{68}$ így az információáramlás jóval szélesebb körü volt, mint amit az egyes példányszámok mutatnak. ${ }^{69}$

\subsubsection{Az újságírói hivatás kialakulása}

Szintén a kiegyezést követően alakult ki az újságírói pálya, mint elsődleges hivatás: a dualizmus időszakában megsokszorozódott a főállású újságírók száma. A politikai lapokat elsősorban az adott újságot támogató párt táborába tartozó országgyülési képviselők szerkesztették, akik közéleti hírnevüket föként a szerkesztői munkájuknak köszönhették. ${ }^{70} \mathrm{~A}$ legismertebb példák erre: Csávolszky Lajos (Egyetértés), Urváry Lajos (Századunk), Csernátony Lajos (Ellenőr), Böszörményi László, illetve Helfy Ignác (Magyar Ujság), P. Szathmáry Károly (Hazánk), Jókai Mór (A Hon) vagy Kemény Zsigmond (Pesti Napló). ${ }^{71}$ Emellett az egyes pártok vezetői szintén rendszeresen írtak különféle eszmefuttatásokat az újságokba, míg az irodalmi, a divat- és az ifjúsági lapoknál leginkább szépírók, költők neveivel találkozunk ${ }^{72}$ (pl. Jókai Mór, Mikszáth Kálmán, Vajda János); a közmüvelődési,

\footnotetext{
${ }^{65}$ Kosáry 1985b. 38-39.

${ }^{66} \mathrm{Az}$ 1880-as évek végén már több napilap jelent meg a magyar fővárosban, mint Bécsben vagy Londonban. (Nemeskürty 2002. 131.)

67, „A városi élet mellett a közlekedés és a hirtovábbitás gyors fejlődése is fokozza az újságok iránti keresletet. Valamikor - a század közepén, vagy akár a hetvenes években - legfeljebb arra voltak kíváncsiak az emberek, hogy mi történik saját házuk táján, legszükebb környezetükben és a közvetlen szomszédságban. A kilencvenes években viszont már távoli országok, söt kontinensek is közelebb kerültek, mindennapi viták, beszélgetések témájává válhattak." (Dersi 1973. 85-86.)

${ }^{68} \mathrm{Az}$ első olvasókörök az 1700-as évek végén jöttek létre városokban, a budait 1792-ben alapította Berzeviczy Gergely. Vidéken is lassan követték a példát, 1878-ban már 433 ilyen jellegű egylet müködött az országban. Az első kaszinók és klubok alapítói jellemzően a nemesek voltak, amelyhez mintául Széchenyi Nemzeti Kaszinója szolgált. (Kósa 2002. 194-196.)

${ }^{69}$ Kosáry 1985b. 38.

${ }^{70}$ Buzinkay 2008. 68.

${ }^{71}$ Buzinkay 2016. 188.

${ }_{72}, A z$ 1840- es évektöl kezdve több mint egy évszázadon át a magyar sajtó egy részének kiemelkedö színvonalát és nyelvi igényességét az biztositotta, hogy a szépírók kereseti forrása és napi írási gyakorlata volt a publicisztika, elsősorban a tárcaírás.” (Buzinkay 2010. 13.)
} 
képes családi, valamint az élclapokat pedig már nagyrészt főfoglalkozású újságírók szerkesztették, illetve írták. ${ }^{73}$ A politikai lapoknál dolgozó újságírógárda azonban nem volt egységes csoport, csak a pártoktól függő, egymással ellenségeskedő klikkek rendszere. Az újságírást a legtöbben csupán átmeneti foglalkozásnak tekintették, amely ugródeszkát jelenthetett a közélet egy másik területe - például a politika vagy a közigazgatás - irányába. ${ }^{74}$

Az 1870-es évek végére egyre nagyobb igény mutatkozott arra, hogy a rohamosan gyarapodó újságírógárda, ${ }^{75}$ illetve a sajtónál egyéb feladatokat ellátó munkatársak érdekvédelmi szervezetekbe tömörüljenek. 1880-ban megalakult a Hírlapírók Egyesülete, amelynek elnöki posztját Jókai Mór töltötte be, 1881-ben megkezdte müködését a Magyarországi Hírlapírók Nyugdíjintézete, majd 1896-tól a nem fővárosi publicistákat tömörítő Vidéki Hírlapírók Országos Szövetsége Kulinyi Zsigmond vezetésével. ${ }^{76}$

\subsubsection{A lapok belső struktúrája, szerkesztési módszerek}

A korabeli hírlapok többnyire egyívnyi terjedelemben és félíves formátumban, tehát négy oldalon jelentek meg. ${ }^{77} \mathrm{Az}$ elsőn általában a vezércikk található, amely ekkoriban már csak nagyon ritkán takart eszmeközlő elmélkedést, inkább valamilyen fajsúlyosabb hírt, illetve az adott olvasóközönség számára fontos ügyet - például Szentesen a vasútépítés kérdéskörét feldolgozó értekezést jelentett. A vezércikkek a híranyag egyöntetüsége miatt fontos, gyakorlatilag egyedüli mutatói az adott sajtóorgánum eszmei irányultságának, pártállásának. Hangnemük a kiegyezés megszilárdulásával egyre durvábbá vált, mert az egyre élesedő parlamenti viták stílusa rátelepedett a hírlapokra is. Szaporodtak a gyalázkodó írások a hasábokon, amelyet csak fokozott az akkor még általános hírlapi névtelenség is: a közismert politikusok cikkeit nem számítva a legtöbb újság legfeljebb jellel látta el a publicisztikákat. Az esküdtszék előtt lefolytatott sajtóper helyett - a tilalom ellenére - gyakran a „lovagias” elintézési módot választották: a párbajt. Vett így erkölcsi elégtételt Jókai Mór, Pulszky Ferenc, Rákosi Jenő - vagy akár a szentesi Sima Ferenc. ${ }^{78}$ A sértő vezércikkek mellett az

\footnotetext{
${ }^{73}$ Buzinkay 1993. 66.

74 Kosáry 1985b. 42-43.

${ }^{75}$ A kiegyezés megkötésének évében 80 magyar hírlap és folyóirat jelent meg hazánkban, 1894-ben már 735. A nyilvántartott, főfoglalkozású újságírók száma 1857-ben 79 volt, 1881-ben már 288, a századforduló évében pedig 579. (Buzinkay 2009. 19.)

${ }^{76}$ Kókay 1994. 150.

${ }^{77}$ Kosáry 1985b. 32.

${ }^{78}$ Kosáry 1985b. 41-42.
} 
ilyen jellegü vádaskodások másik színtere a „nyílt tér” rovat volt, ahol - külön díjazás ellenében - olvasói leveleket közöltek a lapok, de azok tartalmáért nem vállaltak felelösséget.

Ezután következett esetleg egy második vezércikk, valamint a tárcarovat - utóbbi szépirodalmi témával, valamilyen verssel vagy prózai munkával, illetve azok részleteivel. A második és harmadik oldalon döntő többségében aktuális híreket - vagy azokat feldolgozó kisebb publicisztikákat, politikai leveleket - találunk. A híreket általában külön rovatba csoportosították attól függően, hogy bel- vagy külföldi eseményről volt szó, bár ez a rovatszerkezet nem egységes, akár egy lapon belül is történhetett nem egy esetben változás.

A korszakra jellemző, hogy a különféle hírek nagy része különösebb rostálás nélkül került a lapokba. Az egyes orgánumok leginkább hírforrásokat használtak, önálló módszerrel - pl. interjú, tudósítás - ritkábban találkozunk, s ha igen, sokszor az sem professzionális módon történt, hanem például olvasói levelek közlésével. ${ }^{79} \mathrm{Az}$ országos lapokban tekintélyes részt foglaltak el a parlamenti tudósítások, míg vidéki társaik a helyi közgyüléseknek és a megyegyüléseknek szenteltek nagy figyelmet. Emellett állandónak tekinthető a közgazdasági rovat, amely aktuális tőzsdei hírekről, gabonajegyzési árakról stb. tudósított.

Az utolsó oldal többnyire hirdetéseket tartalmazott. (Anyagtorlódás esetén előfordult, hogy félíves melléklettel bővült a lap, amely a vidéki hírlapoknál szintén sok helyütt - például Szentesen is - rendszeressé vált.) A figyelemfelkeltő grafikák a tárgyalt időszakban kevésbé terjedtek el a politikai lapokban, mivel ekkor még a szövegnek tulajdonítottak elsődleges fontosságot, sőt általános vélekedés volt, hogy a képek elvonják a figyelmet az igazi mondanivalóról, vagyis a szavakról, tehát „komoly” közéleti lap nem tartalmazhat ilyesmit. ${ }^{80}$ A szerzői jogokkal nem törődve, egészen 1884-ig a képes újságok fametszetes illusztrációit főként a külföldi sajtóorgánumokból vették át, ezután hazánk is aláírta a nemzetközi szerzői jogi egyezményt. Az illusztrált lapoknál ekkor technikai értelemben ugrásszerü fejlődés következett be. ${ }^{81} \mathrm{Az}$ 1880-as években megjelenő sajtófotók is kezdetben csupán a képes családi lapokat gazdagították, a politikai sajtóban csak a következő évtizedben, illetve a századforduló után kezdtek meghonosodni, széles körü alkalmazásuk pedig már a XX. századra tehető. ${ }^{82}$ A képi illusztrációk fontosságát egyre inkább felismerték a szerkesztőségek, hiszen azok az olvasni nem tudók számára is vonzóvá tették az adott lapot. ${ }^{83}$

\footnotetext{
${ }^{79}$ Kosáry 1985b. 40-42.

80 Tasnádi 2014. 35.

${ }^{81}$ Buzinkay 1993. 64-65.

82 Tasnádi 2014. 35-47.

${ }^{83}$ Révész 2012. 10.
} 


\subsubsection{Hirdetések, bevételek - a sajtó, mint üzlet}

A modern sajtóban a piaci életképességhez nem elegendő az egyes példányszámok eladásából befolyt összeg: a tartós fennmaradáshoz alapvető feltétel hirdetések közzététele. Az 1850-es évektől már rendszeresen találkozhatunk hirdetésekkel a nyomtatott hazai sajtóorgánumokban, de ekkor még viszonylag kis számban, ráadásul ezek többségében az adott lap kiadója vagy sokszorosítója egyéb üzleti vállalkozásainak népszerüsítését, ${ }^{84}$ valamint a különböző állami szervek hivatalos közleményeit jelentették. ${ }^{85}$

A hirdetések egyik típusa az ún. átalányhirdetés volt: ezzel a formával azon intézmények éltek, amelyeknek kötelességük volt rendszeresen értesíteniük a nagyközönséget (pl. a bankházak a mérlegkimutatásokról). Ez mindkét fél számára előnyös volt, hiszen a hirdető kedvezményesen jelenhetett meg a lapban, míg a kiadónak állandó bevételt jelentett. Az állami intézmények nem fizethettek a közzétett hirdetményekért, viszont megjelentetésük vonzóbbá tette az újságot az olvasók számára. A másik típusú hirdetési formát az egyedi sajtóhirdetések jelentették. A nagyobb lapok saját ügynököt alkalmaztak hirdetésgyüjtés céljából, a többiek számára pedig az erre szakosodott vállalkozások biztosították a hirdetőket. A vidéki sajtótermékek esetében a hirdetések nagy részét a helyi vállalkozások tették ki. ${ }^{86} \mathrm{Ha}$ a sajtót mint üzleti vállalkozást vizsgáljuk, elmondható, hogy a legtöbb lap részvénytársaság vagy társas tulajdon formában müködött, a förészvényesek, illetve a kiadótulajdonosok gyakran maguk a szerkesztők voltak. Mivel a befektetést az 1870-es években még elsősorban pártpolitikai érdekeknek rendelték alá, a részvényeket nem jegyezték be a tőzsdén. A jövedelmet az előfizetési díjak és a hirdetésekből befolyt összeg jelentették, viszont a legtöbb esetben ez nem volt elég a nyereséges müködéshez. Számos kevésbé népszerü, kormánypárti lap például állami szubvencióra szorult, hogy fenn tudjon maradni. A szerkesztőségi iroda költségeit a kiadó finanszírozta, emellett általában egy meghatározott összeget átadott a felelős szerkesztőnek, aki azt a munkatársak között elosztotta bérköltség címén. ${ }^{87}$

Összességében tehát elmondható, hogy a tárgyalt időszakban a sajtó - kivéve néhány országosan terjesztett fővárosi lapot - kevésbé számított jövedelmező vállalkozásnak. Mindez az 1880-as évektől, a tömegsajtó fokozatos elterjedésének köszönhetően megváltozott. ${ }^{88}$

\footnotetext{
${ }^{84}$ Szemléletes példa lehet erre a délvidéki Kanizsai Ujság tulajdonosa, Bruck P. Pál, aki az általa kiadott és szerkesztett lap hirdetési rovatának jelentős részét - az esetek nagy részében legalább ötven százalékát - saját egyéb vállalkozásainak népszerüsítésére használta fel, a külső hirdetők rovására. (Pető 2014. 32.)

${ }^{85}$ Kókay 1994. 141.

${ }^{86}$ Kókay 1994. 142-143.

${ }^{87}$ Kosáry 1985b. 31.

${ }^{88}$ Kosáry 1985b. 39.
} 


\subsubsection{A legfontosabb országos lapok (1867-1883)}

Bár a politikai sajtón kívüli laptípusok döntő többsége a kiegyezés után honosodott meg Magyarországon, ${ }^{89}$ az 1867 utáni első tíz évet a pártpolitikai lapok uralma jellemezte, amelyek legszínvonalasabbjai a kormánypárti lapok voltak. Kiemelkedett közülük a Pesti Napló, amely magáénak tudhatta a politikai és írástudó elit jelentős részét. 1868 őszétől már esti kiadása is megjelent Rákosi Jenő szerkesztésében. A Napló az 1875-ös pártfúzió után függetlenebb - később mérsékelt ellenzéki - hangvételt ütött meg, míg a Jókai vezette, eredetileg balközép irányultságú $A$ Hon a kormánypárt szócsöve lett. ${ }^{90}$ Utóbbit következetes alapelvei, illetve az újság nagy mérete miatt „,a magyar Times”-ként emlegették a korban. ${ }^{91}$

A Reform címủ napilap a Lónyay Menyhért pénzügyminiszter köréhez tartozó, tehetős fővárosi polgárok anyagi segítségével indult útjára 1870-ben, Ráth Mór kiadásában és Rákosi Jenő szerkesztésében. ${ }^{92}$ A szerkesztő azt vallotta, hogy a legkisebb hírt is olyan igényesen kell megfogalmazni, mintha vezércikk volna. ${ }^{93}$, A napisajtó játszsza azt a szerepet a modern világ szükségeiben, a melyet a természet rendjében a nap. [...] A nemzeti összeségnek öre, tényezője, irányitója, ébresztő harsonája, biztató szava, ereje, nyugalma és bátorsága a sajtó" - fogalmazott Rákosi. ${ }^{94}$ Az újság szakított tehát a korabeli pártlapok egyoldalúságával, és a politikai hírek mellett igyekezett alaposabban foglalkozni társadalmi problémákkal, új kulturális jelenségekkel is. ${ }^{95}$ Rákosi 1881-ben megalapította a Budapesti Hírlapot, amelynek négy évtizeden át főszerkesztője és állandó cikkírója volt, ${ }^{96} 1896$ után pedig a felsőház örökös tagja lett. ${ }^{97}$ A Reform 1875-ben beolvadt a Pesti Naplóba, munkatársainak jelentős része pedig a Toldy István által szerkesztett Nemzeti Hírlapnál (1875-1879) folytatta. ${ }^{98}$ Utóbbi szerkesztését 1878 nyarán Márkus István vette át, aki az újság megszünéséig, 1879 júniusáig irányította a szerkesztőséget kormánypárti szellemben. ${ }^{99}$ A kormánypárti hetilapok közül a

\footnotetext{
${ }^{89}$ Buzinkay 2008. 79.

${ }^{90}$ Kókay 1994. 129.

${ }^{91}$ Buzinkay 2008. 73.

92 Voit 2000. 519.

${ }^{93}$ Vitéz 2003. 92.

94 Sajó 1902. 2.

${ }^{95}$ Szántó 1973. 69.

${ }^{96}$ Rákosi Jenő közéleti tevékenységét nem csak a sajtóban fejtette ki: 1875-ben megalapította és 1881-ig vezette a főváros második magyar nyelvü kőszínházát, a Népszínházat, hogy segítse az akkor felerészben még német nyelvü főváros elmagyarosodását. Emellett jelentős volt dráma- és népszínmü-írói, valamint müfordítói tevékenysége is. (http://mek.oszk.hu/01100/01149/html/rakosij.htm, letöltés: 2017. július 12.; illetve http://mtdaportal.extra.hu/books/sule_antal_rakosi_jeno_elete_es_muvei.pdf, letöltés: 2017.július 14.)

${ }^{97}$ Nemeskürty 2002. 133.

${ }^{98}$ Kókay 1994. 129-130.

${ }^{99}$ Vasárnapi Ujság, XXVII. évf. (1880) 35. sz. 1.
} 
legjelentősebb volt az 1874-től Mikszáth Kálmán által szerkesztett Magyar Néplap, a Heti Posta, illetve a Hirmondó. ${ }^{100}$

A balközép orgánumok közül a legjelentősebb A Honból kivált, a szabadságharc bukása után párizsi, majd londoni emigrációból hazatérő Csernátony Lajos által alapított Ellenőr volt, amely Tisza Kálmán nézeteinek hüséges követőjének bizonyult. ${ }^{101}$ Csernátony fő célja a politikai manipuláció volt, a sértegető, fenyegető hangnemmel pedig a hazai ellenzéki újságírói stílust tekintve hagyományt teremtett. ${ }^{102}$ Megemlítendő még a Jókai által szerkesztett Igazmondó, valamint a Mocsáry Lajos nevéhez köthető Demokrata Dobos. ${ }^{103}$

A kiegyezést elutasító, Kossuth feltétlen híveként fellépő szélsőbal hívei számos sajtótermék közül válogathattak az 1870-es években. Meghatározó volt a Magyar Ujság, amelyet 1867 tavaszától Böszörményi László országgyülési képviselő szerkesztett, és állandó munkatársaként tudhatta maga mellett Vajda Jánost, illetve Madarász Józsefet. A szerkesztőség rendszeres kapcsolatot tartott fenn az emigrációban élő Kossuth Lajossal, akinek a lap több nyílt levelét leközölte, így soha nem látott népszerüségre tett szert. ${ }^{104}$ Mikor az újság már több tízezres példányszámot produkált, a hatalom Böszörményit perbe fogta alkotmányellenes izgatás vádjával, és fogházbüntetésre ítélték. ${ }^{105}$

A 48-as ellenzék másik vonulatát a Madarász József által irányított $A$ Nép Zászlója néplap, valamint a Nép Szava, illetve a Gyorsposta jelentette. Az 1870 elején indult Szabad Magyarország hetilap jelentőségét fokozta, hogy Kossuth is előfizetett rá. A két esztendővel később kiadott Szombati Lapokkal Simonyi Ernő elsősorban a kisvárosi polgárságot kívánta megcélozni, Csávolszky Lajos pedig Baloldal nevü lapjában a balközéppel egyesülni akaró 48-as érzelműek szimpátiájára alapozott. A részben megszünő, részben egymásba olvadó szélsőbal sajtótermékek végeredménye a már említett Egyetértés lett, szintén Csávolszky szerkesztésében, illetve tulajdonában. ${ }^{106}$

\footnotetext{
${ }^{100}$ Kókay 1994. 130.

101 Buzinkay 2008. 74.

102 Buzinkay 2016. 204-207. Csernátony ellentmondásoktól nem mentes személyisége már az önkényuralom idején is megmutatkozott. A nyugati emigráció körében például gyorsan elterjedt róla, hogy a birodalom fizetett ügynöke. A párizsi magyar emigráció már 1850 öszén kérdőre vonta, hogy a Magyar Hírlap számára küldött - $\mathrm{s}$ ott közzétett - tudósításaiban belső ügyeket is rendszeresen a nyilvánosság elé tár, majd emiatt ki is zárta tagjai közül. A kiegyezés után a ,spicli” múltja, illetve a Tiszához való feltétlen lojalitása között feszülő morális ellentétet figurázta ki egy a Borsszem Jankóban közölt karikatúra. (Deák 2015. 129., 132-133., 566-567., 570.)

${ }^{103}$ Kókay 1994. 132.

${ }^{104}$ Fülöp 1993. 80.

105 Kosáry 1985b. 128-131.

106 Szinnyei 1893. 218-220.; Csávolszky Lajos életéről és munkásságáról lásd még: Digitalizált Törvényhozási Tudástár - Csávolszky Lajos (https://dtt.ogyk.hu/hu/gyujtemenyismertetok/konyvek/szerzoi-eletrajzok/item/334csavolszky-lajos, letöltés: 2017. május 3.)
} 
A Kelet Népe a konzervatívok lapja volt, az 1874-ben Halász Imre szerkesztésében indított Közérdek utódaként müködött, majd - miután a párt beolvadt a Mérsékelt Ellenzékbe 1878 végén - Magyarország néven jelent meg 1879-től. ${ }^{107}$ A lapbizottmány tagjai közé tartozott gróf Apponyi Albert is. Az újság sajtótörténeti jelentősége a vezércikk megreformálása volt: a korábbi, Kossuth-féle szónoklatok helyett közérthetőbb publicisztikák születtek, mintául szolgálva más lapoknak. ${ }^{108}$ A korszak fontos sajtószemélyisége volt a lengyel zsidó származású Ágai Adolf, a Kisfaludy Társaság tagja, aki több lap alapításában és szerkesztésében is vezető szerepet játszott. ${ }^{109}$ Ilyen volt például az élclap Borsszem Jankó ${ }^{110}$ vagy a polgári értékrendü, képes családi lap, a Magyarország és a Nagy Világ. ${ }^{111}$

A közéleti lapok mellett ebben a korszakban kezdtek kibontakozni a különböző folyóiratok, illetve más, kisebb területekre szakosodott újságok is: például a Magyar Bazár elsősorban divattal, háztartási tanácsokkal foglalkozott, az 1871-től publikált Kis Lap (szintén Ágai Adolf gondozásában) pedig az első igazán nagy sikerű hazai gyermeklappá nőtte ki magát. ${ }^{112}$ Jellemző volt az is, hogy egyre nagyobb számban jelentek meg a különféle szakmák számára készült szakfolyóiratok, közlönyök is: például az Ügyvédek Lapja 1884-ben, a Mészárosok és Hentesek Lapja 1893-ban kezdte meg müködését, de volt külön orgánuma a magyar asztalosoknak és kárpitosoknak is, amely 1897-ben látott napvilágot. ${ }^{113}$ Említést érdemelnek a részben még a század első felében alakult, tudományos igényü egyletek folyóiratai is, például a kiegyezés évében induló Századok, a Magyar Mérnök és Épitész Egylet Közlönye (1872), a Földrajzi Közlemények (1873), a Magyar Könyvszemle (1876), az Archaeologiai Értesitő (1879) vagy a Magyar Heraldikai és Genealógiai Társaság közlönye, az 1883-ban alapított Turul. ${ }^{114}$

1878 végén adta ki Légrády Károly ${ }^{115}$ az első magyar tömeglapot, a Pesti Hirlapot: a mutatványszám karácsonykor jelent meg. ${ }^{116} \mathrm{Az}$ alapításhoz szükséges tőke nagy részét maga

\footnotetext{
${ }^{107}$ Buzinkay 2008. 77.

108 Kókay 1994. 133.

${ }^{109}$ Szinnyei 1891. 74-78.

${ }^{110}$ A kormánypárti Borsszem Jankó gyorsan nagy népszerüségre tett szert: példányszáma már az indulás utáni első két évben elérte a 4000-et, amely európai viszonylatban is jelentősnek mondható. (Buzinkay 2016. 214.) Jó ideig nem is akadt versenytársa: a negyvennyolcas szellemiségü Bartók Lajos által kiadott Bolond Miska hamar csődbe ment, majd a vállalkozó új élclapot indított Bolond Istók néven. A szintén függetlenségi párti újság sokszor durván támadta nem csak a kormányt, hanem a kiegyezést támogató írókat, a Kisfaludy Társaság és az Akadémia vezetőit is. (Szántó 1973. 73.)

${ }^{111}$ Kókay 1994. 134-135.

112 Vitéz 2003. 95.

${ }^{113}$ Voit 2000. 615., 419., 335.

${ }^{114}$ Kovács 1987. 1416-1417.

115 Légrády Károly testvérével, Tivadarral együtt birtokolta a Légrády Testvérek vállalatot. Már az ötvenes években nyomdát rendeztek be a Nádor utcában. A testvérek közül Károly volt az agilisabb: 1834-ben született,
} 
Tisza Kálmán miniszterelnök tette le. Kisebb, ún. berlini formátumot $(47 \times 32 \mathrm{~cm})$ használt, és felvágva került a nagyközönség kezébe, ami szintén újdonságnak számított, s jelentősen megkönnyítette az újságolvasást: feleakkora volt, mint a többi napilap „,nagy formátumú papírlepedője". ${ }^{117}$ A példányszám rohamosan növekedett, az első világháború éveiben már naponta félmilliót nyomtak belöle. A Pesti Hirlap megjelenése ,fontos határkö a magyar kapitalista sajtó kibontakozásában... [...] Innen számítjuk a magyar polgári sajtó rohamos növekedését." ${ }^{118}$ Buzinkay Géza a következőképpen fogalmaz: „, a lapkiadás üzleti vállalkozás lett, amelynek törekvéseit és szellemét, söt hangnemét végső soron a kiadó-laptulajdonos üzleti érdeke szabta meg, és nem a szerkesztő meggyözödése." 119 Az újság a tömegeket célozta meg, igyekezett minden szenzációs hírt elsőként közreadni, emellett a korabeli lapok között a legnagyobb terjedelmü hirdetési rovattal bírt. ${ }^{120}$ Számos neves szerzőt tudhatott a magáénak, például Mikszáth Kálmánt, Molnár Ferencet vagy Heltai Jenőt. ${ }^{121}$ „A politika és üzlet összefonódásának iskoláját a Légrádyak teremtették meg a magyar sajtóban. Fellépésükkel meggyorsult a magyar sajtó kapitalizálódási folyamata" - írja Simon Mária Anna. ${ }^{122}$

Végül, meg kell említenünk a - Tisza-kormányzat csökkenő népszerüsége miatt a bukás szélére került két lap, A Hon és az Ellenőr egyesüléséből megszülető - Nemzetet, amelynek főszerkesztője Jókai Mór volt, ${ }^{123}$ valamint az 1877 -ben indult, Külföldi Viktor által alapított Népszavát, amely indulása után három évvel a Magyarországi Általános Munkáspárt, majd 1890-től a Magyarországi Szociáldemokrata Munkáspárt (MSzDP) hivatalos szócsöveként müködött. ${ }^{124}$

\subsubsection{A vidéki sajtó a kiegyezés után}

A vidéki sajtó mind mennyiségi, mind minőségi értelemben jelentős elmaradottságot mutatott a főváros nyomtatott tömegtájékoztatásához viszonyítva. Ez természetesen nem jelenti feltétlenül, hogy a vidéki lakosság kevésbé mutatott érdeklődést a közélet, a friss információk

\footnotetext{
1887-től Kenedi Gézával együtt szerkesztette a Pesti Hirlapot 1896-ig, amikor országgyülési képviselő lett. 1903-ban bekövetkezett halála után a céget három fia, Imre, Ottó és Károly vitte tovább. (Lengyel 1963. 12-13.) 116 Voit 2000. 499.

117 Szántó 1973. 77.

${ }^{118}$ Dezsényi 1954. 157.

${ }^{119}$ Buzinkay 2009. 18.

${ }^{120}$ Fülöp 1993. 80.

121 Vitéz 2003. 96.

122 Simon 1954. 3.

${ }^{123}$ Buzinkay 1993. 93.

${ }^{124}$ Gergely 1998. 395.
} 
iránt: az egyes településeken müködő kávéházak, olvasókörök, különféle egyletek rendszeres előfizetői voltak a jelentősebb országos hírlapoknak - mint azt a későbbiekben Szentes esetében is látni fogjuk.

Mindenesetre az 1870-es években hazánk megyeszékhelyeinek kétharmad része még nem rendelkezett saját újsággal. ${ }^{125}$ A többnyire hagyományosan ellenzéki beállítottságú területeken - az Alföld nagy részén, illetve Erdélyben - a magyar nyelvü politikai sajtó nagyobb mértékben erősödött meg, míg a Dunántúlon, valamint a németek lakta tömbökben (pl. a Szászföldön) a német nyelvü sajtóorgánumok még hosszú évekig meghatározók maradtak. A kormánnyal szemben álló területek magyar nyelvü politikai sajtóját az ellenzéki pártok támogatták, példányszámuk ezer körül mozgott, míg az államilag szubvencionált, kormánypárti orgánumok ennek általában csak a felét voltak képesek elérni - a lapok mindkét esetben a pártok hiányzó vidéki szervezeteit igyekeztek pótolni, illetve a helyi politikai erőket maguk mellé állítani. ${ }^{126}$ Általános volt, hogy minden politikai irányzatnak megvolt a fővárosi vezető napilapja mellett a saját vidéki hetilapja is. ${ }^{127}$ A legfontosabb vidéki közéleti lapok közé tartozott a kiegyezés megkötése utáni években az Aradon, napi rendszerességgel megjelenő Alföld és az Aradi Lapok, a szintén naponta publikált, kormánypárti Temesi Lapok (Temesvár), emellett a heti periodicitású huszonöt vidéki orgánum közül kiemelhetjük a Debreczent, a Nagyváradot vagy a kolozsvári Magyar Polgárt. ${ }^{128}$ A vegyes tartalmú közlönyök esetében már kevésbé mutatható ki ilyen élesen elhatárolható területi megoszlás, az ország szinte minden részén megjelentek, például Nyíregyházán, Marosvásárhelyen, Szatmáron, Jászberényben, Nagykanizsán, Kecskeméten vagy Szegeden. ${ }^{129}$.

Fontos különbség a fövárosi lapokhoz viszonyítva, hogy a vidéken megjelenő politikai hírújságok nem kecsegtettek ebben az időszakban jelentős üzleti haszonnal. Szerkesztői főleg hivatalnokok vagy ügyvédek voltak, akiket elsősorban a különböző kedvezmények (pl. utazás, ingyen reklám) érdekelték, valamint a politikai karrier lehetőségét látták meg a sajtóban, így nem csoda, hogy az egyes orgánumok kiadásában részt vevő pártok még nagyobb befolyást gyakoroltak rájuk, mint a fővárosban. A vidéki sajtó persze igyekezett tartani a lépést a pesti lapokkal, formai szempontból is ottani társaikat tartották mérvadónak (rovatok, tördelés), ám mind tartalmilag, mind példányszám tekintetében alulmaradtak a versenyben; nyomdáik technikai színvonala, a szerkesztőségeken dolgozók szaktudása is általában jócskán alulmúlta

\footnotetext{
125 Vitéz 2003. 95.

${ }^{126}$ Kókay 1994. 136.

${ }^{127}$ Kosáry 1985b. 33.

${ }^{128}$ Dezsényi 1954. 176-178.

${ }^{129}$ Kosáry 1985b. 45.
} 
a fővárosiakét. Meg kell említenünk azt is, hogy az országos lapok a vidéki történésekről általában csak többnapos csúszással számoltak be. Nemegyszer érte őket az a kritika, miszerint „elhanyagolják” a vidéket. Mindebben tudatosság is felfedezhető, hiszen az 1870-es években az országos lapok egyre inkább felesleges konkurenciát láttak a vidéki újságokban, $\mathrm{s}$ érvként gyakran azok színvonalbeli elmaradottságát hozták fel. ${ }^{130}$

A kritika többnyire jogosnak bizonyult - mint látni fogjuk, bizonyos értelemben Szentes esetében is -, azonban a vidéki hírlapok a fogyasztók szempontjából jóval nehezebb helyzetben voltak: heterogén, eltérő igényü olvasóközönséget kellett kiszolgálniuk, s partikuláris jellegüknek éppen ez volt a fö oka. Mindennek ellenére megállapítható, hogy a fővárosi lapok lekicsinylő jelzői túloztak: a vidéki sajtó lassan, de biztosan fejlődött a polgárosodás szellemében, és a szakmai elmaradottság is fokozatosan csökkent ${ }^{131}$ - a Sima Ferenc vezette Szentesi Lap például az 1880-as évek derekára már egy színvonalas, jól jövedelmező vállalkozássá nőtte ki magát.

A vidéki nyomtatott tömegtájékoztatás történetében fontos szerepet játszott két tiszántúli város, Debrecen és Nagyvárad, valamint Erdély központja, Kolozsvár; emellett a délkelet-magyarországi Arad és Temesvár. Ezeken a településeken jellemző volt a kiegyezés után a rohamos gazdasági fejlődés, a viszonylag nagyszámú olvasóközönség, valamint a baloldali ellenzék nagy aktivitása a közéletben, így a sajtóviszonyok terén is. Az említett városok politikai hírlapjai gyakran összefogtak egymással - például a már említett ellenzéki Debreczen a hasonló irányultságú Debreczeni Ellenőrrel, illetve a nagyváradi Biharral és a kolozsvári Magyar Polgárral müködött együtt; a kormánypárti, Debrecenben kiadott Tiszavidék pedig a Nagyváradi Lapokkal vagy a kolozsvári Kelettel ápolt szorosabb kapcsolatot. Így nem egy esetben az egész régióra kiterjedő politikai csatározások alakultak ki, amely a helyi sajtónak nagyfokú élénkséget kölcsönzött, az említett városokban pedig jelentősen fokozta az érdeklődést a nyomtatott sajtótermékek iránt. ${ }^{132}$

\subsubsection{A délkelet-magyarországi hírlapok}

A délkelet-magyarországi - amely régióba Szentes is beletartozik - sajtó történetében Arad és Temesvár mellett jelentős szerepet játszott Szeged is. A három gyorsan fejlődő nagyvárosra jellemző volt a helyi társadalom polgárosultságának magas foka, valamint a nem homogén

\footnotetext{
${ }^{130}$ Fleisz 2005. 9.; Kosáry 1985b. 37-51.

${ }^{131}$ Fleisz 2005. 9.

${ }^{132}$ Dezsényi 1954. 176-178.
} 
nemzetiségi összetétel. Arad és Temesvár esetében a helyi politikának a lakossághoz való viszonyulását sajátságossá tette, hogy ebben az időszakban mind Arad, mind Temes vármegyében már a román népesség került túlsúlyba, ám mindkét városban a magyarok, illetve a németek együttesen még mindig a lakosság közel háromnegyedét tették ki. A kiegyezés megkötése utáni években a régió sajtóorgánumai túlnyomórészt kormánypártiak legfeljebb mérsékelten ellenzéki hangnemüek - voltak, hiszen a megyei és a helyi vezetőrétegeknek szükségük volt a regnáló hatalom támogatására a heterogén etnikai összetételből adódó szociális és politikai feszültségekkel szemben. ${ }^{133}$

Arad két legjelentősebb lapjáról (Alföld, Aradi Lapok) már szóltunk. Később meghatározó volt még a város sajtóéletében az Aradi Hirlap, a regionálisan is népszerü Arad és Vidéke, illetve az 1885-től induló Aradi Közlöny, amelynél négy évig dolgozott az író Reviczky Gyula. ${ }^{134}$ Temesváron még inkább pezsgő sajtóéletet tapasztalhatunk a korszakban. A többtucatnyi német, illetve német-magyar vegyes nyelvü lapon kívül számos magyar nyelvű újság is megjelent a városban. A már említett Temesi Lapok 1880-tól Délmagyarországi Közlöny néven jelent meg, a szerkesztője Áldor Imre lett. Ezen kívül - a teljesség igénye nélkül - megemlíthetjük az 1869-től induló Csanád egyházi folyóiratot, amelynek szerkesztője a második évfolyamtól Csiky Gergely volt; az 1870-től kiadott Gazdasági Értesítőt vagy a Temesvári Hirlap humorisztikus hetilapot. Emellett számos szakfolyóirat és különféle közlöny is megjelent a városban, például a Történelmi Adattár, a Történelmi és Régészeti Értesitő vagy a Délmagyarországi Tanítóegylet Közlönye. ${ }^{135}$

A két megyeközponthoz képest Szeged jelentős elmaradásban volt a sajtóviszonyok terén az 1860-as években, főként az olvasás iránti csekély érdeklődés miatt. Ráadásul az analfabetizmus aránya Szegeden - igaz, a tanyai lakosságot is beleértve - közel kétharmad volt az 1870-es évek elején, de e tekintetben a város nem számított különlegességnek a régióban: Zombor, Szabadka és Újvidék is hasonló adatokat produkált. Fellendülés az 1879-es árvíz után következett, mikor Szeged az országos figyelem középpontjába került. ${ }^{136}$ Mindössze egyetlen hetilapot adtak ki a városban 1859-től a nyomdászvállalkozó, Burger Zsigmond $^{137}$ kezdeményezésére, a Szegedi Hiradót, amely közel két évtizedig

\footnotetext{
${ }^{133}$ Kosáry 1985b. 52-53.

${ }^{134}$ Puskel 2012.

135 Vende 2015. 87-93.

${ }^{136}$ Kosáry 1985b. 54.

${ }^{137}$ Szeged első nyomdáját 1801-ben alapította Grün Orbán. 1805-ben kalendáriumot adott ki, amely több tízezres példányszámot produkált egy idő után. 1828-as halála után özvegye vitte tovább a vállalkozást, 1842 körül pedig a nyomdaalapítójának fia, János lett a nyomda vezetője. Több más kiadvány mellett itt nyomtatták az 1849 májusában megindult Szegedi Hirlapot. Az üzemet 1852-ben vette bérbe Burger Zsigmond, majd három évvel később tulajdonossá is vált. (Novák 1928. 74) A miskolci származású Burger szülővárosában tanulta ki a
} 
egyeduralkodónak számított a településen. Munkatársai között számos neves helyi és országosan is ismert személyiséget találhatunk Bakay Nándortól kezdve, Csaplár Benedeken keresztül egészen Tompa Mihályig. Az újság 1879 nyarán napilappá vált. Az 1870-es években számos új szerző tünt fel a lapnál, például Lázár György későbbi polgármester, a Szeged történetét megíró Reizner János, illetve a Szentesről átkerült Kulinyi Zsigmond. A kiegyezés után voltak ugyan kérészéletű sajtópróbálkozások a városban (például Szegedi Néplap, Tiszavidéki Ujság), a kormánypárti Szegedi Hiradó igazán erős versenytársra csak az 1870-es évek végén lelt: 1878. július 28-án megjelent a Szegedi Napló. Az ellenzéki újság fiatal szerkesztőgárdáját Eisenstädter (később: Enyedi) Lukács vezette, s hamarosan már e lapnál találjuk a legkiválóbb szerzőket, szerkesztőket: Bánfalvi Lajost, Kulinyi Zsigmondot, Mikszáth Kálmánt, később Móra Ferencet, Gárdonyi Gézát, Tömörkény Istvánt. A kezdeti nehézségek utáni fellendülésben nagy szerepet játszott a fiatal Mikszáth írói zsenialitása, valamint - a szintén szentesi - Békefi Antal szerkesztői tevékenysége. Békefi bevezette a modern riport müfaját, emellett neki köszönhetők az országgyülésről való rendszeres tudósítások is. A Napló az 1880-as évekre a város vezető sajtóorgánumává vált. ${ }^{138}$

\subsection{A Csongrád vármegyei sajtó a kiegyezés után}

A Csongrád vármegye jelentős részben ellenzéki beállítottságú lakossága számára készült első nyomtatott sajtótermékek - az országos tendenciáknak megfelelően - többnyire az 1870-es években jelentek meg. Hódmezővásárhelyen az első nyomdát Wodianer Fülöp ${ }^{139}$ létesítette. A később országosan is ismert, sikeres vállalkozó már 1852-ben kérelmet terjesztett be ez ügyben a városi tanácshoz, azonban a helytartótanács elutasította, akárcsak tizenkét esztendővel később. ${ }^{140}$ Végül, 1869-ben megjelenhetett a város első vegyes tartalmú, 48-as

\footnotetext{
szakmát. 1834-ben Pestre ment, és több nyomdában dolgozott, de kezdetektől kitünt precíz munkavégzésével, gyorsaságával. 1844-ben költözött le Szegedre, a Grün-nyomda művezetöje lett, később bérlöje, illetve tulajdonosa. Az addig sikeres, üzemét folyamatosan fejlesztő üzletembernek az 1860-as évek végén anyagi gondjai támadtak jóhiszemü kölcsönügyletei miatt, amelyek vállalkozását csődbe vitték, és egészségét is tönkretették. 1874-ben, ötvenhét éves korában érte a halál. (Bendtner 1892. 17-21.; Gaál 2001. 7-120.)

${ }^{138}$ Lengyel 1999. 19-34.

${ }^{139}$ Wodianer Fülöp nyomdász, könyv- és lapkiadó Hódmezővásárhelyen született 1822-ben (Köszegfalvi szerint - s ezen adat megbízhatóbbnak tủnik - 1820-ban, lásd Köszegfalvi 1991. 4.). A szabadságharcban honvéd volt, majd Kossuth a Pesti Hirlapnál nyomdavezetőként alkalmazta. A kormánnyal együtt később Debrecenbe ment, ahol felállította a kormány hivatalos nyomdáját. 1849 után Pesten sikeres nyomdaipari vállalkozásba fogott. Szülőhelyén szintén ő létesítette az első nyomdát 1865-ben. 1874-ben felvásárolta a Lampel-féle kiadót, ezután ő adta ki többek között a Budapest, a Kis Ujság és a Mátyás Diák c. lapokat. Érdemei elismeréseként 1897-ben az uralkodótól nemesi rangot kapott. 1899 januárjában hunyt el Budapesten. (Újvári 1929. 965.)

${ }^{140}$ Köszegfalvi 1991. 3-4.
} 
szellemiségü hetilapja, a Vásárhelyi Közlöny. A később más sajtótermékeket és hivatalos nyomtatványokat is gyártó Wodianer-nyomda 1886-ban került más tulajdonos kezébe (időközben két másik nyomda is megkezdte müködését a településen), így az ellenzéki újságot sikerült megfojtani, akárcsak az egy másik vállalkozás által kiadott Vásárhelyi Hiradót 1879-ben. 1871-ben jelent meg a kormánypárti Hód-Mezö-Vásárhely, amely egészen az első világháború végéig müködött. ${ }^{141}$ Meg kell említenünk még az 1880-ban mindössze fél évig árusított Hódmezövásárhelyi Lapokat, a szintén ebben az esztendőben indult Heti Lapokat, valamint a Vásárhely és Vidéke „helyi érdekü társadalmi és szépirodalmi lap”-ot. Utóbbi orgánumot 1883-ban publikálták először, pályafutását pedig - több változtatás után, immáron politikai lapként -1912 végén fejezte be. ${ }^{142}$

Csongrád városában a helyi sajtótermékek viszonylag későn jelentek meg: a Csongrád társadalmi és közművelődési hetilap 1890. januárban látott napvilágot. Szentesen, a Sima Ferenc tulajdonában lévő nyomdában sokszorosították, s még az év októberében megszünt. Szintén 1890-ben indult a Tiszavidék. A kezdetben Szentesen előállított, vegyes tartalmú hetilap egészen 1916 nyaráig folyamatosan megjelent. 1891-ben két újabb sajtóorgánummal gazdagodott a város: a Csongrádi Lap hetente publikált, vegyes tartalmú közlönnyel, illetve a mindössze fél évig létező Közérdekkel. ${ }^{143}$ Az 1894-ben induló, ellenzéki Csongrádi Közlöny ${ }^{144}$ a kormánypárti Csongrádi Lappal gyakran vívott szócsatákat, nemegyszer - és a korszakban nem egyedülálló módon - nyíltan antiszemita hangot megütve: „A kormány és zsidópénzen kitartott ujságok a sajtó utján gyaláznak: az állam közegei míg egyfelöl politikai jogainkból kiforgatnak, másfelöl a legkörmönfontabb rágalmakkal és büntetésekkel üldöznek: sőt most már sőt most már vallási intézményeinkre is rátették kezeiket."145 A következő esztendő őszén Karvaly címmel humorisztikus havilapot adtak ki a városban, amely azonban néhány hónap után, 1896 áprilisában befejezte müködését. ${ }^{146}$

Makó egy évvel megelőzte Szentest: 1870. október 2-án jelent meg először a Maros „,ismeretterjesztő, kereskedelmi és közgazdászati hetilap”, amely negyven esztendeig létezett. Kiadója és sokszorosítója 1874-ig Sátory István volt, ${ }^{147}$ aki a lap megjelenése előtt nem sokkal alapította a település első nyomdáját. ${ }^{148}$ Hét évvel később adta ki a városban a

\footnotetext{
${ }^{141}$ Kárász 1974. 55-56.; Kőszegfalvi 1991. 5-6.

142 Kárász 1974. 53., 57., 114-115.

${ }^{143}$ Kárász 1974. 26., 31., 64., 110.

144 Kárász 1974. 31., lásd még:

http://sajtomuzeum.oszk.hu/forrasok/hirlapjaink/pdf/1_27_csongradi_kozlony.pdf (letöltés: 2017.július 10.)

${ }^{145}$ Csongrádi Közlöny, III. évf. (1896) 15. sz. 1.

146 Kárász 1974. 61.

${ }^{147}$ Kárász 1974. 79

148 Gaál 2001. 144.
} 
református egyház a Téli Ujság címü lapot, „vallásos irányú olvasmányok a magyar nép számára" profilmegjelöléssel. ${ }^{149}$ A Csanád vegyes tartalmú hetilapot 1878-ban vehették kezükbe először a makói polgárok Molnár Albert szerkesztésében és kiadásában. ${ }^{150} 1887$ novemberében indult a hetente publikált Makói Hírlap, amely a függetlenségi párt helyi szócsöve volt, és 1906-tól napilappá vált. ${ }^{151}$

Mindszenten a település nevével azonos címet viselő, vegyes tartalmú hetilap 1885. február 22-én jelent meg „Az alapító Egyesület” kiadásában. Az újság négy évig létezett. A sokszorosítást elöbb a szentesi Sima-féle nyomda végezte, majd egy helyi vállalkozás vette át, amelynek tulajdonosa, Diamant Manó 1889 márciusában saját hetilapot indított MindszentSzegvár és vidéke címmel. A Mindszenti Lap névvel két kérészéletü hetilap is kísérletezett: előbb 1890 nyarán jelent meg Darnay Gyula szerkesztésében, a fővárosi Irodalmi Társulat kiadásában, de egy hónap után megszünt. 1894-ben azonos néven vegyes tartalmú hetilapot publikáltak a településen, de féléves müködés után ez az újság is befejezte pályafutását. ${ }^{152}$

\section{Szentes város történetének vázlatos áttekintése 1867-től 1883-ig}

\subsection{Közigazgatás és politikai élet}

A török hódoltság után újra benépesült, többségében földmüvelésböl és állattenyésztésből élő, református hagyományokkal rendelkező dél-alföldi város ${ }^{153}$ lakossága aktívan kivette részét az 1848/49-es szabadságharcból. Kossuth alföldi toborzó körútjának állomásai sorába

\footnotetext{
149 Kárász 1974. 109.

150 Kárász 1974. 23.

${ }^{151} \mathrm{http} / / /$ sajtomuzeum.oszk.hu/forrasok/hirlapjaink/pdf/1_31_makoi_hirlap.pdf (letöltés: 2017.július 10.)

152 Kárász 1974. 83-84.

153 Az oszmán uralom, majd a Rákóczi-szabadságharc idején számos pusztítást megélt település fejlődésében meghatározó szerepe volt a XVIII. század első felének, amikor az uralkodó báró Harruckern János Györgynek adományozta Szentest. A Harruckernek számos kedvezményben részesítették a település lakóit (pl. vallásszabadság, a földesúri kötelezettségek ideiglenes elengedése), emellett országos vásártartási engedélyt is kieszközöltek a királytól, illetve iparos családokat telepítettek be, ezáltal is fokozva Szentes lakosságnövekedését, amely az 1759. évi összeírás alapján már megközelítette az 5000 föt. 1760 tavaszán tüzvész martaléka lett a település. 1773-ban már 7249 lakost írtak össze, többségében református vallásúakat. Később Szentes házasság útján a Károlyi család birtokába került, s 1828-ban lakossága már 16134 fő volt. 1836ban, hosszas tárgyalások után a város és a Károlyiak között megszületett az örökváltsági szerződés, amelynek értelmében Szentes felszabadult a grófi család közvetlen fennhatósága alól. Mindezért a településnek huszonöt évi földesúri szolgáltatás összegét kellett kifizetnie, azonban a megállapodásnak köszönhetően Szentes jobbágyközségből polgárvárossá vált, $\mathrm{s}$ megnyílt az út a gyorsabb fejlödés irányába (http://www.szentes.hu/?page_id=1219, letöltés: 2017. július 17.; bővebben lásd: Sima 1914. 207-548., Barta 2001. 197-239.)
} 
Szentest is bevette, a helyiek pedig több százan vettek részt a háború szinte minden jelentős csatájában. A szabadságharc után a várost sem kerülte el a megtorlás, ${ }^{154}$ emellett korábban szerzett privilégiumai nagy részét elveszítette. A szentesiek így kitörő lelkesedéssel fogadták az 1867-es kiegyezés hírét - elsősorban azért, mert bíztak a kiváltságok visszaszerzésében. ${ }^{155}$

Először is, Oroszi Miklós polgármester ${ }^{156}$ több hónapig tartó politikai csatározás után elérte, hogy a belügyminisztérium 1867. október végén engedélyezze Szentes rendezett tanácsú városi státuszának visszaállítását. Az ehhez szükséges választásokat december első napjaiban tartották, ahol két politikai csoportosulás csapott össze egymással: az Oroszi-párt, amelynek fő bázisát a közép- és kisparaszti rétegek (tehát Szentes lakosságának többsége) alkották, illetve a nagygazdákat, az értelmiségiek java részét, valamint a bukott provizórikus rendszer képviselöit tömörítő Stammer-Farkas-Jurenák-párt. ${ }^{157}$ A botrányoktól sem mentes küzdelemből végül Oroszi hívei kerültek ki győztesen, de az ellentábor - választási szabálytalanságokra hivatkozva, illetve egyéb vádakra alapozva ${ }^{158}$ - végül elérte, hogy a polgármestert 1869. októberben véglegesen eltávolítsák állásából. ${ }^{159}$ Utóda az időközben 48 as elvekre váltó Stammer Sándor lett, akit azonban 1871 decemberében Csongrád vármegye alispánjává választották, így polgármesteri pozícióját fel kellett adnia. ${ }^{160}$ Öt Kristó Nagy István követte a városvezetői székben. ${ }^{161}$

\footnotetext{
154 Több mint négyszáz szentesi vagy Szentesen elfogott személy ellen indult eljárás. Az első áldozat az 1813ban Szentesen született Hajdú Lajos református iskolaigazgató volt, akit a pesti cs. kir. hadbíróság 1849. november végén kötél általi halálra ítélt a felkelés résztvevőinek támogatásáért, illetve felségárulásért. Az itéletet néhány nappal később Haynau húszévi várfogságra enyhítette. Hajdú a büntetését OImützben kezdte meg, majd Josephstadtban folytatta, ahonnan 1856 áprilisában kegyelemmel szabadult. Kisújszálláson telepedett le, a helyi gimnázium oktatója, illetve több alkalommal igazgatója lett, ezen kívül a Magyar Királyi Természettudományi Társulat is a tagjai közé választotta. (Zakar 2014. 35-49., Labádi 2001. 4. )

${ }^{155}$ Labádi 1995. 15-75.

${ }^{156}$ Oroszi Miklós 1849-ben került Debrecenböl Szentesre, a helyi református népiskola tanára lett a bebörtönzött Hajdú Lajos helyett. Négy évig a gimnáziumi szintnek számító latin-német osztályokat irányította. Szembetegsége miatt szakított a tanári pályával, és gazdálkodásba fogott. Mezőgazdasági szakcikkei több országos folyóiratban megjelentek. 1858-ra olyan tekintélyt szerzett a helyi gazdák körében, hogy a település gazdasági ügyeit intéző Községi Választmány tagja lett. 1861-ben előbb városi tanácsnokká, majd Szentes polgármesterévé választották, de a nemsokára visszatérő abszolutista berendezkedés miatt lemondott. Ismét gazdálkodásba kezdett, de a közéletben továbbra is aktív szerepet játszott: 1862-ben bekerült a Váltsági és Gazdasági Bizottmányba, ahol egyik legfőbb szorgalmazója volt a szentesi vasútnak. A város legnépszerübb embereként 1865-ben országgyülési képviselővé választották, de két évvel később lemondott Pulszky Ferenc javára. 1867 végén ismét Szentes polgármestere lett, de politikai ellenfelei lejáratták, sőt két évre ártatlanul börtönbe is záratták. Szabadulása után közéleti szerepet nem vállalt, 1871-ben pedig elköltözött a városból. Nógrádverőcén halt meg 1892-ben. (Labádi 2006a. 4., Ruszoly 1999. 183.)

157 Stammer Sándor volt cs. kir. álladalmi ügyész, majd föszolgabíró, a provizórium ideje alatt a vármegye másodalispánja volt; Farkas Gedeon ügyvéd az önkényuralom évei alatt a városi pénztárnok tisztségét töltötte be, később főbíró, illetve a szentesi Deák-párt vezetője; Jurenák Eduárd pedig a település leggazdagabb embere volt. (Labádi 2005a. 2., Labádi 1995. 83.)

${ }^{158}$ A vád alapját Oroszi sógornője halálának tisztázatlan körülményei jelentették. (Labádi 2003a. 92.)

${ }^{159}$ Labádi 1995. 81-92.

${ }^{160}$ SZLK, I. évf. (1871) 26. sz. 3.;Labádi 1995. 104.; Kis-Rácz 2000. (Várostörténet, 1.10.1. - Közigazgatás)

${ }^{161}$ Kristó Nagy István (1816-1900) Szentesen született, jómódú parasztcsaládban. 1859-töl a szentesi református egyház presbitere, 1861 januárjától városi képviselő, de utóbbiról az önkényuralom restaurációja elleni
} 
Az 1869-es országgyülési választásokra a Deák-párt minden tekintélyét elvesztette a szentesiek körében. ${ }^{162} \mathrm{Az}$ 1868:XXXIII. tc. ugyanis csak azon községek számára biztosított kompenzációt, amelyek az 1840:VII. tc. kihirdetését követően váltották meg magukat földesuraiktól, ${ }^{163}$ így Szentes hiába remélt kárpótlást a Károlyiaknak 1836-tól kifizetett tetemes summáért. Ráadásul Pulszky Ferenc országgyülési képviselő a kérdésről szóló parlamenti vitában nem állt ki a városért. ${ }^{164} \mathrm{Nem}$ csoda, hogy a választásokat az egyesült ellenzék nyerte meg, ${ }^{165}$ és közfelkiáltással Kossuth Lajost szavazták meg Szentes országgyülési képviselőjének. Kossuth udvarias levélben visszautasította a jelölést, ezért a választást meg kellett ismételni. A júniusi referendumra a Deák-párt jelöltje visszalépett, így csak a balközép Horváth Ferenc és a 48-as László Imre ${ }^{166}$ maradt versenyben - végül utóbbi győzött elsöprő többséggel. A szélsőbal a következő évben megalapította a Szentesi 48-as Párt Népkörét, amelynek tiszteletbeli elnöke Kossuth Lajos, rendes elnöke pedig Ferenczy Sándor lett. Ferenczyt hamarosan börtönbe zárták felségárulás és nyilvános lázítás vádjával, így 1871 májusában ifj. Posta János vette át a népkör elnöki tisztségét, őt pedig Buday József lapszerkesztő, tanító, városi pénztárnok követte a pozícióban. ${ }^{167}$

Döntő fontosságú volt a település életében az 1870:XLII. tc., valamint az 1871:XVIII. tc.: elöbbi a megyékre vonatkozott, utóbbi pedig a községek számára alkotott új törvényi kereteket. ${ }^{168}$ Csongrád vármegye élére Rónay Lajos főispán került, a megye községeit pedig két - Tiszán inneni és Tiszán túli - járásba sorolták. A rendezett tanácsú városok - Csongrád,

tiltakozásként ugyanazon hamarosan lemondott. 1863-tól több ízben betöltötte a református egyház főgondnoki tisztségét. 1867 után újra városi képviselő, majd haláláig a megyei közgyülés tagja, illetve részt vett több városi szakbizottság müködésében is. 1872. május 14-én megválasztották Szentes polgármesterévé. 1878-ban a tisztújításon alulmaradt a fiatal Balogh János városi főkapitánnyal szemben. Ezt követően is aktív közéleti szereplő maradt, bár sokat veszített népszerüségéből az ellenzéki beállítottságú lakosság körében, mikor a város és a megye közötti politikai vitákban az utóbbi mellett állt ki. A város fejlesztése érdekében tett korábbi erőfeszítéseit azonban senki sem vonta kétségbe. (Labádi 2000. 4.; Labádi 2010b. 2.)

162 Labádi 1995. 92.

163 1868:XXXIII. tc. $1 . \S$

${ }^{164}$ Labádi 1995. 92-93.

$165 \mathrm{Az}$ 1869-es választásokon a tisztán magyarlakta területeken egyébként is nagyobb számban győztek az ellenzéki jelöltek, hiszen - ha nem is általánosan - a kiegyezés a magyar társadalom nagyobb része számára egyfajta nemzeti sérelem volt. Csupán a választókörzetek aránytalan kialakításának köszönhette a kormánypárt, hogy országos szinten elsöprő győzelmet aratott. (Gerő 2017. 64-65.)

${ }^{166}$ László Imre (1810-1884) fiatal ügyvédként báró Wesselényi Miklós titkáraként részt vett az 1834/35. évi erdélyi országgyülésen. Később tiszteletbeli aljegyző Közép-Szolnok vármegyében, majd diétai követ és táblabíró, 1841 és 1845 között pedig alszolgabíró. 1848-ban a tasnádi választókerület képviselője volt, és a fegyveres harcokból is kivette a részét. A szabadságharc után bujdosni kényszerült, ezután Szatmár megyei birtokain gazdálkodott. Az 1860-as évek első felében újra képviselő lett, a Határozati Párt színeiben. A kiegyezést elutasította, a 48-as párt alapítói közé tartozott. 1869. június 5-én érkezett Szentesre, másnap ismertette programját a helyi lakossággal. Két sikeres szentesi választás eredményeképpen hat évig volt a település országgyülési képviselője, később a csurgói, majd a zilahi kerületből került be ismét a parlamentbe. 1884. februárban hunyt el. (Labádi 2009a. 2.)

${ }^{167}$ Kis-Rácz 2000. (Várostörténet, 1.10.5. - Politikai élet); Labádi 1995. 92-98.

168 Kozári 2005. 205-211. 
Hódmezővásárhely és Szentes - azonban függetlenek maradtak a járásoktól, közvetlenül a megyei hatóság alá tartozó közigazgatási egységekké váltak. A vármegye területét öt választókerületre osztották: a községeket a tápéi és a szegvári kerületbe vonták be, a három rendezett tanácsú város pedig önálló választókerületet alkotott. A megyei közgyülés taglétszáma 274 fö lett, amelynek felét viriliseknek, a másik részét választott képviselőknek kellett alkotniuk a törvény értelmében. ${ }^{169}$ Szentes 44 virilis és 28 választott képviselőt küldhetett a Szegváron székelő megyegyülésbe. Az 1871. novemberi választásokon általános volt, hogy ,álbaloldali” személyek győztek, akik - megtagadva korábbi politikai irányultságukat - személyes ambícióik megvalósításához igyekeztek meglovagolni a vármegye nagy részén érezhető kormányellenes közhangulatot. ${ }^{170}$ Így kerülhetett az alispáni székbe Szentes polgármestere, Stammer Sándor is. ${ }^{171}$ A XIX. század utolsó évtizedében már Sima Ferenc kezében lévő, 48-as szellemiségü Szentesi Lap 1893. szeptember 12-én (XXIII. évf. 109. sz.) mindezt Stammer szemére is veti: „ez az ember, ki mint a Bach korszak zsoldosa vén embereket rugdalt ki hivatalából, s mikor a Bach korszak csillaga lehanyatlott hüséget esküdött a szentesi nép ezre elött az isten szabad ege alatt Kossuth zászlajának, s azt mint alispán esküje letételekor örökre megtagadta..." Másképpen vélekedik Stammerröl a történetíró Nagy Imre: Szentes-monográfiájában neki tulajdonítja az egyik föszerepet a megyeszékhelyi cím elnyerése érdekében indított küzdelemben. ${ }^{172}$

A községek rendezéséről szóló 1871:XVIII. tc. alapján kidolgozták Szentes új szervezési és müködési szabályrendeletét, amelyet 1872 tavaszán hagytak jóvá. Ennek értelmében Szentes rendezett tanácsú város, amely - kiemelkedve a járási rendszerből közvetlenül Csongrád vármegye köztörvényhatósága alá tartozik, s amely hatóságot gyakorol a település területén lakó vagy tartózkodó minden személy, illetve a területén létező összes vagyon felett a polgármester, a képviseleti közgyülés, a városi tanács, a rendőrkapitány, valamint az árvaszék útján. Saját belügyeit - a törvény korlátait figyelembe véve - önállóan intézheti, első fokú fellebbviteli hatósága közigazgatási ügyekben Csongrád vármegye törvényhatósága, másodfokon pedig a kormány. A törvény alapján a város képviselö-testületét

\footnotetext{
169 1870:XLII. tc. 19.§, Gyáni 2001. 97-98., Kövér 2001. 117.

${ }^{170}$ Labádi 1995. 99-100.

${ }^{171}$ Az önkényuralom idején a Bécshez hü, majd hirtelen 48-as eszméket hirdető Stammerrel szemben többen emeltek erkölcsi kifogást a helyi sajtóban. Volt, aki tisztséghalmozását rótta fel neki (SZLK, II. évf. [1872] 3. sz. 3.). Ifj. Bartha János a november 8-i alválasztóköri ülésen kifogásolta a polgármester baloldaliságát, hiszen a Reform kormánypárti lapot járatja (Labádi 1995. 99.). A legélesebb kritikus Babós Bálint városi tanácsnok volt, aki lopással is megvádolta Stammert a helyi olvasókörben (SZLK, I. évf. [1871] 21. sz. 1-2.). A városvezető hivatalos vizsgálatot kezdeményezett, amelynek végeredményeként a vádat bizonyítani nem tudó Babóst elbocsátották állásából (SZLK, I. évf. [1871] 22. sz. 3.).

172 Nagy 1928. 98.
} 
- fele-fele arányban - a település legtöbb adót fizető polgáraiból, vagyis a virilisekből, illetve választott képviselőkből kellett összeállítani. ${ }^{173} \mathrm{~A}$ választójog kiterjedt valamennyi férfi lakosra, aki betöltötte a huszadik életévét, feltéve, ha a saját vagyona után már legalább két éve fizetett helyi adót. A városi tanács és a kétszáz fős képviselő-testület tagjainak mandátuma hat évre szólt. A polgármestert, illetve a legfontosabb tisztviselőket a közgyűlés választotta, szintén hat esztendőre, ezzel felváltva a korábbi gyakorlatot, miszerint a választójoggal rendelkező szentesiek közvetlenül választották meg a polgármestert és a városi tisztikar huszonkét tagját. Az új rendszer 1929-ig változatlan maradt. ${ }^{174}$ A szabályrendelet részletesen meghatározta a polgármester és a képviselő-testület hatáskörét is. ${ }^{175}$

Szentest egészen 1910-ig kizárólag függetlenségi párti jelöltek képviselték a parlamentben, s ez nemcsak hogy rávilágít a dél-alföldi város hagyományosan ellenzéki érzületére, hanem magyarázatként szolgál az egész dualizmus korszakát végigkísérő helyi politikai csatározásokra, ami nagymértékben befolyásolta a település gazdasági és társadalmi fejlődését is. ${ }^{176}$, „A szabadságharc $s$ az ezt követő elnyomatás a gazdasági differenciáltság és anyagi érdekeken nyugvó ellentéteket letompitotta s így ez idő alatt komolyabb küzdelmekre nem került a sor. Annál vehemensebben tört ki aztán a kiegyezés után, amikor már Deák géniusza nem hatott kellö intenzitással és különbözö erők kezdtek érvényesülni. Ekkor aztán ismét önmagára talált az ösi, ösztönös, peturbános szentesi lélek s az alkotmányos küzdelmek országos zajában inscenált olyan lokális politikát, amelyre az egész nemzeti közvélemény felfigyelt" - fogalmaz Schupiter Elemér. ${ }^{177}$

A városban müködő 48-as párt megerősödésében és tartós népszerüségében döntő szerepe volt Sima Ferencnek, aki Buday József után lett a helyi függetlenségi csoportosulás vezéralakja, később pedig a település országgyülési képviselője. ${ }^{178}$ „Mint szónok fóképpen

\footnotetext{
173 Kozári 2005. 212.

${ }^{174}$ Kis-Rácz 2000. (Várostörténet, 1.10.1. - Közigazgatás); 1871:XVIII. tc. 34-56.§

175 Labádi 1995. 102-103.

${ }^{176}$ Kis-Rácz 2000. (Várostörténet, 1.10.5. - Politikai élet)

177 Schupiter 1928b. 250.

178 Sima Ferenc 1853-ban született Nagykőrösön, Sima Lajos asztalosmester fiaként. Kántortanítói oklevelet szerzett, majd 1873-ban Szentesre érkezett, ahol a felsőpárti református leányiskola segédtanítója lett. Hamar népszerü lett a városban, a helyi tanítóegylet ismeretterjesztő munkájából aktívan kivette a részét, emellett cikkeket kezdett írni a Szentesi Lapba. 1875 tavaszán a Szentesi Függetlenségi Párt jegyzőjévé választották, s országos lapokban (Egyetértés, Magyar Ujság) is jelentek meg írásai a település politikai mozgalmairól. Mivel az egyháztanács nem hosszabbította meg álásában, feladni kényszerült a tanítói pályát, s 1875-től a Szentesi Lap fóállású munkatársa lett. Ugyanebben az évben megnősült, feleségül vette egy helyi földbirtokos lányát, Donát Juliannát, akitől tizenkét gyermeke született. 1876-ban elnyerte a városi levéltárnoki állást, illetve átvette a Szentesi Lap szerkesztését. 1878-ban a Szentesi 48-as Népkör, valamint a helyi Függetlenségi Párt elnökévé, majd a település képviselő-testületének tagjává választották, emellett a város gazdasági tanácsnokaként is tevékenykedett. Utóbbi minőségében megszervezte a környék árvízvédelmét, amelynek köszönhetően 1879-ben Szentes elkerülte Szeged tragikus sorsát. 1881-től a Bökény-Mindszenti Vízszabályozó Társulat igazgatója, később a Körös-Tisza-Maros Ármentesítő és Belvízszabályozó Társulat vezetője. 1883-ban megvásárolta a
} 
árvizben dolgozik. Egy órán alól nem adja, s épp ezért nagyon szeretik, ha beszél, azok, akik a büfében kényelmesen óhajtanak ebédelni” - írja Gárdonyi Géza Sima Ferencről, az országgyülési képviselőről. ${ }^{179}$

A Szentesen népszerütlen Deák-párt első elnöke a már említett Farkas Gedeon ügyvéd, városi főbíró, majd 1872-től járásbíró volt, őt pedig Csukás Benjamin követte a pozícióban. ${ }^{180}$ A balközép párt helyi csoportosulását Kiss Zsigmond ügyvéd alapította és vezette, aki az 1875-ös országos fúziót követően a két pártból létrejövő Szabadelvü Párt helyi elnöke lett. ${ }^{181}$

A balközép és a Deák-párt - illetve 1875 után a Szabadelvű Párt - igyekezett a választásokra köztiszteletben álló jelölteket állítani, hátha sikerül megtörni a függetlenségi párt hegemóniáját. Az 1872-es választásokon a balközép Jókai Mórt indította a szentesi választókerületben, a Deák-párt pedig Kerkápoly Károly pénzügyminisztert - mindhiába. A referendumon a 48-as párt jelöltje, László Imre fölényesen győzött. Jókait nem tántorította el a kudarc, 1875-ben ismét elfogadta a jelölést, ezúttal már a Szabadelvű Párt színeiben. A

Szentesi Lap tulajdonjogát és az azt sokszorosító nyomdát. A város legnépszerübb polgáraként kétszer is visszautasította az országgyülési képviselőséget: 1878-ban Törs Kálmánt támogatta, 1892-ben pedig Balogh János javára lépett vissza, azonban a tápéi választókerületben harcba szállt, sikeresen. A parlamentben az Ugronféle csoporthoz tartozott. Az obstrukció „mestereként” tartották számon - a témában könyvet is írt, amelyben európai példákkal is igyekszik igazolni az obstrukció hasznát, létjogosultságát, emellett megállapítja, hogy ,a magyar parlamentnek multja van ezen a téren” (Sima 1897. 12.), valamint, hogy „megobstruálni egy kormányt, egy pártot, egy rendszert, megostromolni magát az uralkodót, elsö rendü hazafiui kötelesség." (Sima 1897. 87.) Hírnevét gyakori párbajaival is fokozta. 1896 őszétől Szentes országgyülési képviselője, 1897-től a Függetlenség társszerkesztője. Saját politikai mozgalmat is alapított Radikális Demokrata Párt néven. Politikai ellenfelei 1898tól jól szervezett támadássorozatot indítottak ellene, emiatt Sima vállalkozásai csődbe mentek, így elveszítette parlamenti mandátumát is. Végül a szegedi törvényszék elfogatóparancsot adott ki ellene, amely elől 1901-ben az Egyesült Államokba menekült. Ott hunyt el 1904 nyarán. (Labádi 2003b. 2.; Labádi 2003c. 2.; Labádi $2003 d$. 2.; Labádi 2009b. 2.; Labádi 2009c. 2.; Farkas 1990. 209-356.)

179 Gárdonyi 1965.

${ }^{180}$ Csukás Benjamin 1833-ban született Izsákon. A Tolna megyei Gyönk gimnáziumában kapott oktatói állást. 1862 őszétől a szentesi református gimnázium tanára és igazgatója. A Szentesi Olvasókör alapító tagja 1867ben, amelynek pénztárnoka is lett. 1868-ban városi képviselővé választották; a Kolera Bizottság és a Vasútügyi Bizottság elnöke volt, emellett több szakosztály aktív tagjaként is dolgozott. Számos településfejlesztő javaslatot készített, például neki köszönhető a polgári fiú- és leányiskolák 1869-es felállítása Szentesen. 1870-ben a városi iskolaszék jegyzője, 1872-ben elnöke lett. Ekkor kénytelen volt feladni gimnáziumi állását. 1871 és 1874 között a szentesi református egyház fögondnoka, emellett a Bökény-Mindszenti Tiszaszabályozási Társulat igazgatói feladatait is ellátta, valamint a helyi Deák-párt és az Úri Kaszinó elnöke volt. Közművelő és politikai témájú publicisztikákat is írt, emellett kiadta a szentesi gimnázium első Értesítőjét 1865-ben. Szentesen hunyt el 1879ben. (Labádi 2003e. 2.; Kis-Rácz 2002. - II. fejezet: A kezdetektől 1912-ig)

181 Kiss Zsigmond szentesi kisnemesi családban született, nagyapja Kiss Bálint református esperes. Iskoláit Szentesen és Temesváron végezte. 1849-ben tüzér hadnagyként részt vett Buda visszafoglalásában. 1850 nyarától a Csongrád Megyei Ideiglenes Polgári Törvényszék írnokaként, majd a szegedi megyei törvényszék előadójaként és a segédhivatal igazgatóhelyetteseként dolgozott. Kecskeméten köz- és váltoügyvédi diplomát szerzett. Ezután visszatért Szentesre, ahol ügyvédi irodát nyitott. 1868-tól 1872-ig városi föügyész. A balközép, majd a Szabadelvü Párt városi elnöke, tagja a megyei és a városi közgyülésnek. Alapítója, később pedig elnöke a Szentesi Honvédegyletnek, szerepet vállalt az első szentesi takarékpénztár 1869-es létrejöttében, amelynek alelnöke, később vezetője is volt. Huszonöt éven keresztül betöltötte a Szentesi Iskolaszék elnöki posztját, 1887 ben a Gimnáziumi Bizottság első emberévé is megválasztották, az ő ideje alatt avatták fel a helyi gimnázium ma is látható, impozáns épületét. Mindemellett számos közéleti tisztséget betöltött, például a Szentesi Segélyegylet igazgatója, az Úri Kaszinó elnöke, a szentesi református egyház főgondnoka is volt. Közéleti tevékenységéért királyi tanácsosi címet kapott az uralkodótól. 1911. december 13-án hunyt el. (Labádi 2005b. 2.) 
kampányát már nem csupán írói hírnevére alapozta: 1875. június 13-án Szentesre látogatott, ahol hatalmas ünneplő tömeg fogadta, pártállástól függetlenül. A választásokon azonban ismét kudarcot vallott a 48-as jelölttel, Simonyi Ernővel ${ }^{182}$ szemben. A következő, 1878. májusi voksoláson a kormánypárt olyannyira meggyengült a településen, hogy már feleslegesnek ítélte a jelöltállítást is Simonyival szemben. A képviselő végül a debreceni mandátumot fogadta el, ahol ráadásul magát Tisza Kálmán miniszterelnököt győzte le. Így Szentesen pótválasztást kellett az ősz folyamán tartani, amelyen a 48-as jelölt Simonyi helyett Törs Kálmán ügyvéd, elismert fövárosi publicista volt, a Szabadelvü Párt pedig a helyi elnökét, Kiss Zsigmondot küldte harcba. Az ellenzék ismét elsöprő győzelmet aratott. Törs Kálmán 1892-ig volt Szentes országgyülési képviselője, utóda Balogh János lett. ${ }^{183}$

\subsection{A megyeszékhelyi státusz elnyerése}

Jelentős változás volt Szentes életében a megyeszékhelyi státusz elnyerése, amely új távlatokat nyitott a polgári fejlődés irányába. Csongrád vármegye központja 1773-tól Szegvár volt, de a település fejletlensége egyre inkább arra késztetett több várost, hogy küzdelembe szálljon a székhelyi címért. Az önkényuralom időszaka alatt Szegedről irányították a vármegyét, azonban 1865-ben a székhely újra Szegvárra került. 1873-ban belügyminiszteri törvényjavaslat született a megyék rendezéséröl, amely szerint Csongrád vármegyét Csanád egy részével egyesítették volna, az új közigazgatási egység székhelyének pedig Szegedet javasolták. A tervezet nem valósult meg, mivel a megyék tiltakoztak ellene, Szeged viszont élt a lehetőséggel, és mozgalmat indított a székhely elnyeréséért, pedig régóta nem is tartozott a vármegyébe, hiszen hosszú évszázadok óta szabad királyi város volt. Szeged ellenében Szentes és Hódmezővásárhely is bejelentette igényét, így heves küzdelem indult a címért. ${ }^{184}$

\footnotetext{
182 Simonyi Ernő Zsámbokréten született 1821-ben. Az 1840-es években Nyitra és Bars vármegye ellenzékének tagja volt. A szabadságharc után az emigrációt választotta: Hamburgban, Párizsban, majd Londonban élt, a Sorbonne egyetemen vegytani és természettani tanulmányokat folytatott. Angliai levéltári kutatásai nyomán kiadta a Magyar történelmi okmánytár (1521-1717) és az Angol diplomáciai iratok II. Rákóczi Ferenc korára címü történeti munkáit, Horváth Mihály emiatt javasolta akadémiai tagságát. 1859-ben csatlakozott az olaszországi magyar légióhoz. A villafrancai békekötés után visszatért Angliába, ahol többek között egy tégla- és cementgyár igazgatója lett, illetve a sheffieldi acélgyárat is képviselte Franciaországban. A kiegyezés után hazatelepült, és 1869-től a németürögi, 1872-től a szentesi, majd 1875-től a debreceni választókerület országgyülési képviselője volt, a függetlenségi párt színeiben. Szentessel először 1870-ben került kapcsolatba, amikor a helyi 48-as Népkör tiszteletbeli tagjává választották. 1882 márciusában halt meg Abbáziában. (Kenyeres 2001.; Labádi 2007a. 2.; Szinnyei 1908. 1094-1096.)

183 Labádi 1995. 105-122.; Labádi 2008a. 2.; Labádi 2010a. 2.

${ }^{184}$ Labádi 1995. 112-113.
} 
Szentes esélyei 1873-tól növekedtek, mikor Hódmezővásárhely törvényhatósági jogú város lett, ezáltal - Szegedhez hasonlóan - közigazgatásilag kiszakadt Csongrád vármegyéből. ${ }^{185}$ Ráadásul 1876-ban Csongrád település anyagi megfontolásokból lemondott a rendezett tanácsú városi státuszról, s községgé minősíttette vissza magát, így onnantól kezdve - közigazgatási értelemben - Szentes lett Csongrád vármegye legnépesebb városa. ${ }^{186}$ Egyébként sem számított kisvárosnak: lakóinak száma ekkoriban már meghaladta a huszonnyolcezer főt, ${ }^{187}$ így joggal remélhette, hogy győztesen kerül ki majd a versengésböl.

Szentes város közönsége a fentiek alapján, 1874 decemberében folyamodványt nyújtott be Csongrád vármegye törvényhatóságához, amelyben kérte, hogy határozatban jelöljék ki Szentest a vármegye új központjául. Cserébe egymillió téglát, elegendő mennyiségủ tetőfedő cserepet, illetve megfelelő telket ajánlott fel ingyen a vármegye számára. A megyegyülés, bár egyhangúlag tetszését fejezte ki a folyamodvány tartalma, a nemes felajánlás iránt, nem hozott az ügyben végleges döntést. Egy esztendővel később végül a testület kimondta, hogy amennyiben változás lesz, kizárólag Szentest tartja alkalmasnak a megyeszékhelyi státuszra. A szavakat viszont tettek nem követték, így a küzdelem folytatódott, azonban a szentesiek reményeit fokozta, hogy Hódmezővásárhely közben kiszállt a versenyböl. ${ }^{188}$

A Szegeddel való hosszú rivalizálás végére Tisza Kálmán miniszterelnök-belügyminiszter tett pontot: 1878. március 31-én kelt leiratában jóváhagyta azt a megyegyülési határozatot, amely Csongrád vármegye központját áttette Szegvárról Szentesre. A székhelyváltoztatás azonban nem ment egyik napról a másikra, s lassan haladt az új székház építésének előkészítése is: az ünnepélyes alapkőletételre csak négy évvel később, 1882. május 18-án került sor. Rónay Lajos föispán tette le az első téglát, amelyre Stammer Sándor alispán egy nemzetiszínű szalaggal díszített kőmüves kalapáccsal ütött rá, majd a megyei főtisztviselők, Balogh János ${ }^{189}$ polgármester, valamint a megyéhez tartozó települések küldöttei helyeztek el

\footnotetext{
185 Kövér 2001. 55., Nagy 1928. 98.

186 Zsilinszky 1900. 316.

187 Érdekességként megjegyzendő, hogy a város lakosságszáma akkoriban nagyobb, illetve közel azonos volt, mint ma: a hivatalos becslések szerint a település népessége 2017-ben 28108 fó (lásd: http://nepesseg.com/csongrad/szentes, letöltés: 2017. augusztus 6.)

${ }^{188}$ Kis-Rácz 2000. (Várostörténet, 1.10.2. - A megyeszékhely elnyerése); Labádi 1995. 113-115.

189 Balogh János 1845-ben született Szabadszálláson. Szentesre gyerekként került, majd középiskolai és egyetemi tanulmányai idejére távozott a városból. A Pesten végzett, fiatal joggyakornokot a Csongrád vármegyei főispán a szentesi járás tiszteletbeli esküdtjévé nevezte ki 1869-ben, majd városi főkapitány lett, de Kristó Nagy polgármester egy jogértelmezési vita miatt hamarosan felfüggesztette. 1874-től városi képviselő lett, 1878-ban, harminchárom évesen Szentes polgármesterévé választották. A modernizáció érdekében számos fiatal politikus például Sima Ferenc - ekkor került felelősségteljes pozícióba a városvezetésben. Balogh idején Szentes fejlődése még inkább felgyorsult. 1883 végén - sokak meglepetésére - a sikeres polgármester megpályázta a megyei árvaszéki elnöki pozíciót, amelyet el is nyert, így benyújtotta lemondását. Döntését a személye elleni támadásokkal indokolta. Utóda Sarkadi Nagy Mihály lett, aki folytatta elődje fejlesztő programját. Balogh később a város mellé állt a megyével folytatott küzdelemben, ennek köszönhetően elveszítette állását, sőt
} 
egy-egy téglát. A város föterén ma is álló, Makay Endre tervezte, klasszicista épületben másfél évvel később, 1883. december 10-én megtartotta első díszközgyülését a megyei tisztikar, így Csongrád vármegye székhelye hivatalosan is átkerült Szegvárról Szentesre. ${ }^{190}$

\subsection{Urbanizáció}

Szentesen az urbanizáció mind infrastrukturális, mind gazdasági, mind pedig társadalmi tekintetben lassú folyamat volt, s igazán csak a századfordulóra teljesedett ki. ${ }^{191}$ A fejlődést nem csupán az anyagi lehetőségek változó mértéke, hanem a város-, illetve a megyei vezetésnek az egyes konkrét fejlesztési ügyekhez való pozitív vagy negatív hozzáállása is nagymértékben meghatározta. A helyi függetlenségi párt tartós sikere jórészt annak is köszönhetö, hogy a 48-as érzelmü politikusok az esetek döntő többségében határozottan képviselték a gyorsabb ütemű fejlesztési terveket, ellentétben kormánypárti ellenfeleikkel. ${ }^{192}$

Bár tárgyalt időszakunkon kívül esik, meg kell említenünk az e tekintetben első tevékeny városvezetőt, Sréter Antalt (1852-1860). A Tisza jelentette állandó veszély ellensúlyozására az ő idején készültek el az első komolyabb védőgátak. A tanyasi gyerekek számára megépíttetett négy külterületi iskolát, s 1859-ben megnyílt a református egyház négyosztályos középtanodája, a gimnázium elődje. 1860-ban döntött a település vezetése a Kurcán túli terület parkosításáról, a ma is meglévő Széchenyi-liget létrehozásáról. ${ }^{193}$ Utóbbi tényleges megvalósítása már Oroszi Miklós (1861, 1867-1868) nevéhez füződik, aki emellett támogatta a vasútépítést, alapítója volt a szentesi olvasókörnek, illetve kiadta Szentes első nyomtatott sajtótermékét, mint azt a későbbiekben látni fogjuk. ${ }^{194}$

\footnotetext{
sikertelenül pályázott 1889-ben az alispáni, majd 1891-ben a polgármesteri pozícióra. Kárpótlásul, 1892 elején a szentesiek országgyülési képviselőjüknek választották. 1896-ban azonban vitába keveredett a helyi 48-as mozgalommal, emiatt ismét kudarcot vallott a helyhatósági választásokon, ahol újra indult a városvezetői székért, de alulmaradt Burián Lajossal szemben. Később a Szentesi Takarékpénztár igazgatója, az utcanévadó bizottság elnöke volt (a mai szentesi utcanevek többsége jórészt neki köszönhetö), helytörténeti tanulmányokat is publikált, emellett a református egyház fögondnoki tisztségét is betöltötte. A világháború után visszavonult a közélettől, elfeledve halt meg 1924-ben. (Labádi 2004a. 2., Labádi 2004b. 2.)

${ }^{190}$ Zsilinszky 1900. 322-324., Labádi 1995. 115., Labádi 2003f., Tóth 2000. 633-637.

${ }^{191}$ Kis-Rácz 2000. (Várostörténet, 1.10.3. - A város fejlődése)

${ }^{192}$ Kis-Rácz 2000. (1.10.5. - Politikai élet)

${ }^{193}$ Ebben az időszakban országszerte egyre jobban terjedt a városok közterületein népkertek, díszkertek, sétaterek kialakítása, amelyek a társas élet újfajta - kikapcsolódási, szórakozási, művelődési lehetőséget, valamint a kertvendéglőknek köszönhetően sokszor gasztronómiai élvezeteket is nyújtó - színtereiként szolgáltak. (Kósa 2002. 294.)

${ }^{194}$ Kis-Rácz 2000. (1.10.3. - A város fejlődése)
} 
Stammer Sándor városvezetése (1869-1871) alatt adták át a Széchenyi-ligeti vendéglőt és a gőzfürdőt (1869), illetve az ő idején jelentek meg a település első nyomtatott sajtótermékei. A liget kedvelt kikapcsolódási lehetőséget jelentett ezután: a vendéglőben mulatságokat szerveztek, a közelében épült fürdő pedig meleg vizes medencét, illetve egy fekvőpadokkal ellátott gőzszobát is kínált a nagyközönségnek. A városi tanács 1870-ben haszonbérbe adta az építményt a vendéglőtulajdonos Rambovszky Józsefnek, aki a kádfürdőt hamarosan sziksós fürdővé fejlesztette. A vendéglő mulatóhely-funkciója azonban 1873-ban megszünt, így a liget vonzereje jelentősen csökkent. ${ }^{195}$

Kristó Nagy István polgármester (1872-1878) idején nagyobb ütemü urbanizációs munkálatok történtek: 1873-ban megnyitotta kapuit a városi kórház, ${ }^{196}$ 1876-ban az első kisdedóvó, valamint a községi polgári fiúiskola. ${ }^{197}$ Elindult a település út- és csatornahálózatának kiépítése, megkezdte müködését a távírda, majd 1877-ben kipróbálták a távbeszélő készüléket is. 1876-ban leginkább az ő szervező munkájának volt köszönhető, hogy Szentes megmenekült az árvíztől, ezért az uralkodótól kitüntetést kapott. Kulturális téren is maradandót alkotott: 1873-ban megalakult a Szentesi Önkéntes Tűzoltó Egylet, a következő esztendőben a helyi lakosság pedig már saját színkörrel is büszkélkedhetett. Végül, ő kezdeményezte először, hogy Csongrád vármegye székhelye Szentesre kerüljön. ${ }^{198}$

Balogh János (1878-1884) folytatta elődei fejlesztési terveit: a nagy horderejü ármentesítési munkálatoknak köszönhetően zsilipek közé szorították a Kurca vizét, Szentes 1882-ben bekapcsolódott a gőzhajózási forgalomba, megkezdődött a közvilágítás kiépítése, az utcák kikövezése. 1882-ben átadták a városi jégpályát, 1883-ban iskolai könyvtárat hoztak létre, hogy a szegényebb diákokat taneszközökkel lássák el. ${ }^{199}$ Balogh két legjelentősebb eredménye: egyrészt hosszú tárgyalásokkal sikerült megindítania a helyi vasút kiépítését, ${ }^{200}$

\footnotetext{
195 Tóth 2000. 665-666.; http://www.szentesinfo.hu/liget/liget/ (letöltés: 2018. január 11.)

${ }^{196}$ Ugyanebben az évben dúlt a korábban már említett kolerajárvány a városban, amely még inkább indokolta az új egészségügyi intézmény létrejöttét: „1873-ik évében az Urnak rettenetes kolerajárvány seperte végig Szentes városát. Egész utcasorok, például a mai Klauzál utca (akkor Kis-völgyaljnak nevezték) népe teljesen kihalt két kicsiny gyerek kivételével. A város elöljárósága tehetetlenül állott szemben a kolera szörnyü rémével. Pollák városi föorvos házának udvarában (mai Havas gyógyszertár helyén) százával feküdtek a kolerás betegek. Akinek még volt annyi ereje, hogy el birt vánszorogni az orvos lakására, ott összerogyott. [...] A járvány alatt szörnyü baja volt a hatóságnak elsösorban a halottakkal, mert a városnak e célra felfogadott emberei egytöl egyig a dögvész áldozatai lettek. Semmi pénzért nem akadt aztán vállalkozó a halottak eltakaritására. Akkor jelentkezett a polgármesternél két derék, becsületes kálvinista iparos, [...] akik minden dijazás nélkül, csupán emberszeretetböl már a haldoklók ágyánál megjelentek, megadták az utolsó segitséget, a halottakat koporsóba helyezték, esténként a város kocsijaira 5-6 koporsót felrakva, kiszállitották a temetöbe valláskülönbség nélkül, ahol már várta a nyitott sir." (Gulyás 1941. 25-26.)

${ }^{197}$ Follajtár 1938. 11.

198 Labádi 2000. 4.; Labádi 2010b. 2.; Kis-Rácz 2000. (1.10.3. - A város fejlődése)

${ }^{199}$ Kis-Rácz 2000. (1.10.3. - A város fejlődése)

${ }^{200}$ Labádi 2004a. 2., Labádi 2004b. 2.
} 
emellett az ő idején lett Szentes Csongrád vármegye székhelye. ${ }^{201}$ Utóda, Sarkadi Nagy Mihály (1884-1891) szintén jelentős városfejlesztő programot valósított meg - például az első vasútvonal felavatása, a gimnázium új épületének átadása, a kórház fejlesztése stb. -, az ő müködése azonban már a jelen dolgozatban tárgyalt időszakon kívül esik. ${ }^{202}$

Mindezen fejlesztéseknek, a település urbanizációs előrehaladásának, a nyilvános közösségi terek - föként a Széchenyi-liget - létrehozásának nem csupán konkrét, fizikai értelemben is kézzelfogható haszna volt, hanem jelentős szerepet játszott a szentesi polgárok közösségtudatának kialakításában, elmélyítésében, komfortérzetük javításában, s így a lakóhelyükhöz való szorosabb érzelmi viszonyulás elmélyítésében is. „A mentális térképek minden viszonylagosság ellenére vagy amellett létezik azonban valami közös a városlakók tapasztalati világában. Ilyen, szinte mindenkit összekötö élményanyaggal szolgálnak a várost, mint egészet szimbolizáló tárgyi elemekröl (térformákról, objektumokról) nyert élmények: nélkülük nem lehetséges a városi identitás érvényes kialakitása, mivel a nekik tulajdonított jelentésnek megfelelöen bennük ölt testet a város fizikailag érzékelhetö és átélhető (érzelmi rezonanciákat keltő) saját külön világa" - fogalmaz Gyáni Gábor. ${ }^{203}$

\subsection{A helyi társadalom szerkezete}

A szentesi társadalom fejlődése a török hódoltság időszakában vált sajátossá, ugyanis a nemesség elmenekülésével a jobbágyság vette át a település irányítását, magisztrátust alakítva. Mindez szabadabb fejlődést biztosított a nem oszmán kézen lévő vármegyék lakosságához képest, amely folyamat a török kiüzése után sem tört meg. „Innen van az, hogy [a szentesi ember] gondolkodása öntudatos, jelleme sajátságos, peturoskodó és politikát kedvelö. Ezt a sajátságot aztán még növeli az etnikumnak összetétele is, amely eredetében kimutathat a magyar mellett jászt, kunt, törököt, de van azonkívül tót, német, szerb, oláh és görög telepes is, akiket a nyelv, mint szétfeszithetetlen pánt egységesen tart össze, olyan ötvözetet kínálva a történelemírás számára, amely minden bizonnyal dacolni fog az újabb ezer évvel is" - írja Schupiter Elemér. ${ }^{204}$

\footnotetext{
${ }^{201}$ Zsilinszky 1900. 322-324.

${ }^{202}$ Labádi 2006b. 2.

203 Gyáni 1999. 55.

${ }^{204}$ Schupiter 1928c. 253-254.
} 
A kiegyezés után Szentes lakossága számottevően, több mint ötezer fővel gyarapodott a század közepén végzett felmérésekhez viszonyítva: 1850-ben 22 136-an, míg 1869-ben 27 658-an éltek a településen. ${ }^{205}$ (A szentesi járásban az 1869-es - valójában 1870 elején elvégzett - népszámlálás szerint összesen 32 637-en. ${ }^{206}$ ) Korábban már említettük, hogy Szentes nem számított kisvárosnak, illetve, hogy a XIX. század utolsó harmadára a település népessége nagyobb volt, mint napjainkban. ${ }^{207}$ Azonban itt szükséges megjegyeznünk, hogy a népességszaporulat a dualizmus időszakában jelentősen kisebb mértékü volt az országos átlaghoz viszonyítva. 1869 és 1920 között összesen 4729 fővel gyarapodott a lakosság, ami 17\%-os népességnövekedést jelent, s ez a gazdasági fejlödés tükrében igen alacsonynak számít. Szeged esetében ugyanebben az időszakban a gyarapodás mértéke 62,8\%, az országos átlag is $51,8 \%$, emellett a rendezett tanácsú városok átlaga szintén meghaladja az 50\%-ot. Azonban a mezővárosokban a népességnövekedés dinamikája kisebb volt, ráadásul Szentes esetében ezt tovább lassította az elvándorlás, amelyet a többszöri telepítések (pl. a bodrogközi, a soltvadkerti vagy az újszentesi telepítés) okoztak. ${ }^{208}$

A házasságkötések száma a tárgyalt időszakunkra vonatkoztatva: 1874-ben 354, 1877 ben 222, 1879-ben 341, 1880-ban 267, 1881-ben 310, 1882-ben 357, 1884-ben pedig 353, amely arányaiban nagyjából megfelelt az országos átlagnak. A halálozások aránya szintén követi az országos tendenciát, viszont az élve születések számában a település megint az utolsók között található a sorban. ${ }^{209}$ A népsürüség tekintetében Szentes szintén sereghajtó: 1890-ben 77,7 fö $/ \mathrm{km}^{2}$, 1900-ban 79,2 fö/ $\mathrm{km}^{2}$, s 1910-ben is csak 79,9 fö $/ \mathrm{km}^{2}$ adatot mértek, míg a hasonló nagyságú városok esetében ugyanezen évek átlaga: 108,1, 124,1 és 136,6 fö $/ \mathrm{km}^{2}$, az országos városi átlag pedig 139,8, 170,9, illetve 198 fö $/ \mathrm{km}^{2}$ volt. Szentes népsürüsége tehát szinte stagnált, míg más városoknál jelentős növekedés mutatható ki. A 138 rendezett tanácsú város rangsorában népsürüség szempontjából Szentes a 109. helyet foglalta el, amelynek legfőbb oka a település agrárius jellege, a birtokeloszlás, valamint a kedvezőtlen egészségügyi viszonyok voltak. ${ }^{210}$

\footnotetext{
205 Labádi 1995. 273.

206 A Magyar Korona országaiban az 1870. év elején végrehajtott népszámlálás eredményei a hasznos házi állatok kimutatásaival együtt. Országos Magyar Királyi Statistikai Hivatal, Pest, 1871. 82.

${ }^{207}$ Koronként változó, hogy mekkora lakosságszám felett minősül egy adott település városnak, s azon belül milyen típusúnak. 1848-ban a szabad királyi városokról szóló törvény például a következő három kategóriát jelöli meg: „Olly városok, mellyekben 12,000 lakosnál kevesebb vagyon, kis városoknak, - mellyekben 12,000 lakosnál több, de 30,000 lakosnál kevesebb vagyon, közép városoknak, - és mellyekben 30,000 lakosnál több vagyon, nagy városoknak neveztetnek". (1848:XXIII. tc. 4.§; Kövér 2001. 56.) Ez alapján Szentes - nem sokkal ugyan, de - elmaradt a nagyvárosi státusztól, viszont mindenképpen középvárosnak minősült.

${ }^{208}$ Kováts 1928a. 259-260.

${ }^{209}$ Kováts 1928a. 263-264.

${ }^{210}$ Kováts 1928a. 260.
} 
Szentes belterületének nagy részét ugyanis vadvizek, mocsarak borították, emellett a várost kettészelö Kurca vize is többnyire poshadt volt - mindez kiváló táptalajt jelentett számos veszélyes baktériumnak, amelyeket az elszaporodó szúnyogok terjesztettek. Korábban a mocsarakat természetes védmüveknek tekintették, ${ }^{211}$ így a lecsapolásra nem is gondoltak. Történtek ugyan részleges lépések a probléma orvoslására, de a nagyfokú belvízmentesítés csak a XX. században valósult meg. Tárgyalt időszakunkban még bőségesen szedte áldozatait a tífusz, a kolera, illetve egyéb bakteriális kórokozók. Mindehhez hozzávehetjük, hogy az utcák döntő többsége még nem volt kikövezve, így ősztől tavaszig a sár, az egyenetlen, csúszós, esetenként szilárdra fagyott föld jelentett állandó balesetveszélyt, míg a szárazabb hónapokban a szállongó por okozott további egészségügyi kockázatot a lakosságnak. ${ }^{212}$

Gyógyszertár három is müködött a városban a tárgyalt időszakban, az elsőt 1815-ben alapították. ${ }^{213}$ A patikák mennyisége és minősége megfelelő volt, azonban az orvosok száma egészen az első világháborúig nem érte el a tízet. Javított a helyzeten a városi kórház 1873-as megnyitása, de a település közegészségügyi rendszerében még a két világháború között is jelentős hiányosságok adódtak, különösen a tanyasi lakosság körében, akik számára a közlekedési viszonyok tovább nehezítették az orvosi segítség igénybevételét. ${ }^{214}$

Az 1869-es összlakossági adatot tovább vizsgálva: a népesség 22,8\%-a (6300 fö) élt külterületen, míg 77,2\% (21 358 fö) belterületen. ${ }^{215}$ A teljes lakosság 48,7\%-a (13 477 fö) volt férfi, 51,3\% (14 181 fö) nő. A szentesiek közel kétharmada református vallású volt (16 418 fö - 59,4\%), bő egyharmada római katolikus (9 582 fö - 34,6\%), emellett az izraelita polgárok száma majdnem elérte az ezret (919 fó - 3,3\%). Emellett élt a településen 420 evangélikus (1,5\%), 289 görögkeleti (1\%), illetve 12 görög katolikus (0,04\%) vallású egyén, 18 fö́t $(0,06 \%)$ pedig az „egyéb” kategóriába soroltak. ${ }^{216}$ Ebből a szempontból Szentes

\footnotetext{
${ }^{211}$ Schupiter Elemér 1928-ban érzékletes leírást ad minderről: „Az Erzsébet-tér, amely a legszebben kiképzett tere, egészen a Kurca-híd mellett fekszik, amelyen átjutva az úgynevezett túlakurcai alsórétre ér az ember. Ezt a területet, amely nem egyéb, mint a Tisza és a Kurca folyók által határolt terjedelmes sziget, joggal nevezhetjük Szentes ösi menedékhelyének, a hajdani várerösségnek, melyet csak hatalmas felkészültséggel vehetett be egykor az ostromló ellenség. Szentes történelmi nevezetességü vársáncai itt a túlakurcai nádasokban keresendök, ahol annyiszor húzta meg magát a szorongatott nép Dónátról, Ecserröl, Nagykirályságról, Fábiánról, Teésről és a többi elpusztult községböl. Éppen ezért méltán nevezhetjük a mai Szentest ezek jogutódainak." (Schupiter 1928a. 209.)

212 Csák 1928. 264-265.

${ }^{213}$ Labádi 2008b. 2.

${ }^{214}$ Csák 1928. 265-268.

${ }^{215}$ Említést érdemel, hogy - hasonlóan a többi alföldi településhez - Szentesnek is kiterjedt tanyavilága alakult ki a XIX. században az örökváltság, majd a közlegelők szétosztása után, s a tanyák száma a század végén tovább emelkedett a vasút kiépítésének köszönhetően. (Kováts 1928b. 292.)

${ }^{216}$ Kis-Rácz 2000. (1.10.4. - Társadalmi szerkezet, demográfiai jellemzők); Labádi 1995. 273.; a katolikusok a kirekesztettség miatt hosszú évtizedekig élesen elkülönülve éltek a hagyományosan protestáns lakosság mellett: „Az Erzsébet-, Kossuth Lajos-tereken, a Kossuth Lajos-, báró Harrucker-, Petöfi- és Tóth József-utcákon kivül még alig pár utcát lehet a tulajdonképpeni belvároshoz számítani. E városrész Szentest két igen elütő félre
} 
felekezeti összetétele - hasonlóan számos dél-alföldi településhez, például Hódmezővásárhelyhez - meglehetősen eltért az országos, sőt a megyei arányoktól is: ${ }^{217}$

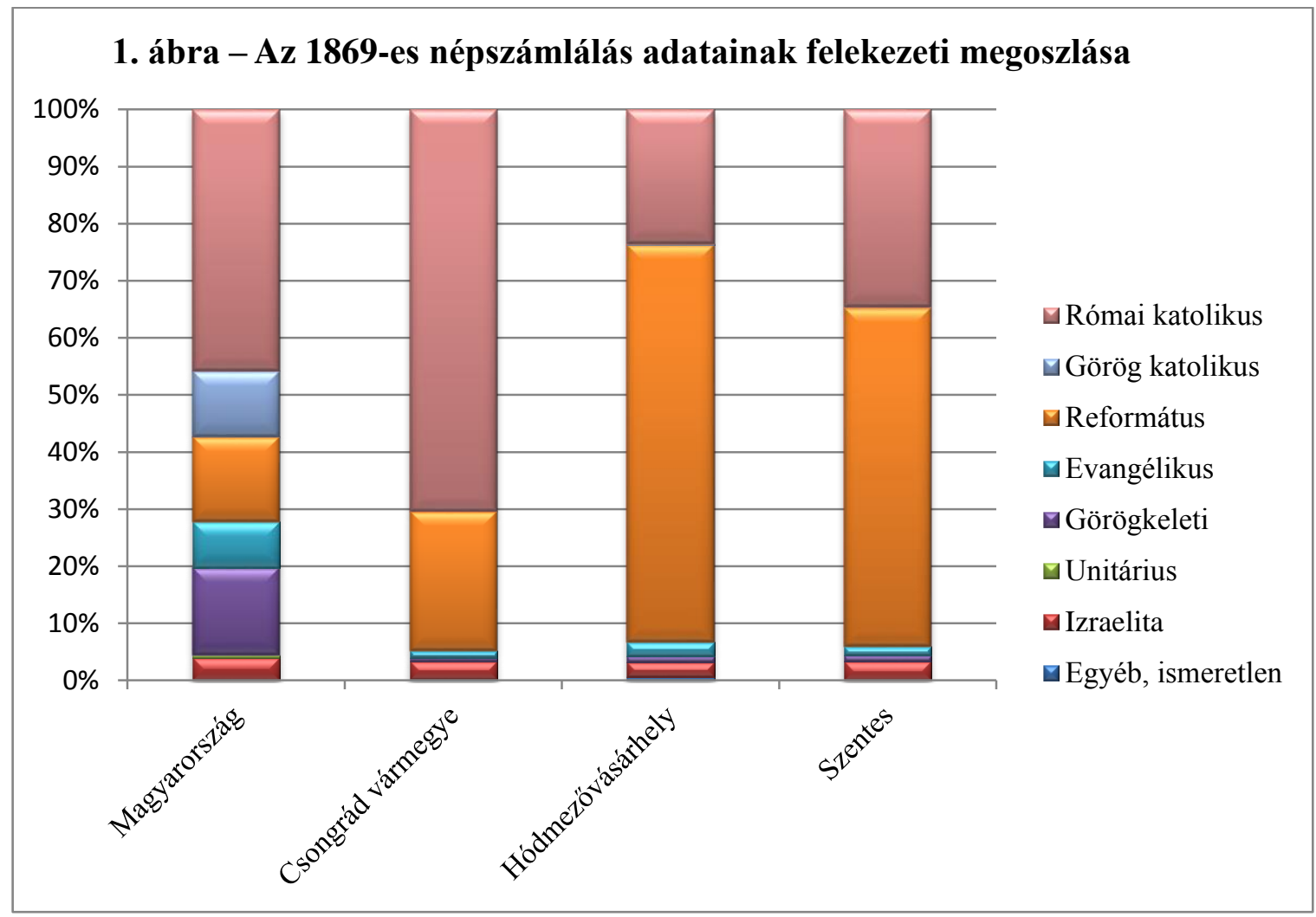

Ha a foglalkozási adatokat vizsgáljuk: az összlakosság 39,8\%-a (11 000 fö) volt kereső, míg 60,2\% (16 658 fö) az eltartott kategóriába tartozott. A közszolgálati és szabadfoglalkozásúak száma összesen 342 volt, ezek közül lajstromba vettek 10 papot, illetve lelkészt; 59 hivatalnokot (11 állami, 5 megyei, 43 pedig községi szolgálatban állt), valamint 38 tanítót, 150 tanulót, 69 művészt és 16 ügyvédet. Az egészségügyben a statisztika szerint 32 fö dolgozott, ebből 6 orvos, 2 sebész, 12 bába, 3 gyógyszerész és 9 „egyéb” kategóriába tartozó személy. A legnagyobb arányt természetesen a gazdászattal foglalkozók tették ki (7402 fö, amely az összlakosság 26,8, míg a kereső népesség 67,3\%-át jelentette), közülük nyilvántartottak 1794 birtokost, 72 haszonbérlőt, 1 gazdatisztet, 2331 éves szolgát, 11 halászt, illetve 3193 napszámost. Az iparüzleteknél összesen 1594-en dolgoztak (794 önálló vállalkozó, 2 hivatalnok és 798 munkás), a kereskedelemben 274-en (108 önálló vállalkozó és 166 munkás), a szállítási vállalatoknál pedig 70-en (10 önálló vállalkozó, 4 hivatalnok és 56

osztja. Az egyik az úgynevezett Kisér, a másik, a nagyobbik rész a Felsőpárt. A Kisér a szegény zsellér, földnélküli katholikusság lakhelye, apró házakkal, girbe-görbe utcákkal, míg a Felsőpárt a földbirtokos reformátusság városrésze, nagy gazdasági udvarokkal." (Schupiter 1928a. 209.) Az említett nevü városrészek, ha nem is tükröznek már éles vallási elkülönülést, a mai napig léteznek.

217 Sebők 2005. 77. 
munkás). Mindezen kívül összeírtak még 6 pénz- és hitelintézeti foglalkoztatottat, 18 háztulajdonost, 89 járadéktulajdonost és 1173 személyes szolgálatot teljesítő - pl. cseléd, kocsis - személyt, utóbbi a kereső népesség 10,5\%-át tette ki. ${ }^{218}$

\subsection{A társadalmi élet színterei: egyletek, népkörök}

Az 1800-as évek első felében - hasonlóan Magyarország legtöbb településéhez - az intézményi keretek között szervezett társadalmi élet Szentesen is gyerekcipöben járt. Az 1840-es években ugyan müködött két kaszinó a városban, de az 1848/49-es szabadságharc vérbe fojtása után mindkettő megszünt. Az abszolutizmus megfélemlítésre épülő évei során még a magánházaknál is ritkán tartottak társas összejöveteleket. ${ }^{219} \mathrm{~A}$ helyi értelmiségiek és tisztviselők az 1860-as évek elején megpróbálták újjászervezni a társasági életet: a Helytartótanács engedélyével megalakult a Szentesi Casino Egylet 165 taggal, azonban a szerény érdeklődés miatt nemsokára a feloszlatást fontolgatták. Az októberi diploma kibocsátása után viszont a Kaszinó újra a társasági élet fontos tényezőjévé vált. Első elnökévé közfelkiáltással Csukás Benjamint választották. ${ }^{20} \mathrm{Az}$ egyletbe elvileg bárki beléphetett, azonban a gyakorlatban ez nem valósult meg: kezdettől fogva csak a tehetősebb helyi polgárok látogatták, s az elit jelleg megörzését a magas tagdíjakkal biztosították. ${ }^{221}$ A Kaszinó azonban - kulturális programjaival, támogatási és segélyezési akcióival, a helyi tehetségek felkarolásával - nagymértékben hozzájárult Szentes polgárosodásához. 1862 tavaszán négy szentesi lakos kérvényt nyújtott be egy másik, polgári kaszinó megalapítása tárgyában, azonban hatósági támogatás híján - mondván, hogy a településen már müködik egy kaszinó szándékuk meghiúsult. ${ }^{222}$ Még ugyanebben az évben szintén kudarcba fulladt egy mükedvelő színtársulat létrehozásának ötlete is: hiába támogatta a kezdeményezést mind az alispán, mind a főispáni helytartó, a Helytartóság nem engedélyezte a társulati formát. ${ }^{223}$

1861. október 23-án megalakult a Szentesi Dalegylet, közismertebb nevén a „Dalárda” a fiatal református orgonista-kántor, Joó Károly vezetésével. Alapszabálya célul tüzte ki a müvészet, a zene gyakorlását és terjesztését, különösen a nemzeti dalokét; ezen kívül

\footnotetext{
${ }^{218}$ Labádi 1995. 274.; Kis-Rácz 2000. (1.10.4. - Társadalmi szerkezet, demográfiai jellemzők)

${ }^{219}$ Kis-Rácz 2000. (1.10.7. - Társadalmi körök, egyesületek)

220 Túri 1994. 25-26.

${ }^{221}$ Kis-Rácz 2000. (1.10.7. - Társadalmi körök, egyesületek)

222 Túri 1994. 28-29.

${ }^{223}$ Kis-Rácz 2000. (1.10.7. - Társadalmi körök, egyesületek)
} 
hangversenyek és kirándulások szervezését. Az egylet tagjai főként a helyi értelmiségből kerültek ki, első fellépésük 1861 szilveszterén volt, amikor nemzeti dalokat adtak elő. Országos hírnévre is szert tettek: 1867-ben megnyerték az Aradon rendezett országos „dalárünnepélyt". ${ }^{224} \mathrm{Az}$ abszolutizmus éveiből meg kell még említenünk az 1864 februárjában alakult Temetkezési Egyletet, az 1866-ban létrehozott Szentesi Segély-Egyletet, valamint az 1865-ben induló Izraelita Nőegyletet. ${ }^{225}$ Utóbbi feltehetően már az 1840-es években is müködött, s megléte is jelzi, hogy az alföldi településen a zsidóság viszonylag jelentős számarányt képviselt, illetve, hogy igyekezett intézményi keretek között gyakorolni a jótékonyságot. Az Izraelita Nőegylet számos rendezvényt is szervezett több évtizedes müködése során. Meghatározó alakja volt Bánfalvi Lajosné, aki hosszú időn keresztül az elnöki pozíciót is betöltötte. ${ }^{226}$

Az egyesületek alakulása tekintetében a kiegyezés hozott igazi áttörést, 1867-től egymás után jöttek létre a különféle kulturális, társadalmi, gazdasági, vallási és politikai társulatok, egyletek, körök. 1867. május 12-én kezdte meg müködését 567 taggal a Szentesi Honvédegylet, amely az egykori szabadságharcos honvédeket és tiszteket tömörítette, $\mathrm{s}$ egészen a XX. század elejéig fennállt. ${ }^{227}$ Első elnöke Hutiray (Lukácsy) Lajos 48-as honvéd őrnagy volt - a 40. honvéd zászlóalj egykori parancsnoka, aki Klapka György alatt teljesített szolgálatot a szabadságharcban -, utolsó vezetője pedig a korábban már említett Kiss Zsigmond egykori tüzér hadnagy, későbbi városi főügyész és képviselő. ${ }^{228}$

1870. június 10-én tartotta alakuló ülését a Szentesi 48-as Párt Népköre. Támogatói főként a parasztság köreiből kerültek ki, 1874-ben már 340 tagja volt. Létrehozása előzményének az 1869-es választásokat tekinthetjük, amikor az ugyanabban az évben megalakult helyi 48-as párt szerette volna híveit a referendum után is valamilyen intézményesült formában egyben tartani. A szervezőmunkát nagyrészt Ferenczy Sándor, a párt jegyzője végezte, aki a Népkör elnöke is lett, míg tiszteletbeli elnökké Kossuth Lajost választották. Egy évvel később a politikai okokból bebörtönzött Ferenczy helyét a korábbi alelnök, ifj. Posta János foglalta el. A népkör számos országosan ismert személyiséget is tiszteletbeli tagjává választott, például Táncsics Mihályt, Madarász Józsefet, Simonyi Ernőt, Irányi Dánielt vagy Vidács Jánost. „A haza alkotmányos és demokratikus jogainak társalgás közben egymással való ismertetése. A valódi népönkormányzatnak eszmecserék segedelmével

\footnotetext{
${ }^{224}$ Derzsi 1928a. 222-225.; Túri 1994. 63-68.

225 Túri 1994. 105.

226 Vajda 1928. 189-190.; Túri 1994. 72-73.; Harsányi 1970. 108.; Follajtár 1938. 10.

${ }^{227}$ Kis-Rácz 2000. (1.10.7. - Társadalmi körök, egyesületek), Túri 1994. 106.

${ }^{228}$ Labádi 2010d. 2.; Labádi 2004b. 3., Labádi 2007b. 2.
} 
való elvileg fejlesztése és arra való hazafias törekvés ébresztése, hogy az törvényes úton hazánkban érvényre emeltessék" - olvasható a szervezet célkitüzései között. A népkör 1871. szeptember 24-én tartott ünnepélyes zászlóavató rendezvényén bemutatták a szervezet díszes zászlóját, rajta a jelmondattal: „Erős akarat nem ismer akadályt!"229

A kiegyezés utáni első években a 48-as Népkör mellett más jelentős egyesületek és társulatok is megkezdték müködésüket a városban. Ilyen volt az 1867-ben induló Jótékony Nőegylet, amely alapszabályában a nevelésügy előmozdítását, a szegény gyermekek támogatását tűzte ki céljául. Első elnöke Beliczai Pálné volt, 1878-ban taglétszáma meghaladta a háromszázat. 1876. július 9-én a nőegylet erőfeszítései nyomán nyílt meg Szentes első kisdedóvója Sonnenfeld Sámuel ${ }^{230}$ Serkocsma közi házában, ahol hatvan gyermek felügyeletére nyílt lehetőség. ${ }^{231}$ Megemlíthetjük még a különböző szakmák (asztalosok, szabók, takácsok, csizmadiák, tímárok stb.) ipartársulatait, amelyek zöme az 1870-es évek első felében jött létre, az Önkéntes Tủzoltó Egyletet (1873), a Polgári Iparos és Gazdasági Kört (1879), az Iparos Ifjak Képző- és Segély-Egyletét (1880) vagy a KorcsolyázóCsónakázó Egyletet (1881), amely a város első sportegyesületét jelentette. ${ }^{232}$

Az 1880-as és 1890-es években még tovább bővült a szentesi egyesületi élet, számos új politikai, vallási, gazdasági és kulturális egylet, népkör kezdte meg müködését, az Ügyvédi Körtől kezdve a Csongrád Vármegyei Történelmi és Régészeti Társulaton keresztül egészen a Sakk Körig. ${ }^{233}$

\subsubsection{A Szentesi Polgári Olvasókör}

Az egyesületek közül - tekintve dolgozatunk tárgyát - külön kiemeljük a helyi olvasókört, amely nem csak a közmüvelődés, hanem sok esetben a politikai élet meghatározó szereplője volt Szentesen a dualizmus idején. Az olvasókörökröl általánosságban elmondható, hogy fontos szerepet töltöttek be az iskolán kívüli művelődésben és a közösségformálásban, hiszen nem csak városokban, hanem falvakban, sőt a tanyavilágban is elterjedtek. Az ilyen jellegü,

\footnotetext{
${ }^{229}$ Bezdán 1974. 3-14.; Labádi 2005c. 2.; Túri 1994. 36-41.

${ }^{230}$ Sonnenfeld Sámuel a város régi iparos családjának sarja, gőzmalom-tulajdonos. 1873-tól 1884-ig a szentesi zsidó hitközség elnöke. Az 1875-ös választásokon az izraelita vallásúakat tömegesen vezette szavazni, akik Sonnenfeld utasítására mind az ellenzéki jelöltet támogatták Jókai Mór ellenében, sikerrel. (Harsányi 1970. 64.) ${ }^{231}$ Feketéné 2001. 17-20.

${ }^{232}$ Túri 1994. 106-107.. A Korcsolyázó- és Csónakázó Egylet 1881-ben alakult ötven taggal, s ugyanebben az évben ünnepélyes keretek között felavatták Szentes első jégpályáját a Kurcán. A szervezet alapszabálya szerint a tagok nyáron eveznek és vitorláznak, míg télen a korcsolyázásnak hódolnak. (Túri 1994. 59-60.)

${ }^{233}$ Kis-Rácz 2000. (1.10.7. - Társadalmi körök, egyesületek)
} 
szerencsés esetben saját helyiséggel is rendelkező egyletek járatták a legfontosabb helyi és országos lapokat, de az olvasás mellett beszélgettek, kártyáztak, tekéztek, illetve alkalmanként bálokat vagy színielőadásokat is szerveztek. Területi, politikai vagy világnézeti alapon is szerveződhettek (lásd a katolikus, református, izraelita stb. egyleteket; a 48-as olvasóköröket, vagy akár a kakasszéki olvasókört Hódmezővásárhely tanyavilágában). ${ }^{234}$

Az első Szentesi Olvasóegyletet az 1860-as évek elején alapították a településen. A Szegedi Hiradó 1861. január 20-i száma beszámol róla, hogy a Szentesi Olvasóegylet Kossuth Lajost, Klapka Györgyöt, Türr Istvánt, Perczel Mórt, Horváth Mihályt és Horn Edét tiszteletbeli tagjává választotta. A kérészéletű egyesület a rövid alkotmányos időszakot követően minden bizonnyal megszünt. ${ }^{235}$ Néhány év múlva az „úri” Kaszinó ellensúlyozása céljából a kis- és középpolgári réteg ismét kísérletet tett egy új egyesület létrehozására. 1866ban Oroszi Miklós országgyülési képviselő, Ónodi Sándor ügyvéd, valamint Csukás Benjamin gimnáziumi igazgató állt a kezdeményezés élére. Elhatározták, hogy felállítják saját polgári olvasókörüket. Mivel biztosak akartak lenni az engedélyezési eljárás sikerében, az egylet alapszabályához a már jóváhagyott Kisújszállási Olvasóköré szolgált mintául. ${ }^{236}$ Kérvényüket 1866. októberben juttatták el a szentesi főszolgabíróhoz, amely szerint az egyesület „czélja semmi más - mint a szegényebb sorsú polgároknak is alkalmat nyújtani arra, hogy a hírlapok olvasás, és illedelmes társalgás által mívelödjenek, a földmívelés és az ipar terén felmerülö czélszerü javitások ösmeretére jussanak, s ez által szellemi és anyagi tekintetben elömenetelt tehessenek". 237

A megyei tisztiszék és a főispán egyaránt a kérvény elutasítását javasolta a Helytartótanácsnak, mondván, hogy egyrészt Szentesen már müködik egy hasonló szerveződés, a Kaszinó, akinek bárki tagjává válhat; másrészt politikai szempontból veszélyesnek ítélték az egyesületet. A hosszas engedélyezési eljárást megakasztotta a kiegyezés, amelynek köszönhetően a Helytartótanács elvesztette illetékességét az ügyben, az új belügyminisztérium pedig zöld utat adott a kezdeményezésnek, így a Szentesi Polgári Olvasókör 1867. május 30-án, 210 taggal megtarthatta alakuló ülését. Elnökké Oroszi Miklóst, alelnökké Ónodi Sándort, pénztárnokká Csukás Benjamint, jegyzővé pedig Buday Józsefet választották. (Oroszitól az 1869-es tisztújításkor Stammer Sándor vette át az elnöki tisztséget, őt pedig 1882-ben Balázsovits Norbert tanár követte a pozícióban.) ${ }^{238}$

\footnotetext{
${ }^{234}$ Andrásfalvy 1996. 373.

${ }^{235}$ Kis-Rácz 2000. (1.10.7. - Társadalmi körök, egyesületek)

${ }^{236}$ Uo.

237 Túri 1994. 30.

238 Túri 1994. 31-32.
} 
Az olvasás, a társasági élet szervezése mellett a kör fontosnak tartotta a jótékonyságot is: 1869-ben az aradi vértanúk szobrára, egy évvel később rokkant szabadságharcos honvédek részére szerveztek bált, de anyagi segítséget nyújtottak az Országos Honvédmenház felépítéséhez, az 1873-as kolerajárvány ${ }^{239}$ miatt elárvult gyermekek megsegítéséhez, a vizsgázott iparostanoncok jutalmazásához vagy a budai 48 -as honvédek emlékművéhez is. ${ }^{240}$

1878 végére szervezeti átalakulás történt az egylet életében: a tagok többségének érdektelensége okán zavarok keletkeztek a müködésben, így felmerült a szentesi általános iparegylettel való egyesülés gondolata - utóbbi szervezet hasonló gondokkal küszködött, így a fúziótól mindkét fél az erősödést remélte. 1878. november 17-én az Olvasókör feloszlató közgyülést tartott, ${ }^{241} \mathrm{~s}$ a következő esztendő első napján kimondták az egyesülést. Az új szervezet Szentesi Polgári Ipari és Gazdasági Kör néven folytatta tevékenységét, három közmüvelődési, iparos, gazdászati - szakosztállyal. Elnöke Stammer Sándor, alelnöke Kristó Nagy István lett. A kibővült egyesület 1882-ben kereskedelmi szakosztállyal is gyarapodott, mikor harminc szentesi kereskedő lépett be együtt a tagok sorába. 1890-ben tavaszán a közmüvelődési szakosztály kivált a szervezetből, és önálló egyletet hozott létre Polgári Olvasókör néven, amely azonban a XX. század első évtizedében feloszlott. ${ }^{242}$

\subsection{Gazdasági élet}

\subsubsection{Mezőgazdaság}

$\mathrm{Az}$ alapvetően agrárius jellegü Szentes mezőgazdasági viszonyainak átalakulását nagymértékben elősegítette a XIX. század utolsó két évtizedében, illetve az 1900-as évek első harmadában az ármentesítés, a belvízszabályozás, a vasutak kiépítése, valamint a modernebb

\footnotetext{
${ }^{239}$ Az említett járvány az egyik legsúlyosabb volt a XIX. század népegészségügyi katasztrófáinak sorában, amely 1872 és 1874 között tombolt hazánkban. A pusztítás mértékét jelzi, hogy a demográfiai veszteséget csak hat év alatt tudta kiheverni az ország. (Kósa 2002. 305.; Fónagy 2001. 151.) Összesen 190000 ember halt meg az Oroszország felöl betörö járvány során, az 1873-as esztendőben a nyers halálozási ráta 65\%-os volt. (Kövér 2002. 221.)

240 Túri 1994. 33.

${ }^{241}$ SZL, VIII. évf. (1878) 46. sz. 1. (Megjegyzés: az 1872-ben indult Szentesi Lap évfolyamszámozása az 1873. április 20-i számtól kezdve tévesen második évfolyamról harmadik évfolyamra vált, és ezt a hibát utána - a későbbi évfolyamok jelölésénél is - következetesen alkalmazza. Az 1878-as esztendő tehát helyesen nem a nyolcadik, hanem a hetedik évfolyam volna, az 1879-es a nyolcadik, és így tovább. Az említett újság elemzése azonban dolgozatunk leghangsúlyosabb része, így a könnyebb visszakereshetőség érdekében mi is a hibás, tehát a fejléceken feltüntetett évfolyamszámozást alkalmazzuk.)

242 Túri 1994. 33-36.
} 
eszközök és a mütrágya alkalmazása. Az intenzív, modern földművelés tehát az 1880-as években kezdődött. A belvízszabályozás lehetővé tette a mezőgazdasági területek jobb kihasználását, viszont új anyagi terhet is jelentett, amit a lakosság többlettermeléssel akart ellensúlyozni. Megemlítendő, hogy szintén az 1880-as években kezdték el használni az első mezőgazdasági gépeket: 1883-ban a szentesi határban már 14 cséplőgép dolgozott. ${ }^{243}$

Túlnyomórészt gabonaféléket, azon belül elsősorban búzát termesztettek, emellett kukoricát, árpát, zabot és rozst. (Mindebben a település az országos tendenciát követte: a búza ekkoriban vált a magyar gabonatermesztés elsődleges fajtájává. ${ }^{244}$ ) A tárgyalt korszakban azonban a belvizek, a tiszai árvizek gyakran jelentős pusztítást végeztek a terményekben, komoly gazdasági és társadalmi problémákat okozva. ${ }^{245}$ Emellett Szentesen is éreztette hatását az 1870-es évektől kezdődő mezőgazdasági dekonjunktúra: nem a termények eladhatóságával adódtak problémák, hanem az árak hirtelen, nagyarányú váltakozásaival, amelyek hol hirtelen felszöktek, hol pedig gyorsan a mélybe zuhantak. ${ }^{246}$ Jelentékeny, de nem meghatározó mennyiségü volt még a szentes-nagyhegyi homokbuckákon folytatott szőlőtermesztés, illetve a gyümölcstermesztés - a talajviszonyok elsősorban a csonthéjasoknak kedveznek, a szentesi meggy például országosan ismert termék volt. Ami az állattenyésztést illeti: a helyiek föként sertést, szarvasmarhát, lovat, juhot és baromfit tartottak. $^{247}$ Meg kell még említenünk az 1869-ben Oroszi Miklós polgármester által létrehozott gyümölcsös, faiskola és sétakertet a Kurca túloldalán (a későbbi Széchenyiligetet), ahol a faiskolában termelt facsemetéket a város önköltségi áron bocsátotta a lakosság rendelkezésére. ${ }^{248}$

\subsubsection{Ipar}

Szentes esetében a XVIII. század második fele előtt helyi iparról gyakorlatilag nem beszélhetünk, hiszen az iparos lakosság a védettebb helyekre húzódott az oszmán veszély elöl. A helyi ipar a Harruckern család alatt jelent meg, illetve kezdett megerösödni: ekkor települt Szentesre nagyobb számú, elsősorban katolikus vallású, német ajkú iparos. A XVIII. század második, illetve a következő évszázad első felében megalakultak az első céhek, amelyek

\footnotetext{
${ }^{243}$ Kováts 1928b. 292-293.

${ }^{244}$ Fónagy 2001. 130.

${ }^{245}$ Kováts 1928b. 292-293.

${ }^{246}$ Für 1996. 217.

${ }^{247}$ Kováts 1928b. 292-295.

${ }^{248}$ Scherg 1928. 297-298.
} 
elsősorban az egyszerű mesterségeket űző iparosokat - csizmadiákat, takácsokat, molnárokat stb. - tömörítették szervezetbe, luxusiparról tehát a városban nem beszélhetünk. 1853-ban Szentesen tizenhét céh müködött, a legnagyobb a csizmadiák céhe volt 131 taggal. A helyi iparosok számára két dolog nehezítette a biztos megélhetést: egyrészt a túltermelés, másrészt a kontárok nagy száma, akik ellen a céhszervezet több-kevesebb sikerrel igyekezett fellépni. Az 1872-es ipartörvény megszüntette ugyan a céheket, az iparüzés szabaddá vált, ${ }^{249}$ de az említett probléma nem oldódott meg, sőt fokozódott, a kontárok száma még tovább nőtt. ${ }^{250}$

A XIX. század második felében több jelentős gyáralapítás történt Szentesen: az első a Tóth József-féle gőzmalom volt, amely 1862-ben kezdte meg müködését, a szintén helyi alapítású Zsoldos-gőzmalom és téglagyár 1856-ban, 1866-ban pedig az Első Budapesti Gőzmalmi Rt. létesített helyi fióktelepet. Az 1870-es években még két gőzmalom és két gőzfürésztelep, a következő évtized végén tégla- és cserépgyár nyitotta meg a kapuit Szentesen. ${ }^{251} \mathrm{Az}$ elsősorban helyi igényeket kielégítő nagyipar mellett jelentősen fejlődtek a korszakban a kisipari vállalkozások, valamint egyes háziipari tevékenységek, például a selyemgubó-termelés, a gyékény- és kosárfonás vagy az árvízvédelem megszervezését követően a talicskakészítés. ${ }^{252}$

\subsubsection{Kereskedelem}

Szentes kereskedelmi lehetőségeit és jelentőségét a Tisza közelsége határozta meg kezdetektől fogva. A Harruckernek időszaka alatt a rendeződő viszonyok a kereskedelem fellendülését is hozták: 1754-ben már öt görög kereskedőt tartottak nyilván, akiknek hamarosan számos zsidó és rác versenytársuk akadt. III. Károlytól a város három országos vásár tartására is engedélyt kapott (április 24., július 22., szeptember 21.), amelyek fő tárgya akkoriban a szarvasmarha volt. Az 1830-as és 1840-es években a település a környék dohányés gyapjúpiacává lett, az örökváltság után pedig a felszabadult Szentes részére újabb országos vásár (február 2.) tartását is engedélyezték. A kereskedelem fejlődését viszont jelentősen gátolták a nagyfokú hiányosságokat felmutató közlekedési és hitelviszonyok. ${ }^{253}$

\footnotetext{
${ }^{249}$ Fónagy 2001. 132.

${ }^{250}$ Kováts 1928c. 301-302.

${ }^{251}$ Kováts 1928c. 302.

${ }^{252}$ Schupiter 1928d. 306.

253 Kováts 1928d. 309.; Szentesen elöször Klauzál Gábor próbált hitelintézetet létrehozni, mikor 1845-ben megalakult a Szeged-Csongrádi Takarékpénztár, de nem sikerült Szentest is bevonni a cég működési területébe. 1869-ben nyitotta meg kapuit a Szentesi Takarékpénztár, majd a következő évben a Szentesi Gazdasági,
} 
A szabadságharcot követően a gabona, a baromfi és a sertés lett a település legfontosabb exportcikke. 1853-ban megalakult a szentesi Kereskedelmi Társulat, az 1870-es évek kereskedelme pedig már jelezte azt az irányt, amely évtizedekre meghatározta az ágazatot helyi szinten: a búza, a liszt, a korpa, a hízott baromfi, a sertés, a tégla és a fürészáruk váltak az elsődleges terményekké, illetve termékekké. 1872-ben például már a szentesiek adták el a legnagyobb mennyiségü (150 000 db) hízott ludat az országban. Fontos megjegyezni, hogy a helyi vásárok forgalma nagymértékben függött az időjárástól: esős időben a tanyán élő termelők nagy része nem tudott szekérrel bemenni a városba, hogy terményét vagy élőállatát áruba bocsássa. ${ }^{254}$ Mindemellett meg kell említenünk a helyi vásárlóerőre építő, különböző profilú - dohány, ruházat, óra, papíráru, tüzelöanyag, élelmiszer, szerszám stb. -, kiskereskedelemmel foglalkozó vállalkozókat, akik száma 1867 után szintén gyarapodott, mint az a helyi lapok hirdetési rovataiból egyértelmüen kiderül.

\subsection{Közlekedés}

„A közlekedési viszonyok rendkivül siralmasak, még a város belterületén is. Sáros időben a föúton is elakadnak a kocsik, a járdákat víz borítja (deszkapallókon járnak); vízvezetöcsatorna alig van. 1873-ban hoz elöször határozatot a közgyülés burkolt járdák létesitéséröl, de most még nem jut pénz kövezésre" - írja Dimák Géza a korabeli viszonyokról. ${ }^{255} \mathrm{~A}$ városon belüli közutak és járdák kikövezését Kristó Nagy István polgármester kezdte meg, majd Balogh János jóval nagyobb méretekben folytatta a munkát. ${ }^{256}$

Kereskedelmi és Bizományi Hitelintézet, utóbbi néhány évvel később Szentesvidéki Takarékpénztár néven müködött tovább. 1885-ben indult a Szentesi Kölcsönössegélyező Szövetkezet, egy évvel később a Szentesi Hitelszövetkezet, 1891-ben pedig a Csongrádmegyei Takarékpénztár, amely azonban 1894-ben átköltözött Csongrádra. (Kováts 1928e. 312.)

${ }^{254}$ Kováts 1928d. 309-310.

255 Dimák 1928. 312-313.

256 Lásd a 2.3. alfejezetet. Megjegyzendő, hogy a szilárd útburkolat kiépítése mellett a biztonságos közlekedéshez elengedhetetlen az azokat használó emberek kulturáltságának bizonyos foka is. Érdekes adalékot olvashatunk minderröl az 1928-as Szentes-monográfiában, amely ugyan már a XX. századi viszonyokat taglalja, viszont nincs kétségünk afelől, hogy nem volt ez másképpen néhány évtizeddel korábban sem: „A gyalogjárók során mindkét oldalon égetett téglából rakott járda húzódik. Van azonban valami, ami még ennél is érdekesebb. Az úttest. Hogy a kocsik a feneketlen sárban el ne süllyedjenek, aszfaltburkolatot kapott. Mindenki ezt használja és sokszor megesik, hogy a sétáló közönség a legelöröl hazatérö jószágokat a járdára szoritja. Hogy ez így van, az nem minden jelentöség nélkül való. Eredete abban a nagy szeretetben gyökeredzik, amellyel a szentesi gazda jószágai, de legföként lovai iránt viseltetik. Az ö életfelfogása szerint elöször a ló, azután az ember. Még ma is gyakran megtörténik, hogy beteg családja vagy cselédje hogylétét egykedvün veszi tudomásul és nagy bölcseségü flegmával mondja: - »Majd meggyógyítja a természet« - ennél többre azonban csak a végső esetben hajlandó. Ellenben, ha a lova gyengélkedik, menten a lódoktor után megy. Nincs ebben semmi gáncsolni való, söt a 
A városon kívüli közlekedés, a többi településessel, az ország más részeivel való rendszeres kapcsolattartás, illetve kereskedelem tekintetében a kiegyezés után még jó néhány évig szintén komoly hiányosságok mutatkoztak. A várostól öt kilométerre volt a böldi (máshol: bődi) rév, amely biztosította ugyan a Tiszán való átkelést, azonban a településről bármilyen irányban kiérve a közutak állapota mindenhol középkori viszonyokat tükrözött. Már a szabadságharc előtt is születtek országos szinten tervek a környék közlekedési viszonyainak javítására, sőt állandó híd építésére is a Tiszán Szentes közelében, azonban a kezdeményezések kudarcba fulladtak. ${ }^{257}$

A vasút szükségességének kérdésköre szintén nem a kiegyezés után vetődött föl először, de az ügy 1867 után kapott újabb lendületet: az Oroszi-, majd a Kristó Nagy- és a Balogh-féle városvezetés is lelkes szorgalmazója volt a megvalósításnak. ${ }^{258}$ Főként a Szentest is érintő Kiskunfélegyháza-Orosháza, illetve a Szolnok-Hódmezővásárhely vonalakról volt szó, s mint azt a későbbiekben látni fogjuk, a vasút kérdése, a megvalósítás ütemezése gyakori téma volt az 1870-es években a helyi sajtóban, nemegyszer éles vitákat is generálva. Az 1870es években a szentesi vezetés több hazai vállalkozóval, sőt amerikai befektetőkkel is tárgyalt, emellett a város 1871-ben a pályaudvar megépítésére 15 hold területet, a vonal részére pedig a határban ingyen földet, valamint a vállalkozónak 30000 forintot ajánlott fel, ha megépíti a Szolnok-Hódmezővásárhely-vonal ezen szakaszát. Vásárhely és a vármegye is támogatta az ötletet, így ez a vonal épült meg elöször. Közben a Kiskunfélegyháza-Orosháza-vonal tervét egy időre félre kellett tenni, mert a kormányzat a gazdasági nehézségek miatt nem adott egyelőre engedélyt a megvalósítására. Az első vasútvonal átadása már tárgyalt időszakunkon kívül esik: Sarkadi Nagy Mihály polgármester regnálása idején, 1887-ben utazhatott először a nagyközönség a Szentes-Kunszentmárton-vonalon. ${ }^{259}$

1882-ben megindult az állandó gőzhajójárat Szentes és Szolnok között, így a város első fő közlekedési vonalát észak-déli irányban - vasút híján - a Tisza jelentette. Természetesen mindez nem pótolta a közúti és vasúti közlekedést, de a csongrádi közúti és vasúti híd megépítésére majd csak a XX. század elején, 1903-ban került sor. ${ }^{260}$

\footnotetext{
szentesi magyarnak ez egyik legszebb jellemvonása, mellyel jószágát, dolgozó és kenyérkeresö társát hüséges ragaszkodással becsüli meg." (Schupiter 1928a. 209-210.)

${ }^{257}$ Dimák 1928. 312.

${ }^{258}$ A külföldi befektetők mellett az állam is igyekezett fokozni a vasútépítési kedvet, az ún. kamatgarancia bevezetésével, vagyis az állam abban az esetben is garantálta a befektetett tőke 3-5\%-os hozamát, ha a létrehozott vasútvonal veszteségesnek bizonyult. Mindez - hasznossága ellenére - óriási pénzügyi visszaélésekhez is vezetett: sok vállalkozó eleve olyan pályákat épített, ahol nem volt tényleges forgalom, csak hogy élhessen a biztos haszonnal. (Kaposi 2002. 215-216.)

${ }^{259}$ Dimák 1928. 312-313.; Rózsa 1987. 3-35.

${ }^{260}$ Dimák 1928. 313.
} 


\subsection{Oktatásügy}

A legfontosabb változást Szentes közoktatásának ügyében a báró Eötvös József-féle, 1868-as népoktatási törvény jelentette, amely egységesen rendezte az alapfokú képzést, ${ }^{261}$ létrehozta a felsőbb népiskolákat és a polgári iskolákat. ${ }^{262}$ Emellett bevezette az általános tankötelezettséget hattól tizenkét éves korig, ingyenessé tette a népiskolai oktatást a rászorulók számára, előírta az anyanyelvü oktatáshoz való jogot és az országban húsz tanítóképző felállítását. A polgári iskolában a fiúk hat-, a lányok négyéves képzésben részesültek, felvételt pedig azok a tízéves gyermekek nyerhettek, akik elvégezték az elemi népiskola első négy osztályát. A törvény rendelkezett az iskolaszék, a népiskolai hatóságok, valamint a tanfelügyelők hatásköréről is. Az iskolaszék kilenctagú testület volt, tagja volt a helyi lelkész, a tanító, valamint a település lakosainak oktatásügyben jártas képviselői, feladata pedig a községi népiskola helyi felügyelete volt. ${ }^{263}$ (Később a felekezeti népiskolák mellé is felállítottak iskolaszékeket, s megszervezték az állami felügyeleti rendszert, amely ellenőrizte az állami és az egyházi népiskolák müködését. ${ }^{264}$ ) Az iskolaszék feladata volt a tanító választása, emellett felügyelte az intézményben folyó munkát, gondoskodott az épületek állagmegóvásáról, a taneszközök beszerzéséröl; képviselői részt vettek az iskolai vizsgákon, és hozzájuk lehetett fordulni, ha a tanító és a szülő között vita támadt. ${ }^{265}$

Szentesen, mint már korábban említettük, 1876-ban megnyílt az első kisdedóvó intézmény. ${ }^{266} \mathrm{~A}$ hagyományosan az egyházak kezelésében lévő belterületi elemi népiskolák számát megnövelte a kiterjedt tanyavilág: az önkényuralom időszakában négy külterületi iskola is létesült, amelyek később egyházi gondozásba kerültek, majd 1869-ben ismét a város vette át őket. 1883-ban megnyílt a derekegyház-oldali, 1885-ben a tőkei, 1891-ben pedig az eperjesi határrészben létesített elemi népiskola is. (A tanyai iskolák száma a XX. század elején még tovább szaporodott. $)^{267}$

\footnotetext{
261 Az addig három-, négy- vagy ötosztályos alapfokú iskolákat hatosztályos elemi népiskolákká kellett fejleszteni, emellett a törvény kimondja: „Oly községben, a hol a törvény kellékeinek megfelelö tanintézettel biró egyház vagy egyházak hivein kivül más hitfelekezethez tartozó, legalább 30 tanköteles gyermek is van, a kiknek szülöi a fennálló felekezeti iskolákat használni nem akarják: köteles a község közös népiskolát állítani. Az ilyen községi iskola költségei mindenekelött a község azon közös vagyona jövedelmeiböl fedezendők, a melyek iskolai czélokra rendelvék, és pedig oly arányban, a minö arányban áll a községi iskolába járó gyermekek száma a felekezeti iskola vagy iskolák növendékeihez.” (1868:XXXVIII. tc. 44.§; Fónagy 2001. 208.)

${ }^{262}$ Fizel 2017. 29.

${ }^{263}$ Pukánszky 1996. 9.2. - Pedagógia és iskoláztatás 1867-1919 között

264 1876:XXVIII. tc. 4-14. §

${ }^{265}$ Pukánszky 1996. 9.2. - Pedagógia és iskoláztatás 1867-1919 között

${ }^{266}$ Lásd a 2.5. A közélet szinterei: egyletek, népkörök pontot

${ }^{267}$ Derzsi 1928b. 191.
} 
Még 1859-ben állította fel a református egyház négyosztályú gimnáziumát, amelyet 1863-ban öt-, 1864-ben pedig hatosztályosra fejlesztett fel. Az 1870/1871-es tanév második felében az intézmény beolvadt az akkor megszervezett községi polgári fiúiskolába, s ettől kezdve mint gimnáziumi tanfolyammal egybekötött polgári fiúiskola müködött 1878 nyaráig, sajátos módon: az ötödik és a hatodik osztályban 1875-től tisztán gimnáziumi jellegű oktatás folyt, s az alsóbb osztályokba is többségében olyan diákok jártak, akik a gimnáziumi képzésben kívántak továbbtanulni. Az iskola a Széchenyi-ligetben, a korábbi vendéglő épületében nyert elhelyezést. (1887 szeptemberében végül megszünt a polgári tagozat, és hatosztályú gimnáziummá lett az intézet, 1891-től pedig már nyolcosztályos képzés folyt. A következő évben, 1892-ben rendezték az első érettségi vizsgákat. Később az állam átvette a várostól az intézményt, amely a ma is müködő Horváth Mihály Gimnázium jogelődje.) ${ }^{268}$

1869-ben a város döntött egy kétosztályos polgári leányiskola felállításáról is, amelynek fő kezdeményezője és első igazgatója a gimnázium vezetője, Zolnay Károly volt. ${ }^{269}$ Az intézmény 1871 februárjában nyitotta meg kapuit, jelentős nehézségekkel: egyrészt a várostól kapott épület csak ideiglenes kényszermegoldás volt (a fötéren, a későbbi vármegyeháza helyén akkor még álló „kis városházában” rendezkedett be az iskola), másfelől - mivel az újonnan felállított tanítóképzők miatt nem volt még elegendő számú képzett oktató - komoly szakmai kifogások is felmerültek. ${ }^{270} \mathrm{Az}$ oktatók többnyire a gimnáziumi és a polgári fiúiskolai tanárok közül kerültek ki, s óraadói minőségben dolgoztak. A színvonal emelkedett, de 1881-ben megkezdődött az új vármegyeháza építése, tehát a régi városházát ki kellett üríteni. Több helyváltoztatás után, majd csak 1913-ban költözhetett be az iskola méltó helyére, az egykori Úri utca végén megépült „Kultúrpalotába”. ${ }^{271}$

Említést érdemel még a református egyház 1854-ben felállított vasárnapi iskolája, amely befogadott mindenkit, aki szerette volna bővíteni vagy pótolni általános ismereteit. A

\footnotetext{
${ }^{268}$ Follajtár 1938. 11.

269 Zolnay Károly, a szentesi középfokú oktatás megszervezője a temesi Végváron született 1833-ban. Középiskolai tanulmányait Temesváron és Debrecenben végezte. A debreceni főiskolán magyar-latin-német szakos tanári diplomát szerzett, majd a debreceni kollégiumban lett oktató. 1859-ben a szentesi református egyház meghívta az új gimnázium első tanárának, ahol az első, második és harmadik osztályos gyerekeket tanította. 1862-ben a harmadik és negyedik osztály saját tanárt kapott, Csukás Benjamint, aki egyben az intézmény igazgatója is lett. A tisztséget 1869-ben átvette Zolnay, azonban 1871-ben felkérték a polgári leányiskola megszervezésére és vezetésére. 1873-tól ismét a gimnázium igazgatója. Nagyrészt neki köszönhető, hogy megépült 1888-ra az új iskolaépület. Érdemei elismeréseként az uralkodó lovagkereszttel tüntette ki nyugdíjba vonulásakor. 1860-ban alapító tagja volt a Kaszinónak, egy évvel később a Dalárdának, ezen kívül többször volt városi és megyei képviselő, tagja a református presbitériumnak, illetve a szentesi református egyház főgondnoki tisztségét is betöltötte. 1925. februárban hunyt el Szentesen. (Labádi 2005d. 2.)

${ }^{270} \mathrm{Az}$ első - és egyedüli - nevelőnő, Fornet Kornélné egy sóraktári ellenőr neje volt, semmiféle szakirányú végzettséggel nem rendelkezett, mindössze közismertsége és viszonylag széles műveltsége alapján kapta meg az állást. A kritikák miatt hamarosan lemondott. (Kis-Rácz 2002. - II. fejezet: A kezdetektől 1912-ig)

${ }^{271}$ Kis-Rácz 2002. - II. fejezet: A kezdetektől 1912-ig, III. fejezet: A „,kultúrpalota”); Tolcsvay 1928. $204-206$.
} 
földmüves fiatalok fokozatosan kikoptak a padsorokból, az 1860-as években már csak kereskedő- és iparostanoncok látogatták. 1869-ben a város átvette az egyháztól a négy évfolyamos intézményt - az első, a második és harmadik osztályba jártak az iparos-, a negyedikbe a kereskedőtanoncok -, amelyet 1883-ban, miniszteri rendelet alapján alsó fokú, közvetlenül az ipartanodai bizottság által felügyelt ipariskolává alakítottak át. ${ }^{272}$

\subsection{Kultúra, múvészetek}

A már említett egyesületeken kívül a település legrégebbi kulturális intézményének a Múzeum és Közkönyvtár tekinthető, amelynek létrejötte az abszolutizmus időszakára tehető, és a gimnáziumnak köszönhető: már az 1860-as évek elején müködött. A benne őrzött tárgyakat az iskola tanárai elkülönítették a tanszerektől, következetesen „Könyvtár és Múzeum"-nak nevezték, s nyilvános közgyüjteménynek tekintették. A múzeum anyagát az 1870-es években tovább gyarapították. A század utolsó éveiben a gimnáziumban kezelt anyag gondozását átvette az akkoriban megalakult Csongrádmegyei Történelmi és Régészeti Társulat, amelynek felügyeleti jogát az állam 1906-ban a vármegyére ruházta át. ${ }^{273}$

A képzőmüvészet terén tárgyalt korszakunkban Szentes nem büszkélkedhet nagy eredményekkel. „Minden, amit a város a szépmüvészet terén kimutathat, azt a kiegyezést követö polgári müveltség terjedésének köszönheti. Az egykori parasztnábobok polgáriasult utódai már az egyetem légkörén át megismerkednek a különbözö müvészi eszmeáramokkal, az alkotások megértői és értékelöivé válnak és közülük nem egy mügyüjtővé, sőt alkotóvá is finomul. [...] Számbavehetö képzömüvészeti megnyilatkozás csak a XIX. század utolsó évtizedeiben tapasztalható, amikor a vármegye néhány arcképet festet; igy Kossuth Lajosról, az uralkodócsalád egyik-másik tagjáról, egy-két nevesebb alispánjáról és alapitványtevőjéről” - fogalmaz Schupiter Elemér. ${ }^{274}$ A nevesebb szentesi képzőművészek pl. Koszta József, Kováts Károly vagy Fetter Frigyes - alkotói pályája már inkább a XX. századi magyar művészet hírnevét öregbíti. Az iparmüvészet terén kiemelhető a híres szentesi fekete kerámia, de csak mint müalkotás: az edények víztárolásra alkalmatlanok voltak. ${ }^{275}$

A helyi zenei életet képviselő egyesületekről már szóltunk. Kiemelhetjük még a színművészetet, amelynek Szentesen a XIX. században nem túl jelentős, de értékelhető

\footnotetext{
${ }^{272}$ Follajtár 1938. 10., Papp 1928. 206-207.

${ }^{273}$ Follajtár 1938. 12.

${ }^{274}$ Schupiter 1928e. 216.

275 Schupiter 1928e. 220.
} 
hagyományai voltak. 1827-ben tartották a városban az első színi előadást, ${ }^{276} \mathrm{~s}$ utána többkevesebb rendszerességgel, elsősorban vendégtársulatok szórakoztatták a szentesi közönséget. Közismert volt például a Várady Ferenc-féle társulat, amelynek egy ideig a településen volt a székhelye, majd, miután elköltöztek a városból, később is visszajártak egy-egy előadás erejéig. Számos szentesi csapott felszínésznek, és futott be kisebb karriert, de mind közül magasan kiemelkedik Tóth József (1823-1870), aki országos hírnévre tett szert: tagja volt a Nemzeti Színháznak, Petőfit személyesen ismerte, és részt vett a szabadságharcban is. ${ }^{277}$

Végül, a kulturális élet alakításában, az egyes közéleti eseményekről való tudósításban, a szellemi javak terjesztésében meghatározó szerepet töltött be a nyomtatott helyi sajtó, amely a kiegyezést követően indult meg Szentesen, s amely kezdeti időszakának részletes ismertetése dolgozatunk fő tárgyát képezi.

\section{A szentesi sajtó kezdetei (1871-1883)}

\subsection{A Szentesi Füzetek}

Mint már említettük, Oroszi Miklós polgármestert politikai ellenfelei 1867-es újraválasztása után koholt vádakkal lejáratták, hivatalától megfosztották, sőt bírósági ítélet nélkül két évre börtönbe is záratták. Szabadulása után Oroszi visszavonult a közélettől, mezőgazdasággal foglalkozott. ${ }^{278}$ 1871. februárban azonban még egy jelentős közéleti tettet hajtott végre: gondozásában megjelent a város első nyomtatott lapja, a Szentesi Füzetek. A hírről a HódMezö-Vásárhely hetilap számolt be több hónapos késéssel, 1871. június 4-i számában. A közlemény szerint a kiadó és szerkesztő Oroszi még további öt füzet megjelentetését tervezi az év során, amelyre két forintért lehet előfizetni. ${ }^{279}$

\footnotetext{
${ }^{276}$ Schupiter 1928f. 226.

277 Érdekes anekdota Tóthról: „A fiatal szinész 1848-ban honvéd önkéntesnek jelentkezett. Ilyen minöségében 1849. július-augusztusában Kossuth Lajostól azt a parancsot kapta, hogy állami pénzeket szállitson az aradi várba. Amikor megérkezett Aradra a társzekerekkel, Kossuth a vállára tette a kezét, s így szólt: „Hát van még becsületes ember?!« Kossuth ezt követöen egy fertályóra múlva már kocsira szállt, és elmenekült az országból. Az Aradra bevonult császári csapatokkal érkezett gróf Mailáth György császári biztos rövidesen hivatta Tóth Józsefet, mondja meg, hová tette az ország pénzét. Tóth azt válaszolta: semmiröl nem tud semmit. A gróf igy felelt: »Holnap déli tizenkét órára tudni fogja, különben lógni fog!" Csakhogy másnapra a császári biztos emberei megtudták, hol a pénz. Gróf Mailáth pedig azt mondta volt: „Édes Tóth, maradjon csak maga a színpad deszkáin, ott jeleskedjék. A világ színpada nekünk való.." (Bucsány 2000. 2.)

278 Lásd: 179. sz. jegyzet

${ }^{279}$ Labádi 1992. 3.; Labádi 2006a. 2.
} 
A Szentesi Füzetek a megjelenés dátuma alapján valóban a város első nyomtatott tömegtájékoztatási médiuma, azonban mégsem tekinthetjük Szentes első polgári sajtóorgánumának, több okból sem. Egyrészt - habár ez még nem volna kizáró ok - nem helyben nyomtatták, hiszen a településen ekkor még nem müködött ilyen jellegű vállalkozás, hanem a szegedi Burger Zsigmond-féle nyomdában. Másfelöl, nem közéleti hetilapról van szó, hanem elsősorban mezőgazdasági szakfolyóiratról: a „Mezőgazdászat, gyümölcstenyésztés és községi élet közlönye” - olvasható a profilmegjelölés az ötvenkét oldalas újság címlapján, jeligéje pedig: „Minden pályának szakismeret a vezér-fonal: E nélkül a legegyszerübb tér is tömkeleggé válik. (Peterdi)". ${ }^{280}$ Az olvasóhoz címet viselö beköszöntő cikkben Oroszi Miklós a következőképpen fogalmaz a folyóirat úttörő szerepét, hiánypótló szándékát illetően: „Mint a mezei gazdászat és gyümölcstenyésztés szenvedélyes barátja egy szerény vállalattal bátorkodom a közönség elé lépni, melyre engem leginkább azon tapasztalatok ösztönöznek, melyeket 20 évi gazdálkodásom alatt a mezei gazdálkodás és gyümölcstenyésztés terén szerezni alkalmam volt. [...] Az európai hírü magyar alföldnek pedig épen ezen része, a mi vidékünk, nagyon is igényli, hogy különösen a kis gazdák érdekében a mezögazdászat és gyümölcstenyésztés fejlesztésére minél elébb egy gyakorlati szaklap indittassék... [...] Ezt követően Oroszi kifejti: a lap megindítására nem a hiúság ösztönözte, hanem kizárólag a közjóra való törekvés, hiszen tapasztalatból tudja, hogy Szentes környékén melyek a legfontosabb hiányosságok a növénytermesztés és az állattenyésztés területén, ráadásul szakemberként ismeri a megoldást a problémák jelentős részére. „Ezek azon szempontok, melyekböl kiindulva lépek e pályára; reménylem, hogy igazságszeretö lelkek méltányolni fogják a közjóra célzó becsületes törekvést."281

A lapban közölt cikkek jelentős hányada az előbbi célt szolgálja: a Mezőgazdászat címü írás Szentes agrárviszonyait taglalja, s hasznos tanácsokkal látja el a gazdákat mind az állattenyésztés, mind a növénytermesztés általános kérdései vonatkozásában, részletesen kitérve a lucerna termesztésének témakörére. ${ }^{282}$ Az ezt követő, Gyümölcstenyésztés címü cikkből megtudhatjuk, hogy a település és környéke elsősorban csemegeszőlő, körte, meggy,

\footnotetext{
${ }^{280}$ SZF 2. - a lapszámozást tekintve hibás a kiadvány, ugyanis a borítólapot nem számolja bele: a számozás a tulajdonképpeni 3. oldalon indul, vagyis azt tekinti 1. oldalnak. A szövegben említett jelige viszont a valós - és nem a korabeli, téves számozás szerinti - 2. oldalon található. Ugyanezen az alapon eltérő lehet a kiadvány megítélése összes terjedelem szempontjából: csupán 48 számozott oldalt találunk, viszont, ha a borítólap négy oldalát is belevesszük - márpedig jogosan, hiszen mind a négy oldalon található szöveg vagy más grafikai objektum -, akkor 52 oldalas újságról beszélhetünk. Jómagam az utóbbi számozást tartom helyesnek, így a további hivatkozások esetén az általam jelölt oldalszám eltérő a folyóiratban olvashatóhoz képest. A félreértések elkerülése érdekében zárójelben közlöm az eredeti számozást is.

${ }^{281}$ SZF 3-6. (eredeti számozás szerint: 1-4.)

${ }^{282}$ SZF 7-17. (eredeti számozás szerint: 5-15.)
} 
cseresznye és alma termesztésére szakosodott - utóbbival kapcsolatban a szerző megjegyzi, hogy bár jól terem, ,fája nem tartós a mi száraz kemény földünkben”. ${ }^{283}$ Ami pedig a szilvát és a barackot illeti, azok „kevésbé otthonosak nálunk”. ${ }^{284}$ A cikk túlmutat eredeti mondanivalóján, hiszen Oroszi itt megemlíti - bár nem részletezi - meghurcoltatását, mikor második polgármestersége idején, saját költségén gyümölcsfaiskolát létesített Szentesen: „az árva fejemhez mért halálos csapás a városi gyümölcsfa-iskolát is megsemmisitette. Midőn a méltatlanul szenvedett hosszas rabság után kiszabadultam, a városi szöllö- és gyümölcsfaiskola helyett egy 35 hold területü nagyszerü mulatókertet találtam, melyet a tanács azon idö alatt nagy költségen, még pedig kölcsönpénzen állitott!"285 Mint írja, a gyümölcsfaiskola megsemmisülése késztette arra, hogy - egyéb lehetőség híján - legalább folyóirata hasábjain népszerüsítse a szőlő- és gyümölcstermesztést: a következő cikkben részletes és igen szakszerü ismertetést kapunk az általa termesztett csemegeszőlő-fajtákról. ${ }^{286}$

Ezután mindössze tizenhárom oldal foglalkozik közéleti témákkal Községi élet címszó alatt, de ott sem aktuális híreket közöl. Elöször a 48-as törvényeket kéri számon a választási rendszer, illetve a megyék rendezéséről, valamint a hamarosan megjelenő, a községek rendezéséről szóló törvény kapcsán, ${ }^{287}$ majd egy erkölcsi jellegü, történelmi példákkal, valamint bibliai idézetekkel alátámasztott eszmefuttatást olvashatunk Igazság a népek jóllétének alapköve címmel, egyértelműen utalva saját személyes meghurcoltatására: „a polgároknak egymás iránti irigykedése és igazságtalansága megrontja a népek jóllétét. - Még százszorta veszélyesebb az igazságtalanság, ha vele hatalom is egyesül ugyanazon embernél. - Nincs nagyobb ostora Istennek, mint az igazságtalan, irigykedö, roszlelkü, ravasz, kétszinü, boszuálló ember, midön hatalomra jut. [...] Boldog azon nép, melynek igazságszeretö elöljárói és birái vannak." ${ }^{288}$ A Szentes város helyzete közlekedési tekintetben című cikkben a településnek az országos vasúthálózatba való bekapcsolását szorgalmazza, amely a gazdasági fejlődés, az urbanizáció szempontjából elengedhetetlen volna ${ }^{289}$ - a kérdéskörben már korábban, az 1860-as évek első felében is tett erőfeszítéseket a Szentesi Váltsági és Gazdasági Bizottmány tagjaként, viszont a településnek még közel negyed századot kellett várnia az első vasútvonal megnyitására. ${ }^{290}$

\footnotetext{
${ }^{283}$ SZF 21. (eredeti számozás szerint: 19.)

${ }^{284}$ SZF 21. (eredeti számozás szerint: 19.)

285 SZF 24. (eredeti számozás szerint: 22.)

${ }^{286}$ SZF 24-37. (eredeti számozás szerint: 22-35.)

${ }^{287}$ SZF 38-40. (eredeti számozás szerint: 36-38.)

${ }^{288}$ SZF 44-47. (eredeti számozás szerint: 42-45.)

${ }^{289}$ SZF 47-49. (eredeti számozás szerint: 45-47.)

${ }^{290}$ Labádi 2006a. 2.
} 
Végül, egy rövid statisztikát találunk a közéleti rovat befejezéseként, amely Szentes főbb demográfiai adatait, illetve a haszonállatok számát tartalmazza az 1857-es és az 1869-es összeírás alapján. A lakosságszámot korábban már említettük, ${ }^{291}$ a haszonállatokkal kapcsolatban pedig Oroszi megjegyzi, hogy számukat tekintve jelentős csökkenés mutatkozik tizenkét esztendő alatt: 1857-ben 50928 darabot írtak össze (lovat, szarvasmarhát, juhot és sertést), míg 1869-ben csak 35 779-et ugyanezen állatfajtákból. A legdrasztikusabban a sertésállomány fogyatkozott meg a bő egy évtized alatt: száma 13 151-ről mindössze 5231-re, tehát alig több mint a harmadára apadt. ${ }^{292}$ Az utolsó előtti, immáron számozás nélküli oldal gyakorlatilag hirdetésként értékelhetö: Szöllö-tövek és körte-oltványok árjegyzéke címmel felsorolja mindazon szőlő- és körtefajtákat, amelyeket a volt polgármesternél meg lehet vásárolni - „A megrendelések egyenesen hozzám intézendők."

A szerkesztő és kiadó több helyen tesz utalást folyóiratában a következő lapszámokra, ${ }^{294}$ de - tudomásunk szerint - több példány már nem jelent meg a Szentesi Füzetekből. Oroszi Miklós sikertelen lapkiadását követően, 1871-ben családjával elköltözött Szentesröl. ${ }^{295}$ A szerencsétlen sorsú volt polgármester egyetlen számot megélt lapja nem tekinthető az első szentesi modern hírközlési médiumnak, azonban sajtótörténeti jelentősége helyi viszonylatban vitathatatlan.

\subsection{A Szentesi Lapok}

Az első helyi - és helyben nyomtatott - hírlap megjelenésére nem kellett sokáig várniuk a szentesi polgároknak: 1871. július 9-én vehették kézbe az olvasók a Szentesi Lapok első számát, az előző évben Gyöngyösről Szentesre települt nyomdász, Cherrier János kiadásában. A modern, nyomtatott polgári hírközlés megindulása tehát ettől a naptól datálható Szentesen.

A vasárnapi megjelenésű Szentesi Lapok - profilmegjelölése szerint „Vegyes tartalmu hetilap" - felelős szerkesztője Honthy László ${ }^{296}$ volt, emellett Balogh János főmunkatársként

\footnotetext{
${ }^{291}$ Lásd a 2.4. A helyi társadalom szerkezete pontot

${ }^{292}$ SZF 50. (eredeti számozás szerint: 48.)

293 SZF 51. (eredeti számozás nincs)

${ }^{294}$ Például: „Ezeknek gyümölcsészeti leirásuk a következö füzetben fog közöltetni” (SZF 51. - eredeti számozás nincs); vagy „A megyék rendezéséröl szóló törvény már készen van, a községek rendezéséröl szóló törvény pedig az országgyülésen rövid időn tárgyalás alá jön. Tehát a jövő füzetben már mi is foglalkozhatunk ösmertetésével." (SZF 38. - eredeti számozás szerint: 36.)

${ }^{295}$ Labádi 1992. 3.

${ }^{296}$ Honthy László 1838-ban született Kiskunfélegyházán, közismert római katolikus család sarjaként. Tanítói diplomát szerzett, előbb Szentesen volt néptanító, később városi tanácsnok, illetve több újságnál lapszerkesztő.
} 
szerepelt az impresszumban. ${ }^{297}$ Utóbbi nem sokáig tevékenykedett a lapnál: már a második számban, az Ujdonságok rovatban olvashatjuk a rövid hírt, miszerint Balogh ,bizonyos okoknál fogva visszalépett”. ${ }^{298}$ Nincs adatunk arra nézve, hogy pontosan mi volt a főmunkatárs gyors távozásának oka, mindenesetre árulkodó, hogy néhány héttel később Balogh János saját készítésü röpiratot osztogatott a város lakosai körében, amelyben kritizálta egykori munkahelyét. Honthy László csípős hangvételü publicisztikában reagált Szerkesztői nyilt levél. Balogh János urhoz címmel. Balogh szerinte „senki más, mint egy kath. segédlelkész [...] mint valami sötét korbeli lovag oly gyönyörüen száguld fekete paripáján", 299 illetve utalást találunk a lap előfizetőinek alacsony számára is - Balogh János röpiratában azt állította, hogy alatta több mint háromszáz előfizetője volt a Szentesi Lapoknak, amire Honthy a következőképpen reagál: „Hová tette ön az eszét, midőn ezt írta?”300 Mindebből arra következtethetünk, hogy - hasonlóan a vidéki orgánumok többségéhez - az újság előfizetőinek száma egy-két száz főnél nem lehetett több. Azt, hogy a lap a kezdetektől fogva küzdött az alacsony érdeklődés okozta hátrányokkal, bizonyítja, hogy fennállása során rendszeresen visszatérő téma volt az előfizetésre történő szerkesztőségi felhívás, hol címlapra beillesztett rövid közlemény, hol rövid hír, hol pedig publicisztika formájában: „Pedig a mely megyének vagy városnak lapja van, abból lehet a megye avagy város szellemi életét megitélni" - írja Honthy László három hónappal az újság megindulása után, a kevés előfizető okán panaszkodva. ${ }^{301}$ Ezen kívül egy év alatt összesen tizenhét alkalommal találunk előfizetési felhívást a Szentesi Lapokra, van, hogy egy lapszámon belül kétszer is - igaz, az ilyen jellegü önreklám gyakran előfordult más újságoknál is. ${ }^{302}$

A fejléc ismerteti az előfizetési díjakat, eszerint egész évre 4, fél évre 2, negyed évre pedig 1 forintot kellett fizetnie az olvasónak - az egyes lapszámok külön megvásárlására nem volt lehetőség. (Az árak megfelelnek az országos átlagnak.) Szintén a fejléc tartalmazza a hirdetési tarifákat: a négyhasábos hirdetés 15 , a háromhasábos 10 , a kéthasábos 6 , az egyhasábos pedig 3 krajcárba került. Az első lapszám címoldalán olvasható, Ok és okozat.

Ezt követően Szombathelyre került, ahol a püspöki iskola igazgatója lett, majd családjával visszaköltözött szülővárosába, ahol levéltárosi állást kapott. Az általa megalkotott levéltári nyilvántartó rendszert a mai napig használják. Emellett folytatta sajtótevékenységét is: a Félegyházai Lapokat, illetve a Félegyháza és Vidékét szerkesztette. 1885 decemberében halt meg. Fia, István újságíró, író és költő volt, két lánya pedig - Berta és Lujza - köztiszteletben álló tanítóként dolgozott Kiskunfélegyházán. (Mayer 2015.; Szinnyei 1896. 1060.)

${ }^{297}$ Nem azonos a hasonló nevü szentesi polgármesterrel: Balogh felszentelt pap volt, később Kunszentmiklósra került plébánosnak, és saját folyóiratot is kiadott, mint azt látni fogjuk a 4. fejezetben. (Szinnyei 1891. 468.)

298 SZLK, I. évf. (1871) 2. sz. 3.

${ }^{299}$ SZLK, I. évf. (1871) 6. sZ. 1.

${ }^{300}$ Uo.

${ }^{301}$ SZLK, I. évf. (1871) 14. sZ. 1.

302 SZLK, II. évf. (1872) 12. sZ. 1., 3. 
(Beköszöntésül.) címet viselő, Honthy által jegyzett vezércikk a sajtó felelősségéröl, társadalmi szerepének fontosságáról értekezik, majd meghatározza az újság célkitüzéseit: „egyrészröl hü tükre leend minden a megyénk és városunk anyagi és szellemi terén mutatkozó mozgalmaknak, addig másrészröl a küszöbön álló törvénykezési s municipalis (helyhatósági) nagy átalakulás, népiskoláink, felsöbb tanintézeteink, ipar, gazdászat s kereskedés, intézetek, egyletek, melyek megyénk és városunk kebelében alkottattaks ezekkel összefüggö kérdések érdekeit fogja képviselni, szóval: megyénk és városunk helyi közlönye leend." Ezt követően a cikkíró leszögezi: a Szentesi Lapok igyekszik minden fontosabb fővárosi, illetve országos eseményről is beszámolni, emellett a szépirodalomnak is igyekeznek megfelelő teret biztosítani, bár vidéki lapként figyelembe kell venni a terjedelmi korlátokat. Végül, a lakosság támogatását kéri az új orgánumhoz: „tisztelettel felkérjük hazánk, megyénk és városunk lelkes közönségét: sziveskedjenek a »Szentesi Lapok « fennállását anyagi és szellemi pártfogolásba részesiteni." ${ }^{303} \mathrm{~S}$ valóban, a lap kerülte a politikai részrehajlást, teret engedett az eltérő vélemények közlésének, a városvezetés iránt azonban nagyfokú lojalitást tanúsított. ${ }^{304}$

A Szentesi Lapok küllemét tekintve a korban széles körben elterjedt formai jegyeket mutatta: a négyoldalas újság első oldalán a legtöbb esetben vezércikket, egy aktuális kérdéskört, problémát feldolgozó publicisztikát találunk. A legtöbbet szereplő téma az újság egyéves fennállása alatt a távolsági közlekedés, ezen belül pedig főként a vasút ügye (kilenc vezércikk), amelynek megvalósítása fontos lépés lett volna a település urbanizációja, gazdasági fejlődése szempontjából. ${ }^{305}$ Mint a cikkekből kiderül: a kérdés nem csupán az volt, hogy mikor kapcsolják be végre Szentest az országos vasúti vérkeringésbe, hanem - a Vasuti kérdésünk címü cikksorozat ${ }^{306}$ keretében - jelentős vita alakult ki azzal kapcsolatban is, hogy a város melyik hálózat megépítését támogassa. A tekintélyes helyi polgár, Ausländer Lajos a Kiskunfélegyháza-Orosháza-vonal mellett érvelt, mások a Szolnok-Hódmezővásárhely-vonal mellett tették le voksukat. Visszatérő téma volt még többek között az iparosítás - különösen az iparegyletek alapítását szorgalmazó írások -, az oktatás, illetve több publicisztika született az 1872-es választások kapcsán is. A vezércikkek nagyobb része aláírás nélkül született, többségüket minden bizonnyal - a kor szokásának megfelelően - Honthy László felelős szerkesztő írta. Állandó rovatnak számított a többnyire a vezércikket követő Tárca, ahol a

\footnotetext{
${ }^{303}$ SZLK, I. évf. (1871) 1. sz. 1.

${ }^{304}$ Az említett Honthy-féle beköszöntő cikken kívül az első szám negyedik oldalán, az Ujdonságok rovatban még egyszer deklarálja a szerkesztőség a lap politikai semlegességét.

305 Lásd Ausländer Lajos: Szentes topografiai, (helyrajzi) közlekedési és kereskedelmi viszonyai. (SZLK, I. évf. [1871] 1. sz. 1-2.)

306 SZLK, I. évf. (1871) 9. sz. 1-2.; I. évf. (1871) 10. sz. 1.; I. évf. (1871) 17. sz. 1-2.; I. évf. (1871) 18. sz. 1.; I. évf. (1871) 20. sz. 1 .
} 
szépirodalom kapott teret: novellákat, úti beszámolókat, anekdotákat, regényrészleteket, valamint verseket közölt. Szintén kiemelt helyen, általában az első vagy a második oldalon szerepeltek a városi közgyülésekről és a Szegváron tartott megyegyülésekről szóló tudósítások; előbbiek gyakorlatilag hivatalos közlemény formájában jelentek meg, hiszen nem újságíró jegyezte le őket, hanem Szentes főjegyzője, Cicatricis Pál. ${ }^{307}$

A lap emellett rendszeresen közölt közérdekü információkat, például árverési és pályázati hirdetményeket, választási felhívásokat és eredményeket; iskolák beiratkozási és felvételi időpontjait, az év végi vizsgák idejét, illetve felhívta a figyelmet a különféle politikai, kulturális vagy más közéleti rendezvényekre, amelyek - elsősorban a bálok sikerességéről később sok esetben be is számolt. A rendezvények közül érdemes kiemelnünk a színi előadásokat. Szentesnek ebben az időben állandó színházépülete még nem volt, de a lap lelkesen támogatta a helyi, Várady Ferenc vezette társulatot: előadásaikról közel három hónapig (1871. július-szeptember) önálló rovatban (Szinészet) tájékoztatta az olvasókat, s a rövid tudósítások mellé általában egy-két mondatos - építő kritikai - megjegyzést is füzött, például: „,nem tudjuk eléggé rosszalni a rendezőség azon hibáját, hogy Ippelberger ${ }^{308}$ szerepét Hegyinek osztá, ki rosszul fogván fel, teljesen elrontá, nemcsak az önszerepét, hanem az egész darabot is". ${ }^{309}$ A rovat rövid életünek bizonyult, mert a Várady-féle társulat 1871 őszén Hódmezővásárhelyre tette át a székhelyét, így a rendszeres előadások egy időre megszűntek a városban. ${ }^{310}$

A második és harmadik oldalon többnyire helyi, megyei és országos, időnként pedig külföldi hírek kaptak helyet. A lap egyik nagy hibája, hogy nem volt állandó rovatszerkezete, ráadásul a rovatcímek is többször változtak az újság közel egyéves fennállása során: a többszöri arculatváltási kísérlettől minden bizonnyal az előfizetők számának emelkedését várták. A helyi és megyei eseményekről történő tudósítások között különösen értékesek számunkra azok a bulvár-, bünügyi vagy egyéb olyan hírek, amelyek a korabeli szentesi társadalom mindennapi életébe engednek bepillantást. Ezekből például megtudhatjuk, hogy a városban rendszeresen tartottak különböző estélyeket, jótékonysági táncmulatságokat, egyleti

\footnotetext{
${ }^{307}$ Cicatricis Pál a Nyitra vármegyei Andacs községben született 1827-ben. A szabadságharcban a 3. (szegedi) honvédzászlóaljnál teljesített szolgálatot, az 1849. jún. 15-én készült kimutatás szerint örmesteri, végül pedig hadnagyi rangban. A kiegyezést követően Szentes város föjegyzöje lett. 1880 nyarán halt meg. (http://www.arcanum.hu/hu/online-kiadvanyok/Bona-bona-tabornokok-torzstisztek-1/hadnagyok-esfohadnagyok-az-184849-evi-szabadsagharcban-2/c-4B9/dezseri-cicatricis-pal-4CF/, letöltés: 2017. augusztus 21.; Vasárnapi Ujság, XXVII. évf. [1880] 32. sz., 14.)

308 A korban népszerü, Karl August Görner által írt, Angolosan című vígjátékról van szó, lásd: http://mandadb.hu/common/file-servlet/document/47430/default/doc_url/187212161900.pdf (letöltés: 2016. augusztus 26.)

${ }^{309}$ SZLK, I. évf. (1871) 8. sz. 3.

${ }^{310}$ SZLK, I. évf. (1871) 12. sz. 3.
} 
bálokat, amelyek szervezésében és lebonyolításában élen járt a város híres vendéglőse, Rambovszky József. ${ }^{311}$ Nem voltak ritkák a különböző büncselekmények, tragédiák sem: olvashatunk vendéglő előtti verekedésről, ${ }^{312}$ részeg fogatos által okozott balesetről, ${ }^{313}$ emellett a lap nagyjából egyéves létezése során tíz erőszakos szentesi halálesetet is közöl (hárman kútba, ${ }^{314}$ öten a Kurcába fulladtak, ${ }^{315}$ egy idős asszony öngyilkos lett, ${ }^{316}$ egy tizenkét éves cselédlány pedig istállótüzben lelte halálát ${ }^{317}$ ). A szerkesztőség néha felületesen kezelte az adatokat, erre utal az egyik vízbe fúlt, a helyi Demeter Antal esete. „10-12 éves gyermek”318 fogalmaz a lap, tehát a pontos életkort nem említi, miközben a személyazonossága ismert, és a halotti anyakönyvböl is egyértelmüen kiderül, hogy a fiút kilencévesen érte a halál: 1863. február 6-án látta meg a napvilágot. ${ }^{319}$ Meg kell még említenünk a viszonylag gyakori tüzeseteket is, az újság összesen hét ilyen balesetről számol be - ebből hatszor az udvaron tárolt széna, illetve szalma okozta a bajt, egy esetben pedig dohányzó fiatalok gondatlansága. ${ }^{320}$

A különféle tragédiák mellett - hasonlóan az országos tendenciához - böségesen jutott hely a könnyedebb híreknek, esetenként humoros történeteknek is a lap hasábjain: olvashatunk fináncokról, akiket bottal kergettek el a helyi árusok a piacról; két illetőről, akik kutyáikra kalapot téve sétáltak a városban a járókelők nagy mulatságára; idegenekről, akik majmokkal okoztak kisebb riadalmat a szentesi utcán. Megemlíthetjük azt a debreceni polgárt is, aki sajátosan reagált a gázgyár díjszedő levelére, mert az németül követelte a tartozást,

\footnotetext{
311 A lengyel származású Rambovszky József 1865-ben költözött Nagyszentmiklósról Szentesre, és kibérelte a város föterén álló (azóta megsemmisült, a helyén áll a közelmúltban felújított Petőfi Szálló) Zöldkoszorú vendégfogadót. Később megszerezte a mai Széchenyi-ligetben álló, általa „Ujvilághoz”-nak keresztelt vendéglő és a fürdő bérleti jogát is. Ö biztosított fellépési lehetőséget a színtársulatok számára is: a főtéri vendéglője udvarán nyári színkört alakított ki, később - a vendéglő jelentős átépítése után - téli színpadot is létesített, emellett díszes kávéházi helyiséget is elkülönített. 1884-ben ő szervezett elöször a városban virágkiállítást. Három évvel később Szegedre költözött, ahol előbb a Fekete Sas, majd a Hétválasztó nevet viselő szállodát müködtette. 1889-ben vendéglősként részt vett a párizsi világkiállításon. Budapesten hunyt el 1894-ben, ötvenkilenc éves korában. (Labádi 2004d. 2.)

${ }^{312}$ SZLK, II. évf. (1872) 20. sz. 3.

${ }^{313}$ SZLK, I. évf. (1871) 7. sz. 3.

${ }^{314}$ SZLK, II. évf. (1872) 13. sz. 3., illetve II. évf. (1872) 21. sz. 3.

${ }^{315}$ SZLK, I. évf. (1871) 2. sz. 3.; I. évf. (1871) 6. sz. 3.; I. évf. (1871) 8. sz. 3.; II. évf. (1872) 19. sz. 3. Megjegyzendő, hogy a Kurcánál történt gyakori balesetekröl - a kiépítetlen, mocsaras partvonal miatt a vízmerítés céljából oda igyekvő cselédek vagy gyerekek a vízbe csúsztak - szóló tudósítások az 1870-es évek során szinte teljesen eltủnnek a helyi sajtó hasábjairól, köszönhetően az akkoriban megkezdett lecsapolási munkálatoknak.

${ }^{316}$ SZLK, II. évf. (1872) 15. sz. 3.

${ }^{317}$ SZLK, I. évf. (1871) 18. sz. 3.

${ }^{318}$ SZLK, II. évf. (1872) 19. sz. 3.

319 MNL CSML Szentes, IV.B.434.a. - Csongrád Vármegye Felekezeti Anyakönyvi Másodpéldányainak Levéltári Gyüjteménye - A római katolikus egyházközségek anyakönyveinek másodpéldányai, Szentes, halotti anyakönyvek, 149. sz. bejegyzés

${ }^{320}$ SZLK, I. évf. (1871) 6. sz. 3.; I. évf. (1871) 7. sz. 3.; I. évf. (1871) 12. sz. 3.; I. évf. (1871) 15. sz. 3.; I. évf. (1871) 18. sz. 3.; II. évf. (1872) 11. sz. 3.; II. évf. (1872) 16. sz. 2.
} 
mire az ember ráírta, hogy „Nichts deutsch”, és visszaküldte a papírost. ${ }^{321}$ Emellett megtudhatjuk, hogy 1872 elején Somogyban egy egyfülü és egyszemű gyerek született, ${ }^{322}$ értesülhetünk egy sziámi ikerpár világra jöttéről is a Muraközben. ${ }^{323}$ Egy állítólag 185 éves korában, 1724-ben Temesváron elhunyt öregemberről is hallhatunk, ${ }^{324}$ vagy arról, hogy a legújabb tudományos kísérletek szerint egy ló étlen huszonöt napig is bírja, viszont víz nélkül öt nap alatt elpusztul ${ }^{325}$ - utóbbi minden bizonnyal felettébb hasznos információ lehetett a többnyire mezőgazdaságból élő szentesi lakosok számára.

\section{2. ábra - A Szentesi Lapok hírei földrajzi megoszlás szerint}

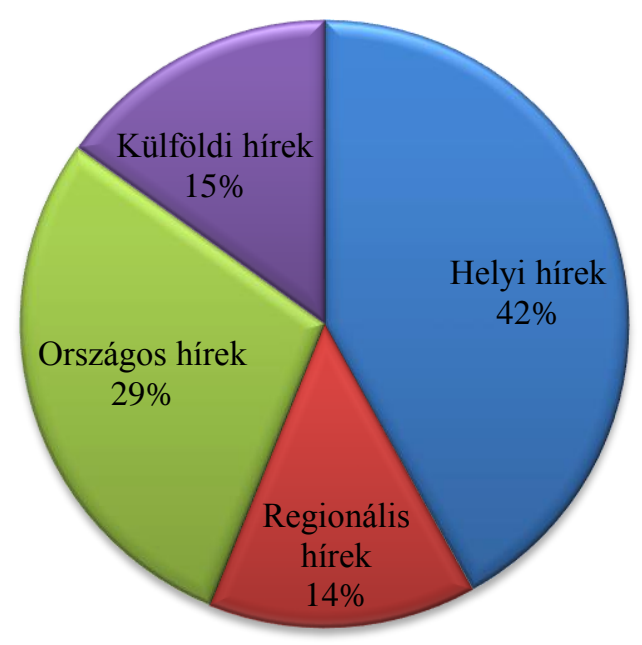

Az ábrából jól látható, hogy a Szentesi Lapok a híreket tekintve elsősorban a helyi történésekre koncentrált, de jelentős teret szentelt az ország távolabbi részein lezajlott eseményeknek is. Fontosnak tartotta a regionalitást, bőségesen találunk tudósításokat a környező településekről. Mindemellett jelentős, a regionális hírekkel közel azonos arányt képviselnek a külföldi hírek, amelyeket elöbb Külföld, majd Hirek a nagyvilágból rovatcímen olvashatunk, meglehetősen rapszodikus módon mind megjelenési gyakoriságukat, mind a tudósításra érdemes országok kiválasztását, mind pedig az onnan közölt információk hírértékét tekintve.

\footnotetext{
${ }^{321}$ SZLK, I. évf. (1871) 12. sZ. 3.

${ }^{322}$ SZLK, II. évf. (1872) 6. sz. 3.

${ }^{323}$ SZLK, I. évf. (1871) 16. sz. 3.

${ }^{324}$ SZLK, I. évf.(1871) 21. sz. 3.

${ }^{325}$ SZLK, I. évf. (1871) 15. sZ. 3.
} 
Az amúgy sem nagy terjedelmet élvező rovatban az aktuális politikai történések mellett könnyedebb, bulvárjellegü hírek is helyet kaptak - kielégítve ezzel az olvasóközönség szórakozás iránti igényét -, mint például egy francia kisasszony, aki XIV. Lajos nevét „Kszui” Lajosnak olvasta, mert a római számokat is betüknek hitte; ${ }^{326}$ vagy egy nyolcvanhat esztendős amerikai hölgy, aki még mindig sokat pörlekedik százhat éves anyósával. ${ }^{327}$ (Említésre méltó következetlenség, hogy az Ausztriában történt eseményeket néha a külföldi rovatban közölték - például egy bủvész bécsi előadásáról való beszámolót, ${ }^{328}$ illetve, hogy Komáromy György volt honvéd százados, országgyülési képviselő meghalt Salzburgban ${ }^{329}-$, máskor viszont az országos hírek között találjuk őket.)

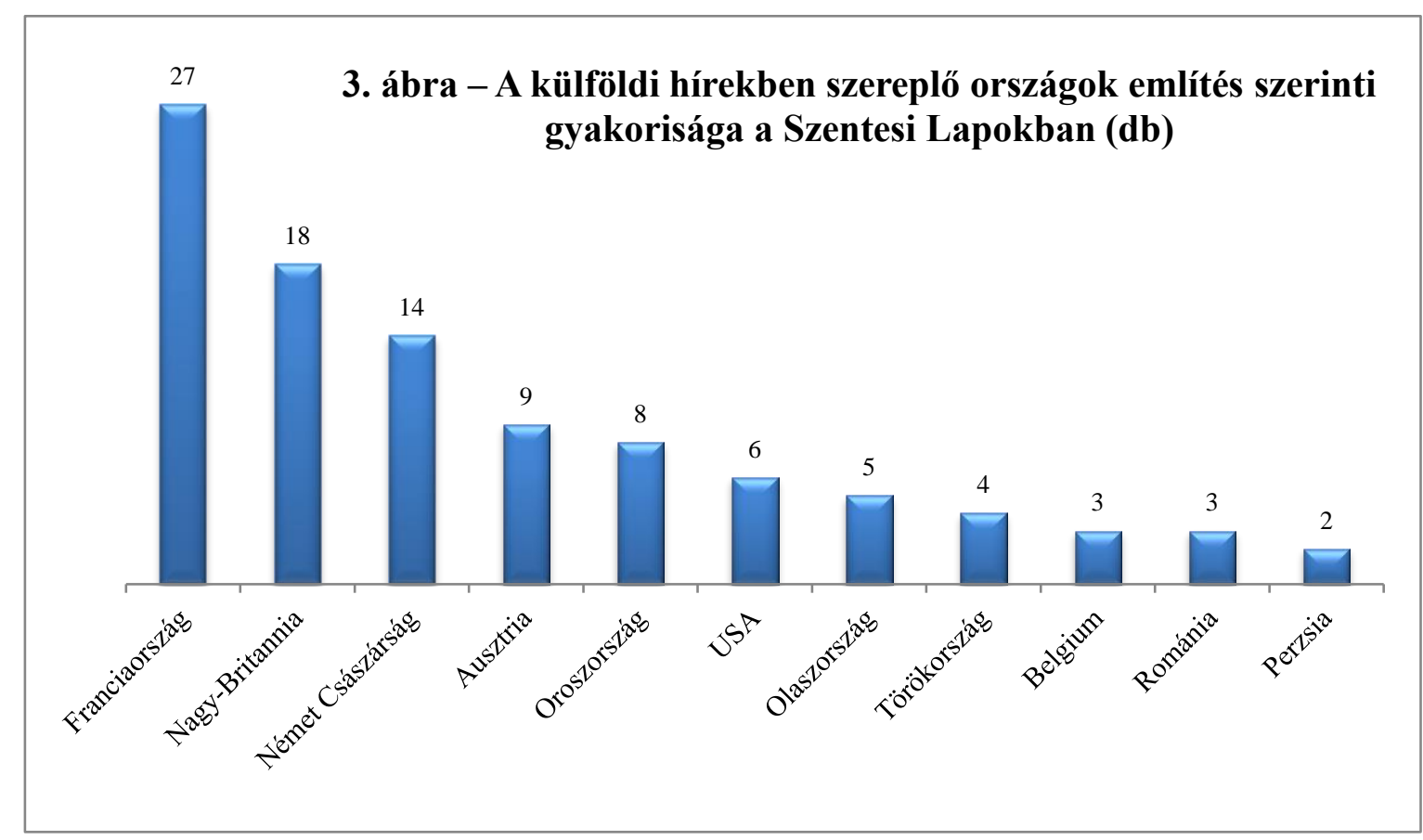

Mint az a fenti összesítésből kitünik, a legnagyobb számban franciaországi eseményekröl értesülhetünk ( 27 db említés), amely a külpolitikai helyzet miatt megfelel az országos tendenciának. A második helyen Nagy-Britannia áll (18 db), majd a Német Császárság (14 db), Ausztria (9 db), Oroszország (5 db), Amerikai Egyesült Államok (6 db), Törökország (4 db), Belgium és Románia (3-3 db), illetve Perzsia (2 db). Ezen kívül egy-egy említés erejéig találkozhatunk hírekkel Argentínából, Ausztráliából, Csehországból, Dániából, a Fülöp-szigetekröl, Indiából, Kubából, Spanyolországból, Svájcból és Szerbiából.

\footnotetext{
${ }^{326}$ SZLK, II. évf. (1872) 13. sz. 3.

${ }^{327}$ SZLK, II. évf. (1872) 14. sz. 4.

${ }^{328}$ SZLK, II. évf. (1872) 14. sz. 3.

${ }^{329}$ SZLK, II. évf. (1872) 19. sz. 3.
} 
Elmondhatjuk tehát, hogy a Szentesi Lapok próbálta szélesíteni az információközlés spektrumát, és nem csak a helyi, regionális, illetve országos, hanem a külföldön történt eseményekről is beszámolt - igaz, csak eseti jelleggel, nem nagy terjedelmű rovatban.

A szerkesztőség folyamatosan igyekezett a sajtó társadalmi felelősségét is éreztetni: gyakran felhívták a helyi hatóságok figyelmét olyan közügyekre, amelyek a polgárok mindennapi életét megkeserítették, s az is előfordult, hogy a közösség bizonyos tagjait próbálták jobb belátásra bírni. A legtöbb esetben óvatosságra intik a lakosságot a csúszós járdákkal kapcsolatban, a hatóságok közül pedig általában a rendőrséget figyelmeztetik különböző problémás esetekre: például, hogy sok cseléd kutyákkal jár az utcán, ami veszélyes a gyerekekre; ${ }^{330}$ a vízmeregetés nem biztonságos a Kurca rozoga és csúszós fahídján; ${ }^{331}$ a rendőrség „piaci járdáinkat az állongáló s beszélgető publikumtól tisztittassa meg”;332 egyesek éjszakánként puskákat durrogtatnak, zavarva ezzel a nyugalmat; ${ }^{333}$ a csirkeüzéreket ki kéne tiltani a piacról; ${ }^{334}$ a hatóság legyen erélyesebb, mert egy éjjeli tüzesethez hiába riasztották a tüzoltókat, nem volt sem ló, sem fecskendő, kész csoda, hogy nem történt nagyobb tragédia; ${ }^{335}$ az utcai üzletek sátrai túl alacsonyak, akadályozzák a gyalogos közlekedést ${ }^{336}$ stb. A szerkesztőség külön közleményben meg is köszönte a rendörségnek az együttműködést: „A helyi sajtónak kötelessége az ellenőrködést megtenni, s hogy szavaink a pusztában kiáltozóiéhoz hasonlók ne legyenek, az az illető hatóság ügybuzgóságától függ". 337

Emellett figyelmeztették a különféle illetékeseket is, például, hogy a szivattyús kutakat pucolják ki; ${ }^{338}$ hogy drága a hal a szentesi piacon, mert darabra adják, nem súlyra; ${ }^{339}$ hogy a révészek túl sokat várakoztatják az utasokat a Tiszán - bezzeg, ha az illető külön fizet nekik, azonnal átviszik a folyón. ${ }^{340}$ A hatóságokon kívül nemegyszer fordult a Szentesi Lapok nevelő célzattal vagy egyéb hasznos tanáccsal a polgárok felé: a színházba járó fiatalok például ne „,császározzanak” annyit az előadás alatt; ${ }^{341}$ ha valaki tetőjavítást végez, zárja el az adott utcaszakaszt a balesetek elkerülése érdekében; ${ }^{342}$ a színielőadásokat zavarják a

\footnotetext{
${ }^{330}$ SZLK, II. évf. (1872) 5. sZ. 3.

${ }^{331}$ SZLK, I. évf. (1871) 10. sz. 3.

332 SZLK, II. évf. (1872) 9. sZ. 3.

${ }^{333}$ SZLK, I. évf. (1871) 13. sz. 3.

${ }^{334}$ SZLK, I. évf. (1871) 11. sZ. 3.

${ }^{335}$ SZLK, II. évf. (1872) 11. sz. 3.

${ }^{336}$ SZLK, II. évf. (1872) 18. sZ. 3.

${ }^{337}$ SZLK, II. évf. (1872) 11. sZ. 3.

${ }^{338}$ SZLK, I. évf. (1871) 6. sZ. 3.

${ }^{339}$ SZLK, I. évf. (1871) 20. sZ. 3.

${ }^{340}$ Uo.

${ }^{341}$ SZLK, I. évf. (1871) 5. sz. 3.

${ }^{342}$ SZLK, I. évf. (1871) 6. sz. 3.
} 
vendéglőkben esténként összegyült kutyák hangos csaholásai ${ }^{343}$ és a nézőtéren helyet foglaló gyerekek sírásai, kiabálásai, rendetlenkedései; ${ }^{344}$ illetve mindenki irtsa a gazt a saját portáján $^{345}$ és kössön biztosítást, különösen a gyerekeire. ${ }^{346}$

Állandó rovat volt még a Városi hirdetőkönyvből, amely apróhirdetéseket, rövid hivatalos közleményeket, felhívásokat közölt; az aktuális gabonajegyzési árakat, illetve esetenként a tiszai vízállást is ismertető Üzleti tudósitás, valamint - bár nem rendszeres megjelenéssel - a Nyilt tér, ahol a szerkesztőség teret engedett - igaz, külön díjazás fejében az eltérő olvasói vélemények ütköztetésének, az országos mintát követve. A legélesebb szóváltás Zuckerman Károly és Ehrlich József között zajlott: az izraelita hitközség két tagja kölcsönösen becsmérelte egymást a hetilap hasábjain. A vitát indító Zuckerman azzal vádolta Ehrlichet, hogy a volt hitközségi elnök nem tartotta be egykori ígéretét, vagyis nem támogatja a szentesi zsinagóga felépítését, mi több, inkább akadályozza azt. ${ }^{347}$ A levelet Ehrlich rágalmazásnak minősítette, és megfenyegette a másik felet: „erkölcsi kötelességem [...] cikkírót komolyan figyelmeztetni, miszerint jövőre igyekezzék nemesebb foglalkozás által kiérdemelni hitsorsosai bizalmát, mivel ellenkezö esetben kényszeritve leszek, ellene a törvényes lépéseket azonnal megtenni". ${ }^{348}$ A vita végül sajtóperhez vezetett - a szentesi sajtó történetében első alkalommal -, amely Ehrlich győzelmével végződött. A bíróság nyilvános bocsánatkérésre kötelezte Zuckermant, aki a Szentesi Lapok hasábjain eleget is tett a hatósági döntésnek. ${ }^{349}$

A Gazdászati rovat mindössze egyetlen megjelenést élt meg, mivel szerzője Balogh János volt, aki már az első szám után távozott a laptól, mint fentebb említettük. Három hónappal később új rovat indult a témában Gazdászati és kereskedelmi értesités címmel, majd a következő év februárjában ismét találkozhatunk Gazdászati rovattal is az előbbi mellett.

Ha a Szentesi Lapokat a többségében a negyedik oldalon közölt hirdetései alapján vizsgáljuk meg, rögtön feltünik, hogy nem csak az előfizetők, hanem a hirdetők is lassan találtak utat a város első saját közéleti sajtóorgánumához. Az első, 1871. július 9-i lapszámban mindössze egyetlen hirdetést találunk: Zoó János festész és fényképész tudatja, hogy ,fényképészeti fölvételi helyiségét" ideiglenesen Joó Károly református kántor udvarában rendezte be. A következő számban is csupán kettőt találunk: Sajó Sándor tanító

\footnotetext{
${ }^{343}$ SZLK, I. évf. (1871) 8. sz. 3.

344 SZLK, I. évf. (1871) 10. sz. 3.

${ }^{345}$ SZLK, II. évf. (1872) 24. sZ. 3

${ }^{346}$ SZLK, II. évf. (1872) 4. sz. 3.

${ }^{347}$ SZLK, I. évf. (1871) 3. sZ. 3.

${ }^{348}$ SZLK, I. évf. (1871) 4. sZ. 3.

${ }^{349}$ SZLK, I. évf. (1871) 24. sZ. 4.
} 
oktatást vállal a nyári szünidő alatt, illetve Weinmann Bernát erősítő italt árul. Ráadásul az első lapszámok hirdetései a vizualitás szempontból is igen kezdetlegesek: szövegszerüek, grafikai elemeket nem tartalmaznak. Az ötödik számtól kezdve jelennek meg a professzionálisabb reklámok, ekkor már a szövegtől elkülönülve, a legtöbb esetben keretbe foglalva, egyre tetszetősebb formátumban, különböző képi megoldásokkal növelve a figyelemfelkeltő szerepet - a lap indulása után tehát egy-másfél hónappal a hirdetők egyre inkább bizalmat szavaztak az újságnak, és a hirdetések száma beállt egy viszonylag állandó szintre, csaknem teljesen kitöltve a negyedik oldalt.

\begin{tabular}{|c|c|c|c|}
\hline Hirdető & $\begin{array}{c}\text { Hirdető } \\
\text { székhelye }\end{array}$ & $\begin{array}{l}\text { A hirdető profilja, } \\
\text { a hirdetés tárgya(i) }\end{array}$ & $\begin{array}{l}\text { Hirdetések } \\
\text { száma (db) }\end{array}$ \\
\hline Handler Mór orvos & Pest & $\begin{array}{l}\text { „titkos betegségek” és } \\
\text { „elgyengült férfierö” } \\
\text { gyógyítása }\end{array}$ & 22 \\
\hline Rambovszky József vendéglős & Szentes & $\begin{array}{l}\text { gőz- és kádfürdő, } \\
\text { kávéház, vendéglő }\end{array}$ & 22 \\
\hline Várady Lajos gyógyszerész & Szentes & $\begin{array}{l}\text { gyógyszerek, } \\
\text { kozmetikumok }\end{array}$ & 22 \\
\hline $\begin{array}{l}\text { Várady Lajos és Dózsa Béla } \\
\text { gyógyszerészek }\end{array}$ & Szentes & $\begin{array}{l}\text { Anatherin szájvíz és } \\
\text { fogpaszta }\end{array}$ & 20 \\
\hline Purjesz Dávid kereskedő & Szentes & ruhakereskedés & 20 \\
\hline $\begin{array}{l}\text { Cherrier János } \\
\text { nyomdász és kereskedő }\end{array}$ & Szentes & $\begin{array}{l}\text { könyv- és papíráru- } \\
\text { kereskedés, írószer; } \\
\text { tanonc részére } \\
\text { álláshirdetés a nyomdába }\end{array}$ & 9 \\
\hline Füchsl és Fia & Szentes & $\begin{array}{l}\text { gözfürész malom, } \\
\text { fakereskedés }\end{array}$ & 9 \\
\hline Weinmann Bernát kereskedő & Szentes & $\begin{array}{c}\text { erősítő ital, lőpor, rosta, } \\
\text { sparhelt, olajfestmények, } \\
\text { bőrgarnitúra, sorsjegyek, } \\
\text { kiadó szoba }\end{array}$ & 9 \\
\hline Abaffy László kereskedő & Szentes & $\begin{array}{c}\text { vegyes- és } \\
\text { füszerkereskedés }\end{array}$ & 8 \\
\hline $\begin{array}{c}\text { Csillag Ármin } \\
\text { arany- és ezüstmüves }\end{array}$ & Szentes & arany, ezüst, pipaáru & 7 \\
\hline Dobray Sándor kereskedő & Szentes & bor, zsindely & 7 \\
\hline Lázár és Sonnenfeld & Szentes & fakereskedés & 6 \\
\hline Sréter Ferenc bádogos & Szentes & $\begin{array}{c}\text { petróleumlámpák, } \\
\text { zsíredények, bödönök }\end{array}$ & 6 \\
\hline Steiner Dávid kereskedő & Szentes & ruhakereskedés & 6 \\
\hline Schwarzkopf Fülöp & Szentes & táncoktatás & 6 \\
\hline Szentesi Takarékpénztár Egylet & Szentes & pénzügyi szolgáltatások & 6 \\
\hline $\begin{array}{c}\text { Vutsák János, Antal János és } \\
\text { Balogh Mihály asztalosok }\end{array}$ & Szentes & koporsókészítés & 6 \\
\hline $\begin{array}{c}\text { Szentesi Gazdasági, } \\
\text { Kereskedelmi és Bizományi } \\
\text { Hitelintézet }\end{array}$ & Szentes & bankbetétek & 5 \\
\hline
\end{tabular}

\section{4. ábra - A Szentesi Lapokban legtöbbet hirdető vállalkozások és magánszemélyek}


A táblázatból láthatjuk, hogy négy vállalkozás kiemelkedik a sorból, különösen Várady Lajos gyógyszerész, aki kétféle reklámot is nagyszámban megjelentetett a lapban: saját gyógyszertára termékeit, illetve Dózsa Bélával (egy másik szentesi patika tulajdonosával) közösen népszerüsítette az Anatherin termékcsaládot.

A hirdetések száma a második évfolyam utolsó márciusi számától fokozatos csökkenést mutat: a korábban reklámokkal telített negyedik oldalnak már alig a háromnegyed részét töltik meg a hirdetések, majd a tendencia folytatódik - az áprilisi lapszámokban már csupán feleannyi hirdetést találunk, mint másfél-két hónappal korábban, s a stagnálás átnyúlik a következő hónapra is. A május 19-i (II. évf. 20. sz.) lapszámban azonban hirtelen ismét sok hirdetést láthatunk, és egy-két kivételtől eltekintve csak olyan vállalkozásokat, amelyek eddig nem reklámoztak a Szentesi Lapokban (például a fóvárosi Rothschild \& Comp.), a régi hirdetők pedig javarészt eltűntek a hasábokról. Nincs adatunk arra nézve, hogy ennek pontosan mi volt az oka, bár a folyamatból egyértelműen látszik, hogy a korábbi hirdetők egyre inkább elpártoltak az ekkor még mindig a kezdeti szinthez hasonlóan alacsony előfizetői létszámmal rendelkező újságtól. A szerény érdeklődést minden bizonnyal három tényező együttes hatása eredményezte: egyfelől a lap tipikus 'gyermekbetegségei' (bizonytalan és többször változó rovatstruktúra, sok esetben a szentesiek számára érdektelen hírek, viszonylag sok helyesírási és tördelési hiba). Másrészt, a helyi lakosságnak - még egy szakmailag makulátlan újság esetén is - több időre lett volna szüksége, hogy megbecsülje első saját hetilapját, és anyagi áldozattal - vagyis minimum negyedéves előfizetéssel - is hozzájáruljon annak fennmaradásához. Mindemellett, figyelembe véve a többségében református vallású, 48-as párti helyi lakosságot - különösen az 1870-es évek elején, mikor a kormánypárt szinte minden hitelét elveszítette a városban -, eleve illúzió volt egy politikai függetlenséget hirdető, de az országos hatalomhoz lojális sajtóorgánum sikerében bízni.

Cherriernek ideiglenesen sikerült új hirdetőket toboroznia, a Szentesi Lapok azonban nem váltotta be a hozzáfüzött reményeket, és végül 1872 nyarán megszünt. Az utolsó számot 1872. június 30-án vehették kézbe az olvasók - a város első közéleti hetilapja tehát mindössze két évfolyamot ért meg, és összességében kevesebb mint egy évig létezett. 


\subsection{Az Alföldi Figyelő}

A település második hetilapja, a szintén Cherrier nevével fémjelzett Alföldi Figyelö még a Szentesi Lapok müködése végén indult. A mutatványszám 1872. május 30-án, csütörtökön jelent meg. A Cherrier János kiadó-tulajdonos, valamint Horváth József társtulajdonos és felelős szerkesztő által közösen jegyzett beköszöntő szerint egy a Szentesi Lapoktól eltérő tematikájú, politikamentes hírlap született, merész célkitüzéssel: nem csupán a szentesiek, hanem az egész Alföld orgánuma akart lenni. „A politikát kizárjuk; mert nézetünk szerint ezen kelme igen tarthatatlan s a nagy közönségre nézve ritkán üdvös hatásu. [...] Okvetlen szükségünk van széles Alföldünkön oly egyetemes lapra, mely átölelje az Alföld általános érdekeit." 350 Az írás alapján az Alföldi Figyelő célja az ismeretterjesztés, a gazdászat, a népnevelés, a szépirodalom népszerüsítése, a különféle nézetek ütköztetése, valamint a külföldi eseményekről való tudósítás. Emellett közlik, hogy „,A lap f. é. juliustól fogva minden szombaton szép fehér papiron, csinosan kiállitva, fog megjelenni." ${ }^{351}$ (Megjegyzendő, hogy az először egy csütörtöki napon napvilágot látott hetilap szombati megjelenést ígért, amely már a második számtól vasárnapra módosult.)

A Szentesi Lapok 1871. június 2-i számában (II. évf. 22. sz.), a harmadik oldalon, a helyi hírek között említette, miszerint új lap indult Alföldi Figyelő néven, mindenféle kommentár nélkül. A városban azonnal felröppent a hír, hogy a Figyelő hamarosan bekebelezi a Szentesi Lapokat, azonban ezt Cherrier és Honthy határozottan cáfolta: mint írták, a két újság programja eltérō, hiszen az Alföldi Figyelő az Alföld érdekeit tartja szem előtt, míg a Szentesi Lapok a hazát, a megyét és a várost képviseli elsősorban. A két lap együttes létezésének mindössze annyi a célja, hogy minél több előfizetőt toborozzanak. ${ }^{352}$

Az első szám vezércikke a közelgő országgyülési választásokon való részvételre, illetve józan ítéletre buzdít, s az újság - akárcsak a Szentesi Lapok - igyekezett semleges maradni politikai kérdésekben. ${ }^{353}$ A második oldalon található publicisztika (Visszapillantás a népnevelés terén történtekre) a néptanítók fizetésemeléséért száll síkra, mert a névtelen cikkíró szerint igencsak sanyarú a sorsuk. ${ }^{354}$ A Tárca rovat itt is állandó szerepet kap, az első

\footnotetext{
${ }^{350}$ AF, I. évf. (1872) 1. sz. 1.

351 Uo.

${ }^{352}$ SZLK, II. évf. (1872) 23. sz. 1.

${ }^{353}$ AF, 1. évf. (1872) 1. sz. 1-2.

${ }^{354}$ AF, 1. évf. (1872) 1. sz. 2.
} 
számban egy verset olvashatunk Szentes városához címmel, „Akárki” tollából; emellett egy név nélküli szerzőtől egy kis novellát (Egy virágcsokor története). ${ }^{355}$

A mutatványszám harmadik oldalán derül ki egyértelmüen, hogy az Alföldi Figyelő nem csak címében tér el a Szentesi Lapoktól, sőt a beköszöntő cikkben meghatározott célok megvalósítása terén a szerkesztőség kissé túlzásba is esett: a Szentesen kiadott újság első száma egyetlen helyi hírt sem tartalmaz. (Minderre természetesen magyarázat lehet, hogy az ugyanazon kiadó berkein belül megjelenő Szentesi Lapok ekkor még létezett.) Emellett az egyébként sem túl terjedelmes Hazai hirek rovat mindössze hat eseményröl számol be, és ebböl csak egy történt az Alföldön: a vásárhelyi földmíves iskola ügye elörehaladt. A többségében országos vonatkozású információk nagy része ráadásul nagyon alacsony hírértékkel bír: valószínüleg kevés helyi olvasót érdekelt, hogy ki lett az új pesti tanfelügyelő, vagy hogy állami ösztöndíjat kapott a fővárosban két mintarajz-tanodai növendék. ${ }^{356}$ (A beígért és az orgánum nevével is fémjelzett tematikát a híranyagok mennyiségi és minőségi összeállítása terén a későbbiekben sem sikerült teljesíteni, s ez minden bizonnyal az egyik fö oka volt annak, hogy az Alföldi Figyelö müködése rövid időn belül kudarccal végződött.)

Újabb szerkesztési hiba, hogy a hazai híreket tartalmazó rovatot megelőzi a Külföldi hirek rovat, amely elsősorban a Német Császárságra koncentrál: beszámol például a hamburgi tanítók gyűléséről vagy a metzi vár parancsnokának hadbíróság elé való állításáról. Emellett értesülünk a Franciaországban bevezetett új adónemekről, illetve megtudhatjuk, hogy Thiers francia elnök engedélyezte Lajos Fülöp földi maradványainak családi sírboltba szállítását. ${ }^{357}$ Megemlítendő még a Különfélék rovat, amely kéri az olvasókat, hogy terjesszék a lapot, majd beszámol a fóvárosba történő gabonaszállításokról; emellett taglalja a gyapjúnyírással kapcsolatos tudnivalókat, illetve olvashatunk egy a Vasárnapi Ujságból átvett írást a gépek hasznáról. ${ }^{358}$

A mutatványszám utolsó oldalán található a rövid Szerkesztői üzenetek rovat, a maradék helyet pedig a hirdetések töltik ki, amelyek nagy része megegyezik a Szentesi Lapokban is hirdető vállalkozásokkal (Purjesz Dávid, Rotschild \& Comp., Füchsl és fia, Schwarzkopf Fülöp, Dobray Sándor, Veill Salamon, Tóth Gyula). ${ }^{359}$ Az alábbi táblázatból az is kitünik, hogy az Alföldi Figyelöben - három kivételtől eltekintve - csak helyi hirdetőket

\footnotetext{
${ }^{355}$ AF, 1. évf. (1872) 1. sz. 2-3.

356 AF, 1. évf. (1872) 1. sz. 4.

${ }^{357}$ AF, 1. évf. (1872) 1. sz. 3-4.

${ }^{358}$ AF, 1. évf. (1872) 1. sz. 3.

${ }^{359}$ AF, 1. évf. (1872) 1. sz. 4.
} 
találunk, ami szintén igazolja az eredetileg vállalt célkitüzés kudarcát: más alföldi települések vállalkozásai, illetve máshol élő magánszemélyek nem hirdettek a hetilapban.

\begin{tabular}{|c|c|c|c|}
\hline Hirdető & $\begin{array}{c}\text { Hirdető } \\
\text { székhelye }\end{array}$ & $\begin{array}{l}\text { A hirdető profilja, } \\
\text { a hirdetés tárgya(i) }\end{array}$ & $\begin{array}{l}\text { Hirdetések } \\
\text { száma (db) }\end{array}$ \\
\hline Purjesz Dávid kereskedő & Szentes & ruhakereskedés & 5 \\
\hline$?^{360}$ & Bécs & $\begin{array}{l}\text { Liebig-féle Kumys- } \\
\text { kivonat }\end{array}$ & 5 \\
\hline Füchsl és Fia & Szentes & $\begin{array}{l}\text { gőzfürész malom, } \\
\text { fakereskedés }\end{array}$ & 4 \\
\hline $\begin{array}{c}\text { Szentesi Első } \\
\text { Fakereskedelmi és } \\
\text { Gőzmalmi } \\
\text { Részvénytársulat }\end{array}$ & Szentes & részvények & 4 \\
\hline Weill Salamon & Szentes & faáru & 4 \\
\hline Steiner Dávid kereskedő & Szentes & ruhakereskedés & 3 \\
\hline $\begin{array}{l}\text { Gunst Lipót m. kir. } \\
\text { dohány fötőzsér }\end{array}$ & Szentes & dohánykereskedés & 3 \\
\hline $\begin{array}{l}\text { Bartutz János és Cakó } \\
\text { József }\end{array}$ & Szentes & tüzifa & 3 \\
\hline Tóth Gyula & Szentes & liszt & 3 \\
\hline $\begin{array}{l}\text { Szentesi Gazdasági, Ipari } \\
\text { és Kereskedelmi Bank }\end{array}$ & Szentes & betétre keres búzát, árpát & 3 \\
\hline Bogyó István óraműves & Szentes & $\begin{array}{l}\text { zseb- és fali órák } \\
\text { eladása, javítása }\end{array}$ & 3 \\
\hline $\begin{array}{c}\text { Szentesi Gazdasági, } \\
\text { Kereskedelmi és Iparbank }\end{array}$ & Szentes & $\begin{array}{c}\text { álláshirdetések (titkár, } \\
\text { magtárnok) }\end{array}$ & 2 \\
\hline Rotschild \& Comp. & Bécs & tőzsdei megbízások & 2 \\
\hline $\begin{array}{c}\text { Csurai Ferenc } \\
\text { kalapgyáros }\end{array}$ & Szentes & kalapok & 2 \\
\hline Schwartzkopf Fülöp ${ }^{361}$ & Szentes & táncoktatás & 2 \\
\hline Dobray Sándor kereskedő & Szentes & zsindely & 2 \\
\hline Bartsch Károly & Szentes & nyilvános tűzijáték & 1 \\
\hline $\begin{array}{l}\text { Holländer Károly } \\
\text { lakatosmester }\end{array}$ & Szentes & lakatosmunkák & 1 \\
\hline Szentes város & Szentes & $\begin{array}{l}\text { városi előfogatozás } \\
\text { haszonbérlete }\end{array}$ & 1 \\
\hline Sinoros-Szabó József & Szentes & föld, ház & 1 \\
\hline $\begin{array}{l}\text { Hazai Kiházasító } \\
\text { Részvény-Társulat }\end{array}$ & Pest & részvények & 1 \\
\hline Rambovszky József & Szentes & eladó varrógépek & 1 \\
\hline Csillag Móric & Szentes & bor & 1 \\
\hline Vutsák János és társa & Szentes & $\begin{array}{c}\text { álláshirdetés } \\
\text { (kereskedésbe tanonc) }\end{array}$ & 1 \\
\hline Csukás Benjamin & Szentes & eladó szekér & 1 \\
\hline
\end{tabular}

\section{5. ábra - Az Alföldi Figyelőben hirdető vállalkozások és magánszemélyek}

${ }^{360}$ A keretes hirdetésből nem derül ki a hirdető neve, sem a termék árusítási helye

${ }^{361}$ Az Alföldi Figyelő 1872. július 26-i és augusztus 4-i számában (I. évf. 5. és 6. sz.) szereplő hirdetésekben ismét helytelen formában - ezúttal Swarczkopf alakban - szerepel a tánctanár neve, akárcsak a Szentesi Lapban több esetben, mint később látni fogjuk. 
Nincs adatunk arra nézve, hogy önmagát beteljesítő jóslatról van-e szó, vagy Cherriernek eleve ez volt a szándéka, mindenesetre tény, hogy a két lap csupán az Alföldi Figyelő mutatványszáma erejéig létezett párhuzamosan. Az első szám után ugyanis egy hónapig az új lap kiadása szünetelt - eközben a Szentesi Lapok még müködött -, majd 1872. július 7-én, vasárnap jött ki a második szám, ugyanakkor a Szentesi Lapok aznap már nem jelent meg. ${ }^{362}$ Az eset minden bizonnyal váratlanul érte az olvasótábor, illetve az előfizetők nagy részét, föként, hogy - mint már említettük - Cherrier és Honthy három héttel korábban még következetesen cáfolta azt, ami végül mégis bekövetkezett. A fúzióról a második lapszám első oldalán található, Tisztelt olvasóinkhoz címü cikk értesíti a nagyközönséget. A Cherrier János kiadó, valamint Horváth József és Honthy László felelős szerkesztők által jegyzett írás az egyesülés tényén kívül közli a hetilap újonnan megfogalmazott célját is: reformigényekről szóló, pártatlan vezércikkeket, különféle tudományos ismeretek terjesztését ígéri a gazdászat, a tanügy, az iparügy területéröl, emellett helyi, országos és külföldi eseményekről való tudósításokat. Az eredetileg vállalt célt, vagyis az egész Alföldre kiterjedő, regionális hírszolgálatot már meg sem említi a közlemény, mindezzel pedig a lap nevét is értelmetlenné és hiteltelenné teszi - az Alföldi Figyelő tartalmi szempontból tehát a Szentesi Lapok irányvonalát folytatta.

$\mathrm{Az}$ egyesülés után tehát Cherrier a felelős szerkesztői posztot nagyvonalúan megosztotta: a fentebb említett közlemény aláírásain kívül a lap második, 1872. július 7-én megjelent számának negyedik oldalán, az impresszumban is olvasható, hogy Horváth József és Honthy László közösen felel az újság tartalmáért. Ugyanebből a számból kaphatunk információt a példányszám jelentős növelésére a Szentesi Lapokhoz képest: „Lapunk ezen száma közel ezer példányban lévén nyomtatva..."363 - bár ez valószínűleg csupán egy egyszeri marketingakció volt, mint arra a megfogalmazás is utal, és a példányszám ezt követően minden bizonnyal már az előfizetői igényekhez igazodott.

A harmadik számtól fogva újabb változás következett, ezúttal a lap vezetőségében: Honthy László megelégelte az egyesülés nyomán létrejött, számára méltatlan helyzetet, és nem kívánt többé az Alföldi Figyelő társszerkesztője lenni. A hírrovatban olvashatjuk, hogy Honthy „bizonytalan idöre visszalépett”, ami a valóságban azt jelentette, hogy véglegesen távozott. ${ }^{364}$ Horváth József egyedül végezte ezután a lap szerkesztését - s maradt egyben társtulajdonos is -, azonban nem sokáig: a következő lapszám első oldalán Cherrier János $A$

\footnotetext{
${ }^{362}$ A Szentesi Lapok utolsó, június 30-i (II. évf. 26. sz.) száma közli - nem címoldalon, csupán a 3. oldal helyi hírei között -, hogy a lap megszünik, és szellemiségét az Alföldi Figyelö fogja a jövőben képviselni.

363 AF, I. évf. (1872) 2. sz. 3.

364 AF, I. évf. (1872) 3. sz. 3.
} 
t.c. olvasó közönséghez címü közleményében tudatja az olvasókkal, hogy Horváth József szintén elhagyta állását, ráadásul előzetes bejelentés nélkül, miután fizetését felvette. ${ }^{365}$ Ezt követően, más megoldás hirtelen nem lévén, a kiadó-tulajdonos saját maga látta el tizenhárom évig tartó szentesi lapkiadói tevékenysége során először és utoljára - a felelős szerkesztői feladatokat is. Cherrier a közleményen kívül kicsinyes módon bosszulta meg munkatársa távozását: két, az előző lapszámban megjelent külföldi cikk folytatásai alól törölte a fordítóként közremüködő Horváth nevét. ${ }^{366}$

Az Alföldi Figyelő rovatszerkezete a Szentesi Lapokkal való fúziót követően a korban megszokott sémát követte: az első oldalon vezércikket olvashatunk, illetve a többnyire a második oldalra átlógó Tárca rovatot, amely a szépirodalomnak enged teret. A második oldal különféle rövidebb véleménycikkeket, tudósításokat tartalmaz, valamint itt és a harmadik oldalon találjuk a híreket, amelyek rovatokba szerkesztése meglehetősen következetlen. Az első lapszámban Különfélék, Külföldi hirek és Hazai hirek rovatcímeket találunk, a másodikban a Hazai hirek módosul Helyi és hazai hirekre - ezzel is jelezve a Szentesi Lapok tematikájának átvételét -, a következő számokban pedig hol az egyik, hol a másik hírrovat elmarad a hasábokról, illetve tartalmi keveredés is történik: az ötödik lapszámban a Különfélék rovat például mindhárom hírrovat szerepét betölti egyszerre, vagyis helyi, országos és külföldi híreket is tartalmaz, a hatodik számban viszont újra megjelennek önálló rovatban a Helyi hirek - ezúttal a „Hazai” jelző elmarad a rovat nevéből.

Az újság minimális mértékben - jóval kisebb mértékben, mint a Szentesi Lapok - tett csak eleget a regionalitás követelményeinek. Találunk tudósításokat csongrádi, mindszenti vagy hódmezővásárhelyi eseményekről, de a szerkesztőség ennél nagyobb hatósugarat nem alkalmazott a hírszolgáltatás terén. Leginkább a helyi hírekre koncentrált, mint azt az alábbi ábra is mutatja, s amelyből jól látszik az is, hogy a Szentesi Lapokhoz képest az Alföldi Figyelő jóval nagyobb hangsúlyt fektetett a külföldi eseményekre.

\footnotetext{
365 AF, I. évf. (1872) 4. sz. 1.

${ }^{366}$ AF, I. évf. (1872) 4. sz. 1-2.
} 


\section{6. ábra - Az Alföldi Figyelő hírei területi megoszlás szerint}

(\%)

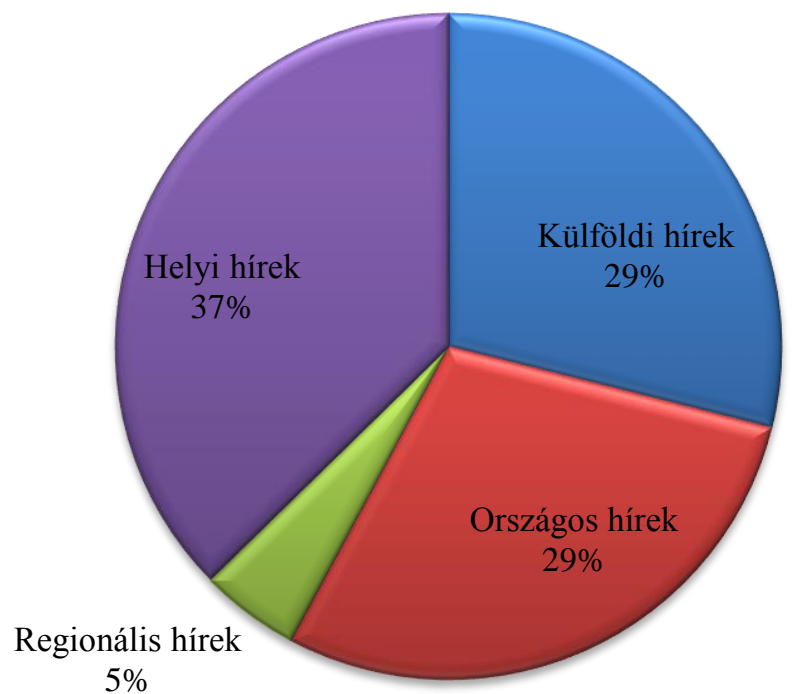

Az Alföldi Figyelö külföldi híreit tekintve jelzésértékü, hogy a bulvárhírek (botrányok, érdekességek, balesetek, katasztrófák stb.) aránya nagyobb a politikai, illetve egyéb közéleti eseményekről való tudósításokénál, amelyből levonhatjuk a következtetést: a színes, sokszor szenzációhajhász hírek túlsúlyával a szerkesztőség igyekezett érdekesebbé, szórakoztatóbbá tenni a lapot, ezzel pedig növelni az előfizetők számát. ${ }^{367}$ Megtudhatjuk például, hogy egy francia gazda ökrét pálinka gyógyította ki a tüdőbajból; ${ }^{368}$ hogy az Egyesült Államokban egy néger pap alaposan berúgott; hogy Ohio államban egy hölgyet pénzbüntetésre ítéltek pletykálkodás miatt - nálunk is hasonló rendszabályokat kellene bevezetni, ajánlja a szerkesztőség. ${ }^{369}$ Mindemellett értesülünk kanadai vasúti tragédiáról, kínai teázási szokásokról, németországi Mária-csodatételről, hogy Londonban uralkodói ékszereket árvereztek el, ${ }^{370}$ hogy New Yorkban sokan napszúrást kaptak a tikkasztó napsütésben, Kijevben ugyanakkor kolerajárvány pusztít, ${ }^{371}$ illetve, hogy meghalt Párizs „legvastagabb” asszonya, aki 514 fontot nyomott, vagy hogy Amerikában egy Duckar nevü egyén repülö szerkezetet talált fel, amely négy darab selyemszárnyból és légszesszel töltött tömlőből áll. ${ }^{372}$

\footnotetext{
367 „A botrány ugyanis nem pusztán valamiféle perverz kiváncsiság kielégítésére kreált médiaesemény, hanem válasz egy alapvetö társadalmi szükségletre.” (Baráth 2006.)

368 AF, I. évf. (1872) 2. sz. 3.

${ }^{369}$ AF, I. évf. (1872) 2. sz. 4.

370 AF, I. évf. (1872) 4. sz. 3.

${ }^{371}$ AF, I. évf. (1872) 5. sz. 2-3.

372 AF, I. évf. (1872) 6. sz. 3.
} 


\section{7. ábra - Az Alföldi Figyelő külföldi híreinek tematikus megoszlása}

$(\%)$

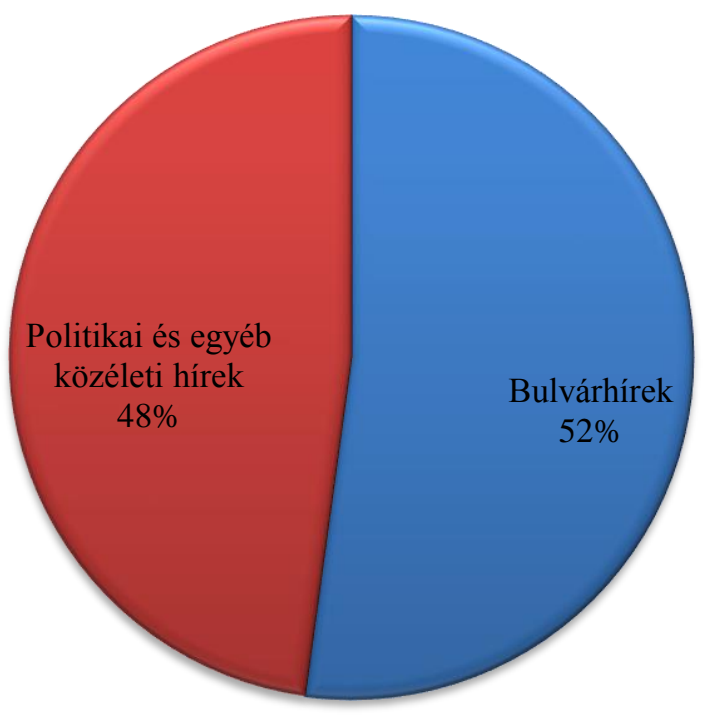

A Szentesi Lapokhoz hasonlóan az Alföldi Figyelö is igyekezett eleget tenni a társadalom iránt felelös orgánum szerepkörének: többször felhívják például a lakosság figyelmét a kötelező gazirtásra, különösen az akkoriban elszaporodott „,szervián tüsök” esetében, amelynek elmulasztása büntetést von maga után. Emellett felszólítják a hatóságot, hogy mielőbb intézkedjék, mert a Kurca csatornái büzös vízzel vannak tele. A probléma elhárítása, vagyis a víz lecsapolása már a következő héten megkezdődött, s ez nagyrészt az újság felhívásának köszönhető - állapítja meg büszkén a szerkesztőség.

Az 1872. július 14-i lapszámban rövid, de sokatmondó statisztikát találunk Orvosi jelentés a szentesi közegészségügyi és légköri viszonyokról címmel, amelyböl - többek között - megtudhatjuk, hogy június hónap folyamán összesen hetven haláleset történt a városban, és ebből harminchárom, tehát az áldozatok közel fele gyermek. Huszonnégy esetben „idültkór”, tizenhat alkalommal pedig ,gyulladásos heveny bajok” okozták a tragédiát, emellett történt három erőszakos halálozás is: egy ember vízbe fulladt, egy megégett, egy személy pedig öngyilkosságot követett el.

Az Alföldi Figyelő nem bizonyult hosszú életünek: mindössze hat száma jelent meg, az utolsó 1872. augusztus 4-én. A tulajdonos minden bizonnyal belátta, hogy túl nagy fába vágta a fejszéjét, mikor az újság eredeti célkitüzéseit megfogalmazta, ráadásul a két 
szerkesztő távozása jelentősen rontotta a lap hitelét. ${ }^{373}$ Cherrier így inkább megint új sajtóorgánummal jelentkezett, mint hogy a megtépázott hírnév helyrehozatalával kísérletezzen egy következő felelős szerkesztő segítségével. A tulajdonos új kiadványa első számában értesítette a nagyközönséget az Alföldi Figyelő megszünéséről: „A folyó évi julius hó elején megjelent »Alföldi Figyelö« cimü lap szerkesztésére vállalkozott urak, mint már ez a julius 21-iki számban jelentetett, a lap további szerkesztésétöl visszalépvén, emlitett lap a legutóbb vasárnap megjelent hatodik számmal pályáját bevégezte."374

\subsection{A Szentesi Lap}

Az Alföldi Figyelő utolsó számát követő héten, 1872. augusztus 11-én vehették kézbe a település lakói Cherrier harmadik helyi újságját, a Szentesi Lapot. (A kiadó, valamint az új felelős szerkesztő, Farkas Lajos ügyvéd a városi tanácsnak tett bejelentésében közölte, hogy az Alföldi Figyelő megszünik, s az olvasók kárpótlása céljából egy új, nem politikai hetilapot indítanak. ${ }^{375}$ ) Az első szám címoldalán található - Cherrier és Farkas által aláírt - beköszöntő a következőképpen fogalmaz a Szentesi Lap célját illetően: „A szerkesztő igyekezni fog a t. c . közönség abeli igényeinek, hogy a városunkat közelebbröl érdeklö közügyekre nézve magának tájékozást szerezhessen, megfelelni, igyekezni fog a községünkben és megyénkben történö eseményekröl értesitést a lehetöség szerint hü forrásból és elsö kézböl közleni; s rajta lesz, hogy a közönséget érdeklö ügyek mikénti elintézése minél szélesebb körben megvitattassék, hogy igy a kifejlö eszmecsere utján az elágazó nézetek tisztába hozassanak; e tekintetböl e lap s szabad vélemény nyilvánitásra bárkinek is nyitva áll, feltévén, hogy a nyilvánitás a tárgyilagosság terén marad." ${ }^{376}$ Emellett hitet tesznek a politikai semlegesség mellett, illetve

\footnotetext{
${ }^{373}$ Nehezen tekinthető reális vállalkozói célnak, hogy egy kevésbé tőkeerős, elsősorban helyi érdekeltségü hetilap akkoriban az egész Alföld érdeklödését felkeltse, több megyét is átfogjon, tekintve, hogy az alföldi települések nagy része ekkor már rendelkezett hasonló profilú és színvonalú hírlappal (lásd pl. az 1871 áprilisában indult Hód-Mezö-Vásárhelyt); illetve a megállapítás fordítva is igaz: a szentesi lakosság föként a saját településének és környékének eseményeiröl kívánt értesülni, és csak másodsorban érdeklődött a tágabb régió, az ország vagy a külföldi hírek iránt.

${ }^{374}$ SZL, I. évf. (1872) 1. sz. 1. (Érdekességként megjegyzendő, hogy Cherrier Jánosnak ez az egyetlen saját cikke tizenhárom évig tartó szentesi lapkiadói tevékenysége során.)

${ }^{375}$ MNL CSML Szentes, V.B.145.b. - Szentes Város Tanácsának iratai 1849-1872 - Tanácsi iratok, 2447/1872.. A lapindítás bejelentését bizonyítja a MNL OL BL K 148. szekciójának nyilvántartásában szereplő, 4248/1872. sz. iratszám is (maga az irat már nem fellelhető).

${ }^{376}$ SZL, I. évf. (1872) 1. sz. 1.
} 
megígérik, hogy a gabonaárak, a városi hirdetőkönyv közlésével továbbra is szolgálni fogják a lakosság gazdasági érdekeit. ${ }^{377}$

Jól mutatja, hogy - a kiadó-tulajdonos személyéből kifolyólag - valójában az Alföldi Figyelő hivatalos utódlapjáról van szó, hogy az első számban egy az Alföldi Figyelőben közzétett hírrel kapcsolatban a korábbi tényeket módosító információkat közöl, egyértelmü helyreigazításként: „Az »Alföldi Figyelö» legutóbbi számában Kátai Pál Mihály szerencsétlenül járt szolgálójára nézve tett abeli közlést, hogy ugy mond az eset megtörténtekor a városi orvos megkapható nem volt, helyesebb értesülés folytán oda igazitjuk ki, hogy a közönség érdekében fáradozó orvos urakat megróni szándékunkban nem állt, s mint jó forrásból tudjuk, a karját tört leány az eset után a városi összes orvosok által nemcsak megvizsgáltatott, hanem sérülései felett együttes tanácskozmány is tartatott." ${ }^{\text {"78 }}$ Ráadásul ugyanezen lapszám címoldalán adnak válaszlehetőséget Cicatricis Pál városi főjegyző számára, akit egy az Alföldi Figyelőben korábban megjelent, Szathmáry Ede ${ }^{379}$ tollából származó nyílt levél hátrányosan érintett: Cicatricis már a Szentesi Lap hasábjain szólítja fel Szathmáryt, hogy legközelebb ne a sajtóban, hanem a közgyülésen adjon hangot bíráló véleményének ${ }^{380}$ - utóbbi példa is a folytonosságot tükrözi a két lap között.

A Szentesi Lap már beváltotta a hozzáfüzött reményeket, hamarosan a település és térsége elsőszámú tömegtájékoztatási eszközévé lépett elő, s két nagyobb megszakítást leszámítva (1899-1906, illetve 1919-1945) egészen 1947. szeptember végéig megjelent. ${ }^{381}$ Küllemét, rovatszerkezetét tekintve nagyjából azt az irányvonalat követte, mint két elődje, a Szentesi Lapok és az Alföldi Figyelő, viszont tartalmi téren egyre inkább változáson ment keresztül, főleg, miután 1873 áprilisától Farkas helyére Buday József református néptanító, városi pénztárnok lépett. ${ }^{382}$ Farkas Lajos visszalépését a lap egészségügyi okokkal

\footnotetext{
377 Uo.

${ }^{378}$ SZL, I. évf. (1872) 1. sz. 3.

379 Szathmáry Ede ügyvéd, városi képviselő. 1835-ben született Hódmezővásárhelyen, Pesten szerzett jogi diplomát. 1861. januártól Szentes városi főjegyzője, majd a rövid alkotmányos időszak végeztével, az újjáéledő önkényuralom elleni tiltakozás jeléül még novemberben lemondott hivataláról, ezután ügyvédként kereste kenyerét. 1872-ben elnyerte a városi ügyészi tisztséget, de mivel ez összeférhetetlen volt ügyvédi tevékenységével, inkább az utóbbit választotta. Közben aktívan részt vett a közéletben: városi és megyei képviselö volt, valamint a református presbitérium tagja. Ezen kívül a Szentes-Vidéki Takarékpénztár és a Körös-Tisza-Maros Ármentesítő Társulat ügyészi teendőit is hosszú évekig ellátta, illetve

Csongrád vármegye tiszteletbeli föügyészévé is kinevezték. 1911-ben hunyt el Szentesen. (Labádi 2011. 2.)

${ }^{380}$ SZL, I. évf. (1872) 1. sz. 1-2.. A lap ekkoriban tanúsított politikai semlegességének, illetve korrektségének jele, hogy a két héttel később megjelent lapszámban Szathmáry Ede is lehetőséget kapott a válaszra: kifogásolja, hogy ha egy országgyülési vitát lehet a sajtóban közölni - amely amúgy is a szabad véleménynyilvánítás eszköze -, akkor egy városi szintü politikai vitát miért ne lehetne? (SZL, I. évf. [1872] 3. sZ., 2.)

${ }^{381}$ Labádi 2013.

382 Buday József 1832-ben született Pesten. Fiatalon állítólag harcolt a szabadságharcban, majd belépett a ferences rendbe. Később, immáron civilként, családoknál nevelősködött. Szentesre kerülve előbb a református elemi fiúiskola tanítója volt, majd 1870-ben a település árva- és váltsági pénztárnoka lett. A Szentesi Lapban
} 
magyarázta. ${ }^{383}$ Buday szakított a korábbi politikai semlegességgel, s onnantól fogva az újság a többségében ellenzéki, a Kossuth-kultuszt lelkesen ápoló Szentes város szócsöve lett fokozatosan szembehelyezkedve a kormánypárti megyével. ${ }^{384}$ Mindennek köszönhetően a Szentesi Lap népszerüsége folyamatosan nőtt.

A megye azonban nem nézte jó szemmel a közvéleményt hamarosan jelentősen alakítani képes Buday tevékenységét, és 1875 szeptemberében a tulajdonos Cherrier engedett a felsőbb nyomásnak: választás elé állította szerkesztőjét, aki inkább lemondott, mint hogy a lap visszatérjen a politikai semlegesség középszerü keretei közé. Buday pátoszos mondatokkal búcsúzott a laptól és a várostól, s szavai jól mutatják az egyre élesedő ellentétet a katolikus vallású, a politikai semlegességet továbbra is elsődleges szempontnak tartó laptulajdonos, valamint a többségében 48-as elveket valló, protestáns szentesi olvasóközönség igényei között: „Midőn most harmadfél év után ugyancsak e lap kiadója felszólitott, hogy a szerkesztöségtöl lépjek vissza, mert az általam követett irány, a szellem, mely e lapokban leng, föleg pedig a sorok közt itt ott kicsillámló politikai elveim nem tetszetösek városunk uralkodó körei elött, és e nem tetszés neki anyagi kárára van: vagy pedig továbbra is megmaradni akarván, más irányt kövessek, más szellemet öntsek e lapokba, változtassak elveimen." Buday leszögezi: nem enged Cherrier felszólításának, és azonnal visszalép a felelős szerkesztői feladatoktól. A cikk végén érzelgős hangon köszön el az őt támogató olvasóktól: „Bucsut mondok e lap olvasóinak, kik rokonszenveztek e lap szellemével, és irányával megelégedve lévén, olykori gyengeségemet, gyarlóságomat kegyesen elnézték; kik rokonszenvvel nem viseltettek e lap iránt, azoktól bucsut nem vehetek, ök rég elbúcsúztak tölünk. Adjon az Isten derültebb, fellegtelenebb eget hazánkra, adjon szebb, boldogabb jövöt e városnak..."385

\footnotetext{
megjelent, a 48-as elveket nyíltan valló, a városi és megyei vezetést egyaránt élesen bíráló cikkei miatt meg akarták fosztani a hivatalától, azonban ekkor már a város egyik legnépszerübb embere volt: 1873 végén a helyiek megyei képviselővé választották. Később részt vett a szentesi Függetlenségi Népkör megalakításában, amelynek jegyzője, majd elnöke is volt, emellett 1875 elejétől a helyi 48-as Népkör vezetője. Nagyrészt az ő egységesítő szervező munkájának köszönhetően tudta a júliusi választásokon Simonyi Ernő legyőzni a kormánypárti Jókai Mórt. A hatalom válaszlépésének eredményeképpen Buday József minden szentesi megélhetési forrását elveszítette, kénytelen volt elköltözni a településről. A fövárosba ment, de a szentesi népkörrel továbbra is tartotta a kapcsolatot. A pesti egyetemen tanári diplomát szerzett, ezután Versecen lett polgári iskolai, majd fógimnáziumi igazgató. Mindemellett müfordítással is foglalkozott, átültette például német nyelvre Arany János Buda halála címü elbeszélö költeményét. 1901 nyarán hunyt el Versecen. (Labádi 2007c. 2.)

${ }^{383}$ SZL, II. évf. (1873) 15. sz. 1.

${ }^{384}$ Kis-Rácz 2000. (1.10.8. - A korszak sajtója)

385 SZL, V. évf. (1875) 39. sz. 1-2.. A szerkesztőség a következő lapszámban válaszolt a távozó Buday soraira, s egyúttal hitet tett amellett, hogy a Szentesi Lap nem a pártok, hanem a város érdekeit fogja a jövőben képviselni (SZL, V. évf. [1875] 40. sz. 1.)
} 
Buday József helyét Kulinyi Zsigmond vette át, aki egy évig irányította a lapot, majd Szegedre költözött, s nagy ívü újságírói karriert futott be. ${ }^{386}$ Ezt követően, az 1876. szeptember 3-i számtól (VI. évf. 36. sz.) az újság hasábjain akkor már rendszeresen publikáló, szintén volt református néptanító, Sima Ferenc lett a felelős szerkesztő, aki Buday irányvonalát követte, így a Szentesi Lap ismét egyértelműen a városi és megyei 48-as ellenzék egyik fö orgánuma lett. ${ }^{387}$ Érdekes megfigyelni, hogy a kiadótulajdonos hogyan hajtott fejet egyre inkább az előfizetők elvárásai - vagyis a nyílt politikai állásfoglalás - előtt, miközben korábban Buday Józsefet éppen emiatt távolította el az újság éléről.

Mint azt korábban már említettük, Sima néhány esztendő alatt a település legnépszerübb, legbefolyásosabb polgára lett, később országos hírnévre is szert tett, mint parlamenti képviselő. 1883-ban megvásárolta a Szentesi Lap kiadói jogait, majd a nyomdát is, ${ }^{388} \mathrm{~s}$ az újságot - immáron sajátjaként - még nagyobb lendülettel vitte bele az egyre erősödő harcba a kormánypárti megyével szemben, ezzel pedig a kezdeti kísérletezési, iránykeresési korszakot - dolgozatunk tárgyalt időszakát - végleg lezárva új fejezetet nyitott a város sajtótörténetében. ${ }^{389}$

A kezdetben vasárnaponként megjelenő hetilap előfizetési díja az induláskor egész évre 4 forint, fél évre 2 forint, negyed évre pedig 1 forint volt, és ez tárgyalt időszakunkban nem is változott. (Az újság 1881-től tért át a szombati megjelenésre.) A háromhasábos hirdetésért egyszeri megjelenés esetén soronként 6 , a kéthasábosért 12, az egyhasábosért pedig 8 krajcárt kellett fizetni, emellett alkalmanként 30 krajcár beiktatási díjat is elkért a szerkesztőség, akárcsak a Nyilt tér rovatban közölt cikkekért, ahol az iktatási összeg 15 krajcár volt. Látható, hogy a legnagyobb hirdetés soronkénti díja volt a legalacsonyabb, amellyel a kiadó-tulajdonos feltehetően új vállalkozásokat és magánszemélyeket kívánt a laphoz csábítani. A nagyvonalú kedvezmény nem tartott sokáig: közel fél év múlva, 1873. március 23-tól (II. évf. 12. sz.) egy rövid ideig új díjszabást vezettek be: a háromhasábos

\footnotetext{
${ }^{386}$ Kulinyi Zsigmond 1854-ben született Szentesen, zsidó gyökerủ családban. Budapesten és Bécsben jogot tanult, azonban - édesapját, Kulinyi Ernőt követve - ő is az újságírói pályára lépett. A Szentesi Lap szerkesztését követően a Szegedi Hiradó munkatársaként dolgozott, később Gelléri Mórral közösen megalapította az Alföldi Iparlapot. 1878-tól a Szegedi Napló főmunkatársa lett, hat évvel később már ő szerkesztette a lapot. Később a Szegedi Kereskedelmi és Iparkamara titkárának választották. Közgazdasági témájú cikkeit az Egyetértés és a Pester Lloyd napilapok jelentették meg. Emellett alapító elnöke volt a Vidéki Hírlapírók Országos Egyesületének, tagja a Dugonics Társaságnak, s két híres önálló kötete is megjelent: Árvíz után (1880) és a Szeged újabb története (1900). Szegeden hunyt el 1905-ben. (Újvári 1929. 516.; Zsilinszky 1900. 412.; illetve lásd a Magyar Életrajzi Lexikon digitális verziójának vonatkozó szócikkét: https://www.arcanum.hu/en/onlinekiadvanyok/Lexikonok-magyar-eletrajzi-lexikon-7428D/k-760F2/kulinyi-zsigmond-767B7/, letöltés: 2017. október 8.)

${ }^{387}$ Kis-Rácz 2000. (1.10.8. - A korszak sajtója)

${ }^{388}$ SZL, XIII. évf. (1883) 24. sz. 2. (Ez az utolsó lapszám, amelynek impresszumában még a Cherrier-nyomda szerepel.)

${ }^{389}$ Kis-Rácz 2000. (1.10.8. - A korszak sajtója)
} 
sordíj 15, a kéthasábos 10, míg az egyhasábos 5 krajcárba került; majd két héttel később ismét módosítottak a tarifákon: 18, 12, illetve 6 krajcárra. (A 30 krajcáros beiktatási díj, valamint a Nyilt tér rovat ára nem változott.) Mindez egészen 1883 nyaráig érvényben is maradt. Az új tulajdonos, Sima Ferenc nem sokkal a lap átvételét követően azonban más rendszert vezetett be az árképzés terén. 1883. július 28-tól (XII. évf. 30. sz.) szakított a soronkénti díjszabással: a lap minden oldalát 40 egyenlő helyre osztotta fel, és egy helyért egységesen 90 krajcárt kellett fizetnie a hirdetőknek. A 30 krajcáros bélyegdíjon nem változtatott, a Nyilt térben elhelyezett véleménycikkek közléséért azonban a korábbi összeg dupláját, vagyis szintén 30 krajcárt számított fel ezután. Fontos változás volt a laphoz való hozzáférés terén, hogy tárgyalt korszakunk végén, az 1883. augusztus 4-i számtól (XIII. évf. 31. sz.) fogva az előfizetés mellett lehetőség volt az egyes példányok megvásárlására is, 8 krajcáros áron.

A „,vegyes tartalmu hetilap” (illetve 1874. május 3-tól 1875. szeptember 26-ig „vegyestartalmu hetilap”), majd 1875. október 3-tól „,vegyes tartalmu hetiközlöny” (amely 1883. július 28-tól „,vegyes tartalmu heti közlöny”-re módosult) profilmegjelölésű újság külső formáját tekintve - akárcsak elődei - szintén a korszak jellegzetes, négyoldalas hírlapi formátumát alkalmazta, s a - több esetben változó - rovatszerkezet szempontjából sem jelentett kivételt korabeli társai alól. Érdemes azonban megemlítenünk a viszonylag gyakori tipográfiai változtatásokat, elsősorban a fejléc betütípusait, valamint a feltüntetett adatok elrendezését illetően: a Szentesi Lap első oldalának külső megjelenése tárgyalt korszakunkban, vagyis az újság 1872-es indulásától számítva 1883 végéig összesen tíz alkalommal alakult át - ebből hat esetben jelentős mértékben, négyszer pedig apróbb módosítások történtek (például a már említett helyesírási korrekciók a profilmegjelölés tekintetében, illetve a szövegdobozok kereteinek megváltoztatása által). Szembetűnő, hogy a Cherrier nyomdokaiba lépő Sima Ferenc, aki akkoriban már a város meghatározó politikai személyisége volt, az 1883. augusztus 4-i (XII. évf. 31. sz.) lapszámtól fogva a saját nevét és titulusát („felelős szerkesztő és kiadó tulajdonos”) már a lap fejlécén tüntette fel. (Az újság fejlécének tipográfiai változásairól lásd a 27. képet a Függelékben).

\subsubsection{Vezércikkek}

Amennyiben az adott lapszámok címoldalon közölt, az egész szerkesztőség véleményét kifejezni kívánó - s emiatt általában a szerző feltüntetése nélküli - publicisztikákat vesszük górcső alá, megállapíthatjuk, hogy azok többnyire olyan témákat részesítenek előnyben, 
amelyek egy dualizmus kori, vidéki város lakosságát leginkább foglalkoztatták: az 1867 után új alapokra helyezett s megélénkült helyi politikai életet, a városi hétköznapok örömeit vagy éppen problémáit, illetve az urbanizációs folyamat aktuális kérdéseit. Szentes esetében mindez kiegészült a megyei politika iránti, az átlagosnál fokozottabb érdeklődéssel, amelynek elsődleges oka, hogy vizsgált időszakunkban folyt a hosszú évekig tartó versengés a megyeszékhely kérdésében, mint azt korábban már említettük. Az alábbi grafikon megmutatja, hogyan oszlanak meg a hetilap 1872 és 1883 között publikált vezércikkei a bennük tárgyalt fő téma alapján. ${ }^{390}$

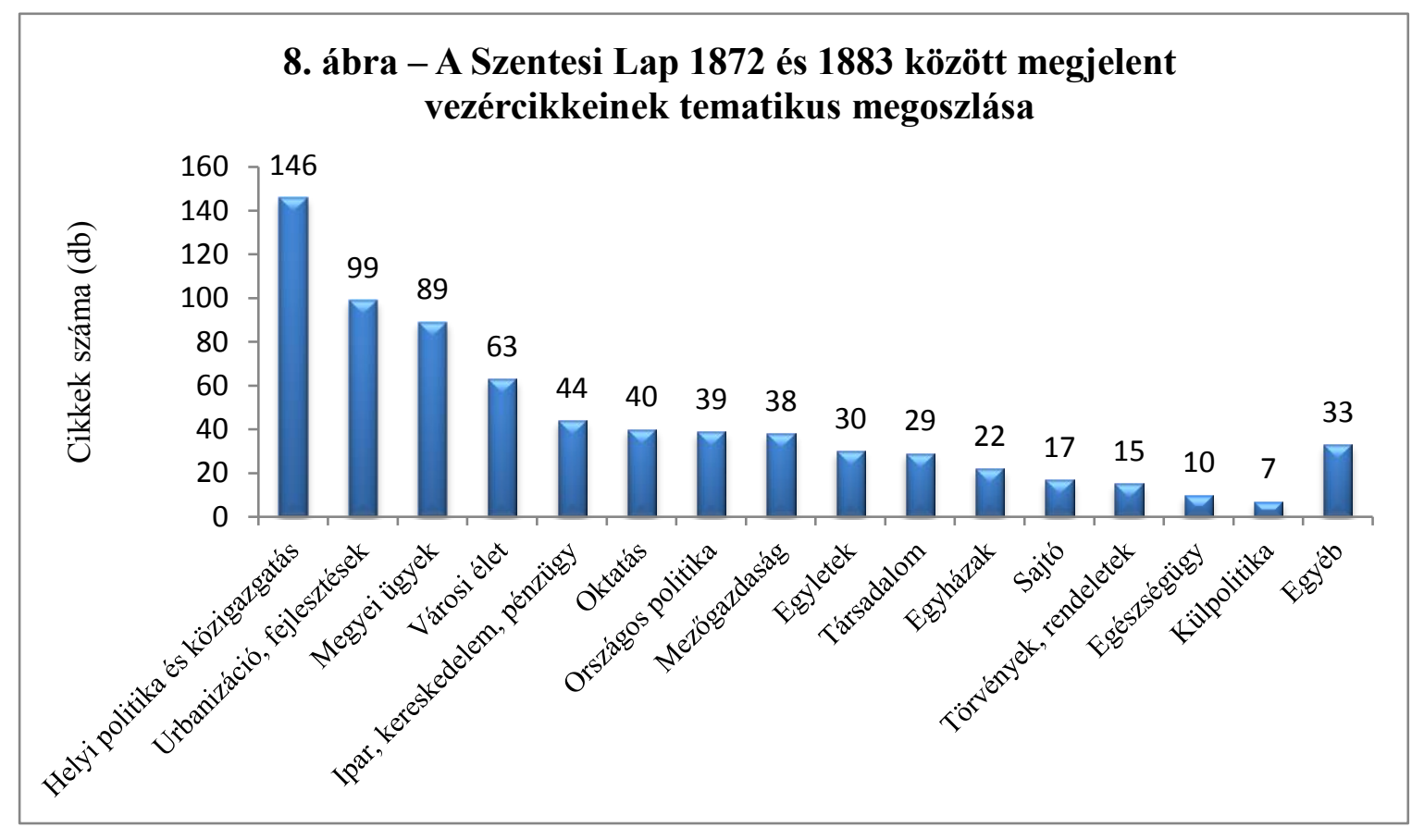

Látható, hogy a helyi politika és közigazgatás témaköre magasan kiemelkedik a többi közül, ami nem meglepö, hiszen az esetek nagy részében ezek a publicisztikák a városi közgyülésen történt aktuális eseményeket dolgozzák fel, illetve azokról tudósítanak, esetenként némi szerkesztői véleményt is megfogalmazva. Számos vezércikk született az urbanizáció, az infrastrukturális elörelépések szorgalmazása témájában is, hiszen a kiegyezésnek köszönhetően Szentesen is ebben az időszakban indult meg a jelentősebb léptékü városfejlesztés. Érzékletes képet fest a város közterületein uralkodó higiéniai állapotokról például az 1872. október elején megjelent, Egyről, másról címü cikk: „ily józan eszü, szorgalmas, csinosan és tisztán öltözködő nép városának köz-épületei miképen lehetnek annyira rondák, utcái, piacterei annyira piszkosok? [...] a régi városháza, - ennek környéke -

\footnotetext{
${ }^{390}$ Megjegyzés: amennyiben egy adott vezércikk több témával is foglalkozik - például az újévi köszöntők -, azt több helyre is besoroltuk.
} 
mondjuk ki nyiltan - valóságos árnyékszék, melyhez közel menve nem csak orrunkat, de szemünket is kénytetünk befogni. Atal vele a vendéglö piszkos, vakolatlan, ronda külsejével, mintha nem is az utas befogadására, hanem elijesztésére épittetett volna." A cikkíró szerint a vendéglő szobái önmagukban tiszták, viszont bennük kiállhatatlan büz, konkrétan elviselhetetlen istállószag érződik, mivel az utcán félölnyi magas trágyadomb ékeskedik, amely minden egyes napon még magasabbá válik az ott tanyázó vidéki kocsik lovainak köszönhetően. Ráadásul szemközt, a Haris-féle ház előtt a víz levezetésére használt árok szintén tele van trágyával, illetve egyéb szeméttel, piszokkal, mindez pedig minden jóérzésü idegent elriaszt, hogy huzamosabb ideig a városban maradjon. „És a piac? Oh ez szép hely, kivált nyáron ha szél kerekedik. Azt hihetné az ember, tele repülvén szeme, szája - hogy a guáno szigetekre van deportálva. Minden kereskedés elött ott diszeskedik a naponta kisepert boltiszemét...” A szerző, miután hosszasan ecseteli a városi magtár szintén rendetlen külsejét is, jobbító szándék által vezérelve felteszi a kérdést: „Lehetne-e azt elérni, hogy Szentesváros középületi csak olyan tiszták legyenek mint egy szegény ember háza, és piactere csak ugy felsöpörtessék olykor, mint egy sok jószágot tartó gazdag ember udvara?" Végül konkrétan megnevezi, kinek kéne elsősorban cselekednie az ügy érdekében: Szentes város tanácsának volna legfőbb kötelessége, hogy hatékony intézkedésekkel érdemi változtatásokat hajtson végre, ezáltal a „városnak tiszteletet, elismerést szerezzen ugy a város lakosai, mint az idegenek elött." 391

A következö lapszámban a cikk folytatódik, s - többek között - a város díszkertjének állapotát illeti éles kritikával: „, ki meg akar bizonyosodni felöle, hogy vajjon Szentesnek vane tehát legszebb kertje az egész alföldön: az ugyan jól vigyázzon a lába alá, mert az az ingóbingó, posványon keresztül nyújtóztatott deszka alkotmány - - mely a kerthez vezető utat képviseli - nagyon könnyen hadat izentet bár kivel is a... békáknak." A szerző megemlíti: a díszkert létrehozása igen nagy anyagi befektetést igényelt a település részéről, ráadásul nem felel meg az eredetileg kitüzött célnak, hiszen a tanács megengedte a vele szerződött bérlőnek, Rambovszky Józsefnek, hogy a kertben felépült mulatóházat „valóságos dorbézoló korcsmává” züllessze. Így a kulturált szórakozásra vágyó szentesiek azóta messziről elkerülik a Széchenyi-ligetet. ${ }^{392}$

A piac kikövezése váratott magára, $\mathrm{s}$ a téma három évvel később is alapjául szolgált egy ironikus hangvételü vezércikknek: „Ha nálunk megfordult külföldi utazók a mi szép

\footnotetext{
${ }^{391}$ SZL, I. évf. (1872) 9. sz. 1-2.

${ }^{392}$ SZL, I. évf. (1872) 10. sz. 1-2. (Mint korábban említettük, a következő évben megszüntették a mulatóhelyet, így a liget nyugalmasabb lett, ugyanakkor sokat veszített közösségi vonzerejéből is.)
} 
magyar hazánk nevezetességeiröl beszélnek, bizonyára nem mulasztják el fölemliteni városaink legjellemzöbb sajátságaként a nyári port és a téli sarat. És ha magunk, megnyalva a mindenek fölött uralkodó divattól, télen bugyogóban járunk, önkénytelenül is minden reggel kövezetért imádkozunk. A divatos magyarok istene meg is hallgatta némileg könyörgésünket, mert immár vannak elég tisztességes gyalogjáróink. Elmehetünk a kávéházba anélkül, hogy bagaria-csizsmát kellene húzni.” Csakhogy - folytatja az írás - akad egy kis bökkenő: egy átlagos szentesi polgárnak máshol is akad dolga, nem csupán a kávéházba kell járnia. Például a gazdasszonyok örülnének, ha esős időben is gond nélkül eljuthatnának a piacra, ami most képtelenség, hiszen télvíz idején, a zsíros szentesi földnek köszönhetően olyan sártenger képződik, „melynek életveszedelem nélkül nem lehet nekimenni”. A szerző ezután javaslatot tesz a piac mielőbbi kikövezésére, amely nem csupán kényelmi szempontok miatt volna hasznos, hanem természetesen az iparnak és a kereskedelemnek is előnyére válna. Végül, felhívja a figyelmet, hogy a városvezetésnek az ügyben tanúsított cselekvésképtelensége folytán több kereskedő igyekszik legalább a saját sátra előtti helyet önköltségen kikövezni, s így hozzáférhetővé tenni. ${ }^{393}$

A viszonyok a következő évben sem javultak. A lap 1876 nyarán a következőket írja Nyáron jut eszünkbe címü vezércikkében: „Az ösi időkben falusi ember nyári időben egyáltalában alig ment nagy városba, vagy ha igen, folytonosan kendöt tartott az orra alá, mert az utcai csatornák és más nagyvárosias kiváltságos szemétdombok büzét ki nem állhatta." Most bezzeg elmehetünk akármelyik világvárosba, nem fogunk különbséget látni falu és város között, köszönhetően a nagyfokú infrastrukturális fejlődésnek. Manapság már a városok utcái és terei is tiszták, hála a csatornázás elterjedésének, illetve a köztisztaság érdekében tett széles körü erőfeszítéseknek. Azonban ez nem mindenhol van így, Szentesen sem, ahol még mindig középkori viszonyok uralkodnak: „a mi utcáink csatornái, illetőleg árkai éppen oly hatalmas büzt terjesztenek meleg napokban, mint akár az ez irányban tán elsö helyen álló Budapesten." A cikk rámutat: a probléma egyik fö forrása a piac, ahol romlott, így betegségeket terjesztő gyümölcsöket, valamint egyéb, hasonló okokból kifogásolható termékeket tárolnak és árusítanak egyes kereskedők, s szorgalmazza, hogy az ilyen árucikkeket tiltsák be, illetve kobozzák el, „,nehogy a nagy közönség egy vagy más tekintetben kárt szenvedjen."394

Egy évvel később, miután a tavasz beköszöntével a levegő felmelegedett, hasonló hangvételü publicisztika hívja fel a hatóságok figyelmét a tarthatatlan állapotokra. A város

\footnotetext{
${ }^{393}$ SZL, V. évf. (1875) 45. sZ. 1-2.

394 SZL, VI. évf. (1876) 28. sZ. 1.
} 
elhanyagoltabb helyein, valamint a nyitott csatornákban egész télen át összegyülik a növényi és állati hulladék, amely rothadásából származó bűz nemcsak hogy kellemetlen, hanem az egészségre is ártalmas, hiszen a kiáramló gázok fertőzik a levegőt. „A tavaszszal együtt tehát elérkezett az idö is, hogy a Haris-ház és nagy vendéglö között az izraelita templom felé huzodó, tehát Szentes város föutcája, föterére hívjuk föl az illetékesek figyelmét. [...] Az a tér, melyröl szólunk heti vásárok alkalmával ugy a helybeli, mint nem ritkán nagy számu vidéki gyümölcs és fơzelék félék árusainak piac helyéül is szolgál." A publicista szerint a legföbb gond, hogy a vidékről, többnyire lovas kocsival érkező árusok közül sokan már az előző nap délután megjönnek, és állataikkal együtt a vásártéren töltik az éjszakát. Mindennek pedig tetemes mennyiségü ürülék a végeredménye, amely az utca két oldalán gyülik nagy rakásokba. Az ürülékdombokat utána az eső kiáztatja, a gusztustalan trágyalé pedig a csatornán keresztül az árokba ömlik. A problémát ráadásul fokozza a kávéház udvarából kikerülő, a bűzös kigőzölgést nagymértékben elősegítő folyadék, amely szintén belefolyik a kérdéses árokba. ${ }^{395}$

Tanulságos az az írás is, amely nem az infrastrukturális elmaradottságokról, hanem a társasági élet alacsony színvonaláról értekezik. A cikk először méltatja a tíz évvel korábban létrehozott ligetet, majd a vendéglő felépítését: „Volt is élvezet; nyakig úsztunk az örömben. Hála isten, akkor voltak jó termések, volt okunk oly nagyon örülni." Azonban a boldogság nem sokáig tartott, mivel „a jövedelmek a rosz termés miatt csökkentek. A sétatéren ritkultak a csoportok; a vendéglös panaszkodott a részvétlenség miatt, később jónak látta odébb is állni. Apránként kezdett elmaradozni mindenki." Ráadásul az emberek többsége restellte bevallani, hogy anyagi okokból nem jár annyit szórakozni, mulatni, inkább mondvacsinált indokokra hivatkozva, a helyet becsmérelve maradt távol a rendezvényektől, s a rossz példa ragadóssá vált. „De hiába, mi magyarok vagyunk - folytatódik a publicisztika -; s mi szentesiek különösen tösgyökeres magyaroknak szeretjük magunkat nevezni, a mi elödeink pedig egész nap bort ihattak, s nem is kellett dolgozniok. Persze hogy jobb volna most is ilyen élet. Csakhogy mai napság már ez nem adatik." A cikk szerint nem az a legfőbb baj, hogy egyesek rossz hírbe hozták a ligetet és a mulatót, hanem a közönyösség, amely eluralta a szentesi társadalmat, illetve a rossz akarat, amely vezérli az egyes embereket ez irányú döntéseikben: „Nem megyünk ki a kertbe, mert: X-né is ott van; mert Y úr ugyanazon állomásra pályázott egykor, mint én, és egész családjával künn sétál, én ugyan találkozni sem szeretek vele; mert W. kisasszonynak szebb ruhája van, mint nekem, (igaz ugyan, hogy az

395 SZL, VII. évf. (1877) 19. sz. 1. 
apjának egy pár ezer frttal több jövedelme van); most Q. barátommal összekaptam a múltkor a fölött..." Emellett sokan azzal hárítják el a ligetbe való invitálást, hogy egy fiatalember nemesebb szórakozást is kereshet magának, mint a bor melletti tivornyázást, az ifjú hölgyek pedig arra szoktak hivatkozni, hogy szeretnék elkerülni a kéretlen udvarlókat - és a kifogásoknak se szeri, se száma. ${ }^{396}$

Ugyancsak a társasági élet hiányosságairól szól $A$ mi társas életünk címet viselő vezércikk: „Más városokban, hol nincsenek is annyian egy rakáson mint mi vagyunk, s talán nem is értelmesebb emberek mint mi, s igy lelki tápra nem lehet nagyobb igényük mint nekünk: télen, nyáron, öszszel, tavaszszal egyformán az időviszonyok igényéhez képest, találnak módot, teremtenek rá eszközt, hogy az emberek olcsón, vagy ingyen szorakozást nyerjenek." Fontos volna Szentesen is, hogy az egy településen, egy közösségben élő emberek ne csak a templomban, a miséken, illetve istentiszteleteken lássák egymást - ha oda egyáltalán elmennek - nagyritkán, hanem az erre célra szánt társas körökben és rendezvényeken minél sürübben érintkezhessenek. Ugyanis ennek köszönhetően kialakulna és megerősödne az egymás iránti őszinte jóindulat, a közéleti és egyéb társadalmi kérdések, a különféle eszmék iránti lelkesedés, amely azért is hasznos, mert a mai világban az emberek lelkét már teljes mértékben eluralta az anyagi javak halmozása utáni vágyakozás. „Minden intelligens érzésü embernek szomorral kell nézni azt a közönyt, melyet közönségünk a zajos megyei, vagy városi köz és országos politikai élettöl eltekintve, bármily üdvös társadalmi eszme iránt tanusit." ${ }^{397}$

Egy súlyos társadalmi probléma korabeli - morálisan igencsak kifogásolható kezelésére világít rá az Egy elhanyagolt ügy címü vezércikk. Az írás első felében megtudhatjuk, hogy számos magyarországi település határába táblákat helyeztek el, amely az adott faluban, községben vagy városban való koldulás tilalmára figyelmeztet. Szentes esetében nincsenek ilyen táblák kihelyezve, azonban ez nem érdem, hiszen a város ennél sokkal megalázóbb módon oldja meg a kérdést: „A városi hatóság, illetőleg a rendörfökapitányság egy darab deszkácskára rá nyomja a város pecsétjét, e rendjel azután a szegénynek nyakába akasztatik, a boldogulásnak eme jelzálogával szépen utnak bocsájtatik, gondoskodva van róla, megélhet a jég hátán is, ha az általa zaklatandó jó lelkü felebarátok adni fognak neki." 398

\footnotetext{
${ }^{396}$ SZL, VI. évf. (1876) 27. sZ. 1-2.

${ }^{397}$ SZL, XI. évf. (1881) 3. sZ. 1.

${ }^{398}$ SZL, IV. évf. (1874) 13. sz. 1-2.
} 
A lap az anyagilag nehéz helyzetbe került szentesiek nyomorát kihasználó uzsorások mellett ügyes csalókra is felhívja a figyelmet: „Városunkban - ugy szólván - egy egész társaság alakult különbözö rendü és rangu egyének soraiból, kik a nép járatlanságát felhasználva, uj hasznosan szivattyuzott kereset forrást nyitottak maguknak. Maguk is fölkeresik a kölcsönre szorultakat, tele beszélik fejüket, hogy ök mint bizonyos banknak (elöljárójában nevét elhallgatják) ügynökei a legrövidebb uton s leggyorsabban pénzt eszközölnek ki, - nem is kötnek ki egyebet, csak hogy a kölcsönkép nyerendö összegnek három száztólija az ö számukra biztosittassék a kölcsönző által.” A szerző ezután kifejti: a pénzügyi ismeretekkel nem rendelkező, kiszolgáltatott emberek ravasz behálózásának megakadályozásából a hatóságoknak is ki kellene venniük a részüket: például azzal, hogy a templomok előtt elhelyeznek hirdetéseket, amelyekben felhívják a lakosság figyelmét a csalás ezen veszélyes formájára. 399

Talán a legszomorúbb az elmaradottság társadalmi következményeinek ismertetéséből az a hír, amelyet az 1878. november 11-i lapszám címoldalának publicisztikája dolgoz fel. Az írás szerint elszomorító, hogy sokan úgy hiszik, a szerényebb anyagi körülmények között élő embert senki nem kötelezheti arra, hogy beteg gyermekéhez orvost hívjon, vagy hogy gyógyszert vásároljon, hiszen nincs rá pénze, ez pedig mentségül szolgál mindenre. A cikk azonban nyomatékosan figyelmezteti azokat, akik így gondolkodnak, hogy nem így van: a törvény mindenki számára kötelező, és bírságra számíthat, aki nem gyógyíttatja gyermekét hétéves koráig. „S ha valakinek a mondott korévig gyógykezelés nélkül hal el gyermeke, [...] pénzbirsággal büntettetik; mert elhanyagolta gyermeke gyógyitását, s igy elmulasztá fölhasználni az eszközst [sic!], melylyel esetleg gyermeke életét megmenthette volna. [...] A törvénynek épen ezen rendeleténél fogva birságoltatott városunk hatósága pár nappal ez elött 25 vagy 30 szülőt." Az újságíró szerint a megbüntetett szülők többsége meglepődött a szankción, illetve sokan panaszt is tettek, arra hivatkozva, hogy nem ismerték a törvényt, ezért igazságtalannak tartották, hogy olyasmiért vonják felelősségre őket, ami önhibájukon kívül esik. Azonban az írás megállapítja, hogy az érv nem helyénvaló, több szempontból sem: „a törvény nem ismerése nem mentség a büntetés alóli kibúvására, a szegénység lehetne, ha hatóságunk ugy nem intézkedett volna, hogy a szegények ingyen kapjanak gyógyszert, s a város orvosa által minden dij nélkül gyógykezeltessenek." ${ }^{400}$ Ha csak a cikk születésének esztendejét (1878) és az abban közölt korosztályt (0-7 év) vesszük alapul, a halotti anyakönyvek is alátámasztják, hogy - akárcsak hazánk legtöbb településén - igen magas volt

\footnotetext{
${ }^{399}$ SZL, IV. évf. (1874) 33. sz. 1-2.

400 SZL, VIII. évf. (1878) 45. sz. 1.
} 
Szentesen a kiskorúak halandósága: az adott évben összesen 563 hétévesnél fiatalabb személy halt meg a városban a négy legnépesebb felekezet tagjai közül (az elhunyt gyermekek közül 315 református, 233 római katolikus, 9 izraelita és 6 evangélikus). ${ }^{401}$

Szintén elkeseredett hangon számol be a lap 1878 nyarán a Bosznia-Hercegovina Monarchia általi megszállásának Szentesen is jól érezhető negatív következményeiről. A bevonulásra kötelezettek ugyanis szinte mindannyian családapák, kilencven százalékuk ráadásul szegény napszámos. „A mozgósitás tényével járó ezen valóság megdöbbentő, ha elgondoljuk, hogy ezen állapot csak városunkban is száz és száz családot fosztott meg kenyerétöl. A vagyontalan, szegény földmives az aratás idején szokta és keresi be rendesen télére kenyerét. Most Bosznia occupatioja letéteti vele a kaszát, menni kell; feleség és 3-4 gyermek néz könyes, siró arccal a távzó után." Mint arra a cikk rávilágít, mindez nem csupán a szeretett apák és férjek iránt érzett féltő aggodalom miatt tragikus: a család egyetlen kenyérkeresője távozott el, talán örökre, ráadásul éppen az aratási időszak előtt, így nem lesz, aki betakarítsa a földekröl a termést. ${ }^{402}$

Az urbanizációs fejlesztéseket szorgalmazó vezércikkek közül kiemelkedik a vasútépítés szükségessége, több publicisztika foglalkozik az akkor már hosszú évek óta húzódó üggyel. 1879 áprilisában keserűen írja az újság: „Szentes vagyonos és munkás népe elöhaladásában, törekvésében meg van bénitva; mert el van zárva a világtól s igy el vannak tőle zárva a források, melyek egy város ipar, kereskedelmi életének lüktető erét táplálják." Vasúti közlekedés nincs, az országutak pedig elhanyagoltak, és olyan mértékben rossz minőségüek, hogy az esős időszakokban teljesen járhatatlanok. Ez pedig bénítóan hat a gazdasági életre, hiszen „a mai korban, midőn az idő a legdrágább, iparunk és kereskedelmünk rovására sokszor hetekig ki sem mozdulhatunk a városból. Valóban várositoknak ezen falusi nyomorusága mellett, hiába terem mindenünk, égetően kell érezni

\footnotetext{
${ }^{401}$ MNL CSML Szentes, IV.B.434.a. - Csongrád Vármegye Felekezeti Anyakönyvi Másodpéldányainak Levéltári Gyüjteménye - A római katolikus egyházközségek anyakönyveinek másodpéldányai, Szentes, halotti anyakönyvek (1878. év); IV.B.434.b. - Csongrád Vármegye Felekezeti Anyakönyvi Másodpéldányainak Levéltári Gyüjteménye - A református egyházközségek anyakönyveinek másodpéldányai, Szentes, halotti anyakönyvek (1878. év); IV.B.434.c. - Csongrád Vármegye Felekezeti Anyakönyvi Másodpéldányainak Levéltári Gyüjteménye - Az evangélikus egyházközségek anyakönyveinek másodpéldányai, Szentes, halotti anyakönyvek (1878. év);

IV.B.434.e. - Csongrád Vármegye Felekezeti Anyakönyvi Másodpéldányainak Levéltári Gyüjteménye - Az izraelita egyházközségek anyakönyveinek másodpéldányai, Szentes, halotti anyakönyvek (1878. év).

E tekintetben Szentes sem maradt el az országos átlagtól: a XIX. század utolsó harmadában hazánk a sereghajtók közé tartozott Európában, ami a csecsemőhalandóság mértékét illeti. A statisztikák csak a század végén mutatnak csökkenő tendenciát, a gyermekekhez való általános hozzáállás pozitív irányú megváltozásának, de legfőképpen a kiskorúakra veszélyes járványos betegségekkel (például torokgyík) szembeni, egyre hatékonyabb küzdelem eredményének volt köszönhető. (Gergely 1998. 409.)
}

${ }^{402}$ SZL, VIII. évf. (1878) 28. sz. 1. 
szegénységünket."403 A következő esztendőben azonban a Szentesi Lap örömmel számol be róla, hogy a megvalósítás új szakaszba lépett, hiszen országos szinten is több intézkedés történt az ügy előremozdulása érdekében, illetve a város is megszavazta, hogy hitelből vállalja a költségek harmadrészét. A szerző büszkén jegyzi meg, hogy az újság mindig is támogatta a vasút részvénytársaság formájában történő megvalósítását, hiszen így minden bizonnyal üzleti szempontból is kifizetődő lesz a dolog: azt az összeget ugyanis, amit a település a vasútba kölcsönből befektet, a vállalkozás későbbi jövedelméből apránként vissza lehet fizetni, ezt követően pedig ,megmarad neki a közpénztár javára előnyösen jövedelmezö forrásul a vasutja, mely ha ma félmillió tökét képvisel, 10 év múlva egy milliót fog képviselni. És igy a vasut nemcsak mint közlekedési eszköz fog hathatósan befolyni városunk anyagi, szellemi jólétére; de mint a város tulajdonát tevö nagy töke, jövedelmével könnyiteni fog városunk lakosságának mai közterhén." ${ }^{404}$

A tárgyalt időszakban számos vezércikk taglalta az ekkoriban többször előforduló tiszai árvizeket is, mintegy biztatva a helyi lakosságot a kitartó védekezési munkálatokra. Az egyik ilyen témájú publicisztika intő példaként hozza fel a szomszédos Csongrádot, ahol elhanyagolták a kérdést, most pedig a szentesiek adományaiból kénytelenek tengődni a víz pusztítása után. A szerző leszögezi: nem az indulatokat akarja szítani, nem is a közeli kisváros lakóit kívánja sértegetni, de szembe kell nézni a szomorú ténnyel: Csongrád saját magának, a nemtörödömségének köszönheti a sorsát. A szentesi polgárokra pedig ugyanez a katasztrófa vár, „ha szorgalmunk, tevékenységünk csak egy órára is lankadna. Mi meg vagyunk gyözödve, hogy Szentes város polgárai a veszély hátralevő, remélhetöleg kisebb részében nem fogják a csatatért elhagyni, hanem mindvégig hösiesen küzdenek azon hatalmas ellenséggel, mely, ha legyöz bennünket, mindenünktöl megfoszt. A kitartás mellett még csak körültekintést ajánlunk mindenkinek, mindenben. Ez a két dolog óv meg attól, ami szerencsétlen szomszédainkat sújtja." 405 A témában a legszakszerübb cikksorozatot a Szegedet romba döntő, 1879-es tiszai árvizet követően közölte a lap. Az ötrészes, Mit teszünk a Tisza leapadása után címü publicisztika levonja a tanulságot, és sürgeti a Tisza szabályozását, illetve a gátépítés fontosságát hangsúlyozza. ${ }^{406}$

A lap 1879. szeptember 7-i száma egy másik katasztrófatípusra, a városban gyakori tűzesetekre hívja fel a hatóságok figyelmét, emellett a sajtó társadalmi felelősségét is kiemeli: „Valóban a városunkban ez idő szerint egyre másra fölmerülö vészes tüzeseteket szomoru

\footnotetext{
${ }^{403}$ SZL, IX. évf. (1879) 14. sz. 1-2.

${ }^{404}$ SZL, X. évf. (1880) 46. sz. 1.

${ }^{405}$ SZL, VI. évf. (1876) 14. sz. 1.

${ }^{406}$ SZL, IX. évf. (1879) 23-27. sz. 1.
} 
kedvünk jön a fenti cimmel jellemezni. Alig felejti el a közönség az egyiket, gondoskodik róla a vészharangok megujuló zúgása, hogy vagy magunkért vagy felebarátunkért újra átszenvedjük egy másiknak minden borzalmait. Ma itten, holnap ottan... Valóságos bolygó tüzek!” Az írás szerint döbbenetes, hogy milyen rövid időközönként fordulnak elő ezek az élet- és vagyonbiztonságot súlyosan veszélyeztető esetek Szentesen, amelyek nem csak a lakosságot és a hatóságokat, hanem a sajtót, ,mint a közélet sokoldalu őrét, a nyilvánosság fökritériumát a legkomolyabban hivják fel figyelemre és cselekvésre." A szerző kiemeli: a Szentesi Lap feladata, hogy föszerepet vállaljon a tüzkárokat okozó emberi mulasztásokra való határozott figyelemfelhívásban, illetve, hogy megoldási javaslatokat is adjon a hatóságok számára. A cikk szerint a legfőbb problémát a „primitiv tüzrendőrségi” viszonyok jelentik, amelyen mindenképpen változtatni szükséges, hiszen „a hatóság köteles vigyázó szemmel arra is fölügyelni, hogy az ily baleseteknek, tüzkároknak, mely által egyesek ipara, szorgalma nem egyszer teljesen tönkre tétetik, melyek tehát a közjóra is veszélyeztetve hatnak, lehetöleg eleje vétessék. Pusztán az óvatosságot, melyre a bakterektől a józan észig annyi figyelmezteti a polgárokat, bizonyára senkisem tarthatja elegendőnek." A publicisztika végül levonja a logikus következtetést: az önkéntes tüzoltókon kívül elengedhetetlen volna egy jól működő városi tüzoltóegylet megalakítása. ${ }^{407}$

Az egyleti élettel egyébként is sok, szám szerint harminc vezércikk foglalkozik fövagy melléktémaként, mint az a grafikonon is látható. Az 1879. január 12-i lapszám például a Jótékony Nőegylet sikeres táncestélyéről számol be. A szerző dicséri a szerinte egyetlen hatékony szentesi egyesületet, amelynek köszönhetően a városban immáron kisdedóvó is müködik: „Ha végig tekintünk városunk köz- és társadalmi életén, amott a korlátolt annyagi helyzet és szük fölfogás miatti meddö küzdelemmel, emitt a közöny miatt a pangó, tétlen élettel találkozunk. [...] Pedig mennyit kellene, s mennyit lehetne tenni!” Az írás szerint azonban szerencse, hogy a város közönyös, eszme és cél nélkül mozgó társadalmi korszakában mégis van egy társaskör, amely aktívan tevékenykedik, ez pedig a nőegylet. Hiszen például, évekig csupán álom volt, de nekik köszönhetően megvalósult az óvoda. „Ezen müvére a nöegylet annyival is inkább örömmel és büszkeséggel tekinthet; mert egy kisdedovoda léte közóhajtása volt városunknak, s e közóhaj kielégitésére hivatott községi és egyházi hatóságoktól ugy lehet még ma is csak óhajtás volna az óvoda léte." ${ }^{408}$ Ugyancsak a nőegyletet méltatja a Közerkölcsiség címü publicisztika, amely új feladatot is javasol az egyesületnek, tudniillik az egyre erkölcstelenebb életvitelü cselédek jó útra térítését: „Tény

\footnotetext{
${ }^{407}$ SZL, IX. évf. (1879) 36. sz. 1.

${ }^{408}$ SZL, IX. évf. (1879) 2. sZ. 1.
} 
ugyan, hogy cselédeink körében az erkölcstelen irányzat megdöbbentö módon terjed, elannyira, hogy ezen osztályból maholnap az erkölcsi érzék teljesen ki fog halni”. A cikk viszont megállapítja azt is, hogy mindez nem csupán a cselédekre, hanem a társadalom minden rétegére jellemző, osztályra és rangra való tekintet nélkül, sőt a cselédek erkölcstelen viselkedése, életmódja kétségtelenül annak folyománya, hogy a felettük álló rétegektől rossz példát látnak. „E tekintetben oly szép hivatása volna a nöegyletnek. Ez volna a kapocs, mely a nöket nemes missiójuk teljesitésére hatalmas phalanxá egyesitené!" 409

A mezőgazdasági témájú cikkek közül talán a legjelentősebb Balázsovits Norbert ${ }^{410}$ két részben, 1880 őszén megjelent, A gazdálkodó közönség figyelmébe címü írása, amelyben a szentesi gazdákat ösztönzi a modernizációra, illetve az önszerveződésre, hiszen a szerző szerint az agráriumban tapasztalható problémákra nincs természetesebb és észszerübb gyógyszer annál, mint tökéletesíteni a földművelést, illetve biztosítani a folyamatos önképzést. „S ha látjuk, hogy észszerü eljárás által tízszerte nagyobb eredménynyel tudjuk hasznositani drága földünket akkor megmentettük a földmiveléstöl szökö nemzedéket, megmentettük önmagunkat és a föld becsülését, melylyel való foglalkozástól s természetének tanulmányozásától igen sokan irtóznak. Az együttmüködés csakis egy jól szervezett egyletben lehetséges $s$ erre igen jó alkalom kínálkozik városunkban is." Balázsovits sajnálatosnak tartja, hogy az egész megye területén semmiféle mozgalom nem jött eddig létre a földművelés előmozdítására, s ezzel összefüggésben a gazdálkodók jólétének növelésére. ${ }^{411}$

Az egyházi témakörből kiemelhetjük Marjai Péter református lelkész írását, amely 1880 júniusában annak ad hangot, mennyire kiveszett az emberekből a vasárnap - mint egyházi ünnep - tisztelete: „Korunk a vallásosság hanyatlásának kora, hitetlenség, közönyösség e veszélyes áramlat terjeszkedik fenn és lenn, ilyen korszellemben - igen természetes - alászálla tekintélyében a vasárnap is. Vásárnappá alacsonyittatott az, csalásokkal, izetlen szóváltásokkal járó üzérkedések, kufárkodások széltire gyakoroltatnak

\footnotetext{
${ }^{409}$ SZL, XII. évf. (1882) 4. sz. 1.

${ }^{410}$ Balázsovits Norbert (1847-1913) Bars vármegye szülötte, Selmecbányán, majd Besztercebányán tanult, ezt követően a fövárosban hallgatott klasszika-filológiát. 1871-ben költözött Szentesre, ahol az akkor induló négyosztályú, gimnáziumi tanfolyammal egybekötött polgári fiúiskola rajz-, később testnevelés, számtan és mértan, világtörténelem, alkotmánytan, valamint német nyelv tanára lett. Az oktatás mellett aktívan részt vett a közéletben is: városi és megyei képviselő is volt, alapító elnöke a Szentesi Iparos Ifjak Képző és Segélyegyletének, alapítója és igazgatója a Szentesi Kölcsönös Segélyező Szövetkezetnek, 1886-tól a nagyrészt neki köszönhetően megalakult Szentesi Ipartestület elnöke, később örökös tiszteletbeli díszelnöke. Több helyi lapban rendszeresen publikált különbözö témákban, 1884 és 1889 között a Szentes és Vidéke hetilap felelös szerkesztője. A Polgári Olvasókör elnöke is volt, valamint a helyi Kaszinó és a Szentesi Római Katolikus Egyháztanács tagja. A Csongrád Vármegyei Történelmi és Régészeti Társulat egyik megszervezöje, illetve választmányi elnöke. 1899-től 1911-ig a szentesi gimnázium igazgatói posztját töltötte be. (Labádi 2007d. 2.; Szinnyei 1891. 408.)

${ }^{411}$ SZL, X. évf. (1880) 40. sz. 1.
} 
vasárnapokon." A lelkész megengedhetetlennek és felháborítónak tartja, hogy a hét utolsó napján a kocsmák és bordélyházak nyitva tarthatnak, így a vasárnap immáron nem ünnep, hanem szégyen és gyalázat a XIX. század számára, amely század ráadásul olyannyira szeret dicsekedni a fejlődéssel és haladással. „Zajos munkák, botránkoztató lármák, utcai csoportosulások, dévajkodások, mind megannyi szomoru bizonyitékai a vasárnap tekintélye lábbal tiprásának." ${ }^{412}$

Számos vezércikk foglalkozik az oktatás kérdéskörével is. Az elért eredmények méltatása mellett a lap többször igyekszik felhívni a figyelmet a hiányosságokra, kívánatos fejlesztési irányokra is. Egy 1882-es publicisztika szerint például véget ért az a korszak, mikor egy iparral vagy mezőgazdasággal foglalkozó férfi elboldogult az életben pusztán azzal az egyoldalú, gyakorlati tudással, amit az apjától annak idején elsajátított. Ugyanis az újabb kornak új vívmányai vannak, amelyeket otthon megismerni nem lehetséges, hiszen azok behatóbb tanulmányozást, szakavatott útmutatást kívánnak, ráadásul bizonyos előismereteket feltételeznek. „Azonfölül a társadalmi kasztok válaszfalainak lerombolása után szükségkép alkalmazkodniok kell a civilizált társadalmi szokásokhoz, fel kell magukat küzdeniük a müveltség emelkedettebb szinvonalára; mert csak igy találhatják magukat bele a változott társadalmi viszonyokba, s igy értékesithetik ön javukra az elöhaladott kor közhasznu vivmányait.” A szerző ezt követően olyan intézetek felállítására ösztönöz, amelyek az „uj férfi nemzedék" képzését hivatottak megfelelő módon végezni, különösen egy ipartanoda, valamint egy gazdasági iskola létrehozását tartja elengedhetetlenül szükségesnek. ${ }^{413}$

Érdemes még kiemelnünk a nőegylet által 1876-ban létrehozott kisdedóvó témakörében született publicisztikákat, hiszen a nemes célú intézmény kiemelt fontosságú ügynek számított a helyi közbeszédben. „Minden bevezetés nélkül szólva, kissé resteljük, hogy 1875-ben kisdedóvoda létesitéséröl kell vezércikkeznünk - Szentesen, hol 30,000 lakos- és ezek közt tekintélyes számú intelligentiával állunk szemben; Szentesen, melynek közönsége (a kisdedóvoda javára fogadást ajánlunk rá) évenként legalább 1000 frtot költ bábokra és egyéb játékszerekre, melyekkel karácsony- és más alkalmakkor a gyerekeknek kedveskedik; Szentesen, hol a modern anyák, ki tudná föl számítani, mennyi ezret költenek egészen fölösleges szalagokra és csokrokra, meg más ily, a fényüzés körébe vágó haszontalanságokra" - fogalmaz a szerző 1875 novemberében, mikor a téma először megjelenik a sajtó hasábjain. $^{414}$

\footnotetext{
${ }^{412}$ SZL, X. évf. (1880) 25. sz. 1.

${ }^{413}$ SZL, XII. évf. (1882) 36. sz. 1.

${ }^{414}$ SZL, V. évf. (1875) 47. sZ. 1.
} 
Az „Egyéb” témájú vezércikkek közül kiemelhetjük például az 1873. október végén megjelent publicisztikát, amely a szerencsejátékok káros hatásairól értekezik. A lap felhívja a figyelmet, hogy a hazárdjátékok manapság annyira divatba jöttek, hogy már nem csak ,sötét és rejtett barlangokban üzetnek, hanem oly helyeken is, melyeknek a müvelödés templomainak és a nemesebb társalgás után sovárgók gyülhelyeinek kellene lenniök". A cikk ezt követően arról értekezik, hogy a szerencsejáték utáni vágyakozás rendkívül gyorsan fajul veszélyes szenvedéllyé, amely családok tragédiájához, a kétségbeesés elől öngyilkosságba vagy egyéb önpusztító cselekedetbe menekülő áldozatokhoz vezet. A publicisztika szerint az ilyen módon szerzett anyagi javak ráadásul nem teremtenek majd jólétet, mert az igazi vagyon mindig a szorgalomnak és a takarékosságnak a gyümölcse - a hazárdjátékokból, hirtelen jött gazdagság tehát óhatatlanul, gyorsan el is fog veszni, a pazarlásnak köszönhetően. Az újságíró ezután ismét a sajtó társadalmi felelősségét emeli ki, hiszen: „e baj ellen nem nyujtanak gyógyszert az iskolákban, hangsúlyoztatik az erkölcsiség óh! de a templomok szó- székjein kelt igék nem hatnak a nyerészkedés székhelyéig; ép azért hivtuk fel a figyelmet mi, mert e baj ellen orvoslást csupán a társadalom ön maga hozhat." ${ }^{415}$

A cikkek szerzői sokszor még a bizakodásra és reményre okot adó jelenségekkel kapcsolatban is megtalálják a dolgok árnyoldalát. Tipikus példa erre az 1878. június 2-i publicisztika, amelyet eredetileg az év legszebb hónapja, a május ihletett: „Az év legszebb, $s$ legkedvesebb hónapja, melyben a mezők, a rétek, kertek illatos virágaival gazdagon pompázik a természet, s az estei és reggeli szellö lágy suttogásával, illattal telt, életadó leheletével fogadja és árasztja el, ki fölkeresi a természetet, kin a szabadban, az ö templomában." Máshol - folytatja az újságíró - ilyenkor elégedettek, boldogok és önfeledtek az emberek, élvezik a május kellemes perceit, viszont Szentesen ez nem így van. A legszebb tavaszi hónap csupán csendesen, eseménytelenül eltelt, semmi maradandót nem hagyott hátra maga után, amely az emberek lelkét képes volna megújítani a hosszú téli időszakot követően. „De hát a május nálunk szegényebb, mint máshol? Nem, mi vagyunk szegényebbek azoknál, kik az életkedv fokozására föl tudják használni a tavasz kellemét." Ezután az író hosszasan ecseteli, hogy sajnos még ilyenkor is üres a város gyönyörü sétakertje, mert a szentesi férfiak a kaszinókban és kávéházakban múlatják az időt, a nők pedig otthon végzik a házimunkát. ${ }^{416}$

Hasonló példa egy három esztendővel korábban született vezércikk, amely örömmel számol be arról, hogy az unalmas téli estékre végre sikerült hasznos elfoglaltságot biztosítani a lakosság számára: a helyi tanárok ingyenes felolvasóesteket tartanak, viszont sajnos nem

${ }^{415}$ SZL, III. évf. (1873) 43. sZ. 1-2.

${ }^{416}$ SZL, VIII. évf. (1878) 22. sz. 1. 
sokat ér a kezdeményezés, mivel nagyon szerény az érdeklődés. ${ }^{417}$ Egy 1880 februárjában közzétett írás viszont, amely a farsangi ünnepek után látott napvilágot, éppen azt ecseteli, hogy a társasági élet alacsony színvonala néha nem az érdeklödés hiányának, hanem a szegényes szervezőmunkának, a rendezvények elmaradásának köszönhető: „Nálunk máskor is unalmas szokott lenni a tél, de legesleginkább unalmas volt ez az idén. Más városokban sür, forr az élet, a mulatságok, szórakozások ezerféle nemével igyekeznek feledtetni a tél unalmait, nálunk tesped, pang az élet, hacsak a házi élet szük körére szorult névnap, ünnepnap, disznótor, kézfogó, lakodalmak nem jönnek számba, hol az 1 frt 50 kosrból [sic!] mégis koccintanak a hazára, társaságban panaszkodnak a kormányra és az adóvégrehajtókra. Disznótor, lakodalmon kivül azután nincs nálunk társaság, s ha valakit ilyenekbe nem hivnak, otthon ülhet négy fal között egész télen át." Az írás megemlíti, hogy bár van a településnek dalegylete, ebben az évben nem tartott koncertet; van a településnek tekintélyes értelmiségi rétege (tanárok, ügyvédek, orvosok), viszont a felolvasások, amelyeket az előző esztendők során rendszeresen szerveztek, most szintén elmaradtak. Mindennek okait - állítja a cikk nem a lakosság érdektelenségében kell keresni, éppen ellenkezőleg: a szentesiek jó része „mindig seregestöl jelent meg, hol a nemes szórakozásra alkalom kínálkozott.” Az idén viszont nincsenek ilyen alkalmak, tehát a feladat nem más, mint hogy ismét cselekedjen aktívan minden olyan személy, „kinek hivatása tenni, hatni, oktatni, szórakoztatni, társaséletünket élénkiteni, s egy unalmas hosszú telet némileg élvezetessé tenni." ${ }^{418}$

Szintén népszerü témakör volt a címoldalon a település későbbi sorsát döntő mértékben befolyásoló új megyeszékhely ügye. Számos vezércikk követte figyelemmel az évekig tartó versengés aktuális állását, valamint a végül Szentes javára történő központi döntés után tudósított a megyeszékház építésének egyes fázisairól. Az újság 1883. december 15-i száma az eseményhez méltó, emelkedett hangnemben számolt be az öt nappal korábban megtartott első megyei közgyülésről: „Megyénk vezérfiai büszke önérzettel tekinthetnek vissza e küzdelemre, mert minél élesebben léptek elötérbe az akadályok, annál hatványozottabb erélyt, buzgalmat fejtettek ki a megye ohajtásának érvényesülése érdekében. S most midön a kivivott diadal felett hangzik el az öröm és megelégedés szava: a gyözelem megyei szempontból a lelkesedés hangulatára emelheti fel még azokat is, kiket apróbb tekintetek távol tartottak e küzdelemben való részvételtől." A szerző szerint a kivívott siker a vármegye alkotmányos küzdelmének eredménye, amely fényesen igazolja, hogy amíg az ősi jogokra támaszkodva, szilárdan összetart mindenki a megye jogos és törvényes óhaja mellett, addig

${ }^{417}$ SZL, V. évf. (1875) 2. sz. 1-2.

${ }^{418}$ SZL, X. évf. (1880) 6. sz. 1. 
nincs ok attól félni, hogy idegen érdekek érvényesüljenek Csongrádban. E tekintetben tehát december 10. méltán tekinthetö örömünnepnek nem csupán a szentesiek, hanem az egész vármegye lakossága számára. ${ }^{419}$

Érdemes kiemelnünk még a sajtó témaköréböl az 1880. január 18-án megjelent, Sajtó és párbaj címü vezércikket, amely, bár fővárosi eseményt dolgoz fel - Verhovay Gyulának, a Függetlenség szerkesztőjének párbaját báró Majthényi Izidorral -, minden bizonnyal nagy érdeklődést váltott ki a szentesiek körében is, emellett érzékletes képet fest a sajtószabadság korabeli helyzetéről is: „Ez az eset az egész országban mély megbotránkozást keltett; mert ebben mindenki erőszakot lát a sajtó azon nemes hivatásával szemben, hogy ez nyiltan, kérlelhetlenül mutathasson a bün, a visszaélés és gyalázatra. [...] És azért hulljon bár vér érte, legyen a sajtó elsö feladata szabad szó kimondás, független itélet föl és le egyiránt." "420

Összegezve, elmondhatjuk tehát, hogy lap vezércikkeinek többsége igyekezett felhívni a figyelmet a kiegyezés utáni Szentes társadalmi, gazdasági és kulturális elmaradottságára, s az addig elért eredmények elismerése mellett - próbálta építő kritikával elősegíteni a város további polgári fejlődését. Végül, meg kell még jegyeznünk, hogy a lap publicisztikáinak hangneme tárgyalt korszakunk végén, 1882-től még keményebbé vált, mert felfokozódott a város és a megye közötti politikai ellentét. Sima Ferenc igyekezett leleplezni a kormánypárti vármegye működésében tapasztalható visszásságokat, és élesen kritizálta a főispánt, illetve az alispánt is. ${ }^{421}$ Például a Lapunk és a megye címü, ötrészes vezércikkben a következőképpen fogalmaz: „Évekig kell küzdeni, mig végrehajtatnak megyénket élet érdekkel érintő fontos kérdések. S ha megyénk törvényhatósági jelentöségének kidomboritása helyett, csak vonaglást, az erö és hatalom érvényesitése helyett unalmat és közönyt, az elörehaladás és törekvés szelleme helyett, tespedést, a kötelesség végrehajtásában muladékosságot, az elsö helyen szereplöknél föltétlenül kivánatos nyilt, öszinte magatartás és küzdelem helyett, fölfelé alázatosságot, lefelé basáskodást, s ha ezek mellett intriguát látunk és tapasztalunk léptennyomon, s ha ezeknek következtében mi azt mondjuk, hogy megyénkben nyomoruságos állapotok uralkvdnak [sic!], ez kötelességünk, mert mi nem tartjuk feladatunknak szépiteni a nyomorult állapotokat." A felelős szerkesztő szerint senki ne csodálkozzon azon, hogy a Szentesi Lap a Csongrád vármegyét jellemző nyomorúságos állapotokért az alispánt teszi felelőssé. Mindez teljes mértékben jogos és indokolt, hiszen ő áll a megye élén. ${ }^{422}$

\footnotetext{
${ }^{419}$ SZL, XIII. évf. (1883) 50. sz. 1.

${ }^{420}$ SZL, X. évf. (1880) 3. sz. 1-2.

${ }^{421}$ Kis-Rácz 2000.(1.10.8. - A korszak sajtója)

${ }^{422}$ SZL, XII. évf. (1882) 24. sz. 1.
} 


\subsubsection{Hírek}

A hírközlés tekintetében a Szentesi Lap folyamatosan változó rovatstruktúrát alkalmazott. Az újság indulásakor a Helyi hirek közölték a városban és a régióban, a Különfélék rovat pedig az országban, illetve a külföldön történt eseményekről való beszámolókat. 1873 nyarától átmenetileg a Helyi és vegyes hirek rovat fogta össze az összes hírt földrajzi elhelyezkedéstől függetlenül, emellett egy kérészéletü rovat is indult decemberben Apróságok néven, amely városi és regionális híreket tartalmazott. Az 1874-es január-februári lapszámokban egy rövid időre visszatért a Helyi hirek, azonban - néhány lapszámtól eltekintve - továbbra is a Helyi és vegyes hirek maradt az elsődleges hírrovat. 1875. októbertől a rovat kettévált, s ismét a lap indulásakor alkalmazott rendszer köszönt vissza: a Helyi hirek a városi és regionális, a Különfélék pedig az országos és külföldi tudósításokat tartalmazta. 1876-ban folytatódott ez a struktúra, azonban indult néhány rövid életű rovat: előbb nyáron a Vegyes hirek, majd ősztől a Vegyesek, mindkettő országos és külföldi hírekkel, valamint a tavasszal és nyáron időnként jelentkező A nagy világból, amely külföldről származó információkat közölt. A következő esztendőben, az immáron Sima Ferenc által szerkesztett újságban csak egyetlen hírrovatot találunk, a Helyi és vegyes hireket, s ez a következetesség majdnem tárgyalt korszakunk végéig megmaradt, azzal a kiegészítéssel, hogy 1880-tól a külföldi híreket elsősorban külpolitikai jegyzet formájában ismertette a Világ folyása címü rovat. 1883-ban végül ismét megváltozott a hírszerkesztés rendszere: márciustól júniusig találkozhatunk az országos és külföldi híreket tartalmazó Vegyes hirekkel, a november 17-i lapszámtól (XIII. évf. 46. sz.) pedig megjelent a Rövid hirek rovat, amely szintén föleg országos és külföldi híreket közölt.

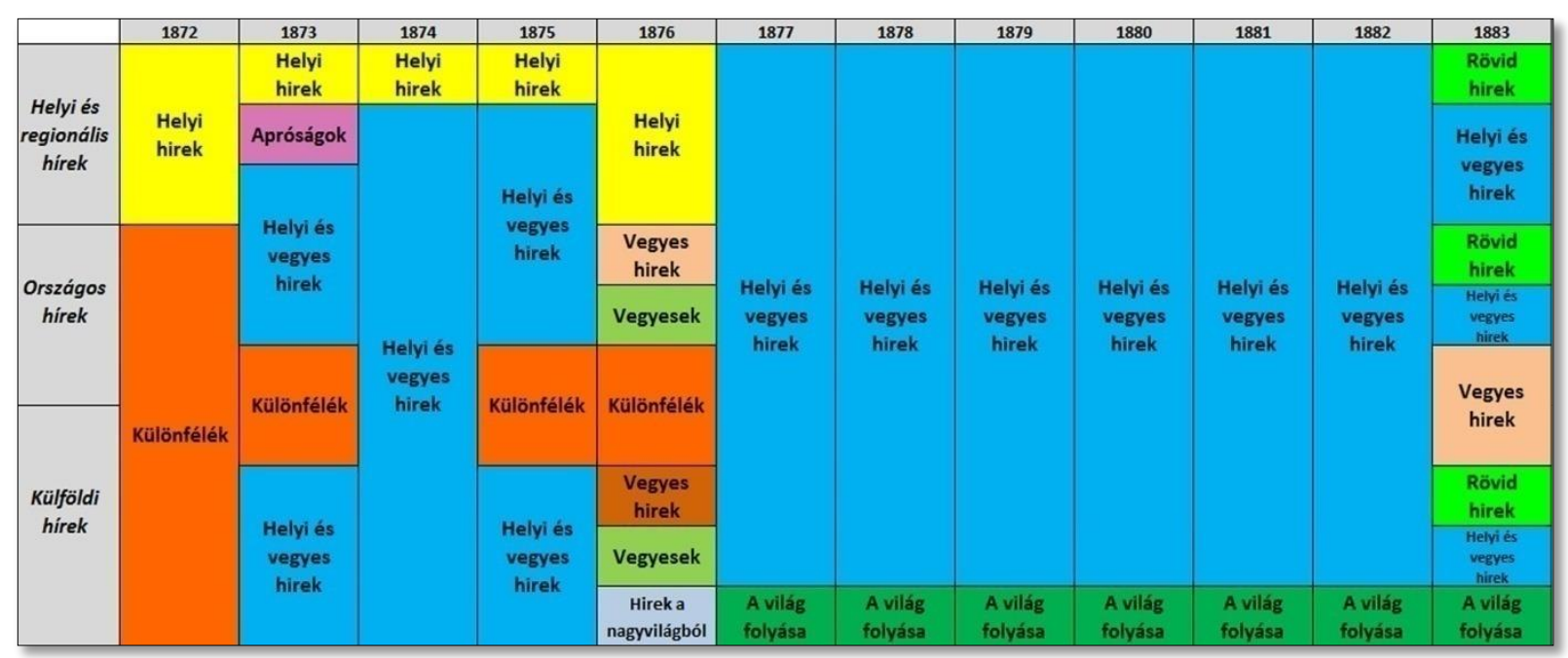

9. ábra - A Szentesi Lap hírrovat-struktúrájának változásai év szerinti lebontásban 
Fontos megjegyeznünk, hogy a közölt hírek mennyiségét tekintve is jelentős változás tapasztalható tárgyalt korszakunkban, amelyet az alábbi diagram szemléltet:

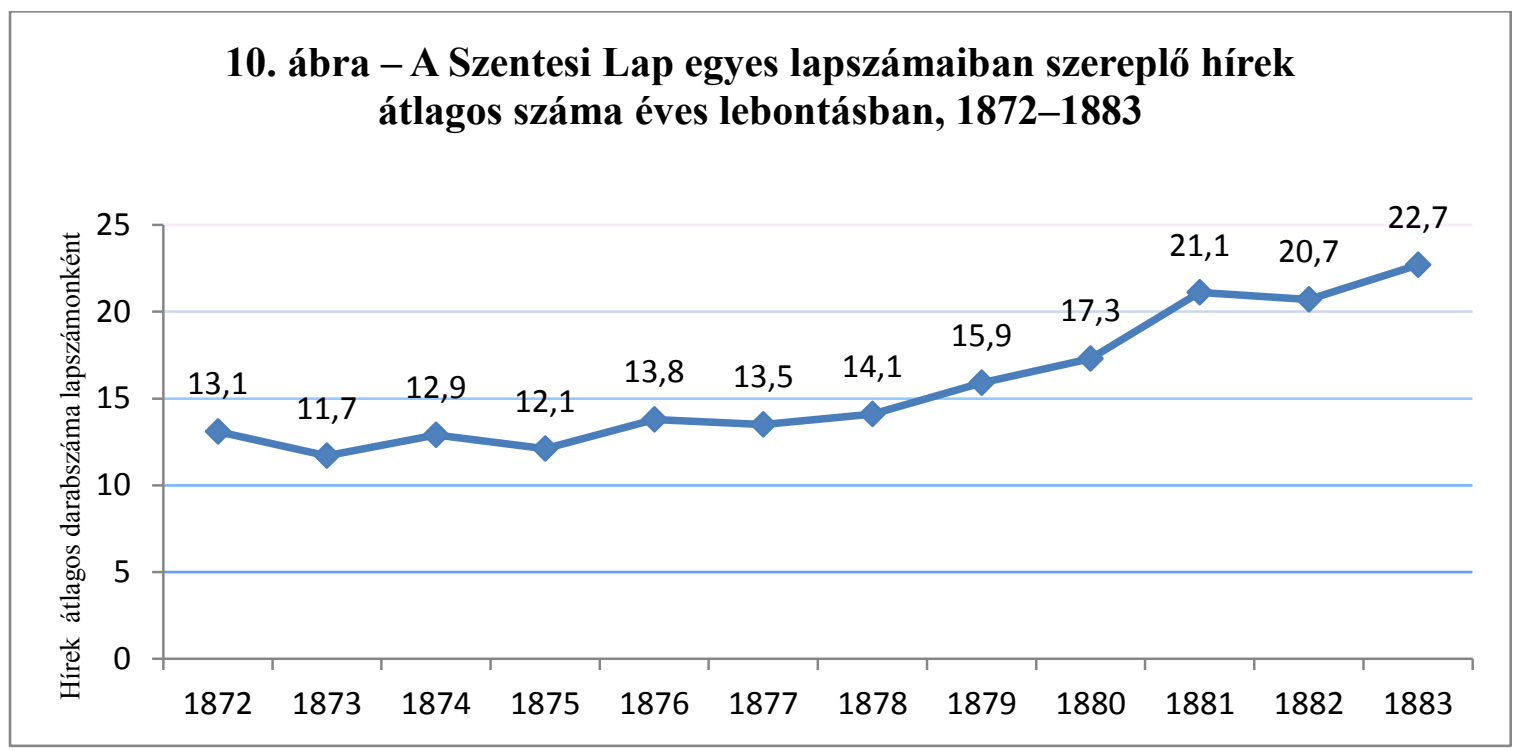

Látható, hogy az első években lapszámonként átlagosan mindössze 10-15 hírt tartalmaztak az egyes újságok, majd ez a szám - egyértelműen Sima Ferenc szerkesztői munkájának köszönhetően - fokozatosan emelkedett: 1881-től már 20-25 különféle eseményről számoltak be a hírrovatok. Megállapíthatjuk tehát, hogy a Szentesi Lap esetében is jól nyomon követhető az országos tendencia: a hír, mint müfaj egyre inkább előtérbe került.

\section{1. ábra - A Szentesi Lap hírrovataiban szereplő hírek földrajzi megoszlása $(\%), 1872-1883$}

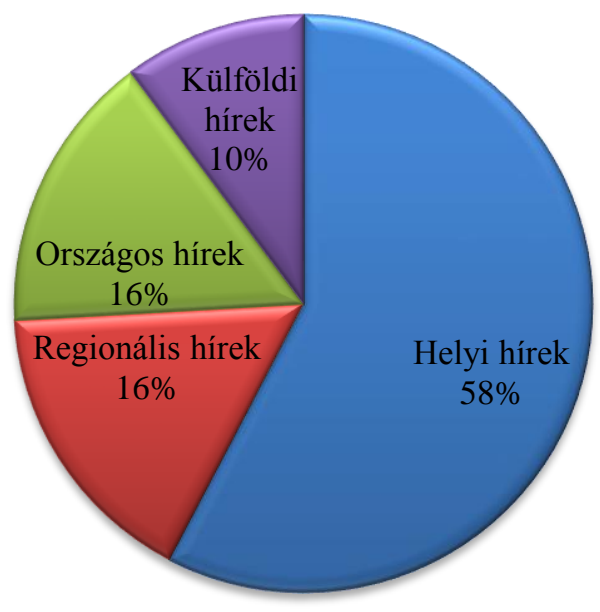


Amennyiben a hírek földrajzi megoszlását vesszük alapul, a fenti diagramból látszik, hogy a Szentesi Lap jóval kiegyenlítettebb arányban szelektált e téren, mint két elödje, a Szentesi Lapok, illetve az Alföldi Figyelő: helyi sajtóorgánum szerepkörének megfelelve elsősorban (58\%-os arányban) a településre és közvetlen vonzáskörzetére koncentrált (a Szentesi Lapoknál ez az arány 42\%, az Alföldi Figyelő esetében pedig csupán 37\%). Mindemellett nagyobb hangsúlyt (16\%) fektetett a regionális eseményekre is, szemben a Szentesi Lapok 14, illetve az Alföldi Figyelö mindössze 5\%-ával. A helyi hírek arányának növekedése elsősorban az országos történésekről való beszámolók rovására ment, hiszen ezek aránya csupán 16\%, amely alig több mint a fele a két elödlap 29-29\%-ának. Végül, a diagramból az is jól látható, hogy a Szentesi Lap a külföldi hírekre fókuszált a legkevésbé: 10\%-os arányt tesznek ki, amely azonban összességében tekintélyes hányad, föként, hogy helyi lapról van szó.

A földrajzi megoszlás évfolyamokra lebontott statisztikája is beszédes adatokat eredményez: mint az alábbi ábra is mutatja, az első években igen változékony volt a helyi, a regionális, az országos és a külföldi hírek aránya - köszönhetően a többször változó felelös szerkesztői pozíciónak is. Látható, hogy az első évfolyam (1872) még nagyjából az Alföldi Figyelőnél tapasztalt hírszerkesztési struktúrát mutatja: a helyi, az országos és külföldi hírek viszonylag egyenlő mennyiségben kerültek be az újságba, regionális eseményekről pedig alig olvashatunk a hasábokon. A helyi hírek aránya a következő évtől jelentősen megnövekedett, azonban a másik három terület évröl évre meglehetősen nagy következetlenséget mutat. Az ábrából egyértelműen kiolvasható, hogy Sima Ferenc felelős szerkesztői tevékenységének köszönhetően - különösen az 1879 és 1882 közötti időszakban - állt be egy viszonylag kiegyenlített arány a földrajzi megoszlás tekintetében, azonban tárgyalt korszakunk végén, 1883-ban - mikor Sima a lap és a nyomda tulajdonjogát is megszerzi - drasztikus fordulatot láthatunk: a külföldi és az országos hírek mennyisége a korábbi többszörösére növekszik, míg a helyi hírek aránya kevesebb mint kétharmadára csökken. Az alábbi diagramot összevetve a 10. ábrával, levonhatjuk a következtetést: a hírek mennyiségének jelentős növekedése elsősorban az országos és külföldi eseményekről való beszámolók, nem pedig a helyi tudósítások javára történt. 


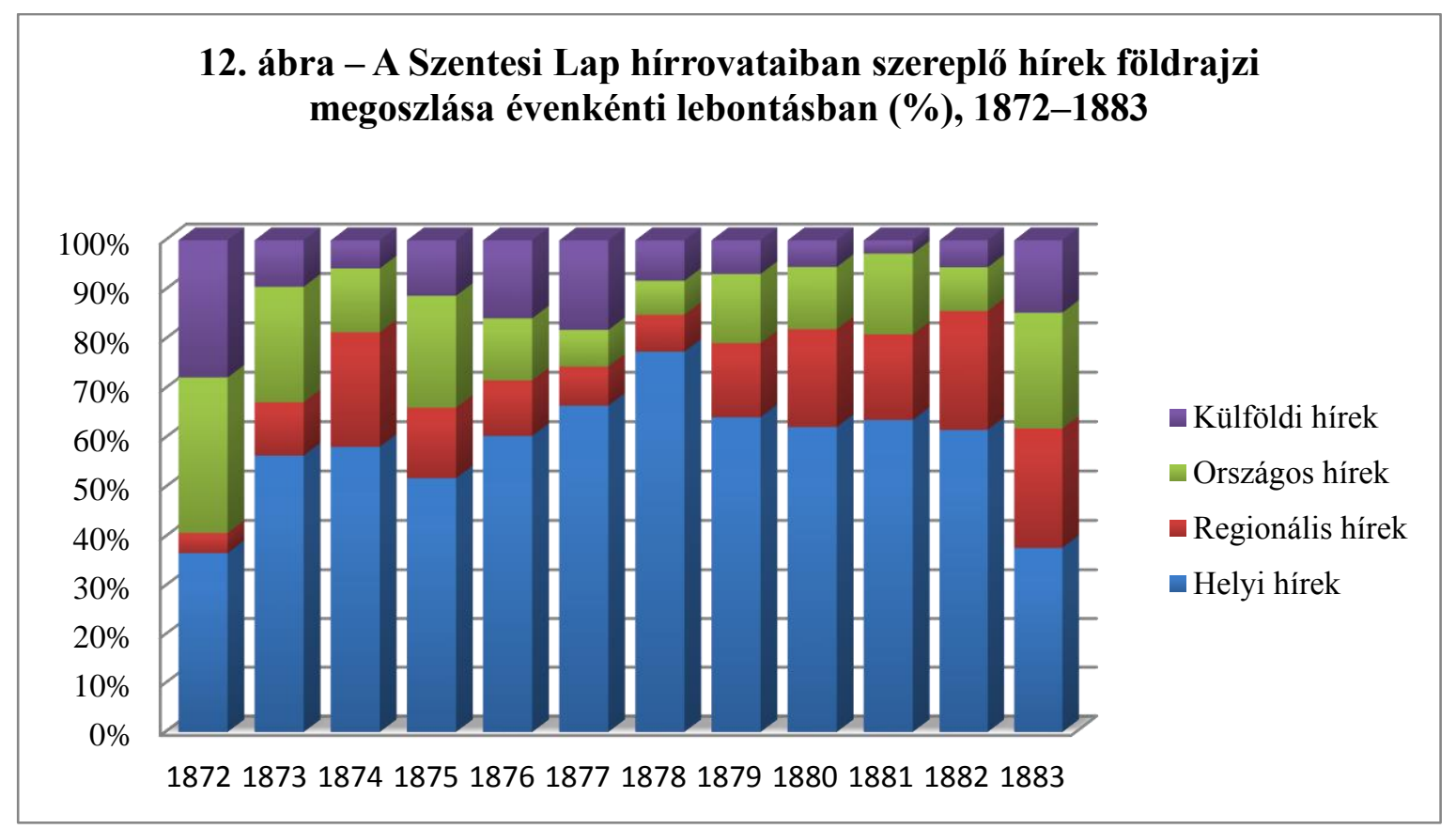

A földrajzi megoszlás tekintetében végül vizsgáljuk meg a külföldi híreket aszerint, hogy mely országokat említi leggyakrabban a Szentesi Lap (már említettük az 1880-tól induló Világ folyása címủ rovatot, amelyet - bár a publicisztika müfajába tartozik - statisztikánkba mégis belevettünk, hiszen egyértelműen legalább annyira az eseményekről való információközlés, mint az újságírói vélemény megfogalmazása volt a célja):

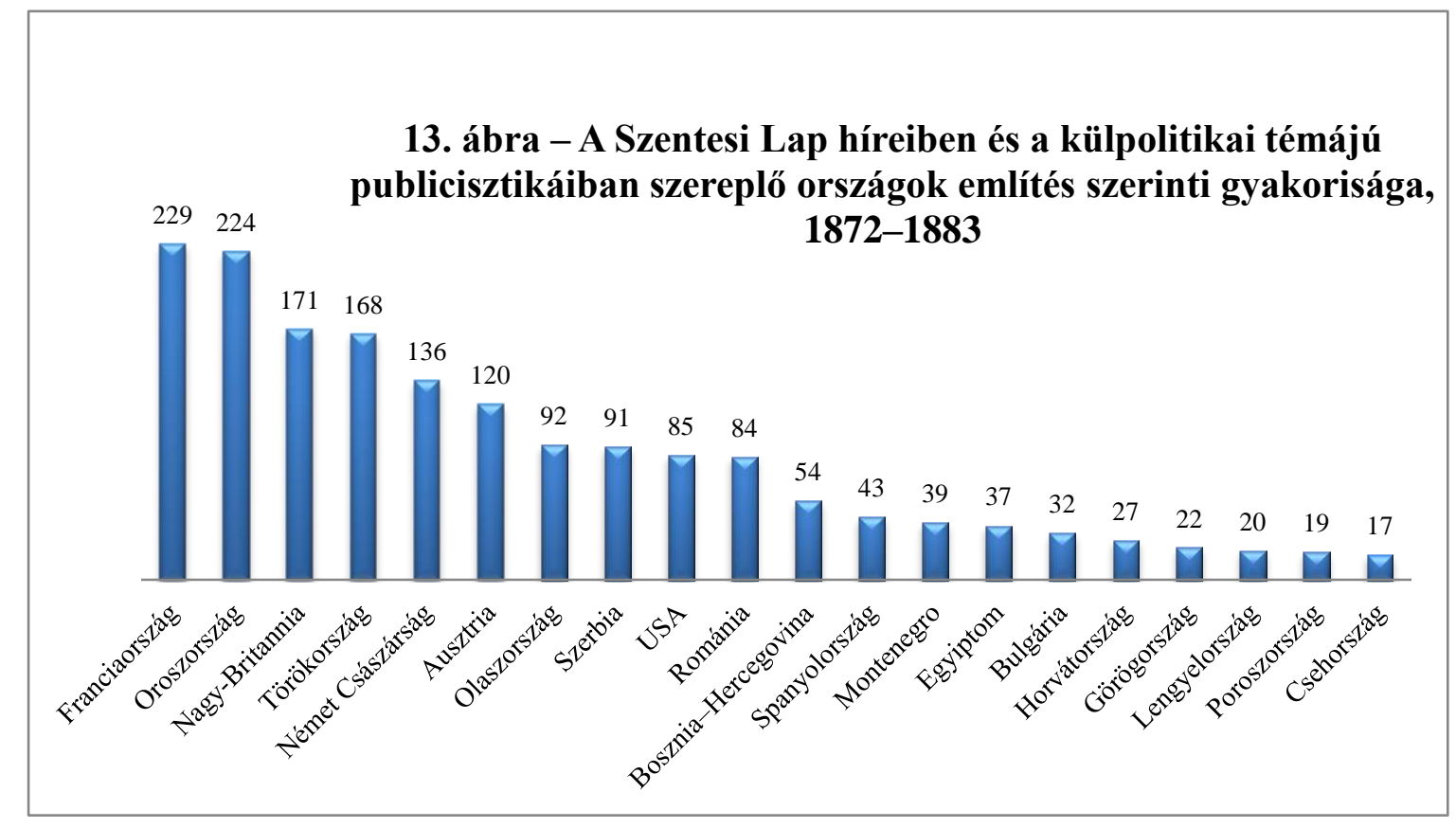


A diagramból látható, hogy a szerkesztőség nagymértékben hasonló arányban súlyozott a külföldi hírek földrajzi megoszlása terén, mint a korábbi Cherrier-féle orgánum, a Szentesi Lapok. Jelen esetben is Franciaország áll az első helyen. Az is egyértelműen látszik a diagramon, hogy a hírszerkesztés igyekezett mindig követni a világ politikai eseményeinek éppen aktuális állását - lásd a Törökországot vagy akár Bosznia-Hercegovinát érintő hírek nagy arányát. Szintén hasonlóan a Szentesi Lapokhoz, itt is megfigyelhetjük, hogy nagy hangsúlyt fektetett az Amerikai Egyesült Államokra, ahonnan elsősorban bulvárhíreket olvashatunk. Megtudhatjuk, hogy egy ottani pár az óceánon mondta ki a boldogító igent egymásnak, ${ }^{423}$ hogy az amerikaiak fa helyett papírból készült kocsikerekekkel kísérleteznek, ${ }^{424}$ hogy Massachusetts államban az adventisták még mindig várják a vízözönt, és emiatt megépítették Noé bárkáját, ${ }^{425}$ vagy hogy egy élelmes ottani asszony eladta a saját férjét. ${ }^{426} \mathrm{Az}$ 1880. május 9-i szám büszkén számol be arról, hogy sikerült egy a lap hasábjain a tengerentúlról közölt, modern mezőgazdasági technikát meghonosítani Szentesen: mint azt az újság korábban megírta, az amerikaiak új módszere, hogy főtt kukoricával etetik a sertéseket, aminek eredményeképpen az állatokat feleannyi idő alatt képesek felhizlalni, ráadásul feleannyi takarmány is elegendő hozzá. Az ötletet Purjesz Náthán helyi mérnök megkísérli átültetni Szentesen is a gyakorlatba: már tíz napja etet fött kukoricával százötven disznót, és úgy véli, a kísérlet már ilyen rövid idő után is azt mutatja, a remélt siker nem fog elmaradni. A sertések ugyanis így sokkal hamarabb megéheznek a könnyebb emésztés következtében, ez pedig jóval gyorsabb hízást eredményez. „Purjesz mérnök ur az eddigi siker által biztatva most már külön hizlalót fog épittetni, hol külön külön nyers és fött kukoricáva, [sic!] fog próbára hizlalni. Nagyon örülünk neki, hogy épen városunkban került ember, ki e próbát megkisérli, hogy példát nyujtson közönségünknek. Érdekes tudni, hogy Purjesz mérnök ur naponta kétszer 150 disznó számára mtként [sic!] fözeti meg a kukoricát? Ez nála igen egyszerüen mégy. A gözmalomban egy szobában van épitve egy nagy fenyöfa láda, melybe a megfözendö kukoricát teszik, s ebbe szolgál be egy csö, melyen a göz vezettetik be, s fél óra alatt a göz megfözi 150 disznó számára a kukoricát." ${ }^{427}$

A teljesség kedvéért felsoroljuk azon országokat is, amelyek a diagramban - helyhiány miatt - nem szerepelnek (zárójelben az említés gyakorisága): Kína (14), Albánia (11), Ukrajna (10), Írország (9), India (8), Svájc (7), Tunézia (6), Afrika (ország megjelölése

\footnotetext{
${ }^{423}$ SZL, X. évf. (1880) 30. sz. 3-4.

${ }^{424}$ SZL, I. évf. (1872) 17. sz. 3.

${ }^{425}$ SZL, V. évf. (1875) 42. sz. 3.

${ }^{426}$ SZL, VIII. évf. (1878) 20. sz. 3.

${ }^{427}$ SZL, X. évf. (1880) 19. sz. 3. (Megjegyzés: a közölt idézet is mutatja, milyen gyakoriak voltak a súlyos, a lap hitelét rontó szedési hibák.)
} 
nélkül, 4), Ausztrália (4), Hollandia (3), Portugália (2), Palesztina (2), Mexikó (2), Brazília (2), Svédország (2), Szíria (2), Vatikán (2), Indonézia (1), Litvánia (1), Új-Zéland (1), Arábia (1), Perzsia (1), Norvégia (1), Grúzia (1), Macedónia (1), Libanon (1), Türkesztán (1), Málta (1), Afganisztán (1), Ciprus (1), Luxemburg (1). A felsorolásból láthatjuk, hogy a Szentesi Lap próbált átfogó képet adni a nagyvilágban történt fontos vagy érdekes eseményekről is.

Amennyiben a politikai és egyéb közéleti, valamint a bulvárhírek arányát vizsgáljuk a Szentesi Lapban az 1872-es indulástól kezdve 1883-ig, a következő arányt kapjuk:

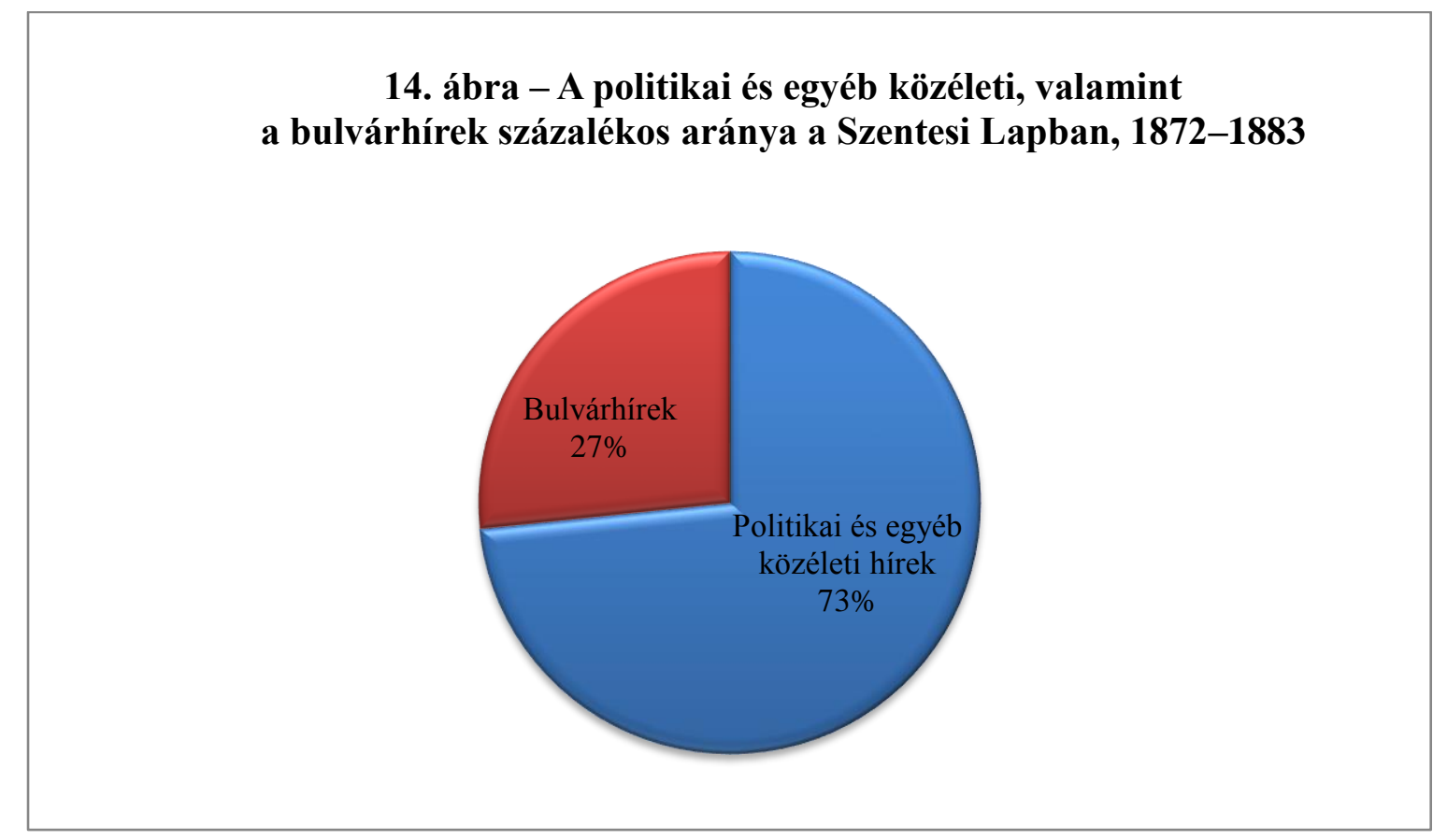

Láthatjuk, hogy a tárgyalt időszakunkban - összességében - a Szentesi Lap számára fontosabb volt a közéleti eseményekről, az aktuális politikai történésekről való tényközlés, mint a könnyedebb, színes vagy akár botrányos hírekkel való szórakoztatás, a szenzációhajhászás: a közéleti hírek közel háromszor akkora mennyiségben vannak jelen a hasábokon a bulvárhírekhez viszonyítva. Azonban, ha ugyanezt az arányt az egyes évfolyamokra lebontva vizsgáljuk meg, egyéb következtetéseket is levonhatunk: 


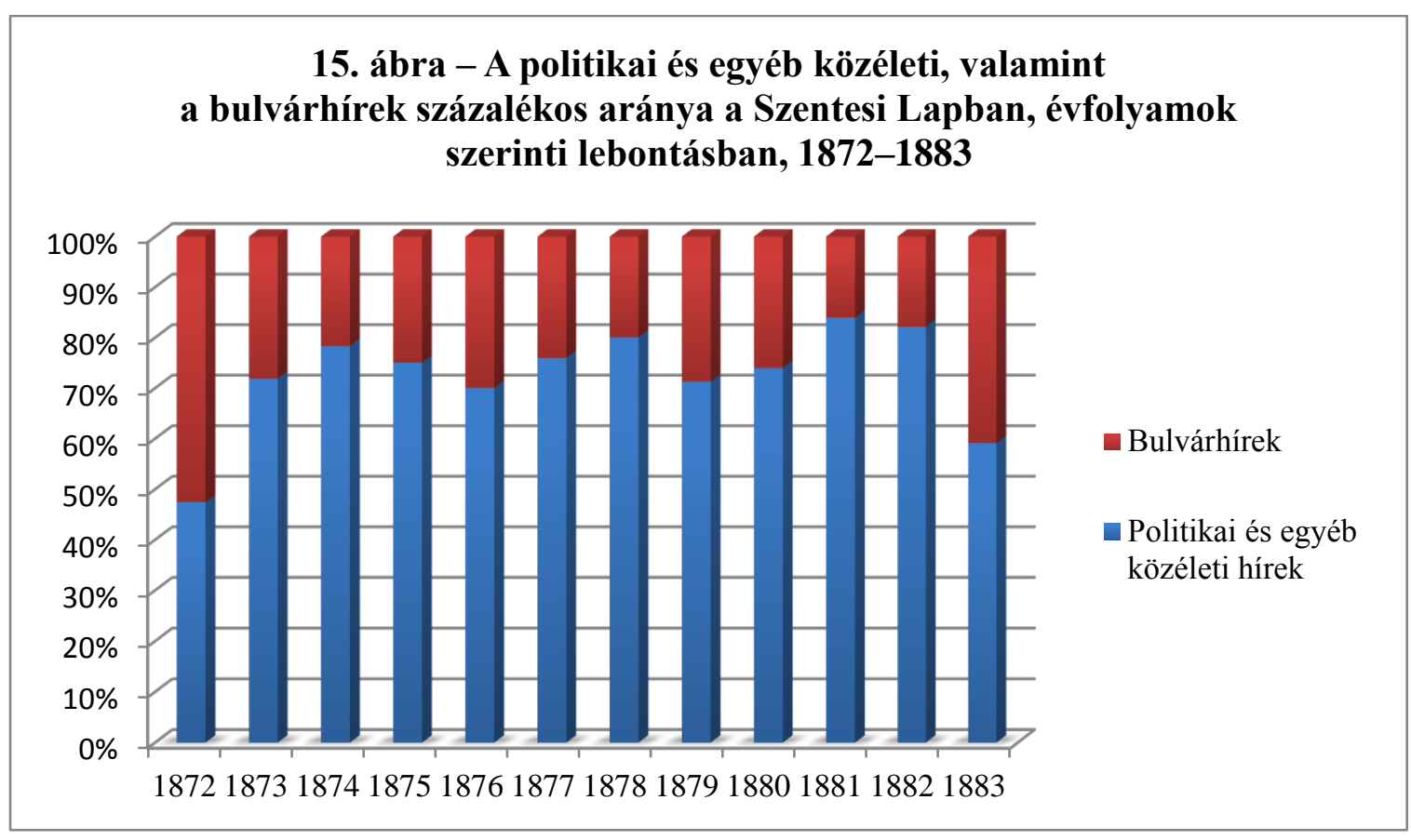

A diagramból egyértelmúen leolvasható, hogy a lap indulásakor - nyilván okulva a korábbi kudarcokból - a tulajdonos igyekezett minél színesebbé, szórakoztatóbbá tenni az új orgánumot, ez magyarázza a bulvárhírek szokatlanul magas, a korszakban általánosan nem jellemző arányát: több mint felét, 53\%-át teszik ki a híreknek 1872-ben. Ahogyan azonban az újság helyzete stabilizálódott, előtérbe kerültek a komolyabb, politikai, illetve egyéb közéleti információk, és hosszú éveken keresztül bő kétharmados többséget képviseltek. Az 1883-as esztendő viszont e tekintetben is fordulópont: az új tulajdonos, Sima Ferenc feltehetően ismét az üzleti szempontokat helyezte előtérbe, és a bulvárhírek arányának jelentős növelésével (42\%) igyekezett további előfizetőkre szert tenni.

\subsubsection{Társasági élet és kultúra a hírrovatok tükrében}

Ebben az alfejezetben elsőként meg kell említenünk a nyilvános társasági összejöveteleket. Ezen rendezvények mennyiségével és minőségével - mint már említettük - a lap publicistái nem voltak mindig feltétlenül elégedettek, azonban a hírrovatok alapján akadt rendszeresen lehetőség a korszakban, ha valaki táncvigalomra, bálra vagy más, hasonló jellegü kikapcsolódásra vágyott. A legtöbb ilyen eseményre bárki ellátogathatott, de természetesen voltak zártkörü rendezvények is, amelyeken csak a lebonyolító szervezet tagjai vehettek részt: ilyen volt például a helyi izraelita hitközség táncestje 1872 öszén, amelynek bevételét a 
zsinagóga díszítésére fordították. ${ }^{428} \mathrm{Az}$ összejövetelek túlnyomó többségét a különféle egyletek rendezték - a Kaszinó, a Jótékony Nőegylet, a dalegylet, a segélyegylet, a 48-as Népkör stb. -, illetve egyéb, az egyleti formát felmutatni még nem tudó, önszerveződő társaságok (például az iparos ifjúság, a szabó ifjúság), de voltak magánkezdeményezések is. $^{429}$

A rendezvények döntő hányada sikeresnek bizonyult, viszont akadtak kudarcok is: „A Kaszinó-egylet mult hét szombatján adott csinos kis báljáról nagy büszkélkedve elmondhatjuk, hogy az szerencésen [sic!] - megbukott. [...] Az egész bevétel a zenészek diján felül nem volt elégséges a meghivók és táncrendek fedezési költségeinek fedezésére. De eltekintve ettöl, ennél jobb mulatságot kívánni is felesleges. Gyanitották volna csak szépeink, mikép ugy fog kiütni, hogy még ábrándokban se lehet vigabb mulatságot teremteni, még jégesöben is megkeresték volna." Az ironikus hangú cikk megjegyzi, hogy hölgyek igen kis számban jelentek meg a rendezvényen, viszont annál több volt a táncos lábú fiatalember. Úgynevezett füzér-tánc is volt, amely azonban nem ment könnyen a jelenlévőknek, ezért egy illető a „,nagyobb harmónia kedveért a székek háta megett félre ismerhetlen szakismerettel verte a taktust. Elvárjuk, hogy a február 8-ára határozott 2-ik táncvigalom, mint farsangi igényben utolsó, hogy tesz ki magáért" - tudósít az eseményről gúnyosan a Szentesi Lap. ${ }^{430}$

A társas rendezvények között szép számmal akadtak - részben vagy egészben jótékony célú hangversenyek, bálok, táncvigalmak. Kiemelhetjük közülük az 1876-os esztendőt, amikor a korábban már említett első városi kisdedóvó javára szerveztek különféle mulatságokat és kulturális eseményeket, s az egyletek, illetve más szerveződések egymást igyekeztek túllicitálni a nemes ügy érdekében. Például a helyi 48-as kör 1876. februári táncvigalma bevételének tekintélyes hányadát ajánlotta fel: „összesitvén, a rendezöség $70 \mathrm{ft}$. 15 krt. adott át a nöegylet pénztárnokának. Midön ezt az összeget nyilvánosan nyugtáznák, egyszersmint erre vett megbizásunk szerint a jótékony nöegylet nevében köszönetet mondunk a rendezö bizottság- és illetve a 48-as népkörnek azon szivességeért, hogy a kisdedóvoda javára ilyen szép összeget juttatott." "431 A Jótékony Nőegylet és a helyi dalegylet által közösen rendezett hangverseny nyereségének (105 forint 28 krajcár) felét szintén az óvoda alapítására szánták, ${ }^{432}$ nem sokkal később a nőegylet saját táncmulatságot is szervezett, ${ }^{433}$ majd az ősz

\footnotetext{
${ }^{428}$ SZL, I. évf. (1872) 9. sz. 3.

${ }^{429}$ Bárdos Flóri például a Szentesi Lap 1880. január 4-i számának (X. évf. 1. sz.) utolsó oldalán arról értesíti a közönséget, hogy helyi csizmadia ipartársulat nagytermében polgári táncvigalmat szervez január 11 -én este hét órai kezdettel, a belépődíj személyenként 60 krajcár.

${ }^{430}$ SZL, II. évf. (1873) 4. sZ. 2-3.

${ }^{431}$ SZL, VI. évf. (1876) 9. sZ. 3.

${ }^{432}$ SZL, VI. évf. (1876) 21. sZ. 3.
} 
folyamán a helyi iparos ifjúság szintén megtartotta saját, jótékony célú rendezvényét. ${ }^{434}$ Sőt még a közeli Mindszent színi társulata is külön elöadást tartott saját településén, $\mathrm{s}$ a bevétellel a szentesi kisdedóvóra szánt alaptőkét kívánta növelni. ${ }^{435} \mathrm{Az}$ óvodaalapítást, illetve későbbi müködését magánszemélyek és cégek is támogatták kisebb-nagyobb adományokkal, $\mathrm{s}$ a lap ezekről is mindig beszámolt: szívélyes felajánlást tett például Plager Jakab, aki a Pócs János ellen indított becsületsértési pert megnyerve, az alperes által fizetett 13 forint 33 krajcárt átutalta a kisdedóvó javára, vele egy időben pedig a két akkoriban müködő helyi takarékpénztár is küldött $15-15$ forintot. ${ }^{436}$

Aki más, inkább kulturális jellegü kikapcsolódásra vágyott, rendszeresen látogathatta a helyi énekkarok vagy a dalegylet hangversenyeit, amelyek közül számos szintén jótékony célt szolgált. 1873 áprilisában például olvashatjuk az újságban, hogy a szentesi református egyházi énekkar a Széchenyi-ligetben hangversenyt rendez, amelynek teljes bevételét felajánlják a település felső részében építendő templom javára. „Volt alkalmunk a próbán jelen lehetne [sic!] s mondhatjuk, hogy az elöadandó ének darabok öszhangzatos elöadása, figyelembe véve, hogy ezen énekkar alig pár hó elött alakult, valóban meglepi a hallgatókat, különösen kiemelendönek tartjuk Lachner szövetségi dalát, mely az elsö zenekar kisérete mellett adatik elö. Bátran felhivhatjuk a mü élvezetre vágyó közönséget, hogy tekintve a nemes célt, e hangversenyt, minél nagyobb pártfogásban részesitse."

Szólnunk kell még a színmüvészetről is, amelyek élvezetére szintén rendszeresen volt alkalom a városban, köszönhetően nagyrészt Rambovszky Józsefnek, aki főtéri vendéglöje udvarán biztosított állandó lehetőséget a különböző vendégtársulatok és helyi színészek előadásainak. „Színházba járó közönségünkre e napokban ritka élvezet vár. Ugyanis Dezsö Ödön, e tehetséges és szép jövőjü fiatal szinész a »Haramiák« tragoediában Mór Ferencet és Károlyt egy személyben fogja játszani, hogy alakitó tehetségét a közönségnek teljes mértekben bemutathassa. Ha tekintetbe vesszük e két, jellemben, ábrázolásban egymással teljes ellentétben álló alakot, érdekkel nézünk Dezső ábrázolása elé. Megjegyezzük még, hogy e két szerepet egy kiváló szinész azért játszhatja egyszerre, miután együtt sohasem jelennek meg a színpadon" - tudósít az újság egy különleges alkalomról 1876 nyarán. ${ }^{438}$ A kor szokásainak megfelelően, a Szentesi Lap színielőadásairól szóló hírei rövid és frappáns kritikák is egyben, amelyek igyekeztek minél több embert a kulturális eseményekre csábítani: „,Mult szombaton

\footnotetext{
433 SZL, VI. évf. (1876) 27. sz. 3.

${ }^{434}$ SZL, VI. évf. (1876) 39. sz. 3.

${ }^{435}$ SZL, VI. évf. (1876) 12. sz. 2.

${ }^{436}$ SZL, VI. évf. (1876) 11. sz. 3.

${ }^{437}$ SZL, III. évf. (1873) 16. sz. 3.

${ }^{438}$ SZL, VI. évf. (1876) 34. sz. 2.
} 
„Girolle és Girolla« cimü vig operette elöadása alkalmával szépen játszott és igen jól énekelt Krecsányi Sarolta, ki nem oknélkül kedvence lett szinház látogató közönségünknek. Jól játszott még Kiss, Dálnoki és Dálnokiné. Vasárnap Csikós. Szigligetinek e kitünő szinmüvét hozták szinre szinészeink. Mily sokszor láttuk már e darabot s jól játszva, mily élvezettel nézzük meg mindig. Bizony több élvezettel mint holmi silány operettet." $" 439$

\subsubsection{Fejlesztésekre ösztönzés, közérdekü figyelemfelhívások}

A Szentesi Lap nem csak a vezércikkekben, hanem a hírek rovatban is minden lehetőséget megragadott, hogy az infrastrukturális elmaradottságra felhívja a közvélemény, illetve a hatóságok figyelmét, folyamatosan hangsúlyozva ezzel is a sajtó társadalmi felelősségének szerepkörét. Ebből a szempontból talán a legnagyobb gondot az jelentette, hogy a városi utak, utcák és terek nagy része az 1870-es években még nem volt kikövezve - mint arról a vezércikkeknél már szóltunk -, s feltehetően az újság erről szóló rendszeres híradásai és kritikája is valamelyest hozzájárult ahhoz, hogy e munkálatok Kristó Nagy István polgármestersége idején megkezdődtek, majd Balogh János regnálása alatt új lendületet vettek. „Az esőzések, miket rendes idöjárás szerint csak november havában várhatánk, mint tapasztaljuk megindultak. Ezeknek kimaradhatlan következménye utainknak járhatatlansága. Hogy mily roszak lesznek utaink, már elöre képzelhetjük, bizvást tarthatunk attól, hogy a közlekedés teljesen fel fog akadni" - írja a lap 1872 szeptemberében. ${ }^{440}$

A helyzet négy esztendővel később számottevően javult, de bőven akadt még tennivaló: „Az illetők szives figyelmébe. Rendesen ugy szokott történi, hogy panaszainkkat akkor állunk elö, midőn legközvetlenebböl érint a méltánytalanság vagy midőn érezzük a kellemetlenséget. - Dicséret, dicsöség, tisztelet és hála azoknak, kik rajta voltak, hogy városunk minél nagyobb terjedelemben keresztül-kasul hálóztassék kövezettel." A szerkesztőség ezután megjegyzi: a legnagyobb gondosság mellett is maradt még néhány forgalmas hely, amely - tekintve a járókelők sokaságát - okvetlenül kikövezésre vár, például a Cukor Ádám és Molec Márton-féle házak között lévő, a katolikus iskolához vezető utca. „A piaci közlekedést ne is tekintsük, hanem vegyük figyelembe, hogy ott van a m. kir. posta-és adóhivatal; ott van a kath. templom és iskola. Elég ok az arra nézve, hogy a kellö intézkedések megtétessenek; méginkább kérhetjük pedig a várost akkor, midön a háztulajdonosok maguk

${ }^{439}$ SZL, IX. évf. (1879) 30. sz. 3.

${ }^{440}$ SZL, I. évf. (1872) 4. sz. 3. 
ohajtják a kiköveztetést." Emellett figyelmeztet a cikk, hogy a temetőkhöz vezető utak is sárosak, illetve javasolja, hogy az egyházak is vegyék ki a részüket a járdák kiépítésének költségeiből, mint ahogyan Zsolnai Ferenc gyártulajdonos már felajánlott 6000 darab téglát díjmentesen a városnak. ,Sürgetjük pedig ezeket télen, mert nyáron nem érezzük az e fajta kellemetlenséget, s könnyebben megfeledkezünk a kérés jogosultságáról is." ${ }^{441}$

Ugyanebben az évben a csúszós járdákról is olvashatunk. Az ironikus stílusban megfogalmazott hír kiemeli, hogy azok szinte életveszélyesek, mióta a nappal elolvadt hó éjszakánként jéggé fagy rajtuk. „A sikamlós útak veszélyességét e lap szerkesztője is oly érzékenyen tapasztalta, hogy egy hatalmas esés következtében jobb karját egy két napon át alig használhatta az irás mesterségéhez, a mi könnyen vonhatta volna maga után azt a szerencsétlenséget is, hogy a publikum egy héttel késöbb olvassa az ime föltálalt pompás újságot.” Az újságíró megjegyzi: már csak az ilyen nagy horderejü eshetőségek elkerülése érdekében is hasznos volna a járdákat hamuval, homokkal behinteni, vagy pedig a jeget megvágni, „nehogy a járókelö közönség patkót legyen kénytelen a csizmákra veretni. A rendörség is gondot fordithatna ilyen dolgokra!"442

Jellemző problémára hívja fel a hatóság figyelmét a következő hír is a közterületek használatával kapcsolatban: „Régebben e lapok is felszólaltak az iránt, hogy a házak melletti járdákra épült s a boltokba vezetö lépcsözetek távolittatnának el, minthogy azok a járó kelöre nézve nappal alkalmatlanok, éjjel pedig veszélyt hozók is lehetnek." Emellett a szerző rávilágít egy piaci kereskedő botrányos szokására is, aki - nem törődve a vásárló polgárok megbotránkozásával - rögtönzött illemhelynek használja üzlete egyik sarkát. „Kérjük tehát a t. rendörséget, ha ama bizonyos ur ez eljárását továbbra is eltürné, a napontai fertöztelenitésre is kényszeritse." 443

Hasonló gondot említ az 1878. február 3-i szám: a lap szerint a környező házak lakói a Kurca partján lévő magtár oldalában lévő térre hordják rendszeresen az udvaraikból kitakarított havat. Az olvadó hólé a térre vezető útra folyik, sártengert eredményez, hidegebb idő esetén pedig újra megfagy, jelentős veszélyforrást okozva. Az utat így képtelenség használni, mert egyre-másra dőlnek bele az egyébként is megrakott szekeret vontató lovak. A cikk szerint az ilyesmire a rendőrségnek kéne odafigyelnie, ugyanis ez közrendészeti ügy. Mellesleg, akik ki akarják vitetni a havat az udvarukból, azoknak ott a Kurca, hordják abba.

\footnotetext{
${ }^{441}$ SZL, VI. évf. (1876) 51. sZ. 3.

${ }^{442}$ SZL, VI. évf. (1876) 7. sZ. 3.

${ }^{443}$ SZL, III. évf. (1873) 45. sz. 3.
} 
„De a közutak nem arra valók, hogy azt egyesek kedvéért járhatatlanná tegyük."444 Azonban nem csak az időjárás okozott bosszantó pillanatokat a közterületeken: egy másik hír szerint a főutcán, a görög templom és a Pollák-ház előtt a hetenként összegyülő vásárosok annyi szemetet hagynak hátra, amely bizony „néhány föld trágyázására becsületesen elég volna. Se szemét eltakaritásáról nem gondoskodik senki. A járók-kelök orrukat kénytelenek befogni, ha utjok erre visz el. Kérjük az illetőket, forditsanak egy kevés gondot arra, hogy idönként eltávolittassék innen e ronda szemét." ${ }^{445}$

Egy héttel később a lap javasolja, hogy az egyes ingatlanok tulajdonosai, illetve lakói vegyenek aktívan részt a köztisztaság fenntartásában: „Nem várjuk meg sem egyesektől, sem a várostól, hogy haladéktalanul intézkedjenek, miszerint a csordára járó teheneknek egy külön utcát nyissanak, s e külön utcában külön ajtót ne feledjenek késziteni; ezt csak Belgiumban képesek megtenni. Söt, még azt sem kivánjuk, hogy az utcán a járók-kelök számára köpládakat készittessenek: hanem azt bátran megvárhatjuk az illető háztulajdonosoktól (vagy a lakóktól; az mindegy), hogy naponként a tehenek által hátra hagyott szemetet letisztitsák a kövezetröl. Tessék elhinni, 3 perc alatt a leglustább cseléd is elvégzi e dolgot; tehát az sem lehet kifogás, hogy nem érnek rá." 446

A szerkesztőség az előzőekhez hasonló, bár nem veszélyes, inkább bosszantó dologra hívja fel 1877 márciusában a hatóság figyelmét. Az írás megemlíti, hogy a piactéren hetivásárok alkalmával túlságosan sok a tétlen ácsorgó, ráadásul csoportokba verődve, akiket állandóan kerülgetni kell a szűkös járdán. „Hiszen ilyen dolgot nem lehet látni még a legnyomorultabb falun sem. Vagy mi szentesiek ebben is kivételek legyünk. Az ellen, hogy akinek nincs semmi dolga, (?) s ott elácsorog egész délelött a piacon: hát hiszen nincs semmi kifogásunk, s ha volna is nagyon keveset tehetnénk ellene, de hogy a rendörségnek nem állna módjában az ut elfoglalás áláltal [sic!] fölmerült s általunk is többször hangoztatott panaszt orvosolni, azt még is kétségbe vonjuk." A cikk megjegyzi: tisztában van vele, hogy a korlátozott létszám miatt a rendőrségnek nem áll módjában mindenhol folyamatosan jelen lenni, ez viszont nem szolgál mentségül az említett probléma megtürésére, hiszen amely helységben csak egy rendőr is akad, ott az ilyen dolgokat nem szabad elnézni. „Különben mi nem tudjuk, hogy egyáltalában mi szükséget pótolnak azok a rendőrök?"447

\footnotetext{
${ }^{444}$ SZL, VIII. évf. (1878) 5. sz. 3.

${ }^{445}$ SZL, VI. évf. (1876) 40. sz. 3. Nem sokkal korábban a szerkesztőség a piaci csavargók kötelező munkára fogását javasolta a hatóságoknak, akik némi fizetségért cserébe feltakaríthatnák a vásárok után maradt szemetet. (SZL, VI. évf. [1876] 32. sz., 3.)

${ }^{446}$ SZL, VI. évf. (1876) 41. sz. 3.

${ }^{447}$ SZL, VII. évf. (1877) 12. sz. 3. Érdekességként megjegyzendő, hogy a dualizmus után is továbbélt a napi és heti vásárok középkori hagyománya: a vásár nem csupán az árucsere-forgalom elsődleges színhelye volt a helyi
} 
Nagy problémát jelentett a települést kettészelő Kurca ér lecsapolatlan, mocsaras, büzös vize is, amely a kellemetlen szagon kívül melegágya volt a szúnyoglárváknak, illetve a különböző fertőző betegségeknek, mint arról korábban már szóltunk. „Meglátjuk, miként fog az egészségügyi bizottmány az idén intézkedni a Kurca posvány vizével. Még csak mártius van, de már is nagy mértékben lehet élvezni az illatot, különösen este felé még a kurcaparti utcában is. Majd lecsapolják augusztus vége felé, hanem aztán lesz is hideglelés" olvashatjuk 1873 tavaszán. ${ }^{448}$ A lecsapolást hathatósan csak az 1880-as évekre sikerült megoldani, addig viszont a Kurca számos komoly problémát okozott, például a korábban már szintén említett kolerajárványt, amely 1873 nyarán végigsöpört Szentesen is, több száz lakos halálát okozva. A lap ebben az esetben is igyekezett hasznos, közérdekü információkkal, jó tanácsokkal ellátni a lakosságot, hogy a betegség minél kevesebb áldozatot szedjen, például: „Nehogy a t. ez. közönség azon hiedelemben legyen, mikép a göz, kádas és zuhany fürdö használata a cholera járvány terjedését bármi részben is elömozdítja, ezennel közhírré tétetik, hogy a fürdők használata, nem hogy káros, sőt az egészség fentartására mulhatlanul szükséges." $" 449$

Az újság több esetben közölte az áldozatok aktuális számát is: 1873. augusztus közepén, a járvány tetöpontján döbbenetes adatokat olvashatunk a hasábokon, miszerint augusztus 8. és 15. között összesen háromszázhat szentesi polgárt ragadott el a kolera, százhuszonkilenc férfit, százharminchat nőt és negyvenegy gyermeket. A szerkesztőség emellett szkeptikusan jegyzi meg: még korántsem biztos, hogy a kór terjedése belátható időn belül alábbhagy. ${ }^{450} \mathrm{~A}$ járvány végül kitombolta magát, az utolsó, a témával kapcsolatos hírt az 1873. szeptember 21-i számban olvashatjuk, ahol az áldozatokról szóló szomorú statisztika is megtalálható. Eszerint a kolera megszünt a városban, s a hivatalos adatok szerint „,sept. 12-én volt 18 beteg, ezek száma a mondatt [sic!] naptól sept. 19-ig szaporodott 5-tel; ugyanezen idötartam alatt meghalt 3 férfi, 2 nö 3 gyermek, összesen 8. - a többi felgyógyult. A járvány egész tartama vagyis május 28-tól sept. 19-ig megbetegedett 2077, meggyógyult 1081, meghalt 990, ezek közül 392 férfi, 437 nö, 167 gyermek."451

\footnotetext{
lakosság számára, hanem sajátos légköréből adódóan a társasági élet egyik fó színtere is volt. Éppen emiatt, napjainkkal elentétben, a vásárokat általában az adott település föterén tartották - így volt ez Szentesen is. (Kaposi 2002. 247-248.)

448 SZL, II. évf. (1873) 13. sZ. 2.

${ }^{449}$ SZL, III. évf. (1873) 28. sZ. 2.

${ }^{450}$ SZL, III. évf. (1873) 33. sZ. 3.

${ }^{451}$ SZL, III. évf. (1873) 38. sz. 3.
} 
1875 végén a lap az akkoriban kiépülő közvilágítás ütemezésének gyorsítására ösztönöz, és a közeli Csany ${ }^{452}$ falut hozza fel példaként, ahol a kivitelezési munkálatokban már jóval elörébb járnak a helyiek. „A kurcaparti utca lakói által tervezett világitás még most is »késik az éji homályban.« Eddigelé még csak egyetlen háziurat tudunk, aki valósággal rendelt háza elé utcai lámpást." Pedig - folytatja a cikk - a nagy buzgóságnak olyannyira híre ment, hogy még egy vidéki lap is megdicsérte Szentest a modernizáció okán. Úgyhogy most már egyrészt illene megfelelni az elvárásoknak, másfelől pedig hasznos volna még a télen befejezni a munkát, hiszen a tavasz beköszöntével, tehát a nappalok meghosszabbodásával már jóval kisebb lesz a szándék és az áldozatkészség a közvilágítás megvalósítására a városlakók körében. Mellesleg elég nagy szégyen, hogy a közeli „Csany község sokkal sikeresebben járt el, mint amire a példa buzditotta. Ott - ugy értesülünk - a müveltebb emberek ez idöszerint már meg is állapodtak abban, hogy közösen kivilágítsák a falut. Most tehát kérdéssé válik: mi adjuk-e a példát, vagy Csany?" "453 A szerkesztőség apróságnak tűnő, de nem elhanyagolható veszélyekre is igyekezett figyelmeztetni a lakosságot, például: „Veszett eb járt e héten a kurcaparti utcán, s több kint ácsorgó ebet megmart. Figyelmeztetünk rá mindenkit, hogy ha ebén a veszettség legkissebb jelét venné észre, mulhathatlan kötelességének ismerje e körülményt a kapitányi hivatalnál bejelenteni." ${ }^{454}$

Az újság mindig büszkén közölte, ha közérdekü figyelemfelhívásainak lett foganatja a lakosság körében, illetve, ha sikerült elérni a hatóságok intézkedését valamilyen ügyben, s ez általában újabb problémákra való rávilágításra ösztönözte a szerkesztőséget: „A mult lapunkban kövezetünk tisztitása érdekében történt fölszólitásunk helyeslésre talált, legalább azt bizonyitja az a tény, hogy több helyen csakugyan is letisztittották a sarat." Ezután a lap közli legújabb indítványát: több forgalmas utcában a magtárak ajtóin keresztül - a folyamatos rostálás következtében - jó adag szemét hullik a járókelök nyakába. Kérik emiatt a magtárak tulajdonosait, hogy a lakosságra nézve igen kellemetlen bajt orvosolják azáltal, hogy rostáikat ne az utca felé, hanem az udvarra nyíló ajtónál állítsák fel - hiszen köztudomású, hogy a magtárak esetében az udvar irányába is van kialakítva ajtó. „Vagy inkább a járók-kelők ruhája s az utca rondittassék el, mint az udvar?"

Az építő szándékú kritikai észrevételek mellett az újság mindig beszámolt az elért eredményekről is. Már említettük az első városi kisdedóvót, amelynek a lap jelentős teret szentelt mind a hír-, mind a publicisztikai rovatokban - bizonyos mértékben hozzájárulva az

\footnotetext{
${ }^{452}$ A mai Csanytelekről van szó.

${ }^{453}$ SZL, V. évf. (1875) 51. sZ. 3.

${ }^{454}$ SZL, X. évf. (1880) 33. sz. 3.

${ }^{455}$ SZL, VI. évf. (1876) 52. sz. 3.
} 
intézmény 1876-os, sokéves fáradozás utáni megnyitásához -, de a hasábok lelkesen adták hírül például a Kurca pangó vizének lecsapolásában elért első eredményt is: „A Kurcatorok $f$. hó 4 én megnyittatott, $s$ f. hó 10 én a vámházi gát is át lett vágva, hogy még a jó idővel az alsó és felső Kurcából lefolyon a viz és a kurca segitségével a rétekről a fakadó vizek is levezettessenek. Ez igen helyes és bölcs intézkedés." "456

\subsubsection{Balesetek, katasztrófák}

A vezércikkek elemzésekor már említettük, hogy a városban az élet- és vagyonbiztonságra az egyik legnagyobb veszélyt a viszonylag gyakori tűzesetek jelentették, amelyek nagy része a gondatlanság - általában a kertbe behordott széna vagy szalma kigyulladása - miatt, illetve gyermekcsíny okán keletkezett. „Tüz ismét, - s ismét a Kisérben, - s ismét gondatlanság által. Vig Mihály, s Tokaji Ferencz lakostársaink házai hamvadtak el mult vasárnap déltaján. Nem tudjuk a gyakori tüzeseteken avagy a rendelkezésre álló hitvány tüzoltó eszközökön kell-e inkább megbotránkozni. - Több lakostársunk s köztük néhány tagja az alakulandó önkéntes tüzoltó-egyletnek dicséretes buzgósággal fáradozott az oltás körüll” - írja a lap 1873 júliusában. ${ }^{457}$ Hasonló módon dicséri a szerkesztőség az önkéntes tűzoltókat - s rója meg az oltást akadályozó polgárt - a következő esetben, szintén 1873-ban: „gondatlanságból eredt tüz által hamvadt el f. hó 5-én reggel Kadánc Sándornak 2446 sz. háza a Kisér nevü város részben." A lap nem győzi hangsúlyozni a nagyobb gondosságot, illetve óvatosságot, főleg a nők esetében; még szerencse, hogy a tetőn és a padláson tárolt apróságokon kívül komolyabb kár nem keletkezett. „A keletkezö tüzoltó társulat ott volt tagjai, s mind azok kik az oltásban részt vettek, általában elösmerést érdemelnek, de megrovást ama bámészkodó kihegyelt nyelvü iparos, ki a tüzoltó egylet ott levö tagjait méltatlan kifakadásokkal sértegette". A szerkesztőség ezek után megfenyegeti az oltást akadályozó rendbontót: amennyiben még egyszer hasonló történik - vagy ha más követ el ilyesmit -, akkor a hasábokon ,,az ily semmit tevö nyelv hösöket névszerint bemutatandjuk a közönségnek." ${ }^{458}$ Ugyanezen esztendő végén, az évfolyam utolsó számában olvashatjuk, hogy porrá égett Szentes egyik ismert vállalkozása is: a Weill Salamon tulajdonában lévő, a város déli részében található gőzmalom gyakorlatilag teljesen megsemmisült a lángokban. Ráadásul az este tíz óra körül támadt vészt a harangok

\footnotetext{
456 SZL, IX. évf. (1879) 37. sz. 3.

${ }^{457}$ SZL, III. évf. (1873) 29. sz. 3.

${ }^{458}$ SZL, III. évf. (1873) 19. sz. 3.
} 
félreverésével nem is jelezték, hiszen akkor a lakosság többsége már nyugovóra tért, így senki nem sietett oltani a tüzet. Mindennek eredményeként „nem csak az épület égett le földig, hanem nagy mennyiségü gabona készület is a kár körülbelöl 10 ezer frtra becsültetik."459

Hat évvel később a szerkesztőség határozottan fogalmaz az átlagosnál is több tüzkár okán felháborodva: „Megdöbbentő. Husz nap alatt 7 tüz eset fordult elö nálunk, s ez utóbbi hétre a 7-böl 3 tüz eset esik. Valóban méltán támadhat sokokban az a gyanu, hogy ez az egymást érö tüzeset aligha a puszta véletlenség dolga." A lap felhívja a rendőrség figyelmét, hogy a város félreeső részein az udvarok tele vannak rakva takarmánnyal és szalmával, pedig ezeknek a rakodókertben volna a helyük. A legutóbbi tüzeset is egy ilyen szalmarakás meggyulladásából keletkezett. Jó volna tehát helyi rendeletet alkotni, amelyben minden háztulajdonost köteleznének a szalma- és szénarakások kitakarítására, továbbá arra is, hogy tartson az udvarában edényekben vizet. Végül, a szerkesztőség ismét javasolja a tüzoltó egylet megalakítását, az igazán hatékony védelem ugyanis anélkül nem lehetséges. ${ }^{460}$

A tüzzel való gondatlan bánásmód okozott más jellegü baleseteket is: „Sólyom János helybeli lakos leánykája e napokban a külsö földeken kukoriczát sütni szándékozván, ruhája meggyuladt, s az égés folytán kapott sebei következtében hosszabb kinok után meghalt" számol be a lap a tragédiáról 1873 szeptemberében. ${ }^{461}$ Hasonló szörnyüségbe torkollott egy neves pirotechnikus szentesi látogatása is, aki a lángokkal éppen hogy szórakoztatni akarta a helyi lakosságot. „Bucsák János tüzmester azon szándékkal érkezett városunkba, hogy közönségünk előtt mesterségét e hó 14 én bemutassa; midőn mult pénteken előkészületeit tenné a leendö elöadásra, nejének kezében véletlenül meggyuladt egy röppentyü, minek folytán löporkészletének egy része felrobbant." A nő ruhája ettől meggyulladt, és bár befutott a Kurcába, annyira összeégett, hogy nem sok esély van az életben maradására. ${ }^{462}$ A lap következő száma beszámol róla, hogy az asszony belehalt a sérüléseibe. Bucsák megköszönte a nejéről való gondoskodást, és bejelentette, hogy a szörnyüség ellenére megtartja tủzijátékát a Széchenyi-ligetben. A szerkesztőség kérte az olvasókat, hogy minél többen jelenjenek meg az előadáson, már csak a részvét és az anyagi segítség okán is. ${ }^{463}$

A Szentesi Lap 1872 és 1883 között összesen hetvenegy helyi tüzesetről számol be, és ebből mindössze öt alkalommal okozta villámcsapás vagy erős napsütés a bajt, minden más esetben emberi mulasztás vezetett a néha emberéletet is követelö balesetekhez. Természetesen

\footnotetext{
${ }^{459}$ SZL, III. évf. (1873) 52. sZ. 4.

${ }^{460}$ SZL, IX. évf. (1879) 36. sz. 3.

${ }^{461}$ SZL, III. évf. (1873) 36. sz. 3.

${ }^{462}$ SZL, IV. évf. (1874) 24. sz. 3.

${ }^{463}$ SZL, IV. évf. (1874) 25. sz. 3.
} 
nem csak a tüz okozott kisebb-nagyobb károkat, tragédiákat Szentesen. Olvashatunk leszakadt hivatali padlóról, ${ }^{464}$ gátról vízbe fordult kocsin meghalt asszonyról, ${ }^{465}$ összedőlt szélmalomról, ${ }^{466}$ két emberre ráomlott házról, ${ }^{467}$ véletlenül elsült pisztolyról, ${ }^{468}$ Tiszába fulladt hajóvontató lovakról ${ }^{469}$ vagy vihar áldozatául esett kétszáz juhról. ${ }^{470}$ Kiemelhetjük az ilyen jellegü hírek közül azt az 1874. július elején történt gázolást, amellyel kapcsolatban a szerkesztőség utal a hatóságok felelősségére is. „Mult vasárnap reggelén egy a városon kivül létező kutról visszatérő szegény szolgáló két eszeveszetten versenyt vágtató kocsi közé került, s annyira összezuzatott, hogy rögtön meghalt. A könnyelmü kocsisok a fenyitö biróság kezei közt várják bünös tettük érdemlett büntetését. - Felkérjük a rendörséget, hogy a városban is gyakran sebesen hajtani szokott lókínzókra figyelmét kiterjeszteni sziveskedjék, hogy hasonló esetek ne ismétlödjenek." ${ }^{471}$ Nyolc évvel később a sáros utak és az emberi gondatlanság okoztak balesetet: „Szerencsétlenség. Idősb Fekete Mártonné, Fekete Márton megyei föjegyzönknek édes anyjával, $f$. hó 8-án este Hankiss Károlyné-féle közben a hintó feldölt, melynek következtében Fekete Mártonné oly szerencsétlenül esett ki, hogy karját törte el." A cikk megjegyzi, hogy már megint egy járdán kívül, tehát az út mentén felállított karó borította fel a kocsit, a rendőrséget pedig kéri, hasson oda, hogy a hasonló esetek elkerülhetők legyenek: „Jó lenne a közrend érdekéből a rendörségnek gondoskodni, hogy egyesek járdájok védelmére karókkal ne foglalhassák el az utcát és akadályozzák, a sáros időben különben is nyomoruságos közlekedést." $" 472$

Ezen kívül számos hír foglalkozik a gyakori árvízveszéllyel is (különösen 1876-ban, 1879-ben és 1881-ben), amely témát a vezércikkeknél már említettük; illetve megemlítendő még a tárgyalt korszakunkban gyakori vízbe - a Kurcába, a Tiszába vagy kútba - fulladás, amivel szintén rendszeresen találkozhatunk a hasábokon.

\footnotetext{
${ }^{464}$ SZL, XIII. évf. (1883) 48. sz. 3.

465 SZL, II. évf. (1873) 15. sz. 3.

466 SZL, III. évf. (1873) 19. sz. 3.

467 SZL, II. évf. (1873) 15. sz. 3.

468 SZL, V. évf. (1875) 19. sz. 3.

${ }^{469}$ SZL, VIII. évf. (1878) 47. sZ. 3.

${ }^{470}$ SZL, VIII. évf. (1878) 51. sz. 3.

${ }^{471}$ SZL, IV. évf. (1874) 18. sz. 3.

${ }^{472}$ SZL, XII. évf. (1882) 10. sz. 3. Megjegyzendő, hogy a már többször említett poros, esős időben sáros közterületek nem csak Szentesre voltak jellemzőek, hanem nagyrészt az egész Alföldre: a vasúthálózat kiépülése előtt ugyanis az utcák és terek kikövezéséhez szükséges nyersanyag szállítása nagyobb tételben lehetetlen volt, így az 1880-as évekig a településeken csak kisebb, központi szakaszok készültek el. (Kósa 2002. 305., 316.). Mindez a lakott területeken kívül sem volt másképpen - Csongrád vármegye 350 kilométeres törvényhatósági úthálózatából az 1890-es évekig egy talpalatnyit sem sikerült kővel lefedni -, ami jelentősen megnehezítette a kereskedelmet, a termények értékesítését, főként, hogy ekkoriban még a vasúthálózat kiépítése is gyerekcipőben járt. (Für 1996. 215.)
} 


\subsubsection{Kriminalisztika és öngyilkosság a hírrovatokban}

A szentesi hétköznapokat a kiegyezés után nem csak balesetek vagy természeti katasztrófák árnyékolták be, hanem az öngyilkosságok és a különféle büncselekmények is, amelyekről tekintve a bulvár iránti fokozódó társadalmi igényt - a Szentesi Lap előszeretettel beszámolt. Rendszeresen olvashatunk kriminalisztikai témájú híreket, amik a városban, a régióban, az ország távolabbi részein vagy akár külföldön történt büncselekményekről tudósítanak. ${ }^{473}$

A helyben történt esetek, illetve különböző, a rendőrség hatáskörébe tartozó ügyek - a baleseteket kivéve, amelyekről az előző fejezetben már szóltunk - az egyes cselekmények típusa szerint a következőképpen oszlanak meg 1872 augusztusától (vagyis a lap indulásától) 1883 végéig:

\begin{tabular}{|c|c|c|c|c|c|c|c|c|c|c|c|c|}
\hline & 1872 & 1873 & 1874 & 1875 & 1876 & 1877 & 1878 & 1879 & 1880 & 1881 & 1882 & 1883 \\
\hline Öngyilkosság & 4 & 7 & 3 & 7 & 5 & 10 & 4 & 1 & 5 & 4 & 12 & 12 \\
\hline $\begin{array}{l}\text { Öngyilkossági } \\
\text { kísérlet }\end{array}$ & 2 & 0 & 1 & 0 & 0 & 0 & 0 & 1 & 0 & 0 & 1 & 0 \\
\hline $\begin{array}{l}\text { Garázdaság } \\
\text { (verekedés, } \\
\text { hangoskodás, } \\
\text { könnyú testi } \\
\text { sértés stb.) } \\
\end{array}$ & 2 & 2 & 2 & 1 & 1 & 1 & 2 & 1 & 1 & 1 & 2 & 3 \\
\hline Emberölés & 1 & 0 & 0 & 1 & 1 & 2 & 1 & 1 & 1 & 2 & 1 & 5 \\
\hline $\begin{array}{l}\text { Emberölési } \\
\text { kíserlet }\end{array}$ & 0 & 1 & 0 & 2 & 1 & 5 & 0 & 0 & 0 & 1 & 0 & 0 \\
\hline $\begin{array}{l}\text { Vagyon elleni } \\
\text { bünseselekmények } \\
\text { (lopás, rablás, } \\
\text { csalás) }\end{array}$ & 4 & 2 & 5 & 3 & 8 & 1 & 7 & 4 & 4 & 5 & 13 & 10 \\
\hline Egyéb & 4 & 2 & 2 & 4 & 3 & 4 & 4 & 2 & 2 & 1 & 2 & 4 \\
\hline
\end{tabular}

\section{6. ábra - A Szentesi Lap hírrovataiban közölt öngyilkosságok, büncselekmények és más kriminalisztikai esetek éves, szám szerinti megoszlása, 1872-1883}

\footnotetext{
$473 \mathrm{Az}$ öngyilkosságok nem minősültek büncselekménynek, elemzésünk során azonban együtt tárgyaljuk a kriminalisztikai cseleményekkel, tekintve, hogy eröszakos halálról van szó, másfelöl körülményeinek kivizsgálása a rendőrség hatáskörébe tartozik, illetve nemegyszer előfordult, hogy más büncselekménnyel összefüggésben vetett véget valaki önkezével az életének, lásd pl.: „Véres szerelmi dráma folyt le f. hó 3-án egyik szentesi tanyán. Oláh János helybeli lakos szivén lötte a vele törvénytelen házasságban élt Lénárt Máriát, $s$ aztán önmaga ellen forditá a gyilkos fegyvert. A rémes eset alkalmával a szerencsétlen páron kivül senki se volt a tanyán, s igy a borzasztó dráma részleteit átláthatlan homály boritja. Söt még az elözményeket és indokot sem lehet tudni; mivel a kiszenvedett szerelmes pár évek óta bensöleg szerette egymást, egy hóval ezelött lépett közösháztartásba s azóta - legalább látszólag - nem zavarta boldogságuk egét semmi felhö. Innét valószínüleg látszik, hogy a szörnyü tett vagy véletlenül vagy féltékenységböl követtetett el. A fegyver, mely a két ifju életét kioltá, közönséges egy csövü puska, mely seréttel volt töltve. Az áldozatok halálának gyorsan kellett bekövetkezni, mert midőn feltaláltattak, hullájuk már egészen ki volt hülve.” (SZL, XIII. évf. [1883] 40. sz. 3.)
} 


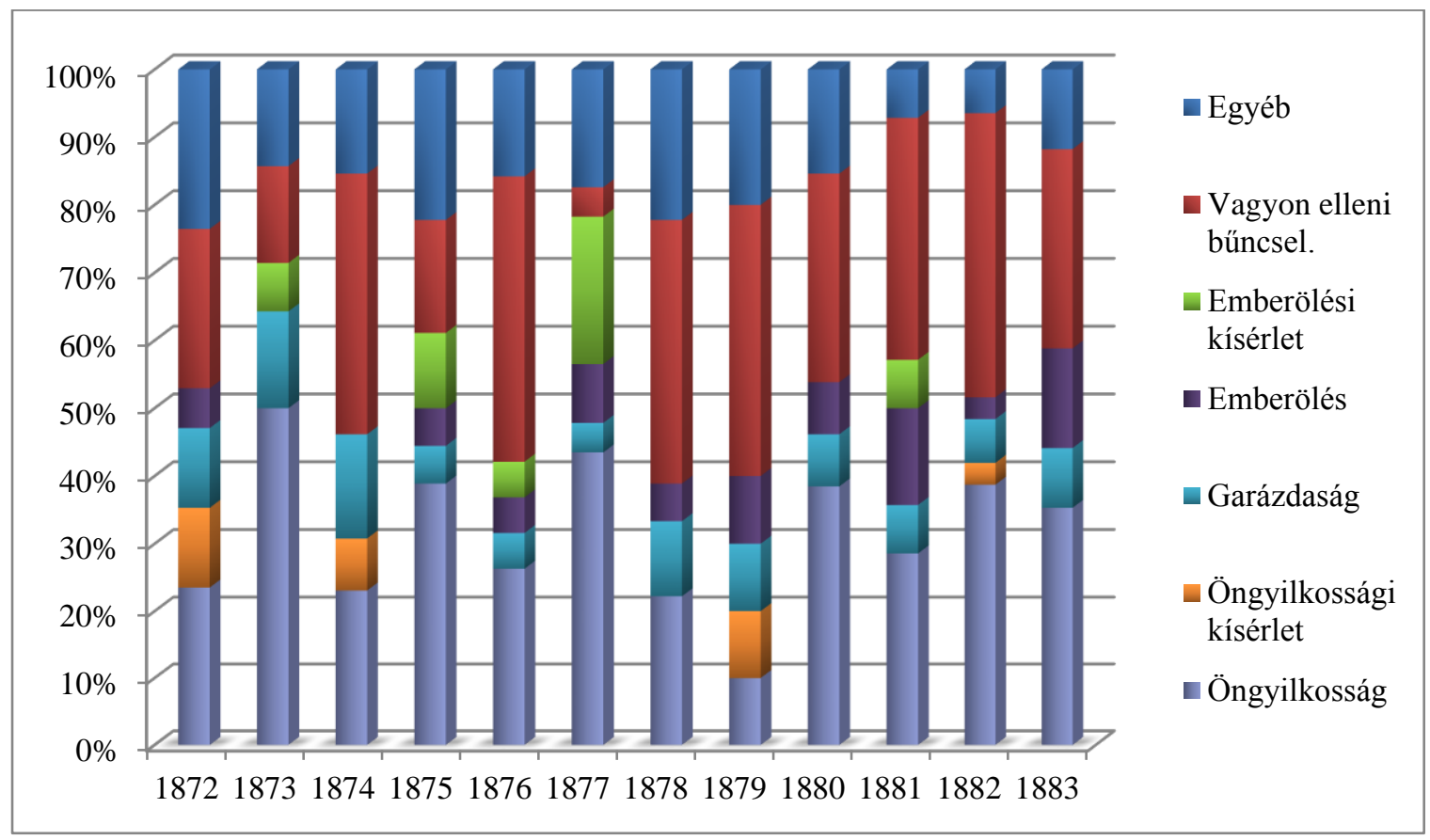

\section{7. ábra - A Szentesi Lap hírrovataiban közölt öngyilkosságok, büncselekmények és más kriminalisztikai esetek éves aránya (\%), 1872-1883}

Ha az éves adatokat összesítjük az egyes cselekménytípusok szerint, tárgyalt időszakunkat tekintve a következő eredményt kapjuk:

18. ábra - A Szentesi Lapban közölt öngyilkoságok és kriminalisztikai hírek típus szerinti aránya (\%), 1872-1883

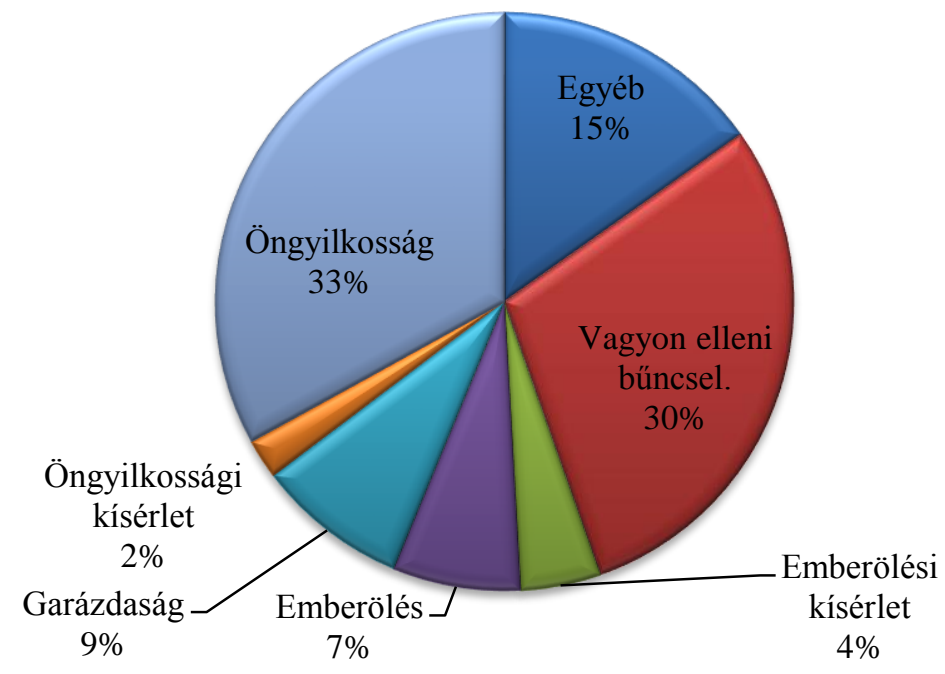


A fenti adatok természetesen nem a valóságos esetszámot jelentik, csupán az önkényes hírszerkesztési szelekció eredményei. Nehezen hihető például, hogy egy közel harmincezer lakosú településen 1877-ben mindössze egy és 1873-ban is csak két vagyon elleni büneset történt volna. Mindez a többi cselekményfajtára is igaz.

A 15-17. ábrából egyértelmüen látszik, hogy két esettípus magasan kiemelkedik a többi közül: az öngyilkosság (33\%, a sikertelen kísérletekkel együtt összesen 35\%), valamint a vagyon elleni büncselekmények (30\%). Ami az elsőt illeti, az adat egyáltalán nem meglepő: a híres-hírhedt „alföldi néplélek” szinte már szociológiai közhely, s bár létezését sokan tagadják, annyi azonban tény, hogy a Dél-Alföldön élő ember már közel másfél évszázada kétszer-háromszor nagyobb arányban vet véget önkezével az életének, mint az ország más részein élők, s az öngyilkosságot elkövetők többnyire protestáns, azon belül is elsősorban a református vallású férfiak. ${ }^{474}$ Ebből a szempontból a dolgozatunk tárgyát képező dél-alföldi, nagyrészt református lakosságú település sem számított kivételnek: a Szentesi Lap tárgyalt időszakunkban hetvennégy befejezett öngyilkosságról, illetve öt kísérletről ${ }^{475}$ számol be.

Ha azonban megvizsgáljuk a különböző felekezetek halotti anyakönyveit, kiderül, hogy a valóság még a sajtóban közölteknél is sötétebb tárgyalt korszakunkban: ${ }^{476}$

\footnotetext{
474 Zonda 2005. 176-179.. Érdemes megjegyeznünk, hogy ha a foglalkozás szerint vizsgáljuk a korabeli öngyilkosságokat, az elkövetők jelentős része a férfiak tekintetében katona, a nőknél pedig cseléd volt (Gergely 1998. 411.), s utóbbit a szentesi adatok is visszaigazolják.

475 Például: „Augusztus 5-én reggeli 7-8 óra tájt egy öngyilkossági kísérlet tétetett. Nevezetesen Fekete Ferenc ur szabómesternek legénye $N$. N. elbusulván magát, hogy valamennyi bor van mind meg nem ihatja, miután felsö kabátját beitta, és a kabát kiváltására munkaadó gazdájától kapott pénzt hasonlóképen valami folyadék alakjában elnyelte, neki ment az örvénynek. Öt azonban akkor, midőn már fuldoklott, a Sonnenfeld ur gözmalmában levö gépész és ugyanott dolgozó napszámos Farkas András a halál torkából kimentették. S midön a megmentett legény a kapitányi hivatalnál e tárgyban töredelmesen kikérdeztetett, bevallotta, hogy részegeskedése hajtotta ezen kisérletre. Nem lehet tudni hogy a másik hétfön nem lesz-e ittas, és ilyen kisérletre nem fog-e vetemedni." (SZL, I. évf. [1872] 1. sz., 3.)

476 MNL CSML Szentes, IV.B.434.a. - Csongrád Vármegye Felekezeti Anyakönyvi Másodpéldányainak Levéltári Gyüjteménye - A római katolikus egyházközségek anyakönyveinek másodpéldányai, Szentes, halotti anyakönyvek (1872-1883. év); MNL CSML Szentes, IV.B.434.b. - Csongrád Vármegye Felekezeti Anyakönyvi Másodpéldányainak Levéltári Gyüjteménye - A református egyházközségek anyakönyveinek másodpéldányai, Szentes, halotti anyakönyvek (1872-1883. év); IV.B.434.c. - Csongrád Vármegye Felekezeti Anyakönyvi Másodpéldányainak Levéltári Gyüjteménye - Az evangélikus egyházközségek anyakönyveinek másodpéldányai, Szentes, halotti anyakönyvek (1872-1883. év); IV.B.434.d. - Csongrád Vármegye Felekezeti Anyakönyvi Másodpéldányainak Levéltári Gyüjteménye - A görögkeleti egyházközségek anyakönyveinek másodpéldányai, Szentes, halotti anyakönyvek (1872-1883. év); IV.B.434.e. - Csongrád Vármegye Felekezeti Anyakönyvi Másodpéldányainak Levéltári Gyüjteménye - Az izraelita egyházközségek anyakönyveinek másodpéldányai, Szentes, halotti anyakönyvek (1872-1883. év); IV.B.434.f. - Csongrád Vármegye Felekezeti Anyakönyvi Másodpéldányainak Levéltári Gyüjteménye - A nazarénus egyházközségek anyakönyveinek másodpéldányai, Szentes, halotti anyakönyvek (1872-1883. év)
} 


\begin{tabular}{|c|c|c|c|c|c|c|c|c|c|c|c|c|}
\hline & 1872 & 1873 & 1874 & 1875 & 1876 & 1877 & 1878 & 1879 & 1880 & 1881 & 1882 & 1883 \\
\hline Református & 4 & 8 & 8 & 8 & 12 & 12 & 11 & 8 & 7 & 8 & 14 & 13 \\
\hline Római katolikus & 1 & 0 & 2 & 0 & 2 & 6 & 0 & 1 & 7 & 3 & 4 & 4 \\
\hline Evangélikus & 0 & 0 & 0 & 0 & 0 & 0 & 0 & 1 & 0 & 0 & 0 & 0 \\
\hline Izraelita & 1 & 0 & 0 & 2 & 0 & 0 & 0 & 0 & 0 & 0 & 0 & 1 \\
\hline Összesen: & 6 & 8 & 10 & 10 & 14 & 18 & 11 & 10 & 14 & 11 & 18 & 18 \\
\hline $\begin{array}{l}\text { A Szentesi Lapban } \\
\text { közölt esetszám: }\end{array}$ & 4 & 7 & 3 & 7 & 5 & 10 & 4 & 1 & 5 & 4 & 12 & 12 \\
\hline
\end{tabular}

19. ábra - Az 1872 és 1883 között Szentesen elkövetett, befejezett öngyilkosságok aránya felekezeti megoszlás szerint, éves lebontásban a halotti anyakönyvek alapján, összevetve a Szentesi Lap hírrovataiban közölt esetszámokkal

A táblázatból láthatjuk, hogy a szerkesztőség által alkalmazott hírszelekció még az egyik legnagyobb olvasói érdeklődésre számot tartó információra is kiterjedt: a legtöbb esztendőben a valós eseteknek csak egy részéről, bizonyos években pedig csupán töredékéről tudósították a lakosságot. Ha a fenti statisztika eredményeit kördiagramban ábrázoljuk, egyértelműen látszik, hogy Szentes ez irányú statisztikai mutatói megfelelnek az országos átlagnak: az öngyilkosok több mint háromnegyede a református lakosság köréből került ki, tehát arányuk (76\%) jóval felülmúlja a reformátusok összlakossághoz viszonyított arányát $(59,4 \%)$. Jóval kisebb, azonban nem elhanyagolható a római katolikus vallású öngyilkosok száma (20\%), emellett négy esetben találkozunk izraelita (3\%), illetve egy alkalommal evangélikus elkövetővel (1\%). A görögkeleti és a nazarénus felekezet halotti anyakönyveiben nem találtunk ilyen halálokot. 


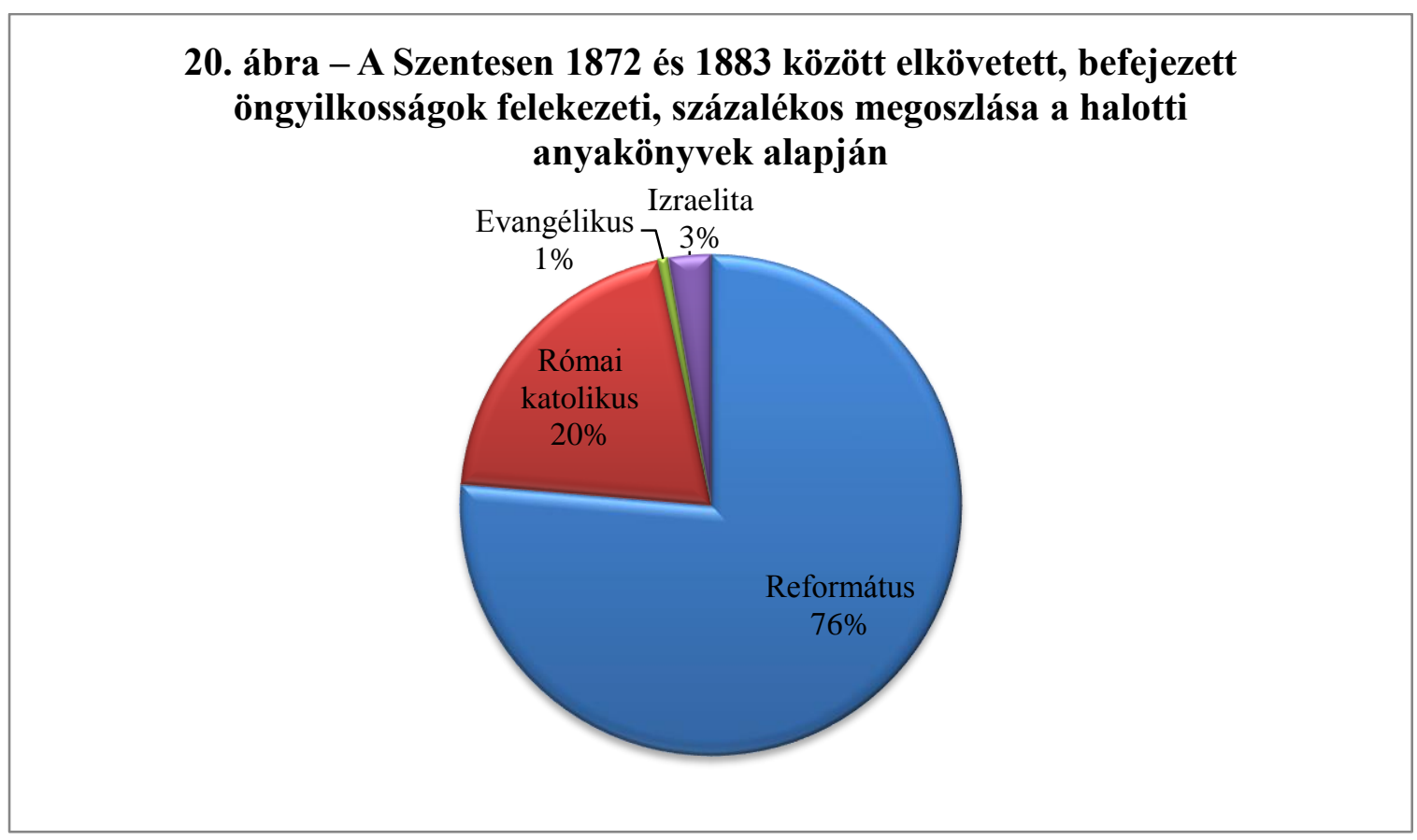

Az öngyilkosságok döntő többsége önakasztással történt, de akadtak más elkövetési módozatok: voltak, akik főbe lőtték magukat; ${ }^{477}$ előfordult, hogy a Kurcába vagy a Tiszába ölte magát az illető, ${ }^{478} \mathrm{~s}$ olvashatunk nemegyszer vízbe áztatott gyufaméreg lenyeléséről is. ${ }^{479}$ A legmegdöbbentőbb eset 1872. október közepén történt, legalábbis, ami az elkövetés módját illeti: „Ny. S. nevü egyén a csendörök által gyanura elfogatott. - Azonban, hogy hogy nem a csendör körme közzül megugrott, - erélyes nyomozás után még az nap feltaláltatott, s midön látta, hogy nincs menekvés, saját maga nálla levö bicskájával hasát felmetszé, s nehány perc múlva meghalt." ${ }^{\wedge 0}$ Az életüket önkezükkel kioltók közül többen olyan cselédek voltak, akik így próbáltak szabadulni a gazda vélt vagy valós önkénye alól, például: „Öngyilkosság. Sipos Rozália 13 éves leány kedden f. h ó 18-án fölakasztotta magát; oka azon szomoru tettnek azon körülmény, hogy ezen leány most elöször lévén szolgálatban, megunta azt és helyét ott akarván hagyni, gazdaaszonya addig nem bocsájtá el, mig anyja helyette másik cselédet hozna.”481 Hasonló esetekről tudósít a lap négy évvel később: „Öngyilkosság. Az utóbbi időben valóságos mániává kezd lenni az öngyilkosság. - Az elmult héten két ily eset adta elö magát. Horváth Mária alig 14 éves leány, állitólag azért, mert kedve ellenére anyja cselédnek állitotta el megmérgezte magát s meg is halt. F. hó 27 én pedig Cakó Imrének Ádám Julianna nevü szolgálója akasztá föl magát állitólag azon okból, mert gazdája csempészkedésben

\footnotetext{
${ }^{477}$ SZL, I. évf. (1872) 2. sz. 3.

${ }^{478}$ SZL, IV. évf. (1874) 49. sz. 3.; V. évf. (1875) 40. sz. 3.

${ }^{479}$ SZL, VI. évf. (1876) 24. sZ. 3.

${ }^{480}$ SZL, I. évf. (1872) 10. sz. 3.

${ }^{481}$ SZL, VI. évf. (1876) 4. sZ. 3.
} 
találta és ezért megpiszkolta."482 Tény, hogy az 1876. évi XIII. törvénycikk szerint a cseléd, mihelyst szolgálatba lépett, a gazda háznépéhez tartozott, így a gazda fegyelmező joga rá is kiterjedt, akárcsak a többi családtagra. ${ }^{483}$ A törvény ugyan kötelességként elöírta a gazda számára, hogy az alapvető személyiségi jogokat és az emberi méltóságot tartsa tiszteletben a cseléddel szemben, ${ }^{484}$ sőt jogot biztosított a cseléd számára, hogy ellenkező esetben a gazdával kötött szerződését felmondhatja, ${ }^{485}$ azonban a valóság sokszor - mindkét fél részéről - felülírta a törvényi passzusokat.

A másik kiugró arányú típus a vagyon elleni büncselekmények (esetünkben főként lopás, emellett rablás, betörés és különböző csalások), a lótolvajoktól ${ }^{486}$ kezdve a gazda pénzes ládájának feltörésén, ${ }^{487}$ a vásári lopásokon, ${ }^{488}$ a váltóhamisításon, ${ }^{489}$ nyertesnek hazudott lutriszelvényen ${ }^{490}$ keresztül egészen az erőszakos rablásig: 1875 decemberében Mintha csak a Bakonyban volnánk! címmel számol be az újság hírrovata arról, hogy egy helyi lakost leütöttek és kiraboltak. ${ }^{491}$ Minden bizonnyal az egyik legarcátlanabb és leginkább pitiáner tolvajról tudósít a Szentesi Lap 1872. október eleji száma: „Merénylet. E hó 3-ára viradóra Fried Zsigmond helybeli kereskedőnek nyitva hagyott ablakából egy szemtelen tolvaj az ablak függönyt leszaggatta és magával vitte. A rendörség a tettesnek nyomában van." ${ }^{492}$

A helyben történt emberölésekről való beszámolók száma nem nagy, évente egy-két esetről olvashatunk, kivéve az 1883-as esztendőt, amikor a Szentesi Lap hírrovatai szerint öt gyilkosság történt a városban - ráadásul ebböl az egyik kettős büntény: a gyilkos, miután agyonlőtte feleségét, végzett saját magával is. ${ }^{493}$ Tárgyalt időszakunkban - az újság beszámolói alapján - összesen tizenhat fö lett emberölés áldozata a településen (lásd a 16. ábrát). Az egyes ügyek közül kiemelhetjük azt a többször is előforduló esetet, mikor kétségbeesett nők így végezték be törvénytelenül született gyermekeik sorsát. Már a lap legelső száma is ilyen jellegü, vérfagyasztó embertelenségről tudósít: Orosz Mihály volt városi gyepmester a Kurcánál egy füzfa tövéhez kötözött csecsemőhullát talált. A holttest nyakára erős zsineget kötöttek, a boncolás pedig megállapította, hogy az áldozat egy

\footnotetext{
${ }^{482}$ SZL, X. évf. (1880) 9. sz. 3.

${ }^{483}$ Kövér 2001. 108-109.; 1876:XIII. tc. 2-9.§

${ }^{484}$ 1876:XIII. tc. $26-34 . \S$

485 1876:XIII. tc. 51.§ II. a-e), illetve 52.§ II. a-f)

${ }^{486}$ SZL, I. évf. (1872) 12. sz. 3.

${ }^{487}$ SZL, I. évf. (1872) 4. sz. 3.

${ }^{488}$ SZL, I. évf. (1872) 7. sz. 2.

${ }^{489}$ SZL, IV. évf. (1874) 42. sz. 3.

${ }^{490}$ SZL, VI. évf. (1876) 45. sz. 3.

${ }^{491}$ SZL, V. évf. (1875) 49. sz. 3.

${ }^{492}$ SZL, I. évf. (1872) 9. sz. 3.

${ }^{493}$ SZL, XIII. évf. (1883) 50. sz. 3.
} 
koraszülött fiúmagzat, akinek az anyja a patológus szerint addig nyomta a szerencsétlen újszülött hasát, amíg az meg nem fulladt. A tettes egyelöre ismeretlen, de megbízható források alapján vannak egyértelmü nyomok, amelyek a hatóságot segíteni fogják a bünös kézre kerítésében. ${ }^{494}$ Kilenc évvel később nem kevésbé szörnyü büncselekményről, egy nem kívánt terhességét gyerekgyilkossággal megoldó nő esetéröl olvashatunk: „Gyilkos anya. Patai Erzsébet f. hó 14-én délután 4 órakor Rozália nevü 10 hónapos kis lányát a sárgaparti oldalon a Kurcába vetette. És a lelketlen anya - mint a rendörfökapitányi hivatalon önmaga bevallotta, végig nézte fuldokló gyermeke halál tusáját." A nő azzal magyarázta tettét, hogy nem volt miböl eltartania törvénytelen kislányát. 495

A garázdaság többnyire az ittas állapotban elkövetett kocsmai vagy utcai verekedéseket jelentette. ${ }^{496}$ Néha a részeg indulatok ilyenkor elképesztő végkifejletet eredményeztek: „[...] Bimbó és a korcsmáros között szóváltás keletkezett, mely csakhamar tetlegességgé fajult s a kifejlett dulakodás közben Bimbó a korcsmárosnak egyik fülét vitézül leharapta. Természetes, hogy a kannibáli élvezet jutalmát a bíróság fogja rá kiszabni. ${ }^{497} \mathrm{~A}$ testi sértésen kívül előfordultak különféle rongálások is, amelyek közül kiemelhetjük egy különleges éjszakai „hobbinak” hódoló szentesi hölgy esetét: „Egy gazdálkodó s vagyonos családbeli nö, kit a közönség mint nevelt (?) kisasszonyt ismer, több helyen éjnek idején a házak falára becstelenitő rágalmazásokat irkált; többek közt Kr.-Nagy Pál házára is, mely firkában ezt s családját illetlenül megsértette." Az illető kilétére hamarosan fény derült, s a nő - hogy a büntetést elkerülje - száz forintot fizetett Kristó-Nagy Pálnak, aki az összeget a helyi kolera-árvák javára adományozta. ${ }^{498}$

Az „egyéb” kategóriába az előző típusokba nem tartozó minden más kriminalisztikai eseményt - például az eltűnt személyekre való figyelemfelhívást - soroltam, amelyek közül egy 1883. októberi eset bír a legnagyobb hírértékkel, a közölt információ botrányosságának foka alapján. Érdemes külön megfigyelnünk az újságíró magas fokú stilisztikai érzékét, amellyel a gyalázatos cselekményt egyértelmüen körülírja, de kerüli a nyers, naturális megfogalmazást: „Ocsmány büntett. Gáspár Imre nevü bérest ki egy helybeli gazdánál szolgált - az állatias ösztön undok gondolatra csábitotta. Egy két éves csikónak lábát

\footnotetext{
${ }^{494}$ SZL, I. évf. (1872) 1. sZ. 3.

495 SZL, XI. évf. (1881) 34. sz. 3.; lásd még: XIII. évf. (1883) 12. sz. 3.

496 Például: „Marsóczki Ferenc, 17 éves parasztlegény, de fiatalsága dacára már is nagyon ismeretes korcsmahös mult hó 30-án Tóth Antal korcsmájában mulatván, ott egy másik fiatal legényt, Liba Horváth Lajost, midön az éppen táncolt, egy hatalmas bunkós bottal orozva leütötte. A fiatal bünös természetesen azonnal hüvösre került, ami reá nézve ez esetben igazán szerencse volt, mert ha egy városi lovas hadnagy kapóra nem jön, a fölböszült mulató közönség tán agyonüti." (SZL, VI. évf. [1876] 6. sz. 3.)

${ }^{497}$ SZL, XIII. évf. (1883) 24. sz. 3.

${ }^{498}$ SZL, IV. évf. (1874) 21. sZ. 3.
} 
összekötözve, - a fékezhetlen nemi ösztön ördögi sugallatából oly aljas büntettet követett el rajta, melyet leirni undorodik a toll. A gyalázatos büntett azonban fölfedeztetvén, az állati vad szenvedély rabja a megtorló igazságszolgáltatásnak lett - kiméletre éppen nem méltó rabjává." 499 Itt kell szólnunk azon sajtóperről is, amelyet 1876-ban kezdeményezett a Szentesi Lap ellen Füchsl Frigyes helyi vállalkozó rágalmazás vádjával: „Sajtópört inditott lapunk ellen Füchsl Frigyes az ez évi 14-ik számban megjelent azon közlemény miatt, melyben mondatik, hogy a Tisza-szabályozó társulatot, illetőleg a város közönségét szándékosan megcsalta az általa átadott fenyőknek vastag végén való mérése által." A lap megígéri, hogy értesíteni fogja az olvasóközönséget a per lefolyásáról, és kijelenti: az orgánum munkatársai örömmel állnak a jogi eljárás elébe, hiszen így alkalom nyílik majd tisztázni önmagukat, és kiderülhet az igazság. ${ }^{500}$ A szerkesztőség később kárörvendően számol be a fövárosban született ítéletről, amely a Szentesi Lap számára kedvező döntést hozott: „Bár mennyire is veri mellét Füchsl Frigyes ur igazsága érzetében, a sors mégis csak csapás után csapást mér reá. Talán épen azon órában, mielött Pesten elbukott, - záratta be a kapitányi hivatal gőzmalmát. Oka pedig az, mert a gépész nem okleveles." 501

Külön említést érdemel a - társadalomért e téren is felelősséget érző - lap bűnmegelőzés iránti igyekezete. A szerkesztőség olykor csupán enyhébb eseteket mutat be, némi nevelő célzattal, például: „Beküldetett. Sajnos dolog az, hogy Szentes városának egynémely ifjai szünidejüket arra használják, hogy a kávéházba beüljenek és ott a legnagyobb lárma közepette egymást a legocsmányabb kifejezések, és rágalmakkal illessék; melyen minden vendég megbotránkozik. - Ohajtandó volna ha városunk derék vendéglöse erélyes fellépése által ezen sajátságos Conferenciát feloszlatná, - mely semmi hasznot, de annál több kárt okoz neki." ${ }^{502}$ Máskor a már megtörtént súlyos tragédiákat tárja kommentárral kiegészített hír formájában a nagyközönség elé, mintegy elrettentésként: „Vigyázni kell a gyermekekre. Gajda Mihály fábiáni lakosnak 1² i éves leánykája a szülei gondatlanságnak a legborzasztóbb módon lett áldozata. Ugyanis G. M. Bagi féle fábiáni majorban lakván, f. év okt. 25 én a gyermek a házon kivül szülei közelében játszogatva, mindig tovább mászott, ugy hogy a szülék nem vették észre midőn a dohány közé ért." A szülők csak későn vették észre, hogy gyermekük eltünt, de ahelyett, hogy azonnal a keresésére indultak volna, hitelt adtak egy arra járó szomszéd szavának, aki azt állította, hogy a kislányt egy kóbor cigány-bandánál látta. A megrettent szülők ekkor a rendőrséghez futottak, elmondták, mi történt, és várták,

\footnotetext{
${ }^{499}$ SZL, XIII. évf. (1883) 43. sz. 3.

${ }^{500}$ SZL, VI. évf. (1876) 24. sZ. 3.

${ }^{501}$ SZL, VI. évf. (1876) 40. sZ. 3.

${ }^{502}$ SZL, I. évf. (1872) 5. sz. 2.
} 
hogy a hatóság majd előkeríti a gyereket. A következő vasárnap azonban két, a major közelében vadászó férfi a dohány között rátalált a kislány holttestére, akinek halálát a szakértő szerint a kihülés és az éhség okozta. A cikk végül a szülők hanyagságának hangsúlyozása mellett megjegyzi: meglepő, hogy a gyermek sírását sem hallotta meg senki. ${ }^{503}$

\subsubsection{Hirdetések}

Az újságban - a korabeli sémához igazodva - a negyedik oldal volt a hirdetési rovat helye, azonban megfigyelhető, hogy az évek során fokozatosan emelkedett a hirdetések száma, így egyre inkább általánossá vált, hogy a reklámok már a harmadik, sőt esetleg a második vagy akár a címoldalon is megjelenhettek. Amennyiben a Szentesi Lapban 1872 és 1883 között megjelent hirdetéseket az egyes megrendelőkhöz köthető mennyiség szempontjából vizsgáljuk meg, a következő összesítő táblázatot kapjuk eredményül::504

\begin{tabular}{|c|c|c|c|}
\hline Hirdető & $\begin{array}{l}\text { Hirdető } \\
\text { székhelye }\end{array}$ & $\begin{array}{l}\text { A hirdető profilja, } \\
\text { a hirdetés tárgya(i) }\end{array}$ & $\begin{array}{l}\text { Hirdetések } \\
\text { száma } \\
\text { (db) }\end{array}$ \\
\hline Várady Lajos & Szentes & gyógyszerek, gyógyszerész-állás & 119 \\
\hline Zsoldos Ferenc & Szentes & téglagyár, tüzifa, kályha & 72 \\
\hline Lázár és Sonnenfeld & Szentes & $\begin{array}{c}\text { malomipari szolgáltatás, deszka, } \\
\text { tüzifa, szén }\end{array}$ & 71 \\
\hline Felsenburg Benedek & Szentes & varrógépek, órák & 61 \\
\hline Brogle J. és Müller & Budapest & gép- és rostalemez & 61 \\
\hline Török József & Budapest & gyógyszer & 56 \\
\hline Cherrier János & Szentes & $\begin{array}{c}\text { nyomda, papír- és könyvkereskedés, } \\
\text { rum, tea }\end{array}$ & 53 \\
\hline Batthyány Karoline & Szentes & rágcsálóméreg & 51 \\
\hline Handler Mór, dr. & Budapest & orvos & 48 \\
\hline $\begin{array}{l}\text { Wellesz Jakabné, Wellesz } \\
\text { Jakab }\end{array}$ & Szentes & eladó föld & 47 \\
\hline $\begin{array}{l}\text { Cicatricis Pál föjegyző (= } \\
\text { Szentes város) }\end{array}$ & Szentes & föld, állat, állás, birtok & 44 \\
\hline Csuray Ferenc & Szentes & kalapkereskedés & 42 \\
\hline $\begin{array}{l}\text { Weisz Bernát, Weisz } \\
\text { Bernátné }\end{array}$ & Szentes & $\begin{array}{l}\text { edénykereskedés, kiadó bolt és lakás, } \\
\text { eladó ház, rőfös áruk, } \\
\text { adósságátvállalás, nádszékek, } \\
\text { bútorok, sírkoszorú, lámpa, tükör, } \\
\text { savanyúvíz }\end{array}$ & 42 \\
\hline Zsoldos János & Szentes & ruhakereskedés & 41 \\
\hline Weill Salamon & Szentes & $\begin{array}{c}\text { tüzifa, liszt, deszka, tégla, szén, } \\
\text { építkezési kellékek, korpa, köles, } \\
\text { malomipari szolgáltatás }\end{array}$ & 40 \\
\hline Krausz Márk & Szentes & sírkő, koporsó & 39 \\
\hline Rambovszky József & Szentes & $\begin{array}{l}\text { vendéglőnyitás, eladó bor, varrógép, } \\
\text { kiadó üzlethelyiség }\end{array}$ & 38 \\
\hline Friedmann A. & Bécs & fejögép & 34 \\
\hline Hamburger Adolf & Budapest & női ruha & 34 \\
\hline Füchsl József és fia & Szentes & $\begin{array}{c}\text { malomipari szolgáltatások, liszt, } \\
\text { tüzifa }\end{array}$ & 33 \\
\hline Temesváry Mór & Budapest & cipőkereskedés & 33 \\
\hline
\end{tabular}

${ }^{503}$ SZL, VIII. évf. (1878) 44. sz. 3.

504 A táblázatban - terjedelmi okokból - csak azokat a rendszeresen hirdető vállalkozásokat, valamint magánszemélyeket tüntettük fel, amelyek, illetve akik legalább tíz hirdetést feladtak a lapban. 


\begin{tabular}{|c|c|c|c|}
\hline Groszmann Adolf & Szentes & varrógépek, férfiszabó-üzlet & 32 \\
\hline Laurentius & Bécs & könyv & 29 \\
\hline Steiner Adolf & Budapest & szálloda & 29 \\
\hline Grossmann J. & Budapest & mezőgazdasági gépek & 27 \\
\hline Hoff János & Bécs & gyógyszer & 27 \\
\hline Lázár Dávid & Szentes & szikvíz & 27 \\
\hline Czukermann Bernát & Szentes & ruhakereskedés & 26 \\
\hline Grünwald József & Szentes & szeszes ital, kiadó bolthelyiség & 26 \\
\hline Dr. Rix özvegy & Bécs & arckrém & 24 \\
\hline $\begin{array}{l}\text { Szentesi Takarékpénztár } \\
\text { Egylet }\end{array}$ & Szentes & $\begin{array}{l}\text { kiadó föld és épületek, közgyülésre } \\
\text { való felhívás, kamatláb-kedvezmény }\end{array}$ & 24 \\
\hline Schwarczkopf Fülöp & Szentes & tánciskola & 23 \\
\hline Winkelmayer J. & Bécs & hajnövesztő szer & 23 \\
\hline Czukermann Soma, dr. & Szentes & orvos, sebész & 22 \\
\hline Győri József & Szentes & eladó ház & 22 \\
\hline Schrantz György & Szentes & mezőgazdasági gépek, bor & 22 \\
\hline Gissfeld Imre & Szentes & tégla & 21 \\
\hline Wiese és Társa & Budapest & pénzszekrény, mülakat, másológép & 21 \\
\hline Popp J. G., dr. & Bécs & szájápolási termékek & 20 \\
\hline Jakó Mihály, Jakó Mihályné & Szentes & ruha, kalap, jelmezek & 20 \\
\hline Reichlinger Henrik & Szentes & rőfös üzlet & 19 \\
\hline Csukás Benjamin & Szentes & $\begin{array}{l}\text { füzfa, rőzse, eladó birtok, } \\
\text { közgyülésre való felhívás }\end{array}$ & 18 \\
\hline Ganz és társa & Budapest & fémöntvényü hengerszékek & 18 \\
\hline Müller J. L. & Budapest & illatszer & 18 \\
\hline Sinoros-Szabó József & Szentes & $\begin{array}{l}\text { eladó föld, kiadó ház és lakás; } \\
\text { aranyozás, régi tárgyak javítása }\end{array}$ & 18 \\
\hline Steiner Dávid & Szentes & ruhakereskedés & 18 \\
\hline Vutsák János & Szentes & $\begin{array}{c}\text { biztosítótársaság, bor, hordó, kiadó } \\
\text { bolthelyiség }\end{array}$ & 18 \\
\hline $\begin{array}{l}\text { Szentesi Első Fakereskedési } \\
\text { és Gőzmalmi } \\
\text { Részvénytársulat }\end{array}$ & Szentes & $\begin{array}{l}\text { faáru, hátralékfizetésre és részvények } \\
\text { átvételére való felszólítás, közgyülés } \\
\text { meghirdetése }\end{array}$ & 17 \\
\hline Graetz Gyula & Bécs & fülolaj & 16 \\
\hline Purjesz Náthán & Szentes & gőzfürdő & 16 \\
\hline Blaha Louiza & Budapest & arcpor & 16 \\
\hline Seres Lajos & Szentes & füszer- és vegyeskereskedés & 16 \\
\hline Sonnenfeld Sámuel & Szentes & eladó vagy kiadó ház & 16 \\
\hline Steinbach Sándor & Budapest & bútor, kárpit & 16 \\
\hline Gombos Károly & Szentes & $\begin{array}{l}\text { vas- és füszerkereskedés, kiadó } \\
\text { üzlethelyiség }\end{array}$ & 15 \\
\hline Varga Béniamin & Szentes & cipőkereskedés & 15 \\
\hline Dr. Schmitd & Budapest & gyógyító likőr & 14 \\
\hline Gárgyán Márton & Szentes & kőfaragás, sírkő, & 14 \\
\hline Schleier István & Szentes & $\begin{array}{l}\text { biztosítótársaság, eladó ház; vas-, } \\
\text { füszer- és festékkereskedés }\end{array}$ & 14 \\
\hline Bárdos Flórián & Szentes & $\begin{array}{c}\text { bormérés, rendezvények } \\
\text { (táncvigalom) }\end{array}$ & 13 \\
\hline Brázay Kálmán & Budapest & sósborszesz & 13 \\
\hline Dobray Sándor & Szentes & $\begin{array}{l}\text { zsindely, boroshordók, cipö, } \\
\text { tombolatárgyak, játék }\end{array}$ & 13 \\
\hline Honthy László & Szentes & könyv & 13 \\
\hline Soós Imre, ifj. & Szentes & $\begin{array}{l}\text { ásványvíz, füszer- és rövidáru- } \\
\text { kereskedés }\end{array}$ & 13 \\
\hline Kohn Gábor & Szentes & $\begin{array}{l}\text { só, mezőgazdasági eszközök, } \\
\text { jószágok }\end{array}$ & 13 \\
\hline Kolodinszky Hippolit & Szentes & varrógép-javítás & 13 \\
\hline Mercur & Bécs & sorsjegy & 13 \\
\hline Molnár József & Szentes & faáru, eladó birtok és ház & 13 \\
\hline Rotschild \& Comp. & Bécs & állampapírok, kötvények, részvények & 13 \\
\hline Stammer Sándor & Szentes & $\begin{array}{l}\text { hivatali állások, olvasóköri } \\
\text { közgyúlésre való felhívás }\end{array}$ & 13 \\
\hline $\begin{array}{l}\text { Szentesi-vidéki } \\
\text { Takarékpénztár }\end{array}$ & Szentes & közgyülésre való felhívás & 13 \\
\hline Werner örökösök & Derekegyház & eladó föld, ingatlan & 13 \\
\hline $\begin{array}{l}\text { Sorsolási tudósító } \\
\text { kiadóhivatala }\end{array}$ & Budapest & előfizetési felhívás & 12 \\
\hline Blau és Kann & Bécs & ezüstáru & 12 \\
\hline Boskovitz család & Szentes & füszer- és vegyeskereskedés & 12 \\
\hline Británi ezüstáru-raktár & Bécs & ezüstáru, háztartási cikkek & 12 \\
\hline Pollák Sándor, dr. & Szentes & eladó ház & 12 \\
\hline G. Hell & Troppau & Berger-féle kátrányszappan & 12 \\
\hline
\end{tabular}




\begin{tabular}{|c|c|c|c|}
\hline Szalay Miklós & Szentes & ügyvédi iroda & 12 \\
\hline Dreher Antal & Köbánya & sör & 11 \\
\hline Gronar János utódja & Bécs & bőrápolási termékek & 11 \\
\hline $\begin{array}{l}\text { Hölgy divatáruk és kész } \\
\text { ruhanemüek csarnoka }\end{array}$ & Budapest & ruha & 11 \\
\hline $\begin{array}{l}\text { Kolvics Julianna, Zsoldos } \\
\text { János }\end{array}$ & Szentes & női ruha & 11 \\
\hline Unio-bank & Budapest & berakodási díjszabvány & 11 \\
\hline Weiss J. & Budapest & orvosi rendelő & 11 \\
\hline Burger Zsigmond özvegye & Szeged & szegedi képes naptár & 10 \\
\hline Geittner és Rausch & Budapest & tüzoltószerek, szerszámok & 10 \\
\hline Gunst Lipót & Szentes & ásványvíz & 10 \\
\hline Kertész Tódor & Budapest & $\begin{array}{l}\text { fegyverek, üveg, nyereg, gumi, } \\
\text { fagylaltgép }\end{array}$ & 10 \\
\hline Pollácsek Jakab & Szentes & bőrkereskedés & 10 \\
\hline Robey \& Comp. & Budapest & gőzmozdony & 10 \\
\hline Ruston, Proctor és társa & Budapest & gözmozdony, göz cséplögépek & 10 \\
\hline Schmidlsdorff G. & Berlin & gyógyszer iszákosság ellen & 10 \\
\hline Steinberg Gyula & Bécs & fülolaj & 10 \\
\hline Szánthó János & Szentes & $\begin{array}{l}\text { szőlő, jégkár elleni biztosítás, kiadó } \\
\text { földek }\end{array}$ & 10 \\
\hline
\end{tabular}

\section{1. ábra - A Szentesi Lapban legtöbbet hirdető vállalkozások, magánszemélyek és szervezetek, 1872-1883}

A legtöbb hirdetést Várady Lajos gyógyszerész adta fel a lapban. A település neves polgárának ${ }^{505}$ hirdetői súlyát tovább növeli a tény, hogy több külföldi reklám közvetve részben vagy akár kizárólagosan - szintén az ő gyógyszertárát népszerüsítette. Több külhoni gyógyászati, illetve kozmetikai termék ugyanis csak nála volt megvásárolható, vagy nála is kapható volt, például a Popp-, a Dr. Rix-féle termékcsalád, a G. Hell kátrányszappan, valamint a Brady-gyomorcseppek - utóbbi esetében a hirdetések külön felhívják az olvasók figyelmét, hogy az orvosság minden szentesi gyógyszertárban megvásárolható, és a Váradypatikát külön is megemlítik.

Stabil hirdetőnek bizonyult a Lázár és Sonnenfeld gőzfürésztelep és malomipari cég, valamint a Zsoldos Ferenc tulajdonában lévő, 1856-ban alapított gőzmalom és téglagyár, ${ }^{506}$ emellett kiemelkedik a helyi hirdetők közül Felsenburg Benedek kisvállalkozó, aki elsősorban a jelentékeny szentesi háziipart kiszolgáló varrógépek, kisebb részben pedig órák forgalmazásával, illetve javításával foglalkozott. Érdekes színfoltja a rovatnak a Wellesz házaspár, akik nem sajnálták az anyagi áldozatot, hogy magánszemélyként eladó földjüket közel egy éven keresztül, kitartóan reklámozzák a Szentesi Lapban.

\footnotetext{
505 Várady Lajos gyógyszerész 1831-ben született Deszken. A szabadságharcban hadnagyként szolgált, a Vitézségi Érdemrend tulajdonosa. Később Szentesen telepedett le, és 1867-ben átvette a városközpontban lévő, legrégebbi szentesi gyógyszertár müködtetését. Volt megyei és városi képviselő is, valamint a Szentesi Takarékpénztár Rt. alapító tagja, illetve tizenkét éven keresztül (1886-1898) igazgatója. 1913-ban hunyt el Szentesen, sírja a Kálvária temetőben található. (Labádi 2008b. 2.; illetve SZL, 1913. XLIII. évf. [1913] 94. sz. 2.)

${ }^{506}$ Kováts 1928c. 302.
} 
Úgy tünik, a kiadó-tulajdonos Cherrier János is végre meglátta a számára ingyenes felületet, és korábbi két lapjával ellentétben jelentős számú hirdetést helyezett el saját lapjában - a 4. fejezetben minderről részletesen szólunk majd. Jellemző volt Szentesen is, hogy számos élelmes vállalkozó igyekezett megragadni a kiegyezés utáni, kedvező gazdasági lehetőségeket, és eleve több - egymástól igen eltérő - profillal kísérletezett. Ilyen volt például a szintén gőzfürésztelepet és malmot müködtető Weill Salamon, aki ezen kívül árusított szenet, téglát, különféle építkezési kellékeket, de foglalkozott gabonakereskedelemmel is; de megemlíthetjük Schleier Istvánt is, aki 1878. április 28-án (VIII. évf. 17. sz.) még egy vas-, füszer- és festékkereskedés átvételét jelentette be az olvasóközönségnek, majd három évvel később, 1881. július 30-tól (XI. évf. 31. sz.) már különféle biztosításokat ajánlott a lakosoknak, több alkalommal, egészen 1883 júniusáig. A legsokoldalúbb helyi vállalkozó a tárgyalt korszakban minden bizonnyal Weisz Bernátné volt, aki férjével együtt elsősorban edénykereskedést müködtetett, azonban kínált rőfösárukat, különféle bútorokat, lámpákat, sírkoszorút, tükröt, savanyúvizet, sőt még adósságátvállalást is; ezen kívül szintén rendszeresen hirdettek ingatlanokat el- és kiadás céljából.

A helyi kisvállalkozók és magánszemélyek jellemzően 5-10 alkalommal helyeztek el hirdetést az újságban. Arról - források híján - többnyire nincs információnk, hogy mindez milyen eredménnyel járt, azonban néhány alkalommal előfordul, hogy egyértelmüen nyomon követhető egy adott vállalkozás sorsa a hasábokon. Gombos Károly újonnan nyitott vas- és füszerkereskedésével például az 1875. augusztus 15-i számban (V. évf. 33. sz.) találkozhatunk először. A tulajdonos azonban nem egészen egy esztendővel később (1876. július 2., VI. évf. 27. sz.) végeladást hirdetett, majd ugyanezen év augusztus 27-től, három számon keresztül (VI. évf. 35-37. sz.) már csak kiadó üzlethelyiséget és lakást reklámoz, s ezt követően nem szerepel többet a lapban - üzlete minden bizonnyal tönkrement, vagy legalábbis nem tudott elérni olyan mértékü sikert, hogy érdemes legyen azt tovább fenntartani.

Hasonló példa lehet Reichlinger Henrik esete is, aki vállalkozásának alakulása szintén jól kirajzolódik a Szentesi Lap hirdetési rovatából. Reichlinger 1874. október közepén díszes hirdetésben hívta fel a szentesiek figyelmét rőfös üzlete megnyitására:507

${ }^{507}$ SZL, IV. évf. (1874) 41. sz. 4. 


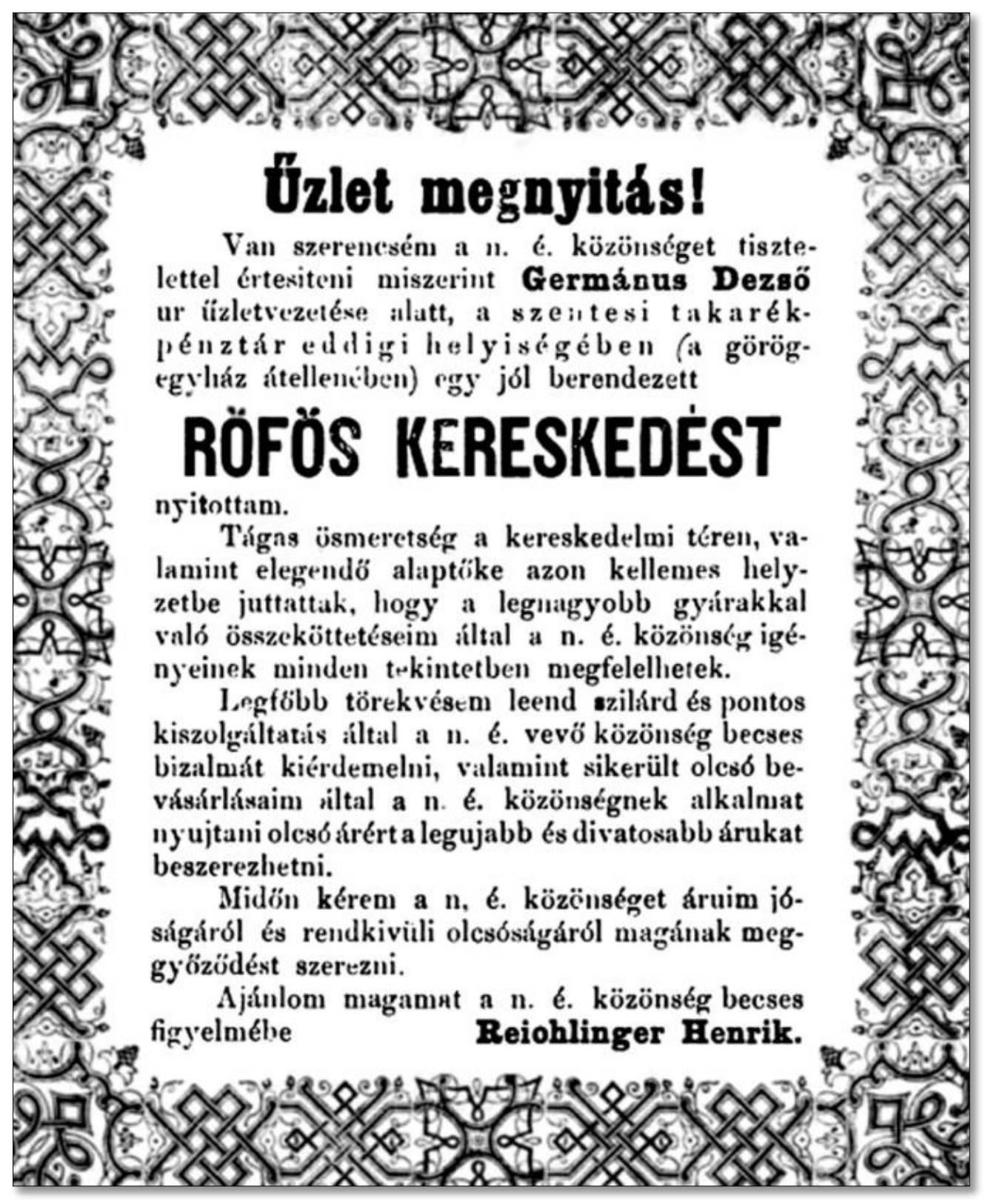

Hiába volt azonban a „tágas ösmeretség a kereskedelmi téren, valamint elegendö alaptőke”, két és fél évvel később, 1877 márciusában a tulajdonos már végeladást hirdetett: ${ }^{508}$

\footnotetext{
${ }^{508}$ SZL, VII. évf. (1877) 11. sz. 4.
} 


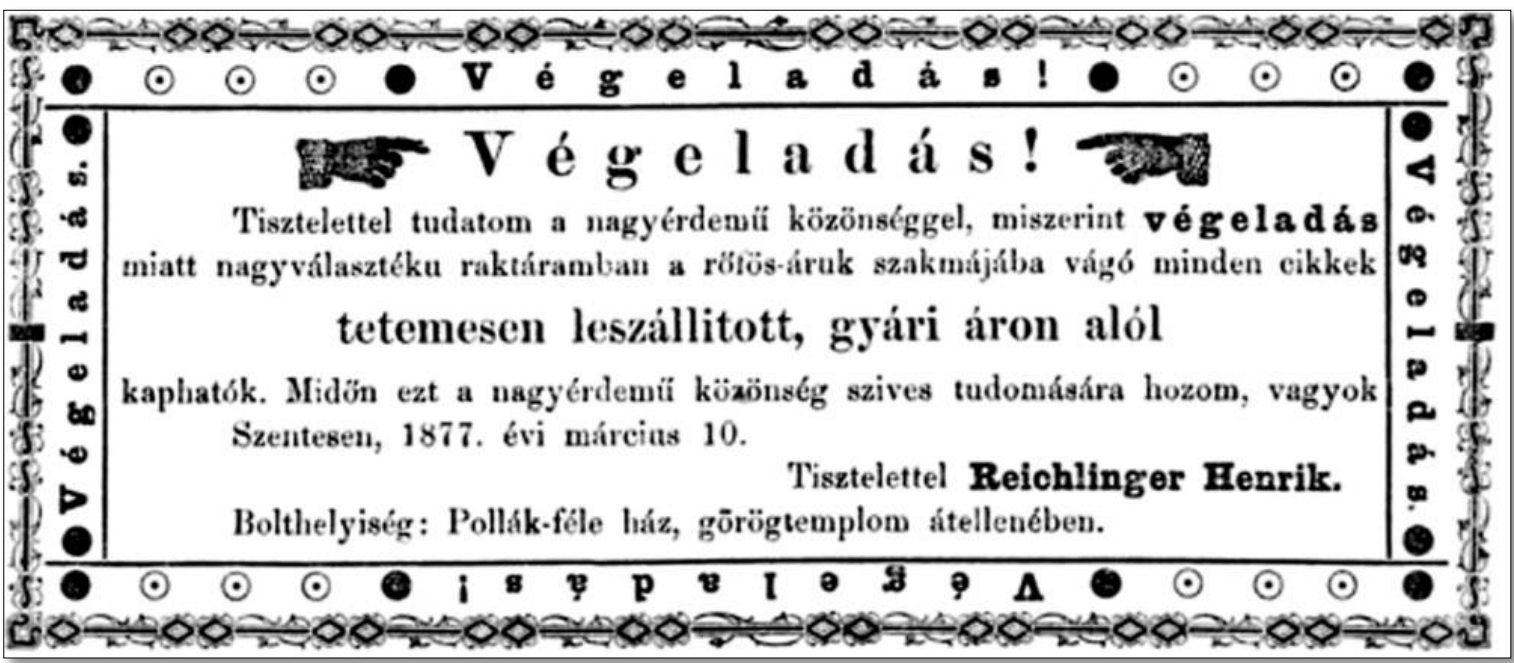

Reichlinger azonban, miután a végeladást négy egymást követő alkalommal (VI. évf. 10-13. sz.) közöltette a Szentesi Lapban, tett még egy kísérletet üzlete újbóli beindítására, s április végén már nem végeladásról, hanem boltja más helyre való költözéséröl jelentetett meg hirdetést: $:^{509}$

\section{Üzlethelyiség változtatás!!}

Tisztelettel hozom tudomására a nagyérdemü közönségnek, miszerint üzletemet a Pollák-féle házból

\section{Czunkermann Bernát háż̀ba,}

a lutheránus templom átellenében, hol eddig Gibba László kávéháza volt - tettem át.

Magamat a nagyérdemü közönség szives pártfogásába továbbra is ajánlva, vagyok

Szentesen, 1877. april 27-én.

Tisztelettel

Reichlinger Henrik.

\footnotetext{
${ }^{509}$ SZL, VII. évf. (1877) 17. sz. 4.
} 
A vállalkozás azonban az új helyiségben sem bizonyult hosszú életűnek, Reichlinger Henrik fél esztendővel később véglegesen elbúcsúzott a szentesiektől: 510

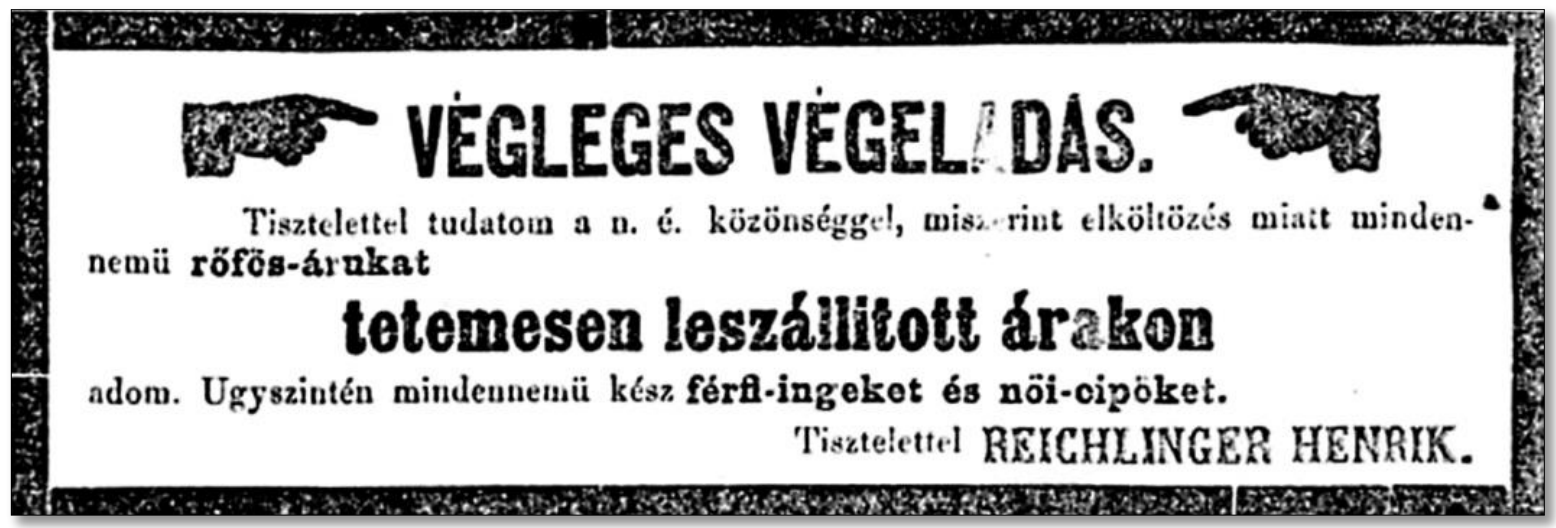

A Szentesi Lap tárgyalt korszakunkban (1872-1883) megjelent számai összesen 4213 darab hirdetést tartalmaznak. A következőkben vizsgáljuk meg őket a hirdetők lak-, illetve székhelye, vagyis területi megoszlásuk alapján.

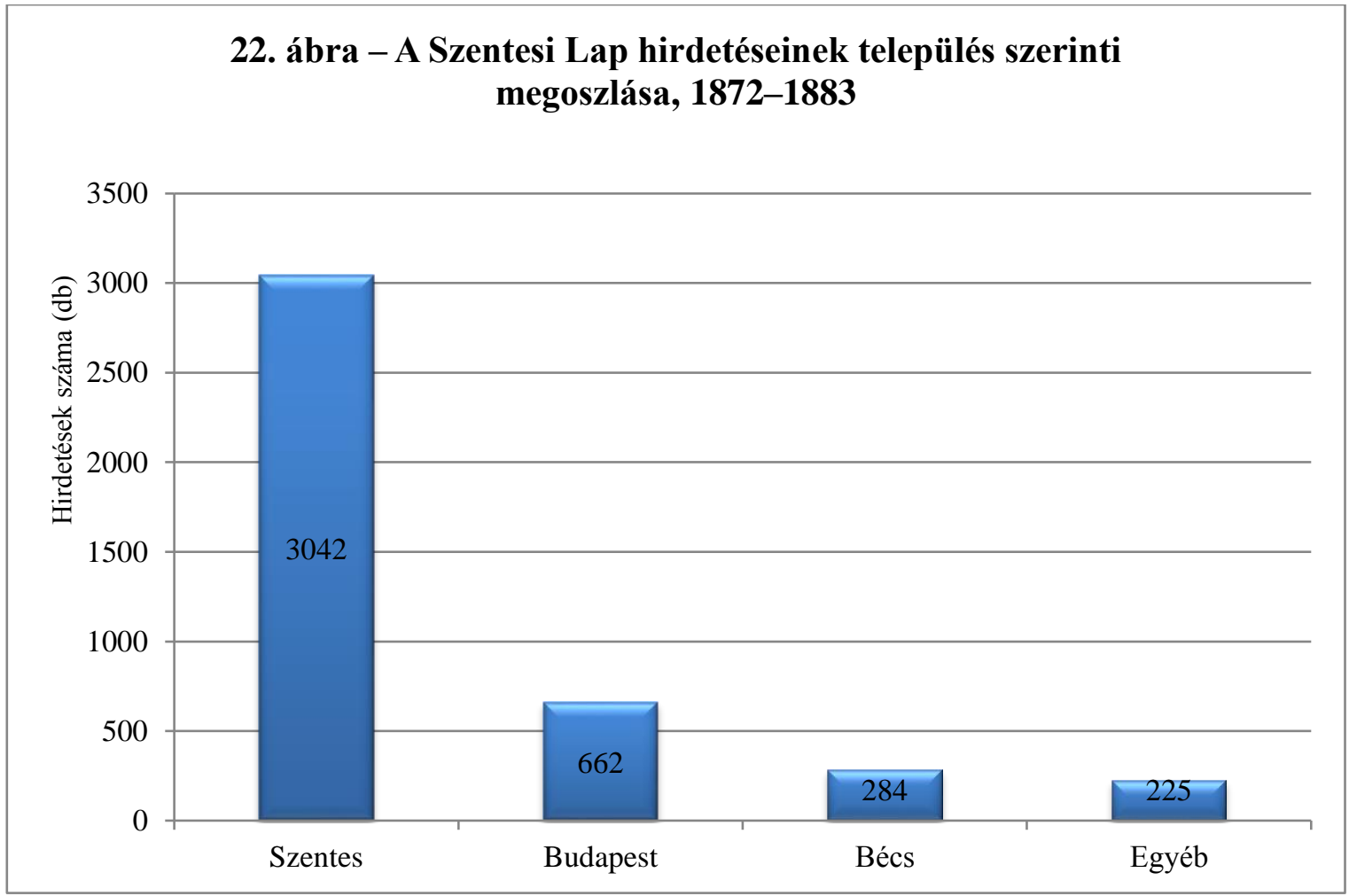

${ }^{510}$ SZL, VII. évf. (1877) 49. sz. 4. Érdekességként megjegyzendő, hogy az egymást követő hirdetések külalakja - talán akaratlanul is - utal a vállalkozás aktuális állapotára: az üzlet megindulását bejelentő első reklám kerete még feltünően díszes, szinte már giccsbe hajló, majd fokozatosan eljutunk az utolsó, komor, vastag fekete körvonalig. 
Amennyiben nem számítjuk a Szentesről, Budapestről és Bécsből beérkező hirdetéseket - lásd a 22. ábra „Egyéb” oszlopát -, a következő helységeket találjuk:

\begin{tabular}{|c|c|c|c|}
\hline Település & Hirdetések száma (db) & Település & Hirdetések száma (db) \\
\hline Csongrád & 30 & Makó & 4 \\
\hline Szeged & 23 & Svájc $\mathrm{c}^{511}$ & 4 \\
\hline Berlin & 18 & Trieszt & 4 \\
\hline Kunszentmárton & 15 & Ehrenfeld & 3 \\
\hline Derekegyház & 14 & Gyalu & 3 \\
\hline Hamburg & 9 & Hont megye $^{512}$ & 3 \\
\hline Troppau & 9 & Kistőke & 3 \\
\hline Mindszent & 7 & Orosháza & 3 \\
\hline Nagymágocs & 7 & Öcsöd & 3 \\
\hline Nagytőke & 7 & Szegvár & 3 \\
\hline Hódmezővásárhely & 6 & Szelevény & 3 \\
\hline Bánfalva $^{513}$ & 5 & Temesvár & 3 \\
\hline Kisszénás & 5 & Tiszaug & 3 \\
\hline Marillavölgy & 5 & Csépa & 2 \\
\hline New York & 5 & Békéscsaba & 1 \\
\hline Szarvas & 5 & Csany & 1 \\
\hline Eperjes $^{514}$ & 4 & Sebesfok & 1 \\
\hline Kiskunfélegyháza & 4 & & \\
\hline
\end{tabular}

\section{3. ábra - A Szentesi Lap hirdetéseinek - kivéve a szentesi, a budapesti és a bécsi érdekeltségúeket - település szerinti megoszlása, 1872-1883}

Ha a táblázatban szereplő településeket földrajzi megoszlás szerint csoportosítjuk, a következő eredményt kapjuk:

\footnotetext{
${ }^{511}$ A hirdetés nem nevez meg konkrét települést.

${ }^{512}$ A hirdetés itt sem nem nevez meg települést.

${ }^{513}$ Bánfalva a Szenteshez közeli Gádoros település neve volt 1901-ig.

(http://www.gadoros.hu/index.php?option=com_content\&view=article\&id=46\&Itemid=57, letöltés: 2017. november 4.)

${ }^{514}$ A Szenteshez közeli, ma is létező településröl, nem az azonos nevü, nagy történelmi múltú felvidéki városról van szó.
} 


\section{4. ábra - A 23. ábra településeinek földrajzi megoszlása}

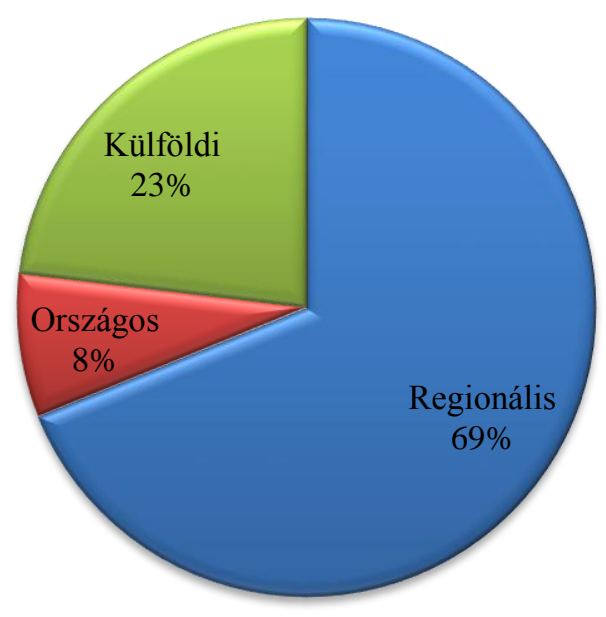

A 22. ábra egyértelmüen mutatja, hogy a Szentesi Lap döntő többségében a helyi vállalkozásokra építette hirdetésekből származó bevételeit (3042 db hirdetés - 72\%), ezen kívül pedig a Monarchia két fóvárosára, Budapestre (662 db hirdetés - 16\%) és Bécsre (284 db hirdetés $-7 \%$ ) koncentrált. ${ }^{515}$ Ha a maradék hirdetést vesszük górcső alá, a 24. ábrán jól látszik, hogy a szerkesztőségnek elsősorban a Szentes közvetlen, illetve tágabb vonzáskörzetében müködő gazdasági szereplök közül sikerült sokakat meggyőznie, hogy reklámozzák magukat az újságban: a regionális hirdetések több mint kétharmad (69\%) részben vannak jelen a hasábokon. Emellett viszonylag csekély számú (8\%) hirdetést találunk az ország távolabbi részeiről - például Marillavölgyből vagy Hont vármegyéből -, viszont elég nagy a külföldi vállalkozások aránya: utóbbiak közel negyedét (23\%) teszik ki a Szentesen, Budapesten és Bécsen kívüli hirdetéseknek.

Végül, de nem utolsósorban meg kell említenünk, hogy nagyfokú következetlenséget tapasztalhatunk a hirdetők neveinek helyesírásában, így sok esetben több alakváltozat tünik fel az oldalakon, például: Dobrai-Dobray, Csurai-Csuray, Dósai-Dósay, GrünvaldGrünwald, Groszman-Groszmann, Kolodinszki-Kolodinszky, Sarkadi-Sarkady, Rambovszki-Rambovszky, Temesvári-Temesvár vagy Weiss-Weisz. A legkínosabb

515 Több országos hírủ, ma már nagy múltúnak minősülő cég is feltűnik a Szentesi Lapban, például Dreher Antal sörgyára (XIII. évf. [1883] 15-26. sz.) vagy a Ganz és társa (IX. évf. [1879] 9-38. sz.), emellett több alkalommal találkozhatunk a Károlyi grófokkal is, akik derekegyházi birtokukat kínálták el- és kiadásra (III. évf. [1873] 18. sz.; XIII. évf. [1883] 34-36. sz.) 
tévedéssorozat e tekintetben egyértelmüen ismét a helyi táncoktató tanárhoz kapcsolódik, akinek német eredetü vezetékneve öt változatban is megjelenik: Schwarzkopf, SchwarczkopfSvarckopf, Swarczkopf, Schwartzkopf. Mindez jelentős mértékben rontja a hirdetési rovat és ezáltal az egész lap hitelességét.

Összességében tehát elmondhatjuk, hogy Cherrier János harmadik helyi sajtóorgánuma, a Szentesi Lap a hirdetések tekintetében - mind mennyiségi értelemben, mind pedig a hirdetők földrajzi szórása szempontjából - jóval magasabb szintet ért el, mint a rövid életü Szentesi Lapok, illetve Alföldi Figyelö. Az alábbi diagramból jól látszik, hogy - bár a Szentesi Lap megrendelöi nagyrészt szintén a helyi vállalkozások közül kerültek ki - jóval nagyobb a Szentesen kívüli hirdetők aránya az két említett laphoz viszonyítva. Mindez professzionálisabb hirdetésszervezői tevékenységre utal.

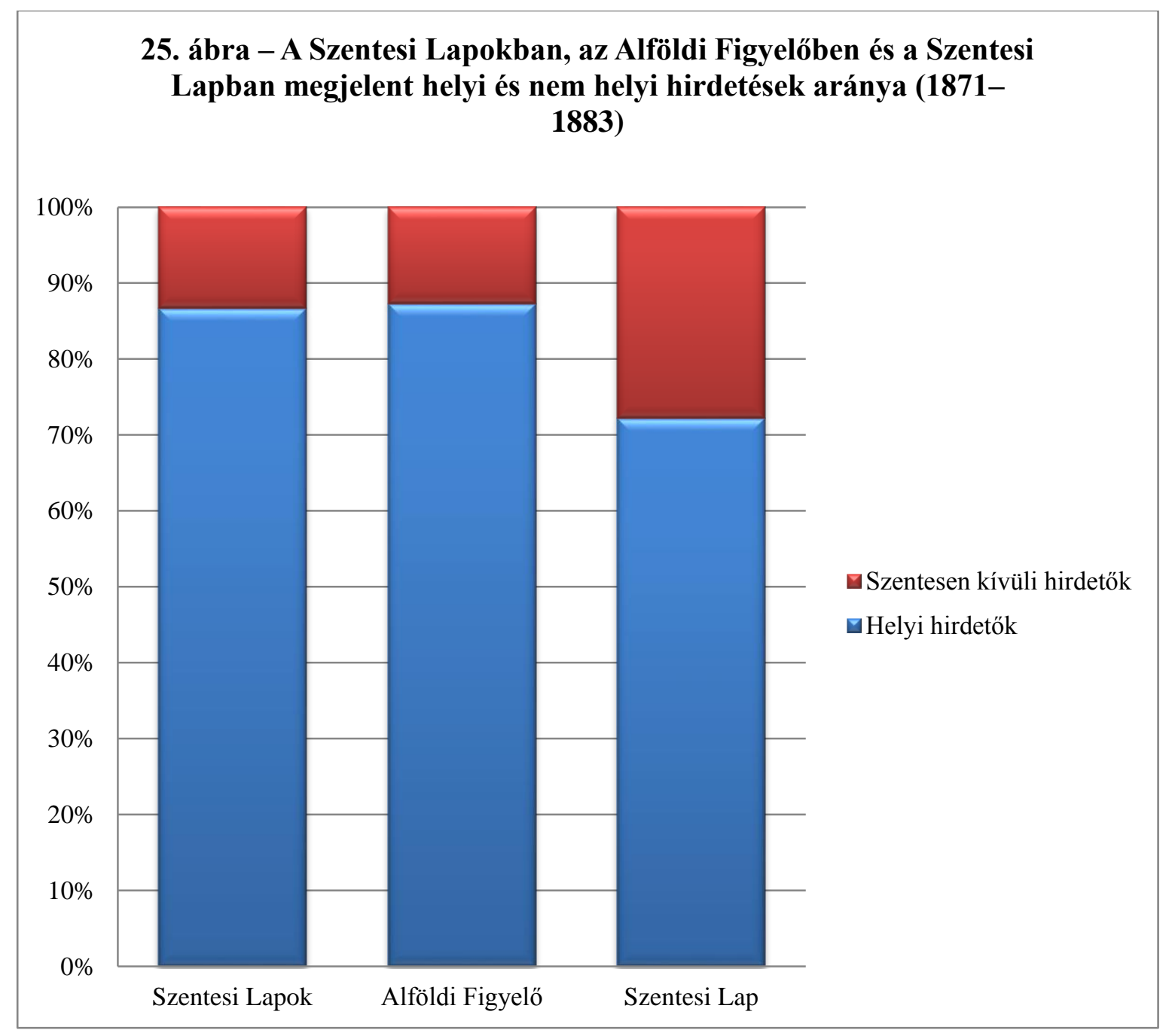


A folyamatosan változó szereplöket felvonultató, de mindenkor állandó mennyiséget biztosító - s ezzel stabil bevételt jelentő - hirdetői gárda pedig nagyban hozzájárult az újság hosszú távú piaci fennmaradásához. Mindemellett a lapban megjelent reklámok fokozatosan emelkedő száma jól mutatja a kiegyezés utáni, egyre inkább élénkülő gazdasági fejlődést, illetve a növekvő vállalkozói aktivitást is mind országos, mind pedig helyi szinten.

\subsubsection{Egyéb rovatok}

A Szentesi Lap számos hosszabb-rövidebb életű rovatot alkalmazott hasábjain indulásától fogva, a már említett vezércikkek, hírek és hirdetések mellett. Kiemelhetjük közülük a szinte folyamatosan jelen lévő Tárcát, amely az irodalomnak szentelt teret, elsősorban prózai, néha verses művek közlésével. A tehetségesebb helyi alkotókon - pl. Csukás Benjamin, Kiss Zsigmond, Sima Ferenc vagy Kulinyi Zsigmond - kívül számos esetben ismert nevekkel is találkozunk a rovatban a magyar és a világirodalomból egyaránt (pl. Katona József, Franz Hoffmann, Pierre Alexis Ponson du Terrail, Pósa Lajos), gyakran írásaik folytatásokban történő publikálásával. Emellett a rendszertelenül jelentkező Irodalom rovat elsősorban kulturális híreket tartalmazott: új lapok, friss könyvek vagy zenemüvek megjelenéséről tudósított, illetve ajánlotta az érdeklődő nagyközönség figyelmébe. A Tárcát 1879-től kiegészítette a vele azonos jellegü Csarnok rovat is.

A városi hiresztelési könyvböl rovat zömében eladó vagy kiadó ingatlanokat, valamint termőföldet, emellett különféle egyéb eladó árucikkeket kínált a lakosságnak. A Gazdászati és kereskedelmi értesités - máskor Üzleti tudósitás - értesített a gabonafélék aktuális tőzsdei árfolyamáról, amely a jórészt mezőgazdaságból élő szentesiek számára minden bizonnyal különösen értékes információnak számított.

A társadalmi vitáknak biztosított teret a Nyilt tér, ahol a lap külön díjazás ellenében közölt le különböző olvasói leveleket (a rovatra egy jellemző példát mutatunk be a Csongrádmegyei Közlönyt ismertető alfejezetben). Érdemes megfigyelnünk, hogy a szerkesztőség milyen gyakran adott lehetőséget a közönségnek, hogy véleményét e rovat hasábjain kifejthesse, illetve, más megközelítésben: az olvasók mennyire éreztek motivációt minderre: 


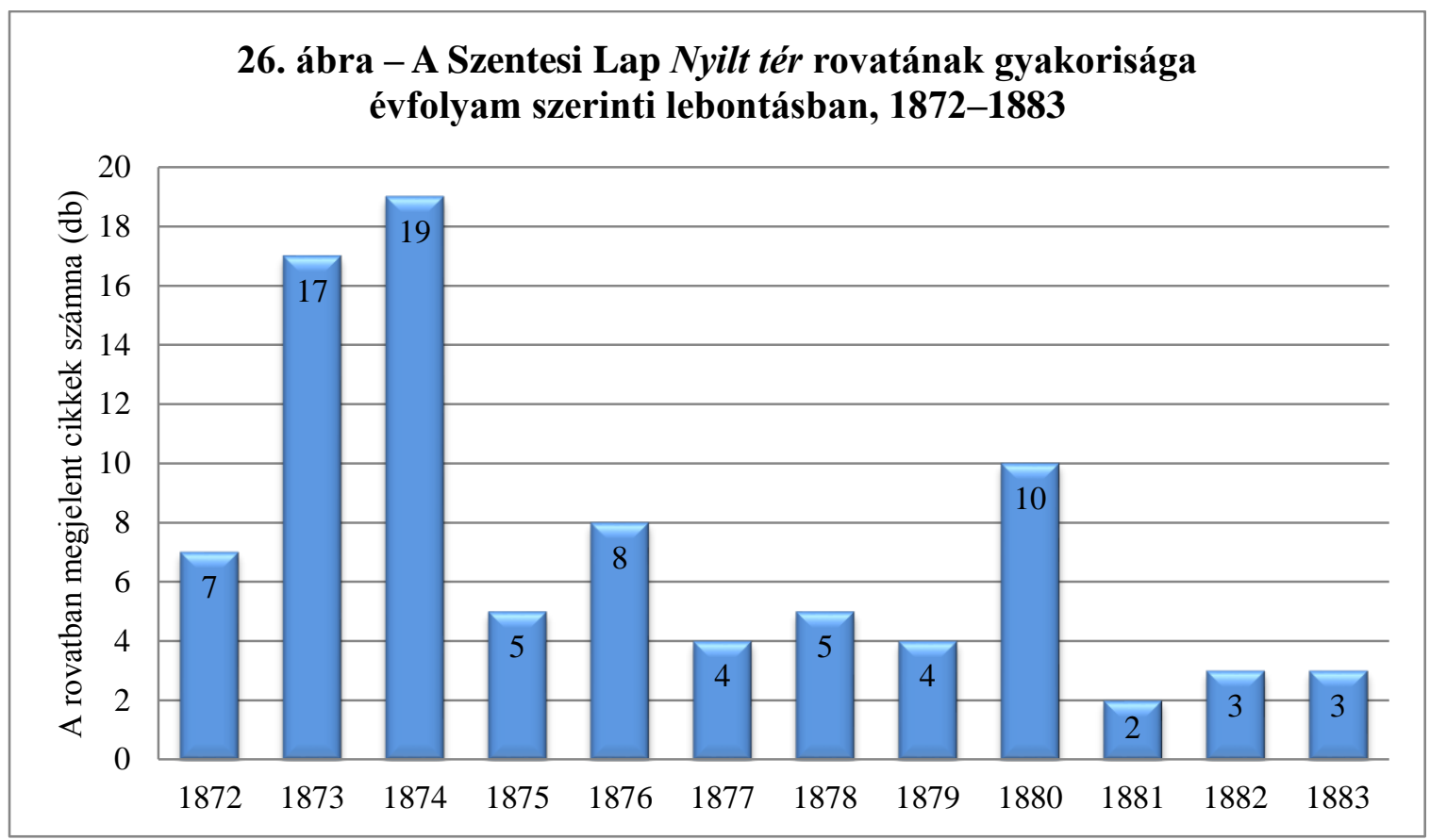

Látható, hogy a rovat már kezdetben sem volt túlságosan népszerü, a szentesiek tehát nemigen éltek a lehetőséggel, hogy - igaz, külön díjfizetésért cserébe - szabadon elmondhassák véleményüket a lap hasábjain. A Szentesi Lap első három évfolyamában még viszonylag rendszeresen találkozunk a Nyilt térrel: átlagosan számítva minden harmadik lapszámban megjelenik egy-egy fizetett olvasói vélemény. (Az 1872-es esztendőben sem ritkább a rovat, hiszen a lap csak augusztusban indult.) 1875-ben hirtelen visszaesett a népszerűsége: egész évben mindössze öt alkalommal szerepelt az újságban, s az alacsony szám később is jellemző maradt, mint az a diagramból is kiderül. 1880-ban tapasztalhatunk az előző éveknél valamivel fokozottabb késztetést az olvasói vélemények nyilvános kifejtésére, s mint azt a közölt levelek is tükrözik, ennek a Szentes és Vidéke hetilap megjelenése, az abban napvilágot látott, nyers hangvételü cikkekre való reagálás volt az oka. Az ezt követő esztendőkben a rovat gyakorlatilag eltünt: 1881-ben egész évben összesen két alkalommal találkozunk vele, míg 1882-ben és 1883-ban is csupán három-három lapszámban.

Az igazi, építő jellegű társadalmi viták helyett a Nyilt tér elsősorban a város befolyásosabb közéleti személyiségei, tehetősebb vállalkozói közötti személyes, vélt vagy valós sérelmek írásos kifejeződései. Ilyen volt például Weill Salamon malomtulajdonos esete, akinek egyik helyi üzeme 1873 decemberében a tűz martalékává vált. ${ }^{516}$ A következő év február 15-én olvashatjuk szívélyes hangú levelét a Szentesi Lap hasábjain, amelyben kifejti: a Triesti Általános Biztosító Társulatnál kötött biztosítást korábban a malomra, és ez nagy

${ }^{516}$ Az esetről korábban már szóltunk, lásd a 3.4.2.3. Balesetek, katasztrófák alfejezetet 
szerencse, hiszen „ama tüzkár alkalmával szenvedett egész káromért oly hiánytalan és egyszersmind gyors kárpótlást nyertem, melynél fogva indittatva érzem magamat, a fent nevezett társulatnak, valóban pontos és lelkiismeretes eljárásáért a nyilvánosság utján köszönetet szavazni." Emellett ajánlja a biztosítótársaság helyi képviselöjét, Kulinyi Bernát urat mindazok figyelmébe, „,kik a szó szoros értelmében biztositani óhajtják épületeiket. ${ }^{" 517} \mathrm{~A}$ levélről hamarosan kiderült, hogy olcsó, reklámfogásról, sőt csalásról van szó, hiszen Weill a március 8-i lapszámban rövid levélben közli, hogy az adott társaságot méltató köszönetnyilvánítás „,ávollétem alatt, s tudtom nélkül közöltetett, s arra Kulinyi Bernát urnak soha felhatalmazást nem adtam." ${ }^{518}$ Ugyanebben az esztendőben parázs vita keletkezett a lap hasábjain Joó Károly református kántor és orgonista, valamint Burián Lajos városi föügyész között is. A kántor felrója Buriánnak, hogy egy hónapokkal korábban neki - levéltárba tétel céljából - átadott irat ügyében még mindig nem intézkedett, és a felszólító levélre sem reagált. ${ }^{519} \mathrm{~A}$ föügyész nem sokáig maradt adós a válasszal, amelyben tagadja a vádat: „A »Szentesi Lap« 19-ik vagy is a legutóbbi számának »nyilttérében« engem bizonyos okmány állitólagos elsikkasztásáért nyilvánosan felhivott; de minthogy az okmány nemét és tartalmát meg nem nevezte: az iránt kérem fel, mikép az ön által rajtam követelt okmány tartalmát és czimét velem e téren közölni sziveskedjék. Addig is azonban kijelenteni kötelességemnek ismerem, mikép ön nekem semmi nemü okmányt levéltárba tétel iránt át nem adott." ${ }^{\circ 20} \mathrm{~A}$ nyilvános vita még három lapszámban folytatódott a két szentesi polgár között. Burián előbb konkrét adatokkal igyekezett igazát bizonyítani, s levelének végén figyelmezteti Joót: „Egyébiránt a rágalmi keresetet ön ellenében meginditani nem késendem."521 Egy héttel később a kántor szintén tényeket sorakoztatott fel álláspontja védelmében, és hosszú levele nem mentes a csípős gúnytól: „Én felteszem önről, hogy még most sem ismerem önt egészen, de arról már most is biztosithatom, hogy nem biznék önre egy garast; ha csak két garas biztositékot nem adna!'522 A föügyész a következő számban azonban ragaszkodik saját igazához, Joó Károlyt pedig vakmerőnek és szemtelennek nevezni, amiért az adott okmány elsikkasztásával vádolta őt meg. ${ }^{523}$ Burián Lajos egyébként nem első ízben szerepelt a díjköteles véleményrovatban: egy évvel korábban az újság egyik legfőbb hirdetőjével, Várady Lajos gyógyszerésszel került összetüzésbe a hasábokon. Várady indította a vitát: a föügyész

\footnotetext{
${ }^{517}$ SZL, IV. évf. (1874) 7. sz. 3.

${ }^{518}$ SZL, IV. évf. (1874) 10. sz. 3.

${ }^{519}$ SZL, IV. évf. (1874) 19. sz. 3.

${ }^{520}$ SZL, IV. évf. (1874) 20. sz. 3.

${ }^{521}$ SZL, IV. évf. (1874) 22. sZ. 4.

${ }^{522}$ SZL, IV. évf. (1874) 23. sZ. 3.

${ }^{523}$ SZL, IV. évf. (1874) 24. sz. 4.
} 
munkavégzésének minőségét kritizálta. ${ }^{524}$ Burián válaszában felrója a gyógyszerésznek: néhány nappal korábban még barátságosan társalognak, és most a nyilvánosság előtt megtámadja őt, csak azért, mert Várady és köre eszközként kívánja felhasználni a személyét a Stammer Sándor alispán elleni küzdelemben $?^{525}$ A szópárbajt a patikus éles hangú viszontválasza zárja, amelyben - többek között - a következőképpen fogalmaz: „Ugy látszik, most már velem akar Burián ur kettesben »haragszom rád«-ot játszani; de most az egyszer oly embert választott bennem, ki még sohasem játszott szavával; s ki komolyan szánakozni tud azon kinszenvedelmes motyogáson, melylyel a t ügyész ur beösmeti [sic!], hogy a rámázolt szegénységi bizonyitványnak még most is birtokában van." 526

A rovatot azonban néha más célból is használta a nagyközönség, nem csupán vádaskodásra, személyeskedő csatározásokra: az 1876. november 26-i számban például Plager Éva és Plager Vilmos feltehetően olyannyira büszke volt eljegyzésére, hogy az ifjú pár fizetni is hajlandó volt a Szentesi Lapnak ezen információ nyilvános közléséért. ${ }^{527}$ Ugyanebben az évben Várady Lajos a Nyilt térben köszönte meg a részvétet mindazoknak, akik kisfia, László temetésén megjelentek. ${ }^{528}$ Hasonló célból fizette ki a megjelenés költségét Zsoldos János nőiruha-készítő, aki dr. Balassa Péter orvosnak fejezte ki ilyen módon háláját, amiért annak ,fáradhatatlan buzgalma, s különösen kifejtett szorgalma folytán” kigyógyult súlyos betegségéből. ${ }^{529}$

Néhol szinte humoreszkbe illő iróniával is találkozhatunk a Nyilt tér rovatban: 1872. december elején történt, hogy Robitsek Sándor helyi lakosnál a Babocsay Gyula vezetésével kivonult pénzügyőrség nagy mennyiségű csempészett dohányt talált, és a tiltott árut lefoglalta. Robitsek pár nap múlva gúnyos hangú, az elkövetett büncselekményt igen átlátszó módon tagadó levelet jelentetett meg a Szentesi Lapban: „Nyilvános köszönet. Ezennel mély köszönetet nyilvánitok Babocsai m. kir. pénztárnok urnak azon szives közbenjárásáért, mely szerint elöttem ismeretlen uton lakásomba csempészett tiltott magyar dohánytól a m. kir. pénzügyőrség által engem megszabaditani kegyes volt." ${ }^{\text {"530 }}$ Babocsay nem maradt adós a tömör, de hasonlóan szellemes válasszal: „Válasz - Robicsek S. urnak, a folyó 1872-iki 18-ik sz. n. a szentesi heti Lapban nyilvánitott köszönetére emberbaráti kötelesség érzetéböl

\footnotetext{
524 SZL, III. évf. (1873) 49. sz. 3.

525 SZL, III. évf. (1873) 51. sz. 3.

526 SZL, III. évf. (1873) 52. sZ. 4.

${ }^{527}$ SZL, VI. évf. (1876) 48. sz. 3.

${ }^{528}$ SZL, VI. évf. (1876) 19. sz. 3.

${ }^{529}$ SZL, VI. évf. (1876) 27. sZ. 3.

${ }^{530}$ SZL, I. évf. (1872) 18. sz. 3.
} 
szivesen máskor is, - de csak ugy ha lehet." ${ }^{, 51}$ Ugyancsak megmosolyogtató tíz esztendővel később dr. Czukermann Somának nyilatkozata, aki a személyével kapcsolatos városi pletykára reagál röviden: „Azon elterjedt légböl kapott hir ellenében, hogy én helyböl távozni szándékozom, kénytelen vagyok kijelenteni, miszerint Szentesröl eltávozni eszem ágában sincsen." 532

A Szerkesztői üzenetek rovatban a felelős szerkesztő válaszolt röviden a különféle olvasói vagy szerzői megkeresésekre. Utóbbi leginkább azt közölte az érintett féllel, hogy beküldött írása publikálva lesz-e, avagy sem. Kulinyi Zsigmond például felelős szerkesztőként néha kissé túlzásba is vitte a nyers őszinteséget e rovatban: „Szegfalusynak, helyben. Nem akarom azt mondani, hogy föltétlenül rosz, de sok jó költeményben levén módom válogatni, - az ön versét nem közlöm.”533 Vagy: „F. F.-nek helyben. Fordításokat, különösen, ha a forrás elhallgatásával, eredetiek gyanánt küldetnek be, csak az esetben közlök, ha magyarban is legalább ép oly jók, mint eredetiben. Az ön által adott fordítás e mértéket nem üti meg, mihez képest kéziratát - 8 napig - rendelkezésére bocsájtom." 534

Végül, említést érdemelnek még az önálló rovatcím nélküli, általában a második vagy harmadik oldalon közölt, jegyzet-, kritika- vagy esszészerü publicisztikák, amelyek a legtöbb esetben - a vezércikkekhez hasonlóan - valamilyen aktuális kérdést, illetve problémát dolgoznak fel, akár helyi, akár országos vagy külföldi vonatkozású témát boncolgatva. Néhány közülük igen magas szakmai színvonalat képvisel, például dr. Pollák Sándor azon négyrészes cikksorozata, amely az 1873-as kolerajárvány okait és lefolyásának körülményeit elemzi. Az írásból szemléletes képet kapunk a korabeli Szentes társadalmi és közegészségügyi viszonyairól: ,[...] A nevezett utczák a városban legmagasabban fekszenek, a lakhelyek tiszták és szárazak, és az ezen utczákban lakó polgárok többnyire vagy foglalatosságuk, vagy vagyoni állapotuknál fogva, leginkább voltak képesek az egészségügyi bizottmány által kiadott óvrendszabályokat megtartani. Vannak ellenben utczák, melyekben rendkivüli sok megbetegülés és haláleset fordult elö..." Az ilyen, mélyen fekvő helyeken például a Kisérben - az odafolyó esővíz az év nagy részében posványokat képez, amely melegágya a fertőzésveszélynek. Emellett a lakóházak nagyobb része a legalapvetőbb egészségügyi szabályoknak sem felel meg: a szobák alacsonyak, padolatlanok, többnyire csak egy kisméretü ablakuk van, a falak pedig sok helyen nedvesek, penészesek. Ráadásul az egész család - sőt esetenként több család is - egy szobában lakik, s a lakók nagy része vagy

\footnotetext{
${ }^{531}$ SZL, I. évf. (1872) 19. sz. 3.

${ }^{532}$ SZL, XII. évf. (1882) 35. sz. 4.

${ }^{53}$ SZL, V. évf. (1875) 46. sz. 3.

${ }^{534}$ SZL, V. évf. (1875) 43. sz. 3.
} 
munkája, vagy szegénysége miatt nem képes az óvórendszabályokat betartani. Mindezek alapján nem lehet csodálkozni azon, hogy a település számos részén a kolerajárvány nagyszámú áldozatot szedett a lakosság körében. ${ }^{535}$

A következő lapszámban folytatódik az írás, amely megállapítja, hogy a probléma egyik fő okozója a szentesi lakosság nagyobb hányadának életmódja: a legtöbb háznál lovat, szarvasmarhát tartanak, sertést hizlalnak, így sok helyen az évekig felgyülemlő trágya az udvarokban tornyosul, egyéb szeméthalmokkal egyetemben. Mindez föleg nyáron okoz nagy bosszúságot, mikor a meleg miatt az állati ürülék, valamint a többi hulladék elviselhetetlen bűzt áraszt magából. Jellemző, hogy az egészségügyi bizottmány az előző télen elrendelte ugyan a trágya kihordását a városból, de „sok helyen ez még is elhanyagoltatott."536 A szerző szerint a helyi lakosoknak az alapvető higiéniai szükségletekkel szemben tanúsított igénytelensége további veszélyforrást jelent a közegészségügyi állapotok romlása, a járványveszély fokozódása tekintetében: „Arnyékszék gyanánt sok házban egy kis gödör szolgál, melyben az emberek ürüléke födetlen fekszenek és kiállhatlan büzt terjesztenek, sok helyen nincsen is árnyékszék, az ürülékek szabadon az udvar valamelyik sarkában hevernek." 537 Pollák ismerteti a kolera terjedésével szembeni óvintézkedéseket is: az iskolákat bezárták, a fogadókban és kocsmákban este tíz óra után tilos volt a kiszolgálás, a piacon napi szinten ellenőrizte a hatóság az árusított élelmiszerek minőségét. Mindemellett a szegényebb betegek részére a város ingyen ápolást biztosított, a halottakat pedig gondosan, egy ideiglenes hullaházban különítették el. Végül, visszatérve az egyes lakóházakban tapasztalható körülményekre, a szerző rávilágít, hogy azokban a házakban, ahol több család lakik együtt, a közös árnyékszék következtében a kolera szinte minden ott lakót megfertőzött. A külön árnyékszék használata mellett viszont nem terjedt tovább a pusztító kór, amint ez egyértelmüen megmutatkozott a módosabb polgárok házaiban: a család árnyékszéke a cselédségétől el van különítve, s bár a cselédek között felütötte fejét a járvány, a szükségét más helyen elvégző család megmenekült a betegségtől. ${ }^{538}$

\footnotetext{
535 SZL, III. évf. (1873) 45. sZ. 3.

536 SZL, III. évf. (1873) 46. sZ. 2.

537 Uo.

${ }^{538}$ SZL, III. évf. (1873) 47. sZ. 2.
} 


\subsection{Az Alföldi Nővilág}

1875 decemberében jelent meg az akkor már a Szentesi Lapnál is dolgozó Sima Ferenc önálló kiadványának mutatványszáma, „Az alföldi művelt magyar hölgyek lapja” profilmegjelölésű Alföldi Nővilág. ${ }^{539}$ Az új vállalkozásról a Szentesi Lap a következőképpen értesíti a nagyközönséget: „Helybeli kollégánk, az »Alföldi Növilág« mutatványszáma elég változatos tartalommal jelent meg és valóban megérdemelné, hogy a folytatása következzék." A cikk azonban felhívja a figyelmet, hogy több lapszám csak abban az esetben fog megjelenni, ha elegendő mennyiségü előfizetés érkezik, amely legalább a nyomtatási költségeket fedezi. S bár az új szépirodalmi orgánum szerkesztője és tulajdonosa, Sima Ferenc nem számít egyelöre rendkívüli támogatásra, annyit azonban - a Szentesi Lap munkatársaival együtt - remél, hogy lesz annyi érdeklődő, hogy a kiadvány fennmaradhasson. „Annyi bizonyos, hogy egy szépirodalmi lapnak nálunk való megélhetése örvendetesen igazolná, miszerint az olvasási kedv és ezzel együtt a müvelödés utáni törekvés nálunk is gyökeret vert. Az »Alföldi Növilág" elöfizetési ára egy évre 4 frt., félévre 2 frt., negyedévre pedig 1 forint." 540

Egy héttel később már maga Sima fordul a Szentesi Lap hasábjain az olvasókhoz, és a nagyközönség támogatását kéri: „Lapunkra (»Alföldi Nővilág“) lapkihordónk buzgalma folytán, oly szép számmal történtek elöfizetések, aláirások, hogy kevés támogatás még egészen biztositaná lapunk megélhetését. [...] Egy kis támogatásért esdünk még, s egy nem jelentéktelen vállalat, - mely egy vidéki városnak valóban dicsérö elismerésül szolgálna - élni fog!” A szerkesztő kéri tehát az ügy érdekében a mélyen tisztelt polgárokat, különösen pedig „, a vállalatunk támogatására hitt intelligenseinket”, hogy fizessenek elő az újságra, hiszen ha még egyszer ennyi érdeklődő volna, az Alföldi Nővilág folytathatná pályáját. Ezután közli, hogy a második lapszám szombaton esedékes publikálását - a megfelelő számú előfizető összegyüjtése céljából - a következő hétre halasztják. ${ }^{541}$

Egy héttel később azonban Sima Ferenc sajtóközleményben jelentette be, hogy az új orgánum megbukott: „E lapok mult számában megkisérlett kérelmem silány eredménye végkép megakadályoz szándékomban. - Ugyanis lapom (»Alföldi Növilág«) további megjelenése - az elófizetők csekély száma mellett - anyagi áldozat nélkül lehetetlenség." Ezt követően reményét fejezi, hogy egyszer majd talán sikerül a lapot elindítani, viszont jelen helyzetben nem mer további pénzügyi kockázatot vállalni. „Ez alkalommal nincs más

\footnotetext{
${ }^{539}$ A lapindítást igazolja a MNL OL BL K 148. szekciójában szereplő 279/1876. iratszám is (a dokumentum már nem fellelhetö).

${ }^{540}$ SZL, V. évf. (1875) 52. sz. 3.

${ }^{541}$ SZL, VI. évf. (1876) 1. sz. 2.
} 
teendőm, mint az ügy érdekében öszinte köszönetet mondani mindazon t. ügybuzgóknak, kik vállalatom támogatására sorakozni kegyeskedtek" - írja a csalódott lapszerkesztő, majd ígéretet tesz, hogy a már befizetett előfizetési díjakat visszaszolgáltatja mindenki számára. ${ }^{542}$ Ugyanezen lapszám hírrovatában a szerkesztőség is röviden értesít a kudarcról. Mint a Szentesi Lap írja: az Alföldi Nővilág megszűnt, mielőtt élni kezdett volna, mert „a kilátásba helyezett elöfizetési pénzek nem födözték volna a nyomatási költségeket sem. No de tán elég lesz nekünk ez az egy lap is ebben a rosz világban." 543

Az Alföldi Nővilág külleméről, tartalmáról nem rendelkezünk információval, ugyanis az egyetlen megjelent lapszám közgyüjteményben nem maradt fenn.

\subsection{A Csongrádmegyei Közlöny}

„Kollega. Folyó hó 5-én, mint igérve volt, Honthy ur szerkesztése mellett »Csongrádmegyei Közlöny« cim alatt egy uj lap fog megjelenni városunkban. Addig is, mig e lap irányával, tartalmasságával megismerkednénk: ajánljuk közönségünk figyelmébe" - számol be tömören a Szentesi Lap a néhány évvel korábban még Cherrier alkalmazásában álló Honthy László új kísérletéről 1876. október elején. ${ }^{544}$

Honthy saját lapját - amelynek egyben felelős szerkesztője is volt - egykori fönöke nyomdájában sokszorosíttatta. A Csongrádmegyei Közlöny - profil-megjelölése alapján „Gazdászati, ipar, kereskedelmi, társaséleti és szépirodalmi hetilap” - 1876. október 5-én jelent meg először. A csütörtökönként publikált orgánum előfizetési díja megegyezett a Szentesi Lapéval: egész évre 4, fél évre 2, negyed évre pedig 1 forint volt, hirdetési tarifái viszont jóval kedvezőbbnek bizonyultak: egy háromhasábos petitsorért Honthy csupán 6 krajcárt kért, míg a Szentesi Lapban ugyanez háromszor annyiba került. A bélyegdíj azonban itt is minden beiktatás után 30 krajcár volt.

Az újság rovatstruktúrájáról nehéz egzakt leírást adni, mivel az újság mindössze másfél hónapig létezett - összesen hét lapszáma jelent meg -, ráadásul közgyüjteményben (OSZK) csak az első, az ötödik és a hetedik szám maradt fenn. A ma is megtekinthető lapszámok sem rendelkeznek teljesen egységes arculattal, ami a szerkesztés alapelveit illeti (például az első szám címoldalán kezdődik a Tárca, az ötödik és hetedik számban viszont már

\footnotetext{
542 SZL, VI. évf. (1876) 2. sZ. 2.

${ }^{543}$ SZL, VI. évf. (1876) 2. sZ. 3.

${ }^{544}$ SZL, VI. évf. (1876) 40. sz. 3.
} 
a második oldalon találjuk az irodalmi rovatot), mindenesetre annyi megállapítható, hogy az orgánum küllemében nagyfokú hasonlóságot mutat a Szentesi Lappal, tehát a korszak jól bevált hírlapi formátumát követi. A legfőbb különbség azonban már első ránézésre megállapítható: a Csongrádmegyei Közlöny cikkei terjedelmesebbek, az újság több publicisztikát tartalmaz, ezzel szemben a Szentesi Lap elsősorban a rövidebb véleményközlő írásokra, illetve még inkább az olvasókat legjobban érdeklő hírekre koncentrált. A Közlöny szakmai színvonala, néhány helyen kissé folyóiratszerü tartalma mindenképp elismerést érdemel, azonban minden bizonnyal ez volt gyors bukásának egyik oka: a müfaji igényességre, a hosszabb lélegzetvételü, nem feltétlenül aktuális információkat feldolgozó publicisztikákra nem akadt a városban piacképes kereslet. ${ }^{545}$ (Természetesen olvashatunk itt is vezércikket, voltak megyei hírek, közgazdasági rovat, sőt vasúti menetrendet is közölt a szerkesztőség, azonban kisebb arányban voltak jelen az aktuális információk, mint a Szentesi Lap hasábjain.)

A kudarc másik okának a vállalt küldetés tekinthető: a szentesiek nem mutattak nagy érdeklődést egy olyan lap iránt, amely elsősorban a megyére, és nem magára a településre koncentrált - úgy tünik, Honthy László nem tanult az Alföldi Figyelő bukásából. Mindehhez még hozzájárulhatott a többségében 48-as beállítottságú helyi lakosság hagyományos ellenérzése a vármegyei vezetéssel - tehát a kormánypárttal - szemben, hiába deklarálta a lap, hogy a társadalom lehető legszélesebb köréhez kíván szólni: „teljes erőnkből arra törekszünk, hogy vállalatunkban egy olyan czélszerü, hasznos, söt sok tekintetben szükséges helyi lapot adjunk Csongrádmegye városai és községeinek, melyben az uri termek éppenugy, mint ez egyszerü falusi lak egy nélkülözhetetlen barátot birand."546 Emellett a szerkesztőség nyíltan vállalta lojalitását a kormány irányába: a november 16-i szám például címoldalon közölte az országgyülési bizottság felhívását, amely szerint a Deák Ferenc hazafiúi nagysága előtti főhajtás jeleként adománygyüjtésbe kezdenek, hogy szobrot állítsanak az elhunyt államférfinak ${ }^{547}$ - mindez feltehetően nem növelte a Közlöny népszerüségét a Kossuthért rajongó szentesi polgárok körében.

A Cherrier-nyomdában készült lap rövid fennállása alatt megfelelö mennyiségű hirdetőt sem tudott toborozni. A mutatványszám még egyetlen hirdetést sem tartalmaz, az ötödik számban - amelynek impresszuma már társszerkesztőként feltünteti Balázsovits

\footnotetext{
${ }^{545}$ Olvashatunk például értekezést Oroszország történelméröl (CSK, I. évf. [1876] 5. sz., 3.) vagy esszét a céhek eredetéröl, fejlődéséről és hanyatlásáról. (CSK, I. évf. [1876] 7. sz., 2-3.)

${ }^{546}$ CSK, I. évf. (1876) 1. sz. 4.

${ }^{547}$ CSK, I. évf. (1876) 7. sz. 1.
} 
Norbertet - pedig mindössze három reklámot találunk: Czukermann Soma orvost, a Szentesvidéki Takarékpénztárt, valamint egy a fővárosban gyártott sósborszeszt.

A kérészéletü Csongrádmegyei Közlöny tehát - érdeklődés hiányában - 1876. november közepén, előzetes bejelentés nélkül megszünt. A nem éppen dicsőséges pályafutást tovább árnyékolja az a levél, amelyet az egykori kézbesítő, Négyesi Albert jelentetett meg a Szentesi Lap Nyilt tér rovatában egy hónappal később. Az írásból az újság megszünésének körülményeiről is kapunk némi információt: „T. Honti László volt szerkesztő urnak! T. uraságod, midőn a »Csongrádmegyei Közlöny«-t meginditotta, nekem jutott a szerencsétlenség azt az illetö elöfizetöknek és nem elöfizetöknek kézbesiteni. - Mint minden rendes ember, ki a maga kárát nem óhajtja, én is megkérdeztem t. uraságodtól, hogy fáradságom diját miben állapitja meg? - Negyedévenként 20 frt s a begyült elöfizetési pénzekböl minden 10-ik forint engem illet, azaz illetett volna közös megállapodás szerint." A lapkihordó ezután megemlíti: ő becsülettel teljesítette feladatát mindaddig, amíg a Közlöny meg nem szünt, s közben egyszer sem kért vagy kapott díjazást Honthytól munkájáért. A kiadó viszont egy reggel közölte vele, hogy több szám már nem fog megjelenni. Ekkor Négyesi kérte a jogos fizetségét, mire Honthy durva hangnemben rendre utasította: szemtelenség olyasmit követelni, ami nem illeti meg az embert. „Ha jól emlékszem, még talán azt is mondta, hogy tartsam szerencsémnek, ha lapját széthordtam. Kipiszkolt és eljöttem. Napok mulva ujra fölkerestem önt, gondolva, hogy nem lesz oly ingerült s ki fog fizetni. Ekkorr [sic!] meg plane 20 bottal és kidobással fenyegetett. - Többször nem is megyek. Hanem elmulaszthatlan kötelességemnek tartom itt a nyilvánosság elött, önön az erkölcsi 20 botot elverni. Szentes, 1876. december 22. Négyesi Albert." ${ }^{\text {548 }}$ Honthy László nem reagált a nyílt levélre.

\subsection{A Szentes és Vidéke}

1880 elején tartósan is megszünt a Szentesi Lap monopolhelyzete a szentesi nyomtatott tömegtájékoztatás terén: az esztendő első napján, csütörtökön napvilágot látott a Szentes és Vidéke „társadalmi, közművelődési, ipar, gazdászati és szépirodalmi hetilap”, a korábban a Szentesi Lapnál főmunkatársként dolgozó Kovács Pál kiadásában és szerkesztésében. A lap az előállítás helyszínét tekintve két évig kivételesnek minősült, hiszen gyártási munkálatait

\footnotetext{
${ }^{548}$ SZL, VI. évf. (1876) 52. sZ. 3.
} 
nem Cherrier Jánosra, hanem a szegedi Burger-féle nyomdára bízták, 1882 márciusától azonban helyben, a Szentes és Vidéke újonnan létesült nyomdájában sokszorosították. Az újság külső megjelenésében, rovatszerkezetében szintén a klasszikus félíves hetilap formátumát követte, s e tekintetben nagymértékben hasonlított a Szentesi Laphoz. Előfizetni rá csak negyedévre lehetett, amelynek díja 1 forint volt, mint a Szentesi Lap esetében, sőt a bélyegdíj is megegyezett a konkurencia árszabásával (30 krajcár). A Nyilt tér rovatba azonban olcsóbban, 10 krajcár ellenében be lehetett kerülni, szemben a Szentesi Lap 15 krajcáros díjával. A hirdetési tarifákat nem tüntette fel a fejléc, mindössze annyit közölt, hogy azok „jutányosan számíttatnak” - tehát feltehetően az ár minden esetben egyéni megállapodás kérdése volt. További előny volt a Szentesi Laphoz viszonyítva, hogy nem kellett feltétlenül előfizetni az újságra: kezdettől fogva meg lehetett vásárolni az egyes példányokat is 8 krajcárért - a Szentesi Lap majd csak 1883 augusztusától vezeti ezt be, azonos áron, mint már korábban említettük.

Az 1919-ig létező Szentes és Vidéke első három évfolyamának részletes vizsgálata, teljes igényü statisztikai feldolgozása nem lehetséges, ugyanis meglehetősen kevés példány maradt fenn közgyüjteményben az utókor számára: az 1880-as esztendőből mindössze két lapszámot őriz az Országos Széchényi Könyvtár, az 1881-es évfolyam teljességgel hiányzik, s az 1882-es év is csak március közepétől indul, ami a megőrzött példányokat illeti. Így tárgyalt időszakunkra nézve átfogó képet nem tudunk alkotni a lap működéséről, és erre nem is teszünk jelen dolgozatban kísérletet, hiszen jórészt csak feltételezésekre hagyatkozhatnánk. (Azt sem tudjuk megmondani pontosan, mikor változott a kezdetben alkalmazott csütörtöki megjelenés szombatira: csak annyi bizonyos, hogy az 1882. március 18-i szám fejlécén már szombat szerepel.) A kevés fennmaradt példány és a Szentesi Lapban közzétett reakciók, olvasói levelek alapján azonban néhány lényeges dolog rekonstruálható az 1882 márciusáig tartó időszakból, tehát Kovács Pál szerkesztői tevékenységéből.

„Ha lapunk irányáról, a követendő vezérelvekről akarunk szólni, lehetetlen azt a nélkül tennünk, hogy a legnagyobb elszomorodással hangot ne adjunk azon szomoru igazságnak, hogy viszonyaink annyira abnormisak, melyeken változtatni nem elégséges sem a sajtó, sem egyesek lankadatlan buzgalma, kitartó fáradozása. Nem is e titáni harcra vállalkozunk mi. Lapunk meginditásával egyszerüen csak eszközt kivánunk szerezni azoknak, kik egyesülve vállalkoznak a nemes harcra.” Kovács szerint a sajtó szigorú kötelessége, hogy minden körülmények között a közvélemény orgánuma legyen, és bizony, ahány ember, annyiféleképpen értelmezi a közélet történéseit. Viszont Szentesen nagy probléma, hogy a közvélemény tájékoztatása meglehetősen egyoldalú, ezen pedig változtatni szükséges - 
szögezi le az első szám programhirdető vezércikke, vagyis deklarálja, hogy az akkor már évek óta Sima Ferenc által szerkesztett, a 48-as elveket nyíltan vállaló Szentesi Lap konkurenciája kíván lenni. A pártoktól való függetlenséget ígérő írás végén egyértelmű üzenetet küld a Szentesi Lapnak: „Mások talán nem lesznek sok tekintetben egy véleményben velünk. Van ut és mód, hogy nézeteiket diadalra juttassák. Győzzön a jobb!"549

Hamarosan azonban kiderült, hogy a higgadt, építő szándékú közvélemény-formálást Kovács másképpen értelmezte. Személyeskedő, támadó hangú, céltalanul vagdalkozó cikkek kezdtek megjelenni az újságban, amelyekre többnyire a konkurens Szentesi Lap hasábjain érkeztek tiltakozó válaszok. Az első ilyen esetet a Szentes és Vidéke 1880. január 22-i számában megjelent cikk váltotta ki, amely azzal vádolta meg Lévi Leopold fogyasztásiadóbérlöt, hogy az adóbeszedésnél sorozatosan csalást követ el. ${ }^{550}$ Lévi mindezt határozottan visszautasította: „A mi a közleményben foglalt azon állitást illeti, hogy én, vagy közegeim bárkinek a bora fölvételénél a hordó ürtartalmat kevesebbre vagy többre vettük volna, hitvány rágalomnak jelentem $\mathrm{ki}$, mely rágalom megtorlása végett a törvényes lépéseket már megtettem." 551 A Szentesi Lap még ugyanezen számában egy hasonló tiltakozó írás látott napvilágot Csüpe Ambrus királyi pénzügyőri szemlész tollából, amely szerint a Szentes és Vidéke negyedik számában a hírek között egy a helyi pénzügyőrséget törvénytelen eljárással, erőszakoskodással és zsarolással vádoló közlemény jelent meg. A cikket Csüpe mind a maga, mind pedig a pénzügyőri hivatal nevében rosszindulatú koholmánynak, hitvány rágalomnak titulálja, majd kijelenti: „e közlemény miatt, nevezett lap ellen, a pénzügyi igazgatóság utján, a törvényes lépéseket már megtettem, ezt azért teszem, hogy a közönség egy percig se legyen a közlemény valóságának hiedelmében." 552

Két hónappal később, szintén a Szentesi Lap Nyilt tér rovatában jelent meg ifj. Kolumban Imre felháborodott hangú levele, Kovács Pálnak címezve. Kolumban megemlíti a Szentes és Vidéke tizenegyedik lapszámában közölt hírt, miszerint ő egy bizonyos napon Szépe Imre kocsmájában néhány embert ólmosbottal bántalmazott, majd a szórakozás kedvéért egy békés polgár ablakát is bezúzta. „Önnel szemben, ki eddig lapja minden számában keresett scandalumokkal és mások gyalázásával mulattatja olvasóit, nem érzem ugyan magamat erkölcsileg utalva, hogy nevemet gyalázó közleménye ellen védelmezzem, mindazon által magam és a közönség iránt tartozó kötelességböl kijelentem, hogy az ön

\footnotetext{
${ }^{549}$ SZV, I. évf. (1880) 1. sz. 1.

${ }^{550}$ Az említett lapszám szintén nem maradt fenn, az írás tartalmára így csak a Szentesi Lapban közölt válaszlevél alapján következtethetünk

551 SZL, X. évf. (1880) 4. sz. 3.

552 Uo.
} 
nevemet gyalázó közleménye nem egyéb rágalomnál, mint majd ezt annak idején a helybeli rendöri kapitányi hivatalnak itéletével is beigazolandom." Kolumban állítása szerint az említett kocsmában ő soha nem járt, mindössze annyi történt, hogy a hely elött sétált el a barátaival, amikor az ivóból kijövő részegek megtámadták. Ekkor élt a jogos önvédelem lehetőségével, majd elmenekült. „Ez az eset, ami velem történt, amiböl Kovács ur piszokmühelye a gyalázó közleményt gyártotta. [...] Engem azonban botrányos támadása feljogosit arra, hogy kipuhatoljak önnek egynehány (mert nem csak egy van) oly cselekményét, melyek önt, ha kötélre nem is (mint ön nekem mondja) hanem arra érdemessé teszik, hogy ön minden tisztességes társasságból kilökessék és koterbe kerüljön." Végül megfenyegeti Kovácsot: legközelebb olyan adatokat fog nyilvánosságra hozni, amelyek alapján a Szentes és Vidéke olvasói előtt is egyértelművé válik, „hogy ujságjában az a legnagyobb botrány, hogy benne ön beszél a becsületröl." 553

A rágalmazó, sértegető hangú cikkek azonban a tiltakozások ellenére is folytatódtak: nem kímélve senkit - pártállástól függetlenül -, a helybeli tisztviselőktől kezdve egészen a föispánig. Az általános felháborodás oly mértéküvé fokozódott, hogy a lapot több szentesi társadalmi egyesület kitiltotta helyiségeiből. Kovács Pál végül kénytelen volt lemondani a felelős szerkesztői pozíciójáról 1882 tavaszán, sőt a városból is elköltözött. ${ }^{554}$ A Szentes és Vidéke 1882. március 18-i (III. évf. 11. sz.) számának címoldalán az új felelős szerkesztő és tulajdonos, Szívós Béla köszönti az olvasókat, és egyértelmüvé teszi, hogy véget vet a sorozatos botrányoknak. Teljes függetlenséget hirdet, valamint leszögezi, hogy kerülni fog bárminemü részrehajlást a hasábokon. „A személyeskedéseket lapomból kizárom, botrány hajhászásokkal azt érdekessé tenni nem igyekszem, a lapkörén kivül esö dolgokba nem avatkozom, sem pedig - csalhatatlan itélönek s erkölcsbirónak magamat feltolni nem fogom" - írja Szívós, majd ígéretet tesz arra, hogy az újság hü tükre kíván lenni a város és a környék közéletének. 555

Az új lapvezér tisztességesen járt el: szintén címoldalon adott lehetőséget Kovács Pálnak, hogy elbúcsúzzon az olvasóktól. A lemondott szerkesztő közli, hogy a fővárosba költözik, emellett - többek között - kifejti, hogy „a közvéleményt csinálják ma a lelketlen kufárok, hogy önös céljaikat annál könynyebben elérhessék. Én ez irányzat ellen esküdtem hüséget. Résen voltam minden pillanatban, hogy ellensulyozzam a helytelen irányú

\footnotetext{
${ }^{553}$ SZL, X. évf. (1880) 12. sz. 3.

${ }^{554}$ Kis-Rácz 2000.(1.10.8. - A korszak sajtója)

${ }^{555} \mathrm{SZV}$, III. évf. (1882) 11. sz. 1.
} 
törekvéseket."556 Szívóst kollégája, Pólya Ferenc segítette a szerkesztésben, s mivel mindketten a függetlenségi párt hívei voltak, a Szentesi Lap és a Szentes és Vidéke közötti ellenségeskedés két esztendőre elcsitult, inkább a harmonikus együttmüködés jellemezte a két helyi sajtóorgánumot. ${ }^{557}$ (Ezt az időszakot már könnyebb vizsgálnunk, hiszen 1882 márciusától viszonylag nagy mennyiségü lapszám fennmaradt a közgyüjteményekben.)

Állandó rovatnak számított itt is a vezércikk - természetesen itt is rovatcím nélkül -, a Tárca, az azt kiegészítö Irodalom és a Csarnok, a Szentesi hírek és közlemények, a regionális és országos információkat közlő Vegyes hírek, a külföldi eseményeket jegyzet formájában tálaló Világfolyása, valamint az olvasói véleményeket közlő Nyilt tér. Az újság ebben az időszakban tehát nem mutatott számottevő különbséget a Szentesi Laphoz képest - mindkét lap a jól bevált országos sémát követte, ráadásul a hét ugyanazon napján, szombaton jelent meg mindkettő. Megemlítendő azonban, hogy Szívós mindvégig kínosan ügyelt a pártatlanságnak legalább a látszatára: a Szentes és Vidéke stílusa jóval visszafogottabb volt, mint a konkurens hetilapé. Utóbbira jó példa az az éles vita, amelyet a Szentesi Lap Le az álcával! című vezércikke indított el 1882. május közepén. A publicisztika szerzője feltehetően maga a felelős szerkesztő, Sima Ferenc - konkrét nevek említése nélkül ugyan, de korrupcióval vádolja meg a kormánypárti megyei és városi képviselőket. A cikkíró állítja, hogy bizonyos képviselők a különböző tisztviselői állásokra beérkezett pályázók közül azokat részesítik előnyben, akik fizetnek a jól jövedelmező állami hivatalokért, s példaként hozza a dorozsmai szolgabíró-választást, ahol az egyik jelölt ilyen jellegü nyilatkozatot tett: Boriszlávszki Leó elmondta, hogy neki kétszáz forintjába került volna a szolgabírói állás elnyerése. ${ }^{558}$ A történtek összefoglalóját leközölte a Szentes és Vidéke hírrovata is, ${ }^{559}$ viszont a következő lapszámban a szerkesztőség - a Szentesi Lappal ellentétben - kommentár nélkül leközölte Udvardi Sándor válaszlevelét, amelyben a városi és megyei képviselő rágalomnak minősíti a vádakat. ${ }^{560}$

A hirdetők tekintetében is látszott, hogy a két lap nem osztotta meg a helyi lakosságot politikai alapon: számos vállalkozó reklámozta magát két helyen egyszerre - pl. Csuray Ferenc kalapraktárát, Dobray Sándor vagy Hoffman Jakab vegyesboltját, dr. Csató Kálmán ügyvédi irodáját, Felsenburg Benedek eladó varrógépeit, Giessfeld Imre téglakereskedését, a Lázár és Sonnenfeld cég pedig tüzifáját és különféle malomipari szolgáltatásait kínálta

\footnotetext{
556 Uo.

${ }^{557}$ Kis-Rácz 2000.(1.10.8. - A korszak sajtója)

558 SZL, XII. évf. (1882) 19. sz. 1.

${ }^{559} \mathrm{SZV}$, III. évf. (1882) 19. sz. 2.

${ }^{560} \mathrm{SZV}$, III. évf. (1882) 20. sZ. 2-3.
} 
mindkét lapban. ${ }^{561}$ A Szentesi Laphoz hasonlóan, a kiadónak ez irányú bevételei szempontjából nem lehetett oka panaszra: általában a teljes utolsó oldalt kitöltötték a reklámok és Szentes város hivatalos közleményei, hirdetményei.

A korrekt egymás mellett élés, illetve a Szentes és Vidéke viszonylagos semlegessége, kevésbé egyoldalú hangneme ellenére is hasonló politikai irányvonal következtében nem meglepő, hogy a kormánypárti Darázs címü élclap 1883-ban mindkét újságot vehemensen támadja majd. (1884-ben a kapcsolat ismét ellenségessé vált a Szentesi Lap, valamint a Szentes és Vidéke között, ${ }^{562}$ de az újabb fordulat már tárgyalt időszakunkon kívül esik.)

\section{8. Élclapok}

„Az élclap az egyik legkésőbb kialakult sajtótípus, a XIX. század szülötte volt. Írók és közönség szempontjából egyaránt feltételezte a polgári értelmiség társadalmi megerősödését és viszonylagos önállóságát. Szükség volt kiterjedt és állandó keresletre a fél lábbal a társadalmon kívül és felül álló, de nem forradalmian vészterhes bírálat iránt, továbbá szükséges volt az állam legalább olyan mérvü liberalizálódása, amely eltürte ezt - ráadásul még a nyomdatechnikának is el kellett érnie arra a fejlettségre, mely lehetövé tette illusztrált lapok elég nagy mennyiségü és elég olcsó kinyomását" - írja Buzinkay Géza. ${ }^{563}$

Az angol gyökerü, később a francia forradalom idején kiteljesedő laptípus első hazai képviselője a Charivari (magyarul: Dongó) volt, amely 1848. július 1-jétől, hetente két alkalommal jelent meg a fővárosban Lauka Gusztáv szerkesztésében, illetve Szeremley Miklós kiadásában. Szintén fontos szerepet játszott az 1858 nyarától publikált, Jókai irányította $A z$ Üstökös, a két évvel később meginduló, Emich Gusztáv-féle Bolond Miska, illetve a szélsőbal irányultságú, Mészáros Károly tulajdonában lévő Ludas Matyi (1867 áprilisától), azonban az első igazán jelentős, a hazai élclapok népszerűségét széles körben és hosszú távon megalapozó orgánum a Deák-párti Borsszem Jankó lett (1868 januárjától) Ágai Adolf szerkesztésében, amely küllemében és tartalmában is évtizedekre mintaként szolgált követői számára. ${ }^{564} \mathrm{Az}$ újság sikerének titka elsősorban a szatirikus humor volt - az addig hazánkban kevésbé ismert zsidó viccek nagyrészt a Borsszem Jankónak köszönhetően vertek

\footnotetext{
${ }^{561}$ Ez nem mindenhol volt így: számos település vállalkozói kizárólag az egyik lapban helyezték el hirdetéseiket, amennyiben a konkuráló orgánumok politikailag ellentétes oldalon álltak, lásd például a délvidéki Magyarkanizsa két lapját, a Kanizsai Ujságot és a Kanizsai Ellenört.

562 Uo.

563 Buzinkay 1983. 6.

${ }^{564}$ Buzinkay 1983. 7-34.
} 
gyökeret a magyar közbeszédben. ${ }^{565}$ A lap olvasottságát nagymértékben növelte, hogy a magánelőfizetőkön kívül - hasonlóan a komolyabb hangvételü politikai lapokhoz olvasókörök, társaskörök, klubok, kaszinók és kávéházak is rendszeresen járatták. ${ }^{566}$

Az élclapoknál nemegyszer előfordult, hogy az olvasóra nem csupán passzív befogadóként, fogyasztóként tekintett, hanem aktív szerzőként is, így „egy-egy élclap állásfoglalása olvasóközönségének müveltségi állapotáról, politikai nézeteiröl tanúskodott". ${ }^{567}$ Jó példa erre Jókai Az Üstököse, ahol a megjelentetett anyagok jelentős részét maguk az olvasók küldték be, cserébe ingyen kapták meg a lapot - a közönség hamarosan gyüjtőhálózatot szervezett a hatékonyabb müködés érdekében. 568

\subsubsection{Az Északi Fény}

Szentes első szatirikus lapját, az Északi Fényt 1874. augusztus 15-én vehette kézbe az érdeklődő nagyközönség. ${ }^{569}$ A félíves - tehát négyoldalas -, „humoristikus hetilap” profilmegjelölésű újság Szakál Mihály kiadásában és Kovács Károly szerkesztésében, szombatonként jelent meg, előfizetési díjként egy évre 5 forintot, fél évre 2 forint 50 krajcárt, negyed évre pedig 1 forint 30 krajcárt kellett érte fizetni. A kormánypárti lap nyíltan vállalt célja „részint a helyi sajtó túlkapásainak szükebb korlátok közé szoritása, részint a közönség mulattatása" volt, vagyis az akkoriban Buday József által vezetett - s a 48-as elveket képviselő - egyetlen helyi orgánum, a Szentesi Lap lejáratása. ${ }^{570}$ (Igaz, a korszakban ez általános volt, hiszen a nyomdaipar elsősorban üzleti vállalkozás volt, morálisan akkor is bizonyos mértékben kifogásolható, hogy az Északi Fényt szintén a Cherrier-nyomdában sokszorosították, amelynek tulajdonosa egyben a Szentesi Lap kiadója is volt. ${ }^{571}$ )

Az újság rovatszerkezete - jellegéből adódóan - nem a korban megszokott hírlapi metódust követte, hanem az élclapokra jellemző szerkesztési elveket alkalmazta: nem

\footnotetext{
${ }^{565}$ Buzinkay 2016. 213.

566 Dersi 1973. 9.

${ }^{567}$ Landgraf 2014. 17.

${ }^{568}$ Landgraf 2014. 17., Tamás 2014. 92-93.

${ }^{569} \mathrm{Az}$ első három lapszám nem maradt fenn közgyüjteményben, a 4-12. számot az Országos Széchényi Könyvtár őrzi.

570 Labádi 2013.

571 Közismert példa az üzleti érdekek előtérbe helyezésére Heckenast Gusztáv, aki kilencvenhét különféle folyóirat megjelentetésében müködött közre, hatvanhét lapot pedig maga adott ki. (Vö. Bódy-Márkus 2012. 179-218.)
} 
feltétlenül politikai tartalmú, szatirikus jegyzetek, rövidebb anekdoták és viccek ${ }^{572}$ követték egymást négy oldalon keresztül (kivéve néhány vezércikket, illetve az 1874. október 24-i számot, amely a megyegyülésen történtekröl ad hírt - a tudósítás nem is illik a lap profiljába. ${ }^{573}$ ). Jellemző volt a nem fővárosi élclapoknál általánosan előforduló alacsony költségvetésre, hogy az arculat vonzerejét jelentősen növelni képes karikatúrákat egyáltalán nem találunk a hasábokon. Hirdetéseket sem láthatunk a lapban, tehát a finanszírozás feltehetően bizonyos, a megyéhez és a kormányhoz hủ személyek támogatásából történt - bár ezt a megyei képviselők határozottan tagadták, perrel fenyegetve meg minden sajtóorgánumot, amely ezt merészeli állítani. ${ }^{574}$

A Szentesi Lap 1874. augusztus 9-én megjelent írása - bár egyértelmüen sejteti, hogy mi lesz az élclap valódi küldetése - még üdvözli az új orgánum mutatványszámát: „Ne a becsületest gunyolja meg azért, mert az becsületes; ne arra szórja gúnyjait, kit tisztviselöi pályájáról a becsületesség és megvesztegethetlenség jó hirneve kisért el: hanem szórja gunyos élczeit azokra a társadalom és községi élet kö-szentjeire, kik csak akkor mozognak, midön saját magok felé haszonnal mozdíthatják kezöket!” Ezen kívül ne állítson senkit pellengérre például vallási meggyőződés alapján, inkább koncentráljon azoknak az elvtelen politikai szédelgőknek a kifigurázására, akik mindig annak a pártnak lesznek a tagjai, ahonnan a legnagyobb hasznot remélik. ${ }^{575}$

A jó tanács azonban hiábavaló volt: az Északi Fény vehemensen igyekezett teljesíteni küldetését. A szerkesztőség legfőbb célpontja a Szentesi Lap akkori felelős szerkesztője, Buday József volt, akit minden eszközzel próbált nevetségessé tenni a közvélemény előtt. „Dudvai Jolsep”-nek nevezte, ,pók természetü”-nek, aki „48-as farkasbőrbe öltözve 47-es bárányka képében szeretne feltolakodni". ${ }^{576}$ Néhány héttel később a hangnem tovább durvult, mikor az élclap „Csuklyási Buthai Józseb”-ről írt: „Ecce homo! Ha akarom vemhes, ha akarom nem vemhes. [...] Ért mindenhez - de nem tud semmit! képzelete élénk, épit légvárakat, tollának hatalma vakmerö, mert vakmerö - merö vak és mert merö vak szemtelen is. - Mondják, hogy odvas koponyájának korcsszülöttje - nem messze esett fájától; és hogy mindenszava egy lábbal tapodott kigyó sziszegése."577 (A stílus azt követően vált még inkább nyerssé Budayval szemben, miután a Szentesi Lap nyíltan kiállt a város színi társulata

\footnotetext{
572 Például: „Pista és Laos fürödni mentek a Tiszára. »Tudsz-e uszni kómé» - szólitja Pista Laost. Laos. »Nagyon, az adósságban. "Pista. »Hát nem félsz a hitelezőktől? « Laos. »Persze hogy nem, féljenek azok. "” (ÉF, I. évf. [1874] 4. sz. 4.)

573 ÉF, I. évf. (1874) 11. sz. 1-3.

${ }^{574}$ SZL, IV. évf. (1874) 39. sz. 3.

575 SZL, IV. évf. (1874) 32. sz. 3.

576 ÉF, I. évf. (1874) 4. sz. 3.

${ }^{577}$ ÉF, I. évf. (1874) 8. sz. 3-4.
} 
mellett: az egyik előadáson a színészek ugyanis kiparodizálták az őket nem éppen úriemberhez méltó modorban kritizáló Északi Fényt, mire az élclap jelen lévő munkatársai alpári bekiabálásaikkal botrányba fullasztották a rendezvényt. ${ }^{578}$ )

Buday József a Szentesi Lap 1874. szeptember 27-i számának címoldalán, Azoknak, a kiket illet címü publicisztikájában határozottan reagált az Északi Fény tevékenységére. Először is, leszögezi: eddigi magatartásából láthatta mindenki, hogy soha nem volt nagyravágyó, sem törtető, és a személye ellen az Északi Fényben közölt sértegetésekkel, alaptalan rágalmakkal nem különösebben törődött. Csak akkor emelte fel szavát a Szentesi Lap hasábjain, mikor a szatirikus újság megtámadta minden tisztességes ember jóérzését, és ezzel hadat üzent az általános közerkölcsnek. Például, mikor az Északi Fény a szentesiek döntő többségének bizalmát élvező függetlenségi párt tagjait gúnyosan „48-as rüpők”-nek nevezte, már egyértelműen túllépte ezt a határvonalat. „Ime ismét itt a Rubikon! fel kell szólalnunk. Uraim! Befolyásos férfiak, szerepet játszó egyének ott az »Északi Fény« háta mögött! Örizkedjenek önök megháboritani czélzatos gunynyaikkal a békés polgárok csendes nyugalmát!" 579

A szentesi lakosság nem mutatott érdeklődést a megye által közvetve - és minden bizonnyal közvetlenül is - támogatott lejárató kampányra. A szerkesztőség az 1874. október 17-i, majd a 24-i és 31-i szám címoldalán is kéri a ,közönség becses pártfogását és támogatását”, emellett ígéretet tesznek arra is, hogy „ha elöfizetöink száma gyarapodni fog, lapunkhoz egy negyed rész iv mellékletet nyomatunk, melyen közleni fogjuk a magán és hivatalos hirdetéseket, piarczi árjegyzéket, börze folyamot stb. ${ }^{, 580}$ Emellett az egyébként sem túl magas szakmai színvonalú lap - nyilván tapasztalva a lakosság elutasító magatartását hangnemét tekintve jelentősen visszafogta magát, de későn: az Északi Fény novemberben már nem jelent meg, kellő számú előfizető és további támogatók híján a vállalkozás csődbe ment.

\subsubsection{A Darázs}

1883-ban a helyi 48-as párt hívei szerettek volna az év végén esedékes vármegyei tisztújításon személycseréket kikényszeríteni, és kampányuk legfőbb fórumát a Szentesi Lap hasábjai jelentették. A megye védelmére kelt kormányerők támogatásával ekkor erőteljes

\footnotetext{
${ }^{578}$ SZL, IV. évf. (1874) 37. sz. 2.

${ }^{579}$ SZL, IV. évf. (1874) 39. sZ. 1.

${ }^{580}$ ÉF, I. évf. (1874) 10. sz. 1.; I. évf. (1874) 11. sz. 1.; I. évf. (1874) 12. sz. 1.
} 
ellenkampány vette kezdetét. Ennek egyik eszköze lett az 1883 tavaszán napvilágot látó, Darázs nevet viselő élclap, amely nyers stílusával, bizonyos személyeket, felekezeteket, népcsoportokat durván sértegető, sőt ellenük nyíltan uszító hangnemével nemcsak a hasonló célból létrehozott elődjén, az Északi Fényen tett túl, hanem példa nélkül áll a szentesi sajtótörténetben. ${ }^{581}$ A Darázs 1883. május 6-án indult, s mivel a Szentesi Lapot is gyártó Cherrier-nyomda feltehetően nem vállalta a sokszorosítását - vagy eleve nem is kértek ajánlatot rá -, a munkát a hódmezővásárhelyi Lévai-nyomdában, a harmadik számtól kezdve pedig a szegedi Burger-féle nyomdában végeztette el Vutsák Sándor laptulajdonos és felelős szerkesztő. Stammer Sándor alispán egykori joggyakornoka ismert személyiség volt a városban: 1882-ben mutatták be a szentesi színházban Szobacicus címü vígjátékát, emellett a kapitányi hivatal alkalmazottjaként dolgozott. ${ }^{582}$ Később Lőcsén kapott állást, ahol a magyar királyi pénzügyigazgatóság fogalmazója lett, és szépírói munkásságát is folytatta. ${ }^{583} \mathrm{~A}$ négyoldalas, vasárnaponként publikált mutatványszámnak már a címlapja sem hagy kétséget az orgánum politikai irányultsága felől: ${ }^{584}$

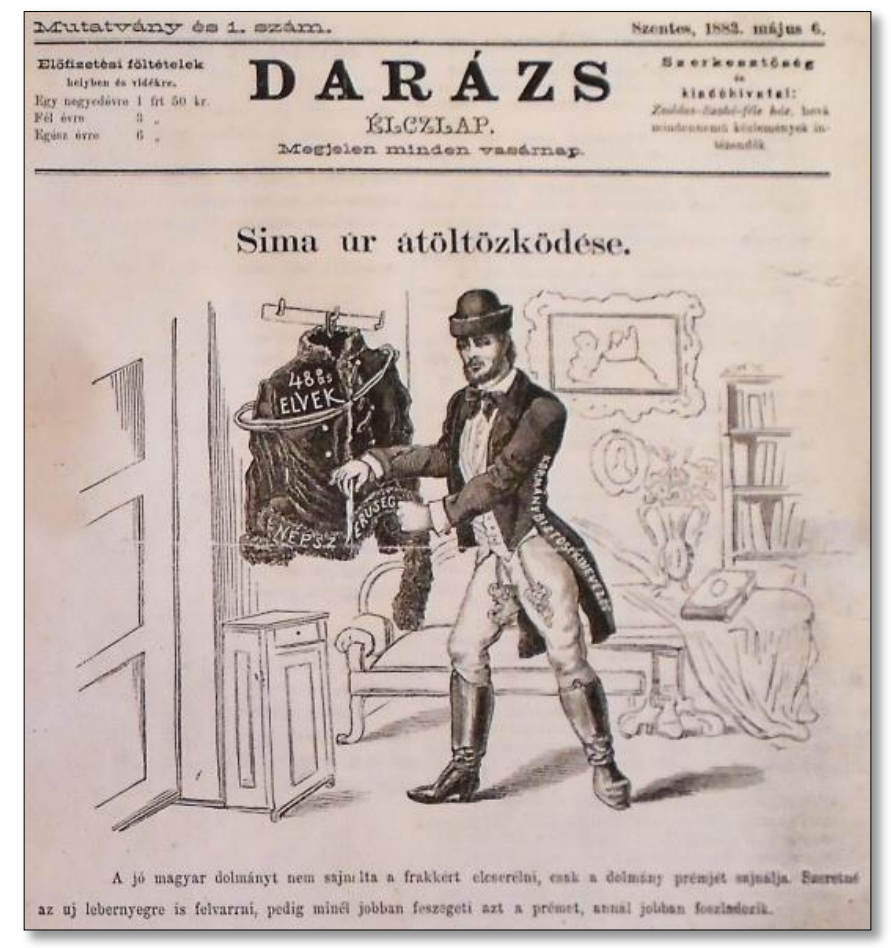

${ }^{581}$ Kis-Rácz 2000. (1.10.8. - A korszak sajtója); azonos névvel 1897 októberétől 1898 februárjáig, valamint 1911. áprilistól 1912. novemberig létezett hetente megjelenő élclap Hódmezővásárhelyen is. (Kárász 1974. 39.) ${ }^{582}$ Labádi 2003g. 2.

583 Fennmaradt müvei: A magyar Kánaán. Budapest, 1900. (ebben válaszolt Vadnay Andor főispán Tiszavidékről címü cikksorozatára); Egyetemi polgár. Budapest, 1900. (három felvonásos népi bohózat); illetve A politikai szarka (Budapest, 1901.), amelyben Horánszky Nándor politikai szereplését taglalja. (Szinnyei 1914. 1368.)

${ }^{584}$ Darázs, I. évf. (1883) 1. sz. 1. 
„A jó magyar dolmányt nem sajnálta a frakkért elcserélni, csak a dolmány prémjét sajnálja. Szeretné az uj lebernyegre is felvarrni, pedig minél jobban feszegeti azt a prémet, annál jobban foszladozik" - vádolja a rajz köpönyegforgatással a 48-as ellenzék szentesi vezéralakját, a Szentesi Lap felelős szerkesztőjét, Sima Ferencet, aki „Kóczos Ferkó” néven állandó szereplöje lett a Darázs gúnyos karikatúráinak. A másik fő céltábla Balogh János polgármester volt, aki a hasábokon „Bársony János” néven szerepel, de az újság nem bánt kesztyűs kézzel Sarkadi Nagy Mihály városi főkapitánnyal, valamint Cicatricis Pál főjegyzővel sem - mindannyian szintén a függetlenségi párt hívei voltak. ${ }^{585}$

Vutsák Sándor a második oldalon a következőképpen fogalmazza meg a lap célját Elöfizetési felhivás címü beköszöntő cikkében: „Czélunk kettős: egyrészt mulattatni, szórakoztatni az olvasó közönséget; másrészt közéletünkben szereplö férfiaink hibáira, ferdeségeire rámutatni, azokért megcsipkedni. Lehet, hogy fájni fog a csipés, de a fájdalmat gyógyulás fogja követni." ${ }^{586}$ Emellett kijelenti, hogy „mindenkinek becsülete és családi tüzhelye elöttünk szent" ${ }^{\prime 587}$ - vagyis tartózkodást ígér az alpári, megalapozatlan sértegetésektől, rágalmazásoktól. (Mindennek már az első szám címlapján közölt karikatúra ellentmond, s a későbbi számok szinte valamennyi írása, képi illusztrációja úgyszintén.) A beköszöntő cikkből megtudhatjuk még, hogy a karikatúrákat a budapesti Pollák Zsigmond, a Vasárnapi Ujság metszője készíti, emellett az írás közli a szerkesztőség címét (ZsoldosSzabó-féle ház, III. tized 248. sz.), illetve az előfizetési díjakat (egész évre: 6 forint, fél évre: 3 forint, negyed évre: 1 forint 50 krajcár). ${ }^{588}$

Az első szám a Simát kigúnyoló karikatúra, valamint a beköszöntő írás után Balogh János polgármestert illeti kemény kritikával $A$ csángók fogadtatása ${ }^{589}$ címü cikkben. A szerző szerint régebbi eseményről van szó, sokan talán már nem is emlékeznek rá, azonban a Darázs kénytelen visszatérni a témára, mivel olyan dolgokat tapasztaltak az ünnepélyes rendezvény alkalmával, amit nem lehet szó nélkül hagyni. A csángók első csoportjának fogadása ugyanis

\footnotetext{
585 Labádi 2003g. 2.

586 Darázs, I. évf. (1883) 1. sz. 2.

${ }^{587}$ Uo.

${ }^{588}$ Darázs, I. évf. (1883) 1. sz. 2.

${ }^{589}$ Az említett „csángók” valójában azokat a székelyeket jelentik, akik az 1760-as évek elejétől - amikor a bécsi udvar megindította a székely határörség erőszakos megszervezését - vándoroltak ki több hullámban Bukovinába. 1882 végén országos mozgalom indult a hazatelepítésük érdekében, amely kísérletre a következő év tavaszától került sor: külön bizottság - majd a Csángó-Magyar Egyesület - foglalkozott a szükséges anyagi források elöteremtésével, a költözni szándékozók összeírásával, valamint a teljes szervezőmunkával. 1883-ban, három hullámban, mintegy négyezer fő indult útnak Bukovinából - ennek az utazásnak az egyik megállója volt Szentes -, és telepedett le több faluban Pancsova környékén, a Duna mellett, illetve 1888-ban a Duna áradása miatt a Bácskában. A társadalmi szempontból kétes sikerü program később is folytatódott, Erdély különböző részeibe is számos családot telepítettek: a Déva melletti Csernakeresztúron például a mai napig a magyar anyanyelvü lakosság van többségben. (Sajti 1984.)
} 
- állítja a lap - kudarccal végződött, és nem is érdekes, ki miatt alakult így, elegendő maga a szomorú tény. „A második csoport fogadtatásával már kissé szerencsésebbek voltunk, habár be kell vallanunk, hogy ez sem elégithetett ki minden tekintetben bennünket. A nép mindkét alkalommal az igaz hazafiui lelkesedésnek nagyszerü jelét adta. [...] Egy ember azonban, kinek az adakozók között elsőnek kellett volna lenni, nem nyitotta meg tárczáját, sem éléskamaráját csángó testvéreink segélyezésére. Ez az ember, a város feje.” Balogh János a cikk szerint arra hivatkozott, mikor távolmaradását számon kérték, hogy mivel a kormány nyíltan nem avatkozik bele a dologba - hiszen nem akar diplomáciai bonyodalmat egy másik országgal -, akkor ö városvezetőként ezt szintén nem teheti meg. Ez védhető álláspont, azonban mint magánember miért nem jelent meg a fogadáson, miért nem tett adományt? érvel a cikkíró, aki szerint Balogh ezzel szégyent hozott az egész városra, majd a feltett kérdésre saját maga adja meg a választ: „a csángók nem választók”. ${ }^{590}$ A Szentesi Lap természetesen másképpen számolt be az eseményről 1883. április 14-i számában, amelyből megtudhattuk, hogy az ezernégyszáz fönyi csángót lelkes tömeg fogadta, a helyi lakosság nevében pedig a köszöntőbeszédet „lapunk szerkesztője” (tehát Sima Ferenc) mondta el. ${ }^{591}$

Sarkadi Nagy Mihály főkapitány, Vutsák volt munkaadója szintén már az első lapszámban megkapja a - lap szerint - neki kijáró gúnyos kritikát: „Ki ez a tudniillik? Bizony nehéz definitióját adni. Se nem ember, se nem állat, hanem olyan öszfér-féle. Külsejére nézve ember. Van jól ápolt böre, sima arcza és modora, a kliensek kegyelméböl pedig elegáns kabátja. A ki nem ismeri, meg merne rá esküdni, hogy: ember. [...] Legvalószinübbnek látszik az a feltevés, hogy nem is született, hanem úgy termett, mint a subagallér." Ezután az újságíró megemlíti: Sarkadi Nagy a Bach-korszakban zsandár örmester volt, így nehezen érthető, hogyan tölthet be az önkényuralom után hivatalvezetői pozíciót. Bár Vutsák nem írja alá a nevét, a cikkből egyértelmüen kiderül, hogy ő a szerző. Megtudhatjuk ugyanis, hogy személyes sértettségének mi a konkrét oka: éjszakánként hódolt írói szenvedélyének, „igy néha egy fél órával késöbben ment a hivatalba”, fönöke pedig ezt egy idő után megelégelte, és elbocsáttatta állásából a fiatal írnokot. ${ }^{592}$

A főkapitány később is rendszeresen szerepel az élcek tárgyaként, például egy humoros anekdotának szánt álhír arról tudósít, hogy egy szegény özvegyasszony hetekig volt kénytelen ácsorogni a kapitányi hivatal folyosóján, hogy panaszát előterjeszthesse. A hosszú várakozásban a nő megőrült: azóta „abban a rögeszmében szenved, hogy a kapitányi hivatal

\footnotetext{
${ }^{590}$ Darázs, I. évf. (1883) 1. sz. 2.

${ }^{591}$ SZL, XIII. évf. (1883) 15. sz. 2.

${ }^{592}$ Darázs, I. évf. (1883) 1. sz. 3.
} 
még az életében el fogja intézni az ö panaszát..." - figurázza ki a lap a szerinte túlságosan lassú ügyintézést. 593

A Darázs 1883. július 22-i számának (I. évf. 12. sz.) címlapján Sima Ferenc („Kóczos Ferkó”) és Balogh János polgármester - ezúttal a saját nevén - együtt látható. A karikatúra a közelgő választások okán ironizál: „Ugy csinálja már kend azt a hidat, hogy megbirja azt a vasutat. Nem szeretném, ha belezuhannánk abba a piszkos folyóba" - mondja Balogh a hidat ácsoló Simának, ahol a közelgő vonat a választásokat, a folyó az önérdeket jelképezi, a hídon pedig a „Csinált népszerüség” felirat szerepel.

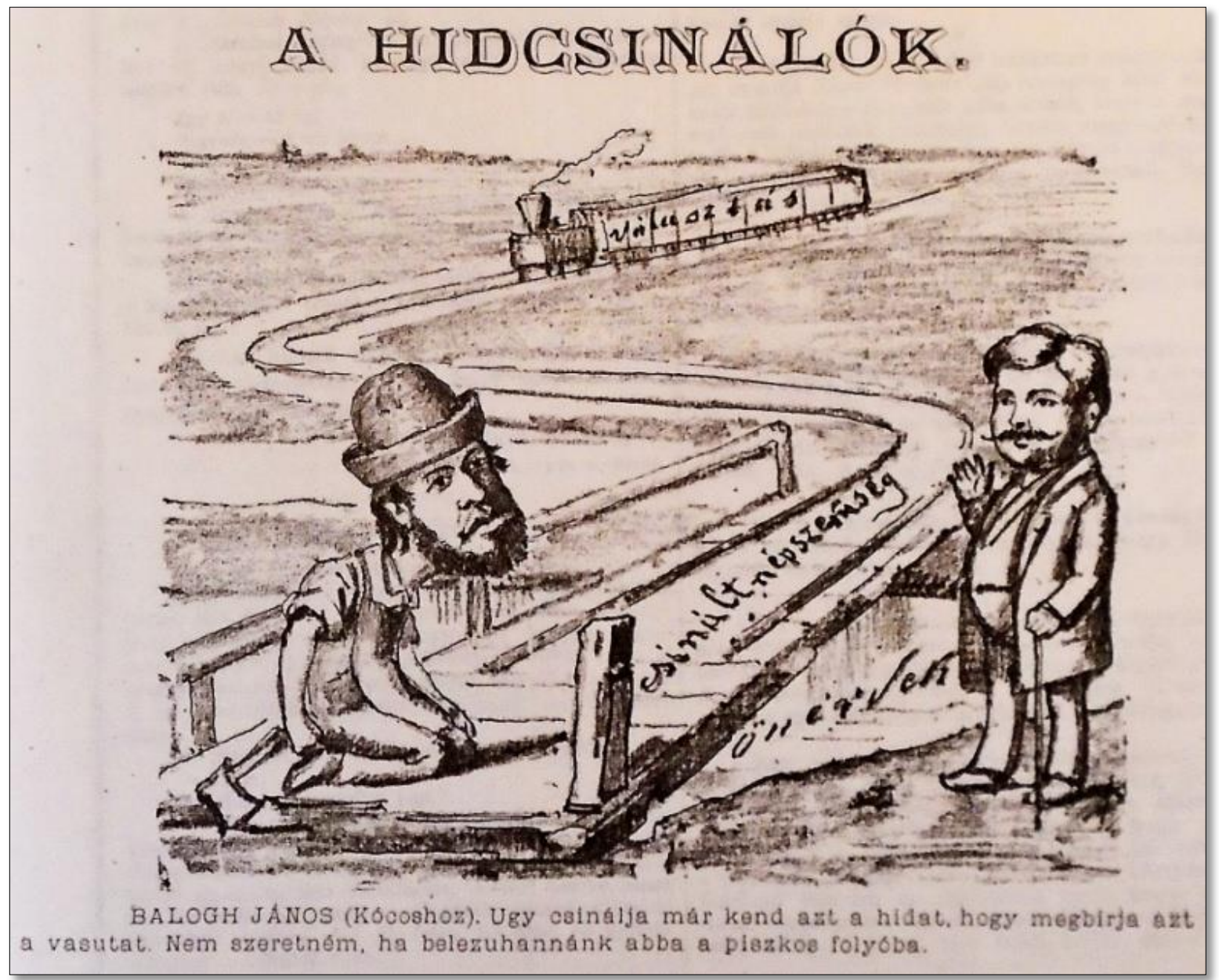

${ }^{593}$ Darázs, I. évf. (1883) 1. sz. 4. 
Az 1883. június 10-i (I. évf. 6. sz.) szám címlapja Szentes első sportegyesületét, a Korcsolyázó- és Csónakázó Egyletet gúnyolja ki, annak függetlenségi párti kötődése miatt: „Ki hitte volna, hogy ez a szép asszony ilyen idétlen gyermeket szül!”

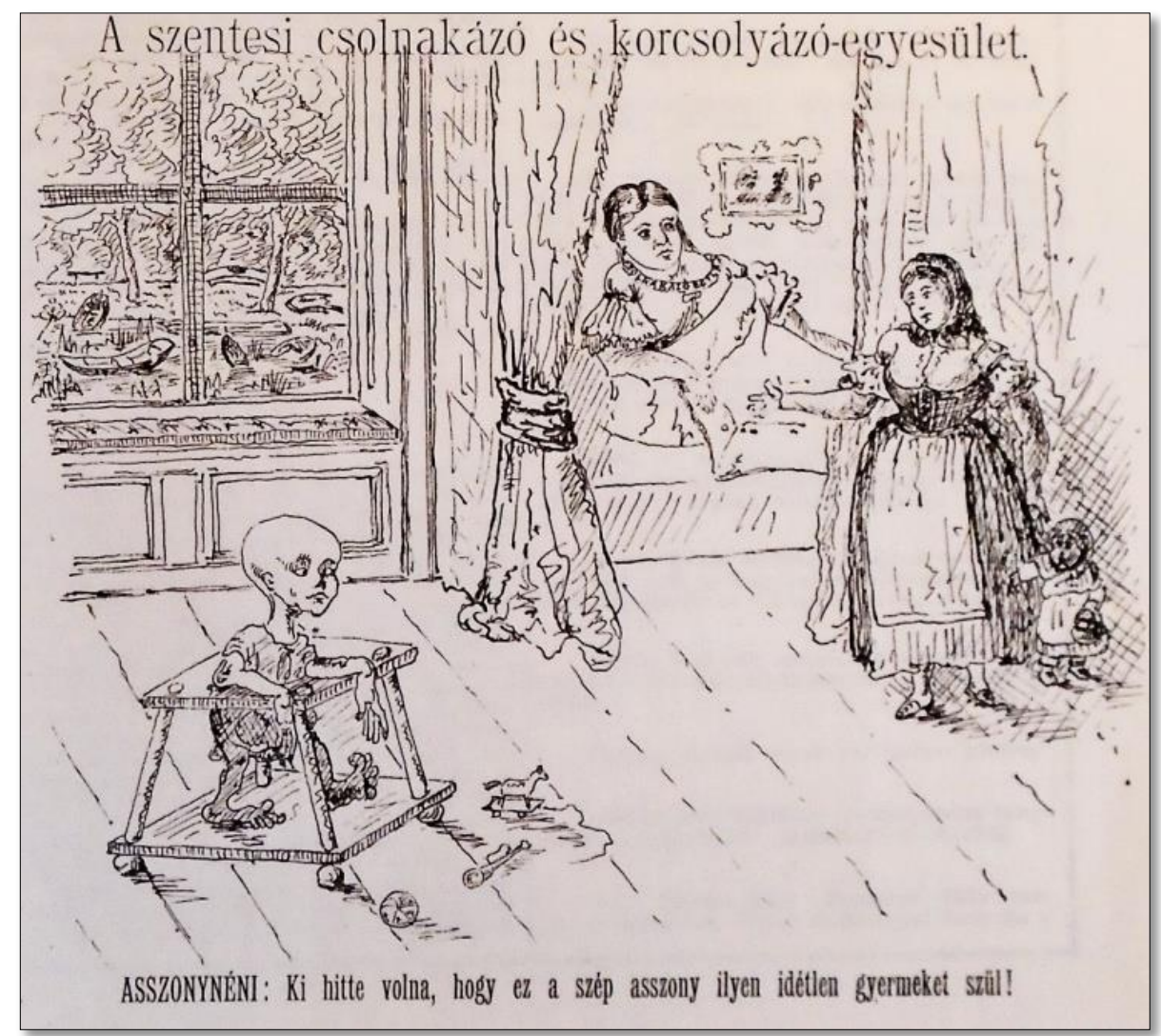

A politikamentes vicceket, humoros anekdotákat is bőségesen tartalmazó Darázs pellengérre állított mindent és mindenkit, aki bármilyen módon kötődött a regnáló városvezetéshez, illetve a 48-as párthoz, vagy csupán azért, mert érdemesnek találta a szerkesztőség a kigúnyolásra: a szentesi takarékpénztártól kezdve, a helyi vendéglőtulajdonoson, Rambovszky Józsefen keresztül egészen Bismarck kancellárig. Emellett nagy gondot fordított a Szentesi Lap, illetve az ekkor még a Szentesi Lap eszmei vonalát követő Szentes és Vidéke hetilap lejáratására is: „Miben különbözik egymástól a »Szentes és Vidéke« és szerkesztöje? Felelet: Mind a kettő irtózatos plundrán van kiállitva”; vagy: „A »Szentes és Vidéke« vesztit érezte, mikor a »Darázs« fészkébe nyult." ${ }^{\text {594 }} \mathrm{Az}$ említett lapot egy egyoldalas ál-számmal is kifigurázza, ${ }^{595}$ amelynek fejléce a következő:

\footnotetext{
594 Darázs, I. évf. (1883) 3. sz. 4.

595 Darázs, I. évf. (1883) 3. sz. 2.
} 


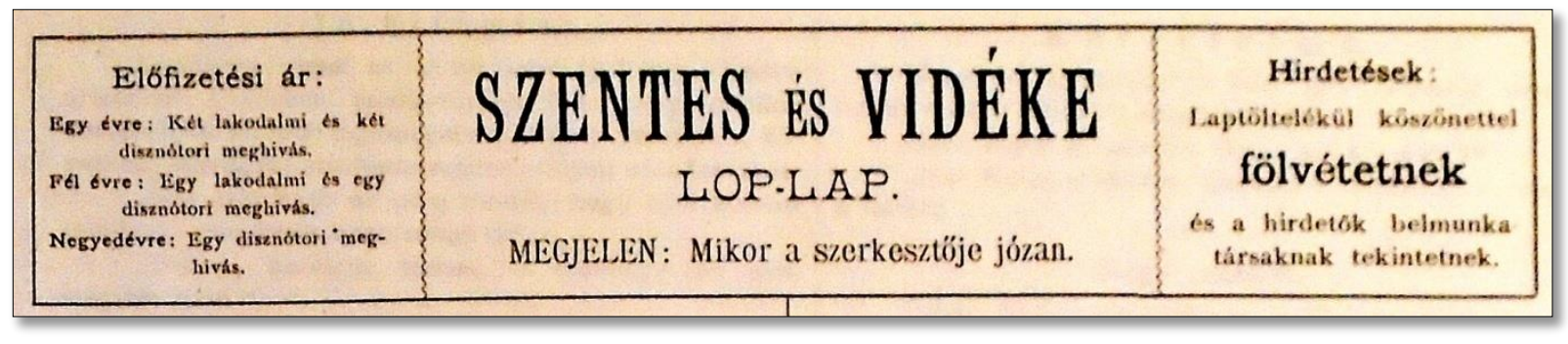

Az újság a Szentesi Lapot sem kíméli, és annak nem csak tartalmi részébe, hanem félreérthető megfogalmazásaiba, stilisztikai hibáiba is beleköt: „»Sarkadi fókapitány beszédjére Marschan a (?) szegedi jószág igazgatóság(i) titkára válaszolt, s azután a két hajón szállitott 900 székely magyar legnagyobb részben férfiak, asszonyok, legények, leányok és gyermekek. (Hát kisebb részben mik voltak?) Igazán meginditó volt látni, mikor a betelepülök a mi népünkkel összevegyülve férfiak a férfiakkal, asszonyok az asszonyokkal ölelkeztek össze és kölcsönös köny csillámlott a szemekben.«(Ez a »kölcsönös köny« egészen uj találmány, s ajánljuk a »Szentesi Lap«-nak, hogy kérjen rá szabadalmat.)”596 „Azt olvasom a »Szentesi Lap«-ban, hogy: »Csalódások láncolatából áll az élet.« Ugy látszik, kezd magába szállani. Bizony ö se gondolta, hogy olyan hamar lejárja magát."597

A szentesiek többsége körében nagy népszerüségnek örvendő közéleti személyiségek alpári stílusú kigúnyolása nem váltotta be a hozzáfüzött reményeket, s erre már a lap indulásakor találunk egyértelmű utalást: a második szám végén közli a szerkesztőség, hogy az újságot 15 krajcárért, példányonként is meg lehet vásárolni bizonyos könyvkereskedésekben tehát nem volt elég előfizető. ${ }^{598}$ (Az erre vonatkozó információ a következő lapszámtól kezdve már a fejlécen is szerepel az előfizetési díjak alatt.) Ráadásul a kisszámú olvasóközönség egy része nem fizette meg az előfizetési díjat, mint arra a tizenharmadik szám (1883. július 29.) második oldalán találhatunk felhívást: „Figyelmeztetem azon tisztelt elöfizetőimet, kik a mult évnegyedre eső elöfizetési dijat még utólagosan sem fizették meg, hogy a Krisztus koporsóját sem örizték ingyen. Azt hiszszük, hogy ez a figyelmeztetés egyelöre elégséges lesz."

A tulajdonos és támogatói egy idő után más módszerekkel is próbálkoztak az olvasottság növelése érdekében: a tizenkettedik számtól (1883. július 22.) egyrészt lehetőséget biztosítottak a havi előfizetésre is 50 krajcár ellenében, másfelöl egy állandó, ötoldalas mellékletet indítottak Szentesi Néplap címen (onnantól kezdve az élclap terjedelme

\footnotetext{
596 Darázs, I. évf. (1883) 6. sz. 4.

597 Darázs, I. évf. (1883) 12. sz. 2.

${ }^{598}$ Darázs, I. évf. (1883) 2. sz. 4.
} 
három oldalra csökkent, így az újság összességében a korábbi négyről nyolcoldalasra bővült), amely küllemében önálló társadalmi hírlap látszatát keltette. Még saját profilmegjelölést is alkalmazott (,heti közlöny”), azonban a két lapot csak együtt lehetett megrendelni, másfelől gyakorlatilag ingyenes volt, hiszen a Darázs előfizetési árai a melléklet megjelenése után vagyis a teljes terjedelem megduplázódását követően - sem változtak. A Szentesi Néplapot tehát semmiképpen sem tekinthetjük önálló orgánumnak, ahogyan a sajtótörténeti bibliográfiák sem teszik. ${ }^{599} \mathrm{Az}$ említett változásokat bejelentő számban Elöfizetési fölhívás címmel Vutsák - többek között - a következőket írja vállalkozása eddig eltelt időszakáról: „Dicsekvés nelkül elmondhatjuk azt is, hogy nem estünk az élclapok azon végzetszerü hibájába, hogy botrányokat hajhászszunk, hogy bárki becsületében gázoljunk és családi szentélyébe betolakodjunk. Lehet, hogy kiméletlenek voltunk olykor olykor, de hiszen annak, ki gyógyitani kiván, sokszor a sebet égetni kell." ${ }^{600}$ Az alacsony előfizetői számra utaló adatok, valamint a lap stílusa inkább ennek az ellenkezőjét bizonyítja. A legsértőbb támadások mind a karikatúrák, mind az írások tekintetében Sima Ferencet érték, bár Balogh János és Sarkadi Nagy Mihály sem sokban marad el a függetlenségi mozgalom szentesi vezetőjétől e téren. Vutsák önigazoló sorait - a már említetteken kívül - még egy Sima Ferencet gyalázó példával állítjuk szembe, amely az 1883. július 15 -i szám (I évf. 11. sz.) negyedik oldalán jelent meg:

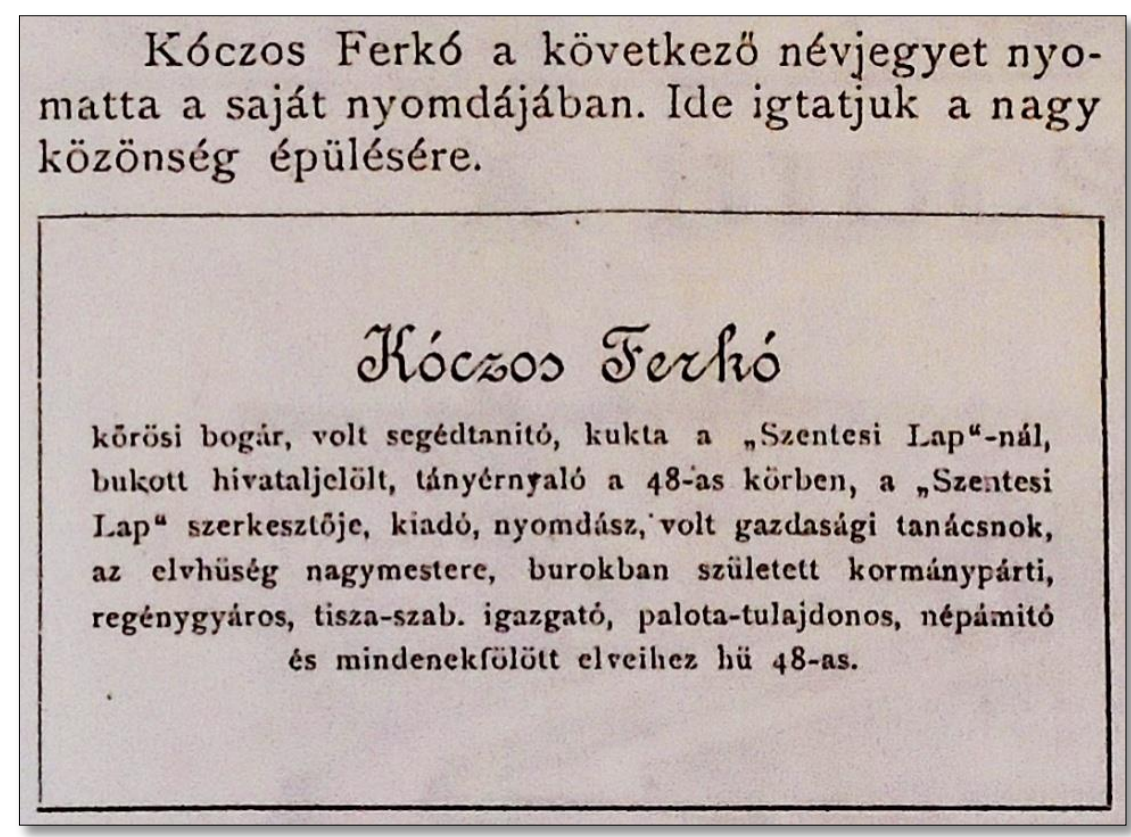

\footnotetext{
${ }^{599}$ Lásd: Kárász 1974. - a Csongrád megye sajtótörténet bibliográfiáját tartalmazó munka meg sem említi a Szentesi Néplapot.

${ }^{600}$ Darázs, I. évf. (1883) 12. sz. 2.
} 
A Szentesi Néplap hangvétele jóval visszafogottabb volt, felépítésében, rovatszerkezetében igyekezett igazodni a korszak klasszikus sémáihoz. A melléklet első oldalán határozott és kritikus hangvételü, de igényes és vállalható stílusú vezércikkeket olvashatunk, melyek témáit a város aktuális ügyei, eseményei jelentették: a rendőrség átszervezése, a Szentháromság-szobor ügye, a háziipar-kiállítás, illetve a Kurca bűzös vizének problémaköre, amely a kellemetlen szagon túl súlyos egészségügyi kockázatot is jelent a lakosság számára. Az 1883. augusztus 12-én publikált mellékletből értesülhetünk, hogy Vutsák fegyelmi ügye lezárult, a megye visszahelyezte őt a főkapitányi hivatalba. Az írásban a szerző - feltehetően maga Vutsák - helyesbíti önmagát: megtudjuk, hogy nem a főkapitány, hanem a polgármester mozdíttatta el annak idején az állásából, ráadásul nem személyesen (pedig erre neki is lett volna joga), hanem meggyőzte az alispánt: távolítsa el az írnokot, akinek „vétke abból állott, hogy egypár hivatalos órát elmulasztott”. ${ }^{601}$ Arról nem szólnak a források, milyen fogadtatás várta a fökapitányi hivatalba visszahelyezett Vutsákot, miután elbocsátása után lapjában nemegyszer tette gyilkos gúny tárgyává főnökét, Sarkadi Nagy Mihályt, mindössze egy szellemes utalást kapunk arra nézve, hogy nem sok jóra számíthat: „Eddig te csipted azokat az embereket, ezután meg majd ők fognak téged csipkedni."602

A mellékletben négy esetben találunk Tárca rovatot, amelyek közül egy az egyetemi hallgatók táncmulatságáról számol be, a másik három elbeszéléseket tartalmaz. A Csarnok rovat szintén az irodalomé, itt prózai műveket vagy verseket találunk. Olvashatunk továbbá híreket a település, Magyarország, valamint a nagyvilág vonatkozásában; találkozhatunk kivonattal a város híresztelési könyvéből, a Gazdászati és üzleti értesités rovat pedig közli a várható időjárást, illetve a tőzsdei gabonaárfolyamokat. Többször szerepelt a lapban kritika a város színtársulatának előadásairól is. Az utolsó oldal a hirdetéseké, amelyekkel kapcsolatban megjegyzendő, hogy a Szentesi Néplap melléklet indulása előtt a Darázs egyáltalán nem tartalmazott reklámot. Azonban mindössze három helyi vállalkozást láthatunk a lap hasábjain: a Várady-féle gyógyszertárat, Weisz Bernátné üveg-, porcelán- és bútorkereskedését, illetve a Littauer és Wellisch cég rövidáru-üzletét. Ezen kívül csupán egy budapesti, pénzszekrényeket gyártó cég hirdetésével találkozunk, valamint a szerkesztőség önreklámjával, amely szerint várják a hirdetőket a Darázs számára jutányos áron. Levonhatjuk tehát a következtetést, hogy - bár a lap nem volt hosszú életü, így kitartó marketingtevékenységre nem volt idő - a helyi vállalkozások néhány kivételtől eltekintve bojkottálták az élclapot, amely hamarosan komoly anyagi gondokkal szembesült.

\footnotetext{
${ }^{601}$ Darázs, I. évf. (1883) 15. sz. 4.
}

${ }^{602}$ Darázs, I. évf. (1883) 14. sz. 2. 
A címoldali karikatúrák elmaradtak a tizennegyedik számtól kezdve, a szerkesztőség be is ismerte, hogy nem tudja finanszírozni a fővárosi rajzolót és metszőt, ${ }^{603}$ a lapban pedig a politikai szatírát, illetve a pártatlan humort egyre jobban háttérbe szorította a gyülölködés, amelynek a közéleti szereplőkön kívül új céltáblája akadt: a zsidóság. ${ }^{604}$ Az országosan megfigyelhető tendencia fő okait Tamás Ágnes a következőképpen foglalja össze a nemzetiségi sztereotípiákat a sajtó tükrében bemutató kötetében: „A 19. század utolsó harmadában a zsidóság szerepe felértékelödött a modernizációban, illetve a modern kapitalista pénzpiac és bankrendszer kialakitásában a Monarchia mindkét államjogi egységében, ami egyesek látványos gazdagodásával és társadalmi felemelkedésével - például nemesitéssel - járt együtt. Sikerük nemcsak az izraeliták keleti bevándorlását serkentette melyet az oroszországi és romániai zsidóüldözések is motiváltak -, hanem ellenséges reakciókat is kiváltott, ami a politikai antiszemitizmusban csúcsosodott ki." A történész rávilágít: a zsidóság lélekszáma az Osztrák-Magyar Monarchia nagyobb városaiban, elsősorban pedig a két fővárosban, Bécsben és Budapesten jelentősen megnőtt, így több területen - például: kultúra, szórakoztatás - felülreprezentáltakká váltak. ${ }^{605}$

Az 1883-as egyébként is - negatív értelemben - kiemelkedő esztendőnek minősül, hiszen ekkoriban zajlott a hírhedt tiszaeszlári vérvád ${ }^{606}$ pere, amely különösen felkorbácsolta az antiszemita indulatokat Magyarországon, és a Darázs is beállt az uszítók sorába. ${ }^{607}$ Ezzel a

${ }^{603}$ Darázs, I. évf. (1883) 14. sz. 1.

${ }^{604}$ Labádi 2003g. 2.

${ }^{605}$ Tamás 2014. 43.

${ }^{606}$ A tiszaeszlári vérvád alapja a keresztény Solymosi Eszter eltünése volt 1882. április 1-jén. A fiatal cselédlányt gazdasszonya, Huri Andrásné küldte a falusi boltba, hogy vegyen festéket, de hazafelé jövet a lánynak nyoma veszett. A helyi lakosság a zsidókat vádolta meg rituális gyilkossággal, akik éppen a pészah előtti szombatot megünnepelni gyültek össze a tiszaeszlári zsinagóga épületében. Az ügyből végül vádemelés lett tizenöt személlyel szemben, az elsőfokú tárgyalást a nyíregyházi törvényszéken tartották 1883. június 20. és augusztus 3. között. A vádlottak védelmét a függetlenségi párti Eötvös Károly képviselő és ügyvéd vállalta el, aki július 30-án megtartotta később híressé vált, hétórás védőbeszédét. A bíróság végül felmentő ítéletet hozott, ami további viharokat kavart az addigra felszított közvéleményben. Számos helyen antiszemita zavargások törtek ki, amelyek erőszakos feloszlatása Zala vármegyében halálos áldozattal is járt. A Magyar Királyi Kúria egy évvel később jogerőre emelte az ítéletet, így az ügy lezárult, viszont számos kedvezőtlen - s részben a mai napig tartó - utóhatása volt, például javarészt a tiszaeszlári vérvád nyomán kialakult néphangulatnak köszönhető, hogy az Istóczy Győző által 1883. október elején megalapított Országos Antiszemita Párt mind az 1884-es, mind pedig az 1887-es választásokon bejutott a parlamentbe. (Gyurgyák 2001. 285-286.; Csernus 2014., Gergely 1978. 167-174., Tamás 2014. 43-46., bővebben lásd Kövér György: A tiszaeszlári dráma. Osiris, Bp., 2011.)

${ }^{607}$ A zsidókon kívül a cigányságot is érték támadások az élclapban, pl.: „Nagy szél fujt, mikor a cigány éppen retket lopott a kasznár kertjében. Nem vette észre a kasznár közeledtét, ki azután jót huzott a cigány hátára. - Ne issen a tees ur, his látja, hogy azsirt kapaskodom ebbe azs ebnek kellö retekbe, hogy a szil el ne issen a lábomrúl." (Darázs, 1883. július 29., I. évf. 13. sz., 2.) „A korszak cigányellenes retorikája erösödött a 19. század utolsó évtizedére, az idöszak cigánypolitikája szorosan összefügg annak szegénységpolitikájával. A hontalan cigányok testesitették meg a kortársak szemében a munkakerülö, a lusta, haszontalan személyeket, akiket a társadalom - szó szerint is - igyekezett kiszoritani" - írja a többi élclapban is rendszeresen feltünő cigány-sztereotípia hátteréröl Tamás Ágnes. (Tamás 2014. 47.) 
lappal szembeni általános ellenszenv csak fokozódott, hiszen Szentesen akkoriban jelentős számú, közel ezerfős, jól szervezett zsidó közösség élt. ${ }^{608}$

Az első, zsidókra vonatkozó negatív véleménynyilvánítás a Darázs 1883. június 30-i számának (I. évf. 9. sz.) címoldalán jelent meg, s a karikatúra egyértelmüen tükrözi a lap állásfoglalását:

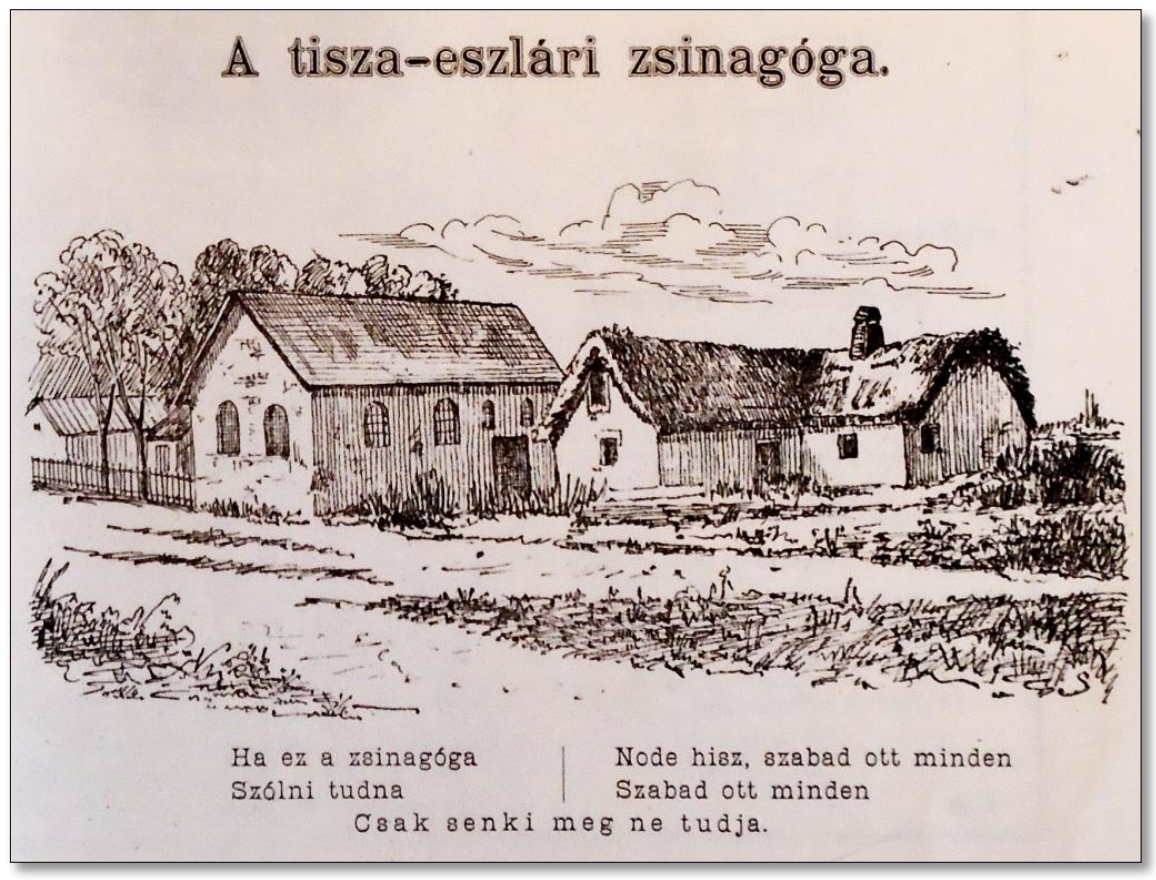

Innentől fogva jelennek meg a hasábokon a zsidóságot kritizáló, gúnyoló írások, s nem csupán az említett büntetöügy kapcsán. „A kis Scharf Móricot a zsidók örültnek deklarálják. Ez bizony furcsa eljárás. Találkozik köztük egy okos ember és arra is azt mondják, hogy: örült."609 „Azt mondja a napokban a »Darázs«, hogy ne irjak többet az ujságába olyan antiszemitikus dolgokat, mert ö reá haragusznak a zsidók. Vigasztalódjál, - mondom én nekiazok csak a becsületes emberre haragusznak." 610 „A sakterek, a lelkiismeret által furdalva, bevallották Solymosi Eszter meggyilkolását. (Jóllehet e hirt a leghitelesebb forrásból kaptuk, de a mennyiben a »sakterek lelkiismeretéröl« van szó, csak föntartással közöljük. Szerk.)"611 „Hányat dobsz egy hatosért a kilencböl? - kérdi egyik kuglista a másikat. - Ha a zsidó sakterek fejei volnának fölállitva, szeretnék minden dobásra 14-et dobni, - válaszolt a

\footnotetext{
${ }^{608}$ Labádi 1995. 273.; Szentesen eleve nem sok esélye volt az antiszemita indulatok gerjesztőinek: az apróbb súrlódásoktól eltekintve, a keresztény többséggel való sok évtizednyi békés - sőt mindkét fél számára többnyire gyümölcsöző - egymás mellett élés nem engedett teret a gyülölet elharapózásának. (Harsányi 1970. 86-87.)

${ }^{609}$ Darázs, I. évf. (1883) 10. sz. 2.; a fiatalkorú Scharf Móric vallomása volt a tiszaeszlári ügyben a vád egyik fö alapja (Csernus 2014.)

${ }^{610}$ Darázs, I. évf. (1883) 10. sz. 2

${ }^{611}$ Darázs, I. évf. (1883) 10. sz. 4.; sakter: közkeletü kifejezés a héber sohét, vagyis mészáros szóra, akinek feladata a vágóállatok leölése és feldarabolása (http://www.zsido.hu/rabbi/rabbi.php?old=122, letöltés: 2017. augusztus 25.)
} 
másik."612 A tizennegyedik szám (1883. augusztus 5.) második oldalán már alpári stílusú, nyílt uszítást találunk, ${ }^{613}$ rímekbe szedve, „Antiszemita” tollából:

Szózat a magyar néphez.

Jól jegyezd meg keresztény magyarom:

Zsidótól pálinkát ne végy semmi áron!

Söt ha eröszakkal töltené szájadba,

Köpjed a zsidónak cudar pofájába!

Fukszinos borával ne mérgezd meg magad,

Mert korai halál hamar sirba ragad.

Semmi élelmiszert ne végy a zsidónál,

Mert a zsidó minden piszkot összezagyvál.

Azt mondván magában: jó ez a gójoknak,

Hogy a földröl hamar mind el pusztuljanak.

Mi pedig azt mondjuk, magyar keresztények:

Ha mi gójok vagyunk, zsidók jaj tinéktek!

Fölmondunk már nektek minden szolgálatot,

Szép Magyarországból, hogy kipusztuljatok!

És menjetek vissza, honnan kijöttetek:

Palesztina legyen rút, piszkos fészketek!

A visszafogottabb Szentesi Néplap melléklet is beszállt a hangulatkeltésbe, a hírrovatában többször igyekezett olyan eseményekről tudósítani, amelyek okot adhattak a zsidókkal szembeni ellenszenvre, így pedig alátámaszthatták a tiszaeszlári vádemelés jogosságát. A tizenharmadik lapszám például arról ad hírt, hogy egy Banilla nevü külföldi községben Weisz Jakab üzletvezetőt fanatikus zsidó hitsorsosai megkövezték. Weisz egy szombati nap délutánján lóháton utazott hazafelé, ez pedig ellenkezik a zsidó vallás törvényeivel. Mikor a sértett a lováról lebukott, egy örjöngő zsidó egészen a csontig harapott bele a bal kezébe. Az összefutott parasztok végül kiragadták a szerencsétlenül járt embert a dühöngő zsidók karmaiból, majd később a zsandárok is megérkeztek a helyszínre. ${ }^{614}$

Az augusztus 5-én megjelent tizennegyedik szám hatodik oldalán - tehát a Szentesi Néplap mellékletben - az újság beszámolt a tiszaeszlári per végéről, még az ítélethirdetést megelőzően, a Heti krónika rovatban. Eszerint a zsidók ügyvédei megtartották védőbeszédeiket, de nem valami nagy sikerrel. Ahelyett ugyanis, hogy a vádlottak ártatlanságát bizonyították volna, a másik oldalt sértegették és gyanúsítgatták - egyikük ellen

\footnotetext{
${ }^{612}$ Darázs, I. évf. (1883) 13. sz. 3.

${ }^{613}$ Mindez azonban a korszakban nem számított kirívónak, inkább tipikus esetnek mondható. (Vö. Tamás 2013. 277-285.)

${ }^{614}$ Darázs, I. évf. (1883) 13. sz. 6.
} 
rágalmazásért pert is indítottak. A cikk érezhető iróniával emeli ki Eötvös Károly szerepét: „, hat és egy negyed óráig tartó beszédet mondott, s hogy némi fogalmunk legyen e roppant terjedelmü beszédröl, fölemlitjük, hogy e beszéd harmincezer szóból állott s megtáviratozása huszonkét teljes órát vett igénybe. A leirásához egy embernek folytonos irás mellett 49 órára volt szüksége." 615 Ugyanazon az oldalon, a Hirek rovatban még egy információt kapunk az ügyről: a megvádolt sakterekről állítólag megfelelő kezek már előre gondoskodtak: mihelyst szabadlábra kerülnek, rögtön Pestre viszik fel őket, ahol az ortodox izraelita egyháznál kapnak majd jól fizető állást. „A sarokigazság tehát, hogy kiki érdemei szerint jutalmaztatik, itt csufondárosan arcul lesz verve!"'616

A per lezárulta, a felmentő ítélet ellenére a Darázs következetesen folytatta az uszítást, $\mathrm{s}$ erre külön rovatot is szentelt Adatok a mi zsidóinkról címmel. Ennek indulásakor a szerkesztőség lábjegyzetben közli is az olvasókkal: „Ezen a cimen állandó rovatot nyitunk, $s$ fölkérjük a t. olvasóközönséget, hogy minden a zsidók szemtelenségét, kapzsiságát föltüntetö adatot velünk közölni sziveskedjenek." ${ }^{617}$ A rovatban valós vagy kreált híreket, anekdotákat olvashatunk a zsidókkal kapcsolatban, amelyek természetesen kivétel nélkül rossz színben tüntetik fel öket. Az egyik ilyen szerint K. József szentesi tanító hét mázsa búzát akart eladni egy Schvarcz nevü terménykereskedőnek. Mielőtt a gabonát a zsidó megvásárolta volna, a tanító megmérette. Azonban az árut megmérte a zsidó is a saját mázsáján, és az negyven kilóval kevesebbet mutatott. A tanító nem egyezett bele a negyven kilogramm levonásába, így az üzlet meghiúsult. K. József később elvitte a búzát Purjesz Henrikhez, ahol pedig a mázsa harminc kilóval többet jelzett. „Ez az eset kirivóan bizonyitja azt, hogy mily lelkiismeretlenségeket követnek el a mázsálásoknál a zsidók a haszon érdekében; de másrészt szomoruan illusztrálja ezen eset azt is, hogy hatóságunk, melynek föladata volna a mértékek ellenörzése, e részben kötelességét hiányosan teljesiti." ${ }^{618}$

Ezen kívül megtudhatjuk, hogy az utcán játszó zsidó gyerekek a legősibb foglalkozások egyikével hangosan azonosítva sértegettek mellettük elhaladó keresztény nőket; ${ }^{619}$ hogy egy Purjesz Móric nevű zsidó komoly összeggel átverte Sarkadi Nagy Ferencet ${ }^{620}$ vagy hogy egy zsidó hölgy a női szabójával hitelben csináltatta meg a ruháját, és tartozását nem egyenlítette ki. ${ }^{621}$ A rovat értesíti a nagyközönséget arról is, hogy ,Mióta a

\footnotetext{
${ }^{615}$ Darázs, I. évf. (1883) 14. sz. 6.

${ }^{616}$ Uo.

${ }^{617}$ Darázs, I. évf. (1883) 15. sz. 2.

${ }^{618}$ Darázs, I. évf. (1883) 17. sz. 1.

${ }^{619}$ Uo.

${ }^{620}$ Darázs, I. évf. (1883) 16. sz. 1-2.

${ }^{621}$ Darázs, I. évf. (1883) 15. sz. 2.
} 
»Darázs« a tisza-eszlári ügyben az igazság mellett állást foglalt, azóta a zsidók folyton inzultálják. Mocskos nyelvük természetesen személyünket és becsületünket akarja bepiszkolni.”622 Akadnak azonban lelkes - „Antiszemiták” néven aláíró - olvasók, akik segítségére sietnek a zaklatásoktól szenvedő szerkesztőségnek: „Tek. szerkesztő ur! Arról értesültünk, hogy önt azért, mert az igazságot megmeri mondani, több oldalról, de különösen a zsidók részéröl azzal fenyegetik, hogy meg fogják önt verni. Ez a fenyegetés ne riaszsza önt vissza. Mi elhatároztuk, hogy meg fogjuk védeni az ön személyét. Résen leszünk s ha valaki csak egy ujjal is meri önt bántani, keservesen fogja megbánni vakmeröségét." "623 A szerkesztőség meleg hangú válaszban köszöni meg a nemes felajánlást barátainak, s egyben megnyugtat mindenkit, hogy nem fog meghátrálni az ilyen fenyegetésnek tünő üres hencegések elől. ${ }^{624}$

A népszerütlenségből adódó anyagi nehézségek miatt az 1883. szeptember 2-i lapszám (I. évf. 18. sz.) már nem tartalmazta a Szentesi Néplap mellékletet, így a Darázs visszavedlett négyoldalas élclappá, de már csak egyetlen alkalom erejéig. Még megtudhatjuk, hogy szemtelen zsidó gyerekek ismét békés járókelőt inzultáltak az utcán, ezúttal éppen Balogh János polgármester kisfiát, a védelmére siető idős hölgyre pedig a nyelvüket öltögették. ${ }^{625} \mathrm{~A}$ címlapon zsidókat kifigurázó karikatúra látható, a későbbiekben pedig szintén zsidókat gúnyoló írásokat, valamint egy hasonló témájú verset olvashatunk. Az említett szám után a lap - előzetes bejelentés nélkül - megszűnt.

Összességében elmondható, hogy a szatíra, az irónia, sőt a maró gúny sem volt szokatlan jelenség a korabeli országos sajtóban, viszont a vármegyét, illetve a kormányt támogató - s így Szentesen ellenzékinek számító - érdekcsoportok által életre hívott Darázs, tekintve a városban különösen kiélezett szembenállást a két tábor között, a megszokottnál még durvább hangvételt alkalmazva próbálta lejáratni politikai ellenfeleit. A kísérlet azonban - akárcsak az Északi Fény esetében - fordítva sült el: a többségében 48-as elveket valló, a település fejlődése mellett elkötelezett vezetőit megbecsülő helyi lakosság körében visszatetszést keltett a lap, amely alig négy hónapig tartó megjelenés után - előfizetők és hirdetők híján - kénytelen volt befejezni müködését.

\footnotetext{
${ }^{622}$ Uo.

${ }^{623}$ Darázs, I. évf. (1883) 17. sz. 1-2.

${ }^{624}$ Darázs, I. évf. (1883) 17. sz. 2.

${ }^{625}$ Darázs, I. évf. (1883) 18. sz. 2.
} 


\title{
4. A szentesi sajtó megteremtője: Cherrier János
}

\subsection{Nagyősztől Léváig (1839-1866)}

\author{
Cherrier János a Torontál vármegyei Nagyőszön ${ }^{626}$ született 1839. április 15-én, római \\ katolikus családban. Édesapja Georg Cherrier - francia emigránsok ${ }^{627}$ leszármazottja -, \\ édesanyja a német Maria Getsch volt. ${ }^{628}$ (A család legnevesebb, nagy ívű karriert befutott
}

\begin{abstract}
${ }^{626}$ A Nagyszentmiklós közelében fekvő Nagyősz - régebbi írásmód szerint: Nagy-Ősz - település ma Temes megyéhez tartozik, németül Triebswetter, románul Tomnatic. Lakosai a dualizmus idején még döntő többségében római katolikus vallású németek voltak. (Reiszig é. n.)

${ }^{627}$ A XVIII. század folyamán, a török kiüzése után érkeztek franciák a Bánát területére. Kisebb részben a bevonuló császári csapatokban szolgáló francia katonákról, illetve - az osztrák örökösödési háború idején deportált hadifoglyokról van szó, túlnyomó többségükben azonban polgári foglalkozású telepesekröl. A Cherrier szülőfaluját jelentő Nagyősz az egyik fő célpontja volt a francia telepeseknek, akik néhány évtized alatt javarészt beolvadtak az öket befogadó német ajkú közösségbe, és a gyors asszimilációban nagy szerepet játszott a németek részéröl tapasztalható intolerancia: a feljegyzések szerint tilos volt Nagyőszön a francia nyelv nyilvános használata, volt, akit ezért deresre húztak a községben. Más adatok szerint azonban a francia telepesek által részben benépesített bánáti falvak közül éppen Nagyősz tartott ki a legtovább a kultúra megőrzése szempontjából: akadtak olyan falubeliek, akik még a XX. század elején is beszélték őseik nyelvét. (Palásti 1958.
\end{abstract} 155-161.)

${ }^{628}$ RNL TL, a római katolikus egyház születési anyakönyvei, Nagyősz, 5. k., 1833-1864. 44. o.. Megjegyzendő, hogy a születés valódi helyének kiderítése - több tényező miatt - nem kis feladatot jelentett, mivel a szakirodalomban többen tévesen Törökszentmiklóst tüntetik fel (időpontnak pedig 1838-at), azonban ez elsősorban a források hibája. A nyomdász egyik Szentesen született gyermekének anyakönyvi bejegyzésénél ugyanis a szülők-rovatban a következő szerepel: „Cherrier János rk. nyomdász, Török-Szentmiklós” (MNL CSML Szentes, IV.B.434.a. - Csongrád Vármegye Felekezeti Anyakönyvi Másodpéldányainak Levéltári Gyüjteménye - A római katolikus egyházközségek anyakönyveinek másodpéldányai, Szentes, az 1877. év születési anyakönyve, 110. sz. bejegyzés). A vonatkozó törökszentmiklósi anyakönyveket leellenőrizve azonban nem találtunk ilyen nevü egyént. Tovább bonyolította a helyszín meghatározását, hogy a nyomdász egy másik, szintén Szentesen napvilágot látott gyermeke anyakönyvezésekor az apa immáron nem törökszentmiklósinak, hanem pozsonyi születésünek - vagy tartózkodási helyünek - vallotta magát (MNL CSML Szentes, IV.B.434.a. - Csongrád Vármegye Felekezeti Anyakönyvi Másodpéldányainak Levéltári Gyüjteménye - A római katolikus egyházközségek anyakönyveinek másodpéldányai, Szentes, az 1878. év születési anyakönyve, 221. sz. bejegyzés), viszont az ottani dokumentumokban (lásd: a pozsonyi római katolikus egyház születési anyakönyvei, forrás: $\quad$ https://www.familysearch.org/ark:/61903/3:1:33S7-8BT7-DL6?owc=9P3P92Q\%3A107654301\%2C107722701\%3Fcc\%3D1554443\&cc=1554443, letöltés: 2017. október 10.) sem szerepel Cherrier János nevű egyén. Nem tudható és nem is érthető, hogy Cherrier miért diktálta be az említett, egymástól eltérő adatokat két gyermeke keresztelésénél is. Ráadásul a nyomdász halotti anyakönyvi bejegyzésénél - az ebben a névváltozatban soha nem is létező - „Nagy Kunszentmiklós”-t írtak be születési helynek, amely végképp megnehezítette a tisztánlátást a kérdésben (a kunszentmiklósi római katolikus plébánia halotti anyakönyvei, 1886. év, 73. sz. bejegyzés). Támpontot a probléma megoldásához a már említett Cherrier Miklós jelentett, aki bizonyítottan Nagyőszön született, s ez már okot adott a további kutatás sikerébe vetett reményre, hiszen Nagyősz Nagyszentmiklós város közelében fekszik, így a 'Szentmiklós', mint kétszer is - igaz, tévesen: Török- és Kunszentmiklós - előforduló névalak sejtetni engedte, hogy a ritka vezetéknevü nyomdász rokonságban áll a pozsonyi kanonokkal. Szinte bizonyossá váltunk közben feltételezésünk igazában, mikor megtaláltuk Cherrier János házassági anyakönyvi bejegyzését (a nyitrai római katolikus egyház házassági anyakönyvei, 1865. év, 31. sz. bejegyzés, forrás: https://familysearch.org/ark:/61903/3:1:33S7-8BT3TP6? mode $=\mathrm{g} \& \mathrm{i}=9 \& \mathrm{wc}=9 \mathrm{PQ} 3-$

SP8\%3A107654301\%2C107660801\%2C110064602\%2C141441901\&cc=1554443, letöltés: 2017. július 5.), ahol már „Triebswetter”, tehát Nagyősz szerepel születési helyként. Végül, az eredeti születési anyakönyvi bejegyzés megtalálása tett pontot az ez irányú kutatás végére. 
tagja Cherrier Miklós hittudós, pozsonyi kanonok. ${ }^{629}$ ). Gyermek- és fiatalkoráról - források híján - keveset tudunk, azonban annyi valószínüsíthető, hogy Bécsben tanulta ki a mesterséget, illetve ott töltötte első éveit is a szakmában, hiszen mikor 1864-ben Nyitrára ment letelepedési és iparüzési szándékkal, a városhoz benyújtott kérelméhez a bécsi L. C. Zamski és C. Dittmarch nyomdából származó munkákat csatolt mellékletként. ${ }^{630}$ Nyitrán azonban akkor már két nyomda is müködött. ${ }^{631}$ Mindenesetre Cherrier 1864 nyarán megkezdte - engedély nélküli - tevékenységét a településen. A konkurencia mindezt nem nézte jó szemmel, és néhány hónap alatt elérte, hogy a helytartótanács visszavonja a várostól kapott engedélyt. A nyitrai alispán ekkor azt javasolta Cherriernek, hogy tegye át székhelyét olyan területre, ahol még nem alapítottak nyomdákat, például Turócba, Liptóba vagy Barsba. Az ifjú nyomdász az utóbbi mellett döntött, és Lévára költözött. ${ }^{632}$ A rövid ideig, hozzávetőlegesen egy esztendeig tartó nyitrai tartózkodás üzleti szempontból tehát kudarcot jelentett a fiatal nyomdásznak, azonban a magánéletben sikert ért el: megismerkedett későbbi feleségével, Sturcz Juliannával, aki a nyitrai járáshoz tartozó Ürményben született 1843. november 23-án, Sturcz György és Majvalder Mária gyermekeként. ${ }^{633}$ A pár 1865. május 29én kelt egybe Nyitrán, de ekkor Cherrier már bizonyosan Léván élt - felesége pedig nyitrai lakos volt -, mint azt a házassági anyakönyv is tartalmazza. (A dokumentum emellett visszaigazolja a születési dátumokat is: a bejegyzés szerint a frigy létrejöttekor a nyomdász a huszonhatodik, neje pedig a huszonkettedik életévében járt. $)^{634}$

A másik bizonyíték Cherrier új lakhelyére, hogy a források szerint a házasságkötés idején, tehát 1865 májusában már állított ki számlákat Léván a helyi gimnázium, a csizmadiacéh és a kaszinó számára is, ráadásul feltehetően olyannyira bízott kérelme pozitív elbírálásában, hogy meg sem várta a hatósági engedélyt: vállalkozása az első időszakban gyakorlatilag illegálisan müködött, akárcsak Nyitrán. Végül 1865. október végén a magisztrátus engedélyezte tevékenységét, amely előbb a Mártonfi (ma Hviezdoslav) utcában, a zsinagóga épülete mellett, később a nyomdász saját házában, a Széchenyi (ma Szent

\footnotetext{
${ }^{629}$ Szinnyei 1893. 39-41.

630 Švoliková 2008. 110.

${ }^{631}$ Novák 1928. 69.

632 Švoliková 2008. 110.

${ }^{633} \mathrm{Az}$ ürményi római katolikus egyház születési anyakönyvei, 1843. év, 23. sz. bejegyzés (forrás: https://www.familysearch.org/ark:/61903/3:1:33S7-8BT7-DL6?i=12\&cc=1554443, letöltés: 2018. január 2.)

${ }^{634}$ A nyitrai római katolikus egyház házassági anyakönyvei, 1865. év, 31. sz. bejegyzés (forrás: https://www.familysearch.org/ark:/61903/3:1:33S7-8BT3-TP6?i=9\&wc=9PQ3 -

SP8\%3A107654301\%2C107660801\%2C110064602\%2C141441901\&cc=1554443, letöltés: 2017. október 5.)
} 
Mihály) utcában folyt. ${ }^{635}$ Cherrier első munkája, amelyet Léván készített, a Barsmegyei Gazdasági Egyesület értesítője volt. ${ }^{636}$

Cherrier János valószínűleg úttörőnek számított Léván: bár egy szlovákiai, nyomdatörténeti összefoglaló említ egy korábbi, kérészéletü, hasonló kezdeményezést a településen, levéltári források ezt nem igazolják. Az viszont kétségtelen, hogy a város első huzamosabb ideig müködő, levéltári források által is bizonyíthatóan létező nyomdáját Cherrier hozta létre, így ipartörténeti jelentősége vitathatatlan. ${ }^{637}$ A huzamosabb idő azonban alig jelentett többet, mint a Nyitrán töltött időszak: a lévai városi tanáccsal ellentétben a vármegyei hivatal nem támogatta vállalkozását, így Cherrier János 1866-ban ismét költözésre kényszerült. ${ }^{638}$

\subsection{A gyöngyösi nyomda (1866-1871)}

Nyomdászunk Gyöngyösön állította fel üzemét, amelyhez hasonló addig még nem müködött a városban. A házaspár első gyermeke, Mária Terézia már itt, feltehetően a költözködés után nem sokkal született, 1866. augusztus 23-án. Az anyakönyvi bejegyzés szerint a kislányt két nappal később keresztelték meg a Szent Bertalan-templomban, a család címeként pedig az 1436. számú házat tüntették fel. ${ }^{639}$ Emellett az 1866-os adózók névjegyzékében már szerepel, hogy „Cheriér [sic!] János Nyomdász s neje Sturcz Julianna” 3 forint 15 krajcár közterhet fizetett, illetve a dokumentumból az is kiderül, hogy a nyomdász új helyre költözött a városban: az 1593. számú házba tette át székhelyét. ${ }^{640}$ A gyöngyösi évek során Sturcz Julianna még két gyermeknek adott életet: János Károly az anyakönyvi bejegyzés szerint 1868. április 4-én született, ${ }^{641}$ míg Anna Berta pontosan négy esztendővel nővére után, 1870. augusztus 23 -án jött világra. ${ }^{642}$

\footnotetext{
635 Švoliková 2008. 110-112.

636 Jaross 1910. 14.

637 Švoliková 2008. 109.

${ }^{638}$ Jaross 1910. 14-15. - Megjegyzendő, hogy Jaross két helyen is téved: egyrészt a nyomdászt nem Miklósnak hívták, emellett nem 1867-ben, hanem már az előző évben elköltözött Léváról (lásd a következő két hivatkozást).

${ }^{639}$ MNL HML, IV.416.191. - Heves vármegye felekezeti anyakönyvi másodpéldányok gyüjteménye (18271895), Gyöngyös Felsőváros római katolikus születési anyakönyvek (1851-1867), 1866. év, 302. sz. bejegyzés ${ }^{640}$ MNL HML, V.142 - Gyöngyös Város Pénztárának iratai (1848-1871), 22. k. - Adózók összeírása (1866. év), 28. oldal

${ }^{641}$ MNL HML, IV.416.193. - Heves vármegye felekezeti anyakönyvi másodpéldányok gyüjteménye (18271895), Gyöngyös Felsőváros római katolikus születési anyakönyvek (1868-1884), 1868. év, 109. sz. bejegyzés ${ }^{642}$ Uo., 1870. év, 289. sz. bejegyzés
} 
Cherrier Gyöngyösön már könyvkereskedést is üzemeltetett, ${ }^{643}$ mint azt a később említésre kerülő, Stammer Sándor szentesi polgármesterhez írt levelének aláírása is bizonyítja. Emellett kölcsönkönyvtárat is müködtetett. ${ }^{644}$ Nyomdája azonban sajtóterméket még ekkor sem gyártott: a város első saját lapja, az orvosi szakfolyóirat Hasonszenvi Közlöny még az ő ottani működése előtt jelent meg (1864-65), és bár a szerkesztősége a településen volt, a lapot Egerben, az érseki líceumi nyomdában sokszorosították ${ }^{645}$ az első helyi hírújság, a Gyöngyös pedig csak 1872-től indult. ${ }^{646}$ Cherrier János nevével találkozunk ugyan az Eger „politikai és vegyes tartalmu hetilap” 1868. december 10-i számában, igaz, nem kiadóként vagy sokszorosítóként, hanem mint a gyöngyösi kaszinó által a svájci és felső-olaszországi árvízkárosultak javára rendezett hangversenyen és táncmulatságon részt vett személyek egyike, aki 2 forintnyi felüladakozással támogatta a nemes kezdeményezést. ${ }^{647}$ A nyomdász neve még egyszer feltünik hasonló indokból a lap hasábjain: két esztendővel később, 1870. december 17-én részt vett a gyöngyösi dalárda által szervezett, jótékony célú hangversenyen, s a „franczia foglyok” javára 50 krajcárt adományozott. ${ }^{648}$ A vállalkozó gyöngyösi müködését említi évekkel később, 1875-ben a Protestáns Egyházi és Iskolai Lap, amely a népi irodalom terjesztéséről szóló cikkében méltatónak tünő, de a szövegkörnyezet alapján egyértelműen ironikus felhangú jelzővel illeti Cherriert: „Már pedig, hogy van köznépünkben jóravaló hajlam, hogy ö szeretne olvasni, ha volna mit: bizonyitja azon elpalástolhatlan tény, hogy országos vásárok alkalmával, még elökelö értelmes kálvinista embereket is látunk, méltó szégyenünkre és boszuságunkra, a piacon kiterített ponyvairodalom hitvány termékeit mohó vágygyal összevásárolni: mint például a disznóvá változott zsidót, s a karansági szent kut csudatévő erejéröl és történetéröl tanitó babonás legendát stb., mely nyomatott becsületes Cherrier János uramnál Gyöngyösön." 649

\footnotetext{
${ }^{643}$ Cherrier még feltehetően Léváról keltezett, Gyöngyös városának szóló kérelme nyomdája és kereskedése áttelepítéséről nem lelhető fel: a Heves Megyei Levéltárban a gyöngyösi tanácsülési jegyzökönyvek közül az iratokat minden bizonnyal tartalmazó 1866-os esztendő dokumentációja teljes egészében hiányzik.

${ }^{644}$ MNL CSML Szentes, V.B.145.b. - Szentes Város Tanácsának iratai (1849-1872) - Tanácsi iratok, 2094/1871.

645 Borovszky, 415.; a Hasonszenvi Közlöny teljes állományának digitalizált verzióját lásd: http://epa.oszk.hu/html/vgi/kardexlap.phtml?id=2523 (letöltés: 2016. február 4.). Mindemellett több szempontból is párhuzamot vonhatunk Szentes és Gyöngyös sajtótörténete között: egyrészt mindkét város első nyomtatott sajtóterméke nem hírlap, hanem szakfolyóirat volt; emellett - helyi nyomda híján - mindkettőt más településen sokszorosították (Szegeden, illetve Egerben).

${ }^{646}$ Borovszky, 133. és 415.; illetve https://www.arcanum.hu/hu/online-kiadvanyok/Petrik-magyar-konyveszet17121920-2/18761885-13040/magyar-hirlapok-es-folyoiratok-16596/1872-gyongyos-gyongyos-vegyes-1878ban-politikai-1879-tol-ismet-vegyes-tartalmu-hetilap-vxiv-evf-18761885-szerk-elobb-csomor-karoly-187-

166CF/ (letöltés: 2018. január 5.)

${ }^{647}$ Eger, VI. évf. (1868) 50. sz. 4.

648 Eger, IX. évf. (1871) 1. sz. 6.

${ }^{649}$ Protestáns Egyházi és Iskolai Lap, XVIII. évf. (1875) 15. sz. 1.
} 
Nincs információnk arról, hogy Cherrier üzletének könyvkereskedés része, illetve magánszemélyeknek vagy különféle vállalkozásoknak is dolgozó nyomdája ${ }^{650}$ mekkora nyereséget hozott tulajdonosának. A házi pénztári dokumentumok meglehetősen hiányosak, viszont a fennmaradt tanácsülési jegyzőkönyvekből kiderül, hogy a település első és egyetlen nyomdásza számíthatott folyamatos bevételre Gyöngyös városától: rendszeres megbízásokat kapott különböző hivatalos nyomtatványok sokszorosítására. Az első ilyen jellegü bejegyzés az 1867-es esztendő tanácsülési jegyzőkönyvében: „Elnök polgármester Cherier [sic!] János nyomdász által a város szükségére tellyesitett munkáról szólló 53. ftos számláját utalványozás végett bemutattja." A határozat kimondja, hogy a követelés jogos, és a házi pénztár fizesse ki a vállalkozónak a tartozást. („Haláleset felvétele” és „Halotti kémlap” formanyomtatványok kinyomtatásáról volt szó. $)^{651}$ A jegyzőkönyv következő határozata szintén a nyomdász számára jelentett bevételt: a fóelemi iskola részére elvégzett nyomtatási munkáért 14 forintos összeget ítélt jóvá neki a tanács. ${ }^{652}$ Október végén Cherrier újabb 14 forintot keresett egy rizma ${ }^{653}$ mutató és egy rizma kézbesítési ív legyártásáért, ${ }^{654}$ majd még ugyanezen évben ismét számlát állított ki: „a vasút ügyben az ország gyüléshez intézett értesitésnek, 500 példányban lett kinyomtatása" ellentételezéseként a város nagyvonalúan felkerekítette a 13 forint 50 krajcáros összeget, és 14 forint utalványozását rendelte el a nyomdász számára, ezúttal a vasúti bizottmány pénztárának terhére. ${ }^{655} \mathrm{~A}$ tanácsülési jegyzőkönyv tanúbizonysága szerint tehát az 1867-es évben Cherrier János összesen 95 forintnyi juttatásban részesült Gyöngyös városától.

Az együttműködés a következő esztendőkben is folytatódott: az 1868. március 28-án kiállított, 500 példányos nyomtatásról szóló számla - a hirdetményt a városkapitányi hivatal

\footnotetext{
${ }^{650}$ Az Országos Széchényi Könyvtár öriz néhány nyomtatványt, amely a gyöngyösi Cherrier-nyomdában készült: A gyöngyösi Nép-Bank törzsaláiróinak névsora használat végett (B1, Kny.D 4.806); Tisztelt közgyülés! Hogy az intézetnek állapotáról alapszabályaink 27. szak c. pontja értelmében a tisztelt közgyülésnek tudomása legyen... (B1, Kny.D 3.998); Gyöngyösi takarékpénztár részéröl 1869-ik év, mart. hó 1-én tartott rendes évi közgyülés jegyzökönyve (B1, Kny.D 3.991), Egri mákvirágok / A vén kertész (B1, Kny.D 3.195), A Deák-párti tisztelt választókhoz! / A rendezö bizottmány (B1, Kny.D 3.102), Szinházi emlény / a müvészet pártfogóinak ajánlja Rejtényi Lázár súgó (Színházi zsebkönyvek, 410.), A gyöngyösi kaszinó alapszabályai (B1, Kny.D 902), A Szent Ferenc-rendü gyöngyösi nagy-gymnasium ifjuságának érdemsorozata (B1, Ért 768), Mélyen tisztelt országgyülési képviselöház! / Főkövy Antal (B1, Kny.D 1.138), a Gyöngyösi takarékpénztár igazgató választmánya által az alapszabályok alapján kiadott utasitás (B1, Kny.B 1.013), Ki legyen a képviselö? Írta, a okosan gondolkodni szeretö magyar polgártársainak ajánlja egy honpolgár (B1, Kny.B 3.386).

${ }^{651}$ MNL HML, V.141.a. - Gyöngyös Város Tanácsának iratai (1841-1871), Jegyzökönyvek (1848-1871), 13. sz. jegyzökönyv, 129/1867. sz. hat.

${ }^{652}$ Uo., 130/1867. sz. hat.

${ }^{653}$ Rizma: olasz eredetủ kifejezés, a papírkereskedőknél a legnagyobb papírcsomag korabeli mértékegysége, amely húsz koncot, vagyis 480 ívet foglalt magában (https://www.arcanum.hu/en/online-kiadvanyok/Lexikonoka-magyar-nyelv-szotara-czuczorfogarasi-55BEC/r-6AE5A/rizma-6B728/, letöltés: 2018. január 6.)

${ }^{654}$ MNL HML, V.141.a. - Gyöngyös Város Tanácsának iratai (1841-1871), Jegyzökönyvek (1848-1871), 13. sz. jegyzökönyv, 353/1867. sz. hat.

${ }^{655}$ Uo., 380/1867. sz. hat.
} 
rendelte meg, s az utcák tisztán tartására hívta fel a lakosság figyelmét - 5 forint bevételt hozott Cherriernek. ${ }^{656}$ A következő számla is március 28-án kelt, s szintén a városkapitányi hivatal számára végzett munka elvégzését igazolta, azonban a „többrendbeli nyomtatványokért" már jóval többet, 68 forint 50 krajcárt követelt a vállalkozó. Ezt az összeget - akárcsak az előzőt - a város házi pénztára fizette ki, ezúttal felfelé kerekítés nélkül. ${ }^{657}$ Két hónappal később, ismét különböző nyomtatványok sokszorosításáért 37 forintot utalt Cherriernek a házi pénztár, ${ }^{658}$ így a dokumentumok alapján az 1868-as év összesen 110 forint 50 krajcár jövedelmet jelentett a nyomdásznak.

1869-ben mindössze egyetlen bejegyzést találunk a tanácsülési jegyzőkönyvekben Cherrier János számláival kapcsolatban, s feltehetően az sem volt a vállalkozó számára túlságosan örömteli, ami az ügymenet lefolyását illeti: a ,helybeli Gymnasiumi ifjúság 1867/8. évi érdem sorozat és a zár ünnepély rendje kinyomtatásáért" hiába írt 39 forintot a számlára, a végzés értelmében csak 29-et kapott meg, mivel 10 forintot levontak tőle az ifjúságnak való adakozás címén. ${ }^{659}$

1870-ben három számlát említenek a jegyzőkönyvek. Május 26-án kelt egy 13 forintról szóló számla (egy királyi törvényszék Gyöngyösön való felállítása érdekében az országgyüléshez intézett folyamodvány 500 példányban való kinyomtatása), ${ }^{660}$ majd még kettő született - a dátum megjelölése nélkül -, amelyek a főelemi iskolai érdemsorozat 450, valamint a gimnáziumi érdemsorozat 480 példányos sokszorosításának ellenértékét követelik, 18 forintot, illetve 43 forint 50 krajcárt. (Mindkét teljesítés a házi pénztár terhére történt.) ${ }^{661}$ Cherrier János tehát összesen 74 forint 50 krajcárt keresett a várostól kapott különféle megbízásokból ebben az esztendőben.

Végül, 1871-ből - amelynek első néhány hónapját Cherrier még Gyöngyösön töltötte - szintén találunk számlákat: az első a helyi férfiispotály számára készített nyomtatványokról szól, és 18 forint 50 krajcár ellenértéket tartalmaz. Az összeget az ispotály pénztárából utalták át. ${ }^{662}$ Ezt követően a város a számára készített különböző munkákért 42 forintot fizetett a nyomdásznak, ${ }^{663}$ majd ,a városi közös iskola részére 1000 példány tanodai bizonyítvány és

\footnotetext{
${ }^{656}$ MNL HML, V.141.a. - Gyöngyös Város Tanácsának iratai (1841-1871), Jegyzőkönyvek (1848-1871), 14. sz. jegyzökönyv, 305/1868. sz. hat.

${ }^{657}$ Uo., 306/1868. sz. hat.

${ }^{658}$ Uo., 373/1868. sz. hat

${ }^{659}$ Uo., 32/1869. sz. hat.

${ }^{660}$ MNL HML, V.141.a. - Gyöngyös Város Tanácsának iratai (1841-1871), Jegyzőkönyvek (1848-1871), 15.

sz. jegyzökönyv, 390/1870. sz. hat.

${ }^{661}$ Uo., 532/1870. és 533/1870. sz. hat.

${ }^{662}$ Uo., 90/1871. sz. hat.

${ }^{663}$ Uo., 123/1871. sz. hat.
} 
350 példány érdem sorozat kinyomtatásáért" 23 forintot. ${ }^{664}$ A következő számla a városi törvényszék által használt jegyzőkönyvek legyártásáról szólt, amelyért 26 forintot számolt fel Cherrier, ${ }^{665}$ majd a rendőrség számára készített 2000 ívnyi formanyomtatványt szintén 26 forint ellenében. ${ }^{666}$

Az utolsó két számla együttes, 1871. áprilisi benyújtása már arra utal, hogy a vállalkozó távozni készült Gyöngyösről. Az egyik még viszonylag aktuális szolgáltatásra vonatkozik (az örökváltsághoz használatos kötvények három hónappal korábban történt sokszorosítása, ellenérték: 44 forint), ${ }^{667}$ a másik viszont már egyértelmüen jelzi, hogy Cherrier igyekezett a még kifizetetlen tartozásait gyorsan behajtani, mielött elköltözik a településről: egy másfél évvel korábban, 1869. október 16-án kiállított számla (a közös iskola megnyitásáról szóló értesítő 3000 példányban való kinyomtatása) alapján további 26 forintot követelt. ${ }^{668}$ A jegyzőkönyvek szerint tehát a nyomdász 1871 első harmadában jóval nagyobb jövedelemre tett szert, mint korábban bármelyik egész év során: összesen 205 forint 50 krajcárt kapott a várostól.

Mégis a távozás mellett döntött, amelynek hátterét - források híján - nem ismerjük. A későbbieket tekintve azonban joggal feltételezhető, hogy ekkor már elsősorban sajtótermék kiadásában és terjesztésében gondolkodott, amelyben okkal láthatott fantáziát, hiszen éppen ebben az időszakban kezdtek alakulni egyre nagyobb számban a vidéki sajtóvállalkozások Gyöngyösön pedig minderre vagy nem látott lehetőséget, vagy egyéb ok miatt volt kénytelen elköltözni a településről. Mindenesetre nincs adatunk arra nézve, hogy megpróbált volna lapot indítani a hevesi városban.

\subsection{A szentesi évek (1871-1883)}

Nem tudjuk, miért esett a választása Szentesre, az viszont tény, hogy a dél-alföldi városban megtalálta a számítását. Áttelepülési kérelmét még 1870 novemberében megfogalmazta (az eredeti dokumentum másolatát lásd a Függelékben: 20. kép):

\footnotetext{
664 Uo., 227/1871. sz. hat.

${ }^{665}$ Uo., 228/1871. sz. hat.

${ }^{666}$ Uo., 229/1871. sz. hat.

${ }^{667}$ Uo., 268/1871. sz. hat.

${ }^{668}$ Uo., 267/1871. sz. hat.
} 
„Tekintetes Polgármester Úr!

Üzletemnek Gyöngyösröl Szentes Városába leendő áttétele engedélyezése érdemében, a Nagyméltóságú Magy. Kir. Belügy Ministeriumhoz szerkesztett kérvényemet $1 \mathrm{db}$ mellékletével, a' végböl bátorkodom a Tekintetes Polgármester Úrhoz utalni, hogy azt a Város Hatóság becses támogatása mellett, illetö helyre eljuttatni kegyeskedjék.

Mély tisztelettel vagyok

Gyöngyösön, 1870. nov. 13.

Tekintetes Polgármester Úr

\author{
alázatos szolgája. \\ Cherrier János \\ nyomdász és könyvkereskedö" 669
}

Stammer Sándor szentesi polgármester minden bizonnyal örült a lehetőségnek, hogy a településen végre a polgári fejlődés egy nem éppen sorsdöntő, de nem is elhanyagolható mérföldköve, egy helyben müködő nyomda létesülhet. A városvezető eleget tett a felkérésnek, továbbította a minisztériumhoz a kérelmet, s a kísérőlevélben támogatását fejezte ki az üggyel kapcsolatban: „kérdéses üzletnek Szentes városábani megnyitása a városi közönségre nézve elönyösnek mutatkozik". ${ }^{670} \mathrm{~A}$ hivatalos engedély hamarosan megérkezett, s Cherrier a következő év tavaszán megnyitotta nyomdáját, könyv- és papíráru-kereskedését, illetve kölcsönkönyvtárát az Úri utca 2053. szám alatti, özv. Balogh Mihályné tulajdonában lévő házban ${ }^{671}$ - minden bizonnyal a helyi lakosság legnagyobb megelégedésére, hiszen ilyen jellegű szolgáltatások korábban nem müködtek Szentesen. ${ }^{672}$ Megjegyzendő, hogy az említett helyen először csak a nyomda müködött, a könyvkereskedés és a papíráru-üzlet csak októberben nyílt meg, mint arra a Szentesi Lapok 1871. szeptember 24-i száma is felhívja a figyelmet: „irodai s egyéb könyveken kivül jóminőségü iró- és rajzeszközök, irka s

\footnotetext{
${ }^{669}$ MNL CSML Szentes, V.B.145. b) Szentes Város Tanácsának iratai 1849-1872 - Tanácsi iratok, 2026/1870.; ill. Labádi 2010c. 2.

${ }^{670}$ MNL CSML Szentes, V.B.145.b. - Szentes Város Tanácsának iratai 1849-1872 - Tanácsi iratok, 2026/1870. (Stammer eredeti levelének másolatát lásd a Függelékben: 21. kép). A MNL OL BL K 148. szekciójának eredeti nyilvántartásaiban találtunk bejegyzést az üggyel („,Cherier János könyvnyomdai könyvkereskedési üzletének Szentesre leendö áttétele iránt") kapcsolatban, de az irat (2913/1870. sz.) már nem található.

${ }^{671}$ SZLK, I. évf. (1871) 12. sz. 4. (Az Úri utca ma neve: Petőfi Sándor utca. Jelentősen megnehezíti az épület egykori helyének beazonosítását, hogy a fennmaradt korabeli térképek szerint a 2053. helyrajzi szám nem az Úri utcában, hanem attól jóval távolabb, a Kisér városrészben, a mai Toldy-közben volt található. További források híján nem bocsátkozunk feltételezésekbe, hogy az Úri utcában pontosan hol müködött Szentesen az első Cherrier-nyomda. Lásd: MNL CSML Szentes térképtárában az SZVK 17. sz. térkép 4. sz. felvételét)

${ }^{672}$ Labádi 2006c. 2.
} 
mindennemü papir" kapható Cherrier új boltjában. ${ }^{673}$ Két évvel később már vállalt könyvkötést is, így a nyomda, a könyvkereskedés és a papíráru-kereskedés újabb szolgáltatással bővült. ${ }^{674}$ Itt kell megemlítenünk, hogy a vállalkozás nem mindvégig ugyanazon a helyen müködött: 1876 tavaszán Cherrier átvitte üzletét a III. tized 32. szám alá, a Vásárhelyi utcába (ma: Vásárhelyi út); ${ }^{675}$ másfél évvel később, 1877. októberben a III. tized 141. szám alá, Pollák Emánuel házába, ${ }^{676}$ majd 1879 májusában ismét költözés következett: ezúttal a III. tized 27. számú épületbe, a régi postahivatallal szemben lévő, Cakó-féle házba. ${ }^{677}$ (A nyomda székhelyét az új tulajdonos, Sima Ferenc 1883 júniusában áttette saját házába, a Kurcaparti utca 31. szám alá - lásd a Függelékben a 33. képet.)

Mint az a saját hirdetéseiböl kiderül, Cherrier 1880 őszén feltehetően nagyobb mértékü átalakítást vagy fejlesztést hajtott végre, hiszen „ujonnan berendezett” könyvnyomdáját ajánlja a nagyközönség figyelmébe. ${ }^{678}$ Érdemes azonban megjegyeznünk, hogy Cherrier János viszonylag kevés alkalommal élt a lehetőséggel, hogy sajtóorgánumait saját vállalkozása népszerüsítésére használja fel. Három helyi lapjában összesen 63 alkalommal adott fel hirdetést - ráadásul az Alföldi Figyelőben egyszer sem -, a három újság összes megjelent példányszámához (Szentesi Lapok: 52 szám, Alföldi Figyelő: 6 szám, Szentesi Lap 1883. április 21-ig: 559 szám - összesen: 617 szám) viszonyítva pedig kiderül, hogy ez mindössze 10,2\%-os gyakoriságot jelent. Vagyis Cherrier átlagosan minden tizedik számban reklámozta csupán saját magát, miközben akadtak olyan laptulajdonosok a korban, akiknél ez az arány közel százszázalékos volt - lásd például a már említett magyarkanizsai Bruck P. Pált vagy Léderer Manót. ${ }^{679}$

Cherrier János hirdetéseinek tartalmi elemei azonban jól mutatják a vállalkozás fejlődését: kezdetben a nyomdán, a könyvkötészeten, a következő esztendőre szóló naptáron, illetve betölthető álláson (tanonc felvétele) kívül mást nemigen kínált, tíz évvel később

\footnotetext{
${ }^{673}$ SZLK, I. évf. (1871) 12. sz. 4.. Megjegyzendő, hogy Battonyai-féle, 1887-ben kiadott országos cégjegyzék mint szentesi könyvkereskedőt tartja nyilván Cherriert, a nyomdát nem említi - ráadásul jellemző a korabeli adattárak összeállításának lassúságára, hogy 1887-ben Cherrier már évek óta nem élt Szentesen, sőt máshol sem müködtetett semmiféle vállalkozást, hiszen egy évvel korábban elhunyt. (Battonyai 1887. 520.) Említést érdemel, hogy az OSZK keretein belül létrehozott internetes adatbázis, a Clavis Typographorum Regionis Carpathicae négy nyomdát kapcsol Cherrier János nevéhez (a nyitrai és a lévai működésröl nem tesz említést), de mindegyik adat hibás. Gyöngyösön ugyanis nem 1870-ig, hanem 1871-ig dolgozott, Szentesen pedig 1883-ig, és nem 1882-ig. A fővárosban sem 1882-ben, hanem értelemszerüen Szentesről való távozása után próbált szerencsét, tehát egy évvel később. Végül, az adattár Kunszentmártont ír, ahol állítólag 1887-től 1890-ig vitte üzletét Cherrier János - $\quad$ helyesen: Kunszentmiklós, 1883-tól 1886-ig. (http:/typographia.oszk.hu/html_clavis/hun/pressnyom.php?kezd=c, letöltés: 2018. január 8.)

${ }^{674}$ SZL, III. évf. (1873) 48. sz. 4.

${ }^{675}$ SZL, VI. évf. (1876) 21. sz. 4.

${ }^{676}$ SZL, VII. évf. (1877) 42. sz. 4.

${ }^{677}$ SZL, IX. évf. (1879) 18. sz. 4.

${ }^{678}$ SZL, X. évf. (1880) 40. sz. 4

${ }^{679}$ Döbör 2018. 381-382. és 391-392.
} 
azonban már jelentősen bővültek a szolgáltatások: vállalta táncmulatságokra szóló meghívók, étlapok, falragaszok, különféle nyomtatványok, gyászjelentések, levélfejek, számlák, egyéb mủvek és névjegyek legyártását, amelyek „amerikai gyorssajtón alig hihető gyorsasággal készittetnek". Emellett kaphatók volt üzletében tankönyvek, illetve író- és rajzeszközök széles választéka „,bolti áron alul” (lásd a Függelékben a 23-26. képet). Megemlítendő, hogy 1877 végén, illetve 1878. január elején rövid ideig bővítette profilját: „díszmü- és apróbb kereskedelmi cikkek", sőt rum és tea is kapható volt boltjában. ${ }^{680}$ (Utóbbi termékeket később nem reklámozta.) Szintén említést érdemel az 1881. január elején közölt egyszeri marketingakciója, amelynek során különféle kedvezményeket, például díjhátralék elengedését, sőt könyvajándékot (a Fehér nő a bécsi várban című regényt) is felajánlott azoknak, akik az adott esztendő első negyedévére előfizetnek. ${ }^{681}$

A kevés fennmaradt irat közül sokatmondó az a hivatalos vizsgálatról szóló jelentés, amelyet Cicatricis Pál főjegyző folytatott le Cherrier Jánossal szemben még 1871-ben, tehát nem sokkal a Szentesi Lapok megindulását követően. ${ }^{62}$ Történt ugyanis, hogy a Magyar Királyi Jogügyi Igazgatóság az iránt érdeklődött a település vezetőségénél, hogy a Szentesi Lapok indítása - a sajtótörvény $30 . \S$ rendelkezései szerint - szabályosan be lett-e jelentve, továbbá, ha az említett lap politikai tartalmú, a nyomdatulajdonos letette-e utána a megfelelő összegü biztosítékot? Mindezeken kívül Cherrier János megfelel-e a sajtótörvény 37. paragrafusának? ${ }^{683}$ A főjegyző előadta, hogy a lapot bejelentették az alispáni hivatalhoz, biztosíték letétele pedig nem volt szükséges, mivel az nem politikai tartalmú. Ami a vidéki nyomdászokra vonatkozó, 2000 forintnyi letétet illeti, Cherrier úgy nyilatkozott, hogy ő még 1865 elött a Helytartótanácstól kapott müködési engedélyt; akkor „,ugyanoda folyamodott több nyomdászokkal eggyütt a biztositék elengedése végett, ez érdemben azonban e mai napig sem nyert határozatot." Szentes város tanácsa tudomásul vette a fentieket, és értesítette a jogügyi igazgatóságot. ${ }^{64}$ Nem tudjuk, hogy végül Cherrier letette-e a 2000 forintos kauciót, vagy sem: a többi irat sajnos már elveszett. ${ }^{685}$

\footnotetext{
${ }^{680}$ SZL, VII. évf. (1877) 51. sz. 4., 52. sz. 4., VIII. évf. (1878) 1. sz. 4.

${ }^{681}$ SZL, XI. évf. (1881) 1. sZ. 1.

${ }^{682}$ MNL CSML Szentes, V.B.145.b. - Szentes Város Tanácsának iratai (1849-1872) - Tanácsi iratok, 2094/1871.

${ }^{683}$ Vagyis: „Nyomdát és könyvnyomdát felállithat minden, a ki az 1840:16. törvénycikk 1-ső és 2-ik fejezetében foglalt rendeleteknek eleget tevén, mellyben lakik, azon törvényhatóság elnökének szándékát bejelenti, a ki erröl a belügyek ministerét értesiti; és a fơvárosban 4,000, egyébütt 2,000 forintot részére 5\%-tek kamatozandót, letesz." (1848:XVIII. tc., 37.§)

${ }^{684}$ MNL CSML Szentes, V.B.145.b. - Szentes Város Tanácsának iratai (1849-1872) - Tanácsi iratok, 2094/1871.

${ }^{685}$ A MNL OL BL K 148. szekciójának (Belügyminisztériumi Elnöki Iratok) régi nyilvántartásaiban találtunk ugyan három tételt is, amelyek az említett üggyel, vagyis Cherrier János biztosíték letétele iránti kérelmével
} 
Az öttagú Cherrier család a Szentesen töltött időszak alatt jelentősen bővült: Jolán Margit 1874. december 2-án, ${ }^{686}$ Ilka Rozália Julianna 1877. március 8-án, ${ }^{687}$ József György Miklós 1878. június 14-én, ${ }^{688}$ Ilona Magdolna 1880. augusztus 28-án, ${ }^{689}$ Lajos András pedig 1882. december 5-én ${ }^{690}$ látta meg a napvilágot. Ilka Rozália Julianna mindössze négy és fél hónapot élt, 1877. július 18-án meghalt - a halotti anyakönyvi bejegyzés szerint vérhas vitte el, teste a szentesi Alsó Temetőben nyugszik, a sírhelye már nem fellelhető. ${ }^{691}$

Cherrier János szentesi sajtótevékenységének (Szentesi Lapok, Alföldi Figyelö, Szentesi Lap) pénzügyi sikerességéről nem rendelkezünk adatokkal - de annyi bizonyos, hogy a Szentesi Lap néhány esztendő alatt stabil üzleti vállalkozássá nőtte ki magát -, ahogyan arról sem, mennyire volt népszerü könyv- és papíráru-kereskedése, kölcsönkönyvtára, könyvkötészete, illetve, hogy milyen gyakran kapott megrendeléseket magánszemélyektől kisebb-nagyobb nyomdai munkák elvégzésére. Azonban a házi pénztár két esztendő kivételével - fennmaradt fökönyveiből kiderül, hogy Szentes városa rendszeres megrendelője volt az első helyben létesült nyomdának. Amikor Cherrier 1871 tavaszán átköltözött Gyöngyösről a dél-alföldi településre, a tanács azonnal felmondta a - korábban már említett - hódmezővásárhelyi Wodianer Fülöppel való együttmüködést, s onnantól fogva a város a hivatali működéshez szükséges formanyomtatványok sokszorosítását, illetve egyéb nyomdai munkákat (pl. iskolai értesítők, lásd 20. kép) a helyi vállalkozóra bízta. Az ebből származó éves bevételeket az alábbi ábrán foglaltuk össze (az 1877-es és az 1880-as esztendő főkönyvei nem maradtak fenn, ezért ez a két év kimaradt az összesítésböl): ${ }^{692}$

\footnotetext{
kapcsolatosak, de az iratokat már nem tudtuk megtekinteni: MNL OL BL K 148., 2771/1871., 2966/1871. és $2988 / 1871$.

686 MNL CSML Szentes, IV.B.434.a. - Csongrád Vármegye Felekezeti Anyakönyvi Másodpéldányainak Levéltári Gyüjteménye - A római katolikus egyházközségek anyakönyveinek másodpéldányai, Szentes, az 1874. év születési anyakönyve, 442. sz. bejegyzés

${ }^{687}$ Uo., az 1877. év születési anyakönyve, 110. sz. bejegyzés

${ }^{688}$ Uo., az 1878. év születési anyakönyve, 221. sz. bejegyzés

${ }^{689}$ Uo., az 1880. év születési anyakönyve, 312. bejegyzés

${ }^{690}$ Uo., az 1882. év születési anyakönyve, 494. bejegyzés

691 MNL CSML Szentes, IV.B.434.a. - Csongrád Vármegye Felekezeti Anyakönyvi Másodpéldányainak Levéltári Gyüjteménye - A római katolikus egyházközségek anyakönyveinek másodpéldányai, Szentes, az 1877. év halotti anyakönyve, 179. sz. bejegyzés

${ }^{692}$ Források: MNL CSML Szentes, V.B.160. - Szentes Város Köz- és Házipénztárának iratai (1846-1873), 26. k. (az 1871. év fókönyve): VI. cím (15., 17. és 19. sz. bej.); V.B.179. - Szentes Város Köz- és Házipénztárának iratai (1871-1949), 24. k. (az 1872. év fökönyve): VI. cím (2., 6., 7., 12., 13., 19., 20. és 22. sz. bej.); 25. k. (az 1873. év fökönyve): VI. cím (1., 3., 8., 9., 11., 12., 13., 17., 18., 19., 22., 24. és 31. sz. bej.); 26. k. (az 1874. év fökönyve): V. cím (6., 9., 12., 14., 19., 23., 24., 25., 26. és 29. sz. bej.) és IX. cím (160. bej.); 27. k. (az 1875. év fökönyve): V. cím (7., 12., 18., 19., 21., 24., 25., 35., 43., 47. és 50. sz. bej.); 28. k. (az 1876. év fökönyve): VIII. cím (7., 15., 20., 23., 27., 30., 36., 39., 41. és 45. sz. bej.); 29. k. (az 1878. év fökönyve): VIII. cím (4., 5., 11., 12., 14., 15., 20., 22., 27., 31., 37., 42., 47., 53. és 59. sz. bej.) és X. cím (50. sz. bej.); 30. k. (az 1879. év fökönyve): VIII. cím (10., 12., 19., 22., 29., 37., 39., 44., 53., 57., 60., 62., 67., 71., 73. és 76. sz. bej.); 31. k. (az 1881. év fökönyve): VIII. cím (6., 15., 17., 21., 23., 27., 34., 34., 37., 39., 44., 46., 49., 52., 54., 59., 63., 67., 70., 72., 75., 77., 84., 86. és 88. sz. bej.); 32. k. (az 1882. év fökönyve): VIII. cím (7., 9., 11., 15., 17., 19., 23., 25.,
} 


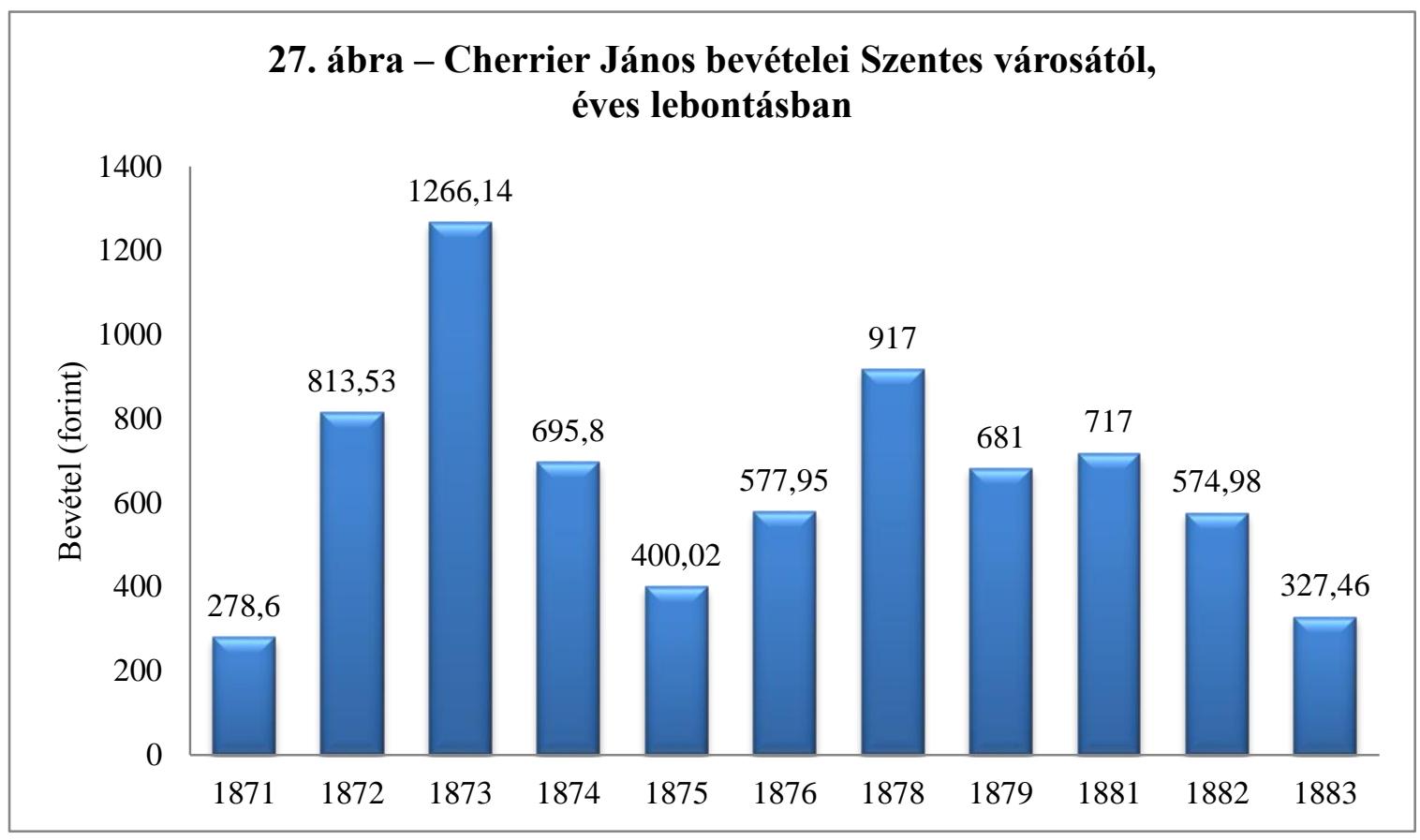

A diagramból láthatjuk, hogy a várostól érkező hivatalos megrendelések változó mértéküek voltak, de minden évben biztos jövedelmet jelentettek a nyomdász számára. Ráadásul - mint az a lábjegyzetből kiderül - a megbízások darabszáma nem feltétlenül állt egyenes arányban a kiszámlázott összegekkel, így az 1873-as év kiugróan magas bevétele sem azt jelenti, hogy Cherrier túl sok megrendelést kapott volna az adott esztendőben: mindössze szerencséje volt, mivel egy konkrét megbízással (könyvnyomtatás) egyszerre 480 forintot keresett. ${ }^{693}$ Emellett természetesen nem mérvadó az 1871-es esztendő, hiszen Cherrier János csak a tavasz folyamán tette át székhelyét Szentesre, s ugyanígy az 1883-as év, mikor elköltözött a városból (az utolsó fökönyvi bejegyzés 1883. június 4-én kelt, ezután Sima Ferenc vitte tovább a városi megbízatásokat). A diagramon láthatunk ugyan bevételcsökkenést 1882-ben az előző évhez képest, de összességében nem mutatható ki romló tendencia a városi megbízatások terén, sőt a hivatalos megrendelésekkel Szentesen jóval több pénzt keresett, mint annak idején Gyöngyösön -, ez tehát semmiképpen nem indokolta, hogy megint új helyen próbáljon szerencsét. (A település elhagyásának indokaként nekrológja említi majd az anyagi gondokat, mint azt később látni fogjuk.)

29., 30., 31., 32., 42., 43., 44., 49., 57., 59., 61., 63., 67. és 72. sz. bej.); 33. k. (az 1883. év fökönyve): VIII. cím (6., 10., 12., 13., 17., 18., 19., 22., 24., 30., 31., 37. és 42. sz. bej.)

${ }^{693}$ MNL CSML Szentes, V.B.179. - Szentes Város Köz- és Házipénztárának iratai (1871-1949), 25. k. (az 1873. év fökönyve): VI. cím, 19. sz. bej. 
Források híján nem tudjuk, hogy hetilapja vagy kereskedése, illetve bármilyen más tényező okozott-e anyagi megrendülést a számára, de tény, hogy 1883-ban az ekkorra már jelentősen kibővült család feje a távozás mellett döntött. Mindebben feltehetően szerepet játszott az is, hogy a Sima Ferenc által 1876-tól szerkesztett Szentesi Lap - a kezdeti politikai semlegességet feladva - fokozatosan a 48-as elvek hirdetőjévé vált, mint azt korábban már említettük. Ezzel kivívta a kormánypárti megyei vezetés ellenszenvét, viszont népszerüvé tette a lapot a református többségü, Kossuthot követő helyi lakosság körében. Valószínüsíthető, hogy az elsősorban az üzleti szempontokat preferáló, határozott politikai értékrenddel nem rendelkező - vagy legalábbis azt nyilvánosan soha nem hirdető -, évekig Bécsben tanuló és dolgozó Cherrier János kiadóként nem akarta vállalni az egyre nyíltabb konfliktust a Habsburgokkal kiegyező kormánypárttal szemben. Ha nem is volt elkötelezett kormánypárti, francia-német származása és római katolikus neveltetése folytán bizonyosan nem vált Szentesen protestáns érzelmüvé, illetve a függetlenségi eszmék elkötelezett hívévé, ezért feltehetően folyamatos és egyre erősödő morális dilemmával volt kénytelen szembenézni az alföldi városban. Nem számít ritkaságnak az üzleti érdek előtérbe helyezése miatt, mégis sokatmondó tény az is, hogy 1874-ben a nyomdász mühelyében sokszorosították a függetlenségi párt helyi politikusait kigúnyoló Északi Fény élclapot is, miközben saját orgánuma, a Buday József által szerkesztett Szentesi Lap akkoriban egyértelműen kiállt a 48as elvek mellett, két évvel később pedig szintén elvállalta a kormányhoz lojális Csongrádmegyei Közlöny legyártását.

Cherrier nem éppen szilárd jellemére bizonyíték, hogy kiadó-tulajdonosként több mint két esztendeig megtürte Buday nyílt politikai állásfoglalását az újság hasábjain, hiszen az anyagilag is kifizetődő volt számára, majd - látva a megyei vezetés határozott fellépését kihátrált a felelős szerkesztő mögül, és távozásra kényszerítette Budayt 1875 őszén. Ugyanez a folyamat ismétlődött meg Sima Ferenc esetében is, aki szintén fokozódó intenzitással állította a lapot a függetlenségi párt szolgálatába. Cherrier ekkor is éveken át „elnézte”, hogy új felelős szerkesztője a Buday-féle irányvonalat követi, sőt kiadóként minden bizonnyal örömmel konstatálta, hogy az újság népszerüsége jelentős mértékben növekedett.

Azonban 1883 tavaszán már befejezéséhez közeledtek a vármegyeháza építési munkálatai, küszöbön állt az átadó ünnepség, ezzel pedig egyértelművé vált, hogy addig soha nem látott, napi szintű politikai harc veszi hamarosan kezdetét az ellenzéki város, illetve a kormánypárti megye között. Nem volt kérdéses, hogy a Sima vezette Szentesi Lap - élvezve a helyi lakosság többségének bizalmát - melyik oldal mellett teszi majd le a voksát. Az ekkor állítólag anyagi nehézségekkel küzdő Cherrier, bár talán szerette volna, nem merte 
megkockáztatni a város legnépszerübb polgárának számító Sima Ferenc eltávolítását, inkább eladta a lap tulajdonjogát, később pedig a nyomdát is szerkesztőjének, és elhagyta a települést. Az is lehetséges, hogy az ekkoriban már számottevő politikai - és nem elhanyagolható anyagi - tőkével is rendelkező Sima gyakorolt nyomást fönökére, illetve tett neki „visszautasíthatatlan ajánlatot”, hogy a már bejáratott újságot végre teljes mértékben saját politikai céljainak szolgálatába állíthassa.

A kiadói jogok átruházásáról a következőképpen számolt be a Szentesi Lap 1883. április 28-án: „Lapunk szerkesztője a lap kiadói jogát az eddigi tulajdonos Cherrier Jánostól megvásárolván, a lap a jelen számtól kezdve már az ö kiadásában jelenik meg. Talán mondanunk is felesleges, hogy a helyzet ezen változása még inkább arra fog bennünket ösztönözni, hogy tehetségünkhöz képest mindent elkövessünk lapunk belsö értékének fokozására, s olvasó közönségünk igényeinek teljes kielégitésére. Azért legyen szabad remény lenünk, hogy a t. közönség az eddig tapasztalt anyagi és erkölcsi támogatásban bennünket a jövőben is részesiteni szives legyen." 694

\subsection{Kunszentmiklós (1883-1886)}

Cherrier János és családja előbb a fővárosba költözött. A Pesten töltött néhány hónapos időszakról források híján nem rendelkezünk információkkal, de annyi bizonyos, hogy bármilyen vállalkozásba is fogott bele a nyomdász, az nagyon rövid ideig tartott, és nem hozta meg a várt eredményt. Minderről a Szentesi Lap hírrovata a következőt írta 1883. december 22-én: „Cherrier János lapunk volt kiadója - miután Uj Pesten nem sikerült jó üzletet csinálnia - Kun-Szent-Miklóson telepedett le és itt nyitott nyomdát és kiadja a »Kunszentmiklós és Vidéke« cimü helyi érdekü lapot. Öszintén kivánunk jó szerencsét ez uj vállalatához." ${ }^{695}$ (Más forrás nem Újpestet, hanem Kispestet említ. ${ }^{696}$ )

Cherrier tehát Kunszentmiklóson állította fel nyomdáját. Élete utolsó állomásán töltött, viszonylag rövid időszakát - két és fél esztendejét - Balogh Mihály helytörténész foglalja össze Bors Károlyról, az ottani sajtó megteremtőjéröl szóló tanulmányában. ${ }^{67}$ Borssal közösen indították el 1883 decemberében a fentebb említett Kunszentmiklós és Vidéke „közművelődési, szépirodalmi, társadalmi és közgazdászati hetilap” profilmegjelölésű

\footnotetext{
${ }^{694}$ SZL, XIII. évf. (1883) 17. sz. 2.

${ }^{695}$ SZL, XIII. évf. (1883) 51. sZ. 3.

${ }^{696}$ Balogh 2005. 43.

${ }^{697}$ Balogh 2005. 40-47.
} 
újságot, amely küllemében, rovatszerkezetében nagymértékben hasonlított Cherrier korábbi, Szentesen megjelent lapjaihoz, tehát a korra jellemző, félíves hetilap formátumát követte. A kezdetben csupán ötven előfizetővel rendelkező orgánum - bár színvonalában nem maradt el társaitól - az 1884-es választások után megszünt, a helyi politikai csatározások áldozatává vált. Utóda a visszafogottabb hangvételü Kiskunság (,vegyes tartalmu hetilap”) lett, szintén Cherrier kiadásában, illetve Bors Károly szerkesztésében. Ez az újság már stabil, ha nem is kiugróan jól jövedelmező vállalkozássá nőtte ki magát. 698

Cherrier János kunszentmiklósi éveiről kevés emléket őriznek a levéltári források, így ottani mủködése nehezen rekonstruálható, javarészt csupán feltételezésekre alapozható. Nyomdájának a településen való felállítását bejelentette a belügyminisztériumnak, ${ }^{699}$ azonban minderről a nagyközség képviselőtestületi jegyzőkönyveiben nem találunk említést. ${ }^{700}$ Furcsa, de Cherrier nem szerepel sem az 1883-as, sem az 1884-es esztendő helyi adózókat összeíró jegyzékében sem, miközben 1883 decemberében már bizonyosan müködött a nyomdája. ${ }^{701} \mathrm{~A}$ következő két év jegyzéke nem maradt fenn, az 1887-es év viszont igen, ahol megtaláljuk Cherrier János nevét, azonban az adókivetés mértékét jelző rubrikák mind üresen maradtak nem csoda, hiszen a nyomdász az előző évben meghalt. ${ }^{702}$

Az - igencsak hiányos - iratok tanúsága szerint Cherrier közel sem számíthatott olyan mértékü jövedelemre Kunszentmiklóson, mint Szentesen. Számlája nem maradt fenn, ${ }^{703}$ nem találunk róla bejegyzést az 1885 -ös községi követelési számlakönyvben sem, ${ }^{704} \mathrm{~s}$ mivel a képviselőtestületi jegyzőkönyvek sem tesznek említést tevékenységéről, valószínüsíthető, hogy a település a különféle hivatalos formanyomtatványainak sokszorosítását - Szentessel ellentétben - más vállalkozóra bízta. (Feltételezésünk helyességét látszik erősíteni, hogy a nagyközség 1884-es árvapénztári szabályrendelete Budapesten, az Idősb. Poldini Ede és társa

\footnotetext{
${ }^{698}$ Balogh 2005. 43-44.

${ }^{699}$ Az MNL OL BL K 148. szekció (Belügyminisztériumi Elnöki Iratok) nyilvántartása szerint az 1193/1884. sz. irat tartalmazta a kunszentmiklósi nyomda felállításáról szóló bejelentést, de a dokumentum már nem lelhető fel; hasonlóan az 2517/1883. sz. irathoz, amelyben Cherrier közölte a minisztériummal, hogy a Szentesi Lap tulajdonjogát eladta.

700 MNL BKML KK, V.355.c. - Kunszentmiklós nagyközség polgári iratai (1872-1939), 1. d. Képviselőtestületi iratok, 1. - Közgyülési jegyzőkönyvek (1879-1885)

${ }^{701}$ MNL BKML KK, V.355.c. - Kunszentmiklós nagyközség polgári iratai (1872-1939), 57. k. - Együttesen kezelt állami adók fökönyve, 1883. év; 58. k. - Együttesen kezelt állami adók fökönyve, 1884. év; 78. k. Községi pótadó fökönyv, 1884. év

${ }^{702}$ MNL BKML KK, V.355.c. - Kunszentmiklós nagyközség polgári iratai (1872-1939), 59. k. - Együttesen kezelt állami adók fökönyve, 1887. év, 44. oldal, 304. sz. bejegyzés

${ }^{703}$ MNL BKML KK, V.355.c. - Kunszentmiklós nagyközség polgári iratai (1872-1939), 13. d. - Külön kezelt elöljárósági iratok, 10. - Kunszentmiklósi vállalkozások céges számlái (1880-1930)

704 MNL BKML KK, V.355.c. - Kunszentmiklós nagyközség polgári iratai (1872-1939), 31. d. - Követelési számlakönyv, 1885. év
} 
nyomdában készült. ${ }^{705}$ ) Saját hetilapján kívül az ő nyomdájában állították elő még az Okos Magyar címü ismeretterjesztő hetilapot Balogh János helyi plébános szerkesztésében 18851886-ban. ${ }^{706}$ (Érdemes megjegyeznünk, hogy ugyanarról a személyről van szó, aki korábban a Szentesi Lapok szerkesztőjeként összeveszett főnökével, sőt még röplapokat is osztogatott a városban az újság ellen. Nem csupán véletlen egybeeséséröl lehet szó: Balogh minden bizonnyal rendezte korábbi nézeteltérését a nyomdásszal, és szerepe volt abban is, hogy Cherrier Kunszentmiklósra költözött.)

Mielőtt anyagi helyzete megszilárdulhatott volna, Cherrier János 1886. június 20-án elhunyt, halálát mellvízkór ${ }^{707}$ okozta. $^{708}$ A Szentesi Lap két héttel később, 1886. július 3-án közölte a hírt: „Lapunk megalapitója: Cherrier Janos nyomdásznak reánk nézve egészen váratlanul jött halálát jelenté Kunszentmiklósról. A derék, becsületes ember halálának hire annálinkább kelthet városunk minden körében öszinte részvétet, mert az ö nevével kezdödik városunkban a nyilvános közélet a »Szentesi Lap«-nak 1871-ben lett kiadásával, melynek ö egészen 1883 jun. l-ig, tehát 13 éven át volt tulajdonosa." A nekrológ szerint Cherriert zavart anyagi helyzete késztette arra, hogy a kedvezőbb lehetőségeket ígérö Kunszentmiklósra költözzön, ahol újból nyomdát hozott létre, és lapot adott ki. Helyzete egy időre javult, azonban „most, monhatni élete delén, 47 éves korában szólítja el a munkás, derék, becsületes családapát, nagy családja éléröl, a halál. A keményen sujtott család, melynek gyásza iránt öszinte részvétet érezünk, a halálesetröl a következö gyászjelentést adta ki: Özvegy Cherrier Jánosné mint neje; Irma Iván, Anna, Jolán, József, Ilka, Lajos, mint gyermekei mélyen megszomorodott szivvel jelentik felejthetetlen férj és apának Cherrier János nyomdásznak élete 47-ik évében melvizkórban f. évi junius 20 án este 8 órakor történt gyászos elhunytát."709

\footnotetext{
705 MNL BKML KK, V.355.c. - Kunszentmiklós nagyközség polgári iratai (1872-1939), 1. d. Képviselötestületi iratok, 6. - Szabályrendelet az árvapénztár kezeléséről (1884)

$706 \mathrm{http}: / / \mathrm{www}$. tinodilantos.hu/index.php?option=com_content\&view=article\&id=393\&Itemid=391\&lang=en , letöltés: 2018. január 31.; OSZK, FM3/2434 és H 1.047

707 A mellvizkór (hydrothorax) a mellhártyagyulladás súlyosabb változata, amelynek során a mellhártyaürben folyadék, savó gyülik össze, s ez nagy mennyiség esetén gátolja a mellkasi szervek, elsősorban a tüdő müködését. Régebben gyakori halálok volt, ma már a folyadék lecsapolásának viszonylag egyszerü módjával, valamint a korszerű gyógyszerekkel kezelhető a betegség. (http://www.informed.hu/?tPath=/betegsegek/betegsegek_reszletesen/lung/pleural/\&article_id=84312, letöltés: 2018. május 8.)

708 A halotti anyakönyv (A kunszentmiklósi római katolikus plébánia halotti anyakönyvei, 1886. év, 73. sz. bejegyzés) június 21-ét említ a halál napjaként, de minden bizonnyal hitelesebb az özvegy által kiadott közlemény.

${ }^{709}$ SZL, XVI. évf. (1886) 27. sz. 2. A nekrológban nehezen értelmezhető az „Irma Iván” kitétel a gyermekek felsorolásánál, és nem csupán az ellentétes nemü keresztnevek közül hiányzó vessző miatt. A házaspárnak ugyanis nem születtek ilyen nevü gyerekei. Források híján csak feltételezhetjük, hogy nevelt gyermekekről van szó. További kérdés, hogy miért nem szerepel a felsorolásban az elsőszülött Mária Terézia, illetve a második, szintén Gyöngyösön világra jött János Károly. Tény, hogy a születésüktől számított családi lakóhelyek Gyöngyös, Szentes, Budapest, Kunszentmiklós - halotti anyakönyveiben nem szerepelnek. Amennyiben életben
} 
A nyomdász a halotti anyakönyv alapján „,végszentségben” nem részesült, s két nappal később, június 22-én eltemették Kunszentmiklóson. ${ }^{710}$ (Sírja a XX. század második felének újraparcellázási munkálatai során megsemmisült.) Nyomdáját feltehetően egy ideig özvegye vitte tovább, erre utal az Országos Széchényi Könyvtárban megörzött, 1887-ben készült kisnyomtatvány is (Gróf Teleki József, a fülöpszállási választó-kerület Szabadelvü Párt képviselö-jelöltjének programmbeszéde), amelyen sokszorosítóként még Cherrier János neve szerepel. ${ }^{711}$ Ezt követően a szerkesztő, Bors Károly vette át az üzemet, és folytatta a lapkiadói, illetve a nyomdai vállalkozást.

Az özvegyet nemsokára újabb három tragédia érte: kevesebb mint két esztendővel férje halála után, 1888 áprilisában vörheny következtében elhunyt az akkor ötéves Lajos, ${ }^{712}$ majd még ugyanabban a hónapban elveszítették a hét és fél éves (az anyakönyv tévesen hat és fél évesnek említi) Ilona Magdolnát is, aki vesebajban szenvedett, ${ }^{713}$ egy évvel később pedig tüdőgümőkór végzett az éppen felnőttkorba lépő, tizenkilenc esztendős Anna Bertával. ${ }^{714} \mathrm{~A}$ településen a férjét és három gyermekét is eltemető Sturcz Julianna a család maradék tagjaival hamarosan elköltözött Kunszentmiklósról - további sorsuk felkutatása jelen dolgozatnak nem célja. $^{715}$

voltak, talán azért hiányoznak a felsorolásból, mert már nem éltek egy háztartásban a családdal: az apa halálának évében Mária Terézia húsz, János Károly pedig tizennyolc esztendős lehetett.

${ }^{710}$ A kunszentmiklósi római katolikus plébánia halotti anyakönyvei, 1886. év, 73. sz. bejegyzés

${ }^{711}$ OSZK, Kny.D 2.246

${ }^{712}$ A kunszentmiklósi római katolikus plébánia halotti anyakönyvei, 1888. év, 52. sz. bejegyzés

${ }^{713}$ Uo., 61. sz. bejegyzés

${ }^{714}$ A kunszentmiklósi római katolikus plébánia halotti anyakönyvei, 1889. év, 46. sz. bejegyzés

715 Jellemzően a korabeli anyakönyvezés pontatlanságára mind a dátumok, mind a nevek és helyszínek tekintetében, magát a család idegen eredetủ vezetéknevét is több alakban - Cherrier, Cheriér, Cherier - említik a korábban már említett gyöngyösi , szentesi és kunszentmiklósi dokumentumok, ráadásul nem egy esetben következetlenül: Kunszentmiklóson például Cherrier János nevét helyesen írja a halotti anyakönyv, míg gyermekeinél helytelenül: „Cherier”. A szentesi anyakönyvek sem kevésbé felületesek: József helyett „Jósef” olvasható, Jolán és Lajos esetében a vezetéknév szintén helytelen („Cherier”), Ilka Rozália Julianna pedig az alig több mint négy hónappal később kelt halotti anyakönyvi bejegyzésben már csak egyszerüsítve, „Ilona”-ként szerepel. Érdekességként megemlítendő, hogy - tekintve a ritka vezeték-, illetve a nem túl gyakori keresztnevet - Jolán Margit feltehetően azonos azzal a Cherrier Jolánnal, aki Budapesten, a VI. kerületben, a Szondy u. 79. szám alatt szatócsboltot üzemeltetett a századforduló után. (Budapesti Czim- és Lakásjegyzék, 24. évf., FranklinTársulat, Budapest, 1912. 1269.) 


\section{Összegzés}

Dolgozatom megírása előtt több célt tüztem ki magam elé. Elöször is, hogy - hiánypótló céllal - átfogó képet nyújtsak egy dél-alföldi város nyomtatott tömegtájékoztatása történetének kezdeti időszakáról: milyen körülmények között, milyen indíttatásból jöttek létre az első lapok, mennyiben feleltek meg a korszak formai és tartalmi követelményeinek, illetve, milyen módszerekkel és milyen sikerrel voltak képesek elnyerni az olvasóközönség bizalmát. Vizsgálódásomnak egy plusz dimenziót adott a helyi társadalom többségének protestáns, függetlenségi párti érzülete, amely tekintetben Szentes nem volt ugyan egyedülálló - lásd például a szomszédos Hódmezővásárhelyt -, azonban a tárgyalt időszakot végigkísérő, fokozatosan élesedő politikai küzdelem a megyeszékhelyi cím elnyeréséért sajátos színezetet kölcsönzött a városi közéletnek. Mindennek legfőbb jellemzője a helyi, nagyrészt református, a Kossuth-kultuszt feltétel nélkül ápoló lakosság, valamint a kormánypárti megyei vezetés között egyre inkább feszülő ellentét. Igaz, mint azt a bevezetésben is említettem, a dolgozatnak nem tárgya ennek a - helyi lapokban is hangsúlyosan megjelenő - közéleti csatározásnak a taglalása, hiszen Szentes politika- és közigazgatás-történetéröl már született a teljesség igényével készített monográfia, több szempontból mégis érintette a téma feldolgozását, elsősorban az egyes lapvállalkozások sikeressége, illetve kudarca okainak elemzése tekintetében.

E sajátosság ugyanis több orgánum esetében az országos tendenciától eltérő folyamatokat eredményezett: a túlnyomórészt a 48-as eszméket pártoló szentesi közönség reakciói nemegyszer éppen ellentétesek voltak azzal, mint amit a kiadó előzetesen feltételezett, illetve lapja sikere érdekében elvárt volna. Gondoljunk csak Cherrier mindhárom vállalkozására: a Szentesi Lapok viszonylag hamar bekövetkező kudarcának talán legfőbb oka az volt, hogy politikai semlegességet hirdetett egy olyan városban, ahol a helyi lakosság eleve hagyományosan szembehelyezkedett az Osztrák-Magyar Monarchia létrejöttével. Ráadásul a kiegyezés után a korábbi megváltás összegét kompenzáló kárpótlás elmaradása még inkább fokozta a csalódottságot, a Deák-párttal szembeni elégedetlenséget, mindez az 1869-es választásokon is egyértelmüen megmutatkozott. A szentesiek tehát az akkori közhangulatban nem az objektivitást, nem az egyes pártérdekektől való elhatárolódást igényelték, hanem éppen az ellenkezőjét, s mivel ezt első közéleti hetilapjuktól nem kapták meg, hiába volt a nemes szándék, a színvonalas küllem, valamint a változatos tartalom, előfizetéssel nem támogatták a kezdeményezést. Az Alföldi Figyelő esetében mindehhez még hozzájárult az is, 
hogy a lap célkitüzése nem Szentes, hanem az egész régió szolgálata volt, vagyis a szentesiek már a tartalmat sem érezhették igazán magukénak - tehát ebben az esetben Cherrier kétszeresen is tévedett, amit bizonyít az újság igen rövid életpályája. A harmadik orgánum, a Szentesi Lap könnyen ugyanerre a sorsra juthatott volna, azonban az indulása után egy évvel felelős szerkesztőnek kinevezett Buday József szakított a pártatlansággal: az újság végre határozottan kiállt a helyi érdekek mellett, nyíltan hirdette a 48-as elveket, nem is csoda, hogy a lap helyzete megszilárdult. Igaz, Cherrier egy idő után engedett a megyei nyomásnak, és Budayt eltávolította a lap éléről, azonban egy idő után kénytelen volt belátni, hogy az üzleti érdek felette áll a személyes meggyőződésének, illetve az óvatos lojalitásnak: a függetlenségi irányvonalat továbbvivő Sima Ferenc szerkesztésében a Szentesi Lap soha nem látott népszerüségre tett szert.

A fentiek alapján kijelenthetjük, hogy tárgyalt korszakunkban minden olyan lapvállalkozás, amely nem vállalta fel a kormánypárttal való szembehelyezkedést, Szentesen eleve kudarcra számíthatott: nemhiába bukott meg igen rövid idő alatt az egyébként színvonalas Csongrádmegyei Közlöny vagy az Északi Fény humorisztikus hetilap. Később szintén nem rendelkezett túlzottan fejlett realitásérzékkel Vutsák János sem, aki a Darázs kiadójaként és szerkesztőjeként úgy gondolta, akad piacképes kereslet a helyiek nagyobb részének bizalmát élvező közéleti személyiségeket lejárató, alpári stílusú írásokra, s még nagyobbat tévedett, mikor azt hitte, meglovagolhatja az országban tapasztalható antiszemita indulatokat, mert a szentesiekben is van fogékonyság a durva, zsidók ellen uszító hangnemre. Vagyis a kiegyezés utáni években minden vállalkozónak, aki helyi lapot indított, elsősorban a szentesi társadalom sajátos attitüdjét kellett, illetve kellett volna figyelembe vennie, és nem az országosan már esetleg bevált „recepttel” próbálkoznia. Ez azonban nem csupán a szentesiek többségéhez közel álló világnézettel, illetve értékrenddel történő azonosulást jelentette, hanem a tartalomnak, a rovatstruktúrának is a fogyasztói igényekhez való igazítását. Láthattuk, hogy a hosszabb publicisztikákat előszeretettel tartalmazó, inkább még az eszmehirdető korszakba tartozó, összességében nehezen emészthető Csongrádmegyei Közlöny nem talált kedvező fogadtatásra a városban, a Sima Ferenc vezette Szentesi Lap azonban egyre jobban a rövid hírekre koncentrált - a nyílt politikai állásfoglalás mellett ez volt sikerének másik kulcsa. A dolgozatban tehát azt is igyekeztem bemutatni - föként a huzamosabb ideig létező Szentesi Lap pályáján keresztül -, hogyan ment át fokozatosan a szárnyait próbálgató szentesi sajtó az első, vagyis eszmehirdető korszakból a következő, ún. üzleties korszakba. ${ }^{716}$

\footnotetext{
${ }^{716}$ Lásd a dolgozat 1.2. A magyar sajtó fellendülése a kiegyezés után alfejezetét
} 
Amennyiben a nyomtatott tömegtájékoztatás kezdetének időpontját vesszük górcső alá, megállapíthatjuk, hogy az első helyi lapvállalkozások, a város méretét figyelembe véve, nagyjából az országos, illetve regionális tendenciának megfelelően, tehát az 1870-es évek elején alakultak. Vagyis Szentes ebből a szempontból átlagosnak mondható - ne feledjük, szép számmal akadtak olyan települések, ahol a helyi lapok története jóval később kezdődött, sőt esetenként át is tolódott a XX. századra, például a délvidéki kisváros, Magyarkanizsa esetében.

Dolgozatomban a sajtó tükrében igyekeztem felvázolni a korabeli szentesi társadalom mindennapi életét, valamint, hogy az 1867 után új alapokra helyezett gazdasági és kulturális fejlődés milyen lehetőségeket teremtett a város számára, illetve, hogy az ezzel szemben álló, nagyfokú hiányosságok milyen ellentmondásokhoz, problémákhoz vezettek. Gondolok itt elsősorban az infrastrukturális elmaradottságból adódó, az életminőséget, a napi szintű komfortérzetet jelentősen rontó bosszúságokra (csúszós járdák, sáros utak), a mocsaras belterület okozta veszélyekre (lásd: járványveszély, gyakori vízbefúlások) vagy akár a társasági élet szerény kereteire. Azt is ismertettem, hogy az elöbbi gondok orvoslásából, az urbanizáció előremozdításából, a település gazdasági, társadalmi és kulturális fejlesztéséből milyen aktívan kivette a részét a helyi sajtó, amely nevelő célzatú publicisztikáival, a különféle hatóságok felé intézett, jobbító szándékú figyelemfelhívásaival, javaslataival folyamatosan hangsúlyozta a város és lakossága iránt érzett felelősségét.

Az utolsó fejezetben Cherrier János, a szentesi közéleti sajtó megteremtőjének karriertörténetét kísértem végig, amely pálya nem csak azért érdekes, mert - bár nem tekinthető vándornyomdásznak - kalandos élete során a Kárpát-medence több, egymástól távol eső pontján megfordult. Nem is csupán azért, mert születési helyének és időpontjának kiderítése - nagyrészt neki magának köszönhetően, s máig megfejthetetlen okból - az átlagosnál jóval nagyobb feladatot jelentett a történész számára. Életútja elsősorban azért méltó a bemutatásra, mert egyrészt négy településen - Léván, Gyöngyösön, Szentesen és Kunszentmiklóson - elsőként létesített tartósan működő, a polgári fejlettségi szint egyik fontos mérföldkövének számító nyomdaipari üzemet, másfelől az utóbbi két helységben a nevéhez füződik a modern közéleti sajtó megindítása is, így gazdaság- és kultúrtörténeti jelentősége vitathatatlan. Tanult szakmájából adódóan szerencsésnek mondható: egy olyan korszakban élt, amely tálcán kínálta az esélyt a gyors felemelkedésre, hiszen a kiegyezés megteremtette, illetve kiszélesítette a jogi kereteket a nyomtatott tömegtájékoztatási orgánumok előállítása és terjesztése vonatkozásában, így soha nem látott mértékben megnövekedett az olvasói kereslet a különféle lapok iránt. Cherrier időben felismerte és 
megragadta a sokat ígérő üzleti lehetőséget, hiszen 1867 után a nyomdászat szabad iparrá vált, gyakorlatilag bárki lehetett nyomdatulajdonos, a külföldről hamarosan behozott technikai vívmányoknak köszönhetően pedig a hazai nyomdák rohamos fejlődésnek indultak. ${ }^{717}$ Bár e tekintetben természetesen nem egyedülálló, mégis példaértékü, ahogyan a számos nehézség, félsiker és súlyos kudarc után mindig talpra állt, s végig kitartott szakmája mellett. Többször vakmerő volt, vállalta a kockázatot, és hivatalos engedély nélkül kezdte meg müködését (lásd Nyitra, Léva, s talán Kunszentmiklós is), ha kellett, új lapot indított a csődbe ment előző helyett, ha pedig a végszükség úgy hozta, egyre gyarapodó családjával inkább új helyre költözött, és máshol próbált szerencsét, semhogy feladja céljait. Életútja, tevékenysége jól példázza a XIX. század folyamán végbemenő professzionalizálódási folyamat újabb szintjét a felvilágosodás-, illetve reformkori sajtóhoz képest: a nyomdász által kiadott újságokat már nem fớri mecénások támogatták, hanem saját tőkéből, illetve hirdetésekből finanszírozta lapjait, hiszen profitorientált üzleti vállalkozásnak tekintette azokat. Mindemellett, alapvetően már alkalmazta azt a munkamegosztást, amely korábban nem volt jellemző, a század végére viszont általánossá vált a sajtóorgánumok esetében: mindhárom lapjánál egyértelmúen elkülönültek egymástól az egyes tevékenységi körök - kivéve a már említett, rövid időszakot, amikor beosztottja távozása miatt kénytelen volt átmenetileg egyszerre végezni a kiadói, valamint a felelős szerkesztői feladatokat is az Alföldi Figyelőnél.

Tartós siker nem adatott meg Cherrier János számára (mint például a szegedi Burger Zsigmondnak vagy a nyitrai Neugebauer családnak), s ha bizonyos tekintetben naiv is volt lásd az Alföldi Figyelőbe vagy akár a fővárosi üzleti sikerébe vetett hitét -, emellett bizonyos cselekedeti morálisan igencsak kifogásolhatóak - gondoljunk a Szentesi Lapok megszüntetésére vagy Buday József eltávolítására a Szentesi Lap éléről -, életművének összességében kevés párja akad a korszak hazai sajtóvállalkozóinak körében.

Mégis, összesen három szerző (Labádi Lajos, Balogh Mihály és Marta Švoliková) szentelt figyelmet müködése egy-egy részletének rövidebb terjedelmü bemutatására. Gyöngyös egyáltalán nem ápolja az emlékét, Szentesen pedig - ahol nyomdászként és lapkiadóként a legtöbb időt töltötte - még közterület sincs elnevezve róla, ellentétben más, sok esetben nála jóval kisebb érdemeket szerzett személyekkel. (E sorok szerzője bízik benne, hogy jelen dolgozat talán változtat valamelyest a helyzeten.)

Végül, említést érdemel, hogy a disszertáció megírása során az új sajtótörténeti kutatási módszereknek, követelményrendszernek is igyekeztem megfelelni: az újságok

\footnotetext{
${ }^{717}$ Fleisz 2005. 7.
} 
szövegelemzéséből és a szekunder irodalomból kapott információk mellett érveimet, megállapításaimat számos esetben különböző diagramokkal, táblázatokkal is alátámasztottam. Mindez azért volt lehetséges, mert a korszak vezető orgánumának, a Szentesi Lapnak vonatkozó számai esetében elvégeztem a teljes tartalom statisztikai feldolgozását, amely egyrészt lehetőséget ad majd más szempontú vizsgálódásokra - például a szépirodalom sajtóbeli megjelenésének elemzésére - a tárgyalt időintervallummal kapcsolatban, másfelöl pedig alapul szolgálhat további kutatások számára is, hiszen a munkát a későbbi évfolyamok tekintetében is folytatni kívánom. 


\section{Felhasznált irodalom}

Andrásfalvy 1996 = Andrásfalvy Bertalan: Az anyagi kultúra változása és az életmód átalakulása. In: Orosz István - Für Lajos - Romány Pál (szerk.): Magyarország agrártörténete. Agrártörténeti tanulmányok. Mezőgazda, Budapest, 1996. 345-381.

Balogh 2005 = Balogh Mihály: Bors Károly, a kunszentmiklósi sajtó megteremtője. In: Honismeret, XXXIII. évf. (2005) 2. sz. 40-47.

Balogh 2007 = Balogh János Mátyás: Napilapok és pénzintézetek kapcsolata a dualizmus korában. Médiakutató, VIII. évf. (2007) 2. sz. 71-92.

Baráth 2006 = Baráth Katalin: Revolver és vasvilla - Kisvárosi médiaritusok (Magyarkanizsa, 1909-1914). Médiakutató, VII. évf. (2006) 3. sz. 51-66.

Barta 2001 = Barta László: Szentes a reformkorban (1832-1848). In: Labádi Lajos (szerk.): Tanulmányok Szentes város történetéböl. Szentes Város Önkormányzata, Szentes, 2001. 197239.

Battonyai 1887 = Battonyai Ödön (szerk.): Czégek kézikönyve az ország területén törvényszékileg bejegyzett kereskedelmi czégekről. Battonyai Ödön, Budapest, 1887.

Bendtner 1892 = Bendtner József - Burger Gusztáv: Egy újabbkori magyar nyomdász Burger Zsigmond. In: Magyar nyomdászok évkönyve 1892 (VII. évf.), 13-21.

Bezdán 1974 = Bezdán Sándor: A Szentesi 48-as Népkör indulása (1870-1874). In: Szegedi Tanárképző Főiskola Tudományos Közleményei, Szeged, 1974. 3-14.

Bódy-Márkus 2012 = Bódy-Márkus Rozália: ,, Neki az irodalom eszköz, nem cél”? Heckenast Gusztáv periodikái 1837-1874. In: Lipták Dorottya (szerk.): A vállalkozó és a kultúra. Heckenast Gusztáv, a legendás könyvkiadó (1811-1878). Budapest-Eger, 2012. 179218.

Borovszky = Borovszky Samu, dr. (szerk.): Magyarország vármegyéi és városai - Heves vármegye. Országos Monografia Társulat, Budapest, é.n.

Bucsány 2000 = Bucsány György: Tóth József. Szentesi Élet, XXXI. évf. (2000) 12. sz. 2.

Buzinkay 1983 = Buzinkay Géza: Borsszem Jankó és társai-Élclapok és karikatúrák. Corvina Kiadó, Budapest, 1983.

Buzinkay 1993 = Buzinkay Géza: Kis magyar sajtótörténet. Haza és Haladás Alapítvány, Budapest, 1993.

Buzinkay 1997 = Buzinkay Géza: Bulvárlapok a pesti utcán. Budapest Negyed, 1997. nyárősz (V. évf. 2-3. sz.) (forrás http://epa.oszk.hu/00000/00003/00014/index.htm\#buzinkaygeza, letöltés: 2017. január 2.) 
Buzinkay 2008 = Buzinkay Géza: Magyar hírlaptörténet 1848-1918. Corvina Kiadó, Budapest, 2008.

Buzinkay 2009 = Buzinkay Géza (szerk.): Hirharang, vezércikk, szenzációs riport-Magyar sajtótörténeti antológia 1780-1956. Corvina, Budapest, 2009.

Buzinkay 2010 = Buzinkay Géza: Gondolatok a sajtó-médiatörténet oktatásáról. ME.DOK 2010/2. sz. (V. évf.), 9-14.

Buzinkay 2012 = Buzinkay Géza: Harc a sajtóreform körül, 1914. In: Pusztai Bertalan (szerk.): Médiumok, történetek, használatok - Ünnepi tanulmánykötet a 60 éves Szajbély Mihály tiszteletére. Szegedi Tudományegyetem Kommunikáció- és Médiatudományi Tanszék, Szeged, 2014. 282-292.

Buzinkay 2016 = Buzinkay Géza: A magyar sajtó és újságírás története a kezdetektől a rendszerváltozásig. Wolters Kluwer kiadó, Budapest, 2016.

Csák 1928 = Csák Béla, dr.: Közegészségügy. In: Nagy Imre (szerk.): Szentes. Magyar Városok Monografiája Kiadóhivatal, Budapest, 1928. 264-268.

Csernus 2014 = Csernus Szilveszter: Tiszaeszlár: a világ leghíresebb zsidó vérvádja. Forrás: mult-kor.hu történelmi portál, 2014. április 4. (http://mult-

kor.hu/20140404_tiszaeszlar_a_vilag_leghiresebb_zsido_vervadja, letöltés: 2017. augusztus 18.)

Deák 2015 = Deák Ágnes: „Zsandáros és policzájos idők”-Államrendőrség Magyarországon, 1849-1867. Osiris, Budapest, 2015.

Dersi 1973 = Dersi Tamás: Századvégi üzenet - Sajtótörténeti tanulmányok. Szépirodalmi Könyvkiadó, Budapest, 1973.

Derzsi 1928a = Derzsi Kovács Ferenc: A zenei élet ébredése, Joó Károly és társai. In: Nagy Imre (szerk.): Szentes. Magyar Városok Monografiája Kiadóhivatal, Budapest, 1928. 222225.

Derzsi 1928b = Derzsi Kovács Ferenc: Tanyai iskolák, népiskolai tanfolyam, ismeretterjesztö tanfolyam, középiskolák. In: Nagy Imre (szerk.): Szentes. Magyar Városok Monografiája Kiadóhivatal, Budapest, 1928. 191-203.

Dezsényi 1954 = Dezsényi Béla - Nemes György: A magyar sajtó 250 éve. I. kötet. Művelt Nép Könyvkiadó, Budapest, 1954.

Dimák 1928 = Dimák Géza: Közlekedés. In: Nagy Imre (szerk.): Szentes. Magyar Városok Monografiája Kiadóhivatal, Budapest, 1928. 312-314.

Döbör 2015 = Döbör András: Sajtópolitika és politikai sajtó Magyarországon a 18. század végén és a 19. század elsö felében. Doktori értekezés, Szeged, 2015. (forrás:

http://doktori.bibl.u-szeged.hu/2608/1/DoborAndrasPhD.pdf, letöltés: 2018. február 1.) 
Döbör 2018 = Döbör András - Pető Bálint: A magyarkanizsai sajtó kezdetei (1909-1918). In: Fejős Sándor (főszerk.): Magyarkanizsa monográfiája 1848-1945 (Kanizsa monográfiája II.). József Attila Könyvtár, Magyarkanizsa, 2018. 352-398.

Farkas 1990 = Farkas József: „,Földet és jogot a népnek!” (A függetlenségi baloldal útkeresése, Sima Ferenc útja a radikalizmusig). In: Blazovich László (szerk.): Tanulmányok Csongrád megye történetéből XVI.. Csongrád Megyei Levéltár, Szeged, 1990. 209-356.

Feketéné 2001 = Feketéné Moldován Mária: A szentesi kisdedóvás története 1876-2001. Szentesi Mühely Füzetek 6. (sorozatszerk.: Labádi Lajos), Csongrád Megyei Levéltár Szentesi Levéltára, Szentes, 2001.

Fizel 2017 = Fizel Natasa: A polgári iskolai tanárképzés professzionalizációja és intézményesülésének utolsó szakasza. Az állami pogári iskolai tanárképzö föiskola és a Ferenc József Tudományegyetem együttmüködése a tanárképzés területén (1928-1947). Doktori értekezés. Eger, 2017. (forrás: http://disszertacio.unieszterhazy.hu/45/1/Fizel\%20Natasa\%20Doktori\%20dolgozat.pdf. letöltés: 2018. február 9.)

Fleisz 2005 = Fleisz János: Az erdélyi magyar sajtó története 1890-1940. Pro Pannonia Kiadói Alapítvány, Pécs, 2005.

Follajtár 1938 = Follajtár Ernő - Fóris Anna, dr. - Kertész János, dr.: Szentes megyei város. In: Csíkvári Antal (szerk.): Csongrád vármegye. II. kötet. Vármegyei Szociográfiák Kiadóhivatal, Budapest, 1938. 3-18.

Fónagy 2001 = Fónagy Zoltán: Modernizáció és polgárosodás. Csokonai Kiadó, Debrecen, 2001.

Fülöp 1993 = Fülöp Géza: Sajtótörténet, sajtóismeret. Nemzeti Tankönyvkiadó, Budapest, 1993.

Für 1996 = Für Lajos: Földtulajdon és agrártermelés. In: Orosz István - Für Lajos - Romány Pál (szerk.): Magyarország agrártörténete. Agrártörténeti tanulmányok. Mezőgazda, Budapest, 1996. 173-225.

Gaál 2001 = Gaál Endre: A szegedi nyomdászat 1801-1918. Tanulmányok Csongrád megye történetéből XXX. Csongrád Megyei Levéltár, Szeged, 2001.

Gárdonyi 1965 = Gárdonyi Géza: Tükörképeim - Önéletírások, karcolatok, esszék. Szépirodalmi Könyvkiadó, Budapest, 1965. (elektronikus formátum:

http://mek.oszk.hu/03700/03737/html/, letöltés: 2017. augusztus 8.; a Sima Ferencre vonatkozó, hivatkozott rész a „Parlamentünk jeles figurái” fejezetben található: http://mek.oszk.hu/03700/03737/html/02.htm\#168)

Gergely 1978 = Gergely András - Szász Zoltán: Kiegyezés után. Magyar História-sorozat, Gondolat, Budapest, 1978.

Gergely 1998 = Gergely András (szerk.): 19. századi magyar történelem 1790-1918. Korona Kiadó, Budapest, 1998. 
Gerő 2017 = Gerő András: Az elsöprö kisebbség - Népképviselet a Monarchia Magyarországán. Habsburg Történeti Intézet - Közép- és Kelet-európai Történelem és Társadalom Kutatásáért Közalapítvány. Budapest, 2017.

Gulyás 1941 = Gulyás Pap Etelka: Régi történetek Szentes multjából. Szerzői kiadás, Szentes, 1941.

Gyáni 1999 = Gyáni Gábor: Az utca és a szalon-Társadalmi térhasználat Budapesten, 18701940. Új Mandátum Kiadó, Budapest, 1999.

Gyáni 2004 = Gyáni Gábor: A Habsburg-múlt emlékezeti kánonjai. In: Cieger András (szerk.): A kiegyezés. Osiris Kiadó, Budapest, 2004. 620-628.

Gyáni 2006 = Gyáni Gábor: Sajtótörténet a társadalomtörténész szempontjából.

Médiakutató, VII. évf. (2006) 1. sz. 57-65.

Gyurgyák 2001 = Gyurgyák János: A zsidókérdés Magyarországon. Osiris Kiadó, Budapest, 2001.

Harsányi 1970 = Harsányi László: A szentesi zsidó hitközség története. Magyar Izraeliták Országos Képviselete, Budapest, 1970.

Jaross 1910 = Jaross Ferenc: Emléklapok a Lévai Casino 50 éves multjából. 1859-1909. K.n., Léva, 1910.

Kaposi 2002 = Kaposi Zoltán: Magyarország gazdaságtörténete 1700-2000. Dialóg Campus Kiadó, Budapest-Pécs, 2002.

Kárász 1974 = Kárász József: A Csongrád megyei hirlapok és folyóiratok bibliográfiája 1843-1970. Somogyi-könyvtár, Szeged, 1974.

Kenedi 1903 = Kenedi Géza, dr.: A magyar sajtójog - Úgy amint életben van. FranklinTársulat, Budapest, 1903.

Kenyeres 2001 = Kenyeres Ágnes (szerk.): Magyar Életrajzi Lexikon 1000-1990. Arcanum, Budapest, 2001. (elektronikus kiadvány, forrás:

http://mek.oszk.hu/00300/00355/html/index.html, letöltés: 2017. augusztus 10.)

Kis-Rácz 2000 = Kis-Rácz Antalné - Labádi Lajos - Vörös Gabriella (szerk.): Szentes helyismereti kézikönyve (tanulmányok). Szentes Város Önkormányzata - Csongrád Megyei Levéltár, Szentes, 2000. (CD-változat, forrás: http://www.szentesinfo.hu/cd/helyismeret/, letöltés: 2016. október 4.; a dualizmuskori közigazgatás-, politika-, társadalom- és sajtótörténeti rész szerzője: Labádi Lajos - a hivatkozások könnyebb visszakereshetősége érdekében a lábjegyzetekben feltüntettem a vonatkozó fejezet, valamint alfejezet számát, illetve címét)

Kis-Rácz 2002 = Kis-Rácz Antalné: A szentesi Petöfi Sándor Általános Iskola képes története 1871-2002. Elektronikus kiadvány, Szentes, 2002. (Forrás:

http://www.szentesinfo.hu/petofi/cd/index.htm, letöltés: 2017. augusztus 8.) 
Kókay 1994 = Kókay György - Buzinkay Géza - Murányi Gábor: A magyar sajtó története. Magyar Újságírók Országos Szövetsége - Bálint György Újságíró-iskola, Budapest, 1994.

Kollega 1997 = Kollega Tarsoly István (föszerk.): Magyarország a XX. században. II. kötet. Babits Kiadó, Szekszárd, 1997.

Kósa 2002 = Kósa László (szerk.): Magyar müvelödéstörténet. Osiris, Budapest, 2002.

Kosáry 1985a = Kosáry Domokos - Németh G. Béla (szerk.): A magyar sajtó története II/1. Akadémiai Kiadó, Budapest, 1985.

Kosáry 1985b = Kosáry Domokos - Németh G. Béla (szerk.): A magyar sajtó története II/2. Akadémiai Kiadó, Budapest, 1985.

Kovács 1987 = Kovács Endre (föszerk.) - Katus László (szerk.): Magyarország története 1848-1890. II. kötet. Akadémiai Kiadó, Budapest, 1987.

Kováts 1928a = Kováts József, dr.: A népesség. In: Nagy Imre (szerk.): Szentes. Magyar Városok Monografiája Kiadóhivatal, Budapest, 1928. 259-264.

Kováts 1928b = Kováts József, dr.: A mezögazdaság kifejlödése. In: Nagy Imre (szerk.): Szentes. Magyar Városok Monografiája Kiadóhivatal, Budapest, 1928. 287-297.

Kováts 1928c = Kováts József, dr.: A nagyipar és kisipar. In: Nagy Imre (szerk.): Szentes. Magyar Városok Monografiája Kiadóhivatal, Budapest, 1928. 301-305.

Kováts 1928d = Kováts József, dr.: Szentes kereskedelme. In: Nagy Imre (szerk.): Szentes. Magyar Városok Monografiája Kiadóhivatal, Budapest, 1928. 309-311.

Kováts 1928e = Kováts József, dr.: Pénz- és hitelviszonyok. In: Nagy Imre (szerk.): Szentes. Magyar Városok Monografiája Kiadóhivatal, Budapest, 1928. 312.

Kozári 2005 = Kozári Monika: A dualista rendszer. Pannonica Kiadó, Budapest, 2005.

Kőszegfalvi 1991 = Kőszegfalvi Ferenc: Adatok a hódmezővásárhelyi nyomdászat, sajtó és könyvkiadás történetéhez 1852-1944. Békéscsaba-Gyoma, 1991.

(http://mek.oszk.hu/02400/02405/02405.pdf, letöltés: 2017. június 25.)

Kövér 2001 = Gyáni Gábor - Kövér György: Magyarország társadalomtörténete $-A$ reformkortól a második világháborúig. Osiris, Budapest, 2001.

Kövér 2002 = Kövér György: A felhalmozás íve. Új Mandátum Könyvkiadó, Budapest, 2002.

Labádi 1992 = Labádi Lajos: Egy elfelejtett polgármester - Emlékezés Oroszi Miklósra (1822-1892). Szentesi Élet, XXIII. évf. (1992) 40. sz. 3.

Labádi 1995 = Labádi Lajos: Szentes város közigazgatása és politikai élete 1849-1918.

Tanulmányok Csongrád megye történetéből XXII. Csongrád Megyei Levéltár, Szeged, 1995. 
Labádi 2000 = Labádi Lajos: Kristó Nagy István polgármester - Száz éve hunyt el a „fejlődés útnyitója”. Szentesi Élet, XXXI. évf. (2000) 8. sz. 4.

Labádi 2001 = Labádi Lajos: Hajdú Lajos emlékezete (1813-1901) - A szabadságharc szentesi bajnoka. Szentesi Élet, XXXII. évf. (2001) 9. sz. 4.

Labádi 2003a = Labádi Lajos: Szentes története évszámokban - Várostörténeti kronológia (1075-1945). Szentes Város Önkormányzata, Szentes, 2003.

Labádi 2003b = Labádi Lajos: A ,garabonciás” néptanitó - 150 éve született Sima Ferenc (I.). Szentesi Élet, XXXIV. évf. (2003) 45. sz. 2.

Labádi 2003c = Labádi Lajos: Az országos politika porondján - 150 éve született Sima Ferenc (II.). Szentesi Élet, XXXIV. évf. (2003) 46. sz. 2.

Labádi 2003d = Labádi Lajos: „, Muszka önkény!” - 150 éve született Sima Ferenc (III.). Szentesi Élet, XXXIV. évf. (2003) 47. sz. 2.

Labádi 2003e = Labádi Lajos: $A$ város elfelejtett tehetsége - 170 éve született Csukás Benjamin. Szentesi Élet, XXXIV. évf. (2003) 30. sz. 2.

Labádi 2003f = Labádi Lajos: $A$ Vármegyeháza története. (Forrás:

http://www.szentesinfo.hu/varmegyehaza/vmh_tortenet.htm, letöltés: 2017. augusztus 10.)

Labádi 2003g = Labádi Lajos: Darázs címü élclap - 120 éve jelent meg. Szentesi Élet, XXXIV. évf. (2003) 18. sz. 2.

Labádi 2004a = Labádi Lajos: „Egy város, akinek szíve van” - 80 éve hunyt el Balogh János polgármester (I.). Szentesi Élet, XXXV. évf. (2004) 9. sz. 2.

Labádi 2004b = Labádi Lajos: ,, Szellemi forradalom” Szentesen. - 80 éve hunyt el Balogh János polgármester (II.). Szentesi Élet, XXXV. évf. (2004) 10. sz. 2.

Labádi 2004c = Labádi Lajos: A márciusi forradalom. Szentesi Élet, XXXV. évf. (2004) 10. sz. 1.,3.

Labádi 2004d = Labádi Lajos: Városunk leghíresebb vendéglöse - Száztíz éve hunyt el Rambovszky József. Szentesi Élet, XXXV. évf. (2004) 41. sz. 2.

Labádi 2005a= Labádi Lajos: Egykor jószágigazgatók, szolgabirók lakták - A Gólyás-ház múltja (II.). Szentesi Élet, XXXVI. évf. (2005) 21. sz. 2.

Labádi 2005b = Labádi Lajos: Dicső ősök méltó utóda - 175 éve született Kiss Zsigmond. Szentesi Élet, XXXVI. évf. (2005) 22. sz. 2.

Labádi 2005c = Labádi Lajos: „Erös akarat nem ismer akadályt!” - 135 éve alakult a 48-as Népkör. Szentesi Élet, XXXVI. évf. (2005) 23. sz. 2.

Labádi 2005d = Labádi Lajos: Középiskolák alapitója - Nyolcvan éve hunyt el Zolnay Károly. Szentesi Élet, XXXVI. évf. (2005) 8. sz. 2. 
Labádi 2006a = Labádi Lajos: Az első szentesi folyóirat - 135 éve jelent meg a Szentesi Füzetek. Szentesi Élet, XXXVII. évf. (2006) 22. sz. 2.

Labádi 2006b = Labádi Lajos: Legtevékenyebb polgármesterünk - Százötvenöt éve született Sarkadi Nagy Mihály. Szentesi Élet, XXXVII. évf. (2006) 46. sz. 2.

Labádi 2006c = Labádi Lajos: $A$ város elsö nyomdásza és lapkiadója - Százhúsz éve hunyt el Cherrier János. Szentesi Élet, XXXVII. évf. (2006) 25. sz. 2.

Labádi 2007a = Labádi Lajos: Jókai Mór és Tisza Kálmán legyőzője - Százhuszonöt éve hunyt el Simonyi Ernő. Szentesi Élet, XXXIX. évf. (2007) 10. sz. 2.

Labádi 2007b = Labádi Lajos: Negyvennyolcas szabadságharcosaink segélyszervezete - 140 éve alakult a Szentesi Honvédegylet. Szentesi Élet, XXXIX. évf. (2007) 19. sz.), 2.

Labádi 2007c = Labádi Lajos: Elüldözött lapszerkesztö - Százhetvenöt éve született Buday József. Szentesi Élet, XXXIX. évf. (2007) 7. sz. 2.

Labádi 2007d = Labádi Lajos: Megbecsült igazgató-tanár - 160 éve született Balázsovits Norbert. Szentesi Élet, XXXIX. évf. (2007) 47. sz. 2.

Labádi 2008a = Labádi Lajos: Jeles publicista, közkedvelt képviselö - 165 éve született Törs Kálmán. Szentesi Élet, XL. évf. (2008) 13. sz. 2.

Labádi 2008b = Labádi Lajos: Az "Angyalhoz" címzett gyógyszertár a Felsőpárton Százhúsz éves a város negyedik gyógyszertára. Szentesi Élet, XL. évf. (2008) 22. sz. 2.

Labádi 2009a = Labádi Lajos: Az irófejedelem és a pénzügyminiszter legyőzőjeSzázhuszonöt éve hunyt el László Imre országgyülési képviselő. Szentesi Élet, XLI. évf. (2009) 11. sz. 2.

Labádi 2009b = Labádi Lajos: Politikai küzdelmek áldozata - 110 éve történt: Sima Ferenc bukása (I.). Szentesi Élet, XLI. évf. (2009) 26. sz. 2.

Labádi 2009c = Labádi Lajos: „,Megtörhettek, de meg nem hajoltam” - 110 éve történt: Sima Ferenc bukása (II.). Szentesi Élet, XLI. évf. (2009) 28. sz. 2.

Labádi 2010a = Labádi Lajos: Tisztelet a legyözöttnek! - Politikai kultúra a múltban. Szentesi Élet, XLII. évf. (2010) 39. sz. 2.

Labádi 2010b = Labádi Lajos: A fejlődés útnyitója - Száztiz éve hunyt el Kristó Nagy István polgármester. Szentesi Élet, XLII. évf. (2010) 8. sz. 2.

Labádi 2010c = Labádi Lajos: Gyöngyösi nyomdász alapított vállalkozást városunkban Évfordulónaptár - 2010. Szentesi Élet, XLII. évf. (2010) 46. sz. 2.

Labádi 2010d = Labádi Lajos: Szentesi nemzetörök és honvédek a szabadságharcban. Szentesi Élet, XLII. évf. (2010) 38. sz. 2. 
Labádi 2011 = Labádi Lajos: Az alkotmányos jogok védelmezöje - 100 évvel ezelött hunyt el Szathmáry Ede ügyvéd. Szentesi Élet, XLIII. évf. (2011) 43. sz. 2.

Labádi 2013 = Labádi Lajos: A Szentesi Laptól a Szentesi Életig - Sajtótörténeti barangolás a legkorábbi városi lapoktól a mai hetilapig (1871-2013)

(http://www.szentesinfo.hu/mozaik/ekonyvtar/szentes-sajtoja.htm, letöltés: 2017. november 6.)

Lakatos 2004 = Lakatos Éva: Sikersajtó a századfordulón. Balassi Kiadó - Országos Széchényi Könyvtár, Budapest, 2004.

Landgraf 2014 = Landgraf Ildikó: Átjárás a regiszterek között-Jókai Mór képes szórakoztató lapjai. In: Paál Vince (szerk.): A sajtó kultúraközvetítő szerepe 1867-1945 Tanulmányok. Magyar Tudományos Akadémia Bölcsészettudományi Kutatóközpont, Budapest, 2014., 9-20.

Lengyel 1963 = Lengyel Géza: Magyar újságmágnások. Akadémiai Kiadó, Budapest, 1963.

Lengyel 1999 = Lengyel András: „,Közkatonái a tollnak...” - Vázlatok Szeged sajtótörténetéhez. Bába és Társai Kft., Szeged, 1999.

Lengyel 2013 = Lengyel András: A magyar sajtótörténet-irás néhány kérdése. ME.DOK 2013/1. sz. (VIII. évf.), 19-42.

Lipták 1997 = Lipták Dorottya: A családi lapoktól a társasági lapokig. Budapesti Negyed 16-17. (1997/2-3.) (http://epa.oszk.hu/00000/00003/00014/liptak.htm, letöltés: 2017. június 28.)

Lipták 2002 = Lipták Dorottya: Újságok és újságolvasók Ferenc József korában. BécsBudapest-Prága. L’Harmattan kiadó, Budapest, 2002.

Lipták 2011 = Lipták Dorottya: A modernkori könyv- és sajtótörténeti kutatások állapotáról. Magyar Tudomány, 172. évf. (2011) 9. sz. 1121-1131.

Mayer 2015 = Mayer László: 34 év a város szolgálatában - Honthy Berta tanitónő (18651917). Múltbanéző (a Bács-Kiskun Megyei Levéltár elektronikus folyóirata), V. évf. 9. sz. (http://www.bacs-kiskun-leveltar.hu/V3/SP07_mbn/Tanulmanyok/mala-01t-1.html, letöltés: 2017. augusztus 30.)

Nagy 1928 = Nagy Imre: Szentes története az örökváltságtól a legújabb időkig. In: Nagy Imre (szerk.): Szentes. Magyar Városok Monografiája Kiadóhivatal, Budapest, 1928. 93-100.

Nagy 1992 = Nagy Zoltán: Százéves az Elsö Magyar Betüöntöde. Magyar Grafika, 1992/5. sz. (XXXVI. évf.), 25-31.

Nemeskürty 2002 = Nemeskürty István: Kis magyar müvelödéstörténet. 4., javított és bővített kiadás. Szent István Társulat, Budapest, 2002.

Novák 1928 = Novák László: A nyomdászat története, V. könyv: 1801-1867. Novák László, Budapest, 1928. 
Palásti 1958 = Palásti László: Franciák és a francia nyelv a Bánátban a XVIII. és XIX. században. In: A Szegedi Pedagógiai Főiskola Évkönyve, Szeged, 1958. 155-175.

Papp 1928 = Papp Lajos: Az iparos és kereskedö tanonciskola. In: Nagy Imre (szerk.): Szentes. Magyar Városok Monografiája Kiadóhivatal, Budapest, 1928. 206-207.

Papp 1982 = Papp Imre: A parasztember élete Szentes tanyavilágában - Válogatott néprajzi irások. Szentes város Tanácsa V. B. Müvelődésügyi Osztálya, Szentes, 1982.

Pető 2014 = Pető Bálint: Magyarkanizsa városi státusának első esztendeje a helyi sajtó tükrében. In: Délvidéki Szemle 2014/1. (I. évf. 1. sz.), 31-39.

Pukánszky 1996 = Pukánszky Béla - Németh András: Neveléstörténet. Nemzeti Tankönyvkiadó, Budapest, 1996. (elektronikus formátum, forrás: http://mek.oszk.hu/01800/01893/html/, letöltés: 2017. augusztus 15.; a hivatkozások könnyebb visszakereshetősége kedvéért a lábjegyzetekben feltüntettem a vonatkozó fejezet címét)

Puskel 2012 = Puskel Péter: Aradi újságíró személyiségek (I.) (forrás: http://www.nyugatijelen.com/allaspont/puskel_peter/aradi_ujsagiro_szemelyisegek_i.php, letöltés: 2017. június 5.)

Reiszig é. n. = Reiszig Ede, ifj., dr.: Torontál vármegye községei. In: Borovszky Samu, dr. (szerk.): Torontál vármegye - Magyarország vármegyéi és városai - Magyarország monografiája. Országos Monografia Társaság, Budapest, é. n. (forrás: http://mek.oszk.hu/09500/09536/html/0024/6.html, letöltés: 2017. december 10.)

Révész 2012 = Révész Emese: A képes sajtó Magyarországon 1780-1880. Budapesti Történeti Múzeum - Bibliotheca Nationalis Hungariae, Budapest, 2012.

Rózsa 1987 = Rózsa Gábor: Száz éves Szentes vasútja. MÁV Szentesi Építési Főnökség MÁV Körzeti Üzemfőnöksége, Szentes, 1987.

Ruszoly 1999 = Ruszoly József: Országgyülési képviselö-választások Magyarországon 18611868. JATE-ÁJK tudományos bizottsága, Szeged, 1999.

Sajó 1902 = Sajó Aladár - Róna Lajos: Az Ujság - Ujságírás - Ujságkiadás. Budapest, 1902.

Sajti 1984 = A. Sajti Enikő: Székely telepités és nemzetiségpolitika a Bácskában - 1941 . Nemzetiségi Füzetek 6., Akadémiai Kiadó, Budapest, 1984. (forrás: http://mek.oszk.hu/01200/01275/01275.htm, letöltés: 2017. augusztus 24.)

Scherg 1928 = Scherg Károly: Fásítástörténeti adatok Szentes vidékéröl. In: Nagy Imre (szerk.): Szentes. Magyar Városok Monografiája Kiadóhivatal, Budapest, 1928. 297-300.

Schupiter 1928a = Schupiter Elemér: Pillanatfelvételek. In: Nagy Imre (szerk.): Szentes. Magyar Városok Monografiája Kiadóhivatal, Budapest, 1928. 209-212.

Schupiter 1928b = Schupiter Elemér: Politikai élet. In: Nagy Imre (szerk.): Szentes. Magyar Városok Monografiája Kiadóhivatal, Budapest, 1928. 249-253. 
Schupiter 1928c = Schupiter Elemér: A társadalmi élet. In: Nagy Imre (szerk.): Szentes. Magyar Városok Monografiája Kiadóhivatal, Budapest, 1928. 253-255.

Schupiter 1928d = Schupiter Elemér: Szentes háziipara. In: Nagy Imre (szerk.): Szentes. Magyar Városok Monografiája Kiadóhivatal, Budapest, 1928. 305-306.

Schupiter 1928e = Schupiter Elemér: Irodalom, tudomány, müvészet. In: Nagy Imre (szerk.): Szentes. Magyar Városok Monografiája Kiadóhivatal, Budapest, 1928. 212-221.

Schupiter 1928f = Schupiter Elemér: Zene, ének, színészet. In: Nagy Imre (szerk.): Szentes. Magyar Városok Monografiája Kiadóhivatal, Budapest, 1928. 225-226.

Sebők 2005 = Sebők László (szerk.): Az 1869. évi népszámlálás vallási adatai. TLA Teleki László Intézet - KSH Népszámlálás - KSH Levéltár, h.n., 2005. (forrás: http://mek.oszk.hu/05900/05936/05936.pdf, letöltés: 2018. január 14.)

Sima 1897 = Sima Ferenc: Az obstructio, mint parlamentaris fegyver. Szentesi Első Könyvnyomda R.T., Szentes, 1897.

Sima 1914 = Sima László: Szentes város története. I. kötet. Szentes Város Közönsége, Szentes, 1914.

Simon 1954 = Simon Mária Anna: Szemelvények a magyar sajtó történetéböl 1849 után. Budapest, 1954.

Švoliková 2008 = Švoliková, Marta: Prvá tlačiareň v Leviciach. Tlačiar Ján Cherrier. In: Acta Musei Tekovensis Levice Zborník Tekovského Múzea V Leviciach - VII - 2008. 109113.

Szabó 1918 = Szabó László, dr.: Athenaeum - Ötven év egy irodalmi és nyomdai társaság életéböl. Athenaeum Irodalmi és Nyomdai Részvénytársulat, Budapest, 1918.

(http://mek.oszk.hu/10400/10415/10415.htm, letöltés: 2017. május 5.)

Szajbély 2005 = Szajbély Mihály: A médiatörténet és a sajtótörténet viszonyáról . Médiakutató, VI. évf. (2005) 1. sz. 71-79.

Szántó 1973 = Dersi Tamás - Szántó Tibor: A magyar sajtó képeskönyve. Magyar Újságírók Országos Szövetsége - Kossuth Könyvkiadó, Budapest, 1973.

Székely 1997 = Székely László, dr.: Magyar sajtójog. Magyar Újságírók Országos Szövetsége - Bálint György Újságíró-iskola, Budapest, 1997.

Szinnyei 1891 = Szinnyei József: Magyar írók élete és munkái. I. kötet. Hornyánszky Viktor, Budapest, 1891.

Szinnyei 1893 = Szinnyei József: Magyar írók élete és munkái. II. kötet. Hornyánszky Viktor, Budapest, 1893. 
Szinnyei 1896 = Szinnyei József: Magyar írók élete és munkái. IV. kötet. Hornyánszky Viktor, Budapest, 1896.

Szinnyei 1908 = Szinnyei József: Magyar írók élete és munkái. XII. kötet. Hornyánszky Viktor, Budapest, 1908.

Szinnyei 1914 = Szinnyei József: Magyar írók élete és munkái. XIV. kötet. Hornyánszky Viktor, Budapest, 1914.

Tamás 2013 = Tamás Ágnes: „Hogyan lehetne Magyarországon a zsidó kérdést a legpraktikusabban megoldani?!” In: Lukács Anikó (szerk.): Felekezeti társadalom felekezeti müveltség. A Hajnal István Kör - Társadalomtörténeti Egyesület 2011. évi, győri konferenciájának kötete. Budapest, 2013. 277-285.

Tamás 2014 = Tamás Ágnes: Nemzetiségek görbe tükörben - 19. századi nemzetiségi sztereotipiák Magyarországon. Kalligram, Pozsony, 2014.

Tasnádi 2014 = Tasnádi Kata: Sajtó és fotó a sajtófotó elött - A nyomtatott fotók megjelenése a magyar képes lapokban az 1880-as években. Médiakutató, 2014/4. (XV. évf.) 35-48. (forrás: http://epa.oszk.hu/03000/03056/00057/pdf/EPA03056_mediakutato_2014_tel_035048.pdf, letöltés: 2017. március 31.)

Tolcsvay 1928 = Tolcsvay Nagy Géza: A polgári leányiskola. In: Nagy Imre (szerk.): Szentes. Magyar Városok Monografiája Kiadóhivatal, Budapest, 1928. 204-206.

Tóth $2000=$ Tóth Ferenc (szerk.): Csongrád megye épitészeti emlékei. Csongrád Megye Önkormányzata, Szeged, 2000.

Túri 1994 = Majtényiné Túri Katalin: Szentesi egyletek és társulatok a XIX. században. Kézirat, 1994. (MNL CSML Szentes, XV.61. - Gyüjtemények - Helytörténeti jellegü kéziratok (pályamunkák, szakdolgozatok, disszertációk, 7123. sz.)

Újvári 1929 = Újvári Péter (szerk.): Magyar zsidó lexikon. Budapest, 1929.

Ujvári 2014 = Ujvári Hedvig: A pest-budai német sajtó jelentősége és irodalomközvetitő szerepe a kiegyezés után. In: Paál Vince (szerk.): A sajtó kultúraközvetítő szerepe 1867-1945 - Tanulmányok. Magyar Tudományos Akadémia Bölcsészettudományi Kutatóközpont, Budapest, 2014., 37-50.

Vajda 1928 = Vajda Antal: A szentesi izraelita egyház története. In: Nagy Imre (szerk.): Szentes. Magyar Városok Monografiája Kiadóhivatal, Budapest, 1928. 183-190.

Végh 1976 = Végh Oszkár: Nyomdászat Magyarországon - Fejezetek a magyarországi nyomdászat 500 éves történetéböl. Táncsics Könyvkiadó, Budapest, 1976.

Vende 2015 = Vende Ernő: Temesvári sajtó. Régi(j)óvilág - Regionális Honismereti Szemle, Temesvár, 2015. június (IX. évf. 1. sz.), 86-95.

Vitéz 2003 = Vitéz Ferenc: A szabadságon innen és túl - Fejezetek a magyar sajtó történetéböl. Kölcsey Ferenc Református Tanítóképző Főiskola, Debrecen, 2003. 
Voit 2000 = Voit Krisztina: A budapesti sajtó adattára 1873-1950. Argumentum Kiadó, Budapest, 2000.

Zakar 2014 = Zakar Péter: Egy református lelkész-tanitó bünhödése a forradalom utánHajdú Lajos református lelkész fogsága (1849-1856). Acta Universitatis Szegediensis: Acta historica, 2014., 136. sz., 35-49.

Zonda 2005 = Zonda Tamás, dr.: A öngyilkosság múltja és jelene Magyarországon . Embertárs, 2005/2. sz. (III. évf.), 175-184.

Zsilinszky 1900 = Zsilinszky Mihály: Csongrád vármegye története. III. kötet. Budapest, 1900 .

\section{Felhasznált források}

\section{Törvények, rendeletek}

1848:XVIII. tc. = az 1848. évi XVIII. törvénycikk - sajtótörvény (https://1000ev.hu/index.php?a=3\&param=5286, letöltés: 2016. július 4.)

1848:XXIII. tc. = az 1848. évi XXIII. törvénycikk a szabad királyi városokról (https://1000ev.hu/index.php?a=3\&param=5291, letöltés: 2018. január 5.)

1868:XXXIII. tc.= az 1868. évi XXXIII. törvénycikk az úrbéri örökváltságokért országos alapból adandó megtérítésről (https://1000ev.hu/index.php?a=3\&param=5355, letöltés: 2017. május 15.)

1868:XXXVIII. tc. $=$ az 1868. évi XXXVIII. törvénycikk a népiskolai közoktatás tárgyában (https://1000ev.hu/index.php?a=3\&param=5360, letöltés: 2017. augusztus 19.)

1869:XXIII. tc. = az 1869. évi XXIII. törvénycikk a hírlapbélyeg eltörléséről (https://1000ev.hu/index.php?a=3\&param=5403, letöltés: 2016. július 4.)

1870:XLII. tc.= az 1870. évi XLII. törvénycikk a köztörvényhatóságok rendezéséről (https://1000ev.hu/index.php?a=3\&param=5448, letöltés: 2016. szeptember 4.)

1871:XVIII. tc. $=$ az 1871. évi XVIII. törvénycikk a községek rendezéséröl (https://1000ev.hu/index.php?a=3\&param=5484, letöltés: 2016. szeptember 4.)

1872:VIII. tc. $=$ az 1872. évi VIII. törvénycikk - ipartörvény (https://1000ev.hu/index.php?a=3\&param=5542, letöltés: 2016. július 15.) 
1876:XIII. tc. $=$ az 1876. évi XIII. törvénycikk a cseléd és gazda közötti viszony szabályozásáról, a gazdasági munkásokról és a napszámosokról (https://1000ev.hu/index.php?a=3\&param=5726, letöltés: 2017 . október 7.)

1876:XXVIII. tc. = az 1876. évi XXVIII. törvénycikk a népiskolai hatóságokról (https://1000ev.hu/index.php?a=3\&param=5741, letöltés: 2017. augusztus 15.)

1886:XXI. tc. = az 1886. évi XXI. törvénycikk a törvényhatóságokról (https://1000ev.hu/index.php?a=3\&param=6214, letöltés: 2017. március 5.)

Magyar sajtójogi szabályok 1867-1914 - Ministeri elöterjesztés 1867. febr. 25-röl, a sajtóügyben, az 1848: 18. t. cz. életbeléptetése, az esküdtszékeknek Pesten, Debreczenben, Eperjesen, Nagyszombatban és Köszegen felállitása, s a sajtó ügyekben a királyi, illetöleg a kerületi táblák biráskodása tárgyában (forrás:

http://mtmi.hu/dokumentum/913/Magyar_sajtojogi_szabalyok_18671914.pdf, letöltés: 2017. július 5.)

\section{Lapok, folyóiratok}

Csongrádi Közlöny, 1896. április 12. (III. évf. 15. sz.)

Csongrádmegyei Közlöny, 1876, I. évf. (teljes fennmaradt állomány)

Darázs, 1883. I. évf. (teljes fennmaradt állomány)

Eger, 1868. december 10. (VI. évf. 50. sz.)

Eger, 1871. január 5. (IX. évf. 1. sz.)

Északi Fény, 1874, I. évf. (teljes fennmaradt állomány)

Kanizsai Ujság, 1914. január 18.(VII. évf. 3. sz.)

Protestáns Egyházi és Iskolai Lap, 1875. április 11. (XVIII. évf. 15. sz.)

Szentesi Füzetek, 1871. február (I. évf. 1. sz.)

Szentesi Lap, 1872-1883, I-XIII. évf. (teljes fennmaradt állomány)

Szentesi Lap, 1893. szeptember 12. (XXIII. évf. 109. sz.)

Szentesi Lap, 1913. november 23. (XLIII. évf. 94. sz.)

Szentesi Lapok, 1871-1872, I-II. évf. (teljes fennmaradt állomány)

Szentes és Vidéke, 1880-1883, I-IV. évf. (teljes fennmaradt állomány)

Vasárnapi Ujság, 1880. augusztus 8. (XXVII. évf. 32. sz.)

Vasárnapi Ujság, 1880. augusztus 29. (XXVII. évf. 35. sz.) 


\section{Levéltári források}

MNL BKML KK, V.355.c. - Kunszentmiklós nagyközség polgári iratai (1872-1939), 1. d. Képviselőtestületi iratok, 1. - Közgyülési jegyzőkönyvek (1879-1885)

MNL BKML KK, V.355.c. - Kunszentmiklós nagyközség polgári iratai (1872-1939), 1. d. Képviselőtestületi iratok, 6. - Szabályrendelet az árvapénztár kezeléséről (1884)

MNL BKML KK, V.355.c. - Kunszentmiklós nagyközség polgári iratai (1872-1939), 13. d. Külön kezelt elöljárósági iratok, 10. - Kunszentmiklósi vállalkozások céges számlái (18801930)

MNL BKML KK, V.355.c. - Kunszentmiklós nagyközség polgári iratai (1872-1939), 31. d. Követelési számlakönyv, 1885. év

MNL BKML KK, V.355.c. - Kunszentmiklós nagyközség polgári iratai (1872-1939), 57. k. Együttesen kezelt állami adók fökönyve, 1883. év

MNL BKML KK, V.355.c. - Kunszentmiklós nagyközség polgári iratai (1872-1939), 58. k. Együttesen kezelt állami adók fökönyve, 1884. év

MNL BKML KK, V.355.c. - Kunszentmiklós nagyközség polgári iratai (1872-1939), 59. k. Együttesen kezelt állami adók fökönyve, 1887. év

MNL BKML KK, V.355.c. - Kunszentmiklós nagyközség polgári iratai (1872-1939), 78. k. Községi pótadó fökönyv, 1884. év

MNL CSML Szentes, V.B.145.b. - Szentes Város Tanácsának iratai (1849-1872) - Tanácsi iratok, 2026/1870.

MNL CSML Szentes, V.B.145.b. - Szentes Város Tanácsának iratai (1849-1872) - Tanácsi iratok, 2094/1871.

MNL CSML Szentes, V.B.145.b. - Szentes Város Tanácsának iratai (1849-1872) - Tanácsi iratok, 2447/1872.

MNL CSML Szentes, V.B.160. - Szentes Város Köz- és Házipénztárának iratai (1846-1873), 26. k. (az 1871. év fökönyve)

MNL CSML Szentes, V.B.179. - Szentes Város Köz- és Házipénztárának iratai (1871-1949), 24. k. (az 1872. év fökönyve)

MNL CSML Szentes, V.B.179. - Szentes Város Köz- és Házipénztárának iratai (1871-1949) 25. k. (az 1873. év fökönyve)

MNL CSML Szentes, V.B.179. - Szentes Város Köz- és Házipénztárának iratai (1871-1949) 26. k. (az 1874. év fökönyve) 
MNL CSML Szentes, V.B.179. - Szentes Város Köz- és Házipénztárának iratai (1871-1949) 27. k. (az 1875. év fökönyve)

MNL CSML Szentes, V.B.179. - Szentes Város Köz- és Házipénztárának iratai (1871-1949) 28. k. (az 1876. év fökönyve)

MNL CSML Szentes, V.B.179. - Szentes Város Köz- és Házipénztárának iratai (1871-1949) 29. k. (az 1878. év fökönyve)

MNL CSML Szentes, V.B.179. - Szentes Város Köz- és Házipénztárának iratai (1871-1949) 30. k. (az 1879. év fökönyve)

MNL CSML Szentes, V.B.179. - Szentes Város Köz- és Házipénztárának iratai (1871-1949) 31. k. (az 1881. év fökönyve)

MNL CSML Szentes, V.B.179. - Szentes Város Köz- és Házipénztárának iratai (1871-1949) 32. k. (az 1882. év fökönyve)

MNL CSML Szentes, V.B.179. - Szentes Város Köz- és Házipénztárának iratai (1871-1949) 33. k. (az 1883. év fökönyve)

MNL CSML Szentes, IV.B.434.a. - Csongrád Vármegye Felekezeti Anyakönyvi Másodpéldányainak Levéltári Gyüjteménye - A római katolikus egyházközségek anyakönyveinek másodpéldányai, Szentes, halotti anyakönyvek (1872-1883. év)

MNL CSML Szentes, IV.B.434.a. - Csongrád Vármegye Felekezeti Anyakönyvi Másodpéldányainak Levéltári Gyüjteménye - A római katolikus egyházközségek anyakönyveinek másodpéldányai, Szentes, születési anyakönyvek (1874., 1877., 1878., 1880., 1882. év)

MNL CSML Szentes, IV.B.434.b. - Csongrád Vármegye Felekezeti Anyakönyvi Másodpéldányainak Levéltári Gyüjteménye - A református egyházközségek anyakönyveinek másodpéldányai, Szentes, halotti anyakönyvek (1872-1883. év)

MNL CSML Szentes, IV.B.434.c. - Csongrád Vármegye Felekezeti Anyakönyvi Másodpéldányainak Levéltári Gyüjteménye - Az evangélikus egyházközségek anyakönyveinek másodpéldányai, Szentes, halotti anyakönyvek (1872-1883. év)

MNL CSML Szentes, IV.B.434.d. - Csongrád Vármegye Felekezeti Anyakönyvi Másodpéldányainak Levéltári Gyüjteménye - A görögkeleti egyházközségek anyakönyveinek másodpéldányai, Szentes, halotti anyakönyvek (1872-1883. év)

MNL CSML Szentes, IV.B.434.e. - Csongrád Vármegye Felekezeti Anyakönyvi Másodpéldányainak Levéltári Gyüjteménye - Az izraelita egyházközségek anyakönyveinek másodpéldányai, Szentes, halotti anyakönyvek (1872-1883. év)

MNL CSML Szentes, IV.B.434.f. - Csongrád Vármegye Felekezeti Anyakönyvi Másodpéldányainak Levéltári Gyüjteménye - A nazarénus egyházközségek anyakönyveinek másodpéldányai, Szentes, halotti anyakönyvek (1872-1883. év) 
MNL CSML Szentes térképtár, SZVK 17. sz. térkép, 4. sz. felvétel

MNL HML, IV.416.191. - Heves vármegye felekezeti anyakönyvi másodpéldányok gyüjteménye (1827-1895), Gyöngyös Felsőváros római katolikus születési anyakönyvek (1851-1867), 1866. év

MNL HML, IV.416.193. - Heves vármegye felekezeti anyakönyvi másodpéldányok gyüjteménye (1827-1895), Gyöngyös Felsőváros római katolikus születési anyakönyvek (1868-1884), 1868. és 1870. év

MNL HML, V.141.a. - Gyöngyös Város Tanácsának iratai (1841-1871), Jegyzökönyvek (1848-1871), 13. sz. jegyzőkönyv (1867. év)

MNL HML, V.141.a. - Gyöngyös Város Tanácsának iratai (1841-1871), Jegyzőkönyvek (1848-1871), 14. sz. jegyzőkönyv (1868. és 1869. év)

MNL HML, V.141.a. - Gyöngyös Város Tanácsának iratai (1841-1871), Jegyzőkönyvek (1848-1871), 15. sz. jegyzökönyv (1870. és 1871. év)

MNL HML, V.142. - Gyöngyös Város Pénztárának iratai (1848-187); 22. k. - Adózók összeírása (1866. év)

RNL TL, a római katolikus egyház születési anyakönyvei, Nagyősz (Tomnatic), 5. k., 18331864. 44. oldal

\section{Egyéb források}

A Magyar Korona országaiban az 1870. év elején végrehajtott népszámlálás eredményei a hasznos házi állatok kimutatásaival együtt. Országos Magyar Királyi Statistikai Hivatal, Pest, 1871.

Budapesti Czim- és Lakásjegyzék. 24. évf., Franklin-Társulat, Budapest, 1912

A nyitrai római katolikus egyház házassági anyakönyvei, 1865. év, 28. oldal (forrás: https://familysearch.org/ark:/61903/3:1:33S7-8BT3-TP6?mode=g\&i=9\&wc=9PQ3SP8\%3A107654301\%2C107660801\%2C110064602\%2C141441901\&cc=1554443, letöltés: 2017. október 5.)

Az ürményi római katolikus egyház születési anyakönyvei, 1843. év, 19. oldal (forrás: https://www.familysearch.org/ark:/61903/3:1:33S7-8BT7-DL6?i=12\&cc=1554443, letöltés: 2018. január 2.) 
A pozsonyi római katolikus egyház születési anyakönyvei, 1838. és 1839. év (forrás: https://www.familysearch.org/ark:/61903/3:1:33S7-8BT7-DL6?owc=9P3P92Q\%3A107654301\%2C107722701\%3Fcc\%3D1554443\&cc=1554443, letöltés: 2017. október 10.)

A kunszentmiklósi római katolikus plébánia halotti anyakönyvei, 1886., 1888. és 1889. év

\section{Egyéb internetes források:}

http://epa.oszk.hu/html/vgi/kardexlap.phtml?id=2523 (letöltés: 2016. február 4.)

http://mek.oszk.hu/01100/01149/html/rakosij.htm (letöltés: 2017. július 12.)

http://mtdaportal.extra.hu/books/sule_antal_rakosi_jeno_elete_es_muvei.pdf (letöltés: 2017. július 14.)

http://nepesseg.com/csongrad/szentes(letöltés: 2017. augusztus 6.)

http://sajtomuzeum.oszk.hu/forrasok/hirlapjaink/pdf/1_27_csongradi_kozlony.pdf (letöltés: 2017. július 10.)

http://sajtomuzeum.oszk.hu/forrasok/hirlapjaink/pdf/1_31_makoi_hirlap.pdf (letöltés: 2017. július 10.)

http://typographia.oszk.hu/html_clavis/hun/pressnyom.php?kezd=c, letöltés: 2018. január 8 .

http://www.arcanum.hu/hu/online-kiadvanyok/Bona-bona-tabornokok-torzstisztek1/hadnagyok-es-fohadnagyok-az-184849-evi-szabadsagharcban-2/c-4B9/dezseri-cicatricispal-4CF/ (letöltés: 2017. augusztus 21.)

http://www.csanytelek.hu/hu/bemutatkozunk/telepulesunk_tortenete/ (letöltés: 2017. november 4.)

http://www.gadoros.hu/index.php?option=com_content\&view=article\&id=46\&Itemid=57 (letöltés: 2017. november 4.)

http://www.szentes.hu/?page_id=1219 (letöltés: 2017. július 17.)

http://www.zsido.hu/rabbi/rabbi.php?old=122 (letöltés: 2017. augusztus 25.)

https://dtt.ogyk.hu/hu/gyujtemenyismertetok/konyvek/szerzoi-eletrajzok/item/334csavolszky-lajos (letöltés: 2017. május 3.) 
https://dtt.ogyk.hu/hu/gyujtemenyismertetok/konyvek/szerzoi-eletrajzok/item/334csavolszky-lajos (letöltés: 2017. május 3.)

https://www.arcanum.hu/en/online-kiadvanyok/Lexikonok-a-magyar-nyelv-szotaraczuczorfogarasi-55BEC/r-6AE5A/rizma-6B728/, letöltés: 2018. január 6.

https://www.arcanum.hu/en/online-kiadvanyok/Lexikonok-magyar-eletrajzi-lexikon7428D/k-760F2/kulinyi-zsigmond-767B7/ (letöltés: 2017. október 8.)

https://www.arcanum.hu/hu/online-kiadvanyok/Petrik-magyar-konyveszet-171219202/18761885-13040/magyar-hirlapok-es-folyoiratok-16596/1872-gyongyos-gyongyos-vegyes1878-ban-politikai-1879-tol-ismet-vegyes-tartalmu-hetilap-vxiv-evf-18761885-szerk-elobbcsomor-karoly-187-166CF/ (letöltés: 2018. január 5.)

http://www.szentesinfo.hu/liget/liget/ (letöltés: 2018. január 11.)

http://www.tinodilantos.hu/index.php?option=com_content $\&$ view=article\&id=393\&Itemid=3 91\&lang=en (letöltés: 2018. január 31.)

http://www.informed.hu/?tPath=/betegsegek/betegsegek_reszletesen/lung/pleural/\&article_id =84312 (letöltés: 2018. május 8.)

A dolgozatban szereplő ábrák (1-27. sz.) kivétel nélkül saját készítésüek, a feltüntetett primer és szekunder források adatainak felhasználásával készültek. 


\section{Rövidítések}

$\mathbf{A F}=$ Alföldi Figyelö

CSK = Csongrádmegyei Közlöny

ÉF = Északi Fény

MNL BKML KK = Magyar Nemzeti Levéltár Bács-Kiskun Megyei Levéltár, Kecskemét, Kossuth téri telephely

MNL CSML Szentes = Magyar Nemzeti Levéltár Csongrád Megyei Levéltár Szentesi fióklevéltára

MNL HML = Magyar Nemzeti Levéltár Heves Megyei Levéltár (Eger)

MNL OL BL = Magyar Nemzeti Levéltár Országos Levéltár Belügyminisztériumi Levéltár

RNL TL = Romániai Nemzeti Levéltár Temesvári Levéltára (Arhivele Naţionale ale României - Timiş)

OSZK = Országos Széchényi Könyvtár

$\mathbf{S Z F}=$ Szentesi Füzetek

SZL = Szentesi Lap

SZLK = Szentesi Lapok

$\mathbf{S Z V}=$ Szentes és Vidéke 
Függelék 


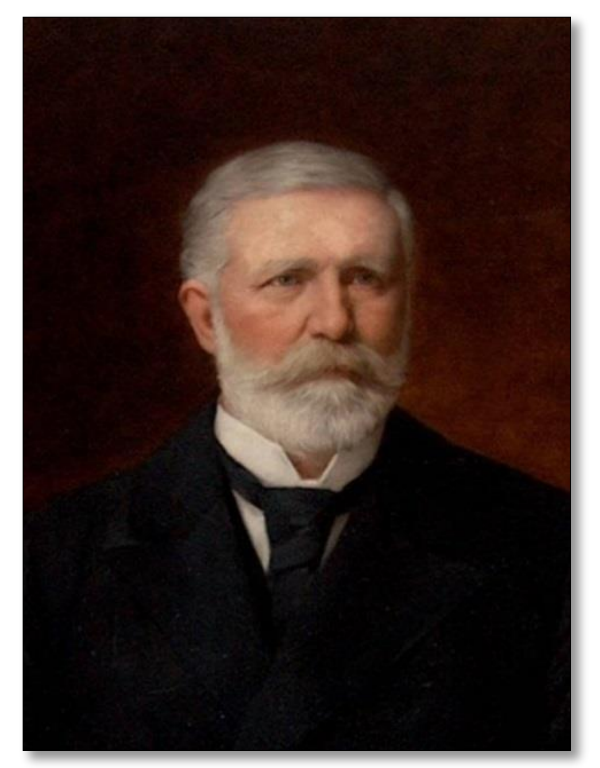

1. kép - Stammer Sándor polgármester, később Csongrád vármegye alispánja (forrás: http://npg.hu/images/jcollection/stammer_sandor.jpg, letöltés: 2017. augusztus 10.)

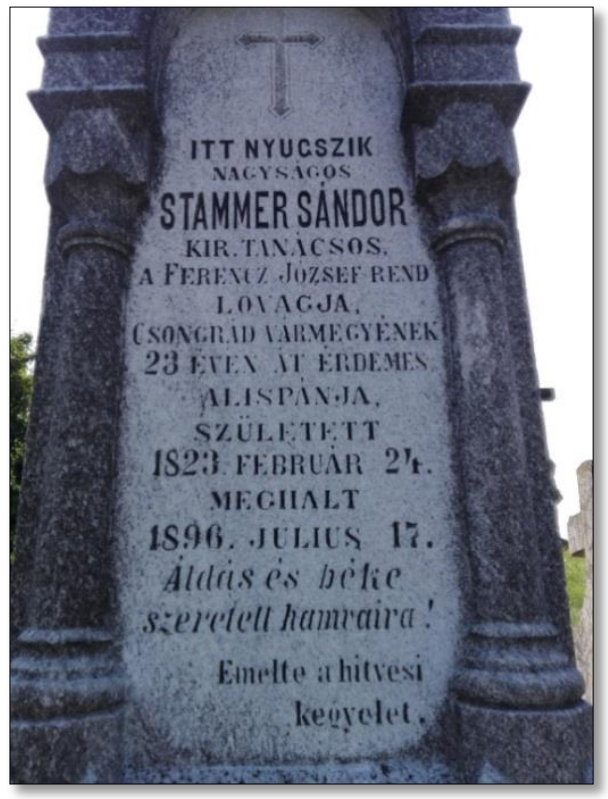

2. kép - Stammer Sándor síremléke Szentesen (forrás: saját készítésü fotó, 2017. augusztus 5.) 


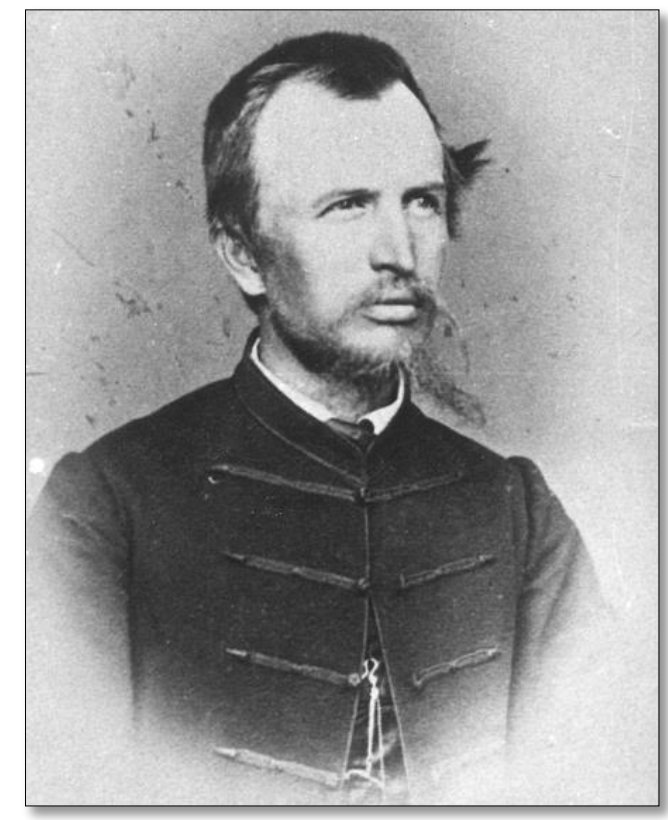

3. kép - Csukás Benjamin iskolaszéki elnök

(forrás: http://www.szentesinfo.hu/cd/helyismeret/varostortenet/index.htm, letöltés: 2017. augusztus 10.)

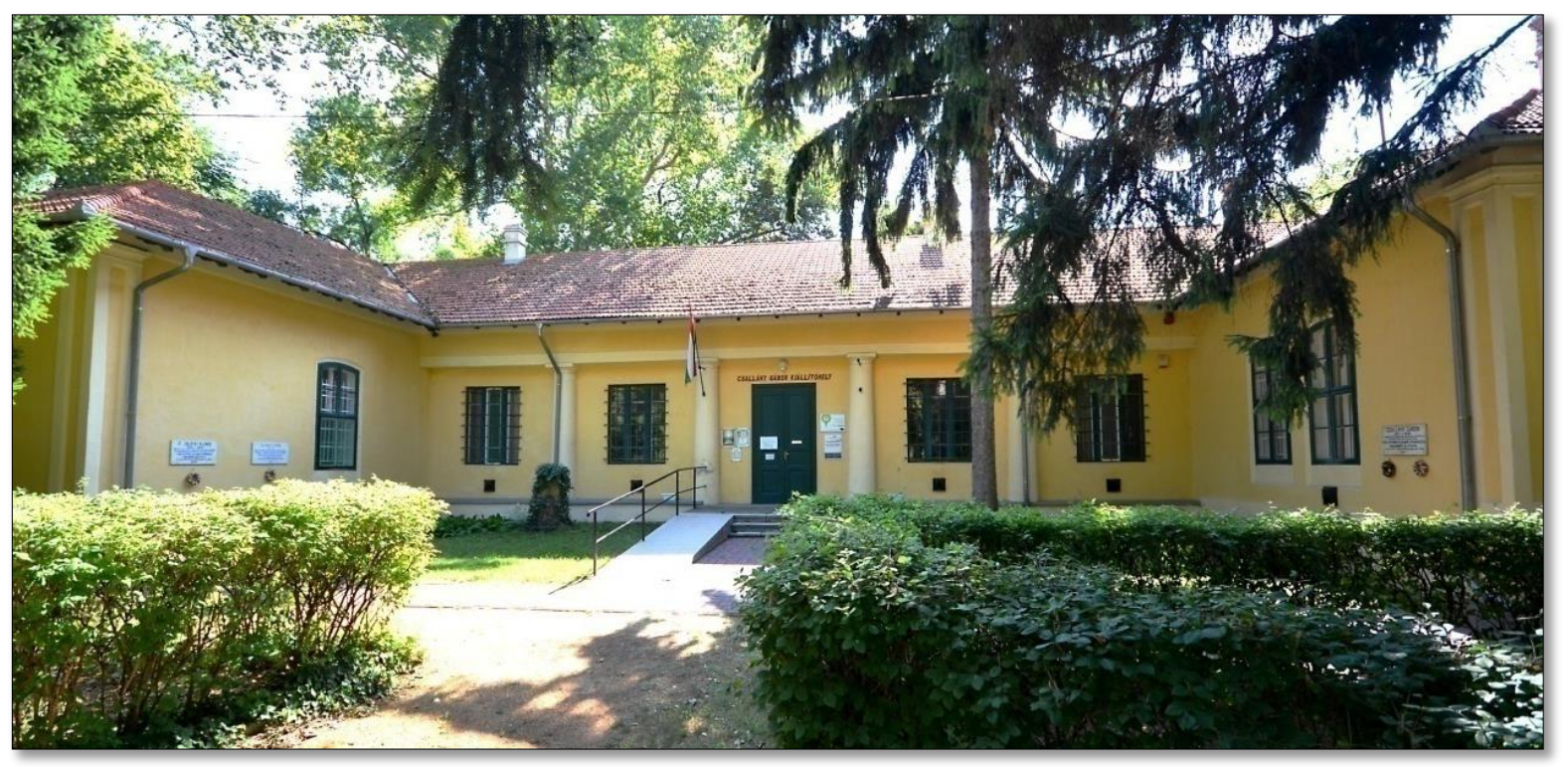

4. kép - A Széchenyi-ligeti vendéglő, amely később a polgári fiúiskolának, a XX. században pedig évtizedekig a Koszta József Múzeumnak adott otthont

(forrás: saját készítésủ fotó, 2017. augusztus 16.) 


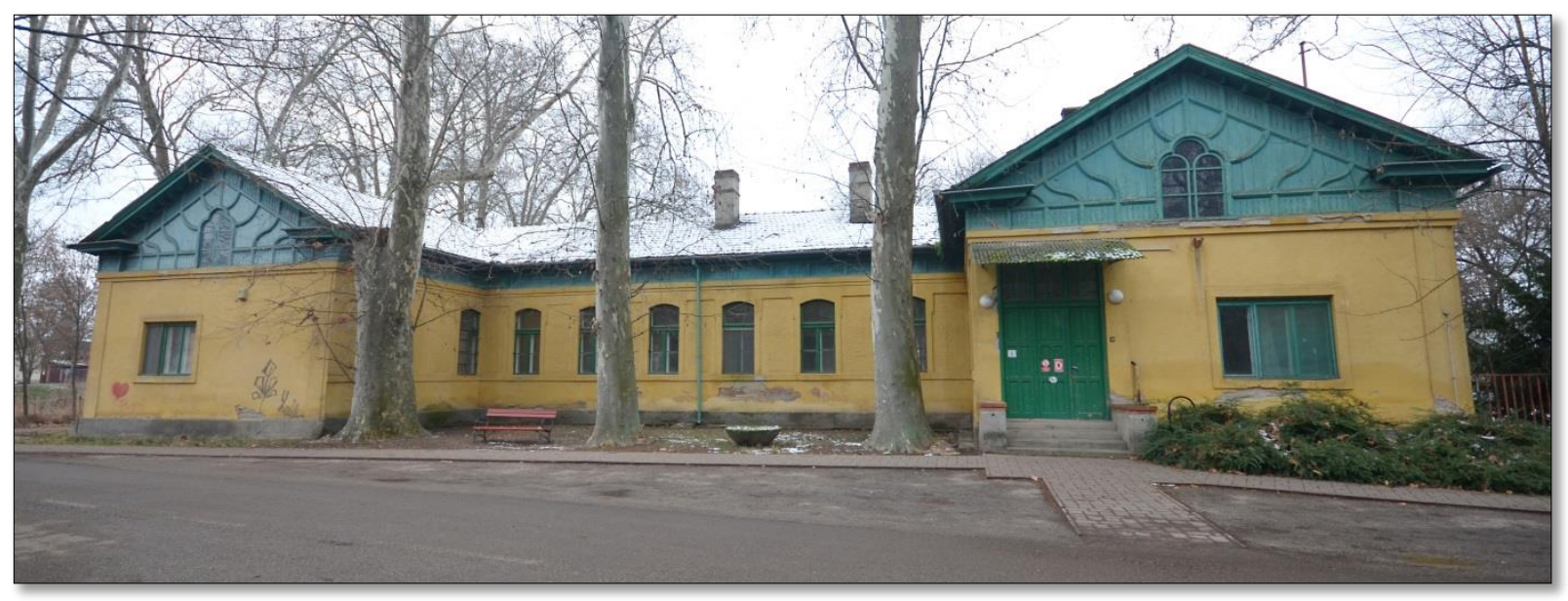

5. kép - Az 1869-ben átadott, egykori gőz- és kádfürdő épülete a Széchenyi-ligetben (forrás: saját készítésű fotó, 2018. január 24.)

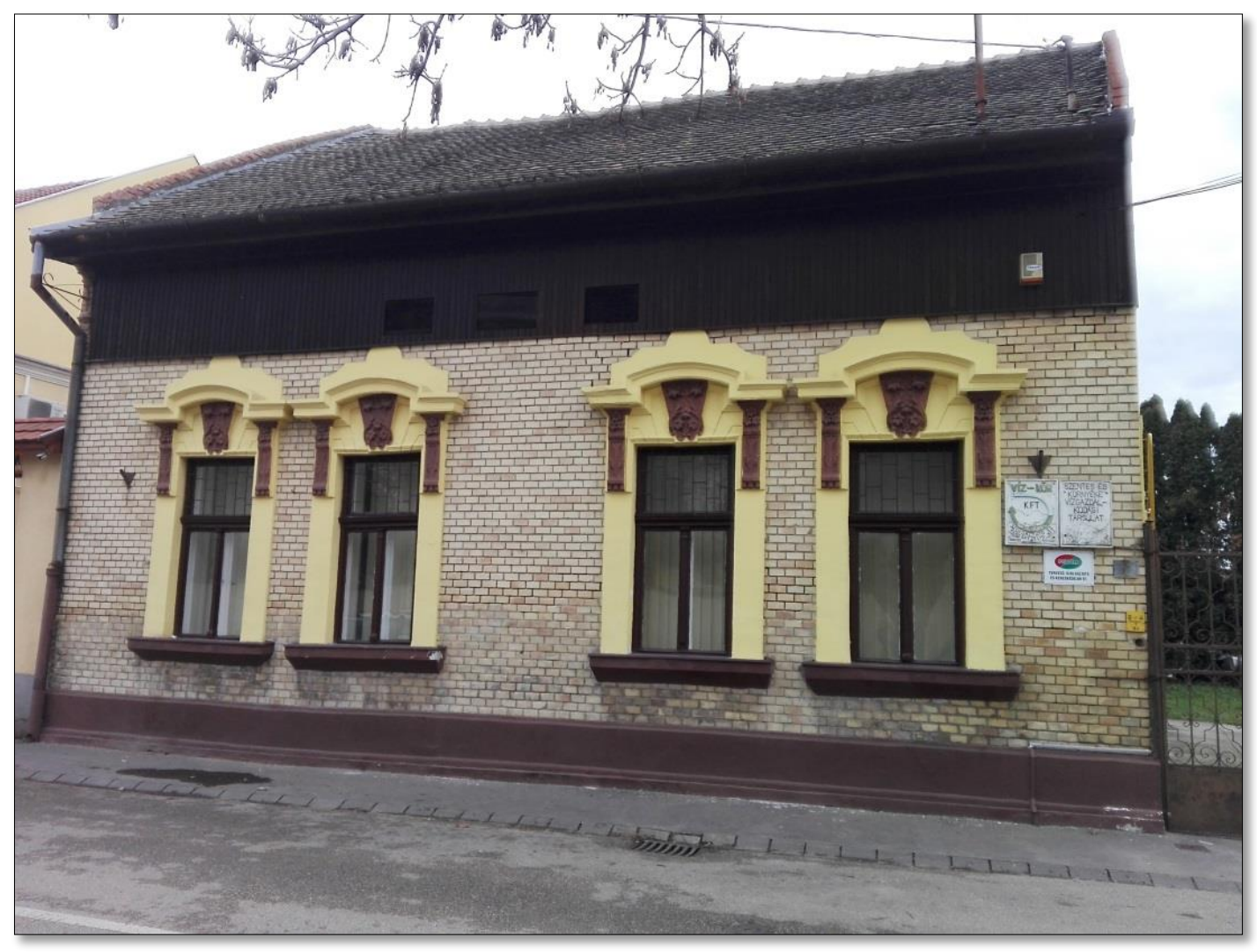

6. kép - Az ezen a helyen álló épületben kezdte meg müködését 1876-ban a Jótékony Nőegylet által alapított első szentesi kisdedóvó

(forrás: saját készítésü fotó, 2017. december 20.) 


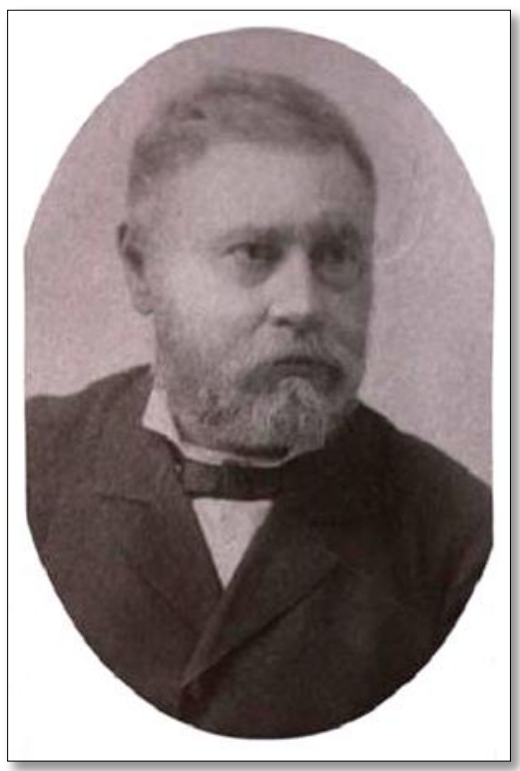

7. kép - Zolnay Károly, a gimnázium, illetve a polgári leányiskola megszervezője és igazgatója

(forrás: http://www.hmg.hu/evkonyv/adatok/igazgatok.htm, letöltés: 2017. augusztus 19.)

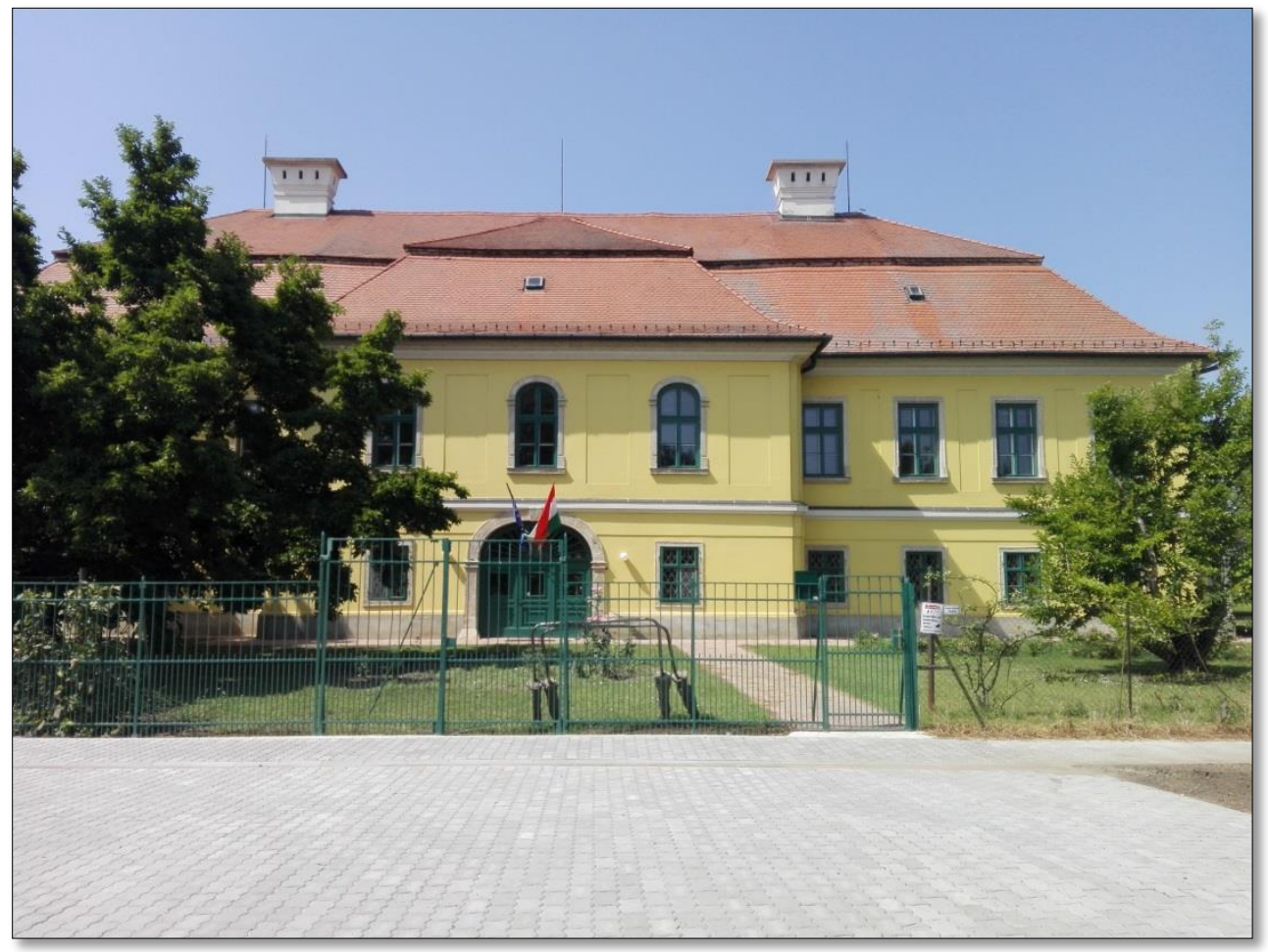

8. kép - Az egykori megyeháza épülete Szegváron (forrás: saját készítésủ fotó, 2017. augusztus 5.) 


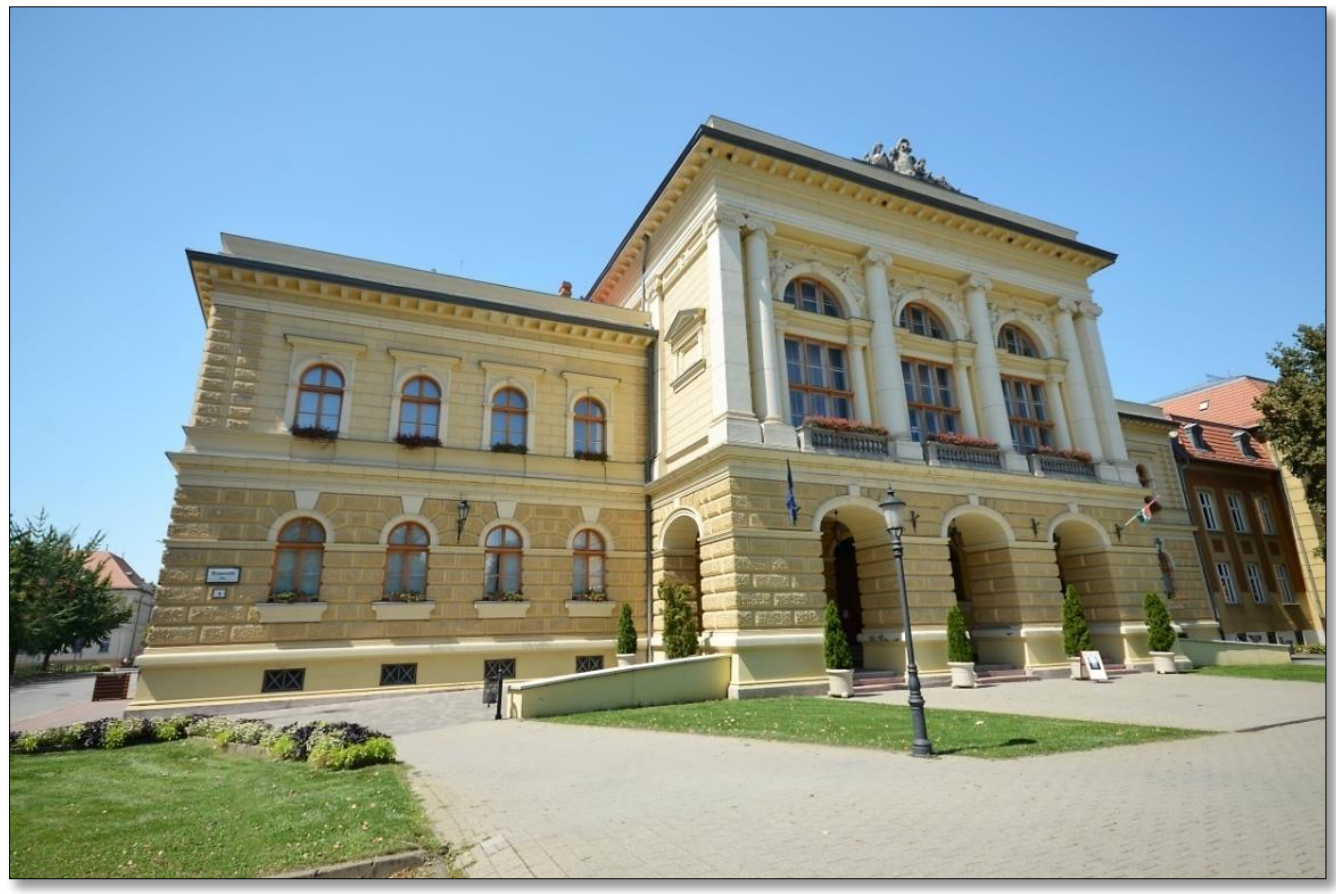

9. kép - A klasszicista stílusú, 1883-ban átadott megyeháza Szentes föterén (forrás: saját készítésủ fotó, 2017. augusztus 5.)

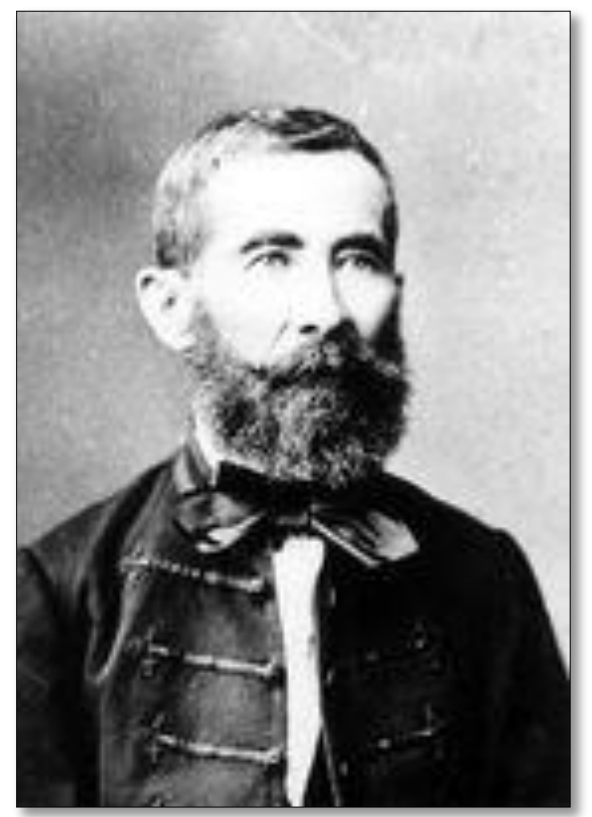

10. kép - Oroszi Miklós polgármester, a város első nyomtatott sajtótermékének kiadója (forrás: http://www.szentesinfo.hu/mozaik/ekonyvtar/szentes-sajtoja.htm, letöltés: 2017. augusztus 10.) 


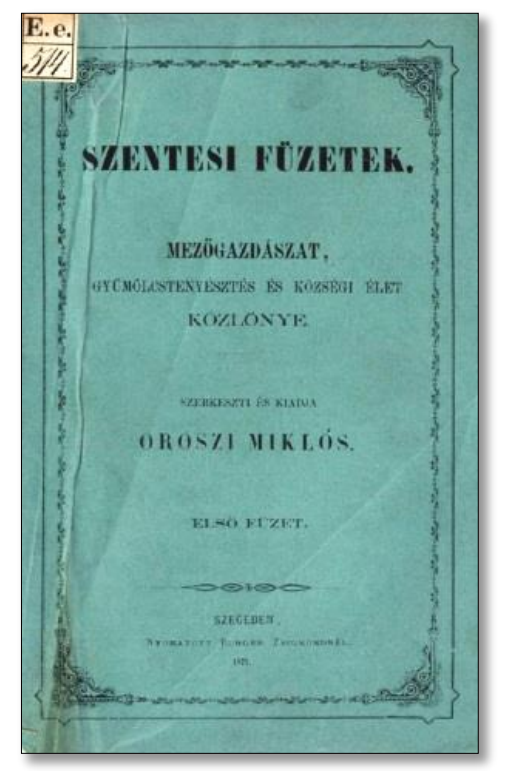

11. kép - A Szentesi Füzetek címlapja

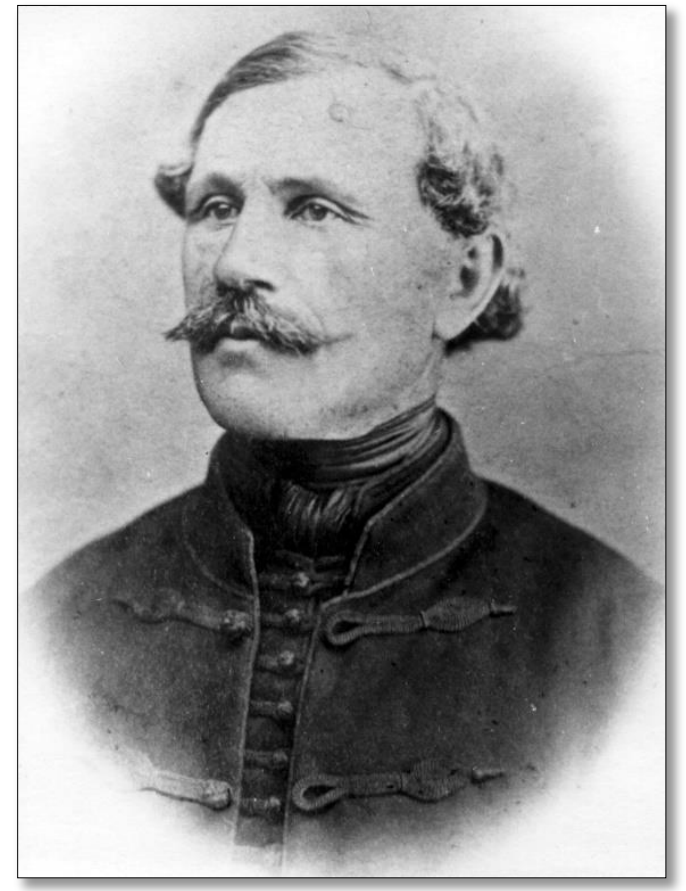

12. kép - Kristó Nagy István polgármester (forrás: Szentesi Élet, 2010. február 26., XLII. évf. 8. sz., 2.) 


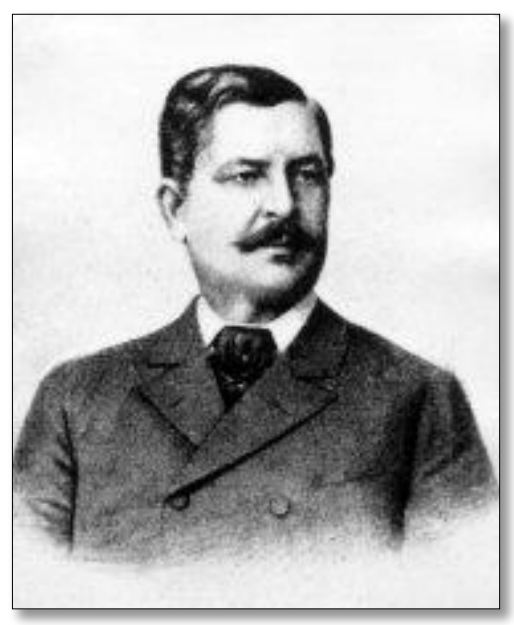

13. kép - Balogh János polgármester

(forrás: http://www.szentesinfo.hu/szentesielet/2004/10_0312/kepek/08.jpg, letöltés: 2017. augusztus 13.)

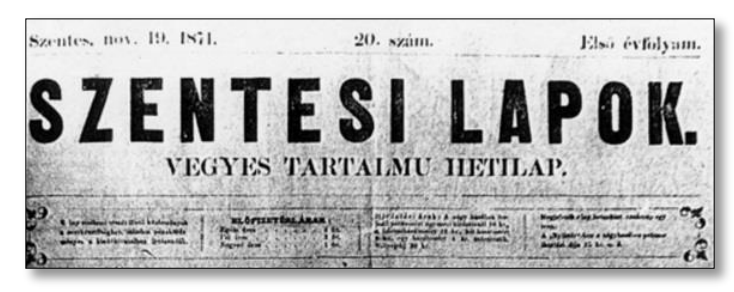

14. kép - A Szentesi Lapok fejléce

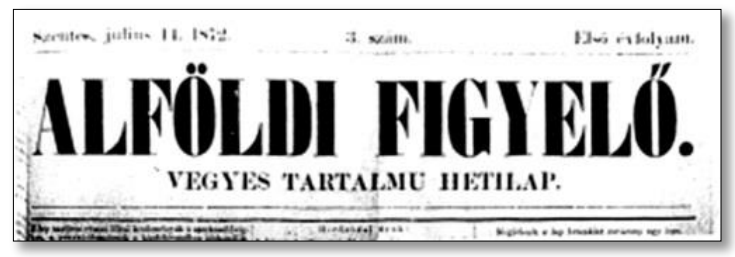

15. kép - Az Alföldi Figyelő fejléce 


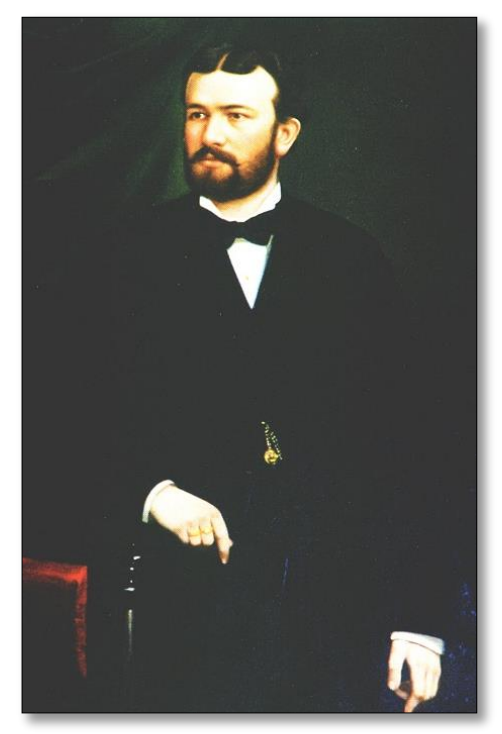

16. kép - Sarkadi Nagy Mihály polgármester

(forrás: http://www.szentesinfo.hu/cd/helyismeret/varostortenet/kepek/02_10_03_06.htm, letöltés: 2017. augusztus 13.)

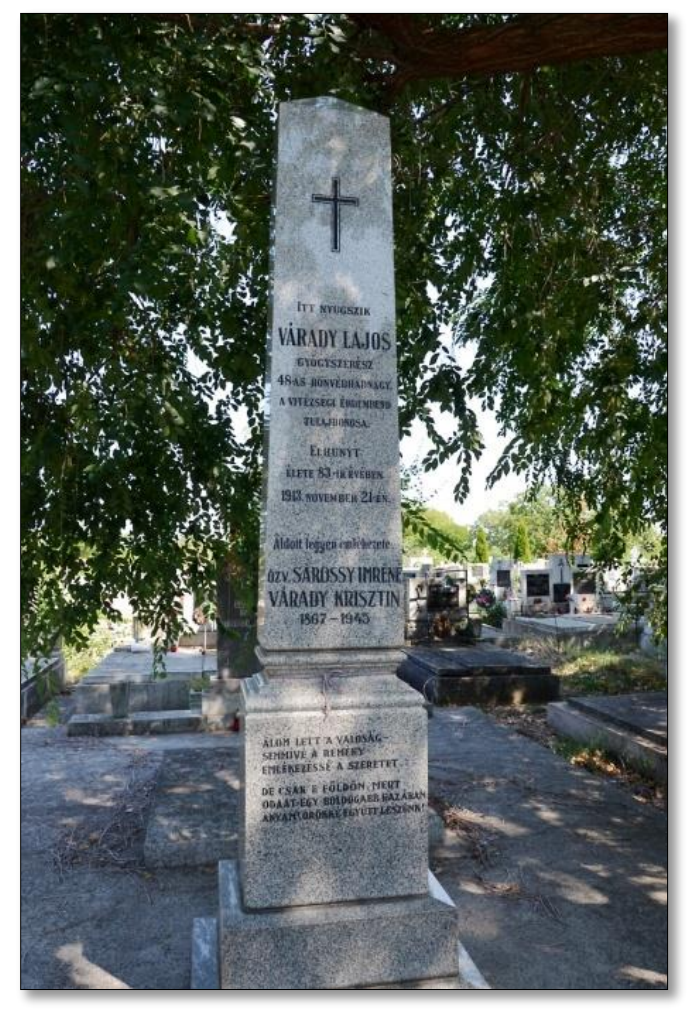

17. kép - Várady Lajos, a helyi sajtóban legtöbbet hirdető gyógyszerész sírja Szentesen

(forrás: saját készítésủ fotó, 2017. augusztus 13.) 


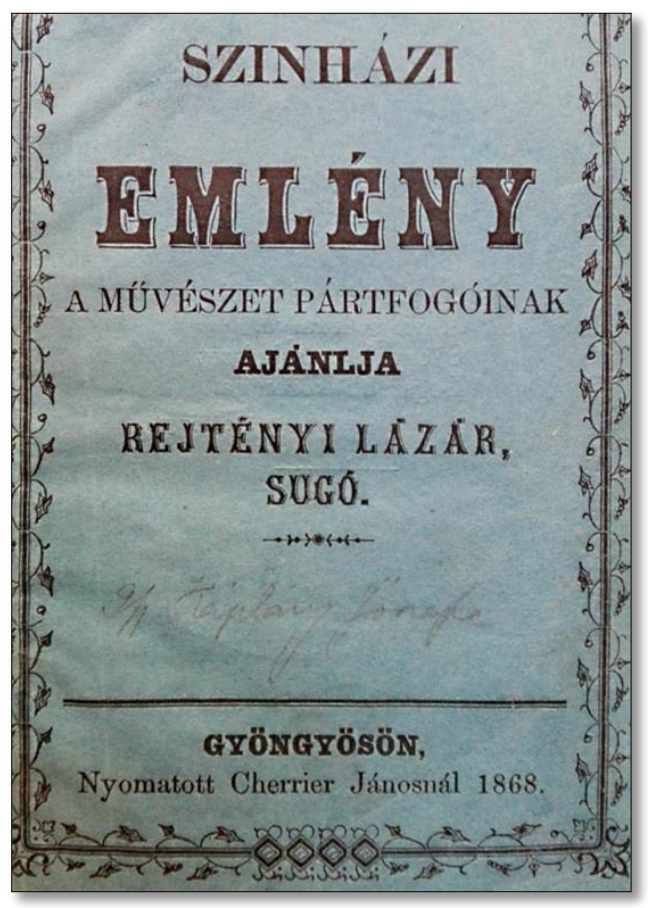

18. kép - Színházi zsebkönyv 1868-ból, a gyöngyösi Cherrier-nyomda munkája

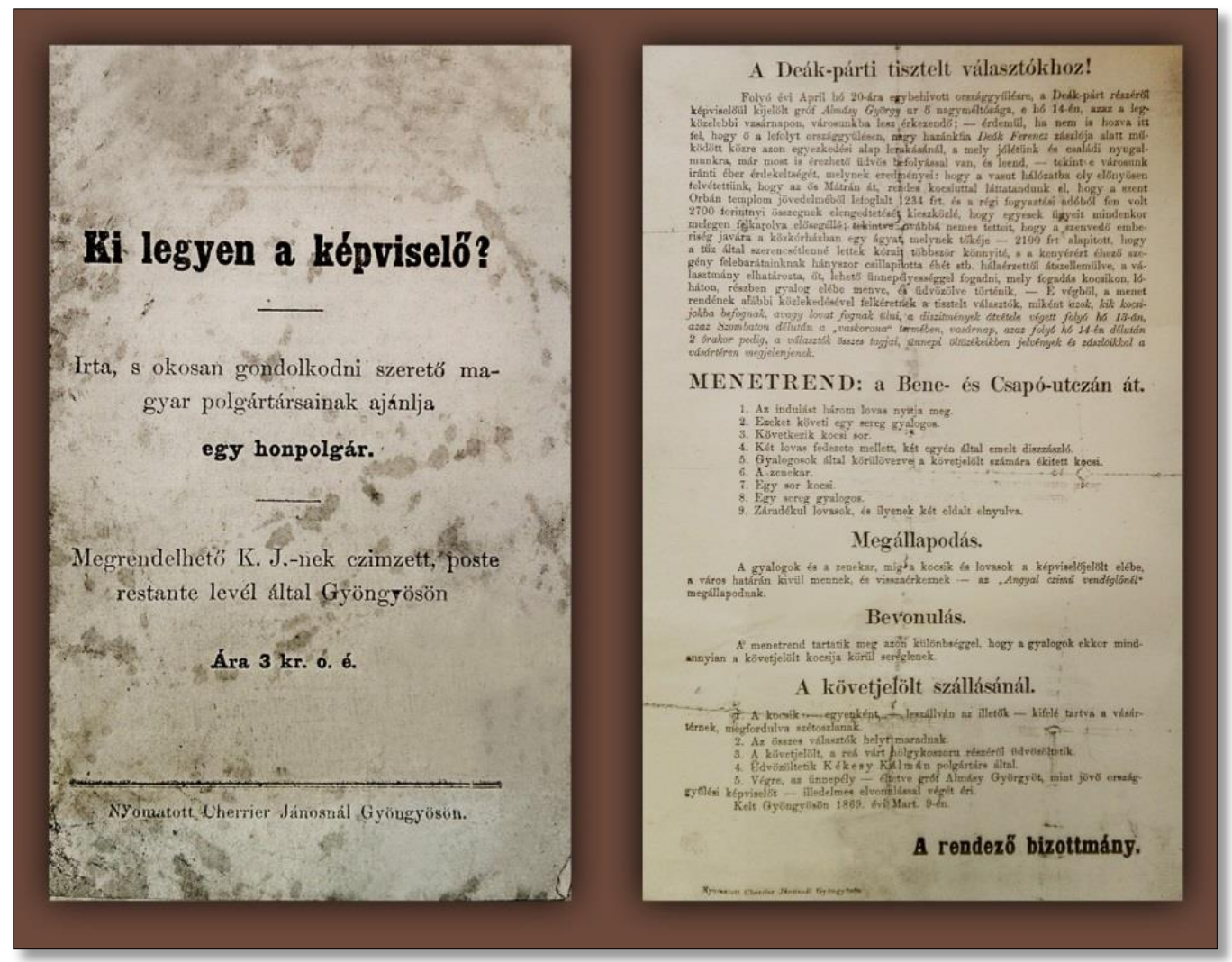

19. kép - Kisnyomtatványok a gyöngyösi Cherrier-nyomdából 


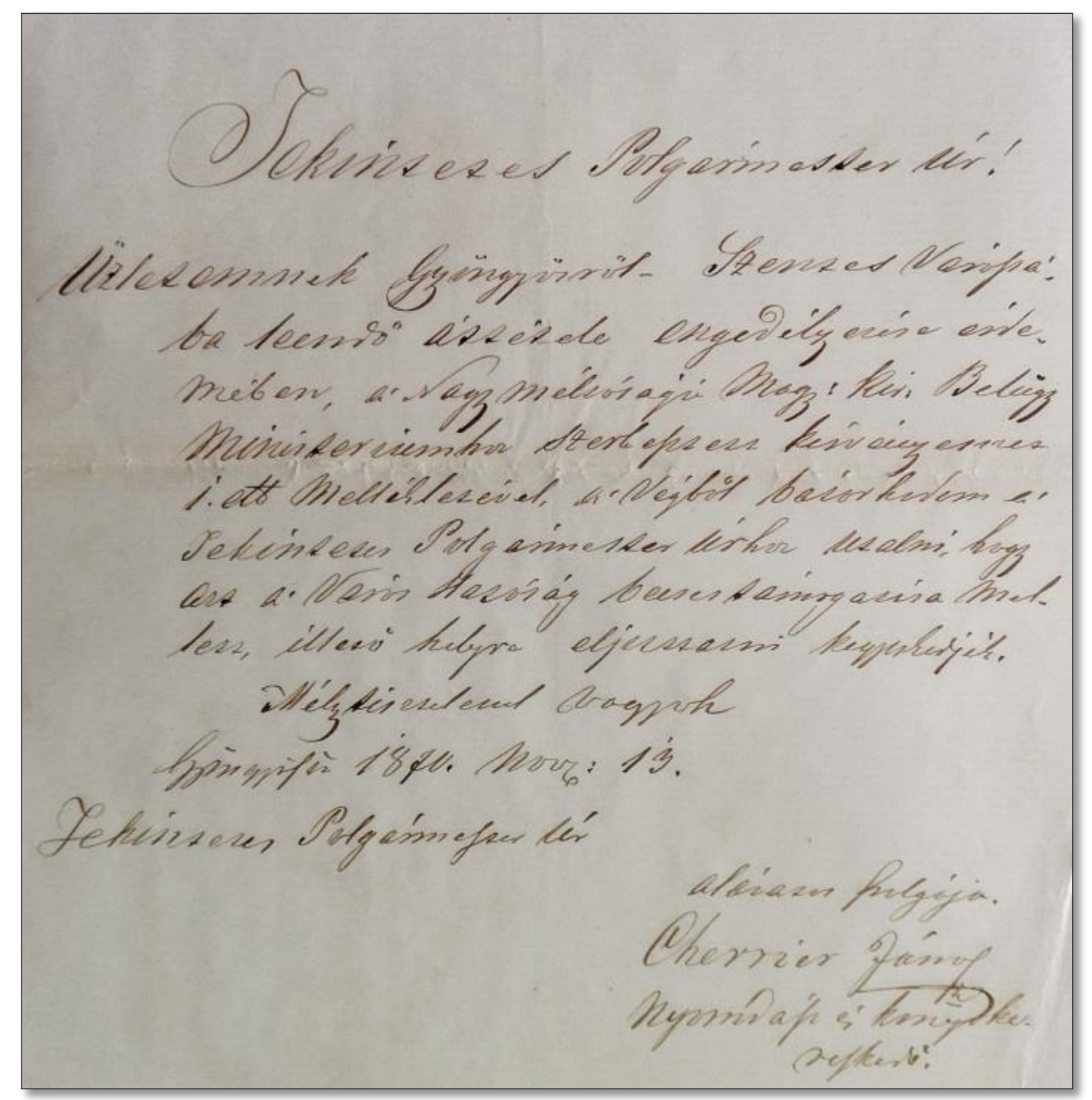

20. kép - Cherrier János Gyöngyösön kelt kérelme Szentes polgármesteréhez nyomdája áthelyezése ügyében (forrás: MNL CSML Szentes, V.B.145.b. - Szentes Város Tanácsának iratai [1849-1872] - Tanácsi iratok, 2026/1870.) 


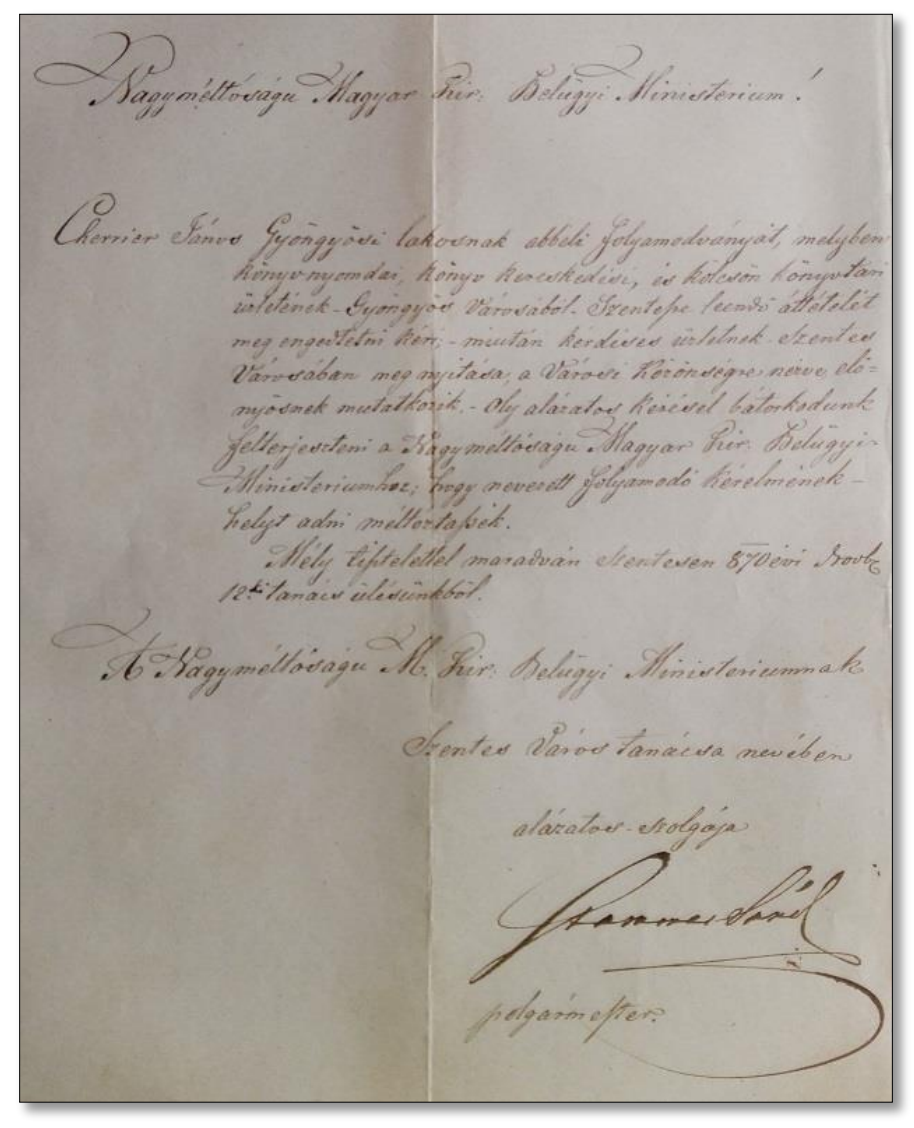

21. kép - Stammer Sándor levele a Belügyminisztériumhoz, amelyben támogatását fejezi ki Cherrier János Szentesre való áttelepülése ügyében (forrás: MNL CSML Szentes, V.B.145.b. - Szentes Város Tanácsának iratai [1849-1872] - Tanácsi iratok, 2026/1870.)

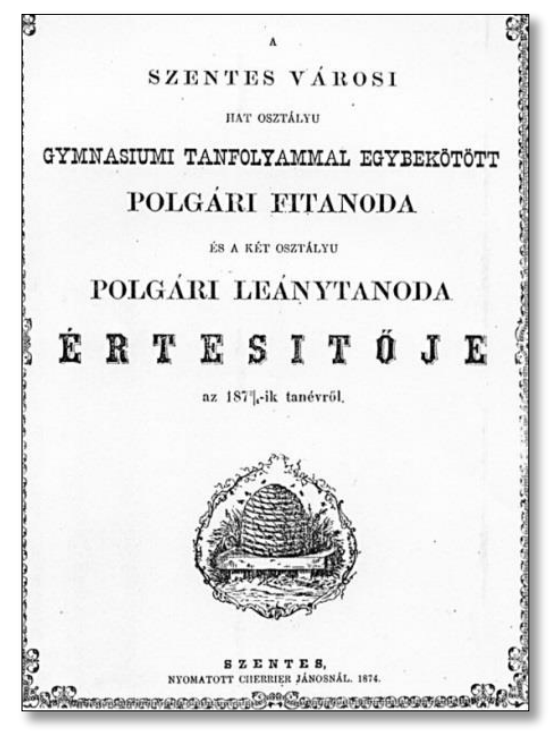

22. kép - A polgári leány- és fiúiskolák értesítője az 1873/1874-es tanévről, Cherrier János szentesi nyomtatásában 


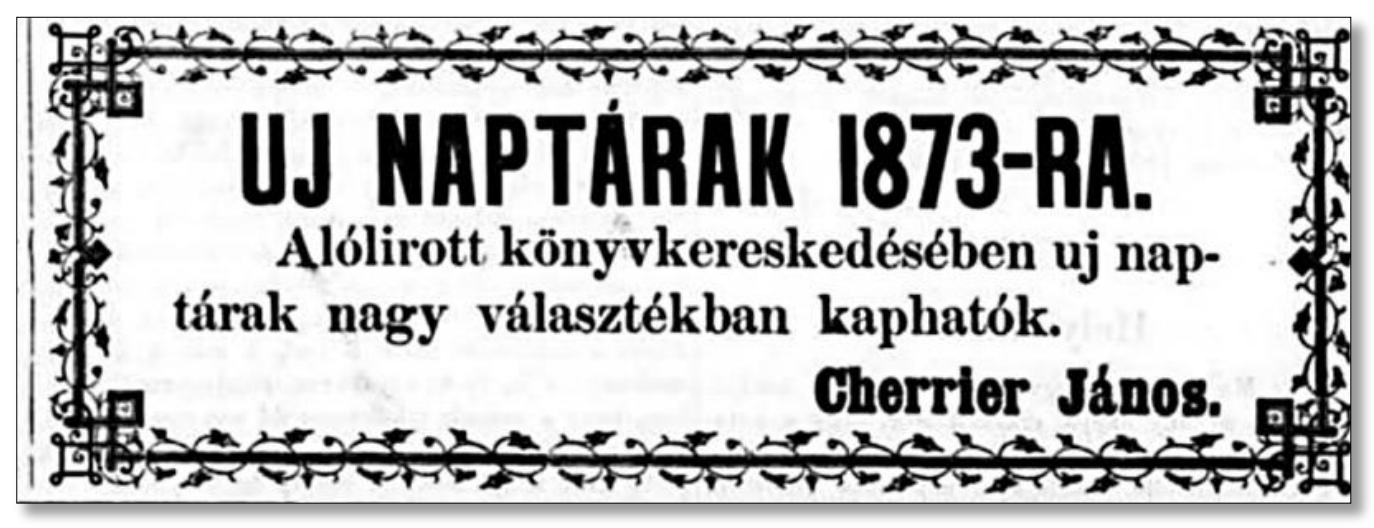

23. kép - Cherrier János hirdetése saját lapjában

(Szentesi Lap, 1872. november 24., I. évf. 16. sz., 4.)

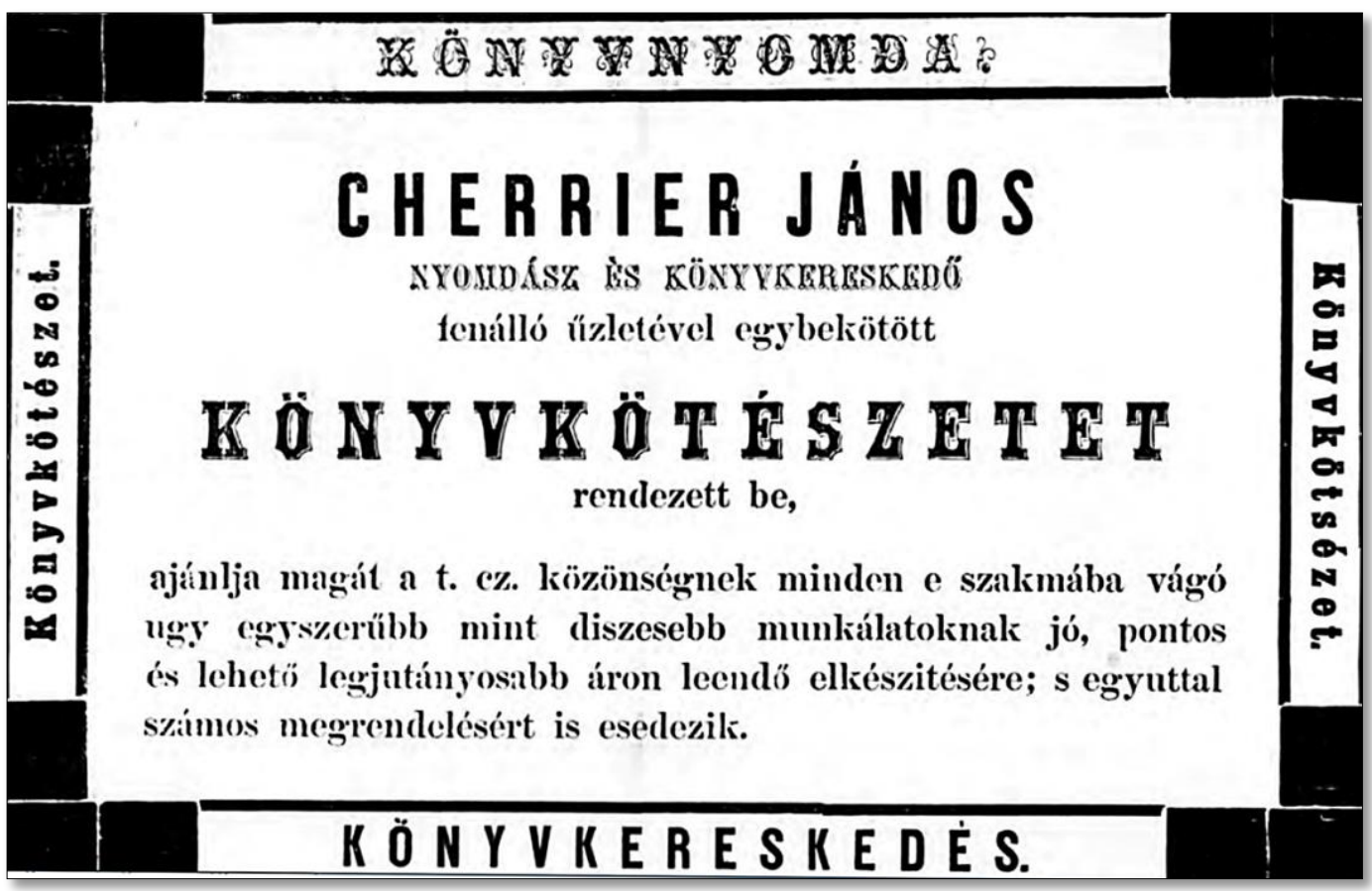

24. kép - Cherrier János hirdetése saját lapjában

(Szentesi Lap, 1873. november 30., III. évf. 48. sz., 4.) 


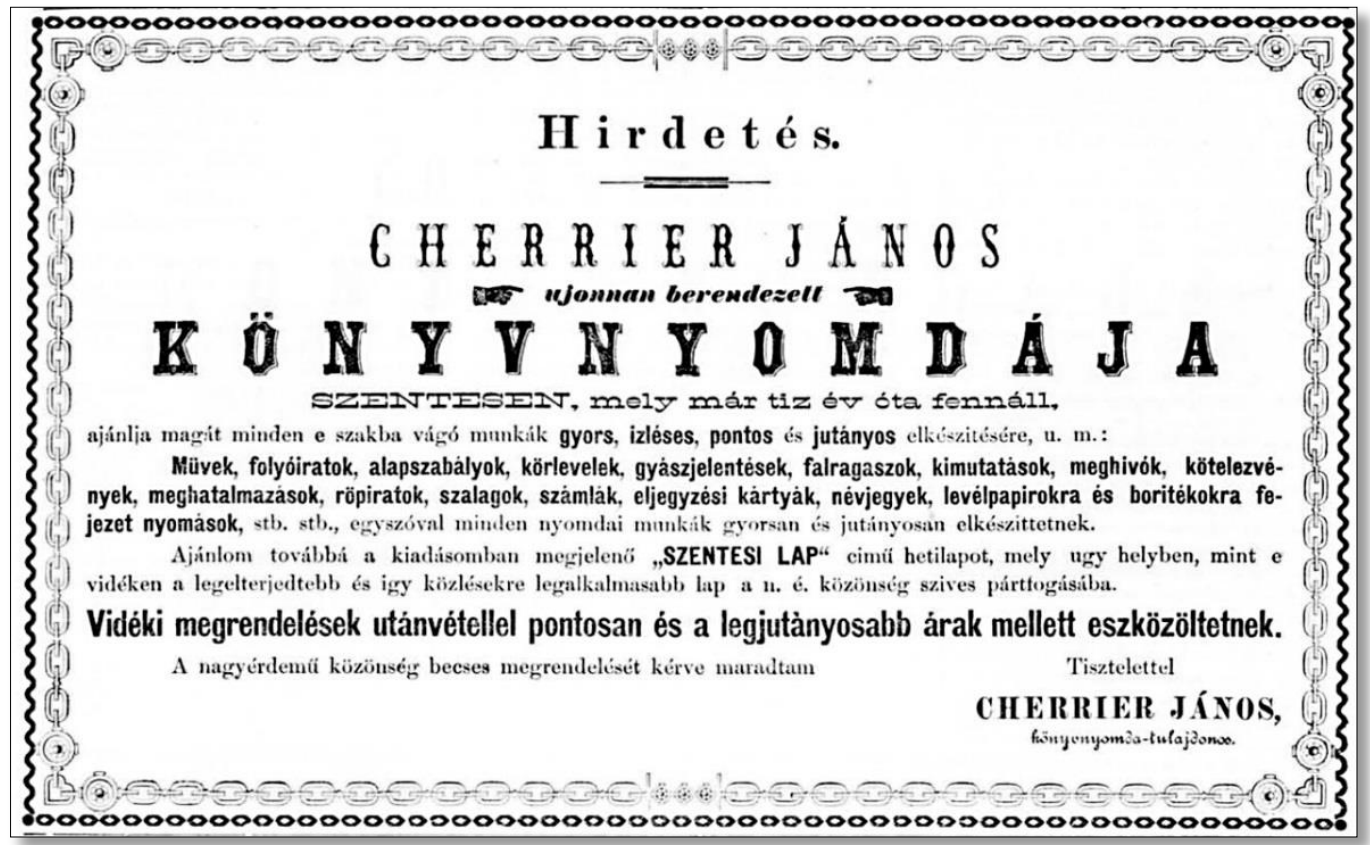

25. kép - Cherrier János hirdetése saját lapjában

(Szentesi Lap, 1881. január 15., XI. évf. 3. sz., 4.)

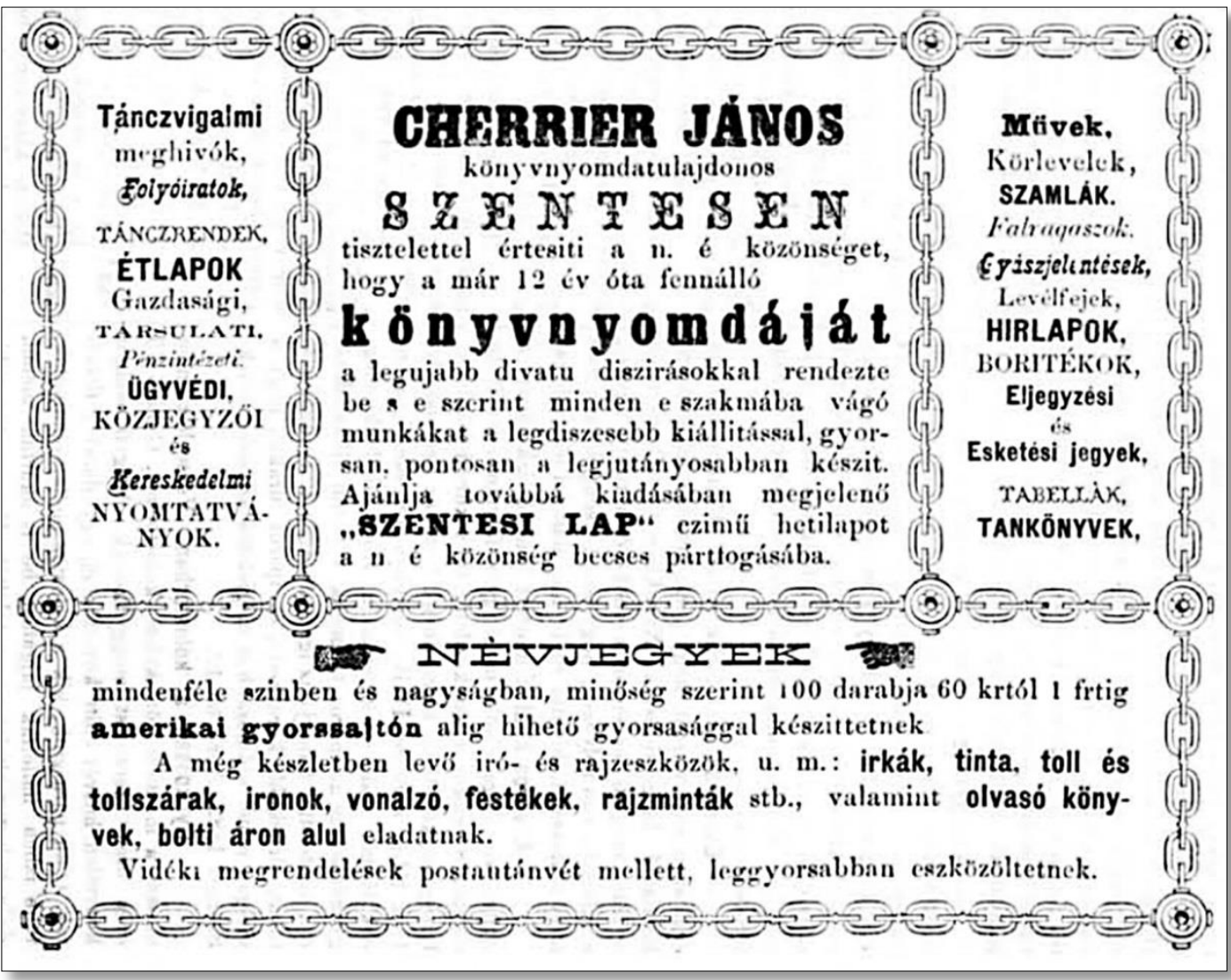

26. kép - Cherrier János hirdetése saját lapjában

(Szentesi Lap, 1882. április 29., XII. évf. 17. sz., 4.) 


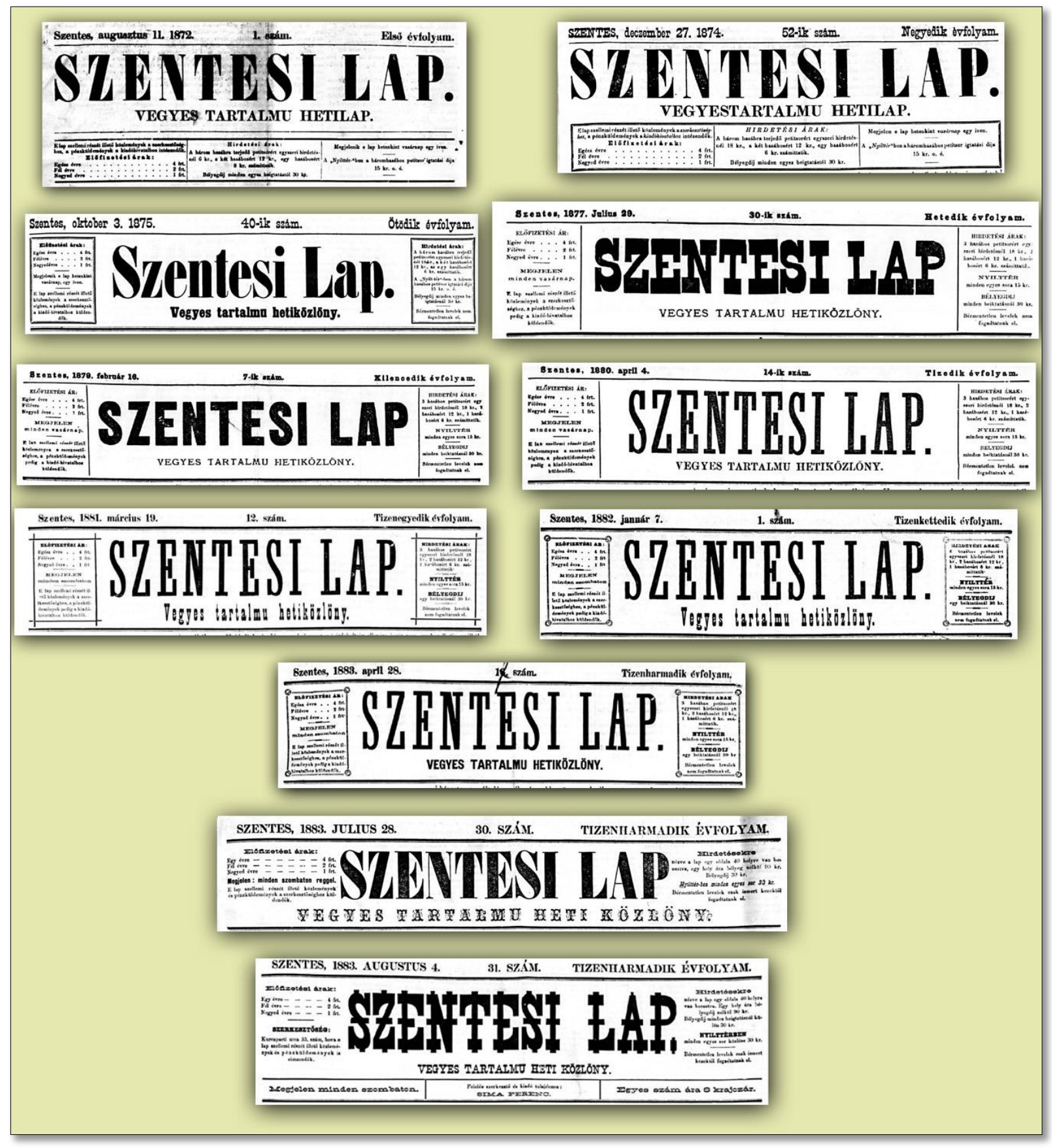

27. kép - A Szentesi Lap fejlécének tipográfiai változásai 1872 és 1883 között

(forrás: saját készítésü grafika) 


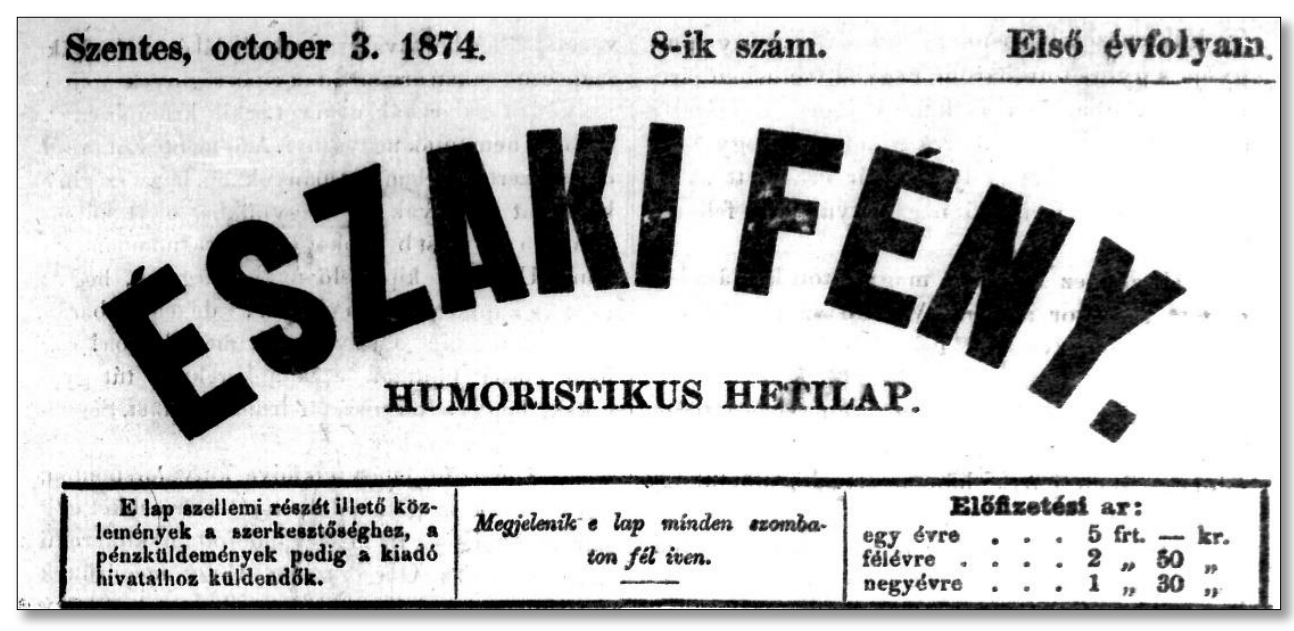

28. kép - Az Északi Fény fejléce

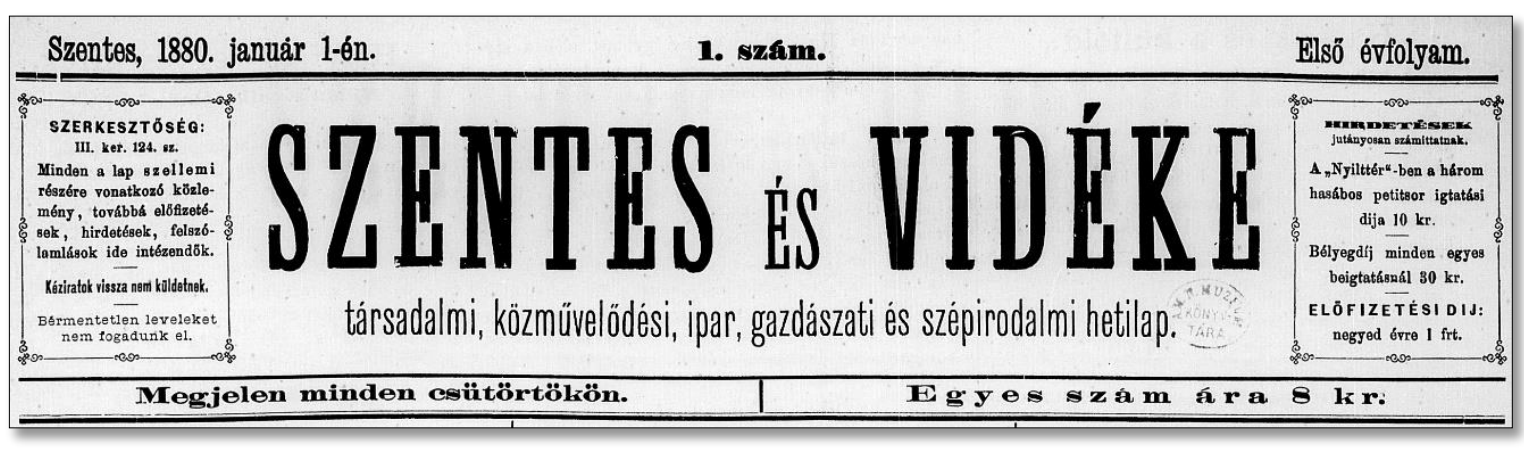

29. kép - A Szentes és Vidéke fejléce

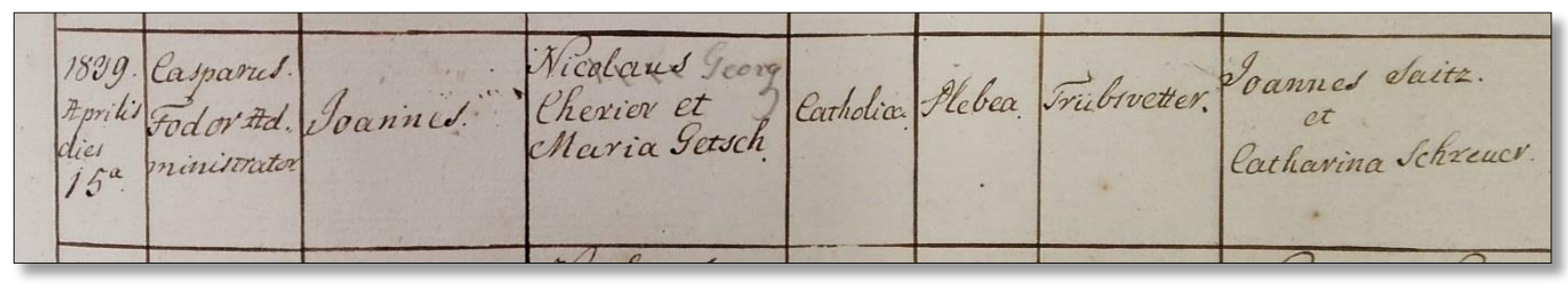

30. kép - Cherrier János születési anyakönyvi bejegyzése

(forrás: RNL TL, a római katolikus egyház születési anyakönyvei,

Nagyősz [Tomnatic], 5. k., 1833-1864. 44. oldal) 


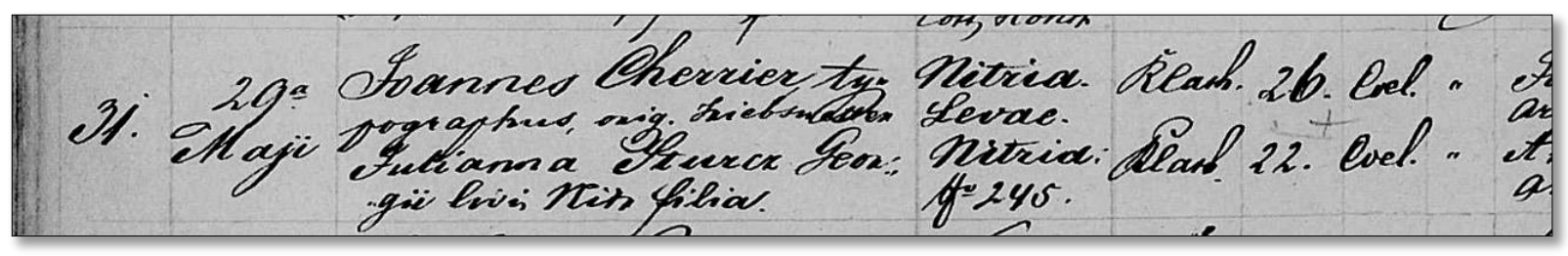

31. kép - A Cherrier János és Sturcz Julianna nyitrai házasságkötéséről szóló anyakönyvi bejegyzés

(forrás: https://familysearch.org/ark:/61903/3:1:33S7-8BT3-TP6?mode=g\&i=9\&wc=9PQ3SP8\%3A107654301\%2C107660801\%2C110064602\%2C141441901\&cc=1554443, letöltés: 2017. október 5.)

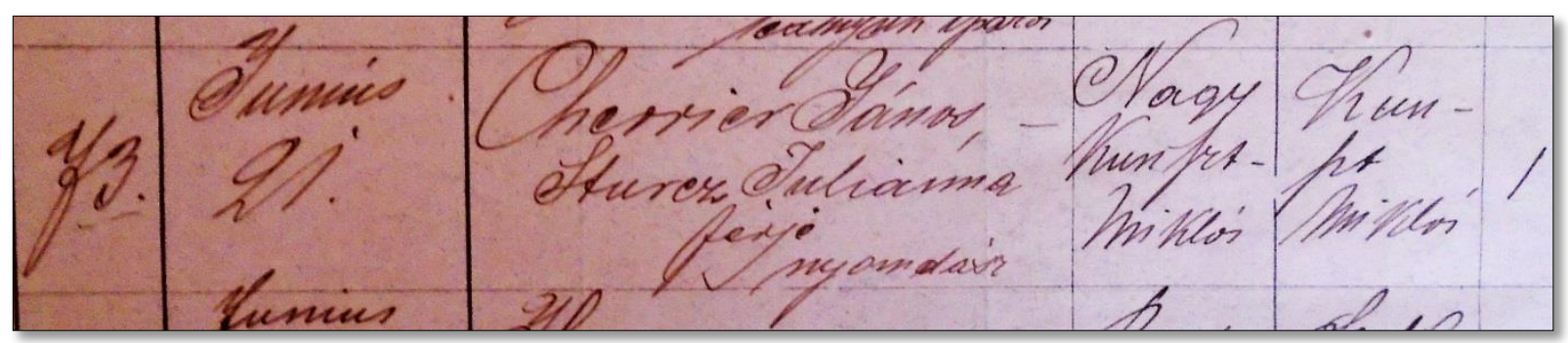

32. kép - Cherrier János halotti anyakönyvi bejegyzése

(forrás: a kunszentmiklósi római katolikus plébánia halotti anyakönyvei, 1886. év)

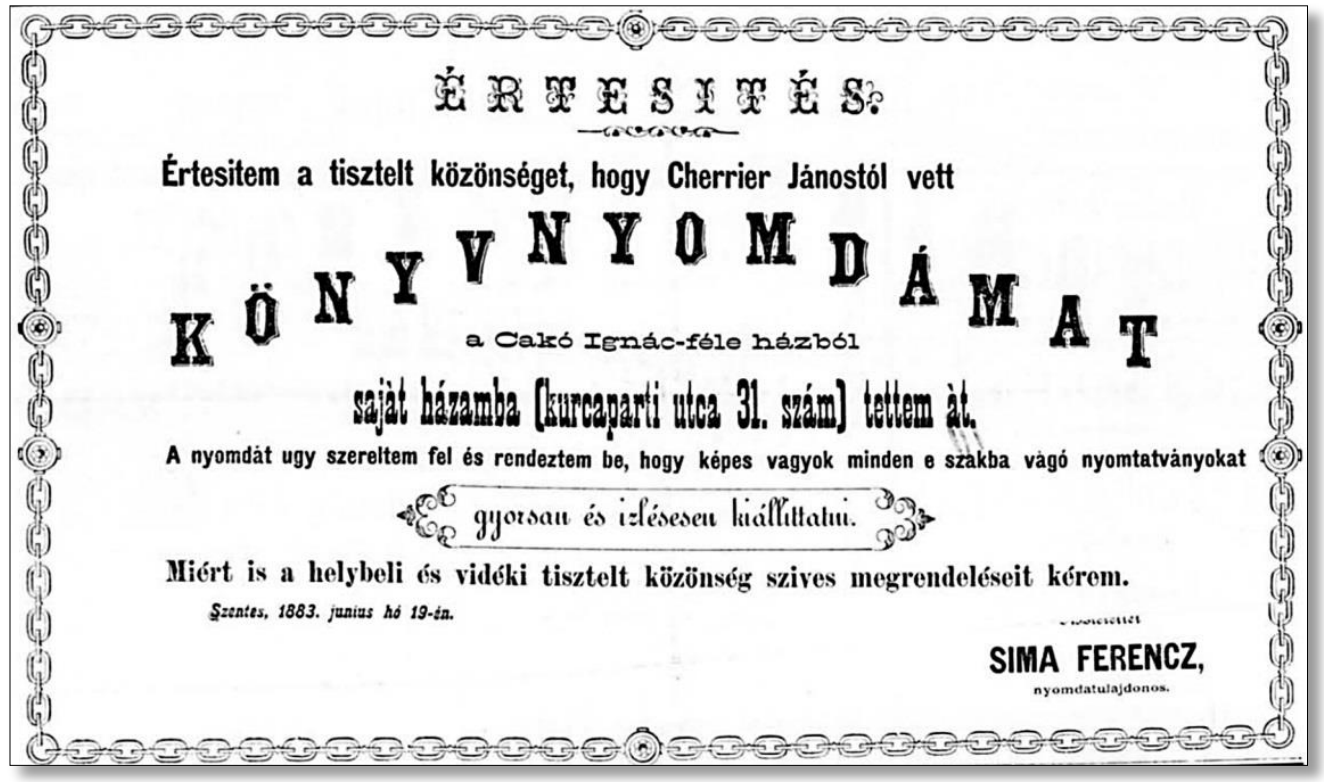

33. kép - Sima Ferenc hirdetése a Cherrier-féle nyomda átvételéről

(Szentesi Lap, 1883. június 30., XIII. évf. 26. sz., 4.) 